UNIVERSIDADE DE SÃO PAULO
PROGRAMA DE PÓS-GRADUAÇÃO INTERUNIDADES EM MUSEOLOGIA

Luciana Ramos Barbosa

Museu da Cúria Metropolitana de São Paulo:

a preservação dos bens culturais da Igreja paulista a partir do pioneirismo de Dom Duarte Leopoldo e Silva.

São Paulo

2021 


\section{Museu da Cúria Metropolitana de São Paulo: \\ a preservação dos bens culturais da Igreja paulista a partir do pioneirismo de Dom Duarte Leopoldo e Silva.}

Dissertação apresentada ao Programa de Pós-Graduação Interunidades em Museologia da Universidade de São Paulo para obtenção do título de Mestre em Museologia.

Área de Concentração: Museologia

Orientadora: Profa. Dra.

Heloisa Maria Silveira Barbuy

Linha de Pesquisa: História dos processos museológicos, coleções e acervos

Versão corrigida ${ }^{*}$ )

$\left(^{*}\right)$ A versão original encontra-se disponível no MAE/USP

São Paulo 
Autorizo a reprodução e divulgação integral ou parcial deste trabalho, por qualquer meio convencional ou eletrônico, para fins de estudo e pesquisa, desde que citada a fonte.

E-mail: lucianarbarbosa@gmail.com

Ficha catalográfica elaborada pelo Serviço de Biblioteca e Documentação, MAE/USP, com os dados fornecidos pelo(a) autor(a)

Ramos Barbosa, Luciana
Museu da Cúria Metropolitana de São Paulo: a
preservação dos bens culturais da Igreja paulista a
partir do pioneirismo de Dom Duarte Leopoldo e
Silva. / Luciana Ramos Barbosa; orientadora Heloisa
Barbuy. -- São Paulo, 2021.
339 p.
Dissertação (Mestrado - Programa de Pós-Graduação
Interunidades em Museologia) -- Museu de
Arqueologia e Etnologia, Universidade de são Paulo,
2021.
1. Museu da Cúria. 2. Dom Duarte Leopoldo e
Silva. 3. Bens culturais. 4. Igrejas de São Paulo.
5. Museus eclesiásticos. I. Barbuy, Heloisa,
orient. II. Título.

Bibliotecária responsável:

Monica da Silva Amaral - CRB-8/7681 
BARBOSA, L. R. Museu da Cúria Metropolitana de São Paulo: a preservação dos bens culturais da Igreja paulista a partir do pioneirismo de Dom Duarte Leopoldo e Silva. 2021. 339 f. Dissertação (Mestrado em Museologia). Programa de Pós-Graduação Interunidades em Museologia, Universidade de São Paulo. São Paulo, 2021.

Aprovada em: 23/08/2021

Banca Examinadora

Profa. Dra.: Heloisa Maria Silveira Barbuy (Orientadora)

Instituição: Programa de Pós-Graduação Interunidades em Museologia /

Universidade de São Paulo (USP)

Julgamento:

Assinatura:

Profa. Dra.: Maria Isabel Rocha Roque

Instituição: Universidade Europeia - Portugal

Julgamento:

Assinatura:

Profa. Dr.: Percival Tirapeli

Instituição: Universidade Estadual Paulista (UNESP)

Julgamento:

Assinatura: 


\section{Agradecimentos}

Cursar um programa de mestrado acadêmico, mar nunca de antes navegado por mim, foi um grande desafio, principalmente durante as turbulentas águas que atravessaram meu caminho nestes dois anos - além, é claro, da pandemia do vírus Covid-19 que assolou o ano de 2020. Mas como mar calmo não faz bom marinheiro, é preciso agradecer a todos que compartilharam esta jornada comigo e me trouxeram bons ventos sempre que necessário.

À mestra Heloisa Barbuy, por toda a sua atenção e paciência comigo durante o processo de pesquisa. Seu vasto conhecimento na área museológica e, especialmente, sobre nossa querida cidade de São Paulo, enriqueceram este trabalho. Sem sua ajuda, esta pesquisa com certeza não teria saído do campo das ideias.

Aos professores Dr. Percival Tirapeli e Dra. Marília Xavier Cury por participarem do meu exame de qualificação e contribuírem com importantes apontamentos que me ajudaram a nortear diversos pontos da minha pesquisa.

Aos professores e colegas do PPGMus, agradeço todas as trocas e discussões a respeito do universo museológico ao longo desses dois anos.

Aos funcionários do Museu de Arte Sacra de São Paulo, em especial à Beatriz Cruz e Rosimeire Santos, pela pronta-resposta a cada solicitação ou dúvida em relação ao acervo. Obrigada por confiarem no meu trabalho.

Ao Jair Mongelli Jr, diretor do Arquivo da Cúria, por abrir todas as portas do Arquivo para minha pesquisa. Agradeço todas as discussões, sugestões e conversas sobre preservação do patrimônio religioso.

À Milena Cattini, minha museóloga-arquiteta favorita, por colaborar com as plantas e perspectivas apresentadas neste trabalho.

A todos os amigos com que a Museologia me presenteou e aos amigos de sempre, que tanto me ajudaram durante esta jornada. Em especial, à minha querida amiga Ruth Maria Santos, por sempre me trazer uma palavra de motivação e por dividir comigo o amor pela arte sacra. E às elementares Juliana Sayão e Marcele Folgati, por estarem ao meu lado em qualquer maré.

Meu eterno agradecimento aos meus amados pais, Telma e William, e querido irmão Guilherme, por sempre me apoiarem e serem meu porto-seguro. Amo vocês. 
He hum labyrinto de encantos em que a razão se acha e a alma se ilustra, e a Religião triunfa.

(Frei José de São Lourenço do Valle. Oração do Muzeo. "Discurso de inauguração do Museu Pacense”, Beja, 15.03.1791. In: ROQUE, M. I. O Sagrado no Museu. Lisboa: Universidade Católica Editora, 2011, p 39). Conhecida como "Oração do Museu" é o mais antigo texto existente sobre museus em língua portuguesa, de acordo com a autora. 
Não sobrou nada.

Nem índios, nem teares, nem padres, nem memórias. A única história possível nos é contada por esses muros desmoronados e por essas estátuas de santos e anjos feitos de pau e pedra cujas faces e corpos são feridos e marcados, os olhos doídos e silenciosos. 


\section{RESUMO}

BARBOSA, L. R. Museu da Cúria Metropolitana de São Paulo: a preservação dos bens culturais da Igreja paulista a partir do pioneirismo de Dom Duarte Leopoldo e Silva. 2021. 339 f. Dissertação (Mestrado em Museologia). Programa de Pós-Graduação Interunidades em Museologia, Universidade de São Paulo. São Paulo, 2021.

A presente pesquisa objetiva investigar, sob a ótica da história dos museus, coleções e exposições, a criação do Museu da Cúria Metropolitana de São Paulo, instituição pioneira na preservação dos bens culturais da Igreja Católica no Brasil, por iniciativa de Dom Duarte Leopoldo e Silva, 1ํArcebispo de São Paulo. Constituído de forma embrionária a partir do final da década de 1900, com concepção de Dom Duarte e gestão de Francisco de Salles Collet e Silva, $1^{\circ}$ Diretor do Arquivo da Cúria, o Museu da Cúria estabeleceu-se como local de guarda de objetos recolhidos de Igrejas, irmandades e outros tantos doados à Cúria, como forma de preservar o passado católico paulista, que estava por se perder com as diversas transformações urbanas e políticas ocorridas a partir do final do século XIX no Estado de São Paulo. O trabalho avança pelos desdobramentos dessa iniciativa nos decênios seguintes, em que foram realizadas exposições e outros esforços de natureza museológica até o ano de 1969, quando o acervo da Cúria deu origem ao Museu de Arte Sacra de São Paulo (MAS-SP).

Palavras-chave: Museu da Cúria; Dom Duarte Leopoldo e Silva; Bens culturais; Igrejas de São Paulo; Museus eclesiásticos. 


\begin{abstract}
BARBOSA, L. R. Museum of the Metropolitan Curia of São Paulo: the preservation of the cultural heritage of the São Paulo Church based on the pioneering spirit of Dom Duarte Leopoldo e Silva. 2021. 339 p. Dissertation (Master in Museology). Postgraduate Programme in Museology, University of São Paulo. São Paulo, 2021.

This research aims to investigate, from the perspective of the history of museums, collections and exhibitions, the creation of the Museum of the Metropolitan Curia of São Paulo, a pioneer institution in the preservation of the cultural heritage of the Catholic Church in Brazil, at the initiative of Dom Duarte Leopoldo e Silva, 1st Archbishop of São Paulo. Constituted in an embryonic form from the end of the 1900s, with the conception of Dom Duarte and management by Francisco de Salles Collet e Silva, 1st Director of the Curia Archive, the Curia Museum established itself as a place to keep objects collected from Churches, brotherhoods and many others donated to the Curia, as a way to preserve the Catholic past of São Paulo, which was about to be lost due to the various urban and political transformations that occurred since the end of the 19th century. The work advances through the unfolding of this initiative in the following decades, in which exhibitions and other museological efforts were carried out until 1969, when the Curia collection originated the Museum of Sacred Art of São Paulo (MAS-SP).
\end{abstract}

Keywords: Curia Museum; Dom Duarte Leopoldo e Silva; Cultural heritage; Churches of São Paulo; Ecclesiastical museums. 


\section{LISTA DE FIGURAS}

Figura 1: Retrato de Dom Duarte Leopoldo e Silva (1913)............................. 55

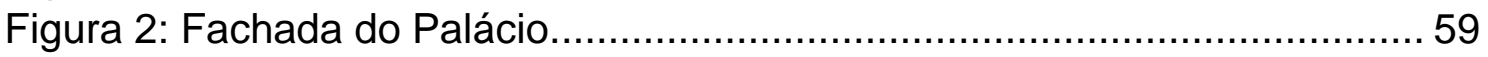

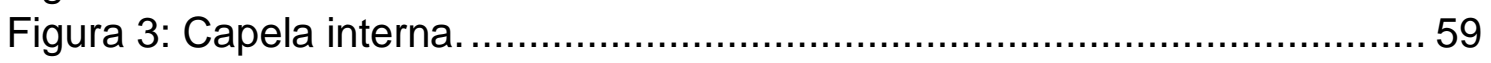

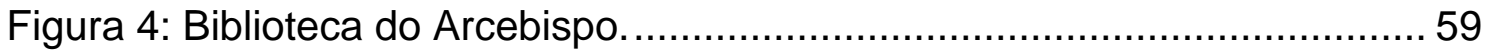

Figura 5: Dormitório de Dom Duarte. ........................................................ 59

Figura 6: Vista aérea do Palácio São Luiz. BJ Duarte, 1940........................... 63

Figura 7: Recorte da planta da cidade de São Paulo, levantada pela

Companhia Cantareira de Esgotos, em 1881.

Figura 8: Rua de Santa Teresa em direção à Rua do Carmo. À esquerda,

lateral do Recolhimento de Santa Teresa e, à direita, esquina da antiga

Rua das Flores. Aurélio Becherini, c. 1915.

Figura 9: Fotografia tirada da esquina da Ladeira do Carmo em direção ao

Pátio do Colégio. Ao centro, em segundo plano, esquina da Rua Santa

Teresa e torre do Recolhimento. Aurélio Becherini, c. 1925.

Figura 10: Recolhimento de Santa Teresa (séc. XIX/XX). Benedito Calixto de

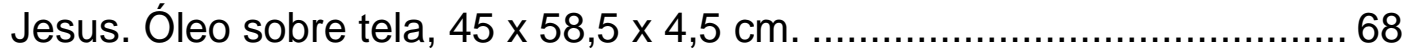

Figura 11: Palácio da Cúria Metropolitana. ……......................................... 70

Figura 12: Vista do hall com escadaria que dá acesso ao pavimento superior do

Figura 13: Vitral criado pela Casa Garcia, inspirado na pintura "Fundação de

São Paulo", de Oscar Pereira da Silva.

Figura 14: Membros do clero e outras pessoas na inauguração do Palácio da Cúria

Figura 15: Membros do clero na inauguração do Palácio da Cúria.................. 72

Figura 16: Projeto aprovado: fachada (elevação). Abelardo Soares Caiuby, 1920.

Figura 17: Projeto aprovado: planta do $1^{\circ}$ e $2^{\circ}$ pavimentos. Abelardo Soares

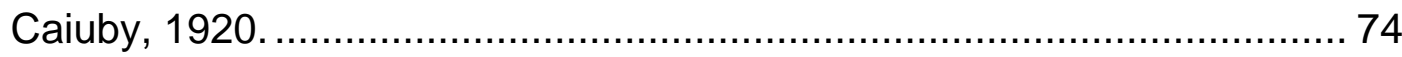

Figura 18: Vista do Palácio da Cúria. BJ Duarte, 1934 .............................. 76

Figura 19: Região central em dois tempos: à esquerda em 1930 e, à direita, em

1954, com a Praça Clóvis Bevilácqua já criada. Em destaque nas duas

imagens, a localização do

Figura 20: Demolição de edifícios na Rua Irmã Simpliciana, à esquerda, e Rua

Santa Teresa à direita, com o Palácio da Cúria próximo à esquina.

Camerindo Ferreira Máximo, 1974.

Figura 21: Largo da Sé [no período colonial]. Aquarela de J. Wasth Rodrigues,

1954.

Figura 22: Antiga matriz da Sé. Fotografia de Aurélio Becherini, 1907........... 99

Figura 23: Porta de entrada da Igreja da Sé. ............................................ 99

Figura 24: Vista do altar-mor da antiga Igreja da Sé.................................. 100

Figura 25: Altar da capela do Santíssimo Sacramento. Aurélio Becherini, 1910. 
Figura 26: Reproduções da pintura "A Conversão de São Paulo a Caminho de Damasco", de Almeida Junior. ........................................................... 101

Figura 27: Documento autenticado em cartório sobre guarda provisória de

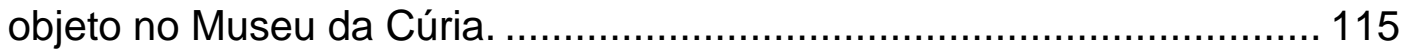

Figura 28: Página 96 do Catálogo do Museu da Cúria.................................... 119

Figura 29: Ficha catalográfica do MAS-SP (frente e verso). ......................... 122

Figura 30: Âmbula, cálices e coroa pertencentes ao Museu da Cúria. .......... 127

Figura 31: Naveta, patena e resplendor pertencentes ao Museu da Cúria. ... 127

Figura 32: Turíbulos do Museu da Cúria................................................. 128

Figura 33: Relicários da antiga Sé, pertencentes ao Museu da Cúria............ 128

Figura 34: Tocheiros e galhetas da antiga Sé, pertencentes ao Museu da Cúria.

Figura 35: Exemplos de lampadários do Museu da Cúria.............................. 131

Figura 36: Cruzes peitorais do Cardeal Arcoverde e de Dom Duarte. ........... 132

Figura 37: Anéis do Cardeal Arcoverde e de Dom Duarte. ........................... 133

Figura 38: Imagens de Nossa Senhora pertencentes ao Museu da Cúria. .... 135

Figura 39: Esculturas de São Jorge e São Pedro em exposição no MAS-SP.137

Figura 40: Armadura do Casaca de Ferro. Séc. XVII, Ferro estanhado, 64 × 79

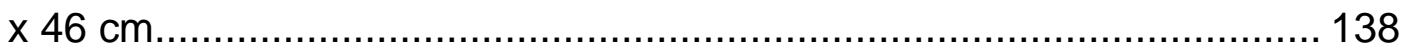

Figura 41: Detalhes das armaduras de São Jorge e do Casaca de Ferro. .... 138

Figura 42: Imagens de Santana Guia e Santa Escolástica, pertencentes ao

Museu da Cúria............................................................................ 140

Figura 43: Imagens de São Paulo e Santana Mestra, pertencentes ao Museu

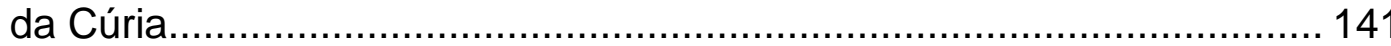

Figura 44: Pinturas dos Evangelistas da Igreja, oriundas do ....................... 143

Figura 45: Pinturas dos Doutores da Igreja, oriundas do Recolhimento de Santa

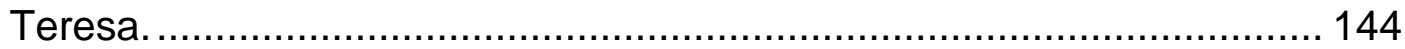

Figura 46: Objetos pertencentes a Dom Lucio, doados ao Museus da Cúria. 147

Figura 47: Uma das salas de exposição do Museu da Cúria. ........................ 152

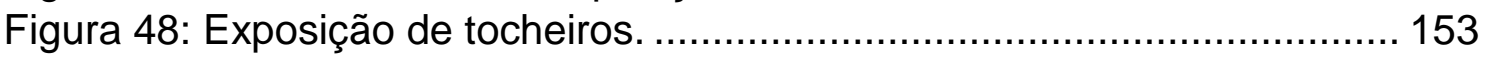

Figura 49: Pintura "Naufrágio do Sírio", de Benedito Calixto de Jesus, exposta no Salão de Conferência............................................................... 154

Figura 50: Naufrágio do Sírio (1907). Benedito Calixto de Jesus. Óleo sobre

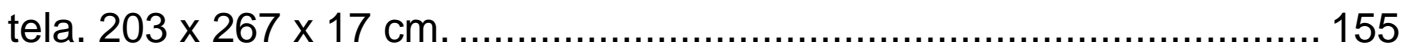

Figura 51: Vista de sala de exposição de Museu......................................... 157

Figura 52: Pia batismal exposta no Museu. ............................................... 158

Figura 53: Lampadários dependurados.................................................... 158

Figura 54: Vitrine com diversos objetos expostos. .................................... 159

Figura 55: Sala expositiva do Museu Paulista, em 1937............................. 160

Figura 56: Cotejamento entre imagens da fachada do Palácio: projeto arquitetônico e fotografia.................................................................... 162

Figura 57: Projeto aprovado: planta do $1^{\circ}$ e $2^{\circ}$ pavimentos. Abelardo Soares

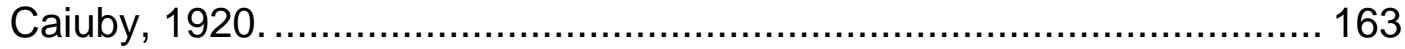

Figura 58: Ampliação e detalhamento da planta interna do Palácio da Cúria. 164

Figura 59: Vista das quatro salas apontadas como utilizadas para o Museu (1ํㅡㄴ pavimento). 


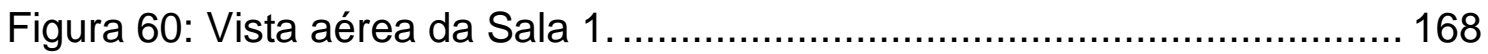

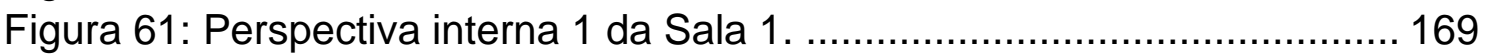

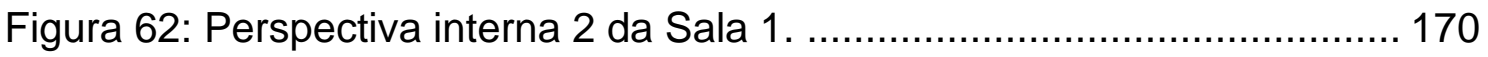

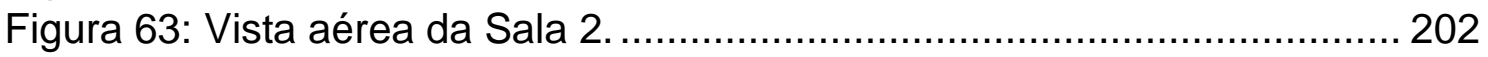

Figura 64: Perspectiva interna 1 da Sala 2. ............................................ 203

Figura 65: Perspectiva interna 2 da Sala 2. .................................................. 204

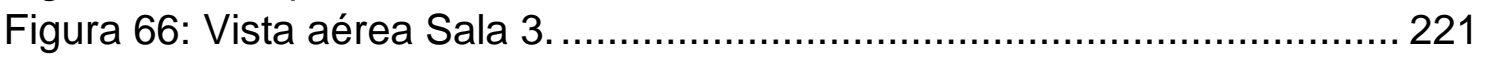

Figura 67: Perspectiva interna 1 da Sala 3. ............................................. 222

Figura 68: Perspectiva interna 2 da Sala 3. ........................................... 223

Figura 69: Perspectiva do $1^{\circ}$ patamar, Entrada do Arcebispo (1ำ pavimento).245

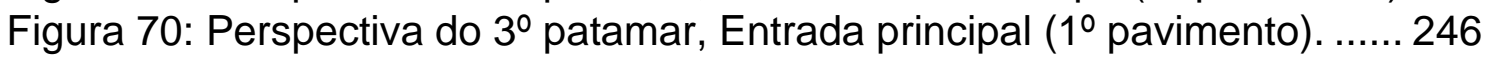

Figura 71: Perspectiva do $5^{\circ}$ patamar (2o pavimento).................................. 246

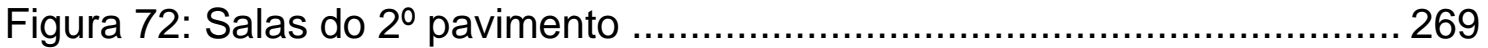

Figura 73: Perspectiva da Sala de espera (2o pavimento). ........................... 270

Figura 74: Perspectiva da Sala de Expediente 1 (2o pavimento)................... 271

Figura 75: perspectiva do Gabinete - Sala do Trono (2ำ pavimento)............... 272

Figura 76: Perspectiva da Sala de Expediente 2 (2o pavimento)................... 273

Figura 77: Lista de objetos solicitados por Guilherme de Almeida para exposição

Figura 78: Vitrines do Museu da Cúria utilizadas no MNSA, década de 1970. 


\section{LISTA DE TABELAS}

Tabela 1: Divisão dos cômodos do Palácio da Cúria por andar

Tabela 2: Paróquias criadas durante o arcebispado de Dom Duarte (19081938)

Tabela 3: Destino dos objetos da Igreja da Sé.

Tabela 4: Prataria procedente da Paróquia de Nazareth e Capela de Santa Luzia, guardadas na Cúria.

Tabela 5: Objetos expostos na Sala 1 do Museu da Cúria ............................ 171

Tabela 6: Objetos expostos na Sala 2 do Museu da Cúria ............................ 205

Tabela 7: Objetos expostos na Sala 3 do Museu da Cúria ............................ 224

Tabela 8: Objetos expostos na Sala 4 o Museu da Cúria .............................. 244

Tabela 9: Objetos expostos pelos patamares do Palácio da Cúria ................ 247 


\section{SUMÁRIO}

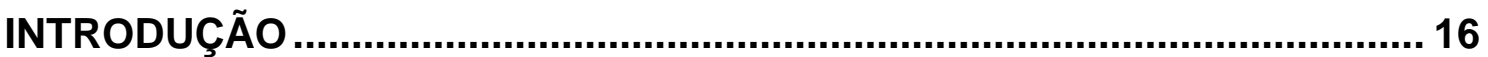

CAPÍTULO 1: O CONCEITO DE BENS CULTURAIS DA IGREJA CATÓLICA

E SUA MUSEALIZAÇÃO........................................................................... 30

1.1 Os papados e o desenvolvimento da salvaguarda dos bens culturais.......................... 30

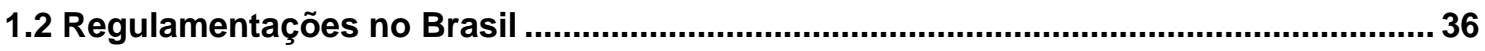

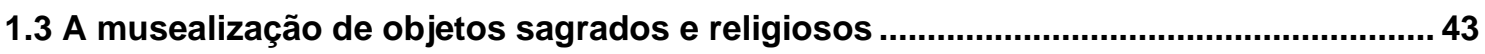

CAPÍTULO 2: O ARCEBISPO DOM DUARTE LEOPOLDO E SILVA............. 55

2.1 A figura de Dom Duarte à frente da Cúria Metropolitana de São Paulo .........................55

2.2 A importância do novo Palácio da Cúria para a preservação da história paulista ...... 66

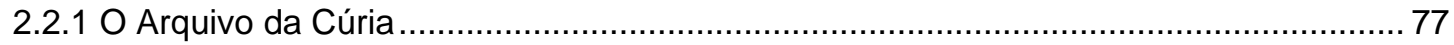

2.3 Dom Duarte e as Igrejas de São Paulo em tempos de romanização ............................. 81

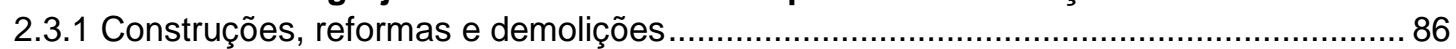

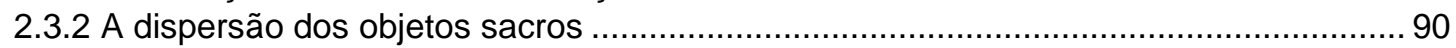

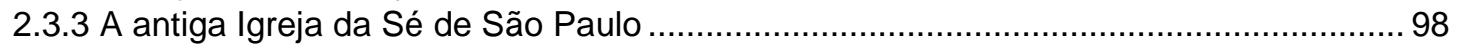

\section{CAPÍTULO 3: O MUSEU DA CÚRIA METROPOLITANA DE SÃO PAULO 102}

3.1 Um museu paulista para os bens eclesiásticos............................................................. 102

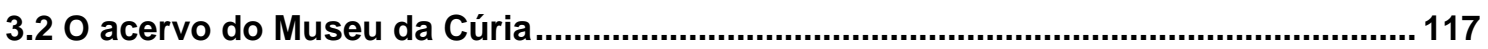

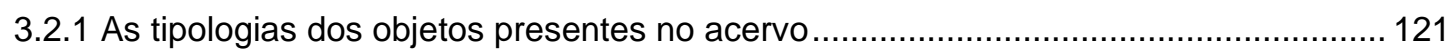

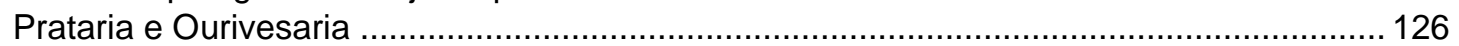

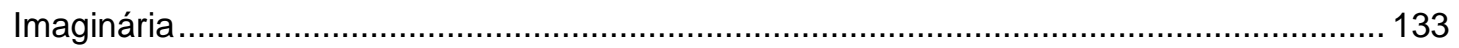

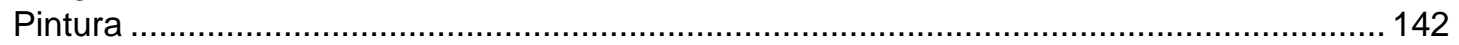

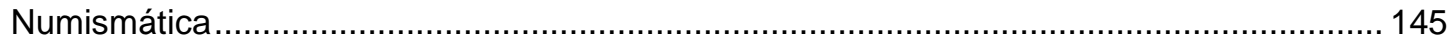

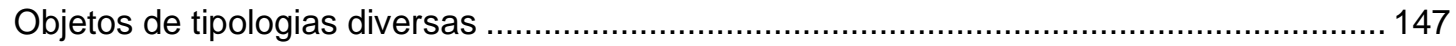

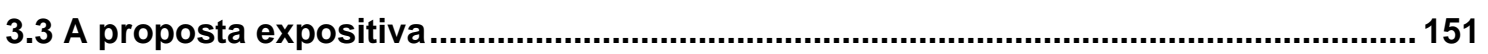

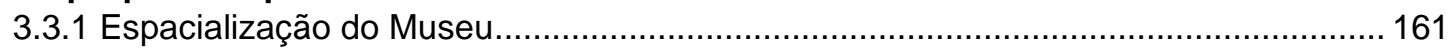

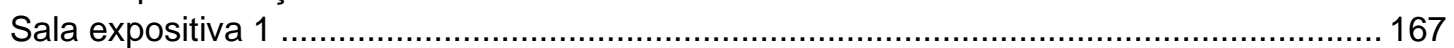

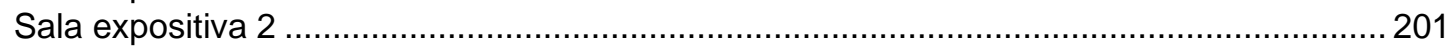

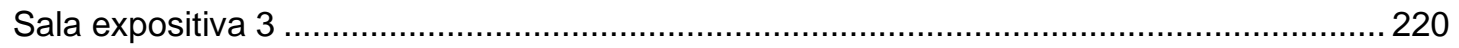

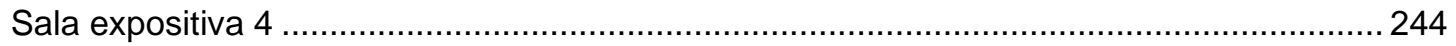

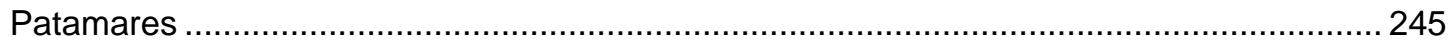

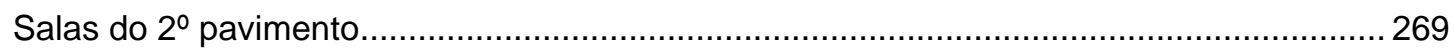

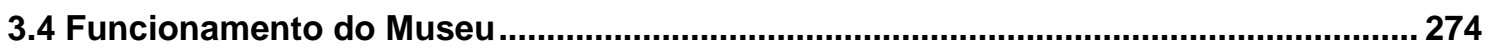

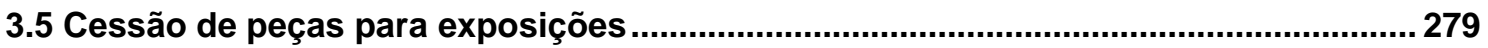

CAPÍTULO 4: UM NOVO MUSEU DE ARTE SACRA EM SÃO PAULO ....... 284 
4.1 Tratativas para criação de um novo museu de arte sacra da Cúria

4.2 Transformando o Museu do Arcebispo em Museu do Estado

CAPÍTULO 5: OUTROS MUSEUS ECLESIÁSTICOS PIONEIROS NO BRASIL

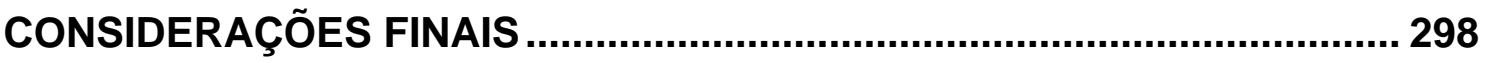

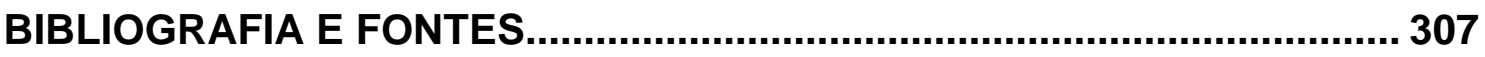

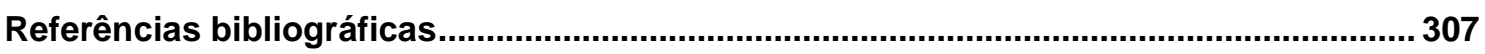

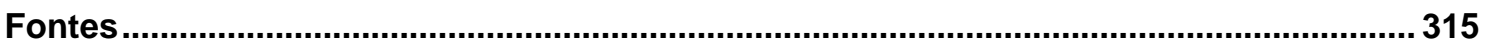

ANEXOS

ANEXO A - Pequeno glossário de arte sacra e objetos de culto católico .......................... 319

ANEXO B - Mapeamento das pinturas pelas salas do Palácio da Cúria ........................... 325

ANEXO C - Descrições mais extensas dos objetos listados no catálogo no 52 do Museu da Cúria, e não incluídas, por sua extensão, nas tabelas de objetos apresentadas no

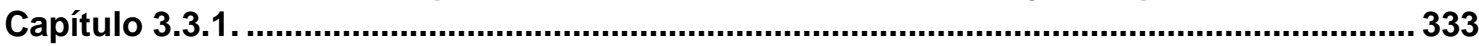




\section{Introdução}

O objeto de pesquisa da presente dissertação foi escolhido como um acaso do destino - ou de Deus, em se tratando de um museu sacro -; os bens culturais da Igreja já eram o nosso campo de interesse mas foi durante pesquisa no Arquivo da Cúria Metropolitana de São Paulo para a redação do pré-projeto a ser enviado à comissão do PPGMus, que descobrimos ter existido na cidade de São Paulo um importante e pioneiro museu de arte sacra por quase 5 décadas e que, entretanto, nunca foi objeto de uma investigação aprofundada.

Seu acervo, hoje preservado no Museu de Arte Sacra de São Paulo, importante instituição do gênero no Brasil, é tema de incontáveis estudos que o discutem dos mais diversos pontos de vista: da História da Arte, da Arquitetura, da História Colonial Paulista etc. Porém, a respeito de sua história como objeto museológico, há modestas referências.

Essa escassez historiográfica a respeito do antigo Museu da Cúria não é uma exclusividade dele; durante essa pesquisa foram poucas as referências bibliográficas encontradas a respeito da criação e formação de museus sacros no país.

A partir desta inquietação, esta dissertação buscou desenvolver, sob a ótica da história dos processos museológicos, coleções e acervos, uma investigação sobre a criação e formação do antigo Museu da Cúria, a fim de contribuir para a discussão acerca da salvaguarda da arte sacra no Brasil do ponto de vista museológico.

As mudanças políticas na virada do século XIX para o século XX, com o início da Primeira República e a laicização do Estado no Brasil, rompendo quase quatro séculos de união entre Estado-Igreja, obrigaram a Igreja Católica a se reorganizar internamente, formando novas sedes episcopais pelos estados a fim de manter sua presença, influência e relevância político-social. Estas ações também se refletiram na forma como seu patrimônio histórico-artístico era entendido, o que demandou um novo olhar em relação à sua coleção. 
Desde sua atuação como vigário da Paróquia de Santa Cecília (1895 a 1904), Dom Duarte demonstrou sua intenção em reforçar o status dominante da Igreja Católica em São Paulo por meio de ações políticas, buscando articulações com as famílias abastadas da cidade e reestruturando o cenário religioso a partir de reformas e construções de novos templos, a fim de acompanhar a modernização que ocorria por toda a cidade.

Ao mesmo tempo em que se empenhava para acompanhar todas as mudanças políticas e arquitetônicas da cidade, Dom Duarte inicia, já como Arcebispo de São Paulo, no final da década de 1900, o recolhimento ${ }^{1}$ de objetos sacros de igrejas e capelas da cidade e do interior, que eram sistematicamente demolidas após a Proclamação da República.

Eis que se iniciava a coleção de arte sacra do Estado de São Paulo. Atendendo à importância de se preservar o legado histórico e artístico eclesiástico do património cultural paulista, Dom Duarte institui o Museu da Cúria, dentro do Palácio da Cúria, sede administrativa da Igreja Católica em São Paulo, como local de guarda.

Apesar da pouca informação encontrada a respeito da formação desse acervo, sua importância como patrimônio histórico, artístico e cultural nos leva a discutir qual foi o papel desempenhado pela Igreja Católica e por Dom Duarte no esforço de preservar os bens culturais da Igreja por meio de uma instituição museal, numa cidade que se modernizava rapidamente no final do século XIX e início do século XX.

Os museus refletem as transformações humanas e seus discursos e coleções indicam os interesses das práticas sociais vigentes. Para um museu de arte sacra, além do entendimento artístico, deve-se ter uma compreensão sobre a dimensão espiritual do trabalho, pois só se pode compreender "a arte sacra a partir da fé que a motivou, da teologia que lhe é subjacente" (CAMPOS, 2011, p.13).

\footnotetext{
1 O termo "recolhimento" foi encontrado em diversas fontes de pesquisa para indicar a ação de coleta de objetos por parte de Dom Duarte. Assim, pela riqueza terminológica da época, decidimos mantê-lo e utilizá-lo ao longo do trabalho.
} 
Dentro da perspectiva de um museu de arte sacra, ou mesmo um museu sob a tutela da Igreja, é preciso se manter fiel às funções museológicas acrescentando uma dimensão eclesial ao desenvolvimento de suas atividades, uma vez que para além da produção artística, há um contexto histórico, social que precisa ser trabalhado também.

Dom Duarte compreendia as diversas funções da arte sacra, principalmente seu papel como documento histórico integrante da construção da memória e identidade do povo paulista e que deveria ser preservado, ainda que sob a ideia de um museu eclesiástico cuja coleção representava, também, a destruição dessa mesma memória que se queria preservar, já que era constituída por remanescentes de um patrimônio desaparecido ou em vias de desaparecimento.

De acordo com o historiador Krzysztof Pomian (1985, p.53) "uma coleção é qualquer conjunto de objetos naturais ou artificiais, mantidos temporária ou definitivamente fora do circuito das atividades econômicas, sujeitos a uma proteção especial num local fechado preparado para esse fim, e expostos ao olhar do público". No caso do objeto religioso, como bem lembra MENESES (1994, p.18), o conceito de relíquia ressalta a necessidade de preservar para prolongar a transcendência do objeto.

Os objetos de arte sacra possuem uma importância social na medida em que são "objetos mediadores do discurso do espaço e do tempo, estabelecendo uma relação de ordem existencial e não cognitiva, de contato com a realidade transcendente, do visível e do invisível” (CARVALHO, 2015, p.19).

Nessa percepção, o espaço e o tempo são apontados por HUYSSEN (2004, p.10) como categorias historicamente enraizadas e interligadas de maneiras complexas, principalmente quando dentro de um discurso de memória, sendo indissociáveis.

Ou seja, ainda que os objetos sacros carreguem sua função original da sacralidade da liturgia, a partir do momento que se tornam musealizados, eles passam a serem entendidos como objetos semióforos, portadores de sentido e significado histórico. 
Essa passagem de objeto sagrado para objeto museológico, segundo ROQUE (2011, p.176), é possibilitada a partir de uma abertura no contexto do cristianismo, uma vez que não existe uma sacralidade absoluta. Assim, o objeto litúrgico pode ser deslocado, sendo sua funcionalidade apenas evocada, ainda que para sua correta musealização "seja indispensável compreender o sentido do ritual a que esteve sujeito".

MENESES (1994, p.14) também discute esta dicotomia tempo/espaço ao afirmar que o museu pode trabalhar as duas dimensões, porém o tempo sempre existirá, uma vez que é no presente que esses objetos são postos como objetos históricos e, assim, devem responder aos anseios contemporâneos.

A arte sacra caracteriza-se como evidência material da relação do Homem com o Sagrado por meio de simbologias e temáticas próprias da liturgia. Ao longo dos séculos, a Igreja Católica incentivou sua produção e defendia a importância das imagens para a vida cristã "por três razões: são acessíveis aos ignorantes, estimulam a devoção dos fiéis e recordam a história da salvação" (CAMPOS, 2011, p.12).

O cristianismo trazido pelos portugueses ao Brasil tinha como premissa 0 devocionismo medieval lusitano e as normativas da Contrarreforma (CAMPOS, 2015, p.12), que propagavam a defesa da tradição católica de devoção aos santos e imagens em oposição aos Reformadores.

A fé por meio da iconografia dos santos trazida pelos portugueses está diretamente presente na produção artística brasileira no período colonial, uma vez que é impossível compreendê-la sem levar em conta a teologia cristã por traz do fazer artístico.

Mais do que reflexos da fé, esses objetos são parte integrante do processo constitutivo desse universo. Um artesão fazendo uma imagem de barro está pondo nela todo um pensamento, um sentimento, uma fé, que fazem parte do processo cultural de sua comunidade ou sociedade.

Quanto a esse sistema de significações, conforme Baudrillard (2015, p. 11), não se trata da definição do objeto segundo sua função, mas dos "processos pelas quais as pessoas entram em relação com eles e da sistemática de condutas e das relações humanas que disso resulta". 
Com o crescimento das dioceses, e consequentemente do número de padres e membros do clero, demandou-se uma grande variedade de objetos e paramentos para compor as igrejas, que vão desde elementos arquitetônicos como os altares, pinturas do forro, pias batismais e azulejos, até tantas outras peças que compunham o culto, como as alfaias, incensários, ostensórios e imagens de santos para os altares.

A arte desenvolvida em São Paulo durante os primeiros anos da Capitania, não contou com trabalhos mais eruditos da talha, como no Rio de Janeiro, pois:

\begin{abstract}
"Naquela região se desenvolveram modalidades populares, que têm elementos da talha do norte de Portugal, da região do Prata posto que São Paulo teve relações mercantis intensas com a região do Prata - e a particularidade de contar com mão de obra indígena" (CAMPOS, 2015, p.46).
\end{abstract}

O prestígio e relevância social da Companhia de Jesus eram tantos que o governo português se viu obrigado a restringir a atuação da ordem na região, passando muitos templos à jurisdição das ordens monásticas beneditinas, carmelitas e franciscanas (AMARAL apud CAMPOS, 2015, p.46).

É possível considerar a arte sacra como "a forma de maior expressão do legado artístico colonial" brasileiro (TIRAPELI, 2008, p.13). Com a chegada da Família Real ao Brasil, em 1808, e elevação da cidade de Rio de Janeiro em capital, foram estabelecidos novos parâmetros culturais, com a criação da Academia de Belas Artes e a chegada da Missão Francesa, que levaram ao fim o período barroco, do ponto de vista cultural e estilístico, e, consequentemente, daquela produção mais intensa de objetos religiosos.

A cidade de Salvador, antiga capital da colônia brasileira, no entanto, permaneceu como sede do poder religioso, que continuou sob proteção do império mesmo depois da Independência do Brasil, "que se esforçava por se distanciar da religião em busca de um estado laico - em conformidade com os ideais da Revolução Francesa e os princípios do lluminismo e Positivismo" (TIRAPELI, 2008, p.15).

Os conceitos libertários da Revolução Francesa ecoaram nas colônias da América Latina por meio de movimentos à independência. No Brasil, esse movimento eclode na Independência em 7 de setembro de 1822, pelas mãos de 
D. Pedro I, filho de D. João VI. A primeira Constituição do país, de 1824, garantia à Igreja Católica o status de religião oficial (SOUZA, 2004, p. 273).

Ainda que a Igreja Católica conseguisse manter seu status dominante, as dificuldades ainda dominavam o cenário, onde o episcopado brasileiro seguia submetido ao padroado e beneplácito português - o imperador tinha o direito de intervir em nomeações para cargos importantes e vetar determinações da Santa Sé (SOUZA, 2004, p. 275).

Essa disputa culminou na chamada Questão Religiosa (1864), quando o Papa Pio IX condenou as relações entre católicos e maçons, sendo que esta proibição não foi aprovada pelo Imperador D. Pedro $\|^{2}$ (SOUZA, 2004, p. 276). A relação entre a Igreja e a monarquia só foi resolvida com a Proclamação da República, em 1889, que introduziu definitivamente a separação Estado-Igreja.

As transformações internas da Igreja no Brasil, em particular em São Paulo, já aconteciam desde a metade do século XIX, com a intensificação da vinda do clero europeu, principalmente italiano, como instrumentos da reforma ultramontana. Segundo explica Ana Cristina Pereira Lage:

"O pensamento da Igreja Católica no século XIX estava centrado principalmente nas propostas ultramontanas, movimento também conhecido como Catolicismo Romanizado. Do latim ultramontanus, o termo designou aqueles fiéis que atribuíam ao Papa um importante papel na direção da fé e no comportamento do homem. A defesa das ideias ultramontanas pode ser encontrada em diversos documentos produzidos ao longo do século XIX com a intencionalidade de expressar o pensamento predominante nos quadros eclesiásticos da época, além de pretender doutrinar os fiéis, quando o mundo moderno, secularizado, constituía-se em um grande perigo para a salvação da alma, pois se fundamentava principalmente na liberdade política e também de pensamentos. Era um mundo que não obedecia aos preceitos católicos e ao controle da Igreja. Tal controle só retornaria com a implantação e a aceitação dos princípios ultramontanos e, principalmente, numa estrutura articulada pela manutenção e pelo fortalecimento do controle do sistema educacional (...)" (LAGE, 2005).

\footnotetext{
2 Desde a introdução da maçonaria no Brasil, no início do século XIX, era comum padres participarem das lojas maçônicas e maçons fazerem parte de irmandades. Segundo SOUZA (2004, p. 276) a Questão Religiosa se deu de fato quando os bispos de Olinda e Belém fecharam algumas irmandades que se negavam a expulsar os maçons. O primeiro-ministro imperial, 0 Visconde de Rio Branco, que era maçom, condenou os bispos em 1874. Eles acabaram sendo liberados no ano seguinte, com a troca de primeiros-ministros. Entretanto, o episódio abalou definitivamente as relações entre Igreja e monarquia.
} 
Os bispos reformadores, em especial Dom Antônio Joaquim de Melo (1852-1861), primeiro bispo nascido na província de São Paulo e primeiro com mentalidade reformadora (SOUZA, 2004, p. 332), buscavam estar mais próximos das orientações da Igreja de Roma, sobretudo em relação à doutrina e à disciplina (SOUZA, 2004, p. 278).

\begin{abstract}
"A imigração italiana, católica e ultramontana, contribuiu com o desenvolvimento da vida eclesial. (...) $\mathrm{O}$ imigrante italiano, sobretudo a maioria veneta que entrou na província de São Paulo, tinha uma compreensão religiosa diferente daquela dos brasileiros" (SOUZA, 2004, p. 278) ${ }^{3}$.
\end{abstract}

A reforma na diocese paulista teve seu avanço a partir do bispado de Dom Lino Deodato Rodrigues de Carvalho (1873-1894), que estreitou os laços com a Santa Sé como estratégia para desenvolver os conceitos reformadores em São Paulo.

Outra ação importante de Dom Lino foi a valorização do Seminário Episcopal, que formou uma importante geração de padres que assumiriam relevantes dioceses pelo país, entre eles Dom Duarte Leopoldo e Silva 4 .

Ao longo de nossa pesquisa, a figura de Dom Duarte foi se tornando cada vez mais importante para compreendermos não só a sua decisão em recolher objetos litúrgicos que se perderiam com as reformas e demolições das igrejas paulistas no início do século XX, como o papel da Arquidiocese de São Paulo durante um período de intensas transformações nas esferas políticas e sociais brasileiras.

\footnotetext{
${ }^{3}$ Com relação à imigração em São Paulo, "no início do século XX a cidade contava com uma população de aproximadamente 250 mil habitantes, dos quais cerca de 150 mil eram estrangeiros" (SOUZA, 2004, p. 406). No período de 1878-1920 emigraram 1.190.800 italianos (SOUZA, 2004, p. 372). Apenas durante o episcopado de Dom Lino, vieram 228 padres seculares estrangeiros, sendo destes 159 italianos, procedentes em sua maioria, do sul da Itália (SOUZA, 2004, p. 370-371).

${ }^{4}$ Outros importantes alunos que foram ordenados durante o período de Dom Lino foram Dom José de Camargo e Barros, bispo de Curitiba e de São Paulo (1904 a 1906), Dom João Batista Correa Nery bispo das dioceses de do Espírito Santo, Pouso Alegre e Campinas, e Dom José Marcondes Homem de Melo, bispo e arcebispo do Pará e bispo da diocese de São Carlos.
} 


\section{Estrutura da dissertação}

As ações de Dom Duarte ao longo de seu arcebispado em prol da preservação dos bens culturais eclesiásticos nos levaram à necessidade de alargar nossa pesquisa para melhor compreendermos como a Igreja Católica entendeu seu patrimônio cultural ao longo do tempo, uma vez que as iniciativas de Dom Duarte se deram no contexto institucional da Igreja.

Essa pesquisa alargada nos foi de grande importância na medida em que corrobora a hipótese de que a iniciativa de Dom Duarte em salvaguardar objetos de antigas igrejas e capelas do Estado e de criar um museu sacro em São Paulo no início do século $X X$ foi pioneira em diversos aspectos, uma vez que as leis eclesiásticas relativas à preservação do patrimônio histórico-artístico religioso permanecem praticamente as mesmas desde o Concílio de Trento (1564), com algumas alterações publicadas somente nos Códigos de Direito Canônico de 1917 e de 1983.

Assim, o Capítulo 1 propõe uma análise sobre a visão da Igreja Católica Apostólica Romana acerca da preservação de seus bens culturais, a partir de instrumentos como as publicações dos supracitados Códigos de Direito Canônico, e normativas brasileiras, como as Constituições Primeiras da Bahia e as Constituições Diocesanas das Províncias Meridionais do Brasil.

Também trazemos neste capítulo a discussão relativa à musealização de objetos religiosos, seu entendimento como documento histórico e devocional e seu papel dentro de uma instituição museal, ligada ou não à Igreja.

Propomos nos capítulos seguintes, a partir do estudo de caso da criação e formação do acervo do Museu da Cúria, refletir sobre as diversas funções da arte sacra, principalmente como documento histórico participativo da construção da memória e identidade paulistas.

O Capítulo 2 abordará a figura de Dom Duarte Leopoldo e Silva como encorajador da salvaguarda do acervo eclesiástico paulista com a formalização de um museu na Cúria Metropolitana. Trataremos de suas articulações políticas e ações, ao longo de seu arcebispado, encetadas para manter a relevância da Igreja Católica no cenário paulista. 
No Capítulo 3 investigaremos como foi o processo de criação e organização desta instituição museológica a fim de compreender de que forma Dom Duarte entendia esses objetos e quais foram os procedimentos estabelecidos para sua preservação. Abordaremos os objetos que compunham a coleção do Museu da Cúria a fim de desenvolver uma análise acerca de suas tipologias e aplicá-los em um mapeamento expográfico da coleção.

No Capítulo 4 apresentaremos as estratégias desenvolvidas pela Cúria paulista para consolidar seu acervo e torná-lo, de fato, um acervo de relevância nacional e internacional, a partir das diversas tratativas para se fundar um museu de arte sacra na cidade, culminando com a inauguração do Museu de Arte Sacra de São Paulo (MAS-SP).

No Capítulo 5 propomos um levantamento por datas de criação de museus de arte sacra no Brasil, a fim de melhor inserir nosso objeto de estudo no movimento de criação de museus dessa tipologia no século XX.

\section{Metodologia}

Nosso corpus documental foi composto por fontes documentais preservadas basicamente em duas instituições e uma hemeroteca: o Arquivo da Cúria Metropolitana, o Museu de Arte Sacra de São Paulo, ambos diretamente ligados ao objeto de estudo, e periódicos do começo do século XX, em especial o jornal Correio Paulistano, pesquisados na hemeroteca digital da Biblioteca Nacional, assim como O Estado de S. Paulo, pesquisado no site do próprio jornal.

No Arquivo da Cúria Metropolitana conseguimos mapear um pequeno conjunto documental relacionado ao antigo Museu da Cúria. Além de dois inventários do Museu, há cartas com conteúdo diversos, regimento do contrato estabelecido entre a Mitra e o Estado de São Paulo para o convênio que resultou na criação do Museu de Arte Sacra de São Paulo, em 1969, e documentos relacionados ao empréstimo de objetos à Casa do Bandeirante para as comemorações do IV Centenário de São Paulo, em 1954. 
A escassez de documentos institucionais do Museu da Cúria, como regimentos internos, relatórios e outros catálogos, trouxe percalços para a primeira parte de nossa pesquisa em conseguir informações mais precisas com relação ao desenvolvimento institucional do Museu, para compreendermos melhor de que forma a instituição entendia este acervo e como era a sua gestão.

A partir desta constatação, estendemos nossa pesquisa para outros documentos relacionados a Dom Duarte e ao cotidiano da Mitra existentes no Arquivo da Cúria, como os diários de visitas pastorais (1906-1920), diários pessoais de Dom Duarte (1907-1911) e diários da Cúria (1920-1923); atas da Comissão de Arte Sacra da Arquidiocese (1948-1954); Fundo da Chancelaria/ Patrimônio; Autos de Ereções e Patrimônio de Capelas (1775-1900); livros de tombo e correspondência da Cúria.

Com relação à pesquisa feita no Museu de Arte Sacra de São Paulo, não foram encontrados documentos oficiais do Museu da Cúria que poderiam ter sido transferidos ao MAS-SP por ocasião do convênio entre a Mitra e o Estado em 1969.

O conjunto documental disponível para nossa pesquisa contava com apenas documentos relativos à criação e formação do acervo do MAS-SP, como seu Decreto de criação; regimento interno; minuta do contrato de convênio com a Mitra e correspondências de 1979 de Pe. Antônio de Oliveira Godinho, segundo diretor do MAS-SP de 1979 a 1990.

Até aqui, as informações encontradas permitiram conhecer o acervo do Museu da Cúria, mas não trouxeram esclarecimentos sobre sua criação e seu modo de funcionamento. Com isto, partimos para aquela que acabou por se constituir em nossa principal fonte de pesquisa, os periódicos.

Em pesquisa sistemática realizada na Hemeroteca Digital da Biblioteca Nacional foram encontrados artigos e matérias que citavam o Museu da Cúria como espaço museológico criado por Dom Duarte e administrado por Francisco de Salles Collet e Silva, primeiro diretor do Arquivo e do Museu da Cúria.

A partir da busca dos termos "museu cúria", entre os anos de 1910 e 1960, foram encontradas 29 ocorrências nos seguintes periódicos: A Cigarra (SP), Correio Paulistano (SP), Correio de S. Paulo (SP), Jornal do Brasil (RJ), Correio da Manhã (RJ), Diário Nacional: A Democracia em Marcha (SP), Diário de Pernambuco (PE), Illustração Brasileira (FRA), O Imparcial (RJ), O Paiz (RJ), 
Jornal do Commercio (RJ) e A Republica: orgam do Partido Republicano (PR).Também foi realizada pesquisa no acervo online do jornal $O$ Estado de $S$. Paulo (SP).

Ainda que a pesquisa inicial tenha sido com o termo "museu cúria", foram realizadas buscas com as outras nomenclaturas encontradas para o museu, como "museu eclesiástico" e "museu da mitra"; no entanto, a denominação Museu da Cúria prevaleceu nas ocorrências, tanto nos periódicos quanto nas referências bibliográficas analisadas ao longo do trabalho.

\section{Enquadramento teórico}

Com a ausência de fontes primárias acerca do funcionamento do Museu da Cúria, optamos por tentar localizar mais informações sobre o assunto em pesquisa bibliográfica, na qual constatamos existir uma lacuna acerca da historicidade dos museus de arte sacra no Brasil, suas respectivas criações e formações de acervo.

Há livros e teses discutindo a documentação pela perspectiva da conservação e da gestão dos acervos, além de catálogos dos próprios museus e estudos específicos das obras. Porém, são raras as menções aos acervos sacros quanto à sua formação e gestão em perspectiva histórica.

Avançamos em nossa pesquisa por meio da busca em repositórios como da USP, UNICAMP e UNIFESP a procura de artigos, dissertações e teses publicadas por pesquisadores das áreas de história, história da arte, museologia e patrimônio, que discutissem a gestão dos bens culturais da Igreja, as potencialidades dos acervos sacros e as necessidades de preservação do patrimônio cultural colonial brasileiro.

É o caso da tese de doutorado "História, gestão e preservação: os bens culturais eclesiásticos na Diocese de Limeira-SP" de João Paulo Berto, que discute a criação de uma política de acervo relativa aos bens eclesiásticos, a partir de um mapeamento das diretrizes da Igreja e o entendimento de seus bens como patrimônio cultural. 
Outra tese consultada é a de António Manuel Ribeiro Pereira da Costa "Museologia da arte sacra em Portugal (1820-2010) - espaços, momentos, museografia" que, apesar de refletir sobre a realidade portuguesa (e não brasileira), relaciona a arte sacra com a disciplina museológica.

Dentro desta discussão acerca da museologia aplicada aos bens culturais da Igreja, foram-nos de grande valia os trabalhos realizados por Maria Isabel Roque, em especial o livro "O Sagrado no Museu", que nos trouxe importante contextualização histórica das práticas colecionistas, formações de acervos eclesiásticos e seus processos museológicos, dentro de uma perspectiva dessas coleções como catalizadoras do patrimônio histórico.

As pesquisas de doutorado "A obra religiosa de Benedito Calixto de Jesus através do mecenato de Dom Duarte Leopoldo e Silva na Igreja de Santa Cecília", de Karin Philippov, e "Santa Cecilia: uma paróquia na confluência dos interesses da elite paulista e da Igreja Católica entre 1895 e 1920", de Cristina de Toledo Romano, nos trouxeram importantes contribuições acerca do papel de Dom Duarte como mecenas de arte religiosa em São Paulo, além de sua articulação política para elevar o status dominante da Igreja Católica junto à elite paulista.

Já as dissertações de mestrado de Marilia Bonas "A(s) vida(s) da pia de água benta da primeira igreja de São Paulo no Museu Paulista da USP" e João Carlos Santos Kuhn "Resistências Sagradas: Pátio do Colégio, secularização e reconstrução", nos ajudaram a compreender as dinâmicas de seleção e apropriação simbólica da cultura material colonial de São Paulo.

O artigo "A reaproximação Estado-Igreja no Brasil durante a República Velha (1889-1930)" de Edgar da Silva Gomes, nos auxiliou a entender quais foram os mecanismos políticos utilizados pela Igreja Católica para manter seu poder após a laicização do Estado.

Para que pudéssemos analisar com maior segurança o nosso objeto de estudo, do ponto de vista da teoria museológica, nos valemos de um conjunto bibliográfico de especialistas que discutem a importância dos procedimentos de salvaguarda e comunicação para consolidar a transformação dos bens patrimoniais em herança cultural, a partir dos processos museológicos, abrangendo o papel do museu na discussão de conceitos como identidade e memória. 
Waldisa Rússio, em sua dissertação de mestrado "Museu: Um aspecto das organizações culturais num país em desenvolvimento" trouxe à nossa discussão a concepção brasileira de museu a partir da influência de fatores econômicos na modernização e industrialização da produção de bens culturais. Também nos valemos do trabalho organizado por Maria Cristina de Oliveira Bruno, "Waldisa Rússio Camargo Guarnieri: textos e contextos de uma trajetória profissional", para compor o pensamento museológico.

A obra de José Reginaldo Santos Gonçalves "Antropologia dos objetos: coleções, museus e patrimônios", também nos auxiliou na discussão acerca das relações entre coleções e memória coletiva, uma vez que aborda, por uma perspectiva antropológica, o papel que os objetos integrantes de coleções, museus e patrimônios desempenham no processo de formação de nossa memória e identidade.

A pesquisa também procurou inserir nas referências bibliográficas especialistas que discutem historicamente o período no qual se deu a criação do Museu da Cúria: a cidade de São Paulo no início do século XX e a relação IgrejaEstado com a Primeira República.

Para isso nos valemos de autores como Roberto Pompeu de Toledo em "A capital da vertigem", Benedito Lima de Toledo com seu livro "São Paulo: Três Cidades em um Século" e, mais recuado no tempo, caracterizando-se mais como fonte documental, Antônio Egydio Martins com "São Paulo antigo - 1554-1910", que nos ajudaram a compor um panorama histórico da cidade de São Paulo no início do século XX. Heloisa Barbuy, em seu livro "A Cidade-exposição Comércio e Cosmopolitismo Em São Paulo, 1860-1914", complementa a análise acerca do crescimento de São Paulo na passagem do século XIX para o XX, ao focar no triângulo inicial da cidade, formado pelas três principais ruas comerciais da passagem para o século XX: 15 de Novembro, Direita e de São Bento.

O entendimento desta região da cidade é importante para nossa compreensão acerca das mudanças que ocorreram na cidade, principalmente no aspecto arquitetônico, quando a cidade de taipa deu lugar à cidade de tijolo, acarretando a demolição de igrejas e conventos na região. O Palácio da Cúria, que se localizava onde é hoje a Praça Clóvis Bevilácqua, também sofreu com as diversas transformações urbanas do centro da cidade, sendo demolido na década de 1970. 
Especificamente para uma perspectiva histórica da importância da Igreja Católica na formação do Brasil e da produção artística religiosa, principalmente paulista, nos valemos da leitura de especialistas como Adalgisa Arantes Campos, que em "Arte Sacra no Brasil Colonial" apresenta uma análise das manifestações iconográficas da arte colonial, privilegiando o contexto histórico das produções e não o estilo artístico em si; e Eduardo Etzel em "Imagens religiosas de São Paulo - Apreciação histórica" que traz um levantamento da arte sacra popular do Vale do Paraíba.

Os artigos e publicações de Percival Tirapeli nos foram importantes fontes historiográficas acerca da arte colonial brasileira, em especial a arte sacra, onde pudemos vislumbrar em títulos como "Igrejas barrocas do Brasil" e "Arte Sacra Colonial: Barroco Memória Viva" todo o seu trabalho como grande pesquisador da arte sacra brasileira.

Leonardo Arroyo em "Igrejas de São Paulo: introdução ao estudo dos templos mais característicos de São Paulo, nas suas relações com a crônica da cidade" apresenta a história dos templos religiosos, relacionando-os com a dinâmica política e social da cidade.

Esta obra nos é interessante do ponto de vista de sua produção, uma vez que por vezes o Museu da Cúria é citado como local de guarda de objetos pertencentes às Igrejas por ele analisadas, o que indica a importância do Museu da Cúria como instituição de preservação do acervo sacro paulista.

A obra "Catolicismo em São Paulo - 450 anos da presença da Igreja Católica em São Paulo", de Ney de Souza, nos serviu como importante fonte de pesquisa acerca da atuação da Igreja na cidade de São Paulo, trazendo textos relativos à cristandade colonial, minuciosos perfis dos membros do clero atuantes e ricas exposições a respeito do funcionamento da Igreja na cidade ao longo dos anos. 


\section{CAPÍTULO 1: O CONCEITO DE BENS CULTURAIS DA IGREJA CATÓLICA E SUA MUSEALIZAÇÃO}

A Igreja Católica sempre buscou preservar seus bens culturais por compreender, desde tempos antigos, a importância de seu patrimônio históricocultural na missão de catequizar e registrar sua história como testemunho da humanidade.

Como meios de proteção e preservação, a Igreja desenvolveu mecanismos dentro de sua legislação eclesiástica ao longo dos anos, por meio de bulas, constituições e cartas circulares que buscavam aproximar o clero às práticas de preservação necessárias.

\subsection{Os papados e o desenvolvimento da salvaguarda dos bens culturais}

O Papa Gregório Magno (540-604) foi um dos primeiros a reconhecer o valor da arte sacra como instrumento do ensinamento cristão, argumentando que as imagens auxiliavam tanto na fixação das histórias narradas nas Escrituras quanto no poder de suscitar nos fiéis o sentimento de arrependimento e ao mesmo tempo adoração (CARTA CIRCULAR, 2017, p. 17).

Houve também desde muito cedo uma preocupação especial com a alienação e doação dos bens culturais, surgindo inúmeras normas que discutiam as penas a serem aplicadas àqueles que cometessem tais infrações sem a devida autorização. O Papa Leão I (400-461) em sua Magnum Bullarium Romanum de 447 proíbe todos os clérigos, "sob pena de excomunhão e até mesmo de laicização, de dar de presente, trocar ou vender os bens preciosos das Igrejas, sem motivo grave e sem o consentimento de todo o clero". (CARTA CIRCULAR, 2017, p. 18).

Os Concílios Ecumênicos também tiveram importante papel na construção de regras a respeito da guarda e preservação dos bens culturais. $O$ Concílio de Niceia II, em 787, declarou lícita a iconografia cristã, tendo em vista sua finalidade de veneração a pessoa ou acontecimento ali representado, e não a simples adoração do ícone em si (CAMPOS, 2015, p. 11). 
O Concílio de Constantinopla IV (869-870) e o II Concílio de Lion (1274) seguiram os ditames acerca da proibição da alienação dos bens sacros, indicando as penas de suspensão e até excomunhão para os infratores, fossem estes membros do clero ou leigos (CARTA CIRCULAR, 2017 p. 19). O Concílio de Trento (1545-1563) reafirmou o papel devocional da imagem religiosa a partir do peso dos dogmas e doutrinas da Igreja (CAMPOS, 2015, p. 41).

Ao longo dos séculos, o Magistério Papal foi incluindo em suas normas indicações de responsáveis pela salvaguarda e conservação de seu patrimônio. Após o Cisma religioso, quando por questões políticas o papado foi transferido para Avignon, retornando apenas em 1414, a cidade de Roma passou por grandes transformações urbanas e artísticas, iniciadas pelo papa Martinho $\mathrm{V}$ (1417-1431).

Sob o papado de Sisto IV (1471-1484) Roma torna-se um centro de arte e aprendizagem, com a abertura da biblioteca do Vaticano ao público, a reforma de diversas igrejas, e outros projetos urbanísticos (SOUZA, 2006, p. 17).

Já no pontificado de Júlio ॥ (1503-1512) foi colocada a pedra fundamental da nova Basílica de São Pedro. Neste período, o papado pode contar com os trabalhos de grandes arquitetos e artistas como Bramante, Rafael e Michelangelo, que pintou o teto da Capela Sistina a pedido do Sumo Pontífice.

Com relação ao pintor Rafael Sanzio (1483-1520) este é nomeado "Prefeito das Antiguidades de Roma" pelo Papa Leão X (1478-1521), um ano após ser nomeado Arquiteto chefe da construção da Basílica de São Pedro (SOUZA, 2006, p. 160).

O trabalho do artista de Urbino consistiria em selecionar os mármores dos antigos monumentos romanos para serem utilizados na construção da Basílica, com o cuidado de não os destruir por completo, isso porque, durante todo 0 Quattrocento, os monumentos eram utilizados como pedreiras para as novas construções encomendadas pelos papas (CHOAY, 2017, p. 56).

A partir desta incumbência, Rafael iniciaria um completo levantamento das construções antigas e das ruínas da cidade, uma das ações implementadas pelo papa Leão X, que tinha como objetivo instituir "um conjunto de procedimentos visando a preservação das construções da Antiguidade" a fim de tornar Roma um "centro de excelência das artes e da cultura, quer da cristandade, quer do poder político" (SOUZA, 2006, p. 18-19). 
A valorização das Antiguidades é uma constante durante o Quattrocento, como necessidade de legitimar o poder papal, uma vez que "o Renascimento arquitetônico italiano é fruto do encontro entre arquitetos que recuperam os clássicos e príncipes que precisam dos clássicos para dar legitimidade às suas figuras" (FANTONI apud SOUZA, 2006, p.17).

Françoise Choay, em seu livro Alegoria do Patrimônio, enumera algumas das medidas tomadas de proteção dos monumentos antigos:

"Os papas não se contentam com medidas preventivas. Eles retiram o entulho, desobstruem, restauram as antiguidades. Martinho V restabelece a função de Magister viarum [administrador das vias públicas]. Eugênio IV recupera o telhado do Panteão e limpa seus arredores. Nicolau V (1447-1455) encarrega Alberti de fazer um levantamento topográfico de Roma (...). Alberti recebe também a tarefa de conservar e colocar em destaque os grandes monumentos da Antiguidade" (CHOAY, 2017, p. 55).

CHOAY ainda comenta que essas ações têm um caráter ambíguo, entre medidas ditadas pela conveniência ou ainda como forma de afirmar uma identidade por meio de um interesse histórico:

\begin{abstract}
"Duas memórias são solicitadas ao mesmo tempo por duas séries de monumentos: uma, mais próxima, de uma instauração religiosa que estrutura a vida cotidiana e define seu horizonte; outra, mais distante, de um passado temporal e glorioso. São essas duas memórias entrelaçadas que evocam conjuntamente São Pedro e - Coliseu, São João de Latrão e a coluna de Marco Aurélio (...)" (CHOAY, 2017, p. 43).
\end{abstract}

Em 1820, o Camerlengo Cardeal Pacca decreta a necessidade de se inventariar todos os bens eclesiásticos do Estado Pontifício 5 :

\footnotetext{
${ }^{5}$ O Estado Pontifício era formado por extensos territórios, basicamente no centro da península Itálica, conquistados pela Igreja por meio de doações de Imperadores e fiéis, sob a autoridade dos Papas. Conhecidos como "Patrimônio de São Pedro", se mantiveram como um estado independente entre os anos de 756 e 1870, até os movimentos revolucionários para a Unificação da Itália. CARLETTI, Anna. Ascensão e queda dos Estados Pontifícios. Disponível em: <http://www6.ufrgs.br/nerint/folder/artigos/artigo1082.pdf>. Acesso em: 28/04/2019.
} 
"Qualquer Superior, Administrador e Reitor, ou que tenha contudo a direção de Estabelecimentos públicos e Locais, tanto Eclesiásticos, que Seculares, compreendidas Igrejas, Oratórios e Conventos, onde se conservam coleções de Estátuas e de Pinturas, Museus de Antiguidades sagradas e profanas, e também um ou mais Objetos preciosos de belas artes de Roma ou no Estado, nenhuma pessoa excetuada, embora privilegiada e privilegiadíssima, deverão apresentar uma exatíssima e distinta Nota dos Artigos acima expressos em duplicata assinada, com distinção de cada peça" (MONOZZI, D. apud CARTA CIRCULAR, p. 20) .

O ultramontanismo, movimento da Igreja Católica em reação às novas tendências sociais e políticas pós Revolução Francesa e Revolução Industrial britânica, trouxe para a segunda metade do século XIX um posicionamento mais conservador por parte da Igreja. Segundo o historiador Ítalo Domingos Santirocchi, o ultramontanismo pode ser resumido nos seguintes pontos:

“(...) o fortalecimento da autoridade pontifícia sobre as igrejas locais; a reafirmação da escolástica; o restabelecimento da Companhia de Jesus (1814); a definição dos "perigos" que assolavam a Igreja (galicanismo, jansenismo, regalismo, todos os tipos de liberalismo, protestantismo, maçonaria, deísmo, racionalismo, socialismo, casamento civil, liberdade de imprensa e outras mais) (...)" (SANTIROCCHI, 2010, p. 24).

Como resposta à valorização do profano em detrimento do sagrado (MEDEIROS, 2013, p. 4), relembrando que é desta época a frase de Karl Marx "a religião é o ópio do povo", o papa Pio IX (1792-1878) realizou o Concílio Vaticano I (1869-1870) para resistir às transformações políticas da época e reforçar a autoridade papal.

\footnotetext{
${ }^{6}$ Todas as citações desta pesquisa tiveram suas grafias atualizadas para maior compreensão durante leitura.

${ }^{7}$ A célebre frase aparece no artigo Introdução à crítica da filosofia do direito de Hegel, de 1844: "A angústia religiosa é, ao mesmo tempo, a expressão da verdadeira angústia e o protesto contra esta verdadeira angústia. A religião é o suspiro da criatura oprimida, o coração de um mundo sem coração, assim como é o espírito de uma situação sem espiritualidade. É o ópio do povo." Segundo Löwy, Marx escreve esta crítica quando "(...) ainda era um discípulo de Feuerbach, um neo-hegeliano. Sua análise da religião, portanto, era "pré-marxista", sem referência às classes sociais e um tanto a histórica - não menos dialética, contudo, pois apreendia o caráter contraditório da "angústia" religiosa: às vezes, legitimação da sociedade existente, às vezes protesto contra tal sociedade" (LÖWY, Michael. Marx e Engels como sociólogos da religião. Lua Nova, São Paulo, n. 43, p. 157-170, 1998. Disponível em: $<$ http://www.scielo.br/scielo.php?script=sci_arttext\&pid=S010264451998000100009\&lng=en\&nrm=iso >. Acesso em: 03/02/2020.
} 
O processo de restauração da doutrina católica culminou na publicação do Código de Direito Canônico (Codex luris Canonici - CIC) em 1917, que sintetiza as coleções de leis então existentes em uma única lei geral. Promulgado por Bento XV, é composto de cinco livros: I Normas gerais, II das pessoas, III das coisas, IV dos processos e $\mathrm{V}$ dos delitos e das penas, com um total de 2.414 cânones.

Apesar de não contemplar o termo "bem cultural", o CIC de 1917 estabelece algumas premissas relacionadas à preservação do patrimônio eclesiástico, como a inventariação dos bens (cân.1522) e um esboço sobre do que se trata este patrimônio, chamados de bens temporais, ao indicar que "têm notável valor em virtude da arte, da história ou de matéria" (cân. 1497).

O Papa João XXIII, com o objetivo de modernizar a Igreja perante novas questões presentes na sociedade moderna, inicia o Concílio Vaticano II (19621965). Dentre os documentos publicados durante o Concílio Vaticano II, a Constituição Conciliar Sacrosanctum Concilium, que orienta sobre a sagrada liturgia, indica como incremento à pastoral litúrgica a necessidade de se criar comissões de liturgia, música sacra e arte sacra ${ }^{8}$.

No capítulo VII, intitulado "A arte sacra e as alfaias litúrgicas", expõe a concepção de arte por parte da Igreja ao afirmar que a "santa mãe Igreja amou sempre as belas artes, formou artistas e nunca deixou de procurar o contributo delas, procurando que os objetos atinentes ao culto fossem dignos, decorosos e belos, verdadeiros sinais e símbolos do sobrenatural"'.

Outro importante documento, publicado 18 anos após o término do Concílio Vaticano II, foi a revisão das leis eclesiásticas reunidas em uma nova edição do Código de Direito Canônico, em 25 de janeiro de 1983.

Ainda que retificasse diversos pontos fundamentais da doutrina, as questões relativas aos bens culturais da Igreja permaneceram muito semelhantes aos encontrados no CIC de 1917, com alguns acréscimos como os cânones relativos à necessidade prévia de autorização do Ordinário para restauro de imagens (cân. 1189); os cuidados de manutenção e segurança para

\footnotetext{
${ }^{8}$ Art. 46. Concílio Vaticano II, Constituição Conciliar Sacrosanctum Concilium sobre a Sagrada Liturgia, 04 de dezembro de 1963. Disponível em: <http://www.vatican.va/archive/hist_councils/ii_vatican_council/documents/vatii_const_19631204_sacrosanctum-concilium_po.html>. Acesso em: 24/02/2020. ${ }_{9}$ Art. 122. Ibid.
} 
a salvaguarda dos "bens sagrados e preciosos que nelas [nas igrejas] se encontrem" (cân. 1220); à definição de propriedade dos bens temporais como bens eclesiásticos da Igreja (cân. 1257); à inventariação do patrimônio; e à alienação de bens (cân. 1292).

Um passo importante com relação à preservação dos bens culturais da Igreja é dado a partir da Constituição Pastor Bonus, sobre a Cúria Romana, promulgada em 1988 pelo Papa João Paulo II, que institui a Comissão Pontifícia para a Conservação do Património Artístico e Histórico. Dentre seus artigos, estabelece a sua função de tutelar o patrimônio histórico e artístico de toda a Igreja, definindo-o como "todas as obras de qualquer arte do passado, que deverão ser guardadas e conservadas com a máxima diligência"10.

Interessante observar, ainda no artigo citado acima, que há a menção de se preservar as peças, cujo uso tenha sido suspenso, sendo "expostas nos museus da Igreja ou noutros lugares". A indicação de museu como local de guarda e exposição aponta o importante papel deste tipo de instituição para a Igreja e preservação de seus bens.

Em 1993, o Papa João Paulo II substitui esta comissão pela Comissão Pontifícia para os Bens Culturais da Igreja, por meio do Motu Proprio Inde a Pontificatus Nostri initio. Essa nova comissão, agora um órgão independente com seu próprio presidente, manteve os objetivos da comissão anterior, em:

“(...) presidir a proteção do patrimônio histórico e artístico de toda a Igreja (obras de arte, documentos históricos, patrimônio dos livreiros e aqueles que são preservados em museus, bibliotecas e arquivos); colaborar na conservação deste patrimônio com as Igrejas particulares e as respectivas organizações episcopais; promover uma crescente conscientização na Igreja sobre esses bens, de acordo com as Congregações para a Educação Católica e para o Culto Divino e a Disciplina dos Sacramentos"11.

\footnotetext{
${ }^{10}$ Art. 100. http://w2.vatican.va/content/john-paul-ii/pt/apost_constitutions/documents/hf_jpii_apc_19880628_pastor-bonus.html

${ }^{11}$ PONTIIFICIA COMISIÓN PARA LOS BIENES CULTURALES DE LA IGLESIA http://www.vatican.va/roman_curia/pontifical_commissions/pcchc/documents/rc_com_pcchc_pr o_20051996_sp.html Tradução nossa.
} 
Desde a sua reformulação, a Comissão Pontifícia para os Bens Culturais da Igreja vem publicando documentos de referência a fim de auxiliar as instituições religiosas na preservação de seu patrimônio, como $A$ formação dos futuros presbíteros à atenção para com os bens culturais da lgreja (1992); Os bens culturais dos institutos religiosos (1994); As bibliotecas eclesiásticas na missão da lgreja (1994); A função pastoral dos arquivos eclesiásticos (1997); Necessidade e urgência da inventariação e catalogação dos bens culturais da Igreja (1999) e A função pastoral dos museus eclesiásticos (2001).

\subsection{Regulamentações no Brasil}

No Brasil, até o século XVIII, a Igreja Católica era regida pelas diretrizes instauradas após o Concílio de Trento por meio do Código Canônico e também pelas Constituições portuguesas, devido ao regime de padroado, privilégios espirituais concedidos pelo Papa à Coroa Portuguesa.

O padroado pode ser entendido como a união do altar e do trono, pois representa a concessão dada pelo papado à Coroa Portuguesa de administrar os assuntos religiosos em suas colônias, que depois se estendeu aos Imperadores brasileiros (SOUZA, 2004, p. 23).

$\mathrm{Na}$ prática, significou a subordinação das necessidades da Igreja aos interesses da Coroa; o poder espiritual nas terras conquistadas a partir dos preceitos portugueses.

"O rei concentrava em suas mãos a jurisdição espiritual e eclesiástica, responsabilizando-se pela administração dos bens, rendimentos, edificações e reparações nos templos em geral, bem como do provimento dos objetos necessários para o culto, sustento de seus ministros, indicação dos reverendos vigários e apresentação dos bispos titulares das dioceses" (CAMPOS, 2015, p. 32). 
Para uma administração política e religiosa eficiente, o governo português instituiu dois instrumentos auxiliares: a Mesa de Consciência e Ordens ${ }^{12}$ e 0 Conselho Ultramarino ${ }^{13}$ (SOUZA, 2004, p. 26).

A primeira diocese brasileira e uma das primeiras da América foi a de São Salvador da Bahia em 155114, estabelecida pelo Papa Júlio III (1487-1555), sendo elevada a arquidiocese em 1676 pelo Papa Inocêncio XI (1611-1689).

Em 1707, D. Sebastião Monteiro da Vide (1643-1722), quinto arcebispo da Bahia, promulga as Constituições Primeiras do Arcebispado da Bahia, conjunto de legislações canônicas adaptadas à realidade local baiana, trabalho inédito à época.

Dom Vide apresenta as Constituições Primeiras durante o primeiro e único sínodo diocesano organizado na América Portuguesa (Constituições Primeiras, 2010, p.52), que tinha como objetivo a organização eclesiástica na colônia brasileira.

Segundo Bruno Feitler e Evergton Sales Souza, no estudo introdutório que acompanha a recente edição, de 2010, das Constituições Primeiras,

"As constituições diocesanas são um instrumento jurídicopastoral, formado pelo conjunto de leis, decretos e disposições episcopais, e por vezes também de bulas e breves papais e leis régias, que regulavam a vida litúrgica, doutrinal e disciplinar de uma diocese, fundadas no direito canônico, na tradição da Igreja e em práticas consuetudinárias locais" (FEITLER e SOUZA, 2010, p. 54).

Esta obra, considerada como um dos mais importantes documentos acerca dos regramentos religiosos nas colônias, tem fundamental importância para compreender o sistema eclesiástico na história colonial brasileira.

\footnotetext{
12 Responsável pela administração espiritual das colônias; "instrumento do poder real para assuntos relativos ao padroado, em virtude da concessão espiritual de todos os territórios ultramarinos à Ordem de Cristo e da incorporação do mestrado dela à Coroa" (SOUZA, 2004, p. 28).

${ }^{13}$ Os Reis de Portugal administravam as colônias por meio do Conselho Ultramarino, órgão consultivo no além-mar.

${ }^{14}$ Ao longo do período colonial foram fundadas sete dioceses pelo território brasileiro, que foram fracionadas nos séculos seguintes: Bahia (1551), Pernambuco (1676), Rio de Janeiro (1676), Maranhão (1677), Pará (1719), Mariana (1745) e São Paulo (1745) (CAMPOS, p. 35).
} 
Além disso, o poder de alcance das Constituições Primeiras perpassa a do prelado baiano chegando a todas as dioceses luso-americanas, por sintetizar as leis eclesiásticas a partir dos preceitos tridentinos, adaptadas à realidade das colônias (Constituições Primeiras, 2010, p. 53). Para se entender a magnitude da obra, deve-se pensar que até o Império, elas permaneceram inalteradas, pois só havia um arcebispado metropolitano no Brasil (CASIMIRO, 2010, p. 8).

Ainda que promulgada durante o Sínodo Diocesano de 1707, a primeira edição só foi publicada em 1719 em Lisboa (Constituições Primeiras, 2010, p. 55-56). Houve outras quatro edições; uma em 1719 em Coimbra, outra publicada em 1765 em Lisboa, uma nova edição em 1853, organizada pelo cônego da Sé de São Paulo Dr. Ildefonso Xavier Ferreira, com atualizações a respeito da catequese dos índios e "uma última edição das Constituições [que] teria sido impressa em 1870 por um comitê preparatório do Concílio I Vaticano" (Oscar Oliveira citado por FEITLER e SOUZA, 2010, p. 56).

Desta importante obra nos interessa o Livro IV, que traz uma perspectiva preservacionista acerca dos bens culturais da Igreja. Segundo a historiadora Ana Palmira Bittencourt Santos Casimiro,

\begin{abstract}
"O Livro Quarto fala das imunidades eclesiásticas, da preservação do patrimônio da Igreja, das isenções, privilégios e punições dos clérigos, do poder eclesiástico, dos ornamentos e bens móveis das igrejas, da reverência devida e da profanação de lugares sagrados, da imunidade aos acoutados, dos testamentos e legados dos clérigos, dos enterros e das sepulturas, dos ofícios pelos defuntos (...)" (CASIMIRO, 2010, p. 8).
\end{abstract}

Outra importante publicação brasileira foram as Constituições Diocesanas das Províncias Meridionais do Brasil, de 1915, título dado ao documento da Pastoral Coletiva dos Arcebispos e Bispos das Províncias Meridionais, que reuniu os prelados das províncias da região para a discussão acerca das resoluções das Conferências Episcopais realizadas em 1901, 1904, 1907 e 1911 (BENCOSTTA, 2000, p. 89).

As Constituições Eclesiásticas, como ficaram conhecidas, substituíram em parte as Constituições Primeiras da Bahia por apresentarem soluções aos principais problemas enfrentados pelos bispos e arcebispos, sempre sob a ótica tridentina, levando em conta também os apontamentos propostos nas 
publicações resultantes do Concílio Plenário da América Latina, convocado pelo Papa Leão XIII em 1899-1900 (BERTO, 2018, p. 78).

Conforme aponta João Paulo Berto (2018), com relação à preservação dos bens culturais da Igreja, a Carta Pastoral Coletiva apresenta, em seu Capítulo XIV (Igrejas e Oratórios), Título III (Culto), a centralidade das decisões nas mãos dos epíscopos:

"Sem audiência Nossa e licença por escrito é proibido aos
Párocos e mais Reitores de igrejas e capelas, mudar a invocação
de igrejas ou altares, deslocar ou substituir imagens,
principalmente antigas e de valor artístico; pintar ou substituir
altares artísticos; inutilizar ou modificar paramentos antigos e
tradicionais, modificar, reformar ou alterar quaisquer vasos,
alfaias ou objetos de arte, e, em geral, tudo aquilo que, por
antiguidade ou tradição, se deve conservar" (CPC apud BERTO,
2018, p. 79).

Mesmo com a publicação do Código de Direito Canônico em 1917 e sua revisão em 1983, é possível afirmar que a questão da preservação dos bens culturais da Igreja no Brasil foi levantada pela Igreja Católica brasileira apenas pontualmente a partir de reflexões em algumas regiões episcopais, como a Carta Pastoral do Episcopado Mineiro ao clero e aos fiéis de suas dioceses sobre o patrimônio artístico, publicada em 1926 (BERTO, 2016, p. 7).

Do ponto de vista da preservação dos bens eclesiásticos como bens culturais nacionais a serem preservados, podemos comentar a atuação do Instituto do Patrimônio Histórico Artístico Nacional (IPHAN).

Segundo Bruna Mallorga, em sua pesquisa a respeito do tombamento de bens católicos pelo IPHAN no Estado de São Paulo (2019), os 33 de 35 processos a que a autora teve acesso, se encaixam nas seguintes situações: "dezessete tombados; cinco indeferidos; um bem cancelado; um bem rerratificado, seis bens que tiveram seus processos anexados a outros processos de tombamento; e quatro processos que estão na fase de instrução" (p. 58-59), com as observações de alguns terem, ao longo dos anos, mudado de status, além da inclusão de mais de um bem no mesmo processo. 
Dos processos por ela analisados, a grande maioria foi aberta entre as décadas de 1930 e 1940, podendo-se destacar a atuação de Mário de Andrade no levantamento desses bens - sendo que o autor deixava claro que os bens paulistas deveriam ser analisados a partir de suas perspectivas históricas em detrimento dos aspectos estéticos.

MALLORGA também aponta que a decisão de tombar esses bens, via de regra, já estava tomada antes mesmo da abertura dos trâmites administrativos (p. 70-73), sendo processos enxutos, abertos já com a notificação enviada ao proprietário, que continha apenas informações legais sobre o tombamento, não explicando, necessariamente, os motivos para tal ação.

Interessante ressaltar que nas primeiras décadas do Instituto houve a participação de diversos membros da Igreja Católica na implementação e consolidação do IPHAN, com destaque para Dom Clemente Maria da SilvaNigra, que por quase 40 anos prestou serviços ao IPHAN, escrevendo cinco artigos para a Revista do Patrimônio, além de atuar como perito e pesquisador sobre arquitetura, pintura e esculturas sacras e responsável pela implementação do Arquivo Geral do IPHAN (MALLORGA, 2019, p. 47).

Sobre a relação entre a Igreja Católica e o IPHAN:

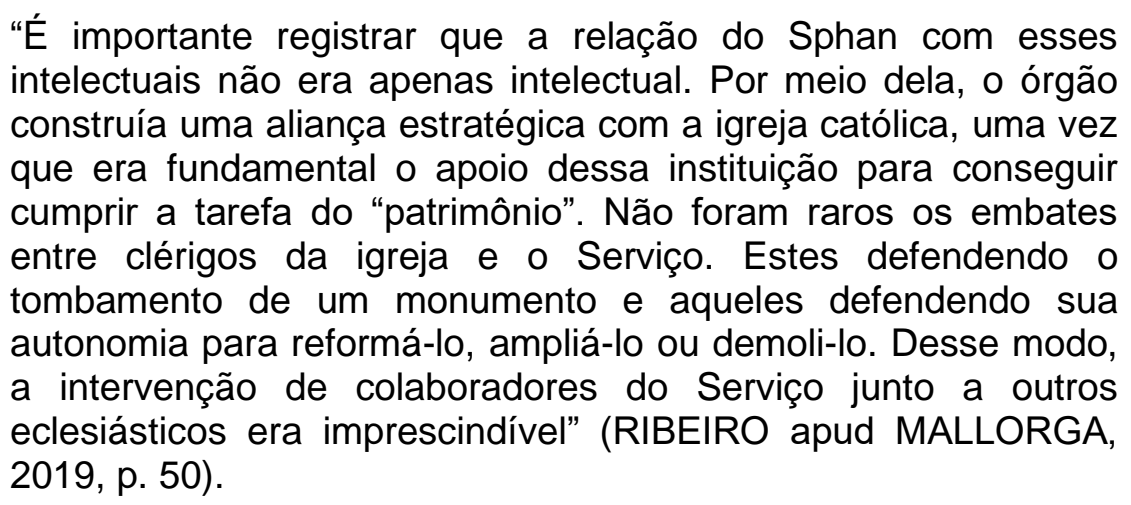

Na década de 1950 havia na Cúria Metropolitana de São Paulo uma Comissão Arquidiocesana de Arte Sacra (CAAS), presidida pelo bispo-auxiliar Dom Paulo Rolim Loureiro, tendo como conselheiros Mons. João Pavesio, Mons. Vicente Zioni, Pe. João Kulay (diretor do Arquivo e do Museu) e o engenheiro Benedito Calixto de Jesus Neto (neto do pintor Benedito Calixto). 
De acordo com suas atribuições, a Comissão era responsável por "tudo o que se refere à arte sacra. Estudo de plantas novas, igrejas e capelas, mobiliário, imagens e decoração das mesmas"15 (Anuário Eclesiástico, 1954, p. 19).

Segundo Paulo Berto, a partir da década de 1960 o patrimônio sacro sofreu diversas perdas - ainda que já houvesse normas estabelecidas para sua salvaguarda -, de igrejas, conjuntos de retábulos e imaginárias dos séculos XVIII e XIX que foram ou destruídos ou dispersos (BERTO, 2016, p. 8).

Esta perda do passado religioso brasileiro levou a Conferência Nacional dos Bispos do Brasil (CNBB), órgão máximo da Igreja Católica no país, a publicar em 1971 o Documento-base sobre a Arte Sacra, onde "apresentou elementos acerca da preservação, conservação e restauração dos bens históricos e artísticos, incidindo sobre a arquitetura, a pintura, a escultura, o mobiliário e as artes decorativas, além dos acervos das bibliotecas e dos arquivos eclesiásticos" (BERTO, 2016, p. 8).

Ainda que essa publicação não apresente normas específicas e nem definições quanto aos procedimentos de conservação, é considerado um importante instrumento que possibilitou o início de um diálogo entre o clero e especialistas, resultando em diversos encontros, seminários e desenvolvimento de comissões diocesanas.

Também serviu para reafirmar a importância dos museus eclesiásticos para a preservação dos bens da Igreja, principalmente aqueles que não se encontram mais em uso e seguem guardados indevidamente, ao recomendar a criação de "museus paroquiais, diocesanos e interdiocesanos para evitar a deterioração tão frequente dos depósitos"16.

Entretanto, foi apenas em 2017 que a CNBB criou sua Comissão Episcopal Especial para os Bens Culturais a fim de auxiliar as comissões de bens culturais existentes entre as regionais. Apesar de sua importância como ponto central das discussões e ações acerca da salvaguarda do patrimônio histórico, artístico e cultural da Igreja, com a organização de seminários e publicações de cartas circulares, a Comissão foi reorganizada, transformada em 2019 em um setor dentro da Comissão Episcopal Pastoral para a Cultura e Educação.

\footnotetext{
${ }^{15}$ Durante a pesquisa não foram encontradas outras informações a respeito desta Comissão de Arte Sacra.

${ }^{16}$ CNBB. Documento-base para a Arte Sacra. Comunicado Mensal n. 227, 1971, p.137.
} 
Outro documento relevante às questões do patrimônio eclesiástico é o Acordo Brasil-Santa Sé relativo ao Estatuto Jurídico da Igreja Católica no Brasil, assinado em 13 de novembro de 2008 após seis anos de tratativas entre os Ministérios das Relações Exteriores do Brasil e do Vaticano, inserindo-se entre os tantos tratados bilaterais celebrados pelo Estado do Vaticano com diversos países a fim de legitimar relações históricas e estabelecer responsabilidades mútuas.

Promulgado pelo Decreto № 7.107, de 11 de fevereiro de 2010, o Acordo compreende 20 artigos que buscam "reagrupar normas existentes na legislação brasileira e canônica, incluindo alguns elementos novos oportunos ou de práxis e jurisprudências consolidadas" (BELDISSERI, 2011, p. 7). Os artigos 6ㅇ e $7^{\circ}$ indicam o reconhecimento do patrimônio da Igreja como parte relevante do patrimônio cultural brasileiro, estabelecendo a cooperação na sua salvaguarda, valorização e promoção contra violação, desrespeito e uso ilegítimo, além de facilitar seu acesso a todos ${ }^{17}$.

Importante ressaltar que, ainda que o Acordo estabeleça que a Igreja e o Estado Brasileiro são autônomos e soberanos, e que caiba ao Estado zelar pelos bens da Igreja por meio de sua legislação, a função religiosa dos bens sempre prevalecerá sobre a cultural (BELDISSERI, 2011, p. 24). Cabe lembrar que a legislação brasileira subordina o restauro de bens tombados à autorização prévia do Instituto do Patrimônio Histórico e Artístico Nacional (IPHAN), que aponta no art. 25 de seu regimento, de 1937, que "procurará entendimentos com as autoridades eclesiásticas, instituições científicas, históricas ou artísticas e pessoas naturais ou jurídicas, com o objetivo de obter a cooperação das mesmas em benefício do patrimônio histórico e artístico nacional”"18.

\footnotetext{
${ }_{17}$ Acordo entre a República Federativa do Brasil e a Santa Sé Relativo ao Estatuto Jurídico da Igreja Católica no Brasil. 11 de fevereiro de 2010. Disponível em: <http://www.planalto.gov.br/ccivil_03/_ato2007-2010/2010/decreto/d7107.htm>. Acesso em: 24/02/2020.

18 IPHAN. Decreto-Lei №25, de 30 de novembro de 1937. Disponível em: < http://portal.iphan.gov.br/uploads/legislacao/Decreto_no_25_de_30_de_novembro_de_1937.pd $f>$. Acesso em 24/02/2020.
} 
Apresentado o contexto geral que esclarece sobre a gestão de bens culturais pela Igreja Católica ao longo do tempo e especificamente no Brasil, cumpre assinalar que a iniciativa de que trataremos e seus respectivos desdobramentos, enquadra-se no período de 1907 a 1969, no qual vigoraram as seguintes legislações ou documentos contendo princípios e recomendação em vigência na Igreja Católica e no Brasil:

- Constituições Primeiras do Arcebispado da Bahia, de 1707

- Constituições Diocesanas das Províncias Meridionais do Brasil, de 1915

- Código de Direito Canônico, de 1917

- Estatuto de criação do Instituto do Patrimônio Histórico e Artístico Nacional (IPHAN), de 1937

\subsection{A musealização de objetos sagrados e religiosos}

O museu desempenha múltiplos papéis em nossa sociedade, sendo principalmente entendido como instituição que preserva as memórias coletivas tangíveis e intangíveis do Homem em seu meio.

A Igreja Católica sempre foi uma grande colecionadora. Durante a Idade Média, os mosteiros e as igrejas eram locais repletos de objetos e relíquias, itens doados às igrejas em função das pregações, manuscritos iluminados, aparatos litúrgicos em metais e em pedras preciosas (LEWIS, 2004, p. 1).

As relíquias ${ }^{19}$ ganhavam uma conotação a mais, sendo vistas como objetos de orgulho e status político e social. Sua existência nos tesouros eclesiásticos "acrescentava-Ihes o valor simbólico que Ihes advinha da relação que os objetos estabeleciam com o universo mítico dos santos protetores" (ROQUE, 2011, p. 22), unindo o temporal com o divino.

Neste sentido, CYMBALISTA sublinha a força poderosa conferida às relíquias pela fé:

\footnotetext{
19 As relíquias sagradas, entendidas como artefatos divinos, podem ser classificadas em três graus de importância: $1^{\circ}$ graus, e mais importante, são os restos físicos de mártires e santos (ossos, cabelos, unhas, sangue, etc.), $2^{\circ}$ grau são os instrumentos de martírio (cruzes, pregos, lanças, setas, correntes, etc.) e $3^{\circ}$ grau as relíquias de contato (roupas e tecidos que estiveram em contato com os restos mortais, terra de sepulturas, etc.) (CYMBALISTA, 2006, p. 133).
} 
"O poder das relíquias não se resumia a uma expectativa de futuro, pois durante toda a Idade Média estiveram cercadas de acontecimentos maravilhosos: tinham poderes de proteção e cura, que justificavam romarias e peregrinações, emitiam perfumes, luzes e óleos milagrosos, ressuscitavam mortos, protegiam cidades inteiras. (...) As relíquias eram também símbolo de riqueza, de prosperidade e de nobreza, e, no Ocidente, acompanharam, através dos séculos, os detentores das maiores fortunas e de prestígio" (CYMBALISTA, 2006, p. 133-134).

Com as grandes navegações dos séculos XV e XVI, os gabinetes de maravilhas foram incorporando outros objetos além das artes e relíquias; animais exóticos, plantas, tecidos e cerâmicas, itens curiosos nunca vistos.

"O oriente continua por todo o período medieval uma fonte de maravilhas e dali vêm os primeiros objetos exóticos e numerosos crocodilos que têm lugar de destaque entre os materiais naturalizados das igrejas" (LUGLI, 1983, p. 20. Tradução nossa).

Para explicar o surgimento destes objetos fantásticos nos templos, a Igreja precisou recorrer às Sagradas Escrituras, que descrevem os seres "monstruosos" e justificam sua presença. Segundo Adalgisa Lugli, Santo Agostinho buscava conciliar os objetos monstruosos ou anômalos colecionados pela Igreja com a ideia da criação perfeita, posto que tudo no mundo é surpreendente, sem insinuar dúvidas sobre a possibilidade de um erro divino (LUGLI, 1983, p. 20).

Assim, os objetos extraordinários trazidos pelos viajantes das peregrinações eram doados à Igreja, que tinha como missão codificar essas curiosidades por meio das mensagens divinas:

“(...) preservar o signo divino e, ao mesmo tempo, exorcizar todos os seus valores inquietantes e inexplicáveis, trazendo-os de volta ao contexto familiar do santuário, da catedral e da cidade. Enquanto espera decifrar as alegorias morais escondidas em fenômenos naturais, a comunidade medieval pode ser apreciada ao redor da igreja ou de outros edifícios públicos, como prédios municipais" (LUGLI, 1983, p. 21. Tradução nossa).

O sagrado é visto como algo que transcende o Homem, divino, mas "que se manifesta neste mundo, e por este fato, o santifica e o torna real" (ROQUE, 2011, p. 11). 
Essa percepção também é analisada por Rita Capurro:

"Na Igreja Cristã Romana, o uso da palavra sagrado está relacionado com lugares ou coisas que conectam a vida na terra com a dimensão de Deus; santos, relíquias e coisas consagradas são sagradas. Em particular, para o último, a condição de sagrado está ligada ao seu uso: das igrejas aos vasos sagrados, todos esses elementos são criados com características e significados específicos e eles cumprem sua condição de santidade quando são usados na liturgia" (CAPURRO, 2018, p. 49. Tradução nossa).

Esses objetos carregados de simbologia transcendental compunham os tesouros eclesiásticos que, segundo Maria Isabel Roque, “(...) ao desempenhar as funções de aquisição, coleção, exposição, e fruição de objetos preciosos e raros, cumpriam, ainda que de forma embrionária, o estatuto que hoje atribuímos ao museu" (ROQUE, 2011, p. 23).

A mistura do sagrado e profano nos tesouros da Igreja e do Estado elevam o status dos objetos para além de seus valores simbólicos, uma apreciação estética. Conforme comenta Maria Isabel Roque, esse novo olhar estético dado aos objetos religiosos permite a isenção da interpretação de suas simbologias litúrgicas pois estes passam a ser vistos como um agente da memória ao serem transferidos para um "universo civil e profano" (ROQUE, 2011, p. 12), tendo como catalizador os museus.

Ao se pensar nas primeiras coleções eclesiásticas, estas foram fundamentais como iniciativas de preservação e exposição museográfica:

"A apresentação do objeto litúrgico ou devocional como documento do culto é tardia no contexto da história da museologia de iniciativa civil, mas foi determinante ao longo da evolução dos tesouros eclesiásticos. Sem descurarem a antiga funcionalidade devocional, os tesouros começaram, desde finais do século XIX, a aplicar normas de conservação, segurança e exposição museográficas, que podem ser paralelamente definidos como museus de religião" (ROQUE, 2011, p. 13).

Rita Capurro argumenta que a religião em museus pode se apresentar de diversas formas, entre elas como: 
Museu religioso: Museus com referência particular à religião, incluindo museus eclesiásticos, ou aqueles que por meio de coleções, missão, escolha da narrativa, referem-se à religião.

Museu das religiões: Museu com o objetivo de apresentar várias religiões do mundo.

Museu de arte sacra: Ocupado principalmente com coleções de arte sacra ou com objetos referentes a um culto.

Museu Eclesiástico: Museu dirigido e de propriedade de uma entidade eclesiástica, com coleções que vão desde arte sacra a coleções científicas.

Museu confessional: Instituição que expressa um grupo ou uma confissão religiosa. Narrativas auto representativas que refletem os ideais e ideologias das confissões atuais (CAPURRO, 2013 apud STRÖM, 2018, p. 224. Tradução nossa)

No caso do Museu da Cúria, podemos dizer que se trata de um museu eclesiástico, pois é administrado pelo clero, e abriga tanto objetos litúrgicos quando objetos de arte sacra e objetos considerados de relevância histórica essa última definição, conforme entendida por Meneses (1994, p. 18) como de ordem ideológica, caracterizados "quaisquer que sejam seus atributos intrínsecos, por sentido prévio e imutável que o impregna, derivado, não desses atributos, mas de contaminação externa com alguma realidade transcendental".

Além disso, podemos identificá-lo com a ideia de "museu relicário", no sentido de um lugar para guarda de objetos preciosos de sentido religioso, tema do qual trataremos adiante, no Capítulo 3.4.

O museu eclesiástico, segundo ROQUE (2011, p. 245), reivindica seu papel de repositório da história do cristianismo no território em que se insere, a partir de uma perspectiva doutrinal, considerando esta abordagem imprescindível no registro da história da cultura e mentalidades.

Entretanto, ainda que um museu eclesiástico surja como espaço que prolonga a ação da Igreja no mundo concreto (AFONSO, 2015, p. 28), ele deve assumir dentre suas funções museológicas a missão pastoral, o que o diferencia das outras tipologias de museu, pois é "um lugar que documenta 0 desenvolvimento da vida cultural e religiosa, para além do gênio do homem, com o fim de garantir o presente" (MARCHISANO, 2001, s/p). 
Conforme Waldisa Rússio Guarnieri (1989, p.177), a identidade é um caráter orgânico que impõe seus registros na memória/consciência coletiva de forma dinâmica e contínua, sendo esta memória não apenas uma perspectiva do passado, mas o registro do presente e a possibilidade do futuro.

Essa ideia dos objetos sacros como fontes documentais também é entendida quando pensamos suas funções como documento museológico. Para isso, é preciso compreender o conceito de musealização do objeto como uma operação prática que define não só o que é herança, mas suas formas de transmissão (VAZ, 2017, p.58) dentro de uma interpretação no presente.

"A interpretação e a comunicação museológicas introduzem o presente - suas questões, problemas, eleições, sonhos, medos no passado do objeto. Já a manipulação sobre o objeto especialmente as ações de conservação e documentação buscam garantir um passado do futuro" (VAZ, 2017, p.89).

O fato museal, ciência que discute a relação entre o Homem e o Objeto, não se confina ao cenário-museu, o que auxilia na ampliação da percepção das múltiplas formas desta relação Homem-Objeto que, por ser aberta e dinâmica, "o homem se conhece e se reconhece nos e através dos artefatos que ele criou e nos e através dos objetos da natureza, ao quais ele deu valor pela atribuição de significados" (GUARNIERI, 1989, p.183).

Para Waldisa Rússio Guarnieri, é por meio da musealização dos objetos que o museu alcança o reconhecimento de sua função: "o museu tem sempre como sujeito e objeto o Homem e seu ambiente, o Homem e sua história, o Homem e suas ideias e aspirações. Na verdade, o homem e a vida são sempre a verdade base do museu (...)" (GUARINIERI apud VAZ, 2017, p.33).

Para Maria Inez Cândido (2006, p.34), se os objetos são suportes de informação, o desafio das instituições museológicas é não só preservar o objeto, como a possibilidade de informação que ele contém e que o qualifica como documento.

É a função documental do museu que distingue um objeto qualquer de um objeto museal; seu trabalho que garantirá não só a preservação das informações implícitas nos bens materiais e imateriais, como a valorização e difusão da memória e patrimônio social a que dizem respeito. 
Conforme Poulot (2013, p.132), “(...) a materialidade do museu manifestase tanto nos objetos que ele possui quanto nos dispositivos de seu tratamento catálogos, fichários, arquivos, diversas publicações".

Ou seja, tanto as ações de salvaguarda quanto as de comunicação e difusão são importantes para entender por completo os processos de concepção e gestão dos acervos museológicos.

Interessante pensar no conceito apresentado por Waldisa Rússio a respeito do fato museal e a relação Homem-Objeto-Cenário quando relacionado com a interpretação do filósofo romeno Mircea Eliade sobre o homem religioso e não religioso.

Em seu livro O Sagrado e o Profano (1992), onde estuda a experiência religiosa, Eliade utiliza o termo hierofania para designar o ato de manifestação do sagrado:

\begin{abstract}
"Manifestando o sagrado, um objeto qualquer torna-se outra coisa, e contudo, continua a ser ele mesmo, porque continua a participar do seu meio cósmico envolvente. Uma pedra sagrada nem por isso é menos uma pedra (...) Para aqueles a cujos olhos uma pedra se revela sagrada, a sua realidade imediata transmuda-se numa realidade sobrenatural" (ELIADE, 1992, p. 18).
\end{abstract}

Esse olhar diferenciado para uma manifestação sagrada é, segundo o autor, uma das diferenças entre o homem religioso e o não religioso, pois a sacralidade é a experiência religiosa através de símbolos e ritos vivenciados por aquele indivíduo ou grupo que tem fé. O sagrado se opõe ao profano, pois manifesta-se como uma realidade diferente da atual, do tempo histórico (ELIADE, 1992, p. 64).

Eliade também argumenta que o homem vive em dois tempos, o tempo presente e o tempo sagrado:

"O homem religioso vive assim duas espécies de Tempo, das quais a mais importante, o Tempo sagrado, se apresenta sob o aspecto paradoxal de um Tempo circular, reversível e recuperável, espécie de eterno presente mítico que o homem reintegra periodicamente pela linguagem dos ritos. Esse comportamento em relação ao Tempo basta para distinguir o homem religioso do não religioso" (ELIADE, 1992, p. 59). 
Assim, se pensarmos que o tempo sagrado acontece na ruptura que se dá no tempo profano (o presente histórico), por meio de hierofanias, caberá ao fato museal e ao processo de musealização destas manifestações também compreender essa dicotomia dos tempos e as relações mutáveis entre esses "dois homens". Será preciso se perguntar: quem é esse homem, o que este objeto significa para ele e em qual ambiente se insere.

A questão do tempo reversível e reintegrável periodicamente, apontada por Eliade, nos remete à discussão abordada por Jean Baudrillard, em $O$ Sistemas dos Objetos, a respeito da dimensão temporal das coleções na perspectiva do colecionador, onde o autor afirma que o homem não busca a imortalidade por meio de objetos-reflexo, mas sim através de um complexo jogo de "reciclagem" da ideia de nascimento e de morte em um sistema de objetos:

"O que o homem encontra nos objetos não é a garantia de sobreviver, é a de viver a partir de então continuamente em uma forma cíclica e controlada o processo de sua existência e de ultrapassar assim simbolicamente esta existência real cujo conhecimento irreversível the escapa" (BAUDRILLARD, 2015, P. 104-105).

Esse sistema de objetos aplicado à musealização do sagrado, deve ser analisado a partir de sua contextualização, conforme aponta ROQUE:

"(...) no cristianismo este conceito de sagrado, no sentido mais
convencional e transversal aos vários contextos religiosos,
apenas surge aplicado a coisa (ou a pessoas) no contexto da vida
sacramental. Pessoas e objetos são apartados do uso comum
através do rito consagratório, isto é, ao serem 'sagradas'. Desta
forma, o âmbito semântico dos termos sacros, sagrado e
sacralidade, quando aplicados aos objetos litúrgicos, só se
esclarece através da análise do contexto do ritual e da
correspondente ação simbólica" (ROQUE, 2011, p. 184).

Ainda segundo a autora, para a correta musealização desses acervos é preciso desempenhar uma reflexão fornecendo elementos de interpretação e compreensão, uma vez que "a questão central da museologia é, neste contexto, identificar a forma como o museu recontextualiza os conteúdos funcionais, semânticos e simbólicos deste patrimônio ligado ao sagrado" (ROQUE, 2011, p. 15). 
A partir da ampla ideia de patrimônio sacro, podemos aqui pontuar a distinção entre os termos arte sacra e arte religiosa, cuja diferença está fundada, não tanto em suas inspirações ou características intrínsecas, mas no destino que é dado à obra. Segundo o filósofo Titus Burckhardt:

Os historiadores da arte, que aplicam o termo "arte sagrada" para designar toda e qualquer obra de tema religioso, esquecem-se de que a arte é essencialmente forma. Para que uma obra de arte possa ser propriamente qualificada de "sagrada" não basta que seus temas derivem de uma verdade espiritual. É necessário, também, que sua linguagem formal testemunhe e manifeste essa origem (BURCKHARDT, 2004, apud BERTO, 2018, p. 38).

A arte entendida como sacra é criada como parte do culto divino, a serviço do rito litúrgico; para além de sua função estética, seu propósito é a ligação ao sagrado, pois sua essência é mística, centrada no dogma e no culto (TOMMASO, s/d), ou como diria o artista sacro Claudio Pastro, "na imagem de culto, Deus se manifesta e o homem emudece, contempla, reza" (PASTRO, 2010, p. 115).

Conforme MAIRESSE, ao discutir nossa relação com o sagrado, aponta a necessidade de alguém para legitimar a sacralidade do lugar ou objeto:

Um segundo princípio de nossa relação com o sagrado é constituído pela ligação entre o lugar (ou objeto) e o intercessor, este último reconhecendo ou fazendo surgir a sagrada fonte. Um feiticeiro, um eclesiástico ou pelo menos um ator reconhecido pela comunidade e com poderes para reunir os dois mundos (profano e sagrado) é solicitado para atestar a presença do sagrado ou para fazê-lo aparecer por meio de um ritual (MAIRESSE, 2019, p. 17. Tradução nossa).

Já a arte religiosa, se empresta de temas religiosos para desenvolver a visão do artista, numa reflexão de devoção pessoal, fora dos lugares de cultos e rituais religiosos.

\footnotetext{
"Assim, a arte sacra está ligada a imagens de culto, enquanto a arte religiosa está ligada a imagens de devoção. A imagem de devoção nasce da vida interior do indivíduo crente e, embora se refira a Deus, o faz com conteúdo humano. A imagem de culto dirige-se à transcendência, enquanto a imagem de devoção surge da imanência" (TOMMASO, s/d).
} 
Existem obras de profunda inspiração religiosa, como por exemplo as pinturas de Caravaggio, e que, não obstante, não são destinadas ao culto, portanto, não devem ser consideradas propriamente como sendo arte sacra.

O Papa João Paulo II, em seu discurso aos participantes na Assembleia da Pontifícia Comissão para os Bens Culturais da Igreja (2000), comenta a importância da arte a serviço da fé:

\begin{abstract}
"De modo especial a arte cristã, "bem cultural" mais do que nunca significativo, continua a prestar um seu singular serviço comunicando com extraordinária eficácia, através da beleza das formas sensíveis, a história da aliança entre Deus e o homem e a riqueza da mensagem revelada. Nos dois milénios da era cristã, ela foi a maravilhosa manifestação do ardor de tantos confessores da fé, expressou a consciência da presença de Deus entre os crentes, sustentou o louvor que de todas as partes da terra a Igreja eleva ao seu Senhor. Os bens culturais revelam-se documentos qualificados dos vários momentos desta grande história espiritual."
\end{abstract}

Assim, podemos dizer que a Igreja Católica reconhece, em sua noção de bem cultural, as várias manifestações da arte, estando elas a serviço da fé, sendo inferidas tanto como artes sacras como religiosas. A arte, no contexto religioso, tem uma função cultural e eclesial histórica, uma vez que a religiosidade permanece no cotidiano das pessoas, evidenciada nas práticas e costumes devocionais através do tempo.

O Código de Direito Canônico de 1983 define apenas duas classes de bens: res sacrae e bona preciosa. Segundo SALVADOR e EMBRIL (1993), as res sacrae são definidas como "coisas e lugares sagrados, conforme cân. 1171, os que, mediante sagração ou benção, foram dedicados ao culto divino" e podem pertencer "a pessoas jurídicas privadas ou a pessoas físicas" (p. 92).

Já as bona preciosa, são entendidas como bens cuja preciosidade "Ihes advém de seu valor artístico e histórico, unido a sua função cultural e ao valor econômico (câns. 1189 e 1292)" (SALVADOR e EMBRIL, 1993, p. 92). 


\section{A musealização dos tesouros e coleções dos Papas}

Abordaremos aqui brevemente os Museus Vaticanos, por sua importância como instituição museológica criada e desenvolvida no seio da Igreja Católica ainda que seu acervo não seja em sua totalidade religioso, e o Museu do Tesouro da Basílica de São Pedro, como exemplos de musealização do sagrado e suas possíveis influências em Dom Duarte na constituição de seu próprio museu de arte sacra.

Os Museus Vaticanos (ou Museus do Vaticano) surgem como coleções de obras arqueológicas clássicas, pois os Papas consideravam-se legítimos herdeiros de todo patrimônio artístico arqueológico do Império Romano (MUSEUS VATICANOS, 2020). Desta forma, tudo deveria ser preservado, salvaguardado e reverenciado para a maior glória de Deus e da Igreja.

Localizado dentro do Estado Vaticano, o menor país do mundo, reconhecido apenas em 1929 pelo Tratado de Latrão, os Museus Vaticanos são um conjunto formado por oito museus, além de salas e galerias especiais, que foram sendo incorporadas como museus ao longo do tempo, decoradas por artistas renomados, como as Salas de Rafael, a Galeria dos Mapas e a Coleção de Arte Contemporânea; todos instalados nos antigos aposentos dos palácios dos Papas - daí o plural no nome, "museus".

O Pátio das Esculturas, hoje Tribunal Octogonal, é conhecido como o núcleo original dos Museus do Vaticano, tendo sido organizado em 1506 quando o Papa Júlio II (1443-1513) transferiu uma impressionante coleção de esculturas antigas ao espaço, incluindo o Belvedere de Apolo e Laocoonte e Seus Filhos, que estão em exposição no local desde esta época.

Influenciadas pelas transformações do século XVIII, sob a luz do lluminismo, e das novas descobertas em escavações nas cidades de Roma e de Lazio, as coleções papais foram expandidas e renovadas, transformando os "Museus do Papa" em uma instituição museológica no sentido moderno, cujo objetivo é proteger obras de arte antigas, promover o estudo e o conhecimento e abri-las ao público ou permitir o acesso a elas.

Durante o papado de Pio XI (1922-1939) iniciaram-se os trabalhos de conservação e restauro das coleções, com a criação do Laboratório de Restauração de Pintura e Materiais de Madeira, em 1923; do Laboratório de 
Restauração de Tapeçarias e Têxteis, em 1930; o Laboratório de Diagnóstico para a Conservação e Restauração, em 1935; e Laboratório de Restauração de Mosaicos, no final da década de 1930.

Já o Museu Histórico-Artístico da Basílica de São Pedro, mais conhecido como Museu do Tesouro da Basílica, está localizado no transepto esquerdo do interior da Basílica, ao lado da Sacristia Comum.

A tradição atribui o nascimento do Tesouro da Basílica ao Imperador cristão Constantino (306-337), que desejava embelezar o sepulcro do Apóstolo Pedro com objetos litúrgicos de grande valor (EDIZIONI CAPITOLO VATICANO, 2021).

O acervo é constituído por objetos que foram doados à Basílica do Vaticano por papas, prelados, soberanos e fiéis, sendo estes ornamentos de igrejas, estátuas, mitras papais e outros objetos de relevância devocional e estética. Entretanto, ao longo dos séculos, o Tesouro foi vítima de numerosos saques.

A visitação do espaço era concedida apenas com a autorização do Cabido Vaticano. A partir de 1909 foram abertas ao público duas salas na Sacristia Vaticana que exibiam os objetos de maior destaque e importância, sendo considerado o primeiro museu da Basílica.

Entretanto, foi apenas em 1974 que, a pedido do Cabido Vaticano e do Papa Paulo VI, inaugurou-se de fato o museu após uma renovação da expografia executada pelo arquiteto Franco Missini, que ampliou o espaço para nove salas no total.

Nas biografias escritas a respeito de Dom Duarte, investigadas durante a pesquisa, constatamos que o arcebispo viajou ao Vaticano pelo menos cinco vezes, entre os anos de 1907 e 1925. Entramos em contato com o Arquivo Histórico dos Museus Vaticanos a fim de pesquisar se haveria algum tipo de registro de visitantes do Museu, a partir da hipótese de que, quando das visitas de religiosos estrangeiros ao Papa para audiências e encontros, também fossem realizados passeios culturais, incluindo a visitação da coleção do Papa. 
Recebemos como resposta que, nos documentos atualmente processados, não há informações referentes às visitações, e que seria necessário realizar uma pesquisa in loco e em outros arquivos ${ }^{20}$.

Ainda que não seja possível comprovar que Dom Duarte tenha visitado os Museus Vaticanos ou o Museu do Tesouro da Basílica de São Pedro, é plausível dizer que, de alguma maneira, ele teria tido essas instituições como referência, uma vez que tinha como projeto a implantação do Museu da Cúria pertencente à Mitra paulista, que atuava em sintonia com suas recomendações.

Constatamos, ainda, que suas visitas ao Vaticano coincidem com importantes transformações ocorridas na estruturação dos Museus Vaticanos, como a criação dos laboratórios de restauro, supracitadas. Além disso, Dom Duarte era um homem culto, estudioso e também um colecionador e um admirador das artes, o que nos permite considerar provável que tenha se interessado por visitar a grande coleção Papal e os tesouros de São Pedro em suas viagens ao Vaticano e, assim, ter se inspirado nessas instituições para a criação do museu de arte sacra paulista que liderou.

\footnotetext{
${ }^{20}$ Em decorrência da emergência sanitária resultante da pandemia do vírus COVID-19 em 2020, não foi possível realizar uma pesquisa mais aprofundada nos arquivos históricos dos Museus Vaticanos.
} 


\section{CAPÍTULO 2: O ARCEBISPO DOM DUARTE LEOPOLDO E SILVA}

\subsection{A figura de Dom Duarte à frente da Cúria Metropolitana de São Paulo}

Figura 1: Retrato de Dom Duarte Leopoldo e Silva (1913).

Henri Bernard. Óleo sobre tela, 133 x 106 x 5,5 cm.

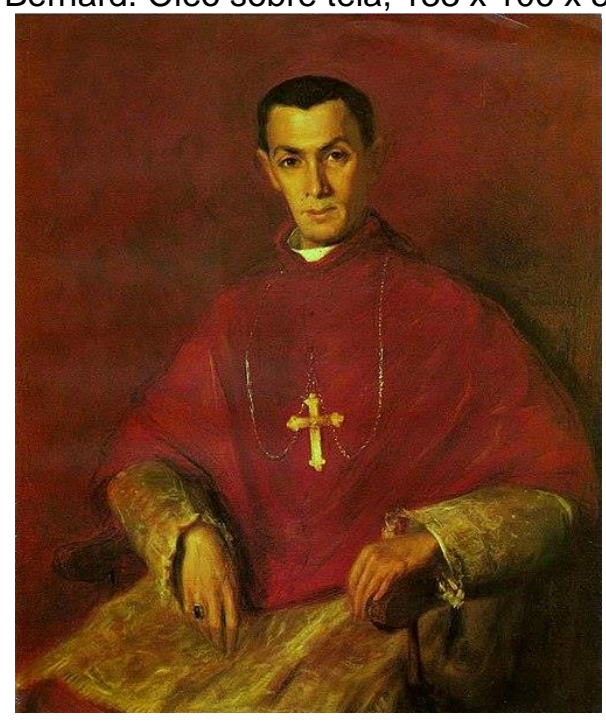

Fonte: Acervo Museu de Arte Sacra de São Paulo. Fotografia Iran Monteiro.

Quando este retrato foi pintado, Dom Duarte tinha 43 anos de idade e estava havia 5 anos à frente da Arquidiocese de São Paulo. Podemos observar Dom Duarte representado com as vestes corais utilizadas em solenidades: solidéu, murça violácea sobre roquete e batina violácea, com cruz peitoral na altura do peito, como símbolo de que os sacerdotes guardam a cruz no coração (esta cruz fez parte do acervo do Museu da Cúria, descrita com mais detalhes no capítulo 3.2.1). Anel não identificado.

Dom Duarte acompanhou as mudanças políticas de São Paulo por toda sua trajetória eclesiástica e viu a cidade colonial e provinciana se transformar numa metrópole. Sempre retratado em suas biografias como homem culto, educado, voltado à escrita e à caridade, tornou-se uma figura emblemática, não só dentro da Igreja Católica, mas também como defensor e preservacionista da história paulistana.

Duarte Leopoldo e Silva nasceu em 04 de abril de 1867 na cidade de Taubaté, filho de Bernardo Leopoldo e Silva, alfaiate português que imigrara ao Brasil ainda jovem, e de Ana Rosa Marcondes Leopoldo. Era o mais velho de 10 filhos.

Quando jovem, desejou tornar-se advogado, concluindo em 1884 o curso preparatório anexo à Faculdade de Direito de São Paulo, localizada no Largo São Francisco (à época ainda no edifício do antigo convento), ao lado da Igreja de São Francisco. 
Ao mudar de ideia quanto à advocacia, mudou-se para o Rio de Janeiro onde iniciou o curso de Farmácia na Faculdade Nacional de Medicina, porém não chegou a concluí-lo devido a sua saúde debilitada, abandonando o curso no $2^{\circ}$ ano.

De volta a São Paulo, cursou Filosofia e Teologia no Seminário da Diocese de São Paulo, sendo ordenado sacerdote em 30 de outubro de 1892. Durante esse período, deu aulas no Colégio Diocesano, anexo ao Seminário. Em seguida à ordenação, foi nomeado coadjutor da paróquia de Jaú, em 1893.

Pouco depois, em 1894, o bispo de São Paulo, Dom Joaquim Arcoverde de Albuquerque Cavalcanti convida Dom Duarte a assumir a paróquia de Santa Cecília e conduzir a construção do novo templo. Ele o faz contratando artistas para decorá-la de acordo com os ditames da Igreja Católica.

A atuação de Dom Duarte na Igreja de Santa Cecília evidencia também um traço peculiar que o caracterizava como mecenas da arte religiosa. Segundo a pesquisadora Karin Philippov (2016, p. 22), Dom Duarte planejou a demolição de igrejas e a construção de outras mas teve a sensibilidade tanto de preservar as obras de arte existentes como, principalmente, de trabalhar com artistas da época, como Benedito Calixto, na concepção artística dos templos.

Assim, pode não ter sido sensível ao valor histórico-arquitetônico que aquelas construções poderiam representar ou ter-se convencido da necessidade de uma modernização neste campo. Entretanto, teve o mérito de promover a preservação dos bens móveis, objetos artísticos que aquelas igrejas continham.

A respeito da relação entre Benedito Calixto e Dom Duarte, Philippov argumenta que os dois talvez tenham se conhecido ou por meio de Dom Joaquim Arcoverde, primeiro cardeal do Brasil, ou pelas reuniões no Instituto Histórico e Geográfico de São Paulo a partir de 1904, ano em que Dom Duarte entra como sócio (PHILIPPOV, 2016, p. 51).

Independente da data, é certo que o Arcebispo e o pintor mantinham laços de amizade que proporcionaram diversos projetos conjuntos com o objetivo de levar uma beleza artística aos novos templos que surgiam. Segundo Arruda Dantas, Dom Duarte costumava descansar na Vila Betânia, em São Vicente: 
“(...) vinha da R. Martim Afonso, 192, para conversar assiduamente com o Arcebispo, horas a fio. Assunto: história, religião e arte, em porfiadas recordações de personagens ilustres e fatos antigos notórios em companhia de Capistrano de Abreu, Domingos Jaguaribe e outros historiadores e amigos" (CAMARGO, 1969, p. 74).

Em 1904, Dom Duarte foi nomeado bispo de Curitiba pelo papa Pio X e, em 1906, foi chamado para a posição de bispo de São Paulo após a morte do então bispo Dom José de Camargo Barros, assumindo o cargo como 13ํㅡㄴ bispo ${ }^{21}$ da cidade em 14 de abril de 1907.

Com a criação da Província Eclesiástica de São Paulo, em 1908, a cidade de São Paulo é elevada a Arquidiocese e Dom Duarte é nomeado primeiro arcebispo metropolitano de São Paulo, tomando posse no dia 11 de outubro de 1908.

No auge da riqueza de São Paulo, Dom Duarte pode contar com o apoio da elite cafeeira para que fosse construída a nova Catedral de São Paulo, lançando sua pedra fundamental em 29 de junho de 1913. A antiga Igreja Sé e a Igreja de São Pedro dos Clérigos já haviam sido demolidas em 1911, quando se iniciaram as tratativas para a nova esplanada no centro da cidade.

Sobre este capítulo da história, Roberto Pompeu de Toledo (2015, p. 7173) comenta a grande influência de Dom Duarte e sua determinação na defesa de seus projetos. Em 09 de julho de 1911, após a cerimônia de lançamento da pedra fundamental do novo Paço Municipal, Dom Duarte levou as autoridades presentes, como o prefeito Raimundo Duprat e o secretário de Justiça do Estado Washington Luís, a percorrerem o pequeno espaço destinado à nova Catedral no plano Bouvard 22 .

\footnotetext{
${ }^{21}$ Durante a pesquisa foram encontradas divergências em relação ao número de bispos de São Paulo e alguns documentos indicavam Dom Duarte como 12ํำ bispo. A confusão se dá em razão de o $4^{\circ}$ bispo nomeado, Dom Frei Miguel da Madre de Deus da Cruz, não ter chegado a assumir o bispado. Segundo SOUZA (2004, p. 211-212), Dom Frei Miguel foi nomeado em 17 de dezembro de 1793 mas não aceitou, permanecendo em Lisboa e assumindo, anos depois, a arquidiocese de Braga naquele país. Apesar de não ter assumido o bispado paulista, recebia mesmo assim "os vencimentos a que teria direito por meio de procuração". Já o site da Arquidiocese de São Paulo aponta que Dom Frei Miguel chegou a ser sagrado em 29 de abril de 1972 pelo bispo de Mariana, porém não aceitou assumir o bispado alegando problemas de saúde (ARQUIDIOCESE DE SÃO PAULO. HISTÓRIA DOS BISPOS E ARCEBISPOS - BISPOS DIOCESANOS / Dom Miguel da Madre de Deus da Cruz. Disponível em: <http://arquisp.org.br/historia/dos-bispos-e-arcebispos/bispos-diocesanos/dom-miguel-damadre-de-deus-da-cruz>. Acesso em: 30/08/2020).

$22 \mathrm{O}$ arquiteto francês Joseph Antoine Bouvard (1840-1920) foi contratado em 1911 pelo prefeito Raimundo Duprat para revisar os projetos de melhorias urbanas que estavam sendo discutidos
} 
Segundo o projeto, a catedral seria construída no mesmo local da antiga, o que seria muito acanhado perto da grandiosidade proposta ao resto do novo centro cívico. Após diversos debates, em 1913, a Mitra assinou acordo com a Câmara e o governo do Estado para transferir a construção da nova Catedral ao alto da esplanada, próxima à futura Praça João Mendes.

Ao longo de seu arcebispado, Dom Duarte realizou inúmeras visitas pastorais pelo Estado, inaugurou em 1929 o Recolhimento São Pedro, para padres idosos e o Seminário Central da Imaculada Conceição, no bairro do Ipiranga, em 1934, além de organizar importantes eventos, como o "Primeiro Congresso Eucarístico de São Paulo", em 1915; o "Congresso Eucarístico Nacional"; de 1922; o "Congresso da Mocidade Católica", de 1928; e o "Congresso Mariano", de 1929 (Arquidiocese de São Paulo, s/d).

Dom Duarte sempre privilegiou o culto a Nossa Senhora (SOUZA, 2004, p. 419) e solicitou ao papa Pio $X$ o título de Basílica à Igreja Velha de Aparecida, cidade que integrou a Arquidiocese de São Paulo até 1958. A sagração da Basílica ocorreu em 5 de setembro de 1909, tornando-se a primeira basílica brasileira. Mais tarde, em 4 de julho de 1980, a nova Basílica seria consagrada pelo Papa João Paulo II, durante sua visita ao Brasil.

Em 1910, Dom Duarte adquire a antiga moradia do Senador Queirós, localizada na Rua São Luiz, № 2, próxima à Rua da Consolação, para transformá-la em residência dos arcebispos, que anteriormente residiam na rua do Carmo, no imóvel que antes havia pertencido à Domitila de Castro Canto e Melo (1797-1867), a Marquesa de Santos, e sucessivamente, a seu filho mais velho, Felicio.

à época. Bouvard era diretor de Arquitetura, Passeios e de Jardins da cidade de Paris e ostentava alguns planos de renovação urbana executados em cidades como Buenos Aires e Istambul. Durante os 40 dias que ficou na cidade, estudou sua topografia e desenhou algumas plantas. $O$ conjunto de medidas aprovado pela Câmara acabou por levar seu nome, sendo conhecido como "Plano Bouvard". Cf. D'ELBOUX, Roseli Maria Martins. Joseph-Antoine Bouvard no Brasil. Os Melhoramentos de São Paulo e a criação da Companhia City: ações interligadas (2015); TOLEDO, Benedito Lima de. Três Cidades em Um Século (1983, p. 99-105); TOLEDO, Roberto Pompeu de. A capital da vertigem (2015, p. 69-70); BARBUY, Heloisa. A cidade-exposição: comércio e cosmopolitismo em São Paulo, 1860-1914 (2006, p. 72-75). 
A antiga residência do Senador Queirós, que viria a se transformar no Palácio Episcopal, ou Palácio São Luiz, foi comprada pelo valor de 180:000\$00 (cento e oitenta contos de réis), que incluía os móveis e alfaias da casa (LEFRÉVRE, 2006, p.132). A arquitetura do palacete estava em consonância com o ecletismo do final do século XIX (Fig. 2-5).

De acordo com José Eduardo de Assis Lefrévre, o palacete:

"Possui um aspecto de vila italiana, com linguagem maneirista na composição dos frontões, umbrais e cornijas. O volume da casa é dividido em três partes, com a central mais recuada, criando um pórtico de acesso no térreo, em que duas colunas com capitéis coríntios suportam um terraço (...)" (LEFRĖVRE, 2006, p.121).

Figura 2: Fachada do Palácio.

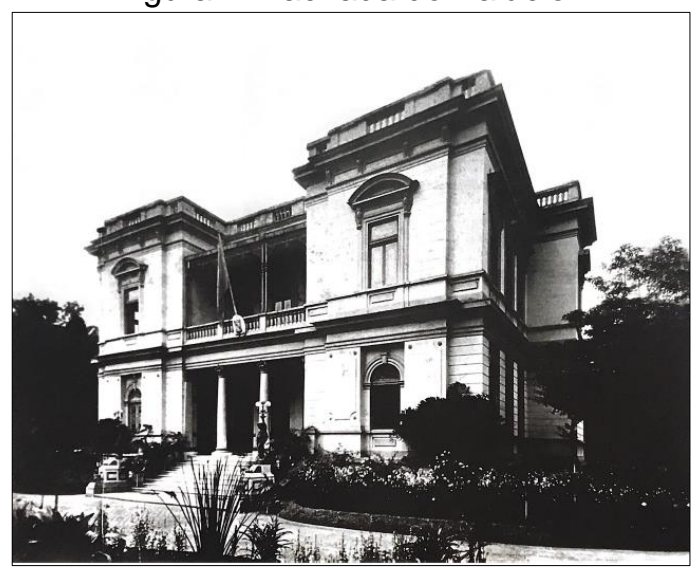

Fonte: LEFRÈVRE, 2006, p.118.
Figura 4: Biblioteca do Arcebispo.

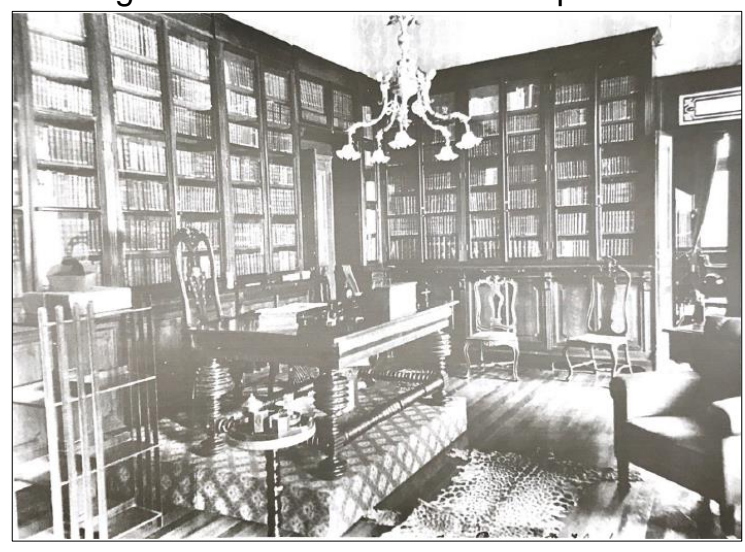

Fonte: LEFRÈVRE, 2006, p.123.
Figura 3: Capela interna.

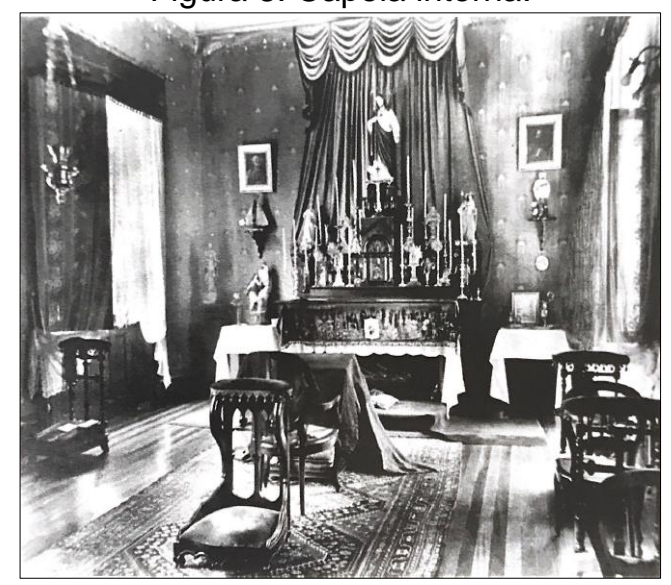

Fonte: LEFRÈVRE, 2006, p.124.
Figura 5: Dormitório de Dom Duarte.

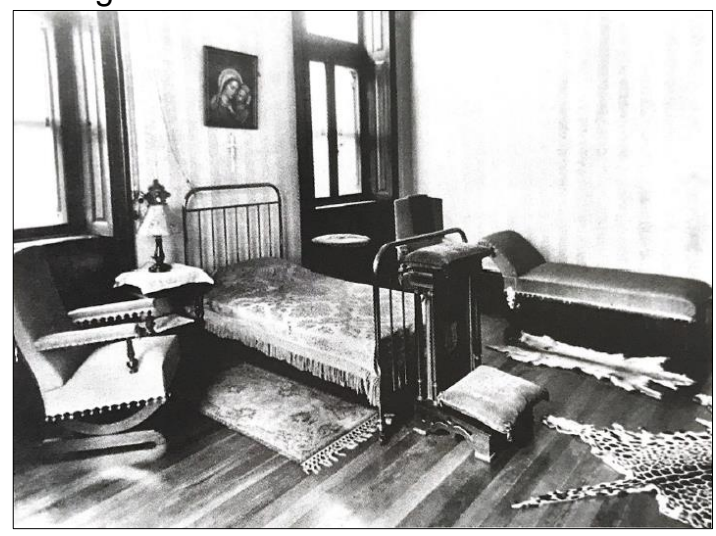

Fonte: LEFRÈVRE, 2006, p.124. 
Apesar dos cômodos suntuosos, o quarto de Dom Duarte (Fig. 5) segue uma decoração mais modesta, com poucos móveis e objetos. Chamam a atenção os tapetes de pele no chão, sendo um deles aparentemente de uma onça, que podem, hoje, parecer-nos incompatíveis com o que imaginamos ser o quarto de um bispo. Também observamos em seu dormitório um mobiliário mais simples, de produção industrial, como a cama de ferro ou madeira (cama Patente), em contraponto aos móveis coloniais de madeira encontrados nos outros cômodos. É espaço íntimo de oração: a devoção mariana que mencionamos acima encontra-se presente na imagem emoldurada na parede, acima da cama. Aos pés da cama, há um genuflexório voltado para essa imagem.

Já a fotografia da biblioteca (Fig. 4) nos apresenta um ambiente mais requintado. O mobiliário colonial, com as mesas com pernas em volutas e cadeiras com espaldar entalhado, compõe o espaço junto à grande estante de livros. A disposição do mobiliário, principalmente a mesa principal em cima de um tablado carpetado, pode nos remeter à ideia de "Sala do Trono", sendo talvez este ambiente local de reuniões entre $o$ arcebispo e seus convidados.

A capela interna (Fig. 3) segue o padrão requintado dos cômodos, devidamente decorada com tapetes, alfaias, e objetos litúrgicos, como ostensórios, castiçais e imagens de devoção. Interessante observar que há um genuflexório ao centro da capela e outros ao redor, indicando que era possível que mais pessoas participassem das missas celebradas ali.

Ocorreu neste Palácio a reunião histórica entre Dom Duarte e as principais famílias da cidade, em 25 de janeiro de 1912, a fim de constituir uma comissão para levantar fundos para a construção da nova catedral da cidade (SOUZA, 2004, p.420), cuja pedra fundamental foi lançada em 29 de junho de 1913.

Em um trecho de seu discurso aos convidados, Dom Duarte exalta a bravura paulista e a necessidade de haver um templo à altura dos cidadãos desta terra: 


\begin{abstract}
"Se os templos se edificam mais para os homens do que para Deus, que, colocado no santuário da sua inesgotável riqueza, nada reclama da nossa abundância, nós católicos e paulistas queremos uma catedral que seja um monumento de fé e um atestado da nossa grandeza; que seja uma escola de arte e um estímulo a pensamentos mais nobres e mais elevados; queremos uma catedral opulenta que, testemunhando a fartura dos nossos recursos materiais, seja também um hino de ação de graças a Deus Nosso Senhor.

Saibam os Paulistas de amanhã que a fibra do bandeirante, lutador e intimorato nas asperezas da selva, não se enfraqueceu nos confortos da vida moderna, como não se entibiou a sua fé nos esplendores da ciência e da civilização.

Por uma lei histórica e fatal, São Paulo que há de sempre caminhar na vanguarda, tem a cumprir uma grande missão política e social, e a sua hegemonia, civil e religiosa, já não pode ser contestada.

Pois bem, o monumento artístico, que breve se há de erguer, na colina do venerando Padre Anchieta, há de ser o selo dessa imensa e poderosa grandeza, e eu me ponho à frente desse tentame com todo o calor da minha fé cristã e com todo o entusiasmo de minha alma paulista" (Dom Duarte citado por ASSIS, 1967, p.104).
\end{abstract}

A irmã de Dom Duarte, Isaltina, dirigiu domesticamente o Palácio até a morte do arcebispo (DANTAS, 1974, p.85). Outro irmão de Dom Duarte, o escultor Francisco Leopoldo e Silva (1879-1948), teve, nos anos 1920, um estúdio artístico na casa (MARTINS, 2008, p.10).

Conhecido também apenas como Leopoldo e Silva, Francisco iniciou seus estudos de escultura e modelagem no Liceu de Artes e Ofícios de São Paulo sob a orientação do escultor ítalo-brasileiro Amadeu Zani. Frequentou a Academia de França junto com o escultor Victor Brecheret (1894-1955) e em 1911 viajou para Roma como pensionista do Governo Estadual de São Paulo, cidade em que residiu por muitos anos, tendo sido aluno do escultor Arturo Dazzi no Instituto de Belas Artes.

É autor de várias esculturas existentes em espaços públicos da cidade, como o Parque Trianon e o Cemitério da Consolação, onde, em 1922, foi o primeiro artista a colocar sobre um túmulo uma escultura de nu feminino (MARTINS, 2008, p. 10). Na Pinacoteca do Estado encontra-se a obra "Sapho", escultura de mármore de 1920. Leopoldo e Silva também colaborou com esculturas na nova Catedral de São Paulo; as figuras de Jó e São Jerônimo estão na cripta. Na Faculdade de Direito do Largo de São Francisco (USP), um busto do Professor Pedro Lessa foi inaugurado em 1923 (BARBUY, 2017). 
A escultura "Nostalgia", que possui uma cópia exposta atualmente na praça Professor Cardim, próxima ao Jockey Club de São Paulo, foi premiada no Salão de Roma de 1918 e adquirida pelo Governo italiano para a Galeria do Campidoglio, em Roma ${ }^{23}$.

Mirian Silva Rossi, em seu artigo sobre a "Circulação e mediação da obra de arte na Belle Époque paulistana" (1999), aponta a importância da exposição de Leopoldo e Silva em 1920 no Palacete Guanabara ${ }^{24}$ como a primeira a levar aos salões paulistanos um grande número de visitantes interessados em esculturas (p. 89). Ao apresentar 22 dos seus melhores trabalhos em bronze e mármore executados em Roma, Leopoldo e Silva recebeu inúmeras críticas positivas nos jornais da época, que elogiavam sua concepção e execução ( $p$. 90).

O relacionamento entre o escultor Leopoldo e Silva e seu irmão, o Arcebispo de São Paulo, nos leva a pensar sobre a proximidade de Dom Duarte ao mundo das artes. Sabemos que durante o período em que foi vigário de Santa Cecilia, Dom Duarte contratou os pintores Benedito Calixto e Oscar Pereira da Silva para executar alguns painéis na nova Igreja. Sendo um homem culto, interessado em História e também um colecionador, há de se supor que o campo das artes também o interessava.

O Palácio Episcopal foi demolido em 1944 após a Prefeitura de São Paulo desapropriá-lo, em 1942, para obras de alargamento da Rua São Luiz. Seu último morador foi Dom José Gaspar d'Afonseca e Silva, que tomou posse como arcebispo em 1939, após a morte de Dom Duarte. Dom José Gaspar morreu em 1943 num acidente aéreo no Rio de Janeiro. Alguns anos depois de sua morte, a praça vizinha à antiga residência do arcebispo, localizada hoje atrás da biblioteca Mário de Andrade, recebeu seu nome e ganhou uma cruz em sua homenagem.

\footnotetext{
${ }^{23}$ Karina Trevizan. Que estátua é essa?, diz leitora; Conheça sua Cidade responde. Portal de Notícias G1 - São Paulo. 27/11/2013. Disponível em: <http://g1.globo.com/sao-paulo/vc-no-g1sp/noticia/2013/11/conheca-sua-cidade-estatua-sem-placa-de-identificacao-gera-duvida.html>. Acesso em: 15/07/2019.

${ }^{24}$ Localizado na Avenida São João, o Palacete desde de 2014 chama-se "Palacete dos Artistas", e serve de moradia popular para artistas aposentados. (Fonte: http://glo.bo/1ArADal)
} 
Figura 6: Vista aérea do Palácio São Luiz. BJ Duarte, 1940.

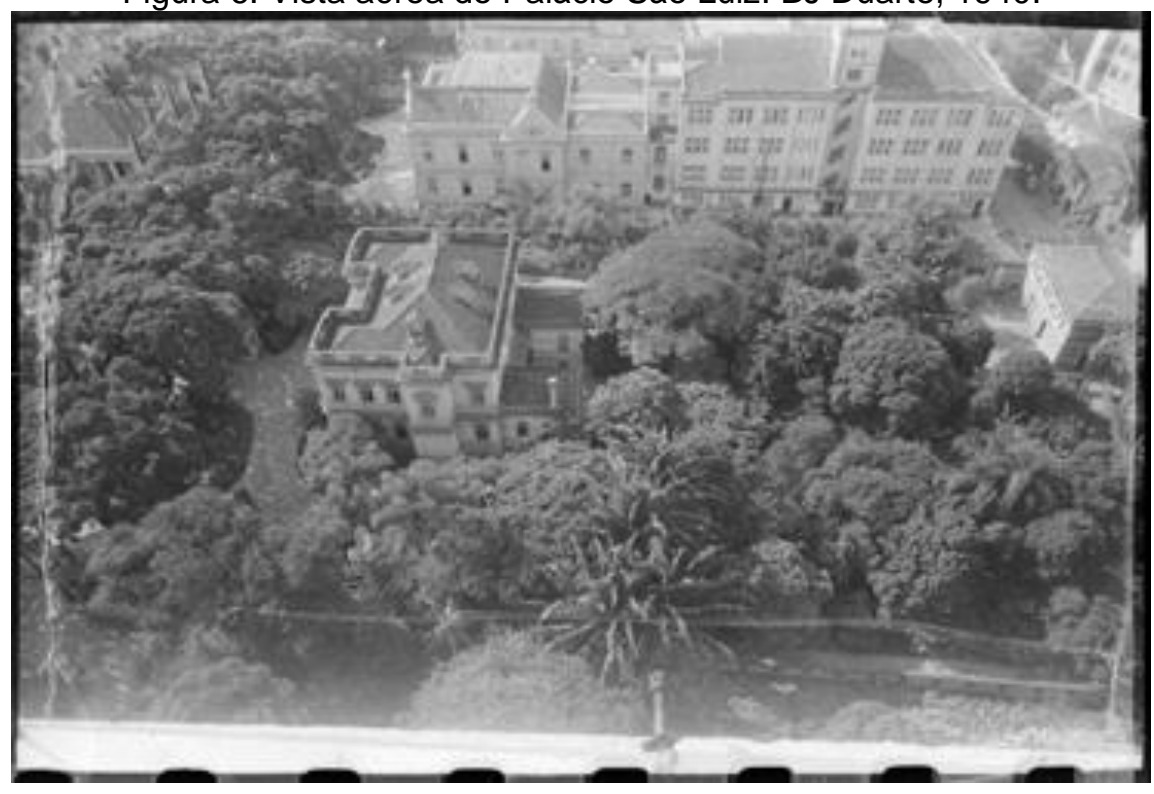

Fonte: Acervo Fotográfico do Museu da Cidade de São Paulo. Vista aérea do Palácio São Luiz, tirada da torre da biblioteca municipal ainda em construção

Sobre a personalidade e intimidade de Dom Duarte pouco se sabe, devido a seu perfil reservado, tanto no âmbito pessoal como no que tange a função que exercia. Durante o discurso no Jubileu do Instituto Histórico e Geográfico de São Paulo, em 1949, Affonso Taunay recorda a memória de sócios com quem conviveu ao longo dos anos, traçando rápidas palavras a respeito de Dom Duarte, que fora membro ativo do Instituto Histórico e Geográfico Brasileiro, tendo sido vice-presidente do Instituto paulista (1919-1922):

\begin{abstract}
"Reservado, distante, em sua polidez impecável, cheio de atenção, mas sem conceder intimidade, dele conservo a agradável lembrança de quanto dentro de seu feitio pouco expansivo lhe foi grato ler o que num ímpeto de justiça escrevi acerca da magna obra que empreendera e realizou, ao organizar o arquivo da sua Cúria Arquiepiscopal" (TAUNAY, 1949, p.158).
\end{abstract}

Já Altino Arantes, Presidente do Estado de São Paulo de 1916 a 1920, em seu livro "Passos do meu caminho", ao escrever sobre os bispos de São Paulo, descreve Dom Duarte como uma figura de nobre feição, de perfil esguio cujas vestes acentuavam sua magreza, e de "voz velada de ligeira rouquidão, que parecia amaciar-Ihe a firmeza do comando e a severidade da advertência" (ARANTES, 1958, p.121). 
Pequenos detalhes sobre a vida cotidiana de Dom Duarte podem ser encontrados no artigo a seu respeito escrito por Mons. Paulo Florêncio da Silveira Camargo à revista do Instituto Histórico e Geográfico de São Paulo, em 1969. Além de fumar ocasionalmente, e jogar bilhar nas poucas horas vagas, Mons. Camargo aponta que Dom Duarte "celebrava diariamente a santa Missa e quando não podia fazê-lo comungava na Missa do secretário particular", "era abstêmio; às vezes nas refeições só tomava um prato de sopa ou apenas dois ovos quentes" e "dava diariamente expediente na Cúria Metropolitana, das 13 às 15 horas" (CAMARGO, 1969, p. 73).

Outra informação sobre Dom Duarte revelada por Mons. Camargo era a autoflagelação:

"Contou-me o Sr. Campos, encarregado de reorganizar a livraria do Palácio arquiepiscopal que, várias vezes por semana, vindas do quarto contíguo a biblioteca, onde D. Duarte dormia, ouvia pancadas de quem se flagelava! Assim, D. Duarte usava para se dominar, o meio violento usado pelos santos: a flagelação" (CAMARGO, 1969, p. 72).

Do alto posto de Arcebispo, Dom Duarte mandou construir o novo Palácio da Cúria, inaugurado em 1920, onde pode dispor de mais cômodos para todas as repartições eclesiásticas e estabelecer espaços adequados para duas de suas principais iniciativas em relação à preservação da história eclesiástica de São Paulo: o Arquivo Geral e o Museu da Cúria, de que trataremos adiante.

Dom Duarte Leopoldo e Silva morreu em 13 de novembro de 1938 no Palácio São Luiz, atendido por seu irmão, o médico Tarcisio Leopoldo e Silva, professor da Faculdade de Medicina da Universidade de São Paulo.

Em seu testamento, publicado na biografia escrita por Monsenhor Victor Rodrigues Assis (1967, p. 98-102), Dom Duarte discorre sobre ter cumprido seu dever como religioso e administrador dos bens eclesiásticos, levando uma vida humilde e pobre, nunca Ihe faltando o necessário para seguir sua vida caridosa de pai e pastor. 
Escrito em 8 de dezembro de 1933 na Basílica de Aparecida, "aos pés de Nossa Senhora Aparecida", Dom Duarte declara que os bens encontrados no Palácio São Luiz, na Cúria e na Vila Betânia, e também os bens recebidos como presentes em seu nome, pertencem à Arquidiocese, pois "tudo foi adquirido com dinheiro da Mitra ou a ela doado por piedosos diocesanos" (p. 100), com exceção de poucos itens pessoais pertencentes à sua irmã Isaltina.

Dom Duarte ainda aponta que, todavia, não foi feita uma relação completa de objetos presentes no Palácio São Luiz e na Vila Betânia, como "móveis, alfaias, louças, obras de arte, etc." (p. 100), mas que, em caso de qualquer dúvida, sua irmã e o procurador da Mitra, o Cônego Nicolau Consentino, poderiam esclarecer por conhecerem tudo que neles se encontram. Um pedido feito por Dom Duarte em seu testamento ao seu sucessor foi de:

“(...) mandar entregar, a título de lembrança, qualquer objeto de pequeno valor e de meu uso pessoal a cada um dos irmãos e cunhados, o que deixo ao seu critério único e exclusivo, entendendo eu que, com isso, não seja a Arquidiocese prejudicada de forma alguma" (ASSIS, 1967, p. 101).

Esse pedido foi cumprido, segundo o relatório escrito por Monsenhor Sylvio de Moraes Mattos (ACMSP, pasta "Museu"), encarregado pelo bispo de São Carlos Dom Gastão Liberal Pinto, testamenteiro de Dom Duarte, a realizar a distribuição das lembranças e providenciar a guarda do que deveria ir para o arquivo.

Seis dias após o falecimento de Dom Duarte, Monsenhor Mattos listou de que forma os pertences foram encaminhados, indicando que os objetos recebidos de aniversário ou datas jubilares já haviam sido doados por Dom Duarte em vida à Mitra e ao Museu da Cúria, o que justificava a quantidade de caixas de joias vazias encontradas no cofre. Outras medalhas, anéis e abotoaduras encontrados no cofre ou foram levados para o Museu ou entregues aos irmãos do arcebispo. 
Documentos como cadernos pessoais e cartas foram enviados ao Arquivo da Cúria; os livros de sua biblioteca, previamente catalogados e de maior importância permaneceram no Palácio e os outros doados como lembranças do arcebispo; as alfaiais da capela permaneceram e o restante das roupas foi doado aos seminaristas pobres; santinhos, cartas e outros itens sem valor foram devolvidos aos remetentes também como lembranças de Dom Duarte.

\subsection{A importância do novo Palácio da Cúria para a preservação da história paulista}

Uma das mais importantes construções encomendadas por Dom Duarte foi o Palácio da Cúria, edifício construído no lugar do antigo Recolhimento de Santa Teresa para suprir a necessidade de mais espaço para a Cúria, que já não comportava todas as atividades realizadas.

O Recolhimento de Santa Teresa de Jesus, primeiro de seu tipo em São Paulo ${ }^{25}$, foi fundado e construído por Lourenço Castanho Taques, a conselho do bispo do Rio de Janeiro Dom José de Barros de Alarcão. Inaugurado em 28 de novembro de 1685, seguiu o desejo de seu fundador em abrigar "todas as pessoas do sexo feminino, suas netas e mais descendentes do mesmo sexo que quisessem abraçar o instinto da Matriarca Santa Teresa" (MARTINS, 2003, p. 247). O terreno pertencia a Manuel Vieira de Barros, que doou duas casas para a fundação do recolhimento. Suas três filhas foram as primeiras recolhidas.

\footnotetext{
${ }^{25}$ A respeito da fundação de conventos e recolhimentos femininos no Brasil, é interessante apontar que "a adesão feminina à vida religiosa ocorreu de forma tímida na colônia, devido as dificuldades criadas pela Coroa portuguesa, como forma de restringir a abertura destas instituições. As restrições portuguesas se explicam pelo fato de que havia na colônia um déficit de mulheres brancas o que dificultava os objetivos da Coroa de embranquecimento da população e a formação de uma classe lusitana no Brasil. (...) Diante desta 'necessidade' colonial, cada vez mais crescente, e das dificuldades impostas pela Coroa quanto à fundação de conventos, surgiu a possibilidade da abertura dos recolhimentos. Estes eram casas religiosas semelhantes aos conventos, porém mais fáceis de serem fundadas, porque estavam livres das questões burocráticas da Coroa e dos compromissos dos votos solenes. E como os conventos existentes na colônia só permitiam o acesso das mulheres que possuíssem dotes e que tivessem 'pureza de sangue', os recolhimentos se constituíam cada vez mais numa alternativa para as negras, índias, descendentes de judeus e mulheres brancas pobres, por sua condição, impedidas de acesso aos conventos, mas desejosas pela vida monástica" (SILVA, S. S. de A. Religião e Condição Feminina no início do século XIX: Controvérsias em torno da Irmã Germana. Anais do I Colóquio do LAHES. Juiz de Fora, 13 a 16/06/2005. Disponível em:< https://www.ufjf.br/lahes/files/2010/03/c1-a63.pdf>. Acesso em: 01/08/2020.
} 
O local onde fora construído o Recolhimento ficava na esquina da antiga Rua de Santa Teresa (Fig. 7-10), que teve sua denominação alterada para Rua do Carmo (atualmente Roberto Simonsen), por proposta do vereador Malaquias Rogério de Salles Guerra que, como forma de homenagear a inauguração do Recolhimento, "sugeriu [em sessão da Câmara realizada no mesmo dia da inauguração] que a denominação de 'Santa Teresa' fosse aplicada à Rua Detrás da Sé, antiga Rua Detrás do Santíssimo"26.

Figura 7: Recorte da planta da cidade de São Paulo, levantada pela Companhia Cantareira de

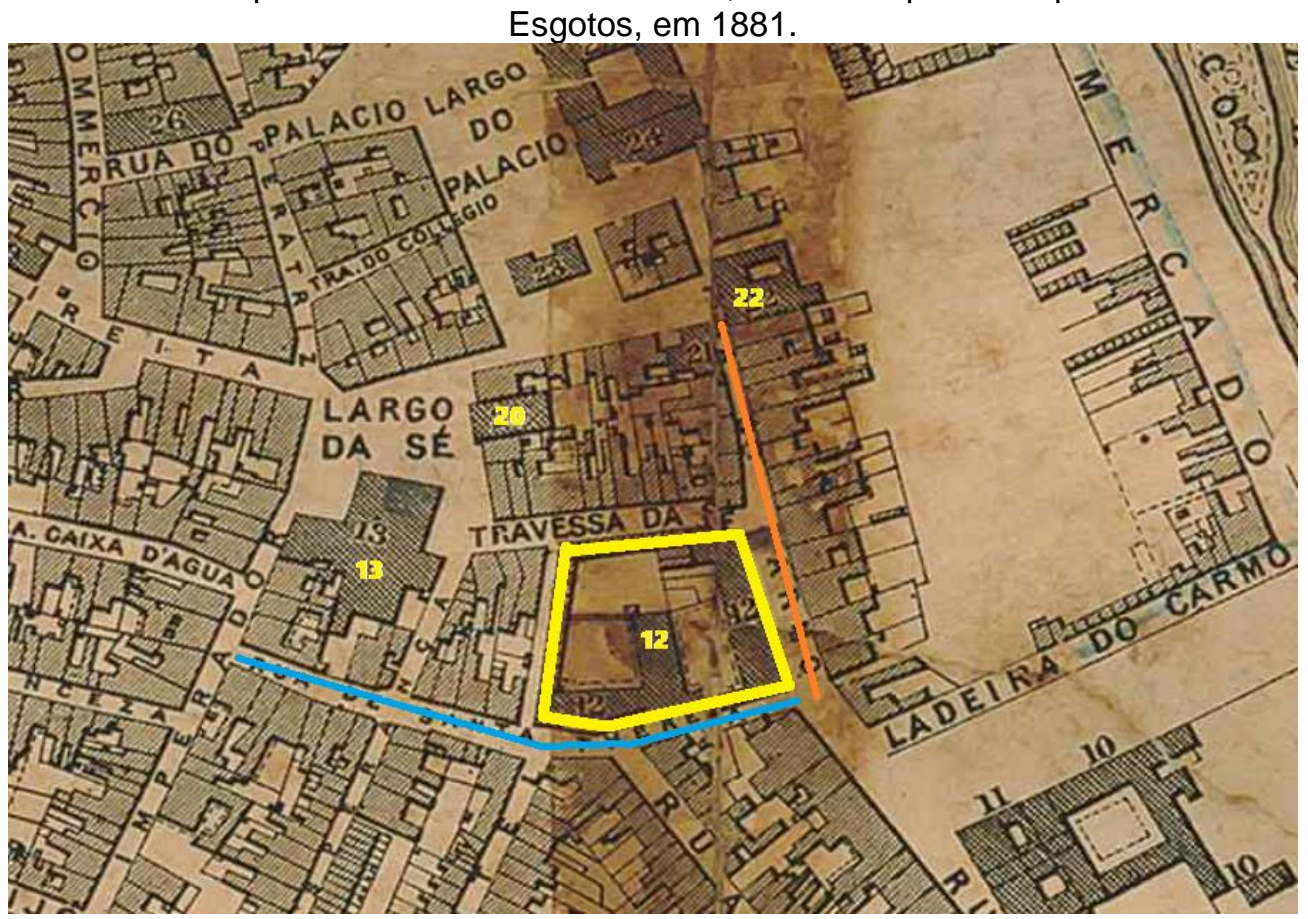

Fonte: Histórico Demográfico do Município de São Paulo, Secretaria Municipal de Desenvolvimento Urbano, 2010.

Em destaque no o 12 está a área onde ficava o Recolhimento de Santa Teresa; a linha azul representa o trajeto da Rua de Santa Teresa e, em laranja, a Rua do Carmo. À esquerda, o no 13 indica o local da antiga Igreja da Sé e o oㅡ 20 a Igreja de São Pedro dos Clérigos (ambas demolidas no início da década de 1910). Acima, o no 22 na Rua do Carmo indica a sede do

Palácio Episcopal, entre 1880 e 1909, no imóvel que anteriormente havia pertencido à Marquesa de Santos, Domitila de Castro Canto e Melo (1797-1867) e, sucessivamente, a seu filho Felicio.

${ }^{26}$ Dicionário de Ruas - Arquivo Histórico Municipal de São Paulo. Disponível em: $<$ https://dicionarioderuas.prefeitura.sp.gov.br/logradouro/rua-santa-teresa $>$. Acesso em: 25/06/2019. 
Figura 8: Rua de Santa Teresa em direção à Rua do Carmo. À esquerda, lateral do Recolhimento de Santa Teresa e, à direita, esquina da antiga Rua das Flores. Aurélio Becherini, c. 1915.

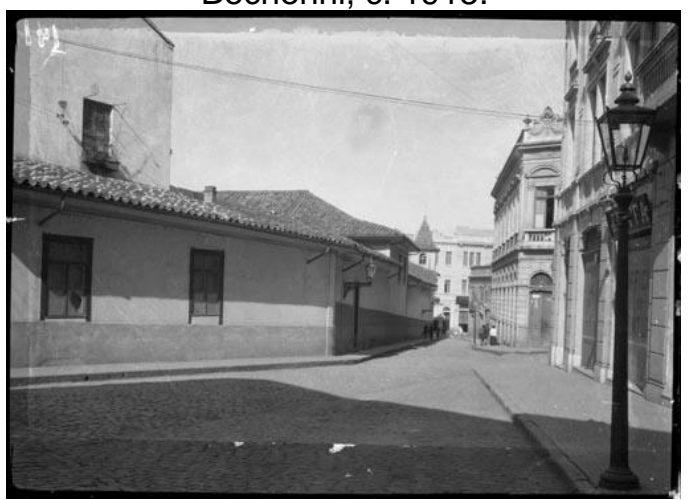

Fonte: Acervo Fotográfico do Museu da Cidade de São Paulo.
Figura 9: Fotografia tirada da esquina da Ladeira do Carmo em direção ao Pátio do Colégio. Ao centro, em segundo plano, esquina da Rua Santa Teresa e torre do Recolhimento. Aurélio Becherini, c. 1925.

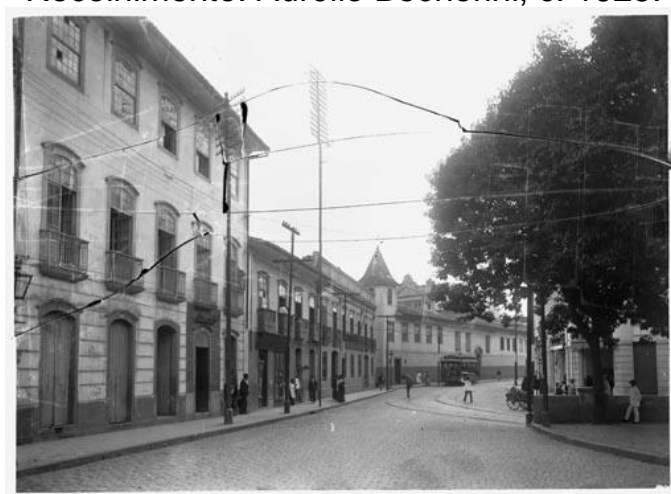

Fonte: Acervo Fotográfico do Museu da Cidade de São Paulo.

Figura 10: Recolhimento de Santa Teresa (séc. XIX/XX). Benedito Calixto de Jesus. Óleo sobre tela, $45 \times 58,5 \times 4,5 \mathrm{~cm}$.

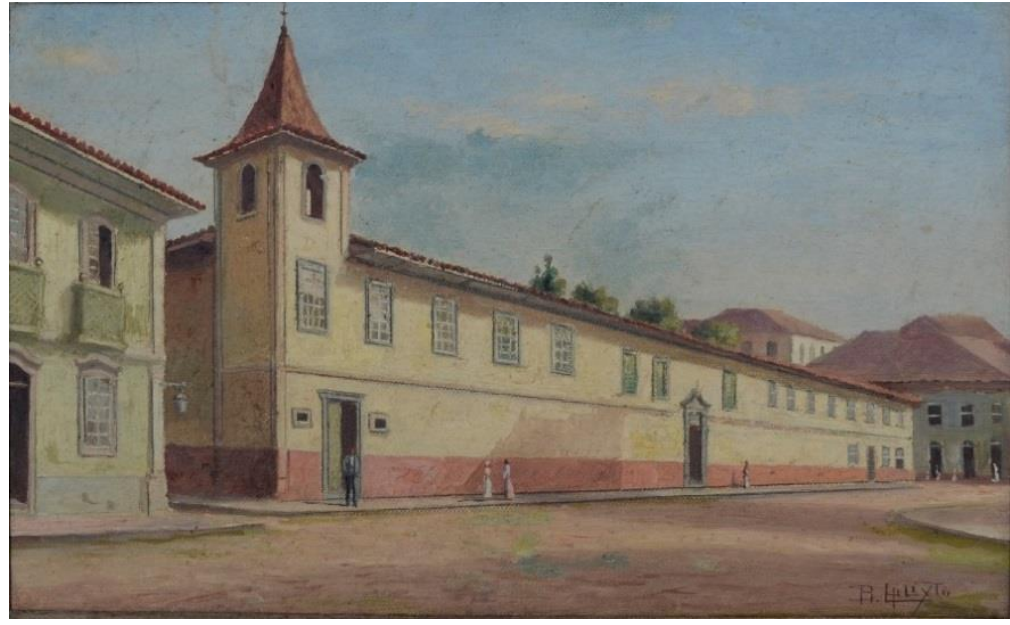

Fonte: Acervo Museu de Arte Sacra de São Paulo. Fotografia Iran Monteiro.

Em 1913, Dom Duarte trouxe três religiosas do Convento de Santa Teresa do Rio de Janeiro para implantar no Recolhimento as regras das carmelitas, tornando-o o Mosteiro Professo da Ordem das Carmelitas Descalças de Santa Teresa ${ }^{27}$.

${ }^{27}$ O Recolhimento da Luz, onde o Museu de Arte Sacra se encontra atualmente, foi fundado em 1774 pelo Frei Antônio de Sant'Ana Galvão e pela irmã Helena Maria do Espírito Santo com mais duas religiosas oriundas do Recolhimento de Santa Teresa. Frei Galvão, à época, era designado confessor do Recolhimento de Santa Teresa (MOSTEIRO DA LUZ, 2020). 
Com a necessidade de um novo espaço mais adequado para o convento, as religiosas se mudaram provisoriamente, em 1918, para o bairro da Penha ${ }^{28}$.

$O$ ato de inauguração do novo Palácio da Cúria foi realizado em 22 de abril de 1920, às 14 horas. Com projeto do arquiteto Abelardo Soares Caiuby, ao valor de cerca de 500:000\$000 (quinhentos contos de réis), o edifício tinha 20 metros de frente por cerca de 60 metros de fundos (O Estado de S. Paulo, n. $14.372,1918$, p. 5 ) e possuía dois andares, mansarda e duas entradas em formato de pórticos. Dentro, escadarias de mármore, móveis de imbuia feitos pelos salesianos de São Paulo e vitrais feitos pela Casa Garcia (Fig. 12-13).

Segundo o artigo publicado no jornal O Estado de S. Paulo, em 27 de março de 1920, o Palácio foi considerado o primeiro edifício de uso exclusivo para a Cúria no Brasil uma vez que, nas outras dioceses, todas as repartições eclesiásticas funcionavam ou nos palácios episcopais ou nas respectivas catedrais.

O artigo ainda traz interessante descrição do interior do imóvel:

“(...) Não era possível, pois, que essas repartições se acomodassem no velho pardieiro, que é o antigo e bissecular convento de Santa Thereza.

O edifício da Cúria faz honra à nossa capital.

(...) À entrada deparamos com um magnífico "hall" com a portaria, no andar térreo. Dois portões da frente, um é particular do sr. arcebispo e outro para o público.

A primeira sala pertence à procuradoria da mitra, com o respectivo "guichet" para o empregado, sala para o guarda-livro, galeria para o arquivo, gabinete do procurador e sala reservada para o mesmo. Em frente vimos os salões para a Caixa Pia e chancelaria, com o gabinete de recepção.

A seguir notam-se as repartições do secretário geral, observandose 0 arquivo eclesiástico com as suas galerias muito bem trabalhadas e 4 salões.

(...) Os portões, esquadrias e painéis são de imbuia executados pelas oficinas salesianas de S. Paulo; os vitrais são fornecidos pela "Casa Garcia", sobressaindo um que representa a fundação de São Paulo.

No $1^{\circ}$ andar, cujo acesso é por escadarias de mármore, vimos a biblioteca, sala do secretário particular, sala particular do arcebispo, salões, gabinete e repouso.

O mobiliário é muito fino e rico.

${ }^{28}$ Em 1923, Dom Duarte inaugurou o Convento das Carmelitas no bairro de Perdizes, onde está hoje a Pontifícia Universidade Católica de São Paulo (PUC-SP). Na década de 1940, as irmãs foram transferidas para o Mosteiro construído no bairro do Jabaquara (História da Paróquia Coração Imaculado de Maria - PUC-SP. Disponível em: <https://capelapuc.org.br/historia>. Acesso em: 25/06/2019). 
Em frente estão as acomodações da vigaria geral com três salas: expediente, trabalho e recepção, seguindo-se da sala do trono, onde efetuam as reuniões do clero, sob a presidência do arcebispo.

(...) As oficinas do arquivo estão instaladas num $2^{\circ}$ andar, aproveitado pelas sobras das salas próximas ao telhado.

Obedecendo às regras de higiene e dando uma ótima impressão ao visitante, o novo edifício da Cúria Metropolitana de São Paulo vai ser o primeiro do Brasil" (O Estado de S. Paulo, n. 15.057, 1920, p. 7).

A revista $A$ Cigarra, em sua edição № 135 de 01 de maio de 1920, apresenta algumas imagens relacionadas à inauguração do Palácio da Cúria, três delas permitindo ver aspectos do edifício (Fig. 11-13).

Figura 11: Palácio da Cúria Metropolitana.

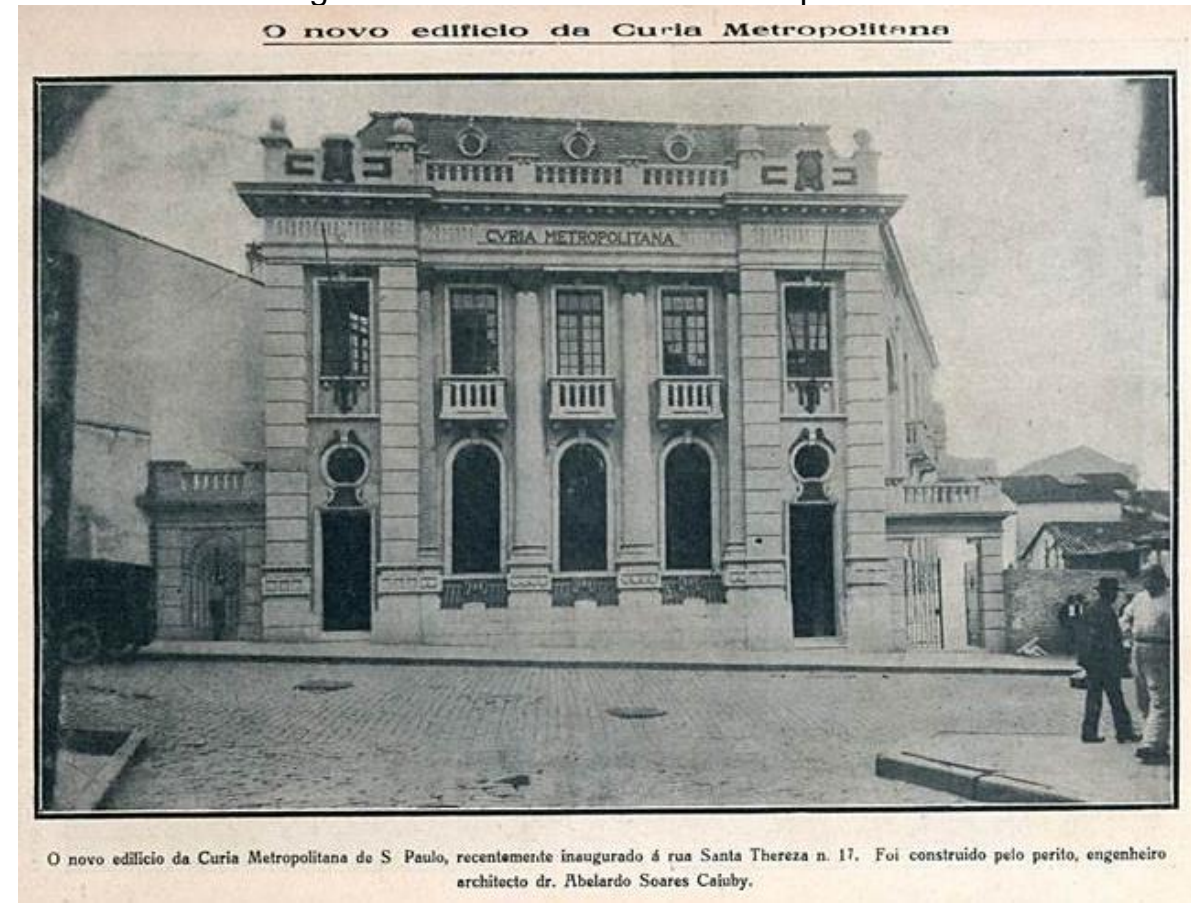

Fonte: Revista A Cigarra, 1920, p. 34. Segundo a legenda original da foto, o recém inaugurado Palácio estava localizado à Rua Santa Teresa, n. 17. 
Figura 12: Vista do hall com escadaria que dá acesso ao pavimento superior do Palácio da Cúria.

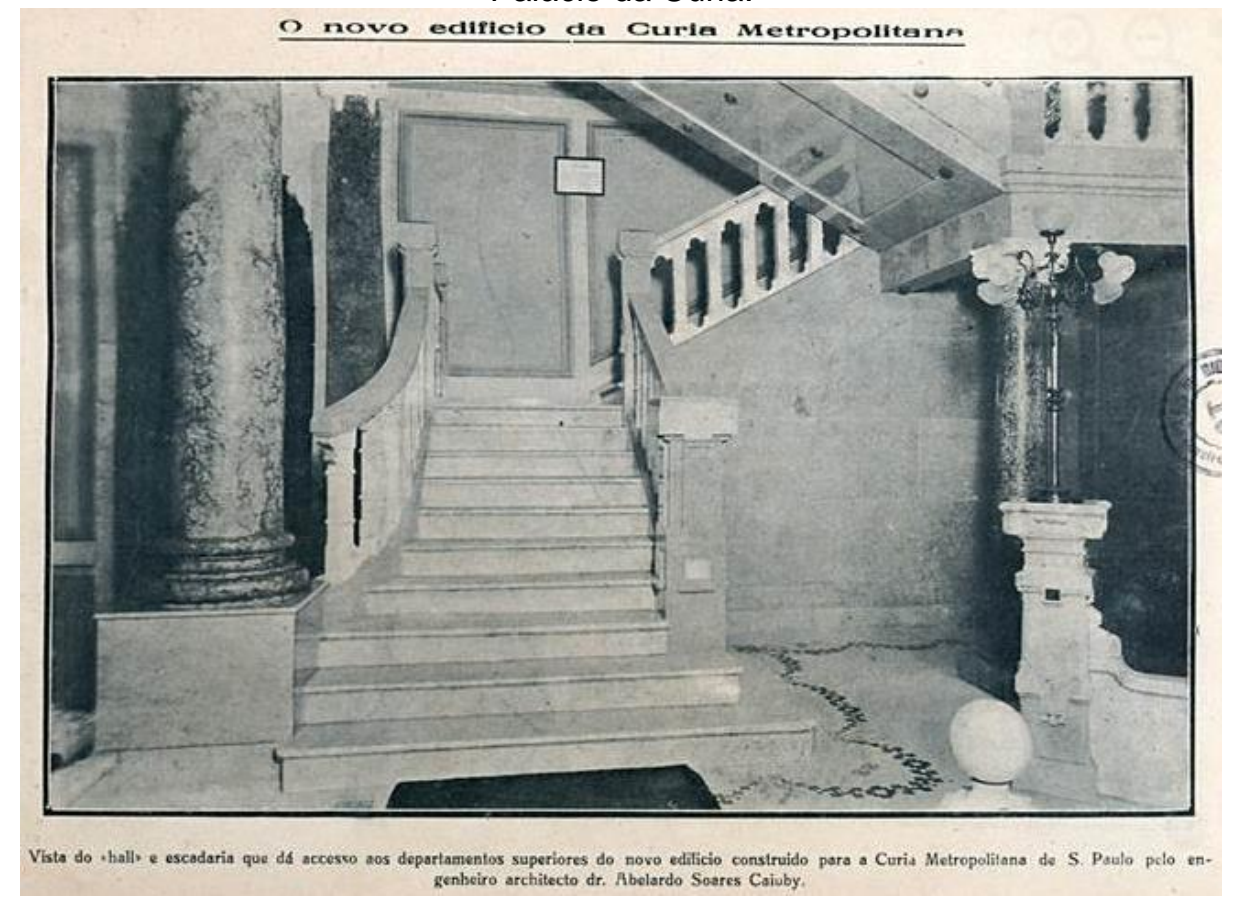

Fonte: Revista A Cigarra, 1920, p. 35. Legenda original abaixo da imagem.

Figura 13: Vitral criado pela Casa Garcia, inspirado na pintura "Fundação de São Paulo", de Oscar Pereira da Silva.

Inauguração do Novo Edificio da Curia Metropolitana

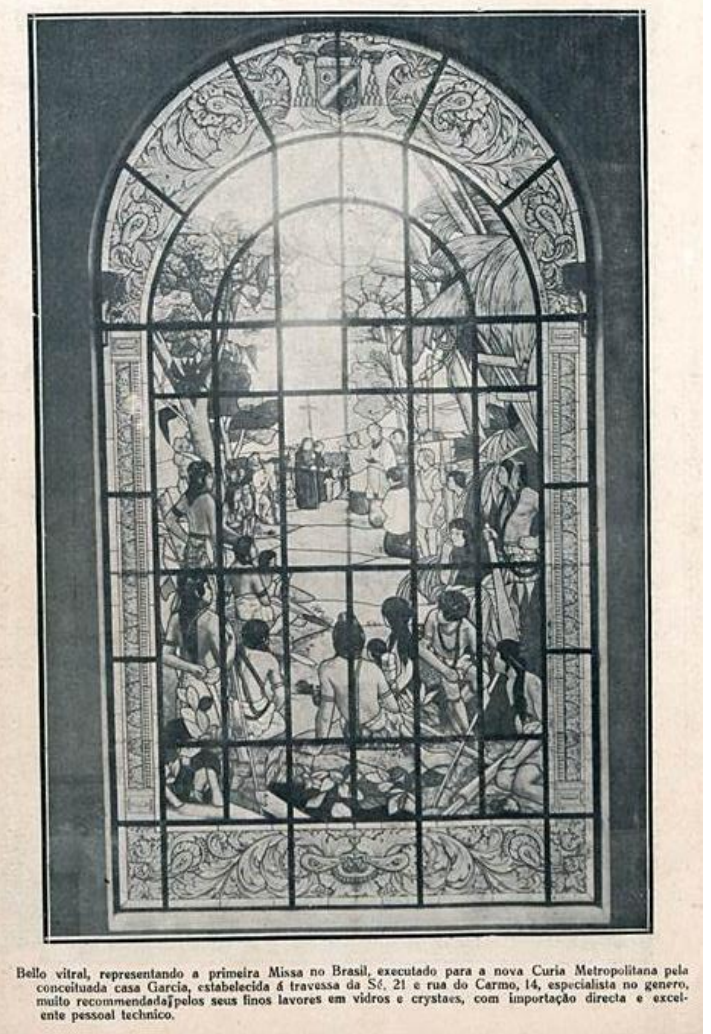

Fonte: Revista A Cigarra, 1920, p. 36. Segundo a legenda original da imagem, a Casa Garcia possuía lojas na Travessa da Sé e na Rua do Carmo, ambas localizadas no entorno do Palácio, e era especialista em trabalhos com vidros e cristais importados. 
Figura 14: Membros do clero e outras pessoas na inauguração do Palácio da Cúria.

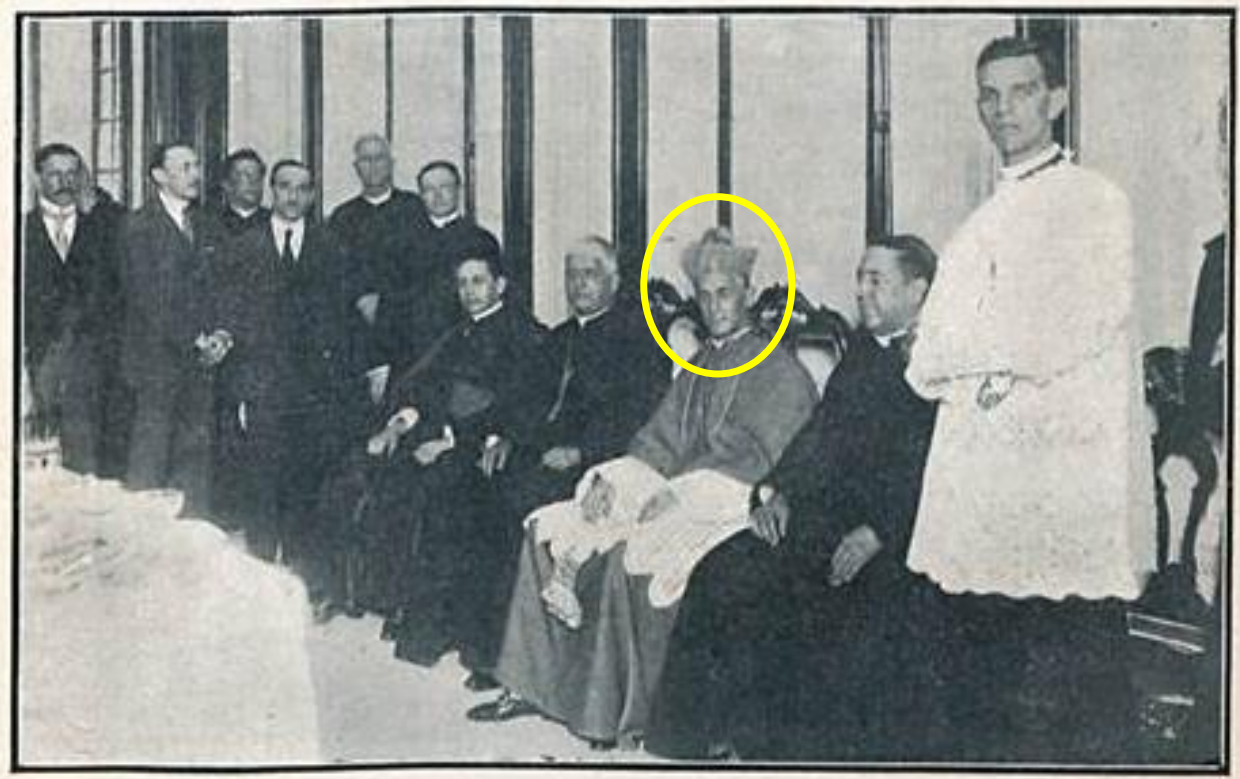

Grupo photographado por occasião da inauguraçăo do novo editicio mandado construir para a Curía Metropolitana de S Paulo, \& rua Santa Thereza n. 17. Veem-se: sentados s exca. revma. sr. D. Duarte Leopeildo, arcebispo de S. Paulo, tendo of sua direita o exmo. Bispo de S. Carlos, D. Jose Marcondes Homem de Mello; e Monsenhor Emilio Teixeira, vigario geral e mais pessoas gradas; á sua esquerda o exmo. Bispo do Espirito Santo, D. Benedicto de Sousa e Conego Pericles Barbosa, vigario das Perdizes.

Fonte: Revista A Cigarra, 1920, p. 33. A legenda original da imagem traz os nomes de alguns convidados para a inauguração do Palácio. Em destaque, Dom Duarte.

Figura 15: Membros do clero na inauguração do Palácio da Cúria.

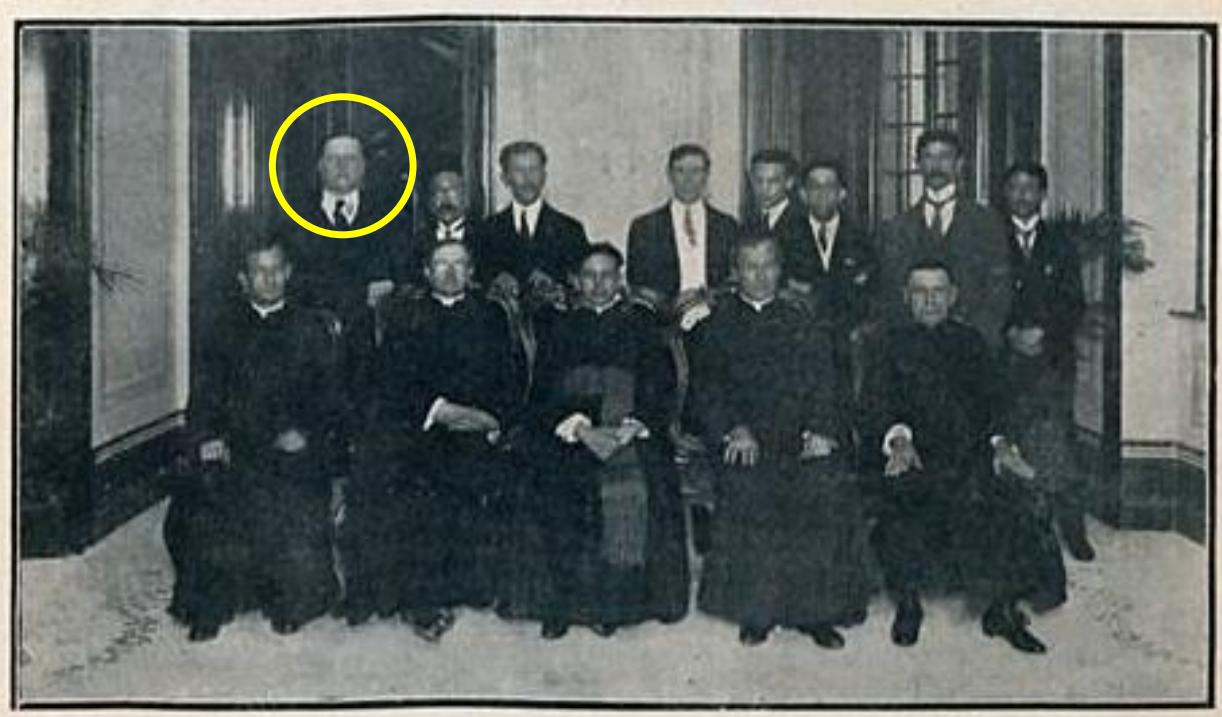

Outro grupo tirado por occasiso de ser inaugurado o novo edilicio da Curia Metropolitana de S. Paulo. Veem se: sentados, da esquerda para a direlta, Padre Allredo Mecca, lunccionario da Curia, conego D. Martins La. deira, secretario do arcebispado, Monx. Emilio Teixeira, vigario geral; Mons. Pereira de Barros, Chanceller da Curia; conego jose Rodrigues de Carvalho, Onicial. Em pe: Francisco Salles Collet archivista; Manueto Mibacete, porteiro; Octavio Braga, guarda-livros; Áltonso de Barros, Fimleto Paneto, Benedicto Junqueira e Rodolpho Rrogào, funccionarios.

Fonte: Revista A Cigarra, 1920, p. 33. Abaixo, na legenda original da imagem, nos permite identificar Francisco de Salles Collet e Silva (em destaque), primeiro diretor do Arquivo e do Museu da Cúria, já citado acima à época como "o arquivista da Cúria". 
Segundo o Inventário de móveis, objetos de arte, alfaias, ornamentos e utensílios, realizado em 31 de dezembro de 1920 pelo Mons. Agnello José de Moraes (ACMSP, Fundo Chancelaria/ Patrimônio 06-03-041), o imponente prédio abrigava os seguintes cômodos:

Tabela 1: Divisão dos cômodos do Palácio da Cúria por andar

\begin{tabular}{|c|c|c|}
\hline TÉRREO & 1 ANDAR & MANSARDA \\
\hline Entrada & Galeria & \multirow{12}{*}{$\begin{array}{l}\text { Oficinas de Arquivo: } \\
\text { - Sala no } 1 \\
\text { - Sala no } 2 \\
\text { - Sala no } 3 \\
\text { - Sala no } 4 \\
\end{array}$} \\
\hline Portaria & Capela & \\
\hline Galeria & \multirow{4}{*}{$\begin{array}{l}\text { Dependências do } \\
\text { Arcebispo: } \\
\text { - Sala de espera } \\
\text { - 1ㅇ Gabinete } \\
\text { - 2 Gabinete } \\
\text { - 3ํ Gabinete } \\
\text { - Sala do Trono }\end{array}$} & \\
\hline $\begin{array}{l}\text { Procuradoria da Mitra: } \\
\text { - Sala da Contabilidade }\end{array}$ & & \\
\hline $\begin{array}{l}\text { - Sala do Procurador } \\
\text { - Gabinete do } \\
\text { Procurador }\end{array}$ & & \\
\hline \multirow{2}{*}{$\begin{array}{l}\text { Chancelaria: } \\
\text { - Sala do Chanceler } \\
\text { - Sala do Vice- } \\
\text { Chanceler } \\
\text { - Sala do } 1^{\circ} \text { Notório } \\
\text { - Sala do } 2^{\circ} \text { Notório }\end{array}$} & & \\
\hline & $\begin{array}{l}\text { Vigararia Geral: } \\
\text { - 10 Gabinete } \\
\text { - 2 Gabinete } \\
\text { - 3ํ Gabinete }\end{array}$ & \\
\hline $\begin{array}{l}\text { Caixa-Pia (Sala do } \\
\text { Tesoureiro-Mor) }\end{array}$ & Sala de Reuniões & \\
\hline Hall & & \\
\hline Arquivo & & \\
\hline Copa & & \\
\hline Escadaria & & \\
\hline
\end{tabular}

Fonte: ACMSP, Fundo Chancelaria/ Patrimônio 06-03-041. Organização Luciana Barbosa, 2019. 
Figura 16: Projeto aprovado: fachada (elevação). Abelardo Soares Caiuby, 1920.

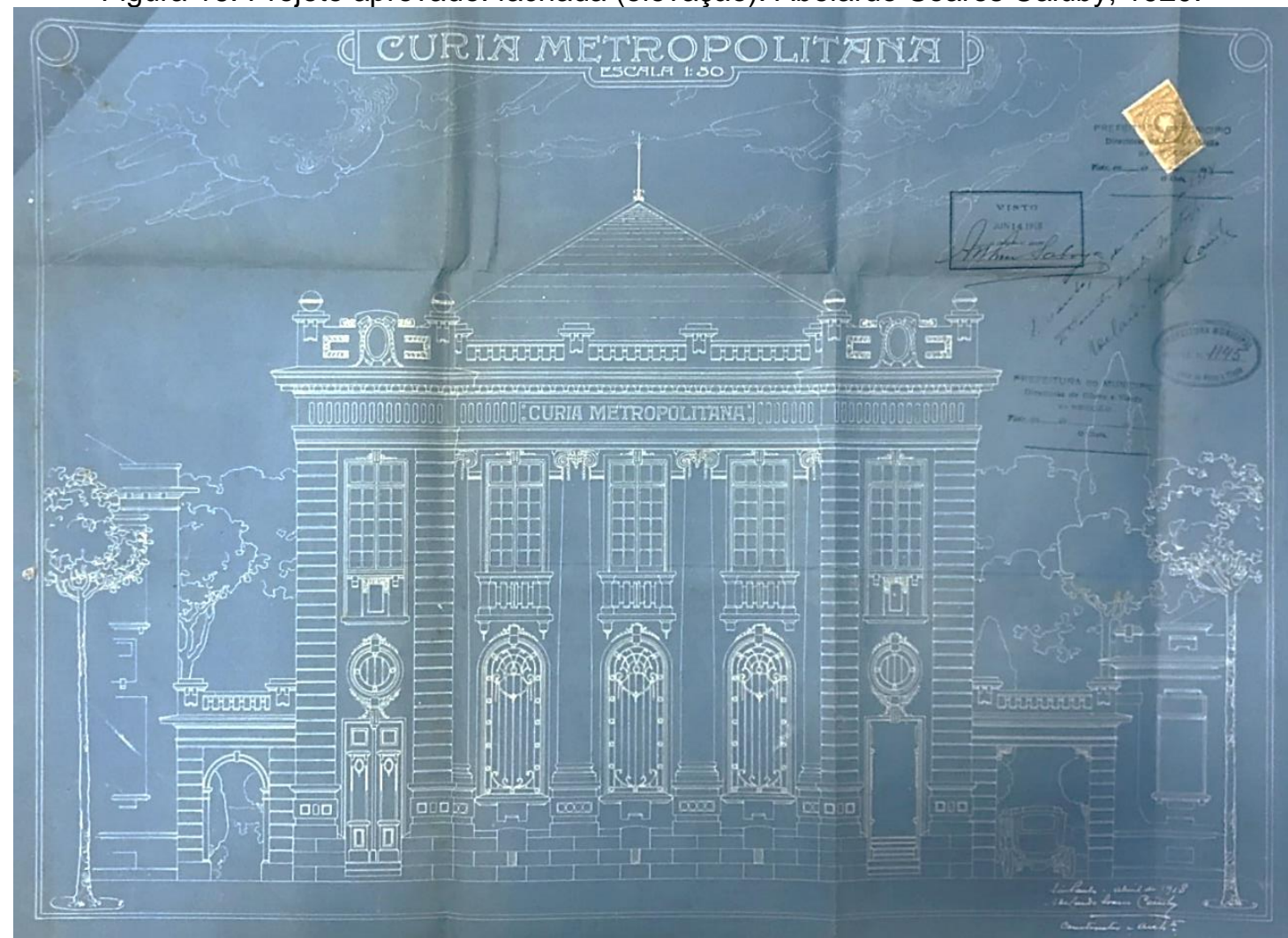

Fonte: Acervo AHMSP. Fotografia Luciana Barbosa, 2019.

Figura 17: Projeto aprovado: planta do $1^{\circ}$ e $2^{\circ}$ pavimentos. Abelardo Soares Caiuby, 1920.

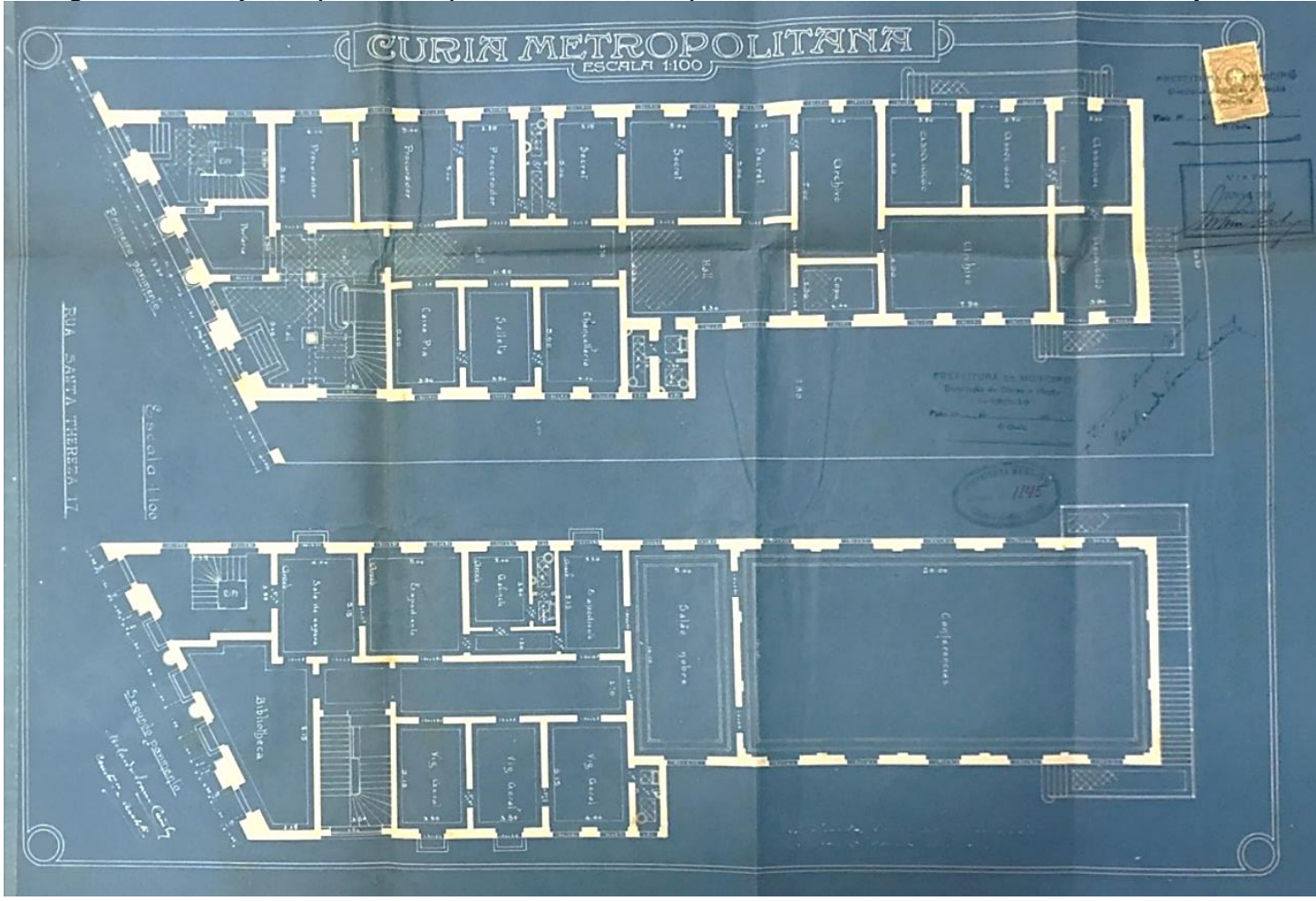

Fonte: Acervo AHMSP. Fotografia Luciana Barbosa, 2019. O detalhamento da planta do Palácio da Cúria será abordado no Capítulo 3.3.1. 
De acordo com o inventário, todos os cômodos eram devidamente decorados com móveis, objetos de arte, alfaias e ornamentos diversos, como por exemplo, uma estátua de São Sebastião feita por Leopoldo e Silva, localizada no hall de entrada, e pinturas de Benedito Calixto de Jesus nas dependências do Arcebispo.

Apesar de este inventário não indicar salas utilizadas pelo Museu da Cúria exclusivamente, dentro da relação de mobiliário do Arquivo constam 10 mostruários para o museu, indicando que já existia uma ideia de expografia para os objetos presentes junto aos documentos e um início da concepção do museu.

No regimento interno ${ }^{29}$ da Cúria, no Capítulo 4 referente ao Arquivo Geral, não há nenhuma menção ao Museu nem a algum trabalho específico a ser desenvolvido pelos arquivistas a respeito dos objetos recolhidos; há apenas artigos referentes ao trabalho e tratamento de livros, papéis e documentos.

A construção de um novo e ostentoso edifício para a Cúria visava não só acomodar melhor as repartições eclesiásticas como demonstrar a força e poder da Igreja Católica em São Paulo.

Também é possível presumir que a coleção de documentos e objetos presentes no Arquivo tenha sido um dos motivos para a construção de um novo edifício para a Cúria, a fim de abrigar e expor adequadamente os documentos e objetos que estavam sendo recolhidos por Dom Duarte e Francisco de Salles Collet e Silva.

\footnotetext{
${ }^{29}$ Regimento publicado no periódico Boletim Eclesiástico, n. 6, ano XII, nov./dez., 1920, p. 165166. O Boletim Eclesiástico foi criado por D. José de Camargo Barros em 1905 como veículo de comunicação entre o clero da Diocese. Em 1909 passou a circular apenas entre a Arquidiocese e suas dioceses sufragâneas até 1956, quando o cardeal Dom Carlos Carmelo de Vasconcelos Motta o substituiu pelo jornal O São Paulo.
} 
Figura 18: Vista do Palácio da Cúria. BJ Duarte, 1934.

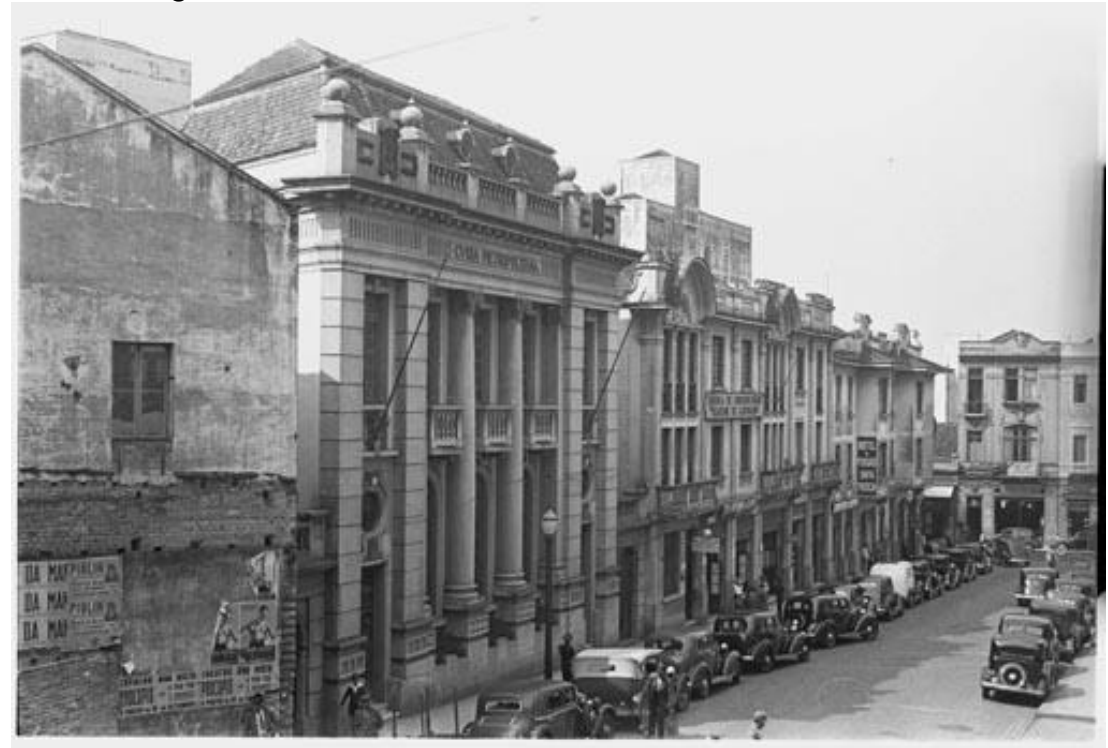

Fonte: Acervo Fotográfico do Museu da Cidade de São Paulo.

Figura 19: Região central em dois tempos: à esquerda em 1930 e, à direita, em 1954, com a

Praça Clóvis Bevilácqua já criada. Em destaque nas duas imagens, a localização do Palácio da Cúria.

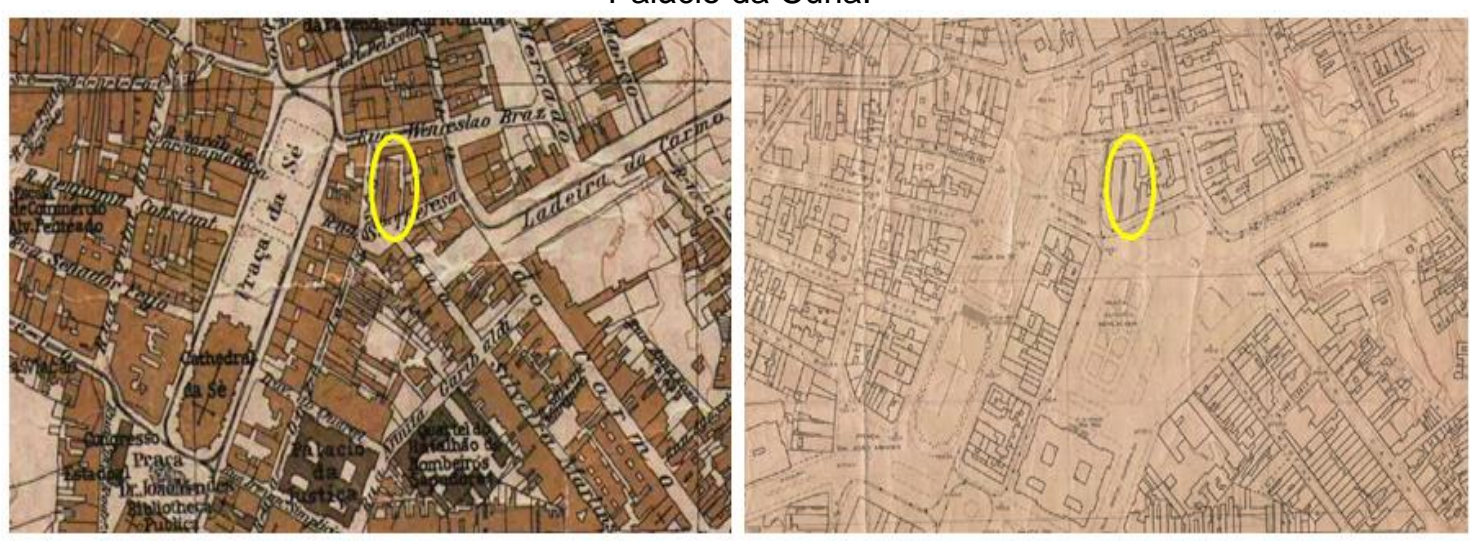

Fonte: GeoSampa - http://geosampa.prefeitura.sp.gov.br/PaginasPublicas/_SBC.aspx.

A Cúria Metropolitana funcionou neste edifício até início da década de 1970, quando a área foi demolida em caráter de urgência pelo então Prefeito de São Paulo Miguel Colassuono, para a utilização do espaço como um canteiro de obras do metrô (Fig. 20). Os edifícios das ruas Santa Teresa e Irmã Simpliciana foram derrubados para ampliação da Praça Clóvis Bevilácqua. 
Figura 20: Demolição de edifícios na Rua Irmã Simpliciana, à esquerda, e Rua Santa Teresa à direita, com o Palácio da Cúria próximo à esquina. Camerindo Ferreira Máximo, 1974.

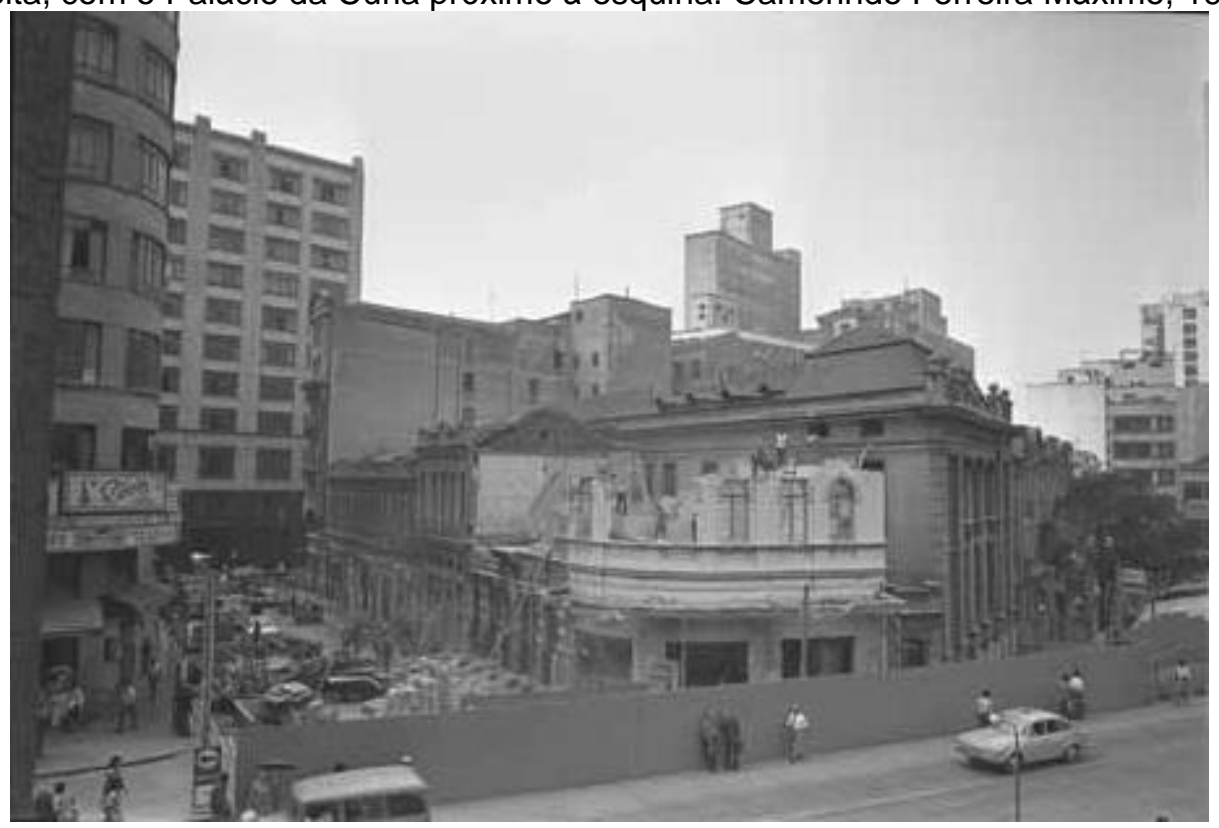

Fonte: Acervo Fotográfico do Museu da Cidade de São Paulo.

Com a demolição do edifício, parte das repartições, incluindo o Arquivo da Cúria, foram alocadas num edifício na Praça Clóvis Bevilácqua, n.37, próximo ao Palácio da Justiça. Após esse período de transição, a Cúria foi estabelecida definitivamente em um casarão no bairro de Higienópolis, onde permanece até os dias atuais.

\subsubsection{O Arquivo da Cúria}

Durante o século XVII havia em São Paulo a Câmara Eclesiástica, responsável pela produção de diversos documentos eclesiásticos, como livros de batismo e casamento, considerado o primeiro arquivo eclesiástico paulistano (SOUZA, 2014, p.435). Em 1746, ano seguinte à criação da diocese de São Paulo e do Cabido da Sé Catedral, organizam-se estes dois arquivos.

A fim de cumprir as determinações estabelecidas pelo Código de Direito Canônico publicado em 1917, Dom Duarte inicia uma reorganização das repartições eclesiásticas, que incluiu a fundação de um arquivo geral da Arquidiocese em $1^{\circ}$ de abril de 1918 (SOUZA, 2014, p.436). 
Seu primeiro diretor foi o comendador Francisco de Salles Collet e Silva, nascido em 14 de setembro de 1873, filho de Francisco Carlos da Silva, diplomado pela Escola Central de Engenharia de Lyon, e D. Eugénie Marle Josephine Collet e Silva. Casou-se com Alice Gomide em 30 de janeiro de 1904, com quem teve seis filhos. Francisco Collet e Silva recebeu do Papa Pio XI a comenda da Ordem de São Gregório Magno. Faleceu em 19 de outubro de 1934.

Segundo Maria Regina da Cunha Rodrigues, Francisco Collet conheceu Dom Duarte quando este ainda era pároco de Santa Cecília (1895-1904), igreja frequentada pela família de Francisco. Os dois nutriam interesses espirituais e culturais comuns, "pois ambos tinham o mesmo apaixonante interesse pelas coleções de documentos" (RODRIGUES, 1965, p. 360), o que possivelmente levou à ideia de organização e criação do Arquivo da Cúria.

Já num artigo publicado no jornal católico O Diário, de 1937 (p. 3), conta que o Padre Péricles Barbosa, da paróquia de São Geraldo (Perdizes), apresentou a Dom Duarte seu amigo Francisco Collet, quem o pároco acreditava ser a pessoa ideal para o trabalho de organização da "papelada antiquíssima que jazia atirada a um canto, coberta de poeira".

Uma das principais ações desenvolvidas por Collet à frente do Arquivo da Cúria foi organizar o antigo arquivo musical da Catedral de São Paulo, constituído em 1774 com a chegada do maestro português André da Silva Gomes (1752-1844) para exercer a função de mestre da capela (SOUZA, 2014, p. 437).

Segundo CASTAGNA (1999, p. 6) a ordenação deste acervo, composto principalmente de música religiosa, impressa e manuscrita, de fins do século XVII a meados do século XX, foi iniciada por Collet e Silva em 1922 “(...) quando mandou encadernar a partitura de um hino composto por D. Pedro I, 'oferecido ao $3^{\circ}$ Regimento de Milícias', cuja cópia foi realizada em um papel fabricado em $1808^{\prime \prime 30}$.

\footnotetext{
30 Os manuscritos musicais do ACMSP estavam em um baú empacotados em 16 volumes, sem ordem definida, assim permanecendo até 1996, quando o professor da UNESP Paulo Castagna iniciou, com seu grupo de pesquisa, um trabalho de organização e catalogação a partir de quatro Séries da Seção de Música do ACMSP. Essa pesquisa inicial e o acervo de Música do ACMSP estão disponíveis ao público. Cf. CASTAGNA, Paulo. A Seção de Música do Arquivo da Cúria Metropolitana de São Paulo. Brasiliana, Revista Quadrimestral da Academia Brasileira de Música, Rio de Janeiro, n.1, p.16-27, jan. 1999.
} 
Em 1921, com a nova proposta de organização dos documentos da Cúria, Dom Duarte teve a iniciativa inédita de solicitar que cada paróquia realizasse a duplicata dos livros de batismo e casamento e enviasse à Cúria um dos exemplares, para que houvesse a preservação das informações, caso acontecesse algo com a paróquia. Esta prática acontece até os dias de hoje.

Além de solicitar os livros duplicados, Dom Duarte também decretou que as paróquias e seminários enviassem ao Arquivo todos os documentos mais antigos que possuíssem, também visando sua preservação.

Desde sua criação, o Arquivo se tornou referência em organização de documentos eclesiásticos, sendo constantemente citado em artigos de jornais e revistas. Em 1924, Dom Sebastião Leme, arcebispo coadjutor do Rio de Janeiro, publicou na revista Illustração Brasileira a circular "A defesa do patrimônio artístico das Igrejas", onde chama a atenção dos vigários e outros administradores dos bens eclesiásticos para as leis canônicas, por vezes esquecidas, a respeito da preservação do patrimônio. Ao recomendar a organização dos arquivos e bibliotecas dos seminários e repartições eclesiásticas, além da formação de museus, cita como exemplar o trabalho executado no arquivo da Cúria paulista:

"Com organização e método, como obra de inteligência e amor dos documentos históricos, dizem entendidos que o arquivo da Cúria Metropolitana de S. Paulo poderia figurar com brilho ao lado dos mais notáveis do orbe cristão. Dele pode escrever o Cardeal Gasquet, quando aqui esteve, há dois anos, o seguinte juízo crítico: 'Não conheço coisa mais perfeita. E sou arquivista'. São palavras que consagram, por virem de um técnico universalmente reputado, ex-chefe de um dos mais célebres arquivos da Inglaterra e ex-Prefeito da Biblioteca Vaticana" (Illustração Brasileira, n.44, 1924, p. 20).

O Cardeal Gasquet, citado acima por Dom Sebastião Leme, visitou o Palácio da Cúria em 12/08/1922, deixando a seguinte mensagem no livro de tombo da Arquidiocese: "To F. de Salles Collet e Silva with very congratulation upon the way the Episcopal Archives are arranged. I have never seen anything better" (ACMSP, Livro de Tombo da Arquidiocese, 06-01-006, p. 61). 
Além do Cardeal Gasquet, outro representante da Santa Sé, o embaixador Francesco Cherubini, elogiou o trabalho executado na Cúria em visita ao Brasil em 25 de setembro de 1922, para as festividades do $1^{\circ}$ Centenário de Independência. Visitou todas as repartições eclesiásticas do Palácio da Cúria, e "(...) demorando-se no Arquivo e Museu, se manifestou satisfeito" (ACMSP, Livro de Tombo da Arquidiocese, 06-01-006, p. 64).

Após a demolição do Palácio da Cúria na década de 1970, o Arquivo foi levado, junto com outras repartições, para um edifício na Praça Clóvis Bevilácqua. Em 1984, o Arquivo foi transferido para o bairro do Ipiranga, dentro do complexo onde funcionava anteriormente o Seminário Central e hoje abriga além do Arquivo e da Biblioteca Teológica Dom José Gaspar, o Campus Ipiranga da PUC-SP, a Paróquia da Imaculada Conceição, o Tribunal Eclesiástico, a Faculdade de Direito Canônico São Paulo Apóstolo, o Seminário de Teologia, a sede da Região Episcopal Ipiranga e a Casa São Paulo (de acolhimento de padres idosos).

Atualmente, o Arquivo da Cúria, chamado oficialmente de Arquivo Metropolitano Dom Duarte Leopoldo e Silva, é o maior arquivo diocesano do Brasili1 por conter "a maior diversidade de séries documentais e processos diversos: 57 [tipos documentais ao todo, entre registros de Batismo, Matrimônio e Óbito, processos eclesiásticos, fotografias, partituras musicais, plantas e projetos arquitetônicos, testamentos e inventários, a maioria datada do final do século XVII" (O São Paulo, 2018). Além disso, há pastas referentes a cada paróquia que pertenceu à Arquidiocese de São Paulo.

"Quando criada, em 1745, a então Diocese de São Paulo abrangia os estados de São Paulo, Paraná, Santa Catarina, Rio Grande do Sul e Sul de Minas Gerais. Portanto, o Arquivo possui documentos dessas regiões pelo menos até o período de abrangência da Igreja particular de São Paulo" (O São Paulo, 2018).

\footnotetext{
31 O Arquivo da Cúria, hoje, em números: aproximadamente 4 milhões de registros de Batismo desde 1640; 2,5 milhões de registros de Matrimônio desde 1632; cerca de 300 mil registros de Óbito (anteriores à República); 12 mil livros manuscritos; 2 milhões de processos matrimoniais desde 1640; 5 mil processos de habilitação de ordenação desde 1686; cerca de 40 mil fotografias impressas desde 1871; 250 partituras musicais dos séculos XVIII e XIX; 4 mil plantas e projetos arquitetônicos de igrejas. Jornal $O$ São Paulo. 2018. Disponível em: <http://www.osaopaulo.org.br/noticias/ha-100-anos-arquivo-metropolitano-conta-a-historia-daigreja-em-sao-paulo>. Acesso em: 22/01/2020.
} 
Este grande volume de documentos recebido pelo Arquivo da Cúria ao longo das décadas o tornou importante fonte de pesquisa histórica, principalmente de informações anteriores à República, uma vez que não havia ainda a instituição dos cartórios, cabendo às paróquias os registros de nascimento, batismo, casamento e morte de suas freguesias.

A criação de um arquivo central para os documentos eclesiásticos e de um museu com objetos sacros recolhidos de diversas igrejas e instituições eclesiásticas (que será abordado com mais profundidade no Capítulo 3), nos revelam a faceta preservacionista de Dom Duarte que, mesmo estando diretamente envolvido nas mudanças políticas e arquitetônicas da cidade, fez questão de desenvolver instrumentos que conservassem a história eclesiástica de São Paulo.

\subsection{Dom Duarte e as Igrejas de São Paulo em tempos de romanização}

Para entendermos as ações executadas por Dom Duarte durante seu arcebispado é preciso compreender as orientações seguidas pela Igreja Católica em São Paulo desde antes da Proclamação da República, onde há um predomínio de um catolicismo ultramontano, ou romanizador (como vimos no Capítulo 1), que pauta a reforma clerical a partir de uma série de medidas para maior moralização do clero (WERNET, 1987, p. 91-92).

A diocese de São Paulo foi criada a partir do decreto de D. João V em 22 de abril de 1745, sancionado pelo Papa Bento XIV em dezembro do mesmo ano. A nova diocese abrangia os estados de São Paulo, Paraná, Santa Catarina, Rio Grande do Sul e Sul de Minas Gerais. Até sua criação, São Paulo pertencia à diocese do Rio de Janeiro. Ao longo dos anos, seu território foi diminuindo com a criação de outras dioceses, como a de Porto Alegre em 1848 e de Florianópolis em 1906. 
Com a criação da Província Eclesiástica de São Paulo, em 1908, a cidade de São Paulo é elevada a Arquidiocese $^{32}$, com seis dioceses sufragâneas ${ }^{33}$ : Taubaté, Campinas, Botucatu, São Carlos, Ribeirão Preto e Curitiba (esta última se tornou Arquidiocese em 1926). Nos anos seguintes, outras cidades do Estado de São Paulo tornaram-se dioceses, como Santos e Sorocaba em 1924; Bragança Paulista em 1925, Cafelândia (atual Lins) em 1926; Assis em 1928; Jaboticabal e Rio Preto em 1929.

Dom Duarte, em sua Carta Pastoral de 22 de outubro de 1908, na qual anuncia a nova Província Eclesiástica, enaltece o papel da diocese de São Paulo no cenário religioso brasileiro:

\begin{abstract}
"Não calaram ainda de todo os ecos da pomposa recepção com que nos acolhestes, à nossa volta da Cidade Eterna. Mais do que afeto e filial demonstração de acatamento, significam essas festas que o Bispo soubera interpretar, junto do Santo Padre, as vossas mais legítimas e piedosas aspirações. Trata-se, com efeito, de dar corpo a uma ideia desde há muitos anos acariciada, tratava-se de constituir uma nova Província Eclesiástica onde um único Bispo mal podia sopesar a responsabilidade de tantos encargos; tratava-se de impulsionar esse valente movimento religioso que tem feito de São Paulo um baluarte de fé e de piedade; de multiplicar, enfim, os centros de atividade católica, com desdobrar em seis a vastíssima Diocese de São Paulo" (ARQUIDIOCESE DE CAMPINAS, 2020).
\end{abstract}

Com a elevação de São Paulo a Arcebispado, o número de paróquias administradas por Dom Duarte diminui de 233 para 45 (ROMANO, 2007, p. 113). No entanto, esse movimento de expansão territorial religiosa estava de acordo com os ditames ultramontanos da Igreja Católica no Brasil.

O Estado de São Paulo, ao se destacar no cenário de progresso econômico, levou a Igreja a também querer fazer parte desta empreitada, com o desejo de ser a balança moral e social da política paulista:

\footnotetext{
32 Hoje, a Arquidiocese de São Paulo compreende apenas uma parte do Estado, abrangendo as dioceses de Campo Limpo, Guarulhos, Santa Amaro, Mogi das Cruzes, Santo André, São Miguel Paulista e Santos. A cidade de São Paulo é dividida em seis regiões episcopais: Belém, Brasilândia, Ipiranga, Lapa, Santana e Sé.

${ }^{3}$ Província Eclesiástica é o termo dado à reunião de igrejas diocesanas de uma mesma região. "A primeira diocese da província é a arquidiocese, cujo pastor é chamado arcebispo metropolitano ou metropolita. É ele quem preside a Província Eclesiástica, formada pela arquidiocese (chamada sede metropolitana) e pelas outras dioceses (chamadas sufragâneas)" (Diocese de Piracicaba. Disponível em: <https://diocesedepiracicaba.org.br/capa $\cdot$ asp?p=452>. Acesso em: 08/04/2021).
} 


\begin{abstract}
"A ereção da Província Eclesiástica em São Paulo confirmou, por um lado, a autonomia e o prestígio do estado paulista na república brasileira durante a primeira década do século XX. (...) Por outro lado, a criação da Província Eclesiástica atendeu aos projetos e às necessidades da Igreja que desde, pelo menos, o ano de 1904, pretendia criar novas dioceses no interior paulista para enfrentar os desafios suscitados ao catolicismo com a imigração, o crescimento demográfico, a expansão ferroviária e urbana, a extensão da economia cafeeira, o surgimento de novos líderes políticos, o avanço das ideias liberais, a demanda escolar e assistencial, a ação dos protestantes e os discursos anticlericais dos anarquistas" (AQUINO, 2012, p. 105).
\end{abstract}

A expansão territorial religiosa no Sudeste está relacionada aos aspectos políticos da época. Conforme a ferrovia ganhava força, ligando diversas cidades do interior paulista a São Paulo e ao porto de Santos, tornava-se fundamental a presença da Igreja Católica nas mais diversas regiões, a fim de fortalecer sua influência religiosa, criando novas paróquias e dioceses para controlar o clero e manter os fiéis afastados das novas crenças, receosa de que os novos valores que se disseminavam com a modernidade laica os afastassem da religião.

Segundo ROSENDHAL (2006), "os templos, os cemitérios, os pequenos oratórios à beira da estrada, os caminhos percorridos pelos peregrinos, representam, entre outros, os meios visíveis pelos quais o território [religioso] é vivenciado e reconhecido como tal".

Conforme explica AQUINO (2012) sobre a expansão como estratégia da Igreja:

\begin{abstract}
"A expansão territorial e institucional da Igreja no Brasil da Primeira República, redimensionando lugares físicos, políticos e discursivos, foi assumida pela Cúria Romana e pelo episcopado brasileiro como a estratégia basilar da reforma ultramontana do catolicismo e da renovação da presença eclesiástica na sociedade como se percebe na análise dos principais documentos do período" (AQUINO, 2012, p. 102).
\end{abstract}

A respeito da necessidade de se expandir, Zeny Rosendhal explica que a territorialidade é um conjunto de práticas desenvolvido por grupos dominantes a fim de controlar certos territórios e que "é nesta poderosa estratégia geográfica de controle de pessoas e coisas, ampliando muitas vezes o controle sobre espaços, que a religião se estrutura enquanto instituição, criando territórios seus" (ROSENDHAL, 2002, p. 59). 
Ou seja, em tempos de Romanização, a Igreja Católica brasileira necessitava não só manter seu status político, como também ampliar seu território de atuação para manter-se relevante. E o papel da elite paulista, principalmente aquela ligada à cafeicultura desde o final do século XIX, foi fundamental para legitimar seu poder, assumindo a reforma ultramontana da Igreja como um de seus mecanismos.

\begin{abstract}
"É fundamental atentar para o fato de que o posicionamento de apoio dos paulistas ao projeto reformador da Igreja Católica alcançou uma dimensão nacional, ou seja, os paulistas, por sua liderança econômica e, sobretudo, política, fixaram-no no âmbito nacional. A maior expressão dessa comunhão entre a Igreja reformadora e o Estado, representante dessa elite vinculada à economia cafeeira, é o deslocamento de D. Joaquim Arcoverde de Albuquerque Cavalcanti, então bispo de São Paulo, para o Rio de Janeiro, em 1897, na época, sede do governo republicano, para assumir a Arquidiocese neste Estado" (ROMANO, 2007, p. 30-31).
\end{abstract}

A despeito da ida de Dom Arcoverde ao Rio de Janeiro, Mons. Victor Rodrigues de Assis comenta na biografia de Dom Duarte que o Arcebispo do Rio de Janeiro chegou a convidar Dom Duarte para ser seu Arcebispo-coadjutor, com direito a sucessão. No entanto, Dom Duarte não aceitou a oferta, sendo-lhe atribuída a seguinte frase: "não troco a Mitra de São Paulo pela púrpura do Rio de Janeiro" (ASSIS, 1967, p. 52).

Outro desejo negado por Dom Duarte veio da Embaixada italiana, que gostaria de vê-lo como Cardeal, na década de 1930, solicitando ao vigário geral Mons. Ernesto de Paula que repassasse ao arcebispo o desejo da colônia italiana de São Paulo, que tanto o estimava por suas contribuições à comunidade. Apesar do apelo, Dom Duarte pediu que nunca mais se tocasse neste assunto e que "São Paulo será, um dia, Sede Cardinalícia, mas ainda não está preparado" (ASSIS, 1967, p. 52).

Dom Duarte, como discípulo de Dom Arcoverde, e tendo acompanhado desde o início de seu sacerdócio as mudanças políticas entre Estado e Igreja, atua conforme os ditames romanizadores, buscando manter a posição estratégica da Igreja Católica em São Paulo frente às diversas transformações sociais e econômicas do país. 
Um exemplo disso é a expansão territorial religiosa na própria cidade, com a criação de 35 paróquias ao longo de seu $\operatorname{arcebispado}^{34}$ (Tab. 2).

Tabela 2: Paróquias criadas durante o arcebispado de Dom Duarte (1908-1938)

\begin{tabular}{|l|l|c|}
\hline \multicolumn{1}{|c|}{ BAIRRO } & \multicolumn{1}{c|}{ PARÓQUIA/INVOCAÇÃo } & ANO DE EREÇÃO \\
\hline Brás & São João Batista & 1908 \\
\hline Santa Cecília & Divino Espírito Santo & 1908 \\
\hline Consolação & Espírito Santo & 1908 \\
\hline Lapa & Nossa Senhora da Lapa & 1911 \\
\hline Barra Funda & Santo Antônio & 1914 \\
\hline Bom Retiro & Nossa Senhora Auxiliadora & 1914 \\
\hline Pari & Santo Antônio & 1914 \\
\hline Perdizes & São Geraldo & 1914 \\
\hline Pinheiros & Nossa Senhora do Monte Serrate & 1914 \\
\hline Mooca & São Januário & 1914 \\
\hline Vila Mariana & Santa Generosa & 1915 \\
\hline Vila Mariana & Nossa Senhora da Saúde & 1917 \\
\hline Brás & Bom Jesus & 1918 \\
\hline Ipiranga & São José & 1920 \\
\hline Tatuapé & Nossa Senhora do Bom Parto & 1925 \\
\hline Bexiga & Nossa Senhora Achiropita & 1926 \\
\hline Tremembé & São Pedro Apóstolo & 1926 \\
\hline Tucuruvi & Menino Jesus & 1926 \\
\hline Casa Verde & São João Evangelista & 1927 \\
\hline Itaquera & Nossa Senhora do Carmo & 1928 \\
\hline Bosque da Saúde & Santa Terezinha do Menino Jesus & 1929 \\
\hline Paraíso & Santo Agostinho & 1929 \\
\hline Jardim Europa & São José & 1930 \\
\hline Higienópolis & Santa Terezinha do Menino Jesus & 1930 \\
\hline Vila Esperança & Nossa Senhora da Esperança & 1930 \\
\hline Lapa & São João Maria Vianney & 1933 \\
\hline Vila Maria & Nossa Senhora da Candelária & 1933 \\
\hline Moema & Nossa Senhora Aparecida & 1933 \\
\hline Jaraguá & Nossa Senhora da Conceição & 1934 \\
\hline Mooca & São Rafael & 1935 \\
\hline Brooklin & Sagrado Coração de Jesus & 1936 \\
\hline Carrão & São João Batista & \\
\hline & & \\
\hline
\end{tabular}

${ }^{34}$ Segundo as biografias de Dom Duarte escritas, respectivamente, por Arruda Dantas e Mons. Victor Rodrigues de Assis, o arcebispo criou 44 novas paróquias. No entanto, para esta discussão acerca das paróquias criadas na cidade de São Paulo, excluímos da Tabela 2 algumas paróquias elencadas por Mons. Assis por se localizarem em outro município, como Ponte São João e Vila Arens (Jundiaí), ou por terem sido erigidas após a morte de Dom Duarte, como a de Ponte Pequena, cuja paróquia de São Sebastião foi erigida oficialmente apenas em 1939. 


\begin{tabular}{|l|l|c|}
\hline \multicolumn{1}{|c|}{ BAIRRO } & \multicolumn{1}{c|}{ PARÓQUIA/INVOCAÇÃO } & ANO DE EREÇÃO \\
\hline Pari & Santa Rita de Cássia & 1937 \\
\hline Tatuapé & Cristo Rei & 1937 \\
\hline Jaçanã & Santa Terezinha do Menino Jesus & 1937 \\
\hline
\end{tabular}

Fonte: Anuários Eclesiásticos, 1908-1954. Organização Luciana Barbosa, 2019.

Como é possível observar na tabela acima, o surgimento de novas paróquias acompanhou o ritmo de expansão territorial da cidade, que se alargava na medida em que se desenvolvia industrialmente.

Importante dizer que muitas paróquias já possuíam capelas ou igrejas antes de suas ereções, e que muitos dos templos foram desmembrados de paróquias antigas com a criação de novas, resultando também na reforma ou construção de novas igrejas. Exemplo disto é a Igreja do Divino Espírito Santo, localizada na Rua Frei Caneca, no bairro da Consolação, em São Paulo. A capela do Divino Espírito Santo da Bela Vista foi construída em 1903 em terreno doado por Mariano Antônio Vieira. Em 1904, sua esposa ratificou por escritura pública a doação verbal de seu marido à Irmandade do Divino (estabelecida em 1903 por uma comissão). A irmandade transferiu a capela para a Cúria Metropolitana em 1908, ano em que a capela foi elevada a paróquia por Dom Duarte, e oficializou-se a construção da nova igreja ${ }^{35}$.

\subsubsection{Construções, reformas e demolições}

As ações políticas de Dom Duarte para manter a Igreja Católica relevante surgiram antes mesmo de ser nomeado arcebispo de São Paulo, como é possível observar em sua atuação como vigário da paróquia de Santa Cecília, de 1895 a 1904, com a construção do novo templo, realizada em estreita relação com a elite paulista.

A paróquia de Santa Cecília estava localizada numa região da cidade onde as principais famílias da elite cafeeira se estabeleceram, tornando-se a paróquia modelo em tempos de romanização.

\footnotetext{
${ }^{35}$ ARQUIDIOCESE DE SÃO PAULO. Matriz paroquial do Divino Espírito Santo. Disponível em: http://www.arquisp.org.br/regiaose/paroquias/paroquia-divino-espirito-santo/matriz-paroquialdivino-espirito-santo. Acesso em: 20/05/2020.
} 
A justificativa para a ereção de uma igreja à altura de sua paróquia também revela o caráter romanizador da época e a importância de novos templos concomitantemente à criação de novas paróquias, uma vez que estes espaços se constituíam no "principal centro das cerimônias litúrgicas; nele propagava-se a doutrina, promoviam-se os atos de culto, e distribuíam-se os sacramentos fundamentais para a 'salvação'” (ROMANO, 2007, p. 96).

Como uma das primeiras paróquias criadas no contexto republicano, no qual não era mais possível contar financeiramente com o Estado, Dom Duarte conseguiu o apoio da elite paulista para a construção do novo templo, que estaria de acordo com as expectativas deste grupo social, que se aplicava nas transformações urbanas de cunho modernizador, buscando substituir os traços caipiras da cidade provincial por novos modos mais europeus, considerados mais inovadores:

"No mês de agosto de 1899, a empresa The São Paulo Tramway Light and Power Company Limited passa a fornecer luz elétrica para a região central da cidade, incluindo o novo bairro de Santa Cecília, permitindo acesso não só a iluminação, quanto ao bonde elétrico. Com isso, desde o início, a nova Igreja de Santa Cecília recebe energia elétrica feita através de "fios de pano", ou seja, fios de cobre envoltos em tiras de tecidos (...)" (PHILIPPOV, 2016, p. 28).

O moderno projeto executado na Igreja de Santa Cecília norteia o pensamento de Dom Duarte de como deveriam ser os templos da cidade:

\begin{abstract}
"Dentre as várias igrejas nossas, algumas velhíssimas, outras modernas e outras ainda em levantamento, quase todas, na maioria, de um deplorável e incorrigível mau gosto, respeito não só a construção bruta como ao extravagante acabamento, merece destaque especial a nova Matriz de Santa Cecília"36
\end{abstract}

Conforme trecho acima, Dom Duarte destaca a Matriz de Santa Cecilia como exemplo de extravagância em oposição ao "mau gosto" de outras igrejas da cidade, algumas antigas e outras até novas, modernas.

\footnotetext{
${ }^{36}$ Artigo do Jornal Correio Paulistano (s/d) na seção Matriz de Santa Cecília. MP, ano 2, n. 7, 4 abr. 1902. In: ROMANO, 2007, p. 99.
} 
Ao citar, as "ainda em levantamento" Dom Duarte refere-se às tantas reformas e demolições de igrejas em São Paulo desde o final do século XIX, que acompanhavam o ritmo da cidade que era reurbanizada, "substituindo-se as antigas casas térreas e sobrados de taipa da área central por edifícios mais altos, maiores, mais imponentes, construídos com materiais mais sólidos e em estilos mais europeizados" (BARBUY, 2006, p. 73).

LEMOS nos lembra que a atitude de Dom Duarte em iniciar a coleta de objetos sacros pelas igrejas de sua arquidiocese foi providencial em decorrência das mudanças estéticas arquitetônicas:

\begin{abstract}
"Àquela época, auge do ecletismo introduzido pelos imigrantes, na sua maioria italianos, formadores de $40 \%$ da população paulista, foi ato de clarividência essa atitude do Arcebispo salvaguardando o acervo dos Setecentos e da primeira metade dos Oitocentos, antes que o café e a incipiente industrialização nos trouxessem a riqueza e o crescimento urbano, a expensas de um passado pobre, mas importante, como ficou evidente não muito mais tarde. (...) de então para cá, ocorreu a sistemática destruição do patrimônio cultural anterior ao ciclo de café, nada, ou quase nada, restando da velha cidade de taipa de pilão" (LEMOS, 1983, p. 5).
\end{abstract}

A influência europeia, principalmente italiana na cidade de São Paulo, passou a condicionar a produção artística e arquitetônica nas primeiras décadas do século XX, inclusive na arte sacra:

\begin{abstract}
"Passou a ser moda a substituição dos velhos altares pelos preciosos mármores italianos, as antigas imagens pelas de papier-mâché, enquanto os objetos de prata e madeira eram simplesmente substituídos pelo latão reluzente. O neogótico, último respiro do Romantismo agonizante, tornou-se o estilo dos novos templos, em seguida ao curto domínio do neoclássico dos "capomastri" peninsulares. (...) Boa parte do clero era de origem estrangeira sem raízes na terra e, por isso, as antigas igrejas foram sendo substituídas por construções anódinas, sem estilo e sem caráter" (LEMOS, 1983, p. 6).
\end{abstract}

Era preciso modernizar todos os aspectos da cidade, e os templos religiosos estavam incluídos nesta conta. Cabe aqui relembrar que essa prática de reconstrução das igrejas em função de uma nova visão política faz parte da história da Igreja Católica. 
Neste sentido, Françoise Choay discute em Alegoria do Patrimônio (2017) a noção do monumento como ideal de memória transformado no ideal de beleza, o que ela chama de uma "dialética da destruição", apontando como exemplos dentro do contexto religioso a demolição da catedral de São Pedro, em Roma, substituída "por um edifício grandioso, cuja magnificência e cenografia pudessem lembrar o poder conquistado pela lgreja desde a época de Constantino e as novas inflexões de sua doutrina" (p. 27), ou as diversas igrejas em estilo gótico antigo na França, demolidas nos séculos XVII e XVIII, para fins de embelezamento e substituídas por edifícios barrocos ou clássicos (p. 15).

Com relação às igrejas paulistas no final do século XIX, Ernani Silva Bruno comenta em seu livro Histórias e tradições da cidade de São Paulo que, "consciente ou inconscientemente, o governo municipal e o poder eclesiástico iam eliminando da cidade os seus aspectos e os seus costumes de feição tradicional ou provinciana mais acentuada":

\begin{abstract}
"As próprias igrejas antigas, feitas de taipa segundo os rudes moldes coloniais - a de Santa Ifigênia, a de São Bento, a Sé desapareceram para dar lugar, no começo do novecentismo, a templos edificados segundo estilos universalmente consagrados e portanto mais de acordo com a feição tanto quanto possível europeia que a cidade procurava assumir - às vezes sem dúvida mediante esforço deliberado de administradores como Antônio Prado - escondendo ou eliminando qualquer traço não-europeu ou "caipira" que porventura perdurasse em suas ruas, em suas casas, em seus jardins, em seus costumes" (BRUNO, 1954, p.911).
\end{abstract}

Ernani nos dá outros exemplos de edificações religiosas que não escaparam do "progresso incontrolável" de São Paulo:

- 1872 - Lançou-se a pedra fundamental do frontispício novo e da torre da igreja da Boa Morte;

- c. 1878 - Início das obras da fachada nova da de São Gonçalo; remodelada quase que totalmente a igreja de São Bento; restauração da igreja de Santa Teresa;

- 1881-1884 - Construção da igreja Sagrado Coração de Jesus, nos Campos Elíseos; 
- 1887-1891 - Construção das capelas de Santa Cruz, na Ladeira Porto Geral, e de São Miguel, na Rua Bráulio Gomes;

- 1895 - Conclusão da igreja de Nossa Senhora da Glória, no Cambuci, que se originou de uma capela;

- 1891 - Início da construção da igreja de São José do Ipiranga;

- 1897 - Construção da igreja de São José do Belém, que se originou de uma capelinha reedificada;

- 1895-1905 - Construção do templo do Sagrado Coração de Maria, na rua Jaguaribe;

- 1906 - Inauguração da nova igreja do Rosário dos Pretos, no Largo do Paissandu, após a original, localizada na Praça Caio Prado, ter sido demolida por motivos de reurbanização da área;

- 1906-1922 - Nova edificação da igreja de Santa Ifigênia;

- 1908 - Início da demolição da parte dos fundos do antigo convento jesuítico para no seu local ser edificado o novo palácio do governo (essa parte dos fundos já havia sido reconstruída em 1882-1884);

- 1910-1914 - Nova edificação do Mosteiro de São Bento.

Os exemplos dados por Ernani Bruno nos mostram que as diversas igrejas tradicionais, de traços simples coloniais, foram reconstruídas ou destruídas para dar lugar a templos maiores e mais de acordo com o estilo europeizado vigente.

\subsubsection{A dispersão dos objetos sacros}

Com tantas reformas e reconstruções em andamento, há de se perguntar o que aconteceu com os objetos e ornamentos presentes nos templos. Sabemos que muitos acabaram sob a guarda da Cúria Metropolitana, o que levou à criação do Museu da Cúria, porém outros tantos foram recolhidos por famílias ricas para sua preservação, outros acabaram em antiquários e muitos foram adquiridos ou recebidos ao longo dos anos pelos museus, como Museu de Arte Sacra de São Paulo, Museu Paulista e Museu Anchieta. 
Leonardo Arroyo nos traz algumas pistas em seu livro Igrejas de São Paulo - Introdução ao estudo dos templos mais característicos de São Paulo nas suas relações com a crônica da cidade, onde apresenta importante histórico das igrejas da São Paulo, dividido por século.

No capítulo relativo à igreja de São Gonçalo, Arroyo faz um interessante apontamento ao comentar que não há documentos acerca do destino de muitos itens da igreja do Bom Jesus (Pátio do Colégio), que teriam migrado para a Igreja de S. Gonçalo:

"São Gonçalo Garcia subsistiu a todas essas tormentas de reformas e aí se encontra hoje, muito simpática com suas cores amarelas do exterior. Igreja que herdou alguma coisa também da antiga Igreja do Colégio, que foi destruída em 1896. Embora nenhum documento registrasse o destino de muitas alfaias $e$ objetos da antiga Igreja do Colégio, o que se sabe, por tradição é que muitos destes objetos foram parar na lgreja de São Gonçalo. A pedra de granito, de 60 centímetros de diâmetro, por exemplo, gravada com as letras "I.H.S." encontra-se nesse templo. Herdou também o quadrante do relógio que está na torre, uma pedra com o nome de Jesus e algumas outras pequenas relíquias, que para lá foram em 1901" (ARROYO, 1966, p. 197. Grifo nosso).

O fato de a igreja de São Gonçalo ${ }^{37}$ ter recebido objetos da igreja do Colégio pode ter sido uma opção preservacionista dos jesuítas, que receberam a cessão da igreja de Nossa Senhora da Conceição e São Gonçalo Garcia em 1893.

Vale lembrar que em 1759, com a expulsão da Companhia de Jesus, todo o seu patrimônio, "com todos os bens que o incorporavam, as igrejas, os colégios, os objetos de culto, as casas, as fazendas, as bibliotecas, os móveis e utensílios - foi sequestrado, como dispunha a Carta Régia de 19 de fevereiro" (BONAS, 2011, p. 56), então há de se compreender a necessidade de se preservar objetos que representam sua história.

Em 1896, a igreja do Bom Jesus sofreu danos por causa de uma tempestade, sendo demolida para construção de uma nova. Os ornamentos e objetos que sobreviveram foram distribuídos:

\footnotetext{
${ }^{37} \mathrm{~A}$ igreja também possui dois altares laterais provenientes da antiga igreja de Nossa Senhora Aparecida, cedidos pelo Con. Joaquim do Monte Carmello (ARROYO, 1966, p. 196).
} 


\begin{abstract}
"Parte das alfaias sobreviventes e alguns dos objetos da Igreja do Bom Jesus ficaram sob a guarda da Cúria Metropolitana e de particulares. O altar principal, o mais antigo de São Paulo, foi redimensionado em menos de um terço de seu total e alocado em uma igreja nova, construída com valor pago pelo Estado à Diocese para o novo uso do espaço da antiga Igreja. Os restos mortais dos primeiros paulistanos foram trasladados em procissão solene para a Igreja da Sé, permanecendo em sua cripta até os dias de hoje" (BONAS, 2011, p. 57).
\end{abstract}

Sobre o recolhimento de objetos por particulares, BONAS (2011, p. 7475) comenta que as famílias tradicionais paulistas "se incumbiram de guardar em suas casas imagens e alfaias do primeiro templo de São Paulo" e dá como o exemplo o caso da família do poeta Pedro Oliveira Ribeiro Neto, que teria se responsabilizando pela guarda "de dois objetos em sua fazenda - um lavabo de sacristia e uma pia batismal, ambos em pedra". Apesar de colaborar com as celebrações do IV Centenário, o poeta só devolveu a pia batismal aos jesuítas em 1979 quando da inauguração do novo Museu Anchieta.

Com relação ao altar-mor citado por BONAS, este foi levado à igreja Imaculado Coração de Maria, construída para substituir a primitiva igreja do Colégio. A respeito dessa transferência, o jornal O Estado de S. Paulo em 1952 (p. 7), comenta, numa matéria sobre a história da Igreja do Colégio, que teria sido mais acertadamente este altar estar no Museu da Cúria ou no Museu do Ipiranga.

O altar permaneceu na Capela do Santíssimo até 1970, quando retornou à igreja do Bom Jesus. Entretanto, em 2009, a igreja passou por uma última reforma, e o altar "foi retalhado com pés-de-cabra da Igreja do Beato Anchieta, com perda substantiva de seus ornatos, para dar lugar a azulejos contemporâneos" (BONAS, 2011, p. 59), sendo recolocado no pátio interno do Museu Anchieta.

TIRAPELI nos lembra de que o deslocamento de retábulos entre igrejas, como também a construção de novas para abrigar retábulos, eram comuns no início do século XX, sendo estes chamados, na expressão do autor, de retábulos peregrinos: 
"Com a República (1889) e a Igreja finalmente totalmente liberta do Estado, padres do norte da Europa chegaram ao Brasil, e trouxeram novas e lastimáveis atitudes quanto às reformas das igrejas e suas ornamentações. A insensibilidade dos religiosos que a todo custo queriam apagar os traços da cultura lusobrasileira promovendo reformas drásticas ou demolições das igrejas, especialmente no princípio do século $X X$, no centro da cidade de São Paulo - visava implantar um gosto pseudoromânico. Mesmo assim, acabaram por abrigar partes de retábulos que passamos a denominar de retábulos peregrinos" (TIRAPELI, 2006, p. 276).

Outros exemplos de "retábulos peregrinos" conhecidos são:

"Da antiga Matriz de Mogi das Cruzes para a Igreja de Nossa Senhora do Brasil, em São Paulo;

Do antigo mosteiro beneditino de Santana de Parnaíba para o de Sorocaba;

Da igreja do bairro de Pinheiros para o mosteiro de Jundiaí;

Dois altares do segundo mosteiro beneditino para a igreja dos terceiros franciscanos, em São Paulo;

Aqueles da antiga Sé para a igreja da Imaculada conceição na Av. Brigadeiro Luís Antônio;

Da antiga basílica de Aparecida para a Igreja de São Gonçalo em São Paulo;

E o exemplo mais antigo, da primitiva capela do Rosário para a atual (1730) igreja da residência dos jesuítas no Embu" (TIRAPELI, 2003 apud TIRAPELI, 2016, p.17).

Sobre a Igreja de Nossa Senhora do Rosário de Embu, Leonardo Arroyo (1966, p.119) conta que muitos de seus tesouros se perderam ao longo dos anos, desde a expulsão dos Jesuítas, e que possivelmente foram levados para as paróquias a que a igreja foi subordinada, como Itapecerica ou Cotia, ou então que poderiam estar guardados no Museu da Cúria. No catálogo antigo do Museu, constam 20 objetos entre pratarias e indumentária da "Antiga Igreja de M'Boy"38.

Já no capítulo a respeito da igreja da Nossa Senhora da Consolação, ARROYO traça as "andanças" de sua imagem primitiva ao longo dos anos:

${ }^{38} \mathrm{O}$ antigo distrito de M'Boy, do município de Itapecerica, só passou a denominar-se Embu em 1938. 
"A imagem primitiva de Nossa Senhora da Consolação permaneceu durante algum tempo, cremos que por ocasião da reforma de 1840, na igreja do Colégio. Após o desabamento do histórico templo, na noite de 13 de março de 1896, voltou à sua igreja por rápido tempo. Essa primitiva imagem encontra-se hoje no Museu da Cúria Metropolitana, na solidão e no sossego dos justos que realizaram uma grande jornada pelos anos. Em companhia boa de outras imagens das igrejas de São Pedro, dos Remédios, de Santana do Parnaíba... sabe-se lá de quantas!" (ARROYO, 1966, p. 205).

A prática de receber objetos de outras igrejas durante suas reformas era comum. Quando a antiga matriz da Sé foi demolida, a igreja de Santa Ifigênia passou a ser a catedral provisória da cidade e muitas igrejas, além da própria Cúria, receberam a guarda dos objetos da antiga Sé.

No livro de Monsenhor Sylvio de Moraes Mattos "A Igreja Matriz da Velha Vila de São Paulo e a Velha Sé" (1986), que traz um rico histórico desde a primeira igreja da Sé até sua última construção antes da atual Catedral, apresenta em anexo uma relação das destinações dos objetos da antiga Sé (Tab. 3) elaborada por Dom Duarte, que teria ficado amargurado por não a terem seguido à risca (MATTOS, 1986, p. 61).

Tabela 3: Destino dos objetos da Igreja da Sé.

\begin{tabular}{|c|c|}
\hline $\begin{array}{l}\text { DESTINAÇÃO DA GUARDA DOS } \\
\text { OBJETOS DA ANTIGA SÉ }\end{array}$ & OBJETOS GUARDADOS \\
\hline Matriz do Brás & 32 bancos; instalações elétricas \\
\hline Matriz de Santa Ifigênia & Órgão da capela-mor \\
\hline Igreja dos Remédios & 6 vasos de madeira \\
\hline Capela da Saúde & $\begin{array}{l}\text { Altar da Sacristia; Retábulo de tapa-vento e grade } \\
\text { do coro }\end{array}$ \\
\hline Matriz do Cambuci & $\begin{array}{l}\text { Altar de São João Nepomuceno; Altar do Senhor } \\
\text { Bom Jesus; } 2 \text { portas de tapa-vento; } 12 \text { castiçais de } \\
\text { madeira; } 12 \text { ramalhetes de madeira; } 24 \text { canudos de } \\
\text { folha; } 2 \text { nichos estilo colonial }\end{array}$ \\
\hline Cônego Meirelles Freire & A cortina azul da boca do trono do altar-mor \\
\hline Matriz de Itapecerica & $\begin{array}{l}\text { Entregue ao vigário Pe. Antonio Maria do Carmo: } 4 \\
\text { tribunas }\end{array}$ \\
\hline Padre Antonio Morato de Carvalho & 6 armários $n^{0} 10,11$ e 12 \\
\hline $\begin{array}{l}\text { Irmandade de Nossa Senhora das } \\
\text { Dores }\end{array}$ & $\begin{array}{l}\text { Entregues ao procurador Benedito Ribeiro da } \\
\text { Silveira: } 2 \text { imagens de Nossa Senhora das Dores; } 1 \\
\text { crucifixo grande que estava no Altar de Nossa } \\
\text { Senhora das Dores; } 1 \text { imagem do senhor morto; o } \\
\text { esquife charola e Banqueta do Altar }\end{array}$ \\
\hline
\end{tabular}




\begin{tabular}{|c|c|}
\hline $\begin{array}{l}\text { DESTINAÇÃO DA GUARDA DOS } \\
\text { OBJETOS DA ANTIGA SÉ }\end{array}$ & OBJETOS GUARDADOS \\
\hline Cônego Antonio A. Lessa & 3 peanhas; 2 castiçais; o altar da sala do Cabido \\
\hline Capela do Bom Jesus dos Perdões & $\begin{array}{l}\text { Entregue ao Sr. Vicente da Costa Neves: Altar do } \\
\text { Sagrado Coração de Jesus }\end{array}$ \\
\hline Frades Capuchinhos & $\begin{array}{l}1 \text { Banqueta e Cruz; todos os castiçais de madeira; } \\
\text { todos os vasos de madeira; } 1 \text { Quadro a Óleo } \\
\text { grande; toda a coxia da igreja; todas as grades de } \\
\text { ferro; outros objetos; } 1 \text { sacrário velho; as grades de } \\
\text { ferro dos altares; diversas miudezas; } 2 \text { púlpitos com } \\
\text { letra de Dom Duarte; } 1 \text { altar-mor }\end{array}$ \\
\hline $\begin{array}{l}\text { Irmãs da Divina Providência - } \\
\text { Mooca }\end{array}$ & $\begin{array}{l}1 \text { Banqueta completa com cruz; } 1 \text { confessionário; } 2 \\
\text { mesas; } 1 \text { genuflexório; diversas carroçadas de } \\
\text { madeira velha }\end{array}$ \\
\hline $\begin{array}{l}\text { Irmãs do Sagrado Coração de } \\
\text { Jesus - Uberaba }\end{array}$ & 1 Banqueta completa com cruz; Ramos de madeira \\
\hline Missionárias do Coração de Jesus & 1 Banqueta de madeira completa com o crucifixo \\
\hline Cônego Eugênio & $\begin{array}{l}\text { Imagem de Sant'Ana - Está na Igreja dos Remédios } \\
\text { (com letra de Dom Duarte) }\end{array}$ \\
\hline Cônego Krauss & 1 resplendor de madeira \\
\hline Padre Jacob Saliba & $\begin{array}{l}\text { Diversos castiçais de madeira; diversos vasos de } \\
\text { madeira; outras miudezas }\end{array}$ \\
\hline Padre Capra & $\begin{array}{l}12 \text { castiçais; } 2 \text { banquetas de castiçais; todas as } \\
\text { palmas velhas; os tapetes velhos }\end{array}$ \\
\hline Padre Aluvas & 1 confessionário \\
\hline Francisco de Almeida Cardoso & $\begin{array}{l}\text { A imagem de São Miguel; a peanha e o esplendor } \\
\text { sobre os quais apoiava-se a Imagem encontra-se } \\
\text { em poder do Sr. Gonçalo dos Santos Coimbra } \\
\text { (informação da Sra. D. Rita Cardoso) } \\
\text { Prata: - A imagem de São Miguel encontra-se na } \\
\text { casa de Rita Matoso. Exma. Sra. D. Sinhorinha } \\
\text { Matoso - residência à rua Conselheiro Furtado no } \\
28 \text { - informação do Sr. Gonçalo dos Santos } \\
\text { Coimbra. } \\
\text { - Ao sacristão da Irmandade dos Passos - João de } \\
\text { Barros conhece a dita senhora e poderá conseguir } \\
\text { a devolução da Imagem para o Museu a) Francisco } \\
\text { Collet. O Sr. Coimbra declarou que a Sra. Rita } \\
\text { Matoso está pronta a restituir a Imagem assim logo } \\
\text { que seja reclamada (6-II-1932) }\end{array}$ \\
\hline Manoel Altenfelder Silva & $\begin{array}{l}\text { A coluna e placa do Relógio do Sol } \\
\text { Foi entregue ao Museu da Cúria, exceto a coluna } \\
\text { que não se encontra em poder do acima nomeado. } \\
\text { a) Diretor do Arquivo e Museu da Cúria }\end{array}$ \\
\hline Convento de Santa Teresa & $\begin{array}{l}1 \text { pedra mármore grande; } 1 \text { cruz; } 1 \text { placa; a imagem } \\
\text { do Senhor Bom Jesus; Nicho da antiga Igreja do } \\
\text { Colégio; Todas as alfaias de prata; todas as } \\
\text { imagens restantes }\end{array}$ \\
\hline Convento do Carmo & $\begin{array}{l}\text { Todos os paramentros; todos os móveis; algumas } \\
\text { pratas; } 2 \text { estantes do Coro e } 2 \text { estrados do Coro - } \\
\text { Entregues ao Sr. Furio Franceschini; } 1 \text { pote de } \\
\text { barro; Coroas imperiais }\end{array}$ \\
\hline
\end{tabular}




\begin{tabular}{|c|c|}
\hline $\begin{array}{l}\text { DESTINAÇÃO DA GUARDA DOS } \\
\text { OBJETOS DA ANTIGA SÉ }\end{array}$ & OBJETOS GUARDADOS \\
\hline Diocese de Ribeirão Preto & Poltronas dos srs. Cônegos \\
\hline Gonçalo dos Santos Coimbra & O presépio da Sé \\
\hline $\begin{array}{l}\text { Relação das pratas da Catedral, } \\
\text { que estão no Convento do Carmo } \\
\text { sob a guarda do Sr. Gonçalo dos } \\
\text { Santos Coimbra (inventariadas em } \\
2 \text { de dezembro de 1921) }\end{array}$ & $\begin{array}{l}2 \text { salvas grandes de prata lavada; } 6 \text { outras } \\
\text { pequenas, sendo } 2 \text { com pé; } 1 \text { canela de prata; } 1 \\
\text { cruz grande de prata; } 1 \text { cruz grande de prata com } \\
\text { relicário; } 1 \text { cálice de prata lisa; } 1 \text { cruz grande de } \\
\text { prata com relicário; } 1 \text { cálice de prata lisa; } 1 \text { cálice } \\
\text { de prata dourada na cripta da catedral; } 2 \text { vasos } \\
\text { para santos óleos com colher e mão; } 1 \text { patena de } \\
\text { prata; } 1 \text { dita de prata dourada; } 1 \text { caldeirinha com } \\
\text { hysoppe em estojo; } 1 \text { cálice rico com patena, de } \\
\text { prata dourada de uso do exmo. Sr. Arcebispo em } \\
\text { potificiais, em estojo; } 1 \text { jarro e bacia de prata; } 1 \\
\text { turíbulo e naveta; } 1 \text { cálice e patena de prata } \\
\text { dourada; } 2 \text { ciriais de prata }\end{array}$ \\
\hline $\begin{array}{l}\text { Relação das pratas da Catedral, } \\
\text { guardadas na Cúria, e } \\
\text { inventariadas em } 2 \text { de dezembro de } \\
1920\end{array}$ & $\begin{array}{l}7 \text { lâmpadas grandes de prata lavrada; } 1 \text { lâmpada de } \\
\text { metal inutilizada; } 6 \text { castiçais grandes de prata } \\
\text { lavrada; } 1 \text { castiçal para Pontifical; } 4 \text { castiçais lisos } \\
\text { médios de prata; } 8 \text { castiçais lavrados médios de } \\
\text { prata; } 6 \text { castiçais lavrados menores; } 4 \text { castiçais } \\
\text { lavrados pequenos; } 1 \text { cruz de prata com o pé; } 6 \\
\text { ramos de metal prateado; } 3 \text { Salvas de prata; } 2 \\
\text { salvas grandes de prata com pé; } 4 \text { Coroas de prata } \\
\text { lavradas estragadas; } 1 \text { Coroa do Divino Espírito } \\
\text { Santo; } 4 \text { ramos de prata lavrada; } 8 \text { resplendores de } \\
\text { prata lavrada; } 5 \text { Caixinhas de metal com tampa; } 1 \\
\text { Candela quebrada; } 1 \text { Cetro do Espírito Santo; } 2 \\
\text { Relicários de prata lavrada; } 1 \text { Pé de hissope de } \\
\text { prata; } 2 \text { Cálices de prata dourada; } 2 \text { Âmbulas de } \\
\text { prata dourada; } 2 \text { Relicários de metal; } 8 \text { Patenas; } 1 \\
\text { Resplendor pequeno de ouro (?); } 1 \text { Coroa de ouro; } \\
2 \text { Relicários de São Paulo; } 4 \text { Setas de prata de S. } \\
\text { Sebastião; } 4 \text { Galhetas de prata; } 1 \text { Galheta de } \\
\text { cristal; } 2 \text { Chaves de prata de São Pedro; } 1 \text { Cruz de } \\
\text { prata de São João; } 1 \text { Caldeirinha de prata; } 1 \\
\text { Caldeirinha de metal; } 1 \text { Cruz pequena de prata; } 1 \\
\text { Jarro de prata lavrada; } 2 \text { Turíbulos de prata; } 1 \\
\text { Naveta de prata; } 1 \text { Candela de prata; } 1 \text { Emblema do } \\
\text { Divino Espírito Santo, em metal; } 1 \text { Jarro pequeno } \\
\text { de prata estragado; } 1 \text { Vaso pequeno de prata } \\
\text { estragado; } 1 \text { Bastão de Canto Chão; } 1 \text { Crucifixo } \\
\text { quebrado; } 1 \text { Jarro, bacia oval, entregues ao Exmo. } \\
\text { Sr. Arcebispo, para estarem no Palácio São Luiz - } \\
15-6-1920 ; 1 \text { Belo sinete; } 1 \text { Quadro de prata } \\
\text { Descida da Cruz; } 1 \text { Resplendor de prata dourada; } 1 \\
\text { Naveta de prata lavrada do Maranhão (?); } 1 \text { Campa } \\
\text { de prata lavrada do Maranhão (?); } 1 \text { Lâmpada de } \\
\text { prata grande (entregue ao Sr. Collet em } 7-11-1928 \text { ); } \\
1 \text { Lâmpada de prata pequena }\end{array}$ \\
\hline
\end{tabular}

Fonte: ACMSP; Monsenhor Sylvio de Moraes Mattos "A Igreja Matriz da Velha Vila de São Paulo e a Velha Sé", 1986. Organização Luciana Barbosa, 2021. 
Interessante observar que além de igrejas e membros do clero, Mons. Sylvio faz a distinção do destino da prataria da Sé (as duas últimas linhas da tabela acima), estando este acervo dividido entre a Igreja do Carmo e a Cúria Metropolitana.

Além disso, Mons. Sylvio não indica a data da primeira parte da lista, mas sinaliza quando foram inventariadas as relações da prataria, o que pode nos indicar, observando as datas 1920 e 1921, e comentários junto a algumas peças, tratar-se de inventários do acervo existentes na Cúria realizados por Francisco Collet após a inauguração do Palácio da Cúria, tal qual o fez Mons. Agnello José de Moraes em 31 de dezembro de 1920, quando realizou o Inventário de móveis, objetos de arte, alfaias, ornamentos e utensílios do Palácio da Cúria (citado no Capítulo 2.2 pág. 97).

Mons. Sylvio também lista em seu livro, na parte anexa, uma relação da prataria da Paróquia de Nazareth e da Capela de Santa Luzia guardadas na Cúria, e também inventariadas em 1920 (Tab. 4):

Tabela 4: Prataria procedente da Paróquia de Nazareth e Capela de Santa Luzia, guardadas na Cúria.

\begin{tabular}{|l|l|}
\hline \multicolumn{1}{|c|}{ Destinação da Prataria } & \multicolumn{1}{c|}{ Objetos guardados } \\
\hline $\begin{array}{l}\text { Relação de objetos de prata da } \\
\begin{array}{l}\text { Paróquia de Nazareth } \\
\text { guardados na Cúria em 1 de } \\
\text { dezembro de 1920 }\end{array}\end{array}$ & $\begin{array}{l}\text { 1 Coroa de prata - formato resplendor com ametistas } \\
\text { falsas; 3 Coroas de prata lavrada; 1 Coroa de prata } \\
\text { lavrada; 1 Coroa de prata dourada estragada; 1 Coroa } \\
\text { de prata dourada pequena com cruz; 1 Coroa de prata } \\
\text { dourada simples com cruz; 1 Resplendor grande de } \\
\text { prata com 1 pedra de vidro; 4 Resplendores menores; } 1 \\
\text { Resplendor com uma ametista falsa; 1 Luneta de prata } \\
\text { dourada; 1 Caixa com 1 anel, 1 par de brincos, 1 brinco } \\
\text { avulso, missangas; 1 Caixa com Relicário de prata } \\
\text { dourada, 5 cruzes de prata dourada, 5 medalhinhas e } \\
\text { berloque; 1 Caixa com contas de ouro avulsas }\end{array}$ \\
\hline $\begin{array}{l}\text { Relação dos objetos de prata } \\
\text { pertencentes à Capela de Santa } \\
\text { Luzia da Rua Tabatinguera, } \\
\text { inventariadas em 1 de } \\
\text { dezembro de 1920, na Cúria (no } \\
\text { cofre da Procuradoria) }\end{array}$ & $\begin{array}{l}\text { 8 Castiçais de prata grandes; 2 Castiçais de prata } \\
\text { menores; 4 castiçais de prata pequenos; 1 Candelabro } \\
\text { pequeno de chumbo para Presépio; 1 Par de galhetas } \\
\text { com prata de prata }\end{array}$ \\
\hline
\end{tabular}

Fonte: ACMSP; Monsenhor Sylvio de Moraes Mattos "A Igreja Matriz da Velha Vila de São Paulo e a Velha Sé", 1986. Organização Luciana Barbosa, 2021. 


\subsubsection{A antiga Igreja da Sé de São Paulo}

Talvez o maior exemplo desta perda histórica seja a antiga Igreja da Sé. Sua história pode nos servir como um bom indicador de como se deram as transformações das edificações religiosas da cidade, sendo reformadas, reconstruídas e/ou demolidas de forma abrupta, sempre com o aval da Cúria.

Segundo Leonardo Arroyo (1966, p. 22-25), a primeira matriz de São Paulo foi construída no início do século XVIII após solicitações da população à Câmara desde 1588. Já em ruínas, foi demolida em 1745 para a construção de uma nova matriz, concomitantemente com a criação do bispado de São Paulo. Dez anos depois, a igreja passou por nova reedificação, cuja construção perdurou intacta até o início do século XX.

Localizava-se no antigo largo da Sé, na confluência entre as ruas Direita e 15 de Novembro, ao lado da igreja São Pedro dos Clérigos, de 1740. Durante o arcebispado de Dom Duarte, tanto o largo quanto as igrejas da Sé e de São Pedro foram demolidos para dar espaço à nova esplanada que surgiria na região central, a atual Praça da Sé. A construção da nova Catedral da Sé ganhou localização privilegiada no novo projeto, estando no alto da esplanada, próxima à Praça João Mendes.

A antiga matriz da Sé construída em taipa de pilão, seguia o padrão de construção colonial, de fachada simples, com brasão da coroa real portuguesa em seu portal, escadaria e possuía apenas uma grande torre quadrada. Seu interior apresentava elementos arquitetônicos do período, como a talha dourada.

Hoje é possível reconhecê-la a partir dos registros iconográficos realizados desde sua última reconstrução (Fig. 21-25), tendo sido representada em desenhos, gravuras e fotografias, a partir dos anos 1860, e pinturas, ganhando um maior destaque nas pinturas realizadas a partir do século XIX (BARBUY, 2010). 
Figura 21: Largo da Sé [no período colonial]. Aquarela de J. Wasth Rodrigues, 1954.

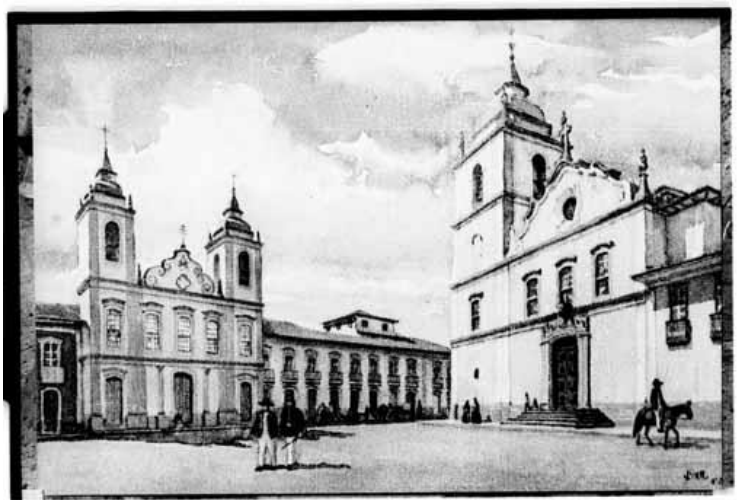

Fonte: Acervo Fotográfico do Museu da Cidade de São Paulo.
Figura 22: Antiga matriz da Sé. Fotografia de Aurélio Becherini, 1907.

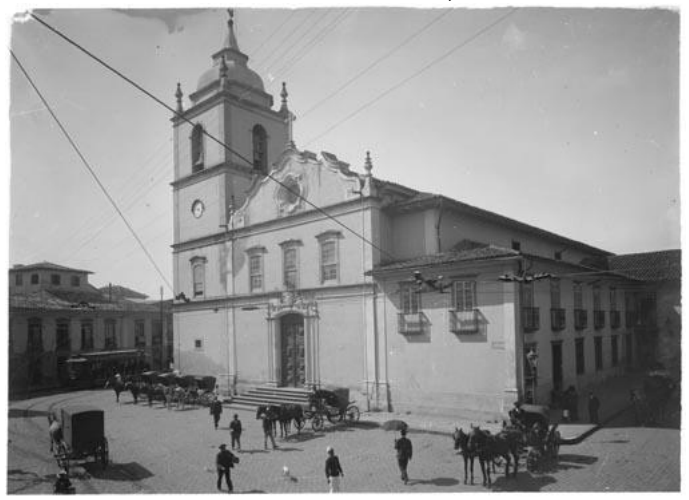

Fonte: Acervo Fotográfico do Museu da Cidade de São Paulo

Figura 23: Porta de entrada da Igreja da Sé.

Fotografia de Aurélio Becherini, 1910.

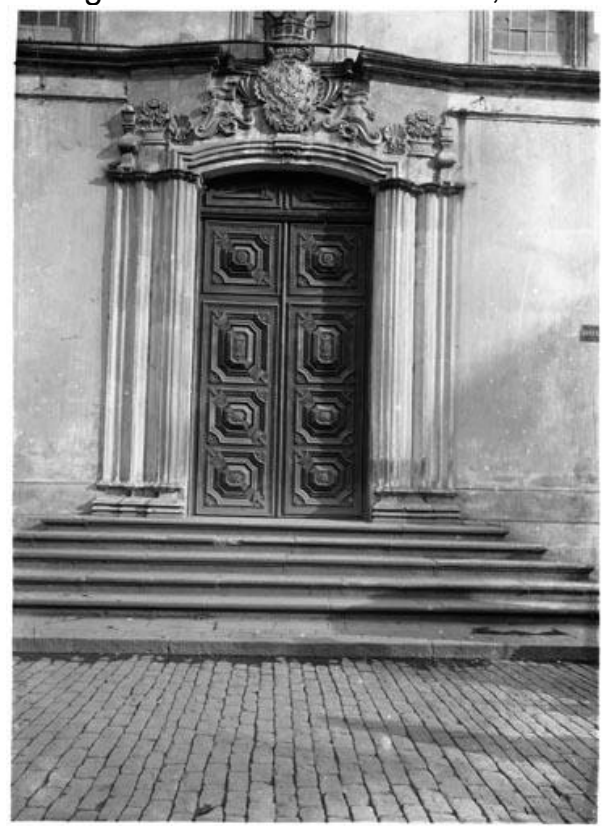

Fonte: Acervo Fotográfico do Museu da Cidade de São Paulo. 
Figura 24: Vista do altar-mor da antiga Igreja da Sé.

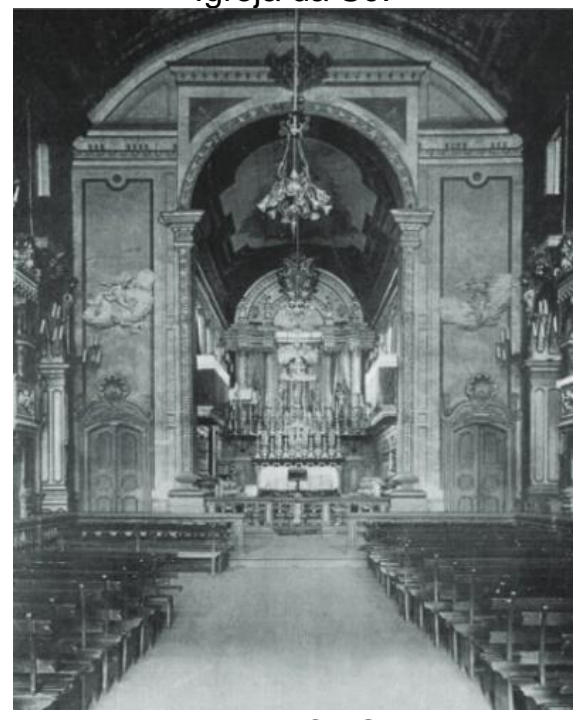

Fonte: ACMSP.
Figura 25: Altar da capela do Santíssimo Sacramento. Aurélio Becherini, 1910.

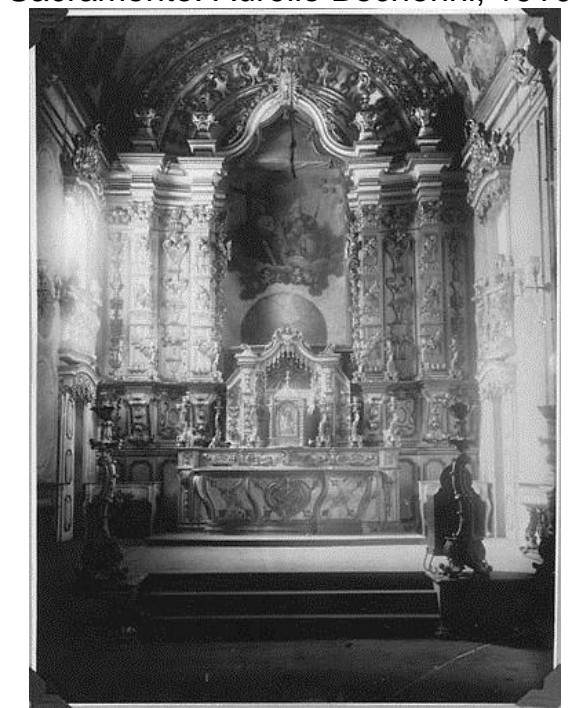

Fonte: Acervo Fotográfico do Museu da Cidade de São Paulo.

Interessante apontar, no entanto, que, apesar do pouco interesse pela arquitetura colonial das igrejas, seus interiores puderam contar com artistas já renomados à época para sua decoração interna, como é o caso de Benedito Calixto e Oscar Pereira da Silva nas igrejas de Santa Cecília e da Consolação, Pedro Alexandrino na igreja de Santa Teresa, onde colaborou durante sua restauração em 1880, e Almeida Júnior na antiga matriz da Sé.

Com relação a Almeida Júnior (1850-1899), o pintor ituano realizou as pinturas A Conversão de São Paulo a Caminho de Damasco no teto da nave e uma Nossa Senhora no altar-mor da antiga matriz da Sé, por encomenda do bispo Dom Lino Deodato Rodrigues de Carvalho, que ordenou "um conjunto de reformas e implementações ornamentais encetadas naquela Igreja em 18881889" (BARBUY, 2010).

A pintura A Conversão de São Paulo (Fig. 26) se encontra hoje no Museu Paulista, tendo sido oferecida ao Museu por Dom Duarte, segundo o Guia da Seção de História do Museu Paulista, de 1937 (p. 72). 
Figura 26: Reproduções da pintura "A Conversão de São Paulo a Caminho de Damasco", de Almeida Junior.

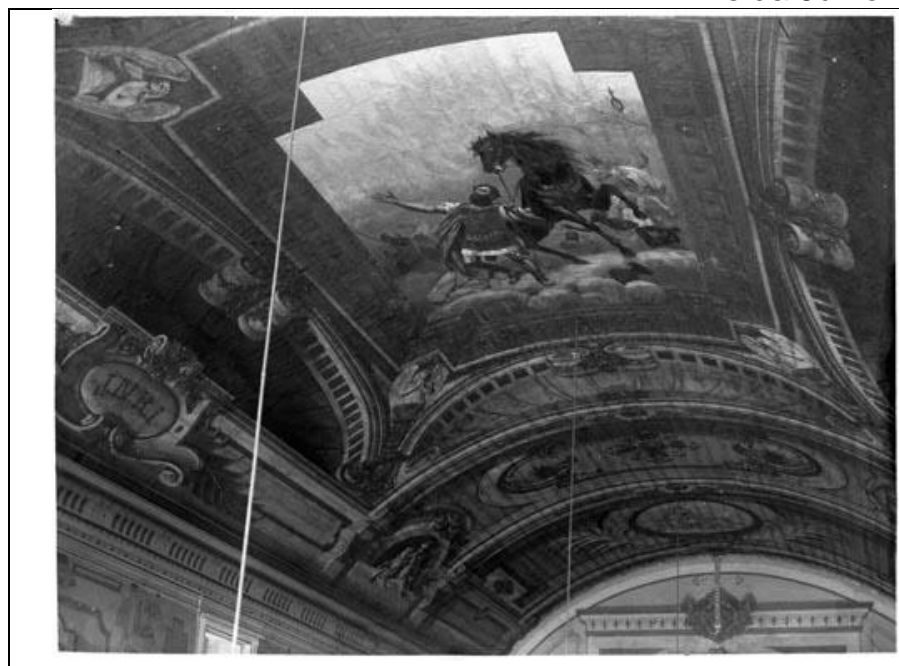

Fotografia do teto da nave da antiga Igreja da Sé mostrando em destaque a pintura "A Conversão de São Paulo a Caminho de Damasco", realizada por Almeida Junior em c. 1888.

Autor desconhecido. 1890.

Fonte: Acervo Fotográfico do Museu da Cidade.

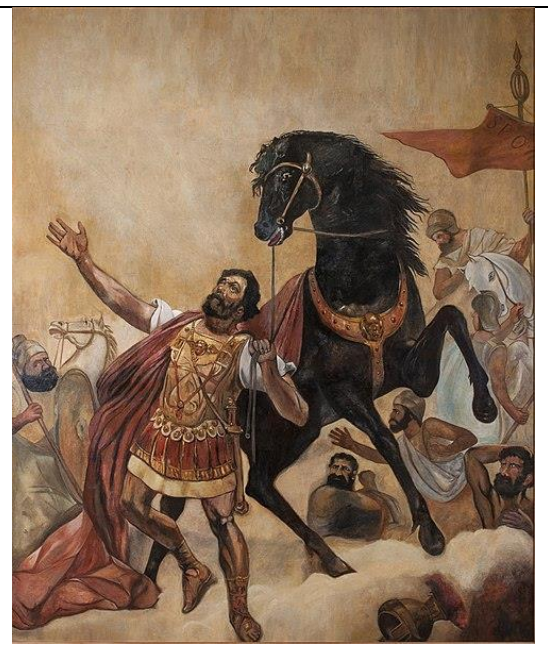

A CONVERSÃO DE SÃO PAULO A CAMINHO DE DAMASCO

Procedência: antiga Igreja da Sé de São Paulo, Brasil

Óleo sobre tela | c.1888 $460,0 \times 378,0 \mathrm{~cm}$

Acervo Museu Paulista da USP

Fonte: José Rosael/Hélio Nobre/Museu Paulista da USP.

Conforme apontado no subcapítulo anterior (Tab. 3), com a demolição da Sé, seus objetos foram distribuídos entre lgrejas e membros do clero para sua preservação, incluindo a destinação da prataria para a Cúria Metropolitana. Destes objetos, sabemos que alguns retornaram à Sé quando do término da construção da Catedral, como tocheiros e crucifixos, porém a grande maioria permaneceu na Cúria, sendo entendidos como objetos museológicos para compor o Museu da Cúria. 


\section{CAPÍTULO 3: O MUSEU DA CÚRIA METROPOLITANA DE SÃO PAULO}

Dom Duarte iniciou de forma pioneira o recolhimento de objetos de valor histórico e artístico que estavam por se perder na progressiva demolição das igrejas pela cidade e pelo interior do Estado, ainda que a própria Igreja fosse quem ordenasse as demolições a fim de reconstruí-las de acordo com as exigências modernas da época, num contexto de entendimento com as elites paulistas, suas aspirações e seus projetos para a cidade, como vimos acima.

Altino Arantes, Presidente do Estado de São Paulo de 1916 a 1920, a respeito desta ação de Dom Duarte, comenta que o faz "recolhendo para os seus ordenados mostruários as alfaias, as pratarias, os móveis, as joias e toda uma preciosa e multiforme infinidade de relíquias e objetos, a que se prendem fatos e reminiscências do nosso passado" (ARANTES, 1958, p. 245).

Importante assinalar, com relação a seu perfil pessoal, que Dom Duarte era numismata - colecionador de moedas, medalhas, cédulas, sinetes e carimbos -, tendo sido membro fundador da Sociedade de Numismática Brasileira, na década de 1920 (MUSEU DE ARTE SACRA, 2014, p. 30).

\subsection{Um museu paulista para os bens eclesiásticos}

Durante nossa pesquisa, foram encontradas diversas citações enaltecendo o papel de Dom Duarte como guardião do passado colonial religioso, sem especificar de que maneira o faz e quando se inicia o movimento de coleta e musealização desse acervo.

Para se determinar então a data de criação do Museu da Cúria foi preciso investigar diversas fontes históricas secundárias, uma vez que não foi encontrada documentação substancial primária do Museu, como regimentos, relatórios, ofícios ou outros documentos de caráter arquivístico.

Entretanto, as fontes pesquisadas acabaram por nos trazer informações divergentes, conforme segue. 
O site da Arquidiocese de São Paulo (http://www.arquisp.org.br) afirma, no texto sobre a biografia de Dom Duarte, que o Museu da Cúria foi de sua criação e que originou, mais tarde, o Museu de Arte Sacra de São Paulo. Logo depois, ainda no mesmo parágrafo, há a menção da fundação também do Arquivo da Cúria em 1918, que posteriormente recebeu seu nome em sua homenagem.

Já no site e em catálogos do Museu de Arte Sacra (MAS-SP), existe a informação de que Dom Duarte começou a colecionar objetos oriundos de igrejas e capelas que foram demolidas a partir de 1907 (ano em que se tornou bispo de São Paulo). Também consta na entrada do museu uma inscrição em pedra referente às comemorações de 10 anos de criação do MAS-SP (em 1980), na qual novamente aparece $o$ ano de 1907:

\begin{abstract}
"Iniciado por Dom Duarte Leopoldo e Silva em 1907 e instalado em 1931 na Cúria Metropolitana, o Museu de Arte Sacra foi transferido para o Mosteiro de N.S. da Luz em 1970 através de convênio firmado entre a Mitra Arquidiocesana e o Governo do Estado de São Paulo. Em 1980, foi totalmente restaurado em homenagem à visita de Sua Santidade João Paulo II ao Brasil".
\end{abstract}

A referência utilizada para a informação de sua instalação em 1931 na Cúria não foi encontrada, mas supomos que possa ter-se baseado num livro de visitas (ACMSP, Livro de Visitas 11-02-42) do Arquivo da Cúria, aberto em 19 de outubro de 1931 pelo Pe. Ernesto de Paula, Secretário-geral do Arcebispado, no qual é possível encontrar mensagens de visitantes que citam o Museu da Cúria. Entretanto, se o livro é de 1931, as menções ao Museu nele aparecem somente a partir de 1936.

Entre as mensagens deixadas referentes ao Museu, há recados de padres e bispos de diversas regiões do Brasil, funcionários de museus como Alfredo R. Rusius, secretário do Museu Imperial (visita em 15/07/1944) e R. Peres, técnico de documentação do Museu Paulista (em 09/03/1949). Também há assinaturas de artistas, como os poetas Aluisio de Castro e Giuseppe Unguetti e do pintor E. Di Cavalcanti; não há data dessas visitas, porém de acordo com a página, supõese que ocorreram em 1940. 
Entretanto, de acordo com o supracitado Inventário de móveis, objetos de arte, alfaias, ornamentos e utensílios, de 1920, já há a indicação de 10 mostruários para o museu, listados juntos com o mobiliário do Arquivo. Com isto, é possível afirmar que a organização do Museu, ou apenas de seus objetos, inicialmente, se deu antes de 1931, podendo ter ocorrido concomitantemente com a criação do Arquivo da Cúria (ou como parte dela), que tem como data de fundação $1^{\circ}$ de abril de 1918.

Esta afirmação é reforçada pelo artigo escrito por Affonso Taunay ao Jornal do Commercio (RJ), em 1935, sobre o amigo Francisco de Salles Collet e Silva, que havia falecido no ano anterior. Entre fatos biográficos a respeito de Francisco Collet, Taunay relata o início da organização do Arquivo da Cúria, o trabalho árduo devido à desordem em que os documentos se encontravam, suas visitas às instalações do arquivo, o trabalho de restauração dos papéis e, em dado momento do artigo, Taunay relata a vontade de Dom Duarte em estruturar um museu de arte religiosa anexo ao arquivo:

"Contemporaneamente resolvera o Senhor D. Duarte Leopoldo que se organizasse um museu de arte religiosa anexo ao arquivo. Numismata, apaixonado, conhecedor profundo deste ramo da nossa heurística possuía o ilustre Prelado coleção vultosa e valiosa.

Entregue a Collet este a dispôs com toda a proficiência pois desde muito era a numismática brasileira uma de suas grandes paixões e dela conquistara largos conhecimentos.

Com o mesmo desvelo prosseguia na instalação dos outros setores do Museu da Cúria Metropolitana os da iconografia, de joalheria religiosa, das relíquias de velhas igrejas, etc. etc.

Valeu-se dos recursos excelentes da antiga Sé Catedral e desenvolveu imensa atividade escolhendo elementos aqui e acolá com um faro de catador eminente. Em certa ocasião desencavou numa velha casa de Pinheiros "às babas" da cidade de S. Paulo, em destruição, telas horrivelmente rotas e negras. Restauradas mostravam efígies regias setecentistas de belo aspecto.

Realizou excelentes compras, tornou-se um fazedor de requisições incansável de vigários, irmandades e particulares. Dentro em pouco podia apresentar um conjunto realmente digno do maior apreço. É o "Museu do Arcebispo" como familiarmente se diz em São Paulo, e com toda a justiça aliás, grande e linda coleção cheia de coisas preciosas, dispostas do modo mais agradável. E única no gênero no Brasil, como apresentação, sistematização e gosto" (Trecho do artigo "Um grande archivista" de Affonso Taunay. Jornal do Commercio, no 195, 1935, p.3). 
Como é possível observar, o artigo de Taunay nos apresenta importantes constatações a respeito do papel desempenhado por Francisco de Salles Collet e Silva na organização do museu e formação de seu acervo.

Dom Clemente da Silva-Nigra, organizador e primeiro diretor do Museu de Arte Sacra da Bahia e membro do primeiro Conselho de Orientação Artística do MAS-SP, faz um relato semelhante ao de Taunay ao apontar o trabalho de Collet e Silva como "curador" do Museu da Cúria:

"Foi o saudoso arcebispo de São Paulo, Dom Duarte Leopoldo e Silva (1907-1938), o primeiro realizador de um Museu de Arte Sacra no Brasil. A sua cultura, clarividência, sensibilidade artística e energia administrativa deram a São Paulo um conjunto de objetos sacros, imagens, pinturas, prataria e alfaias valiosas, artísticas e tradicionais, como é difícil encontrar em qualquer outro lugar do Brasil. Encarregou o seu Chefe do Arquivo da Cúria Metropolitana, o Comendador Francisco de Salles Collet e Silva, de retirar peças antigas e de valor artístico das igrejas e capelas mais antigas da Capital e do Interior da grande Arquidiocese de São Paulo, e por sinal das capelas mais importantes, como São Vicente, Santos, Embu, Escada, Parnaíba, Itu, Moji das Cruzes e tantas outras. Ao construir um prédio próprio, grande e sólido, o Museu da Cúria Metropolitana veio reunir aí esse valioso tesouro religioso de São Paulo antigo" (SILVA-NIGRA, 1970, p. 9).

O entendimento de que o Museu se iniciou no ano de 1918 também é apontado por Vinício Stein Campos, no volume 3 de seu livro Elementos de Museologia: História dos museus (1977), onde num pequeno histórico sobre o MAS-SP diz que:

\footnotetext{
"O Museu de Arte Sacra foi fundado nesta Capital pelo venerável arcebispo de São Paulo D. Duarte Leopoldo e Silva em 1918. Com admirável perseverança, amor às tradições e desvelo na preservação das relíquias religiosas da arquidiocese, o eminente prelado se aplicou empenhadamente na formação do riquíssimo acervo, que dotou a terra paulista de um dos mais belos patrimônios de arte sacra do Brasil" (CAMPOS, 1977, p. 119).
}

Corrobora a suposição de criação do Museu junto ao Arquivo em 1918 uma anotação de Pe. João Kulay, que assume como diretor do Arquivo em 1939, na qual há o início de um pequeno esboço da história do Museu da Cúria: 
"Não houve fundação oficial.

Dom Duarte Leopoldo e Silva (Ressaltar a personalidade ilustre e culta do Primeiro arcebispo de São Paulo).

Aos poucos conseguiu algumas peças, e em 1919 já existia pequena sala.

Em 1922 o número de peças diversas ocupava 4 salas, 3 patamares e escadas.

Colaborador e primeiro Diretor Comendador Francisco Salles Collet e Silva" (ACMSP, pasta Museu/Música).

A data 1922 nos remete ao novo Palácio da Cúria que fora inaugurado em 1920, podendo proporcionar assim salas de exposição mais adequadas aos objetos, constituindo definitivamente os espaços como um museu propriamente dito.

Esta hipótese evidencia-se quando analisada publicação do jornal Correio da Manhã (RJ), em 29 de maio de 1922, que traz trecho de matéria produzida por Eurico Sodré ao Diário Popular, na qual este apresenta o Museu da Cúria, pequeno e ainda desconhecido pelos próprios moradores da cidade, porém de grande estima e importância para a preservação da arte religiosa.

O jornalista faz uma descrição do Palácio da Cúria, devidamente ornado com mobiliário de jacarandá e cabreúva; do Arquivo e sua gama de documentos históricos e do museu propriamente dito, formado por "todas as coisas da arte antiga que [Dom Duarte] encontrou nas velhas igrejas e conventos paulistas":

"Há na Cúria Metropolitana de S. Paulo, um museu desconhecido da maioria dos próprios habitantes desta cidade.

Pequeno ainda - pois de pouco está sendo organizado é, entretanto, duplamente precioso nos valores intrínseco e estimativo dos objetos que guarda.

O arcebispo d. Duarte Leopoldo - recomendável ao respeito de seus patrícios, também pelo seu nacionalismo inteligente e elevado - resolveu colecionar no seu lindo palácio de trabalho todas as coisas da arte antiga que encontrou nas velhas igrejas e conventos paulistas. Com elas, o ornou. Quase todas as mesas e cadeiras de sua mobília são obras de escultura de jacarandá e Cabreúva, seculares algumas, trabalhadas a formão pelos entalhadores que fabricavam o luxo dos nossos antepassados.

Pelas paredes, telas com motivos brasileiros, paisagens aqui, velhos retratos acolá, (...).

(...)

Aqui estão maravilhas da joalheria antiga que fizeram o esplendor do culto externo nas cerimônias religiosas assistidas por nossos avós.

Enormes lâmpadas de prata maciça, oriundas talvez de oficinas portuguesas, relembram a igreja de S. Pedro, onde estiveram, 
bem como a de Sant'Anna da Vila de Parnaíba, de onde foram retiradas e ao pé de cujo altar, muito bandeirante rezou comovido antes de se aventurar Tietê abaixo, numa entrada para o sertão. Além dessas lâmpadas que por si só, constituem relíquias, reúnem-se ali, como numa casa rica de ourives, mil objetos outros, de prata e de ouro, com pedrarias algumas, que sugerem a relativa opulência das igrejas aqui levantadas, em tempos coloniais, (...). E são ostensórios, ambulas, sacras do tempo de d. João V, custódias, resplendores, coroas, salvas, ceptos, navetas, castiçais, ornatos, campas, caldeirinhas, crucifixos, cálices, turíbulos, hissopes, conchas, tudo que faiscava nos altares ou resplendia nas procissões e fazia luxo dantanho, nas igrejas e capelas de são Paulo, Itanhaém, Iguaçu, Santo Amaro, Parnaíba, Itu...

(...)

Não está, talvez, nessas joias custosas, a mais valia deste Museu. Está, sem dúvida, nos seus demais objetos antigos que exprimem várias épocas de nossa vida de povo, relembrando faustos passados e sofrimentos de artistas cujos nomes se perderam.

(...)

Benditas, pois, as mãos piedosas que o organizaram" (Correio da Manhã, no $8.485,1922$, p.2).

Em outra reportagem, do Correio Paulistano de 28 de novembro de 1922, revela a visita do jornal ao Arquivo e Museu da Cúria, apresentando pequeno descritivo do Museu que vinha sendo organizado por Francisco Collet e Silva, e que conta com preciosos objetos como joias, quadros, obras variadas de arte, indumentárias, lampadários e relicários que "constituem uma profunda lição de civismo, na recordação de fatos e acontecimentos que formaram há séculos a estrutura da nossa civilização e da nossa nacionalidade" (Correio Paulistano, no 21.336, 1922, p. 6).

Outro visitante ilustre do museu foi o Dr. Percy Alcin Martin, catedrático de História da América da Universidade de Leland, Califórnia, que passeou por São Paulo em 1926 acompanhado de Affonso Taunay, visitando instituições culturais como o Museu Paulista, o Museu da Cúria e o Liceu de Artes e Ofícios. Também quis conhecer a igreja e colégio de M’Boy Mirim (Embu) por sua história jesuítica (Correio Paulistano, no 22.604, p.3).

A importância do ano de 1922 é reforçada no livro $A$ lgreja nos quatro séculos de São Paulo: 1554-1954, editado em 1955 em comemoração ao IV Centenário da cidade, em que consta um artigo referente ao Arquivo e Museu da Cúria indicando que, entre os anos de 1922 e 1927, o museu "foi pacientemente ampliado" (1955, p. 109). 
A investigação realizada nos periódicos entre os anos de 1910 e 1970 trouxe à pesquisa diversas menções a respeito do Museu e a importância de sua coleção, porém apenas a partir do ano de 1922.

Em sua maioria, exaltam a iniciativa de Dom Duarte em recolher e expor objetos da história religiosa paulista, preservando o "legado de um povo", conforme podemos observar no artigo assinado por A. Tavares de Almeida no Jornal do Brasil (RJ), em 1922, que após visitar o Museu, classificou-o como uma obra nacionalista de Dom Duarte, ao comentar a indiferença do povo para com o seu passado, como no Museu se trabalha com amor e crença na nação e que Dom Duarte o faz "com a grandeza e abnegação de um apóstolo" (Jornal do Brasil, no 248, 1922, p.6).

Diversos periódicos noticiaram a realização do Congresso da Mocidade Católica, organizado por Dom Duarte em setembro de 1928. Entre as atividades, os congressistas participaram de missas, almoço no Trianon, lançamento da pedra fundamental do retiro sacerdotal e visitas ao Museu da Cúria, onde puderam "admirar" documentos e objetos dos antigos templos de São Paulo (Correio Paulistano, № 23.347, 1928, p.5).

Leonardo Arroyo, ao discorrer sobre outras igrejas e capelas vizinhas a São Paulo que também eram, a seu tempo, históricas e pouco preservadas, aponta o recolhimento de objetos tanto pela Cúria Metropolitana para seu Museu como também recolhidas pelo Museu Paulista para integrá-los à sua coleção (ARROYO, 1966, p.283).

Com relação ao Museu Paulista, é interessante comentar uma carta enviada por Affonso Taunay a Dom Duarte em 11 de junho de 1917, ano em que Taunay assume como diretor do Museu Paulista e inicia sua transformação em um museu de história, tendo como centro das atenções a história e o povo paulistas.

Na carta, Taunay, ao ler nos jornais sobre a transferência das irmãs carmelitas que estavam no Convento de Santa Teresa, a ser demolido para construção de novo edifício, pede a Dom Duarte que reserve para o Museu Paulista algumas pinturas da velha igreja que seria demolida, mobiliário de que as monjas quisessem se desfazer e "objetos de antanho em deposito por acaso tenham, de outras eras, coisas de uso comum como sejam: louças, talheres, utensílios de cozinha, lampeões etc, objetos que por imprestáveis acaso hajam 
guardado em algum sótão, como tanto acontecem em grandes casas, antigas" (ACMSP, pasta Museu).

Como justificativa, Taunay argumenta que o Museu até aquele momento era principalmente de História Natural, mas que a partir dali cuidaria também de reunir coleções que dissessem respeito ao passado de São Paulo, e tudo que pudesse ser doado seria "uma dádiva não valiosa, mas valiosíssima" como atestados de eras longínquas bem-vindos a esta nova coleção, que carece de objetos e depoimentos das gerações que se antecederam (ACMSP, pasta Museu).

Em pesquisa no acervo online do Museu Paulista não foram encontrados objetos provenientes do convento de Santa Teresa ${ }^{39}$. Entretanto, em outra carta enviada, Taunay dá a entender que a resposta de Dom Duarte a respeito de sua solicitação foi positiva (ACMSP, Pasta Museu).

Pelas datas das correspondências trocadas entre Dom Duarte e Taunay, 1917, e ao se pensar na criação do Arquivo da Cúria em 1918, quando Dom Duarte e Francisco Collet iniciaram o recolhimento de objetos na Cúria, podemos perceber uma similaridade entre as ações de Taunay no Museu Paulista e aquelas de Dom Duarte no estabelecimento do Museu da Cúria, com a salvaguarda de objetos que representassem a história paulista, e assim iniciado de forma embrionária a ideia de criar um museu com objetos sacros.

Desde o início de sua gestão no Museu Paulista, Affonso Taunay imprimiu um discurso ideológico à construção da identidade paulista, por meio do incremento das coleções de objetos históricos e documentos da época colonial. Segundo Ana Cláudia Fonseca Brefe:

\footnotetext{
${ }^{39}$ A respeito da destinação dos objetos do Convento de Santa Teresa quando de sua demolição, sabemos que alguns itens foram guardados no Museu da Cúria; já as pinturas representando cenas da vida de Santa Teresa nos caixotões do teto da nave da capela foram doadas em 1924 por Dom Duarte à Ordem Terceira do Carmo de São Paulo, estando hoje expostas no corredor lateral da Igreja.
} 


\begin{abstract}
"A invenção do passado nacional, com uma origem determinada, marcos históricos precisos, heróis e símbolos memoráveis, apresentava-se naquele momento da história de São Paulo como poderoso instrumento pedagógico capaz de forjar uma identidade nacional intrinsecamente comprometida com os interesses das elites políticas e intelectuais paulistas. As camadas dirigentes de São Paulo certamente vislumbraram, no universo cultural a ser representado no Monumento do Ipiranga, a possibilidade de se auto afirmarem por meio da construção de um campo simbólico" (BREFE, 2005, p. 118-119).
\end{abstract}

Assim também o faz Dom Duarte, a partir do recolhimento dos objetos sacros das igrejas de São Paulo, para construir a identidade religiosa paulista, reforçando o caráter dominante da Igreja Católica como religião soberana de um Estado que, à época, se sobressaia no cenário político nacional.

Deste modo, de acordo com as evidências apresentadas, podemos concluir que o Museu da Cúria se iniciou de forma embrionária a partir do retorno de Dom Duarte a São Paulo, em 1907, ainda como bispo da cidade, e suas ações políticas de modernização dos templos, tomando contornos como instituição museológica de fato somente a partir de 1918, com a criação do Arquivo da Cúria.

É possível ainda afirmar que a presença de Francisco Collet como diretor do Arquivo, em contato direto com documentos das dioceses e paróquias do Estado, proporcionou uma pesquisa e levantamento do patrimônio religioso paulista, possibilitando assim se realizar uma espécie de inventário de objetos que merecessem serem recolhidos e salvaguardados na Cúria, iniciando então a coleção do Museu da Cúria.

Entretanto, as maneiras com que os objetos foram sendo incorporados de fato ao acervo do Museu da Cúria ao longo do tempo segue incerta. Além de algumas poucas cartas relacionadas à doação de objetos, as fontes de pesquisa analisadas sempre apontam para uma ação de recolhimento por parte de Dom Duarte e de Francisco Collet, no intuito de salvaguardar a arte religiosa paulista, sem descrever ou dar pistas, no entanto, de como foram realizadas essas coletas. 
Durante a pesquisa em diversas séries documentais no ACMSP, foi possível encontrar algumas pistas acerca da incorporação das peças. É o caso do livro de correspondências do Arquivo da Cúria, que contém cópias de cartas assinadas pelo diretor do Arquivo Francisco Collet, enviadas aos vigários, solicitando documentos e livros de tombos de suas paróquias para arquivamento na Cúria, de acordo com a política estabelecida por Dom Duarte, como já mencionado.

Há, entretanto, apenas algumas poucas cartas a respeito de objetos presentes no Museu. Estas, porém, oferecem indicações suficientes para vislumbrarmos o tipo de coleção que se vinha formando e o quanto se dava relevo à paróquia ou irmandade a que tinha pertencido.

Numa dessas cartas, de 1922, Francisco Collet comunica a Frei Agostinho Christobal, vigário da paróquia de São Vicente, que há quatro objetos recolhidos ao Museu da Cúria, que pertenceram à citada paróquia:

São Paulo, 24 de junho de 1922

IIImo. e Revmo. Sr. Pe. Frei Agostinho Christobal M. D. Vigário da Paróquia de São Vicente

Prezado Sr. Saudações.

De ordem de S. Exa. Revmo. O Sr. Arcebispo Metropolitano, comunico a V. Revmo. que se acham recolhidos no Museu desta Cúria os seguintes objetos que pertencem a essa Paróquia:

1 Crucifixo de marfim que pertenceu a Frei Gaspar de Madre de Deus;

1 Paramento para Missa (Casula, Estola, Manipulo, Pala e Véu de Cálice, e Bolsa para Corporaes) que pertenceram ao Pe. Diogo Antônio Feijó;

7 cruzes processionais e 4 castiçais de prata.

Sem outro motivo, me subscrevo com muita consideração e estima

De V. Revmo. [ilegível]

Francisco de Salles Collet e Silva Arquivista da Cúria Metropolitana 
Em outra carta encontrada, de 14 de fevereiro de 1924, Francisco Collet relembra Monsenhor Domingos Magaldi, de Botucatu, que Ihe havia prometido enviar ao Museu os sinetes de Armas do finado bispo daquela paróquia, Dom Lucio Antunes de Souza.

São Paulo, 14 de Fevereiro de 1924

Exmo. Revmo. Sr. Monsenhor Domingos Magaldi

M. D. Vigário Capitular do Bispado de Botucatu, Sede Vacante, Botucatu

Prezado Sr. Saudações.

Em nome do Exmo. e Revmo. Sr. Arcebispo Metropolitano venho, por início desta, lembrar a $V$. Exa. Revmo. a promessa que me fez de remeter para o Museu da Cúria os sinetes de Armas de exmo. Bispo dessa Diocese - o finado D. Lucio Antunes de Souza, de saudosa memória. Antecipando os agradecimentos pelo [ilegível] aqui fico sempre ao inteiro dispor de V. E. Revmo. e me subscrevo o mais alto apreço e muita consideração.

De V. Exa. Revmo. [ilegível]

Francisco de Salles Collet e Silva Diretor Arquivista da Cúria Metropolitana

Há também correspondências endereçadas a irmandades e a leigos que fizeram doações ao Museu, como é o caso da carta enviada à Irmandade do Santíssimo Sacramento da Candelária, em 1924, solicitando informações a respeito da origem da irmandade para incluir no verbete da peça "cruz de ouro com fitão vermelho" no catálogo do Museu e a carta de 1922 ao sr. José Augusto de Loyolla, agradecendo em nome do Arcebispo Dom Duarte o envio de uma pistola da Guerra do Paraguai e uma bala de canhão da Revolta da Esquadra de 1893, oferecidos ao Museu.

Além dessas cartas, o catálogo do Museu da Cúria também aponta a doação de muitos objetos. Nas cartas enviadas pelos doadores e encontradas nas pastas relacionadas ao Museu da Cúria no ACMSP, podemos vislumbrar a honra que era poder colaborar com o museu que estava sendo formado por Dom Duarte. 
Segundo a carta enviada por Dom Benedito Paulo Alves de Souza, bispo do Espirito Santo, na qual faz a doação da caneta utilizada no Concílio Plenário da América Latina em 1899. Este seria um objeto de grande valor para a Igreja Católica Latina, e por isso seria uma honra que figurasse no museu organizado por Dom Duarte:

São Paulo, 15 de outubro de 1921

Excelentíssimo Arcebispo de São Paulo Beijo as sagradas mãos de V. [ilegível] sabendo que V. Exa. está empenhado em organizar um Museu arquidiocesano, tenho a honra de enviar a V. [ilegível] um objeto pobre e de pouco valor material, mas que eu julgo de imenso valor para a Igreja Católica na América Latina. É a caneta de que se serviram os IImos. Arcebispos e Bispos presentes ao Concílio Plenário da América Latina, realizado em Roma e encerrado no dia 9 de Julho de 1899, para assinarem os Decretos do referido Concílio.

Como notário que fui dessa respeitável Assembleia que se reuniu pela primeira vez, tive a incumbência de apresentar essa caneta a cada um dos llmos. Arcebispos e Bispos, na reunião da assinatura.

Fazendo [ilegível] para que o Museu Arquidiocesano de São Paulo seja enriquecido de muitos outros objetos de igual valor, apresento a V. [ilegível] minhas sinceras felicitações por mais esse benefício feito por V. Exa. a amada arquidiocese de São Paulo.

Queira V. Exa. abençoar sempre a [ilegível]

Benedito, Bispo do Espírito Santo

Na descrição do objeto no catálogo do Museu da Cúria, há a observação que a referida carta era exposta junto ao objeto.

Em outra carta, de 1922, Monsenhor José Francisco de Moura Guimarães, secretário particular do Cardeal Joaquim Arcoverde, diz entregar o objeto "com o maior prazer" a Dom Duarte: 


\begin{abstract}
Atesto que este tinteiro de louça serviu a um dos IImos. Cardeais no Conclave realizado em Roma, na Capela Sistina no Vaticano, de trinta e um de Agosto de mil novecentos e catorze, a três de setembro do mesmo ano, em qual tomou parte o primeiro Cardeal da América Latina, Exa. Cardeal Joaquim Arcoverde de Albuquerque Cavalcanti, a quem tive a honra de acompanhar como conclavista. Apenas eleito Papa o Cardeal della Chiesa, que tomou o nome de Bento $X V$, de quem tomei a benção pela primeira vez no coro da lgreja de S. Pedro, donde [ilegível] a benção sobre a multidão compacta na nave do templo, dirigi-me à Capela Sistina e dali retirei como lembrança o tinteiro acima referido, que com o maior prazer entrego nesta data ao Exmo. e Revmo. Sr. D. Duarte Leopoldo e Silva, Arcebispo de S. Paulo, para ser guardado no museu arquiepiscopal de sua Secretaria Eclesiástica.
\end{abstract}

Rio de Janeiro, 13 de Junho de 1922, ano centenário da independência do Brasil.

Monsenhor José Francisco de Moura Guimarães, Arcediago da Catedral Metropolitana de S. Sebastião do Rio de Janeiro e Secretário particular do Eminentíssimo Sr. Cardeal Joaquim Arcoverde

À margem da primeira folha da referida carta, podemos observar uma anotação feita em tinta vermelha, onde se lê "Museu da Cúria - Registrado sob o $\mathrm{n}^{\circ}$ 279" e a assinatura de Francisco Collet como "D. Arquivista". Essa observação inserida no documento nos mostra uma das formas de organização de Collet para as cartas recebidas junto às doações de objetos, onde se registra o número que o objeto recebeu no Museu.

Entre os documentos encontrados nas pastas sobre o Museu da Cúria no ACMSP, há um documento de 1933 registrado em cartório, no qual Francisco Collet atesta ter recebido joias de uma doadora, que ficariam depositadas no Museu da Cúria até o momento em que fossem reclamadas de volta (Fig. 27). 
Figura 27: Documento autenticado em cartório sobre guarda provisória de objeto no Museu da Cúria.

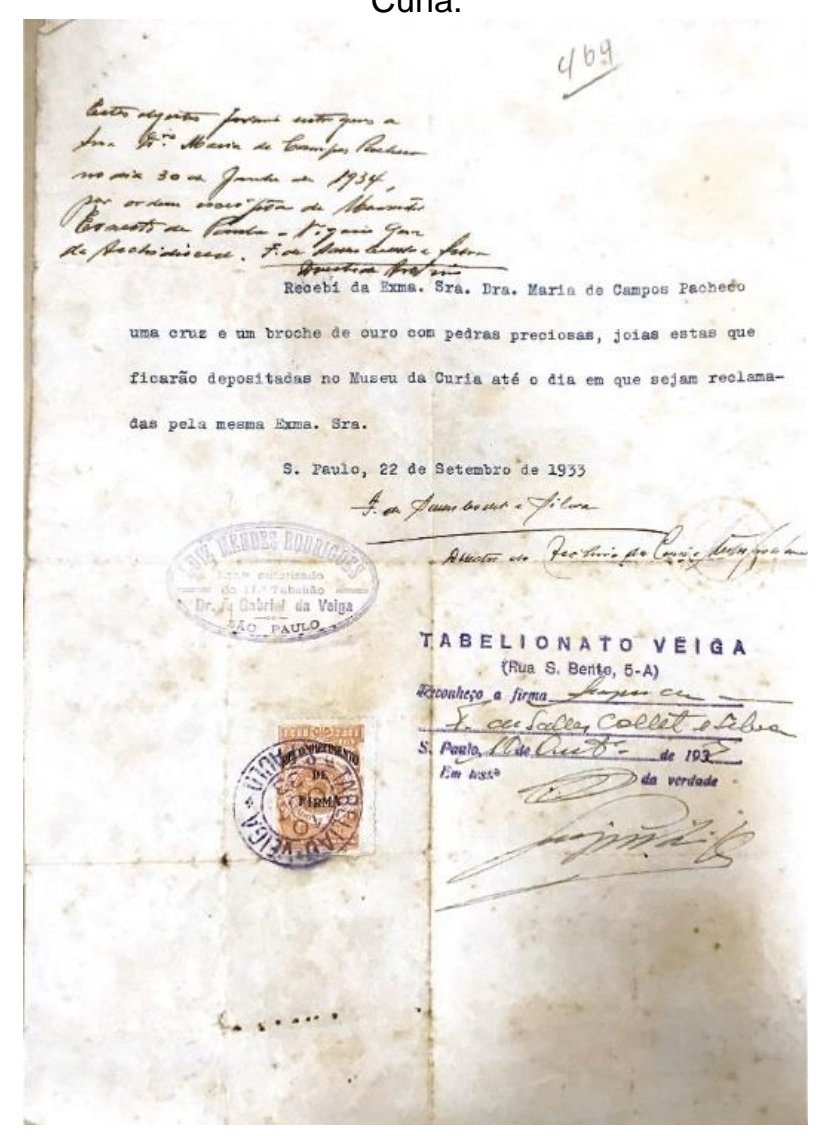

Fonte: ACMSP.

Podemos observar no canto superior esquerdo, uma anotação manuscrita assinada por Francisco Collet informando o retorno dos objetos à doadora, em 30 de junho de 1934, por ordem do Vigário da Arquidiocese. Também há na parte superior um número, que supomos ter sido o número temporário de entrada dos objetos - no catálogo do Museu, o objeto no 469 corresponde a um cálice de prata dourada procedente do Mato Grosso.

Interessante observar a confiança dessa doadora no Museu da Cúria como local de guarda provisória de suas joias, por um período menor que 1 ano, e o procedimento do diretor do Arquivo em registrar em cartório o recebimento dos objetos, inseri-los no Museu e devolve-los assim que solicitado. Não encontramos maiores informações a respeito dessa senhora ou o porquê de deixar suas joias no Museu.

Ao longo de nossa pesquisa também encontramos outras informações a respeito da entrada de objetos ao acervo do Museu da Cúria. 
O Instituto Histórico e Geográfico de São Paulo (IHGSP) doou ao Museu da Cúria, em 1939, uma cômoda, duas folhas de porta, um oratório e dois vasos com seus pertences, todos originários da Igreja de São Miguel. Segundo carta publicada no jornal O Estado de S. Paulo, em 04 de novembro de 1939, assinada por José Torres de Oliveira, então presidente do IHGSP, as peças foram adquiridas de um antiquário pela quantia de 1:300\$, com o objetivo de "salvar do extravio e da ruína esses interessantíssimos documentos do nosso patrimônio histórico e artístico" (O Estado de S. Paulo, 1939, n. 21.512, p. 4).

O presidente do IHGSP ainda diz que, não tendo acomodações e pessoal habilitado para cuidar dos objetos, e em se tratando de itens pertencentes "a uma casa de culto divino", reitera a doação já feita anteriormente a Dom Duarte, para que os objetos sejam recolhidos ao Museu da Cúria.

$\mathrm{Na}$ edição do jornal no dia seguinte foi publicada a carta-resposta de Dom José Gaspar, em que se diz honrado com a oferta e que "aplaude a patriótica iniciativa que [o IHGSP] tomou nas circunstâncias referidas" (O Estado de $S$. Paulo, 1939, n. 21.513, p. 9). Esses objetos, entretanto, não foram encontrados no catálogo do Museu, porém podemos supor que tenham sido colocados em outros cômodos do Palácio da Cúria.

Havia também no Museu da Cúria uma coleção de 57 imagens que pertenceram a Paul Israel Hirsch. A coleção foi depositada no Museu já na década de 1950, por força de decisão do Juízo de Direito da 2ª Vara da Família e das Sucessões (Proc. RUSP 2761/58), uma vez que Paul Israel Hirsch faleceu sem deixar herdeiros. Segundo lei que vigorava à época a respeito de heranças vacantes do Estado, determinava-se que bens deixados nessas circunstâncias fossem para as Universidades - neste caso, o Estado repassou a coleção de imagens para a USP, que a direcionou ao acervo do Museu Paulista.

Essas imagens, porém, nunca foram fisicamente para o Museu Paulista, instituição à qual pertencem juridicamente. No decorrer do processo, foi estabelecido o depósito das imagens no Museu da Cúria, onde permaneceram até o convênio de 1969 entre a Mitra e o Estado de São Paulo para a criação do Museu de Arte Sacra de São Paulo ${ }^{40}$, onde se encontram atualmente. ${ }^{40}$ Segundo registros, as imagens foram incorporadas ao acervo do MAS-SP, quando do convênio
em 1969, como sendo pertencentes à coleção da Cúria Metropolitana. Em 1973 a situação foi 


\subsection{0 acervo do Museu da Cúria}

No Arquivo da Cúria (ACMSP) foram encontrados dois catálogos do Museu: catálogo ํㅡㄴ 52, datilografado, que apresenta 1.122 objetos inventariados, e o catálogo ํㅜ 53, manuscrito e que soma 1.126 objetos, sendo que há duas folhas anexas com o restante dos objetos que não couberam no livro com o término das páginas. Os dois catálogos registram os mesmos objetos com poucas diferenças: apenas o objeto de número 1.122 difere entre os catálogos, além dos quatro últimos (números 1.223 a 1.226), que não constam no primeiro.

Para nossa pesquisa, utilizamos o conteúdo do oㅡ 52, que está datilografado e possui anotações manuscritas de suma importância, combinado com os 5 últimos objetos inventariados no catálogo de ํㅡㄴ 53, para termos uma compreensão total do acervo.

Apesar de não ser datado, supõe-se que o catálogo tenha sido iniciado na década de 1920, uma vez que, com a mudança para o novo Palácio da Cúria, os objetos possam ter sidos inventariados tal qual ocorreu com o restante dos objetos presentes no novo edifício, além das evidências constatadas nas matérias jornalísticas acerca do Museu e seus objetos.

Também corrobora a presente suposição, extensiva, no máximo, até os anos 1930, o fato de que há anotações datilografadas no verso que indicam a retirada e devolução de objetos por Dom Duarte, que permaneceu à frente da Cúria Metropolitana de São Paulo até sua morte, em 1938.

Entretanto, as últimas entradas correspondem a objetos incorporados durante o arcebispado de Dom José Gaspar d'Afonseca e Silva, na década de 1940, como antigos objetos litúrgicos usados por Dom Duarte e itens confeccionados para eventos específicos, como dois cálices de ouro utilizados no Congresso Eucarístico Nacional realizado em São Paulo, em 1942. Assim, podemos concluir que o catálogo foi muito provavelmente iniciado na década de 1920 e finalizado no início da década de 1940.

regularizada com o Museu Paulista, estabelecendo-se o MAS-SP como comodatário das imagens por tempo indeterminado (Proc. RUSP 2761/58; Of. MAS ST. №10/83). 
É possível observar algumas anotações feitas à caneta e a lápis nas décadas seguintes, como por exemplo, uma nota indicando que a pintura de Nossa Senhora de Guadalupe está em exposição na Casa do Bandeirante (década de 1950) e outra que aponta quais peças foram separadas para serem vendidas pelo Cardeal Rossi (década de 1960).

Essas marcações dão a entender que, apesar de os catálogos não terem mais sido preenchidos como inventários a partir da década de 40 , ainda eram utilizados para controle dos objetos.

As anotações foram entendidas como dados para nossa investigação, porém, não nos detivemos nas informações a respeito da retirada e venda de peças pelo Cardeal Agnelo Rossi por se tratar de fato ocorrido na década de 1960 e fora do escopo desta pesquisa ${ }^{41}$.

O catálogo segue o formato de livro de inventário, conforme é possível ver na imagem abaixo (Fig. 28), com os seguintes campos: № de ordem, Objecto, Sala, Patamar e Mostruário. Na listagem, há dados a respeito dos objetos que compunham o museu e algumas poucas descrições acerca dos materiais e técnicas, proveniências e informações a respeito dos locais, sua forma de entrada no museu - recolhimento ou doação, e seu respectivo doador.

\footnotetext{
${ }^{41}$ Durante a pesquisa no ACMSP foram encontradas, na pasta MAS, cartas avulsas do Cardeal Rossi se explicando sobre a venda de objetos do acervo, principalmente joias apontadas por ele como de "ouro baixo", para obras de reparação do telhado da Igreja Nossa Senhora da Conceição, na praça Silvio Romero. Pelo que pudemos analisar durante a investigação do catálogo, as peças indicadas como retiradas para venda eram joias antigas, muitas com pedras preciosas, pertencentes a igrejas como velha Matriz de Santo Amaro e Igreja da Penha de França, e objetos como um resplendor de ouro maciço da Matriz de Santa Ifigênia. Esta pesquisa não se ateve em conferir se esses objetos foram de fato vendidos e nem em entrar no mérito da polêmica a respeito da venda das peças, muito criticada à época.
} 
Figura 28: Página 96 do Catálogo do Museu da Cúria.

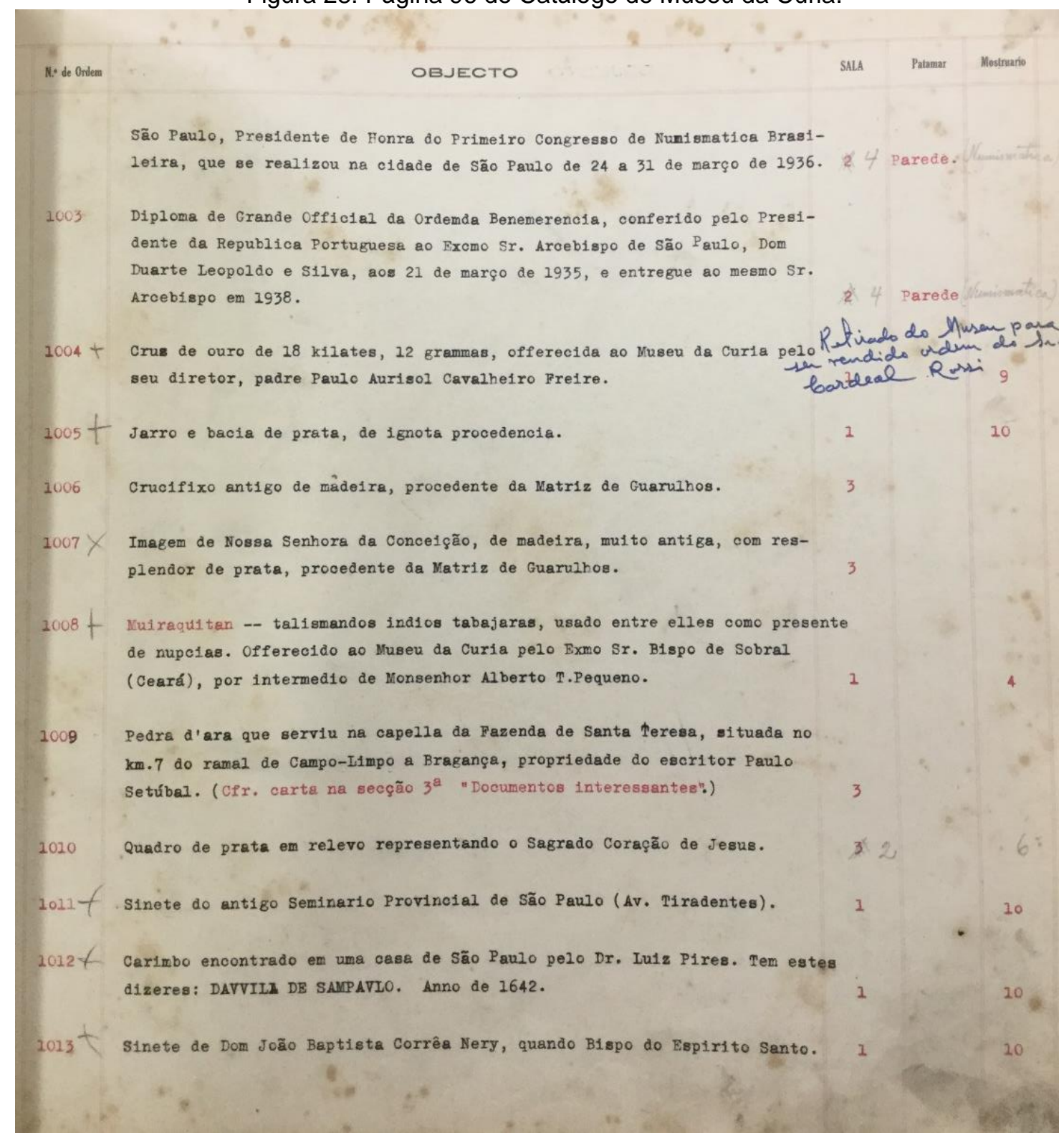

Fonte: ACMSP, 06-03-052. Fotografia Luciana Barbosa.

Para análise do catálogo elaboramos uma planilha Excel com as informações nele contidas, tabuladas entre os seguintes campos: № de ordem, Objeto, Procedência, Pertenceu a, Doado por, Cidade, Estado, País, Sala, Patamar, Mostruário, Descrição /Observação. A escolha dos campos se deu a partir da necessidade de desmembrar as informações contidas no campo Objecto do catálogo, por apresentar informações pertinentes para o estudo de cada objeto. 
Além disso, também incluímos campos que foram primordiais para a investigação e entendimento do acervo e sua proveniência, como Cidade, Estado e País.

As transcrições das informações foram atualizadas para as regras gramaticais atuais do idioma português, exceto nomes próprios e transcrições literais de cartas e inscrições presentes nos objetos.

Foram 1.127 objetos tabulados ( 1.122 do catálogo $\mathrm{n}^{\circ} 52$ e mais as últimas 5 entradas presentes no catálogo $n^{\circ}$ 53). Cabe ressaltar que muitos objetos, como as joias, por exemplo, foram inventariados num mesmo número de ordem ainda que fossem objetos distintos; em nossa planilha cada objeto ficou em uma linha seguindo o mesmo número repetido, por isso a discrepância entre o número total de objetos por origem e a numeração presente na planilha.

Dos objetos que possuíam identificação de país de origem, 28 foram encontrados, havendo itens oriundos do Chile, França, Israel, Itália, Paraguai, Portugal e Vaticano. Do Brasil, há 843 objetos dos estados: Alagoas, Bahia, Goiás, Maranhão, Mato Grosso, Mato Grosso do Sul, Minas Gerais, Pará, Paraná, Pernambuco, Rio de Janeiro, Rio Grande do Sul, Santa Catarina, São Paulo e Sergipe.

O Estado de São Paulo concentra o maior número de objetos encontrados no catálogo do Museu da Cúria, com 659 peças provenientes das seguintes cidades: Aparecida, Apiaí, Araçariguama, Araraquara, Batatais, Botucatu, Caconde, Campinas, Carapicuíba, Casa Branca, Cotia, Embu, Franca, Guarapuava, Guararema, Guarulhos, Itanhaém, Itapecerica da Serra, Itapetinga, Itatiba, Itu, Jaboticabal, Jarinu, Mogi das Cruzes, Nazaré Paulista, Piracaia, Pirapora do Bom Jesus, Porto Feliz, Santana de Parnaíba, Santos, São Carlos, São Domingos, São Paulo, São Vicente, Sorocaba, Taubaté e Tietê. Apenas cinco objetos não possuem informação de procedência da cidade.

Já a cidade de São Paulo, como era de se esperar, registra o maior número de objetos inventariados: 381, sendo que 189 são oriundos de igrejas e irmandades, 60 são de repartições eclesiásticas e apenas 9 não possuem nenhuma informação. 


\subsubsection{As tipologias dos objetos presentes no acervo}

Segundo o primeiro catálogo do MAS-SP (1970, p. 23), publicado em 1970 após abertura do Museu, a catalogação do acervo foi organizada por Pedro Antônio de Oliveira Ribeiro Neto, primeiro diretor do Museu, e a classificação das peças foi feita seguindo o agrupamento sequencial do fichário da Cúria Metropolitana.

As fichas do antigo Museu da Cúria não foram encontradas para serem cotejadas, porém toma-se como certo, a partir da informação acima, que a primeira ficha catalográfica do MAS-SP foi baseada nelas.

Entretanto, apesar de as fichas do MAS-SP serem baseadas no fichário da Cúria, quando da catalogação do Museu em 1969-1970 foi estabelecido um novo sistema de ordenação das peças, levando em conta as tipologias existentes. Isso é comprovado ao compararmos as numerações das peças, que não seguem a mesma ordem da Cúria.

Tomemos como exemplo o resplendor de prata dourada da antiga Igreja da Sé. A Figura 29 apresenta a primeira ficha catalográfica do objeto no MASSP; vemos os campos padrões de uma ficha de catalogação, preenchidos datilografados, com revisões à lápis. O número do objeto é "193-c", sendo a letra "c" designação para a coleção da Cúria no MAS-SP. 
Figura 29: Ficha catalográfica do MAS-SP (frente e verso).
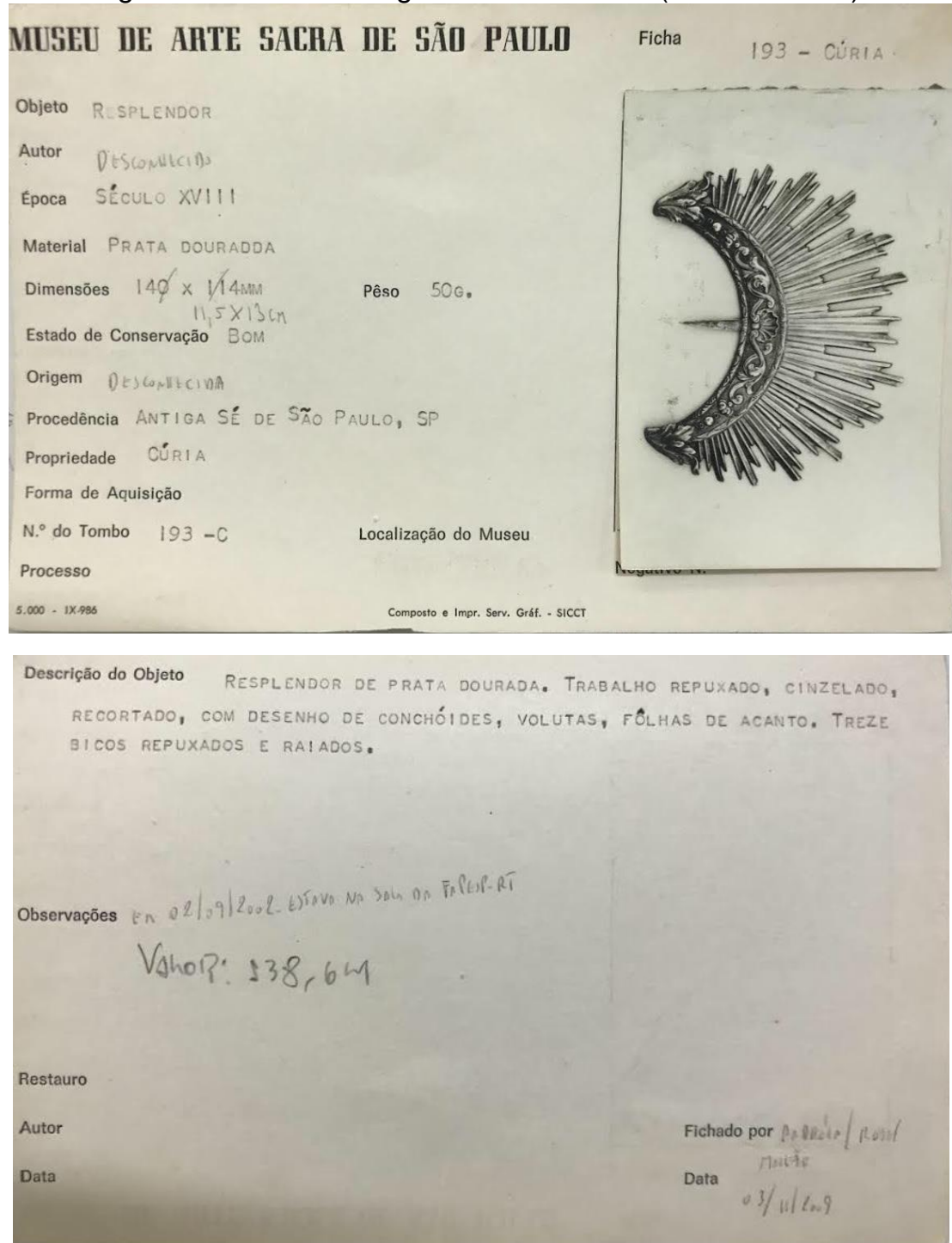

Fonte: Acervo Museu de Arte Sacra de São Paulo. Fotografia Luciana Barbosa, 2020.

Já no catálogo do Museu da Cúria, este objeto foi inventariado com o número de ordem "90", e apresenta apenas título "Pequeno resplendor de ouro", procedência "Velha Catedral de São Paulo" e a indicação de estar exposto no Mostruário 2.

Vale ressaltar que, em uma antiga listagem de inventário da Cúria encontrada no MAS-SP, este resplendor possuía como numeração antiga o número "3201/90". Não podemos afirmar ao certo o que o número "3201" representa, porém é possível supor se tratar de uma numeração dada pelo Museu da Cúria quando da listagem geral do acervo, talvez nos seus últimos anos de existência. 
Assim, nossa análise do acervo do Museu da Cúria baseia-se nas denominações e descrições encontradas no Catálogo no 52 . O acervo abrangia objetos do século XVII, como a imagem de São Paulo da primitiva Igreja do Pátio do Colégio, ao século $X X$, como os sinetes de Dom Duarte, com grande predomínio de objetos do século XVIII, de acordo com as descrições dos objetos analisadas no catálogo do Museu.

A predominância de objetos do século XVIII se justifica pelo auge da arte barroca no Brasil, que "foi proporcionada pela riqueza criada com a produção de açúcar, fumo e madeira nos séculos XVI, XVII e XVIII e com predomínio da mineração do ouro durante o século XVIII e princípio do XIX" (ETZEL, 1974, p. 23).

O barroco, caracterizado como a arte da Contrarreforma, "valoriza o movimento, as curvas e contra curvas, o claro-escuro, a instabilidade da composição visual, o artifício e as formas descentradas e complicadas em detrimento do mundo natural e do despojamento" (CAMPOS, 2011, p. 123).

O Concílio de Trento (1546-1563), conhecido também como o Concílio da Contrarreforma, foi convocado pelo Papa Paulo III para estabelecer qual seria a atuação da Igreja frente ao avanço protestante, definindo como objetivo principal o fortalecimento da autoridade papal através de uma disciplina mais rigorosa. Ao mesmo tempo, procurou o esplendor da arte para neutralizar o apelo protestante junto aos fiéis.

\begin{abstract}
A Igreja mesclava seus interesses à apelação característica do barroco. A opulência dos púlpitos, altares e até paredes inteiras repletas das mais variadas formas, tais como: conchas, anjos e outras simbologias, de imediato captam nossa atenção e é justamente essa a intenção nas pregações. Toda uma encenação ritualística envolvendo visão, oralidade e música era montada para fixar os fiéis à mensagem que estavam passando" (ALVES, 2007, p. 39).
\end{abstract}

Esse gosto pelo monumental em oposição à sobriedade protestante levou as manifestações artísticas no período colonial a reproduzirem a hegemonia portuguesa, uma vez que "conduzem as pessoas a conceitos e práticas" vigentes, como símbolos de poder e correta conduta cristã (TIRAPELI, 2018, p. 95). Entretanto, essa herança barroca portuguesa ganha uma nova interpretação frente à realidade do Novo Mundo: 
"A alma tropical brasileira proporcionou ao barroco português o aparecimento de um estilo vibrante, colorido, exibicionista, voluptuoso e sensual nas esculturas, talhas e pinturas parietais de centenas de igrejas construídas no período colonial dos séculos XVII, XVIII e começo do XIX. Do norte ao sul do Brasil, colocouse o nome de Deus nas alturas" (ARAÚJO, 2018, p. 32).

A América portuguesa recebeu os missionários que utilizaram as artes plásticas, a música, teatro como instrumentos de evangelização conforme os ditames do Concílio de Trento. A presença de ordens religiosas regulares ${ }^{42}$, como jesuítas, beneditinos, franciscanos e carmelitas no Brasil desde o final do século XVI, possibilitou que a arte religiosa fosse produzida de acordo com os padrões artísticos europeus, pois as ordens "tinham condições para trazer ao Brasil o que de melhor havia em conhecimentos artísticos na época" (ETZEL, 1974, p. 68).

A respeito deste mecenato das ordens religiosas regulares, CAMPOS nos aponta duas modalidades praticadas:

a) a ordem encomenda a obra e remunera o artista - desenhos arquitetônicos, talhas, esculturas, pinturas e policromia, ourivesaria, música, etc. $O$ contrato e recibos de pagamento podem, inclusive, estar registrados em livro contábil da instituição monástica.

b) a congregação religiosa apoia deliberadamente o trabalho de um membro seu, com talento em potencial para as artes, sem que isso represente necessariamente remuneração em espécie. Assim o faz por que acredita naquela expressão cultural/religiosa. (CAMPOS, 2011, p. 39).

\footnotetext{
$42 \mathrm{O}$ termo clero regular é utilizado para designar os religiosos que seguem a regra de uma determinada congregação. "A regra é a norma condutora, baseia-se no ideário do santo fundador, compreendendo as formas doutrinais e teológicas vivenciais, bem como o programa iconográfico observado no culto cotidiano dos conventos. As orações, os cantos e os ritos expressam o carisma do fundador ou inspirador da associação religiosa em questão, constituindo, ao longo dos séculos, um patrimônio cultural e artístico das comunidades monásticas" (CAMPOS, 2011, p. 33). Já o clero secular é "(...) aquele que vive no século, ou seja, em permanente contato com os fiéis, e que se estabelece em uma divisão regional denominada 'Diocese'. O sacerdote (presbítero ou clérigo) habita a respectiva paróquia (também chamada de freguesia), onde prega e ministra os cinco sacramentos: batismo, eucaristia, penitência, matrimônio e extrema-unção" (CAMPOS, 2011, p. 35).
} 
Além dos cleros regulares e seculares, as associações religiosas (irmandades, confrarias e arquiconfrarias) também foram fundamentais para 0 desenvolvimento da arte sacra no Brasil. Segundo ETZEL, o papel das associações religiosas no interior do país equivale ao das ordens no litoral, pois ambas "atuavam, sobretudo, com um profundo substrato emocional, num ambiente de rivalidade constante; daí resultou uma proliferação impressionante de igrejas, cada uma melhor, maior e mais luxuosa" (1974, p. 76).

Com relação às técnicas de construção, ETZEL aponta que os primeiros conventos e igrejas levantados na orla marítima eram feitos de pedra e cal; já "nas regiões interioranas, a partir de São Paulo, depois em Minas Gerais, Mato Grosso e Goiás, a taipa de pilão ou o adobe foram empregados com exclusividade" (1974, p. 42).

Essa devoção fervorosa do mundo ibero-americano, segundo CAMPOS, era manifestada na beleza da ação cultual, uma vez que,

\footnotetext{
"De acordo com a concepção cristã: quem economiza não investe no sagrado e não confia na providência divina. Não por acaso, houve no contexto colonial uma enorme demanda de objetos para o culto e de produtos confeccionados por artesãos, artífices e artistas. Para o estudioso da arte interessa a fé com devoção, pois nela os investimentos para louvar a Deus são fartos" (CAMPOS, 2011, p. 107. Grifo da autora).
}

Já a arte religiosa colonial no contexto paulista difere-se da apresentada nas principais cidades litorâneas, como Salvador e Rio de Janeiro, e das cidades de Minas Gerais, por diversos motivos, como a pobreza econômica e pelo seu isolamento geográfico, ainda que o Estado tivesse "diversos caminhos de grande movimento: a estrada do litoral, para Santos; a estrada do caminho das minas de Cataguases, pelo Vale do Paraíba; a estrada do caminho das minas de Goiás, por Jundiaí; a estrada das minas de Cuiabá, por Itu e Porto Feliz" (TIRAPELI, 2001, p. 104).

Segundo ETZEL, “(...) na Capitania de São Paulo também houve a evolução do barroco que não deixou de ter algumas brilhantes manifestações, ainda que sempre de acordo com o baixo padrão econômico-social dessa região" (1974, p.178). 
A maioria das peças que constituíam o acervo do Museu da Cúria é originária de igrejas e capelas da cidade de São Paulo, e de seus arredores, e representam a sobriedade e simplicidade cultural paulista.

O fato de recolhê-las para o Museu da Cúria, aliado ao seu declarado entusiasmo pela história de São Paulo, permite supor que Dom Duarte estivesse empenhado em salvaguardar a materialidade do culto católico em São Paulo.

A seguir destacamos as principais tipologias encontradas no Museu da Cúria, de acordo com nossa análise feita no Catálogo do Museu, a partir da contabilização de itens por categoria. Não nos deteremos na análise artística dos objetos que compunham o Museu da Cúria; pretendemos aqui fazer uma breve explicação sobre as tipologias quantificadas e os meios de fabricação, destacando algumas peças que julgamos ter maior relevância dentro da coleção.

As respectivas informações catalográficas foram retiradas das fichas encontradas no MAS-SP. A explicação da função primária de cada objeto encontra-se no ANEXO A, que consiste num pequeno glossário de arte sacra e objetos de culto católico, que elaboramos, sem maior pretensão do que apenas auxiliar à compreensão de diversos termos referidos ao longo do trabalho.

A relação completa dos objetos listados no catálogo no 52 do Museu da Cúria encontra-se no Capítulo 3.3.1, disposta de acordo com a localização do objeto na expografia por nós reconstruída e analisada.

\section{Prataria e Ourivesaria}

O acervo do Museu da Cúria é constituído majoritariamente de objetos litúrgicos em ouro, prata ou prata dourada; cerca de $60 \%$ de seu acervo é formado por alfaias, termo utilizado para denominar todos os objetos que se prestam para o culto católico: "cálice, custódias, âmbulas, patenas para celebração das missas; navetas, turíbulos para os diversos cultos, vasos de santos óleos para crisma, batismo e unção dos doentes; coroas, resplendores e atributos como espadas para ornamentar os santos; as palmas, salvas, candelabros e relicários para ornar os altares; lampadários e candelabros para iluminação e as vestimentas dos padres com ricos bordados em fios de ouro e de prata" (TIRAPELI, 2007, p.31). 
Figura 30: Âmbula, cálices e coroa pertencentes ao Museu da Cúria.

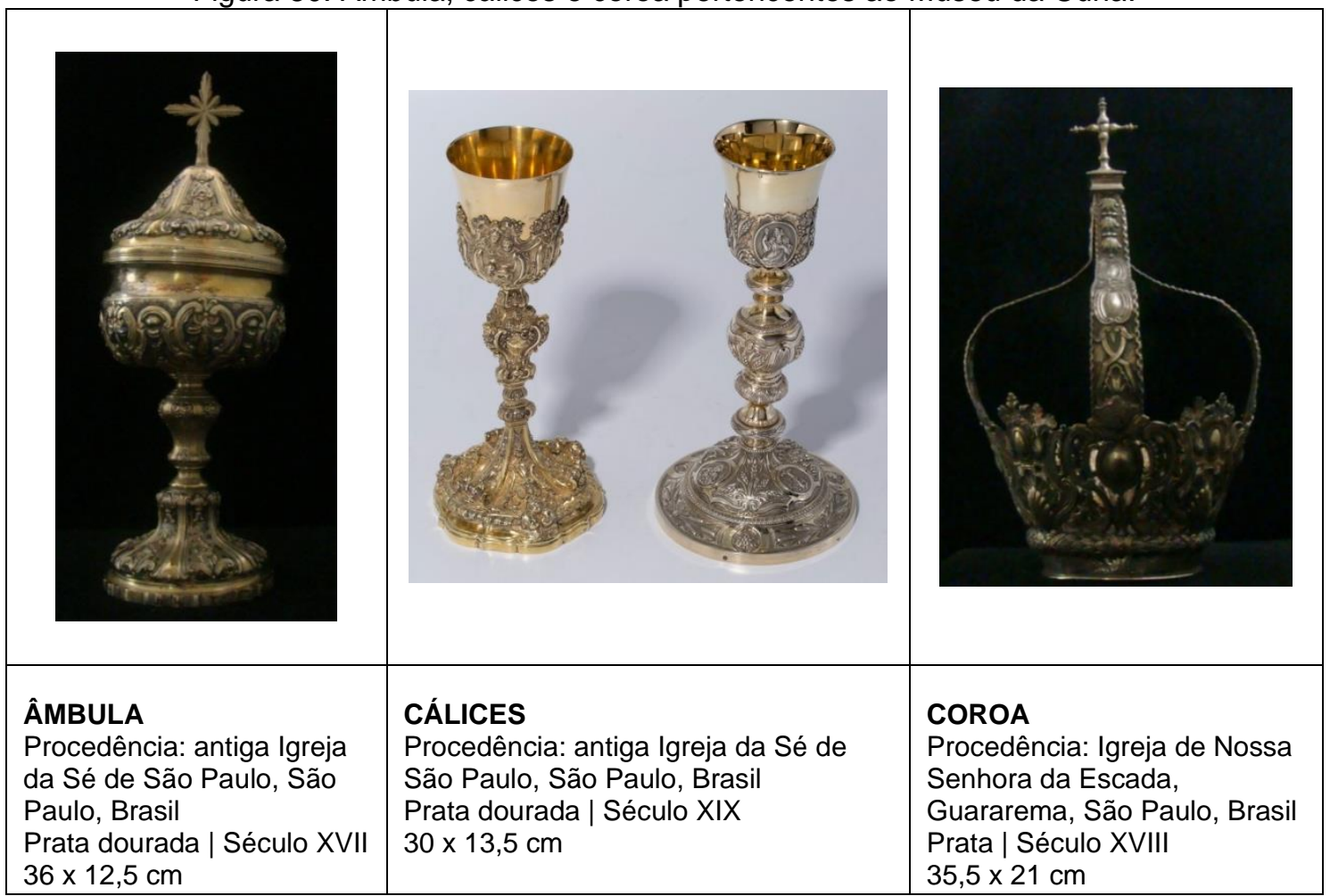

Fonte: Acervo Museu de Arte Sacra de São Paulo. Fotografia Iran Monteiro.

Figura 31: Naveta, patena e resplendor pertencentes ao Museu da Cúria.

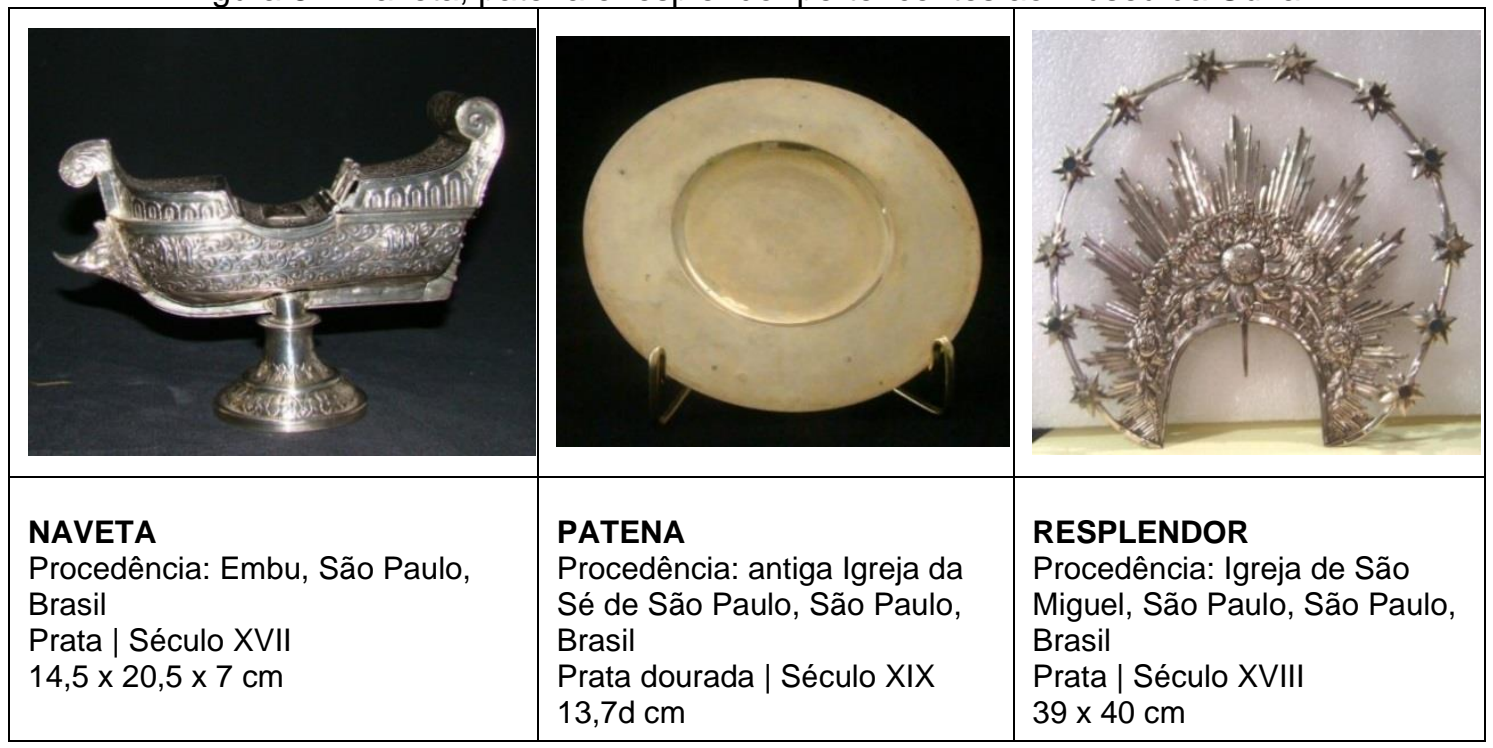

Fonte: Acervo Museu de Arte Sacra de São Paulo. Fotografia Iran Monteiro. 
Figura 32: Turíbulos do Museu da Cúria.

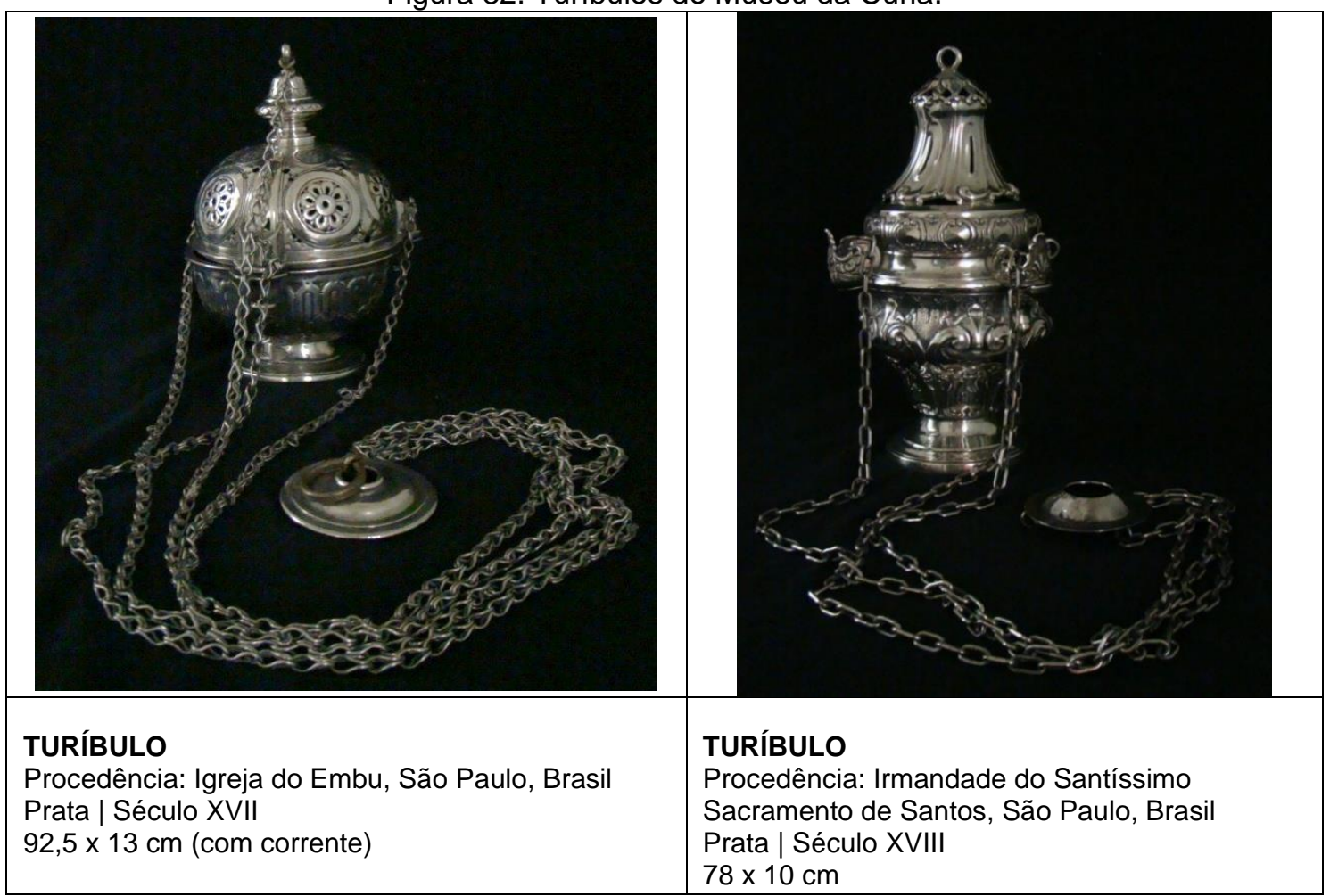

Fonte: Acervo Museu de Arte Sacra de São Paulo. Fotografia Iran Monteiro.

Figura 33: Relicários da antiga Sé, pertencentes ao Museu da Cúria

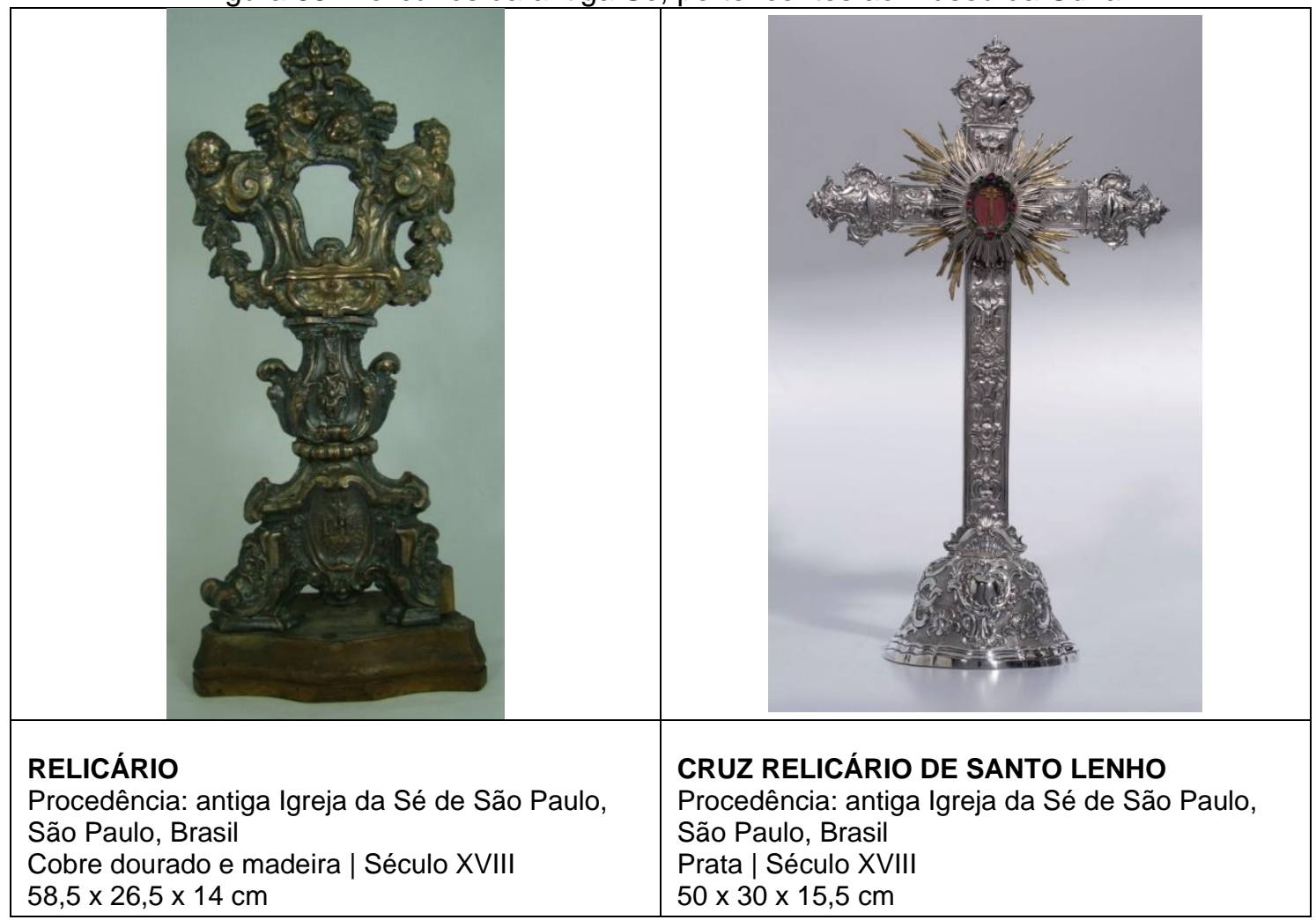

Fonte: Acervo Museu de Arte Sacra de São Paulo. Fotografia Iran Monteiro. 
A prata nunca foi descoberta no Brasil, porém o comércio intenso com os espanhóis forneceria a matéria-prima necessária para execução dos trabalhos:

"A prata seria proveniente do tráfico regular que passava pelo Brasil, via Buenos Aires, de origem peruana, sobrevindo daí o nome de peruleiros aos notórios traficantes de metal em nossa colônia. Esses peruleiros trocavam a prata por arroz, tecidos e chapéus" (COLOMBO FILHO, 2001, p. 158).

Em seus estudos publicados em "O barroco no Brasil" (1974), Eduardo Etzel analisa diversos testamentos para corroborar a ideia de que se faziam alfaias em São Paulo já no início do século XVII, e que muitos dos ourives citados nos Inventários e Testamentos deveriam ser, provavelmente, profissionais que trabalharam à margem da profissão, não estando arregimentados como os ourives de Portugal. Assim, é raro encontrar marcas de contrastes e de ourives na prataria litúrgica, salvo peças produzidas no século XIX, em que "a presença de peças com contrastes dos prateiros do Rio de Janeiro é a regra" (ETZEL, 1974, p. 279).

A Coroa Portuguesa, ainda que tivesse ouro e prata em seu próprio território, sempre invejou a prata encontrada na América Espanhola:

\footnotetext{
"Boa parte do mesmo ouro das minas foi utilizado na compra de prata para a confecção de objetos os mais variados. O português sempre teve um fraco pela prataria, o que se vê em todos os inventários de certa importância, nas alfaias das igrejas e na sempre famosa prata portuguesa de nossos dias". (ETZEL, 1974, p. 136).
}

Essa valorização da prata pode ser exemplificada na atitude de Dom Duarte em preservar na Cúria o acervo de prataria da antiga Sé de São Paulo quando da sua demolição; ao contrário dos outros objetos, que foram distribuídos pelas igrejas, as alfaias em prata foram levadas e guardadas na Cúria (Tab. 3, Capítulo 2.3.2, p. 94).

Outro destaque da prataria proveniente da antiga Igreja da Sé é a banqueta de tocheiros (figura 34, abaixo à esquerda) doada à igreja por dom João V em comemoração à criação do bispado de São Paulo, em 1745. 
Já o par de galhetas abaixo, à direita, foi doado por Altino Arantes, Presidente do Estado de São Paulo, à Catedral da Sé, por ocasião da epidemia de gripe, em 1918.

Figura 34: Tocheiros e galhetas da antiga Sé, pertencentes ao Museu da Cúria.

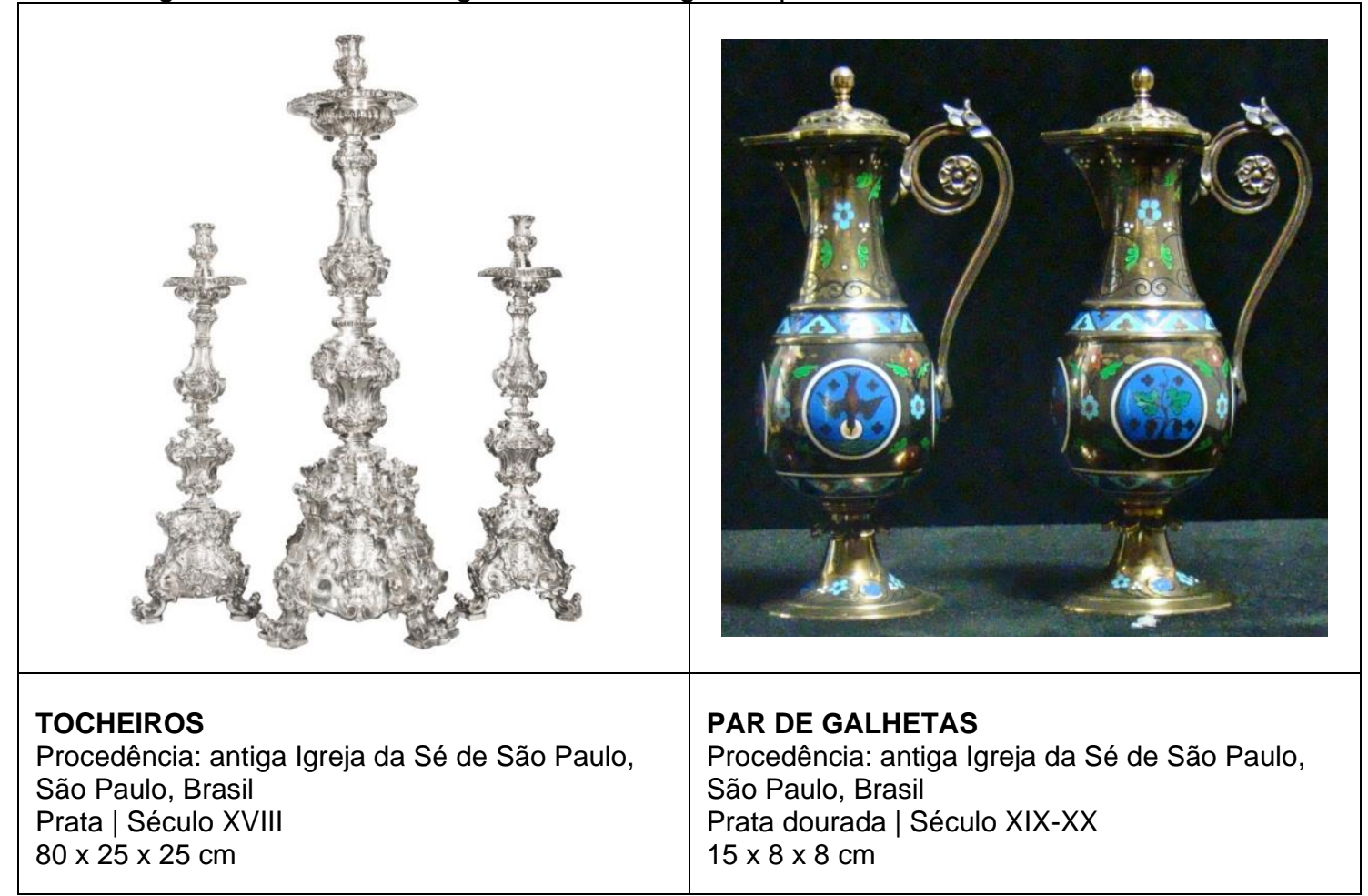

Fonte: Acervo Museu de Arte Sacra de São Paulo. Fotografia Iran Monteiro.

A coleção de lampadários do acervo do Museu da Cúria (Fig. 35) inclui importantes doações, como o exemplar proveniente da antiga Sé, que traz o brasão do Império, doado por Dom Pedro I e um exemplar proveniente de Santana de Parnaíba, doado pelo Padre Guilherme Pompeu de Almeida ${ }^{43}$.

A produção dos lampadários desenvolveu-se principalmente no período barroco, com ornamentos simbólicos como "espirais, conchas, flores de lis, folhas de acanto, flores de lótus, cariátides, frutos, olivas, anjos e serafins" (TIRAPELI, 2007, p. 116).

43 O MAS-SP possui hoje uma coleção de 20 lampadários, sendo que 14 são da Cúria e 6 comprados pelo Estado. Segundo informações do site do Museu, o acervo de lampadários do MAS-SP é o 2ํㅡㅁor do mundo, atrás apenas da coleção do Vaticano. 
Figura 35: Exemplos de lampadários do Museu da Cúria.

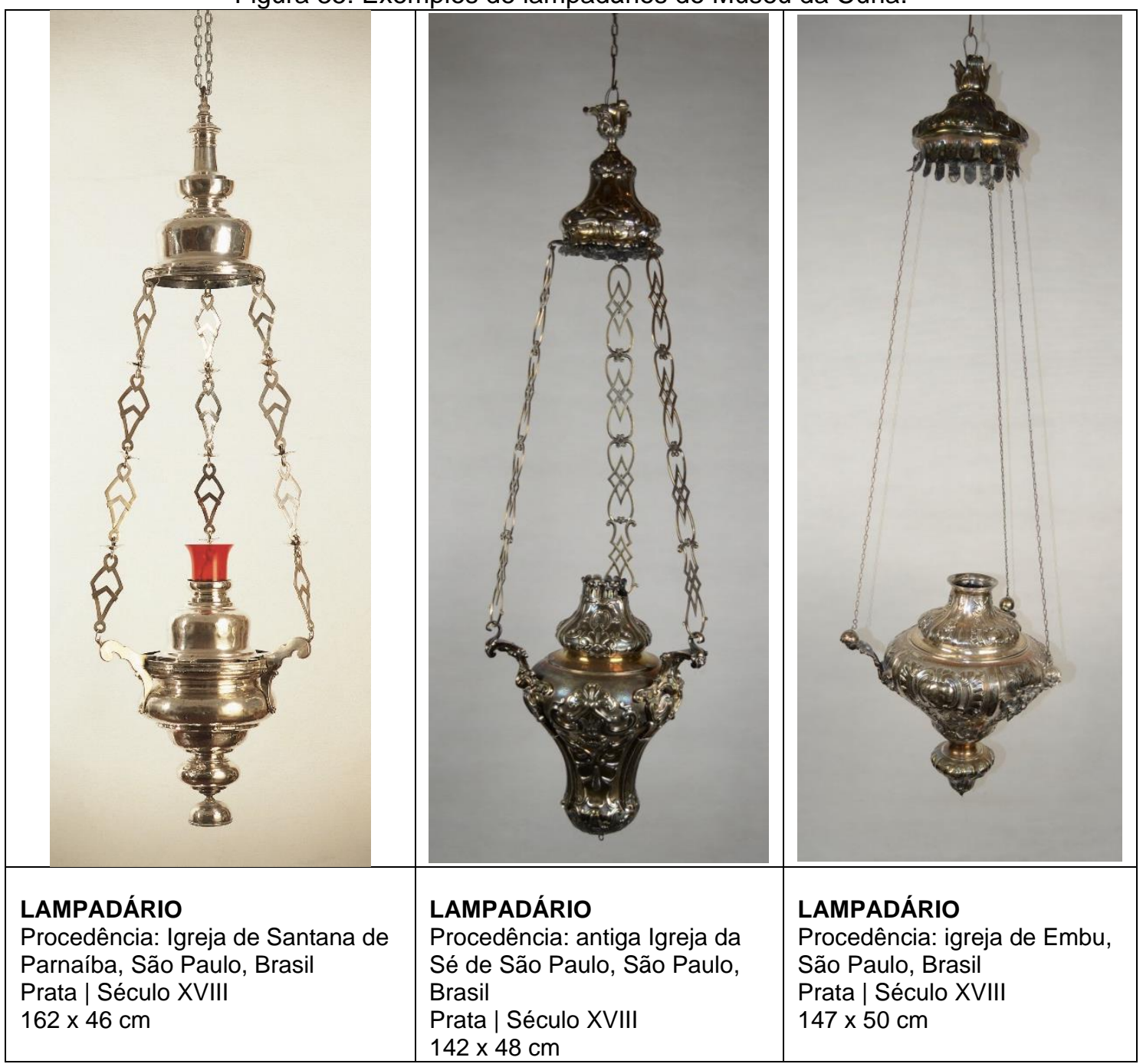

Fonte: Acervo Museu de Arte Sacra de São Paulo. Fotografia Iran Monteiro.

Também se encontra no acervo do Museu da Cúria uma interessante coleção de joias de autoridades eclesiásticas e pertencentes a imagens de santos.

A cruz do Cardeal Joaquim Arcoverde de Albuquerque Cavalcanti (abaixo à esquerda) foi, segundo descrição no catálogo do Museu (p. 13), um "presente oferecido pelos católicos paulistas a S. Excia. o Sr. Cardeal Arcoverde e por este doada à Arquidiocese de São Paulo em 1917".

Já a cruz peitoral de Dom Duarte, abaixo à direita, é a mesma identificada no retrato do arcebispo, pintado por Henri Bernard em 1913 (reproduzido no Capítulo 2.1). 
Figura 36: Cruzes peitorais do Cardeal Arcoverde e de Dom Duarte.

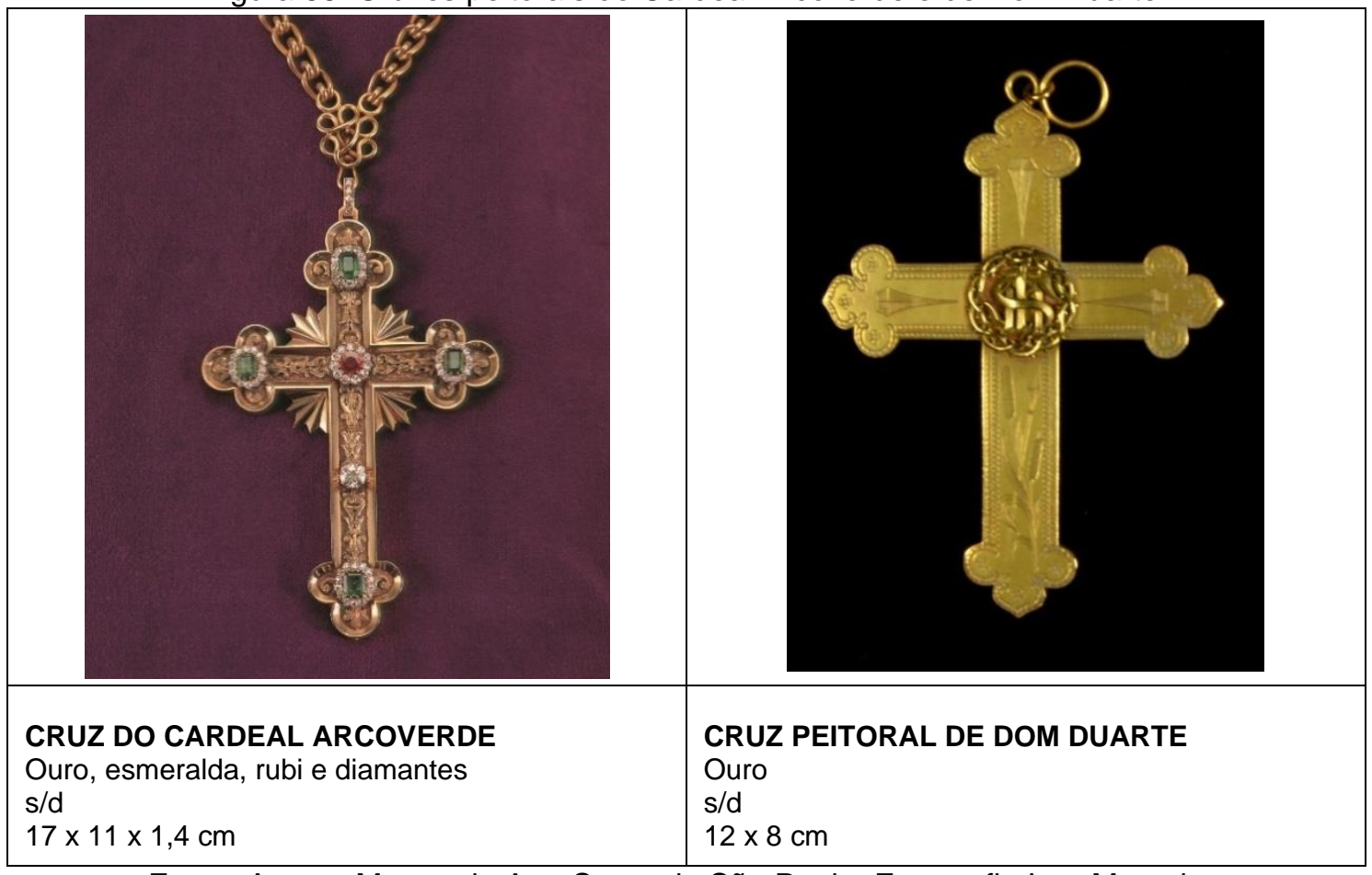

Fonte: Acervo Museu de Arte Sacra de São Paulo. Fotografia Iran Monteiro.

Já os anéis cujas imagens seguem abaixo possuem as seguintes descrições no catálogo do Museu da Cúria:

Anel do Cardeal Arcoverde (abaixo à esquerda): "Oferecido a Sua Santidade o Senhor Cardeal Arcoverde pelos Diocesanos do Rio de Janeiro, por ocasião do seu jubileu episcopal. No ato da entrega orou o Dr. Aloysio de Castro, da Academia de Medicina e Academia de Letras. Legado por Sua Eminência a Nossa Senhora da Conceição Aparecida, Padroeira do Brasil. 1890 - 26 de outubro de 1915" (Catálogo ํo 52, p. 56-57).

Anel de Dom Duarte (abaixo à direita): "Enviado ao Exmo. Sr. Arcebispo de São Paulo, Dom Duarte Leopoldo e Silva, pelo Santo Padre Pio X, após a instalação da Província Eclesiástica de São Paulo. Foi portador o então Bispo de Orthosia, Dom Sebastião Leme, que o entregou em sessão solene da Confederação, celebrada no salão do Mosteiro de São Bento, em 1911" (Catálogo no 52, p. 18). 
Figura 37: Anéis do Cardeal Arcoverde e de Dom Duarte.

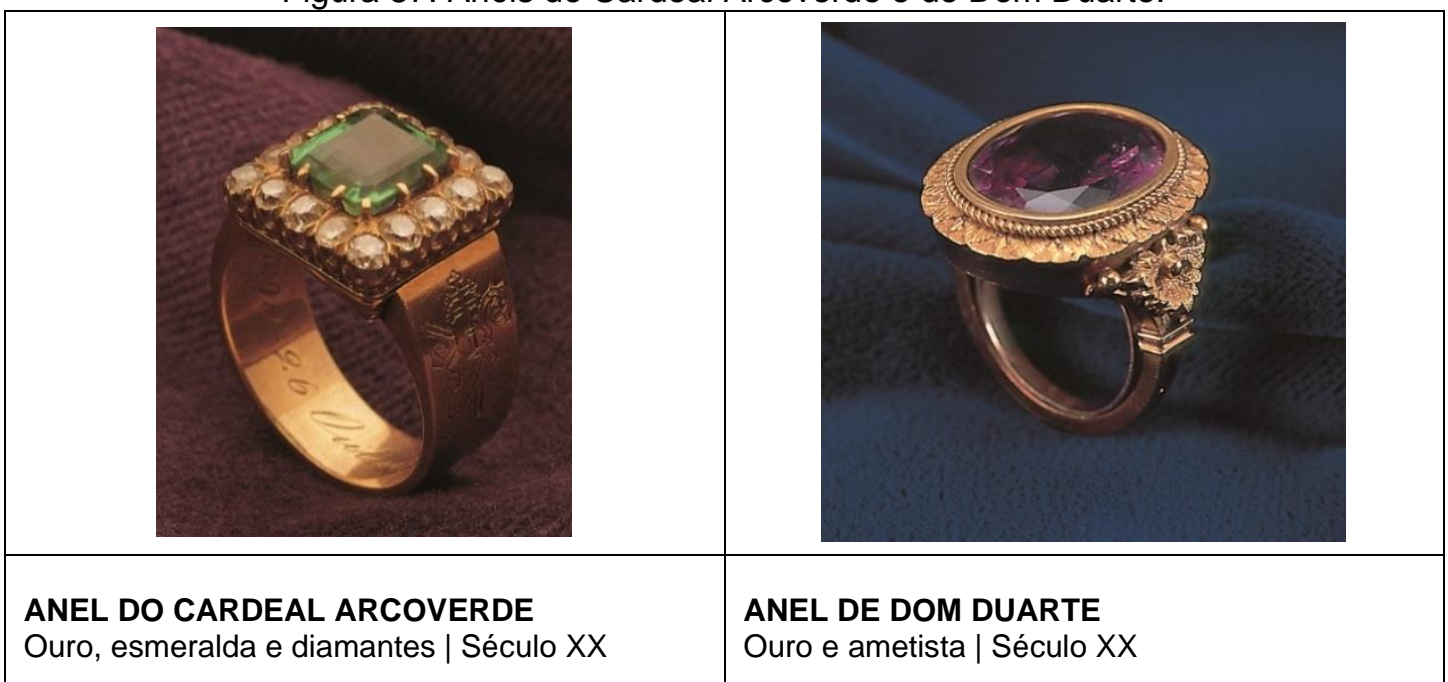

Fonte: Acervo Museu de Arte Sacra de São Paulo. Fotografia Iran Monteiro.

\section{Imaginária}

O termo imaginária é amplamente utilizado no Brasil para designar "arte de esculpir ou talhar imagens religiosas em madeira ou outros materiais; conjunto de imagens que constituem o acervo da espécie em determinado museu, igreja etc." (TIRAPELI, 2007, p. 133).

A Igreja Tridentina estimulava a veneração das imagens e relíquias de santos mártires entendendo que esse ato não era semelhante à adoração pagã, mas sim uma manifestação da admiração pela pessoa representada e o desejo de seguir seus passos. As imagens, verdadeiras mediadoras entre o homem e o divino, foram vastamente utilizadas como estratégia de evangelização quando a Igreja envia seus representantes para o Novo Mundo.

Entretanto, as primeiras imagens destinadas a altares foram importadas de Portugal pelas ordens religiosas:

"A importação de imagens de Portugal é uma constante desde o descobrimento. Acentua-se no século XVII e principalmente no XIX pelo incremento da população da Província de São Paulo e sobretudo do Vale do Paraíba, por causa da riqueza proporcionada pelo café. Além das grandes imagens de igrejas e capelas que chamamos de culto coletivo, encontra-se a pequena imaginária doméstica: imagens de barro e de madeira, decorativas, de luxo, cujos detalhes de confecção desconhecemos" (ETZEL, 1971, p.29). 
Aos poucos, a colônia foi descobrindo sua própria linguagem através da interação dos elementos europeu, negro e índio. Mas, mesmo assim toda a produção até o final do século XVIII esteve alinhada às normas estabelecidas lá atrás no Concílio de Trento, mesmo porque havia uma grande vigilância da Igreja em relação a feitura das imagens e seu uso.

Com uma maior demanda de imagens para as novas capelas e igrejas, nos séculos XVI e XVII, iniciou-se uma produção brasileira, sendo os santeiros brasileiros ensinados nas oficinas conventuais segundo as tradições medievais (TIRAPELI, 2007, p.15). Seguindo os padrões estéticos e iconográficos, utilizando-se o barro como matéria-prima, as próprias ordens possuíam fazendas onde funcionavam as olarias (SALA, 2014, p. 13).

Essa produção entra em decadência no final do século XVII, "abrindo caminhos para a ascensão de artistas leigos, contratados e pagos pelas irmandades, criando um campo de extensão para o novo estilo [o barroco] com obras maiores em madeira" (TIRAPELI, 2007, p. 23).

São Paulo e as vilas vizinhas como Santana de Parnaíba, Sorocaba e Jundiaí são consideradas uma região de produção de imaginária em barro cozido policromado (TIRAPELI, 2007, p. 21), por sua posição geográfica longe do mar, o que dificultava o acesso a bens e materiais, percorrendo todo o período colonial "com os santeiros copiando os modelos eruditos" (Lemos apud TIRAPELI, 2007, p. 21).

Além da necessidade de imagens para as capelas e igrejas que surgiam, a partir do século XIX também houve uma crescente demanda de imagens de menor porte para os oratórios domésticos, a partir da prática de reunião familiar e celebrações em torno desses altares, principalmente em regiões mais afastadas dos centros das cidades (PIZA, 2005, p. 316)

No Museu da Cúria há poucos exemplares de imaginária, talvez pelo fato das imagens, ainda que fossem transportadas de uma igreja para a outra em casos de demolições e reformas, usualmente retornassem aos seus templos depois de finalizadas as obras.

Abaixo, elencamos algumas das imagens pertencentes ao Museu da Cúria e listadas no catálogo consultado, que julgamos serem destaques da coleção por suas características históricas e estéticas: 
A imagem de N. S. da Conceição (abaixo à esquerda) recebeu, no Catálogo do Museu da Cúria, uma nota interessante, em primeiro lugar por seu teor informativo mas também por denotar o cuidado com que eram feitos os registros no caso de peças que, podemos presumir, eram consideradas mais importantes:

\begin{abstract}
"Belíssimo e rico trabalho de arte antiga, oferecido ao Museu da Cúria pelo Exmo. Sr. Cardeal Dom Sebastião Leme da Silveira Cintra, Arcebispo do Rio de Janeiro.

Nota: O Palácio da Conceição foi primitivamente "Hospício da Conceição" dos Capuchinhos franceses, que o haviam edificado em 1668 e nele permanecido por espaço de 40 anos, mais ou menos, a serviço da catequese dos índios. Dom Francisco de São Jeronimo, 3ํㅗㅇㅗ do Rio de Janeiro (1701-1721) o reconstruiu, adaptando-o para ser seu Palácio Episcopal, tendo falecido a 7 de março de 1721 e sido sepultado na dita capela do mesmo Palácio. No Palácio da Conceição residiram 9 Bispos: Dom Francisco de São Jeronimo, Dom Antonio de Guadalupe, Dom João da Cruz, Dom Antonio do Desterro Magalhães, Dom José Joaquim Mascarenhas Castelo Branco, Dom José Caetano da Silva Coutinho, Dom Manuel do Monte Rodrigues Araújo, Dom Pedro Maria de Lacerda e Dom José Pereira da Silva Barros. Ali também residiram dois Arcebispos: Dom João Esberard e Dom Joaquim Arcoverde de Albuquerque Cavalcanti” (Catálogo nำ52, p. 67-68).
\end{abstract}

Figura 38: Imagens de Nossa Senhora pertencentes ao Museu da Cúria.

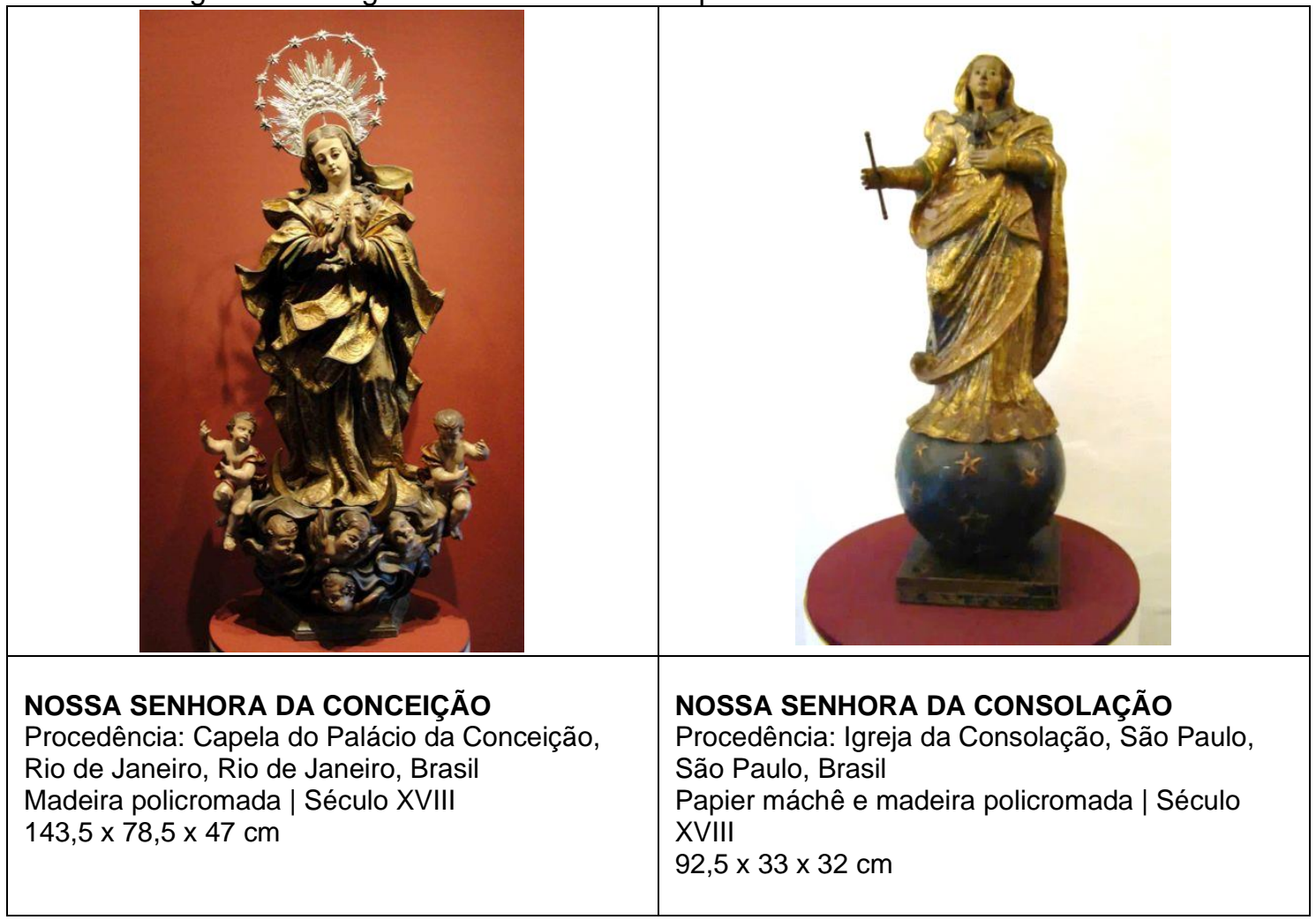

Fonte: Acervo Museu de Arte Sacra de São Paulo. Fotografia Iran Monteiro. 
Já a famosa imagem de São Jorge em tamanho real (abaixo à esquerda) costumava participar da procissão de São Jorge, realizada no mesmo dia da Procissão de Corpus Christi ${ }^{44}$. O desfile seguia a seguinte ordem:

\begin{abstract}
"(...) três cavaleiros negros, vestindo calções amarelos, coletes vermelhos e capas agaloadas da mesma cor, tendo na cabeça chapéus com plumas, sendo que dois deles tiravam de dois clarins sons descompassados e o outro tangia dois timbales. (...). Depois vinham: o Anjo da Guarda, ricamente vestido e montado num cavalo branco e São Jorge, também montado num cavalo branco, trazendo de cada lado um soldado, que o segurava sobre a sela (...) por último vinha o legendário Casaca de Ferro, montado num cavalo preto e envergando armadura de folhas de Flandres pintada, hasteando bandeirola vermelha com uma cruz branca e um escudo (...)" (MARTINS, 2006, p.37).
\end{abstract}

A escultura de madeira policromada possuía capa de veludo carmesim, chapéu com pluma branca, lança e escudo com uma cruz branca pintada. São Jorge saiu em Procissão pela última vez em 1872, quando "o santo se desequilibrou da sela, caiu sobre a cabeça de um dos soldados da sua guarda $e$ o matou. O pânico espalhou-se entre os fiéis diante da visão terrível. Como punição, ele nunca mais saiu em procissão. Foi recolhido ao Museu da Cúria Metropolitana (...)" (Diário Oficial de São Paulo, № 41, 03/03/2006, p.3).

Segundo Antonio Egydio Martins (2006, p.36), a imagem de São Jorge ficou por muito tempo no antigo Quartel do Corpo Fixo (localizado onde está hoje o Palácio da Justiça, na Praça da Sé), tendo o comandante Tenente-Coronel Pacífico Antonio Xavier de Barros solicitado, em 1853, a transferência da imagem para um local mais adequado ${ }^{45}$. Após sua solicitação ter sido aprovada, a escultura esteve na Igreja do Senhor Bom Jesus do Colégio e, após o desabamento da igreja em 1896, foi transferida para a Igreja de São Gonçalo.

\footnotetext{
${ }^{44}$ Apesar do estranhamento, as fontes consultadas afirmam que as duas procissões ocorreriam no mesmo dia (MARTINS, 2006, p. 37).

${ }^{45}$ Segundo o autor, também se encontravam no Quartel vários objetos sagrados, depositados no armazém de artigos bélicos, porém ele não faz menção de quais seriam estes objetos e se também teriam sido transferidos (p.36).
} 
Figura 39: Esculturas de São Jorge e São Pedro em exposição no MAS-SP.

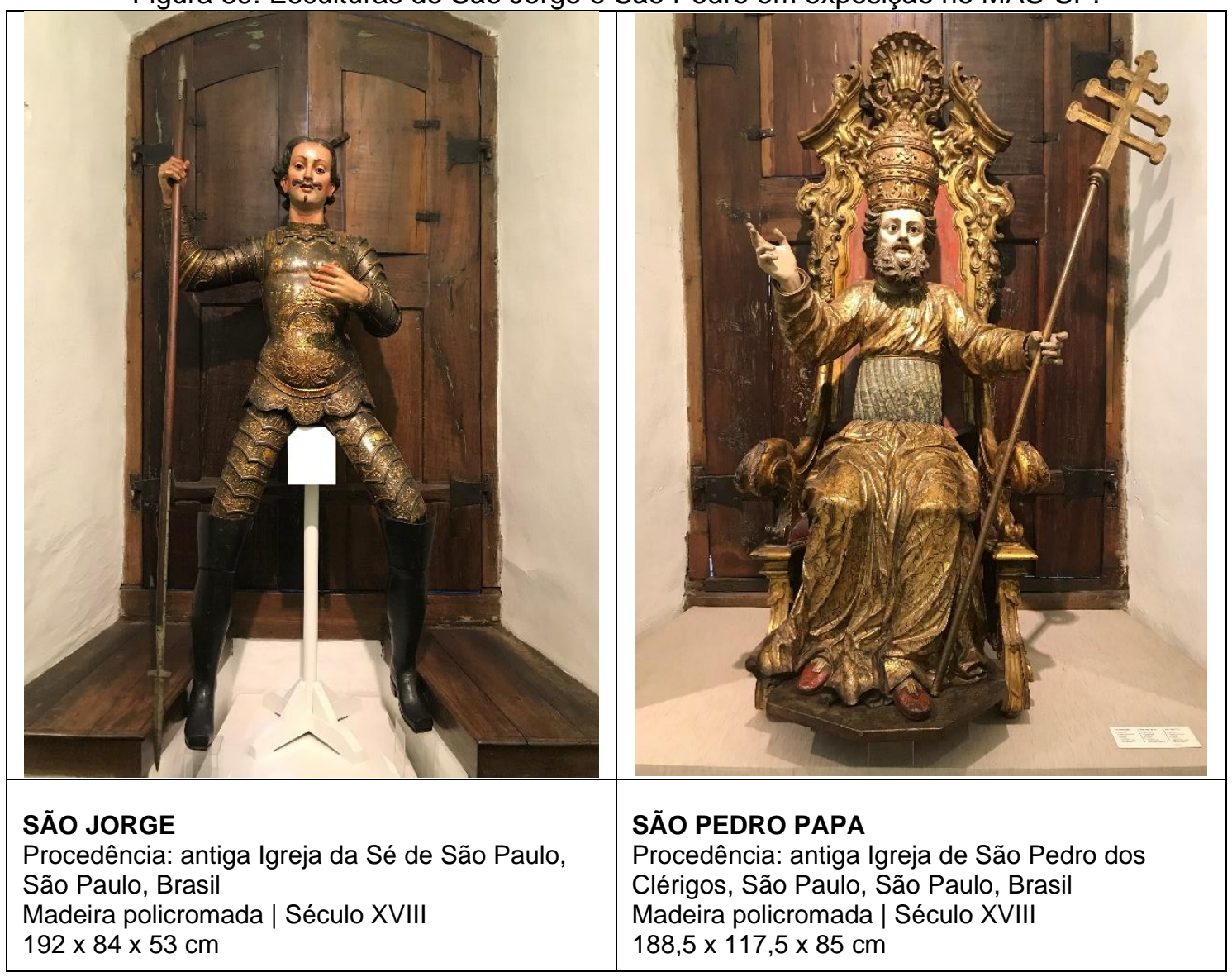

Fonte: Acervo Museu de Arte Sacra de São Paulo. Fotografias Luciana Barbosa, 2019.

A armadura utilizada pelo Casaca de Ferro (Fig. 40), último personagem da Procissão de São Jorge citado por Antonio Egydio Martins, encontra-se hoje no Museu Paulista. Segundo a informação encontrada no site de consulta online do acervo do Museu ${ }^{46}$, a armadura é de ferro estanhado, confeccionada na Alemanha por volta de 1530-1550, e apresenta restos de enegrecimento e ornamentos de ouro (Museu Paulista, 2021).

${ }^{46}$ Museu Paulista USP - Consulta on-line do acervo. Disponível em: < http://acervo.mp.usp.br>. Acesso em: 20/03/2021. 
Figura 40: Armadura do Casaca de Ferro. Séc. XVII, Ferro estanhado, 64 × 79 × $46 \mathrm{~cm}$.

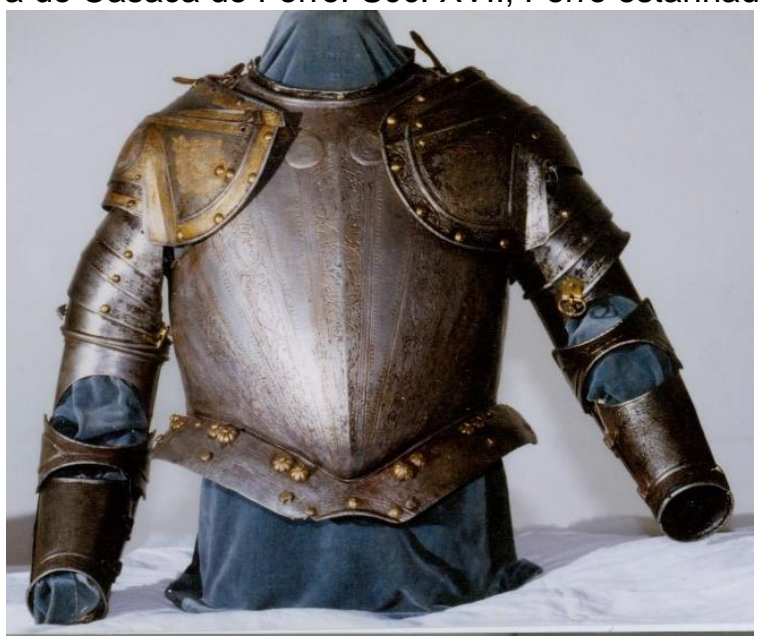

Fonte: Acervo do Museu Paulista da USP. Créditos fotográficos das reproduções: Hélio Nobre/José Rosael.

Interessante observamos o trabalho desenvolvido na execução das duas amaduras (Fig. 41). Enquanto a armadura de São Jorge, representando 0 guerreiro cristão em sua luta contra o mal, além de possuir símbolos mais elaborados ornamentando seu peitoral e barriga, como o sol e a cabeça de um animal, tem seus braços e pernas trabalhadas com ornamentos em dourado, a armadura do Casaca de Ferro representa o soldado seguindo seu comandante, com poucos detalhes ornamentados em dourado nas ombreiras.

Figura 41: Detalhes das armaduras de São Jorge e do Casaca de Ferro.
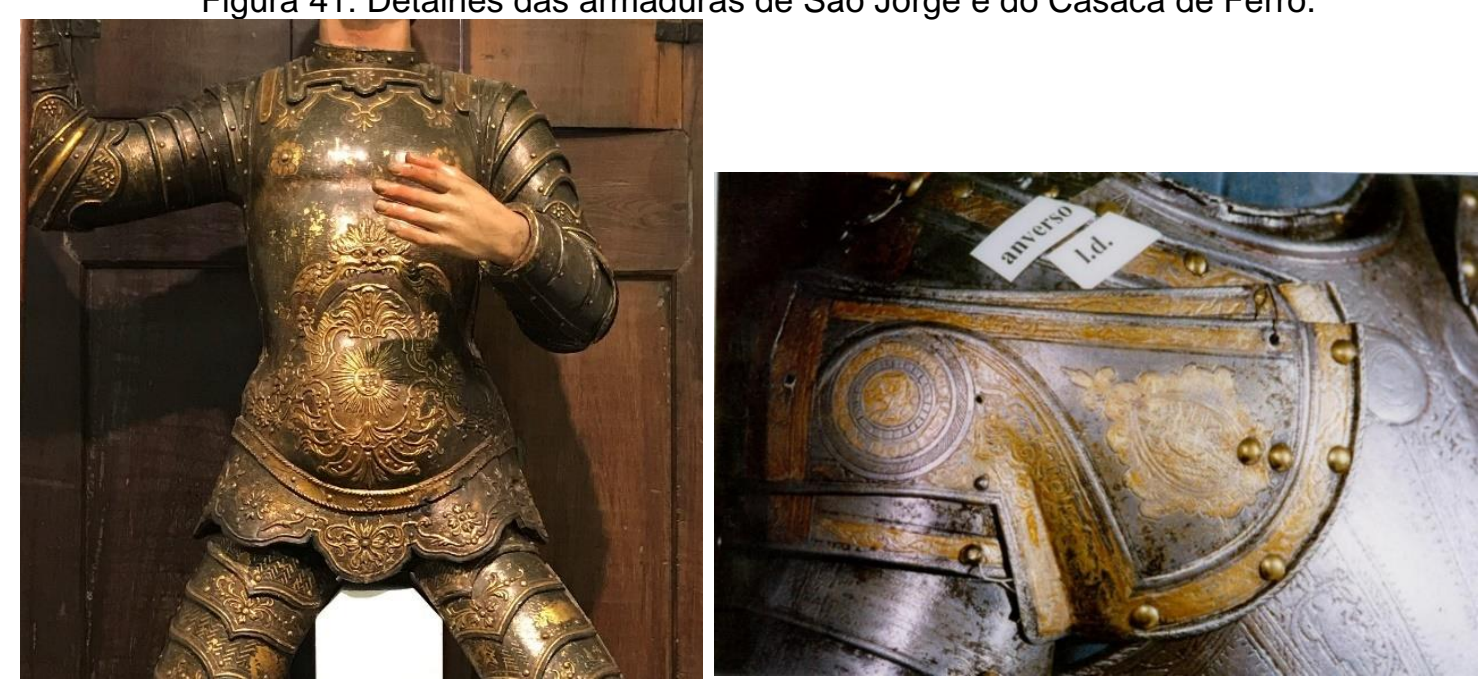
Outra importante escultura do acervo do Museu da Cúria, cujo tamanho também impressiona tão qual a escultura de São Jorge, é a imagem de São Pedro Papa (Fig. 39 à direita). Quase de tamanho natural, apresenta diversas insígnias papais: a Tríplice Tiara, utilizada pelos papas em cerimônias solenes não litúrgicas até o Concílio Vaticano II, representando a tripla condição de poder doutrinal, sacerdotal e pastoral; Cruz Papal ou Hierofante, com três hastes horizontais representando as funções do Papa; o santo encontra-se sentado no trono, demonstrando sua autoridade frente à Igreja; a mão esquerda em sinal de benção; manto ornamentado.

A escultura de Santana Guia (abaixo à esquerda), procedente de Santana de Parnaíba, data do século XVII e sua autoria atribui-se ao Frei Agostinho de Jesus. No Catálogo do Museu da Cúria encontramos um verbete que conta a história da primitiva capela:

"Imagem venerada na primitiva Capela de Parnaíba, construída em 1580 em sua honra, como padroeira da povoação. Esta imagem foi benzida com licença do bacharel Padre Bartolomeu Simões Pereira, primeiro administrador da Prelatura do Rio de Janeiro. Pelos anos de 1624-1625, Susanna Dias e André Fernandes, seu filho, fizeram diversas doações de terras para o patrimônio da Capela e para o culto da referida Santa. Transferida, mais tarde, a Capela para o local onde se ergueu a Igreja de São Bento, para lá foi transferida a imagem, onde permaneceu até o ano de 1646, data em que foi colocada definitivamente no Altar-Mor da primitiva Matriz, edificada no mesmo local em que se encontra a atual. Em 1812, tendo ruído a Capela-Mor da Matriz, foi a mesma reformada pelo padre Gonçalves Lima, o qual, então, colocou sobre o Altar-Mor outra imagem de Sant'Ana, que é a mesma atualmente ali venerada. Foi por esta ocasião retirada para uma dependência interna da Matriz a histórica e tradicional imagem, mais tarde, a instâncias do sr. F. de Salles Collet e Silva, trazida para o Museu da Cúria" (Catálogo no 52, p. 71). 


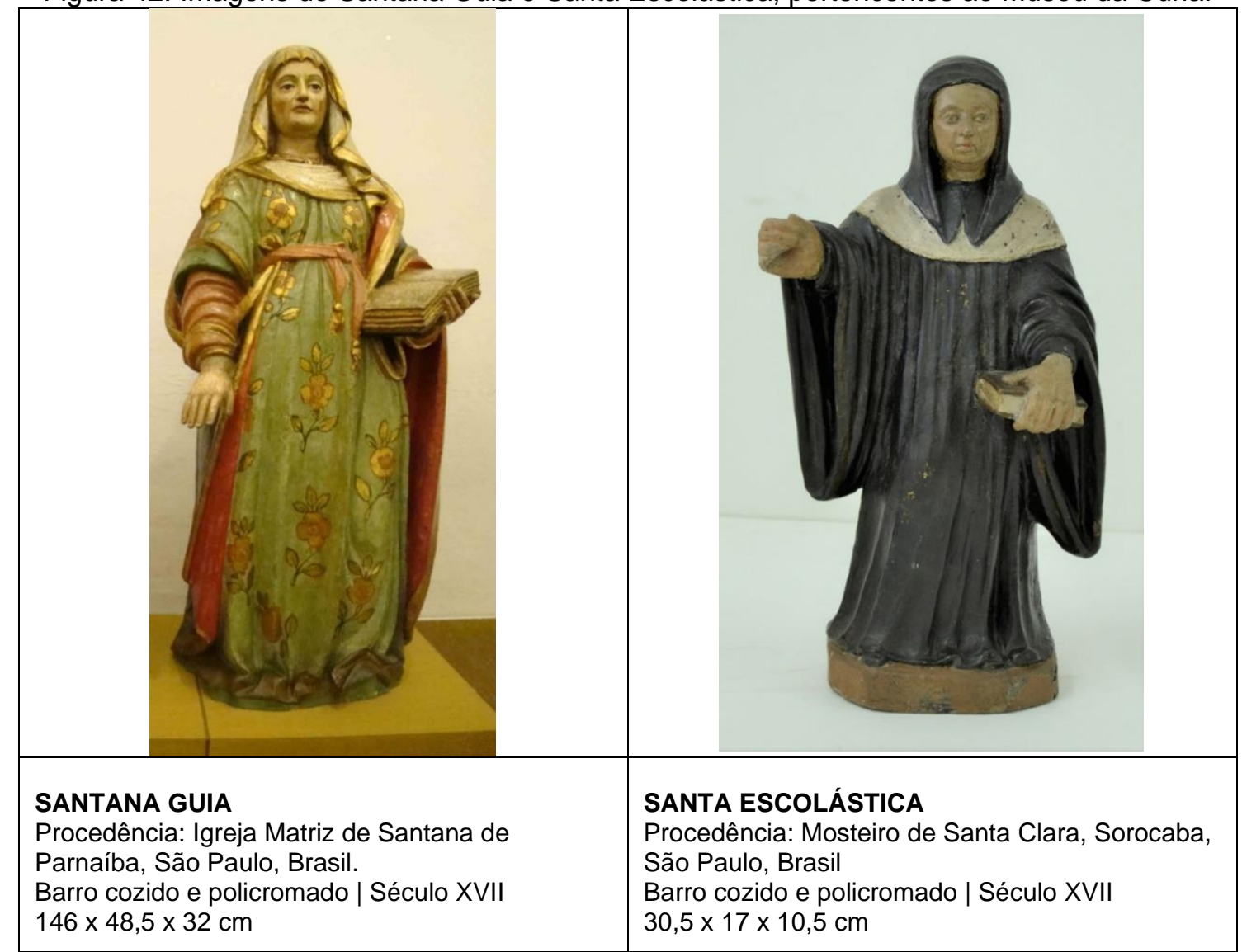

Fonte: Acervo Museu de Arte Sacra de São Paulo. Fotografia Iran Monteiro.

Conforme apresentado no verbete acima, a imagem de Santana Guia foi, posteriormente, retirada da Igreja Matriz de Santana de Parnaíba e trazida ao Museu da Cúria pelo seu diretor Francisco Collet. Essa informação reforça o papel de Collet no trabalho de pesquisa e coleta dos objetos das igrejas no Estado de São Paulo para compor o acervo do Museu da Cúria.

Já a escultura de Santa Escolástica, acima à direita, apresenta em sua descrição a informação de que se tratava anteriormente de uma escultura de Santo Amaro, sendo inserido o véu posteriormente. A imagem é procedente do Mosteiro de Santa Clara de Sorocaba, cuja história de fundação, assim como o Mosteiro da Luz, tem como personagem o Frei Antônio de Santana Galvão. Após fundação do Mosteiro de Sorocaba em 1811, as duas irmãs fundadoras solicitaram ao bispo de São Paulo o envio de irmãs para compor o Recolhimento, para o qual vieram três religiosas do Convento da Luz acompanhadas de Frei Galvão, que "permaneceu entre fins de 1811 e 1813, ajudando na consolidação do Mosteiro de Santa Clara, (...) trabalhando, pelos relatos históricos, inclusive como pedreiro em sua edificação (DIÁRIO DE SOROCABA, 2021). 
Figura 43: Imagens de São Paulo e Santana Mestra, pertencentes ao Museu da Cúria.

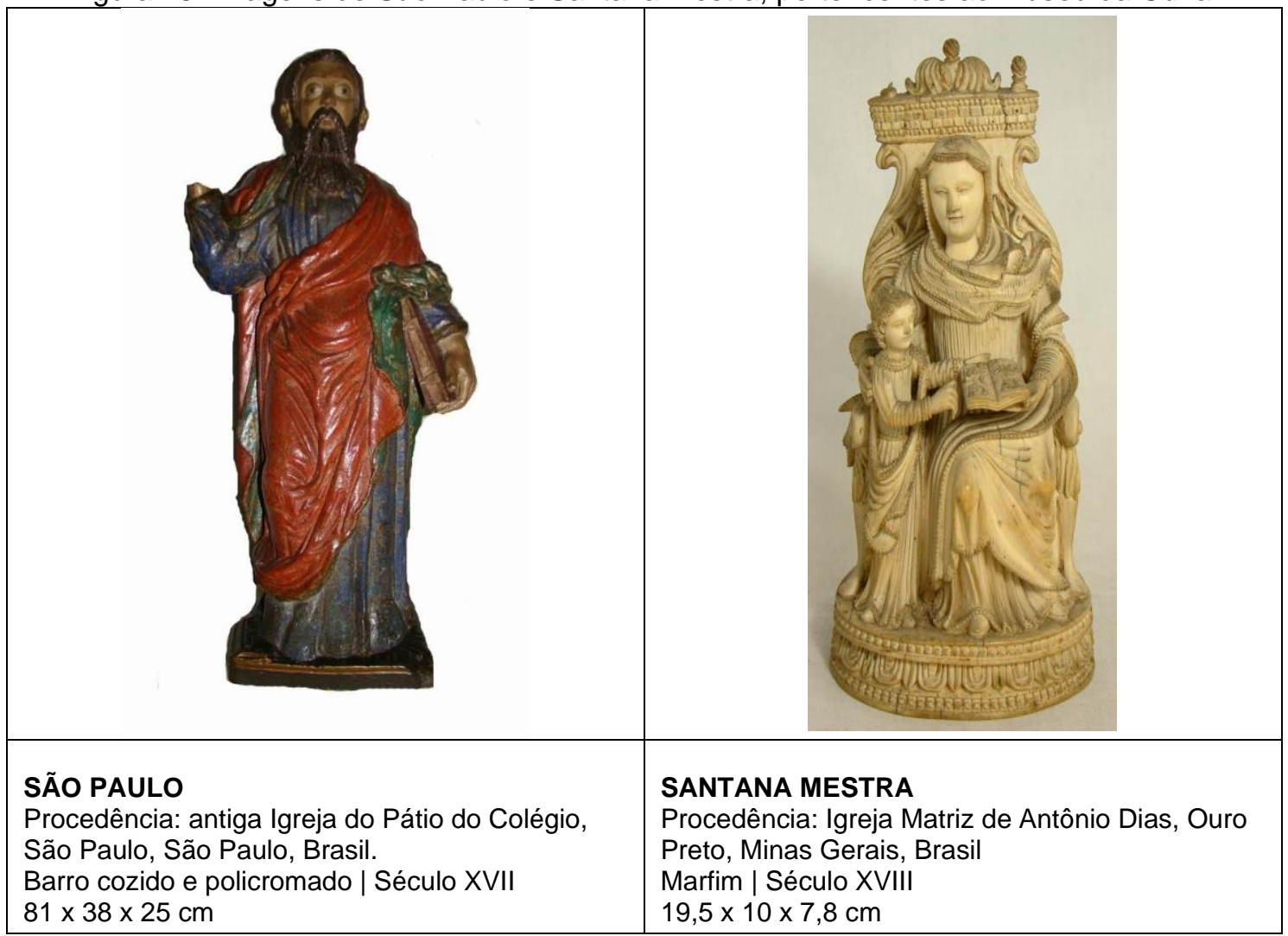

Fonte: Acervo Museu de Arte Sacra de São Paulo. Fotografia Iran Monteiro.

A imagem de São Paulo, acima à esquerda, é remanescente da antiga Igreja do Pátio do Colégio e data do século XVII. Segundo o catálogo do Museu da Cúria, a imagem está mutilada - conforme observamos na imagem acima, o santo está sem a mão direita.

Já a escultura de marfim de Santana Mestra, acima à direita, segundo catalogação do MAS-SP, traz vestígios de policromia, sabendo-se que as imagens de marfim setecentistas, no Brasil, muitas vezes policromadas, foram lavadas no século XIX, quando esse tipo de policromia caiu em desuso.

A ficha catalográfica dessa obra no MAS-SP também aponta sua origem como Goa, Índia. Não há informações detalhadas sobre a peça no catálogo do Museu da Cúria mas a presença de outras peças em marfim, como uma escultura de Santa Luzia pertencente à Capela de Santa Luzia, SP, e um Cristo crucificado da Velha Igreja Matriz de Santo Amaro, SP, pode apontar o interesse em se preservar objetos desse tipo de material. 
A respeito das esculturas em marfim provenientes da Índia e denominadas "indo-portuguesas", Jorge Lúzio (2018) comenta que essas imagens aportaram no Brasil, na Bahia especificamente, a partir do século XVII, tendo sua ampla circulação influenciado a produção artística local (LÚZIO, 2018, p. 61).

\begin{abstract}
"Os vestígios indo-portugueses ou orientais, de modo geral, se fizeram notáveis na formação histórico-cultural da sociedade patriarcal brasileira. No barroco, assim como as chinoiseries, a imaginária indo-portuguesas, a principal tipologia na classificação de marfins luso-orientais, nos levou a centenas de peças em marfim que se espalharam como objetos preciosos no mundo português do período moderno, onde a religião foi, também, o elo que vinculou, entre as terras portuguesas separadas por mar, uma unidade em seu mosaico mesclado pelo mercantilismo e religiosidade, como características principais de uma das mais importantes culturas do século XVII" (LÚZIO, 2018, p. 65).
\end{abstract}

\title{
Pintura
}

No catálogo do Museu da Cúria há poucas pinturas listadas, possivelmente pelo fato de que as principais pinturas eram expostas pelos diversos cômodos do Palácio da Cúria, assim como diversos objetos que não foram incluídos no catálogo.

Há também o fator de que a pintura religiosa em São Paulo está mais ligada às exigências de decoração de tetos e murais das igrejas e capelas, além de telas que muitas vezes adornavam as laterais dos altares, com seu papel importante no próprio monumento arquitetônico (PIZA, 2005, p. 316-317).

Os destaques desta coleção ficam a cargo das pinturas dos seis doutores e dos quatro evangelistas da Igreja, quadros procedentes do Recolhimento de Santa Teresa e atribuídos ao Padre Jesuíno do Monte Carmelo ${ }^{47}$.

\footnotetext{
47 A discussão em torno da autoria dos respectivos 10 quadros pelo Pe. Jesuíno foi alvo de análise feita por Mário de Andrade em seu livro Padre Jesuíno do Monte Carmelo, publicado em 1945, no qual Mário acredita não se tratar de pinturas executadas pelo Pe. Jesuíno (Cf: ANDRADE, Mário de. Padre Jesuíno do Monte Carmelo. Publicações do Serviço do Patrimônio Histórico e Artístico Nacional, n. 14. Rio de Janeiro: Ministério da Educação e Saúde, 1945). A dúvida também é levantada no próprio Catálogo da Cúria, na entrada n. 1.067 correspondente aos quadros dos evangelistas, onde se vê anotado à caneta um ponto de interrogação ao lado do nome do pintor e a frase "me parecem do pintor José Jorge Pinto Vedras!" (p. 101).
} 
Figura 44: Pinturas dos Evangelistas da Igreja, oriundas do

Recolhimento de Santa Teresa.

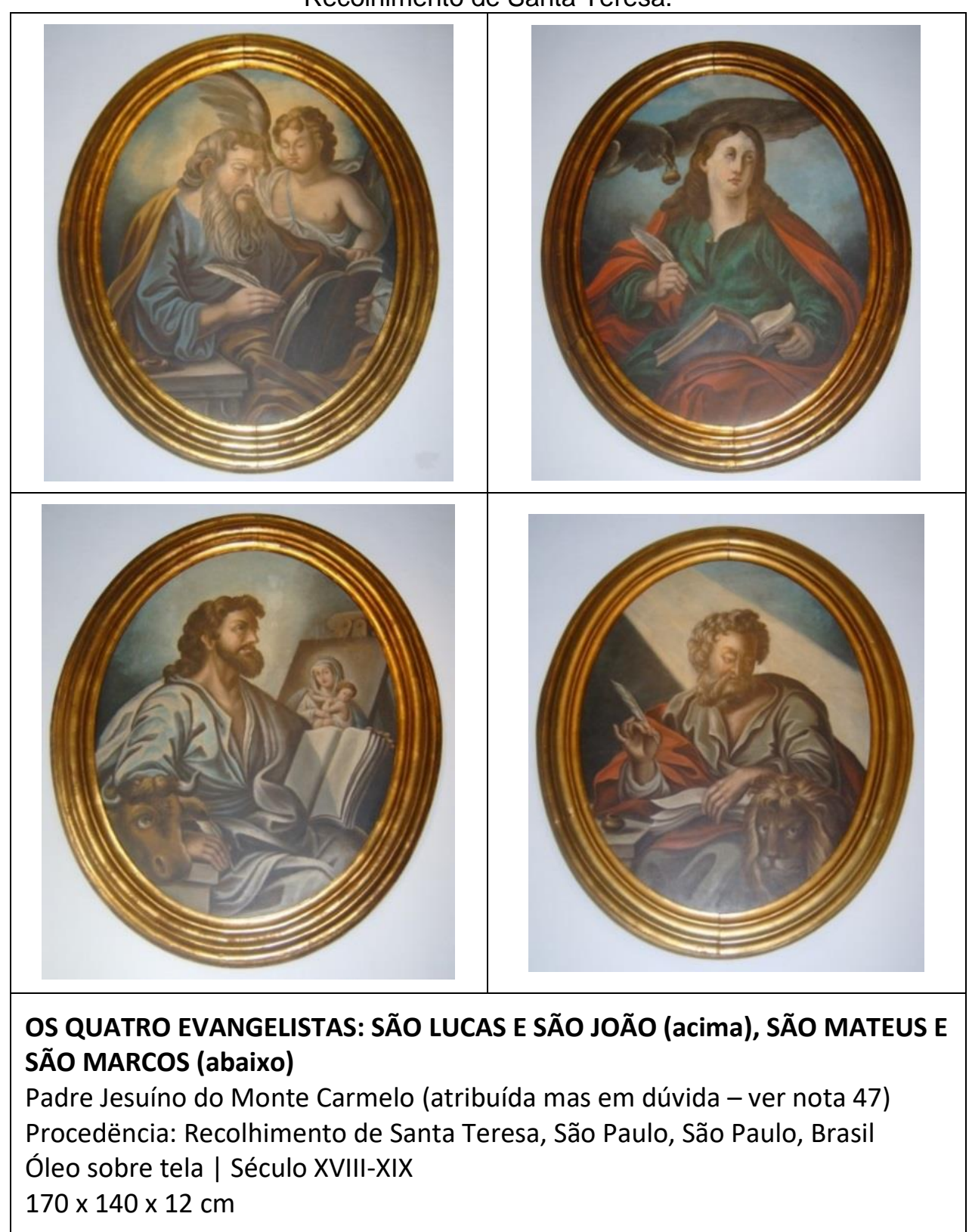

Fonte: Acervo Museu de Arte Sacra de São Paulo. Fotografia Iran Monteiro. 
Figura 45: Pinturas dos Doutores da Igreja, oriundas do Recolhimento de Santa Teresa.

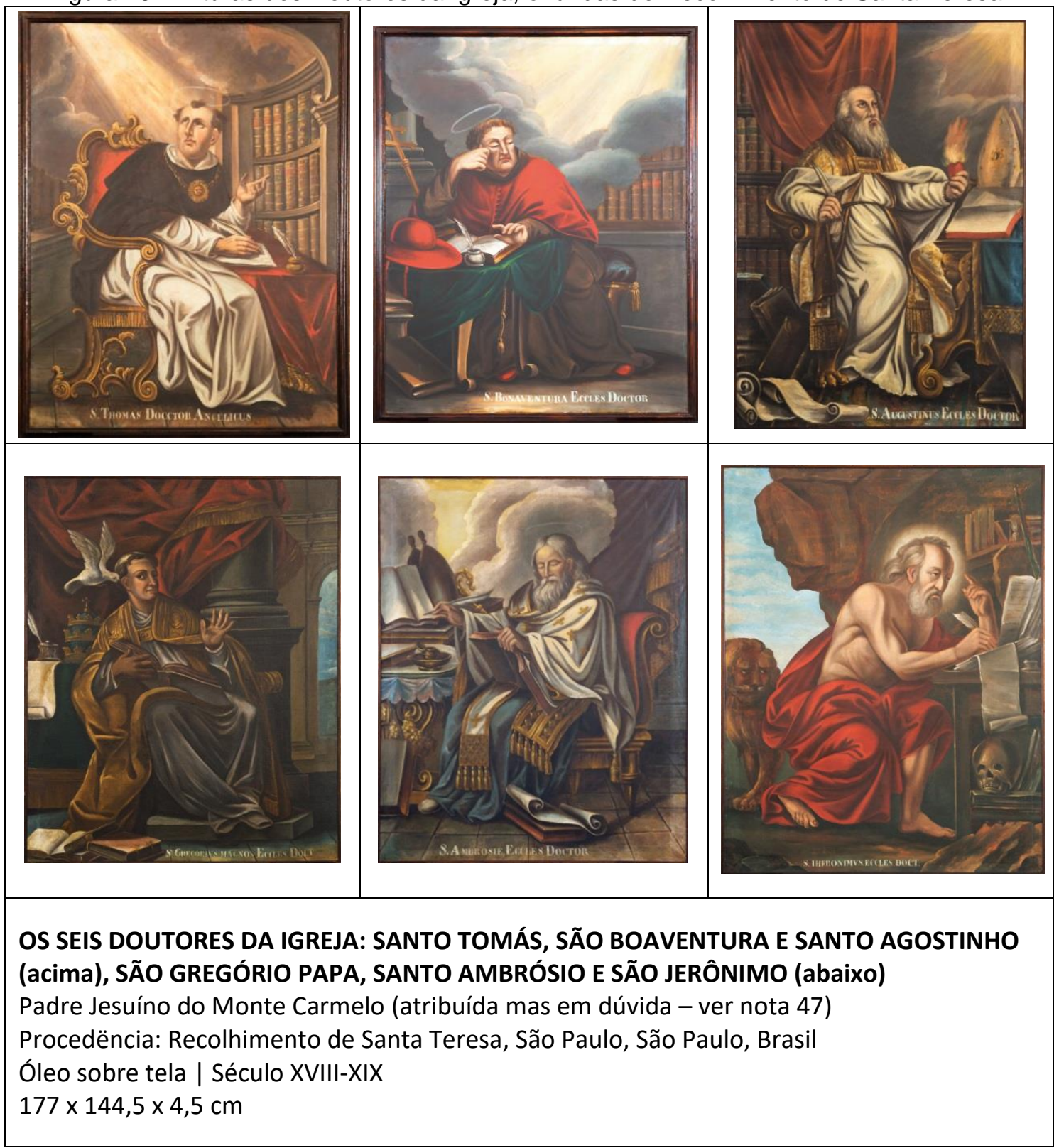

Fonte: Acervo Museu de Arte Sacra de São Paulo. Fotografia Iran Monteiro.

A respeito dos doutores da Igreja, DIAS (2017, p.9-10) explica que o papel atribuído aos Doutores pela Igreja Católica era de servir como exemplos de vida e espiritualidade ligados à tradição. Utilizar a imagem destes homens e mulheres religiosos, a partir do Concílio de Trento, "seria reforçar as imagens dos membros do clero, que são herdeiros da tradição de Cristo". Já a imagem dos evangelistas reforça a fé e a crença, sendo estas representações dos primeiros seguidores de Jesus, legitimando os textos bíblicos. 
"Esses personagens pensavam sobre os poderes de Deus e os poderes dos homens. Santo Ambrósio, por exemplo, entendia que os religiosos tinham uma importante atuação nos governos: aconselhando os reis ou ensinando as pessoas a serem leais aos seus governantes devotos" (DIAS, 2017, p.13).

Ainda na tipologia pintura, o Museu da Cúria possui uma interessante coleção de retratos à óleo: dos 11 bispos da diocese de São Paulo ${ }^{48}$ (Dom Bernardo Rodrigues Nogueira, Dom Frei Antônio da Madre de Deus Galvão, Dom Frei Manuel da Ressurreição, Dom Mateus de Abreu Pereira, Joaquim Gonçalves de Andrade, Dom Antônio Joaquim de Melo, Dom Sebastião Pinto do Rego, Dom Lino Deodato Rodrigues de Carvalho, Dom Joaquim Arcoverde de Albuquerque Cavalcanti, Dom Joaquim Arcoverde de Albuquerque Cavalcanti, Dom Antônio Cândido de Alvarenga e Dom José de Camargo Barros); da família imperial (Dom João V, Dom João VI, Dona Carlota Joaquina, Dona Maria Leopoldina e Dom Pedro II quando criança e mais velho) e dos Papas Bento XIV e Clemente XIV.

\section{Numismática}

O acervo de numismática foi iniciado a partir da coleção pertencente a Dom Duarte Leopoldo e Silva, que a doou ao Museu da Cúria, grande parte desses objetos ainda em vida. Entretanto, é importante sinalizar que esta coleção não consta no Catálogo do Museu da Cúria, não tendo sido possível identificar seus itens.

De acordo com nossa pesquisa, o acervo de numismática pertencente à Cúria e hoje sob a guarda do MAS-SP é constituído de aproximadamente 9.000 peças entre moedas, cédulas, barras de ouro e medalhas pontifícias, com exemplares dos períodos Colonial, Império e República, e em metais nobres como ouro, prata e cobre.

\footnotetext{
48 O retrato de Dom Duarte Leopoldo e Silva, ilustrado no Capítulo 2.1, não se encontra no catálogo do Museu da Cúria, como também não há o retrato do $4^{\circ}$ bispo da cidade Dom Frei Miguel da Madre de Deus da Cruz (sua história é explicada no Capítulo 2.1, nota 21, pág. 57).
} 
Esse acervo só foi incorporado ao MAS-SP em 1972, com um novo convênio firmado entre a Cúria e o Governo do Estado. Após classificação e catalogação, essa coleção permaneceu na Secretaria da Fazenda até 1978, quando foi incorporada definitivamente ao MAS-SP. Parte da coleção ficou exposta no Centro Cultural do Banco Safra por 10 anos, retornando ao Museu em 2001.

Interessante apontar que a coleção de sinetes de bispos e arcebispos brasileiros é sim listada no Catálogo do Museu da Cúria, porém foi incorporada à coleção de numismática, que foi desmembrada da coleção original quando do convênio Mitra-Estado para a criação do MAS-SP.

Ao todo são 118 sinetes listados no catálogo do Museu da Cúria, de membros do clero de diversos Estados, como Alagoas, Bahia, Ceará, Espírito Santo, Goiás, Maranhão, Mato Grosso, Mato Grosso do Sul, Minas Gerais, Pará, Paraná, Pernambuco, Rio Grande do Sul, Santa Catarina e São Paulo.

Entre os membros estão Dom Duarte Leopoldo e Silva (quando bispo de Curitiba e Arcebispo de São Paulo), Dom Claudio José Gonçalves Ponce de Leon, terceiro bispo e primeiro arcebispo de Porto Alegre (1910-1912), Dom João Becker, primeiro Bispo de Florianópolis (1908-1912), Dom João Batista Corrêa Nery, primeiro bispo de Campinas (1808-1920), Dom Manuel Joaquim da Silveira, décimo quinto Arcebispo da Bahia (1861-1874), Dom Carlos Luiz D'Amour, segundo bispo e primeiro Arcebispo de Cuiabá (1878-1921), Dom Francisco de Paula e Silva, décimo sétimo Bispo do Maranhão (1907-1918).

Conforme apontado no Capítulo 3.1 (p. 112), a respeito da carta enviada por Francisco Collet ao Monsenhor Domingos Magaldi, de Botucatu, relembrando a promessa de envio dos sinetes do finado bispo daquela paróquia, Dom Lucio Antunes de Souza. Esta promessa foi cumprida, pois há no catálogo do Museu da Cúria três sinetes e uma bandeja de marchetaria pertencentes a Dom Lucio, $1^{\circ}$ Bispo de Botucatu (1909-1924), conforme imagens abaixo: 
Figura 46: Objetos pertencentes a Dom Lucio, doados ao Museus da Cúria.

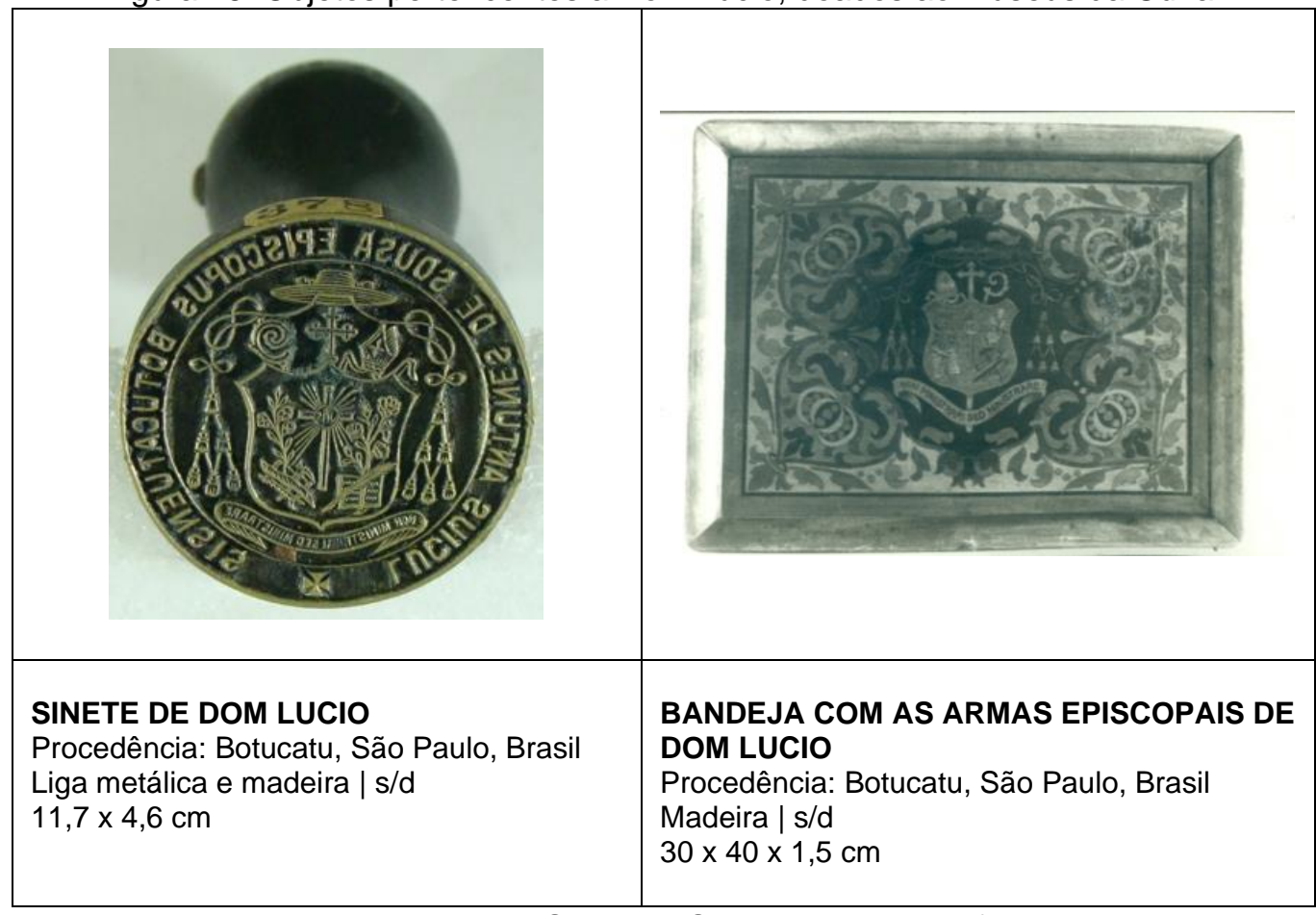

Fonte: Acervo Museu de Arte Sacra de São Paulo. Fotografia Iran Monteiro.

\section{Objetos de tipologias diversas}

Além das tipologias apresentadas acima, que concentram a maior parte dos objetos inventariados, o catálogo do Museu da Cúria apresenta outros objetos interessantes que julgamos merecerem destaque, tanto por suas excentricidades quanto pelos valores que Ihes foram atribuídos, a partir da visão dos fundadores do Museu:

\section{Muiraquitã}

Descrição do catálogo: "Talismã dos índios Tabajaras, usado entre eles como presente de núpcias. Oferecido Ao Museu da Cúria pelo Exmo. Sr. Bispo de Sobral (Ceará), por intermédio de Monsenhor Alberto T. Pequeno".

\section{Crucifixo com peanha de barro ${ }^{49}$}

Doado por R.P. Roberto Hausmair, redentorista, em 22/04/1927.

Descrição do catálogo: "Pertenceu a Alexandrina - última índia remanescente do antigo aldeamento de São Miguel, falecida a 15 anos. Esta Imagem, presente de velho missionário, conservou-se por muitíssimos anos em casa de seus antepassados".

\footnotetext{
${ }^{49}$ Escolhemos trazer este objeto nesta categoria, e não em Imaginária, pelo contexto histórico apresentado em sua descrição, relacionando-se com o objeto "Muiraquitã", pertinente para a discussão da presença de objetos etnográficos no acervo.
} 
As duas peças listadas acima estão relacionadas ao contato entre religiosos e índios, podendo a primeira ser entendida como indício de uma visão que aproximaria costumes indígenas e costumes católicos (presente de núpcias); já a segunda, um remanescente de processos de evangelização, lembrando que muitos dos objetos do Museu pertenceram às igrejas situadas em antigos aldeamentos, como São Miguel e M’Boy (hoje Embu).

Esses objetos, hoje entendidos como etnográficos dentro das coleções, não possuíam este caráter no acervo do Museu da Cúria; foram preservados levando em conta mais sua relação com os doadores - que eram membros do clero - do que por suas características históricas ou artísticas. Isso porque não há outros objetos de origem indígena no acervo, apenas esses dois exemplos que contam em suas descrições a quem pertenceram.

\section{Taça do banquete da Proclamação da Independência do Brasil}

Descrição do catálogo: "Serviu no banquete realizado nesta cidade de São Paulo, no dia 7 de setembro de 1822, dia da Proclamação da Independência do Brasil, no qual banquete estiveram presentes as pessoas ilustres que faziam parte da comitiva do Príncipe Regente na ocasião em que proferiu o grito de "Independência ou Morte". Esta taça pertenceu à finada Dona Veridiana Valéria da Silva Prado, que a ofereceu, como recordação daquela data histórica, ao Revmo. Monsenhor Manuel Vicente da Silva, por morte do qual passou às mãos da Família Santos Silva e, falecido o chefe desta, a viúva Dona Paula dos Santos Silva fez presente da taça ao Revmo. Sr. Vigário de Santo Amaro, Padre José Maria Fernandes, o qual, por sua vez, a ofereceu ao Museu da Cúria".

\section{Bandeira do $7^{\circ}$ Batalhão de Voluntários da Guerra do Paraguai}

Descrição no catálogo: "A cerimônia da benção desta bandeira, bordada por senhoras paulistas e por elas oferecida ao 7ํㅡㄹ Batalhão de Voluntários da Pátria, realizou-se na Catedral de São Paulo aos 9 de julho de 1865, tendo oficiado o Bispo Dom Sebastião Pinto Rego. Das mãos do ilustre prelado paulista passou o pavilhão - que se devia cobrir de glória na célebre tomada da ilha da Redenção e em toda a campanha contra o Paraguai - para as mãos do Presidente da Província, Dr. João Chrispiniano Soares, o qual, depois de vibrante discurso de exortação cívica, o entregou ao comandante do $7^{\circ}$, tenente-coronel Francisco Joaquim Pinto Pacca. Voltou a bandeira quando findou a guerra, a $1^{\circ}$ de março de 1870, dos campos do Paraguai, empunhada por um reduzido grupo de voluntários daquela unidade a qual, no fim da campanha, para formar batalhão, teve que fundir-se, sob o no 35 , com os restantes também paulistas do $42^{\circ}$ e $45^{\circ}$ batalhões, e foi entregue ao Corpo Capitular da Sé, às 4 horas da tarde de 27 de abril de 1870. O glorioso emblema da Pátria, que voltava salpicado de sangue e perfurado pelas balas paraguaias, mas virgem do contato impuro das mãos inimigas, foi entregue perante a tropa, pelo comandante do $53^{\circ}$, coronel Antonio Martins do Amorim Rangel, ao Presidente da Província, Dr. Antonio Candido de Andrade Rocha que, por seu turno, o entregou ao Vigário Capitular, Arcediago Dr. Joaquim Manuel Gonçalves Andrade, sendo a relíquia por este colocada ao 
pé do altar-mor. Subiu então ao púlpito o padre Francisco de Paula Rodrigues, que proferiu belíssimo discurso alusivo ao grandioso e comovente ato, findo o qual discurso, cantou-se o TE DEUM, oficiando o Arcediago Monsenhor Joaquim Manuel Gonçalves de Andrade. --- No laço de fita da coroa de louros lê-se a seguinte inscrição: "Campanha do Paraguay - Aos voluntários Paulistas - Ilha do Carvalho 2 e 24 de maio de 1865 - 18 de julho - Estabelecim.to Pikiciri Angostura Tupium - O corpo Academico de 1870".

\section{Meio bilhete da primeira grande e extraordinária loteria no Império}

Descrição do catálogo: "Para o monumento no Ipiranga à Independência do Brasil, com o prêmio maior de 1000 contos de réis, loteria essa decretada pela lei provincial de São Paulo n 49 de 6 de abril de 1880".

Os objetos 3, 4 e 5 relacionam-se com a história paulista no Primeiro e Segundo Reinado. Na descrição do no 3, a taça do banquete da Independência, pertencente à Dona Veridiana Valéria da Silva Prado, filha de Antônio da Silva Prado, o Barão de Iguape, de uma das famílias mais ricas e influentes na cidade de São Paulo nos séculos XVIII e XIX, podemos observar o caminho percorrido pelo objeto até ser doado ao Museu da Cúria, passando por membros da elite paulista a membros do clero.

Já a bandeira do 7ํㅡㄹathão de Voluntários da Guerra do Paraguai, traz uma longa descrição sobre o batalhão e seu "glorioso emblema da Pátria", bordado por senhoras paulistas e abençoado na Catedral de São Paulo 1865. Segundo Mons. Mattos, essa bandeira foi transferida para o Museu Missionário dos padre redentoristas em Aparecida (MATTOS, 1986, p. 61).

O objeto $\mathrm{n}^{\circ} 5$ representa os esforços para se construir o monumento à Independência (o Museu Paulista) a partir da criação por lei de uma loteria a fim de arrecadas dinheiro para as obras.

\section{Martelo e colher de pedreiro de metal dourado e cabos pretos}

Descrição no catálogo: "Tendo esta gravado os seguintes dizeres: 'Lançamento da pedra fundamental da Nova Catedral de São Paulo em 29 de junho de 1913, pelo Exmo. E Revmo. Sr. Dom Duarte Leopoldo e Silva, Arcebispo Metropolitano"'.

O 6 objeto, descrito acima, traz a inscrição presente no martelo e colher de pedreiro, objetos cerimoniais utilizados simbolicamente no início da construção da Catedral da Sé, cuja obra simbolizou o poder e influência de Dom Duarte e da Igreja Católica junto às autoridades políticas paulistas pós Proclamação da República. 


\section{Quadro com cabelo}

Descrição no catálogo: "O cabelo pertencia ao Exmo. E Revmo. Sr. Bispo de Mariana. Dom Antonio Ferreira Viçoso, falecido no dia 7 de julho de 1875. Oferecimento no verso do quadro: 'Ao Exmo. E Revmo. Sr. Arcebispo de São Paulo oferece esta lembrança do grande e santo Bispo Antonio Ferreira Viçoso o pobre amigo daquele e indigno sucessor deste. 17.1.1922. + Silverio Arcebispo de Mariana'".

\section{Garrucha}

Descrição no catálogo: "Oferecida ao Museu da Cúria pelos Revmos. Padres Redentoristas da Penha. Esta garrucha veio acompanhada de um certificado firmado pelo Revmo. Padre Estevam Maria, Reitor da Casa da Penha, nos seguintes termos: Veio acompanhada de um certificado firmado pelo Revmo. Padre Estevam Maria, Reitor da Casa da Penha, nos seguintes termos: "Essa garrucha é o instrumento que o bandido Guasca matou na Av. Celso Garcia O Redentorista P. João Schaumberger. A garrucha foi guardada na Delegacia do Braz sob o $n^{\circ} 23$, com os dizeres: "Nํ⒉ 23 . Garrucha que pertenceu ao Guasca..." O Exmo. Sr. Dr. Ribeiro Cardoso, Secretário da justiça, entregou-a a pedido dos Padres Redentoristas e estes entregam-na ao Exmo. Sr. Arcebispo Metropolitano para ser guardada no Museu da Cúria Metropolitana de São Paulo. 'In fide" Pe. Estevam Maria M. Reitor da Casa da Penha. Penha aos 2 de maio de 1924' (V. à pag. $35, n^{\circ} 295$, notícia sobre o assassinato do padre Schaumberger)".

Podemos considerar os objetos 7 e 8 , acima, como itens que contam costumes e histórias de membros do clero. No $7^{\circ}$ observamos um antigo costume de se guardar mechas de cabelo de entes falecidos como forma de lembrança. Já a garrucha nos conta a história do assassinato de um padre redentorista, João Batista Schaumberger, no bairro da Penha. A nota ao final da descrição remete ao retrato do padre Schaumberger, também objeto do acervo, onde se conta a história do assassinato e a observação de que "está sobre o retrato um pedaço de pano perfurado pela bala mortífera: retalho da batina que vestia no momento o virtuoso sacerdote" (ANEXO C).

\section{Jogo de breviário de uso pessoal de Sua Santidade o Papa Pio $X$}

Descrição no catálogo: "Papa Pio X ofereceu ao Exmo. Sr. Dom Francisco do Rego Maia, Arcebispo titular de Nicopolis, por este oferecido a Dom Sebastião Leme da Silveira Cintra, enquanto Bispo Coadjutor do Rio de Janeiro, o qual, por sua vez o ofereceu ao Museu da Cúria. Traz no tomo $1^{\circ} \circ$ o oferecimento autografo de sua Santidade: "Venerabili fratri Francisco do Rego Maia Archiepiscopo titulari Nicopolitano grati et benevolenti amicus ergo. Die 13 Maji 1911 (a) Pius PP.X" Cópia original de dois documentos que acompanham esta preciosa relíquia:

Vaticano 14 Maggio 1911

Monsignor Giovanni Bressan, Capellano Segreto di Sua Santité

Inchinato al bacio del Sacro Annello, ossequia rispettosamente l'lllmo e Revd. Mons. Francesco do Rego Maia Arcivescovo de Nicopoli e per disposizione del Santo Padre, Gli transmette um Breviario, che Sua Santitá há usato in questi primi anni del Pontificato fino al giorno 12 di questo mese. 
Rio de janeiro, 10 de outubro de 1927

A S. Exa. Revma. O Sr. Dom Duarte Leopoldo e Silva, Arcebispo de São Paulo, ofereço este breviário de Pio X, lembrança de S. Santidade ao Sr. Dom Francisco do Rego Maia, e deste a mim. Nas mãos de V. Exa. a preciosa relíquia está melhor guardada e será atestado seguro da grande afeição e o profundo reconhecimento que para seu bispo tem.

+ Sebastião Arceb. De Phars. Coadjutor de S. Eminência".

\section{Cédula de Conclave}

Descrição no catálogo: "Cédula que se utilizou o Eminentíssimo Sr. Cardeal Arcoverde, no Conclave de 1914, que elegeu o Papa Bento XV. Tendo-se enganado no escrever o nome, ou quiçá mudando o parecer, Sua Eminência deixou de parte esta cédula, entregando-a mais tarde a Monsenhor Benedicto, que, por sua vez, a doou ao Museu da Cúria. Note-se que as cédulas do Conclave são todas queimadas após o escrutínio, salvando-se esta pelo motivo acima indicado, pois não chegou a ser depositada na urna".

Por fim, os objetos 9 e 10, peças relacionadas aos Papas da Santa Sé, também nos mostram os históricos dos objetos até chegarem ao Museu, sendo passados como lembranças e presentes aos diversos membros do clero até serem doados ao Museu da Cúria, como forma de salvaguardar, perpetuar essas memórias.

\subsection{A proposta expositiva}

Conforme a anotação supracitada de Pe. João Kulay, em 1922 os objetos ocupavam quatro salas, três patamares e as escadas do Palácio da Cúria. Entretanto, em artigo publicado no jornal Diário Nacional: $A$ Democracia em Marcha (SP), em 1929, consta que o Museu ficava num pequeno quarto, "onde a luz entra com dificuldade, por uma janela estreita, munida de grossos varões de ferro. Os objetos históricos que lá se veem, estão colocados em vitrines ou suspensos pela parede" (n. 500, 1929, p. 8).

Este "pequeno quarto" descrito no artigo foi fotografado no ano anterior pela Revista Illustração Brasileira, que publicou em janeiro de 1928 um artigo a respeito do Museu da Cúria com fotos das salas expositivas. Ainda que estejam escuras, as imagens nos ajudam a entender de que forma os objetos eram expostos (Fig. 47-49). 
Figura 47: Uma das salas de exposição do Museu da Cúria.

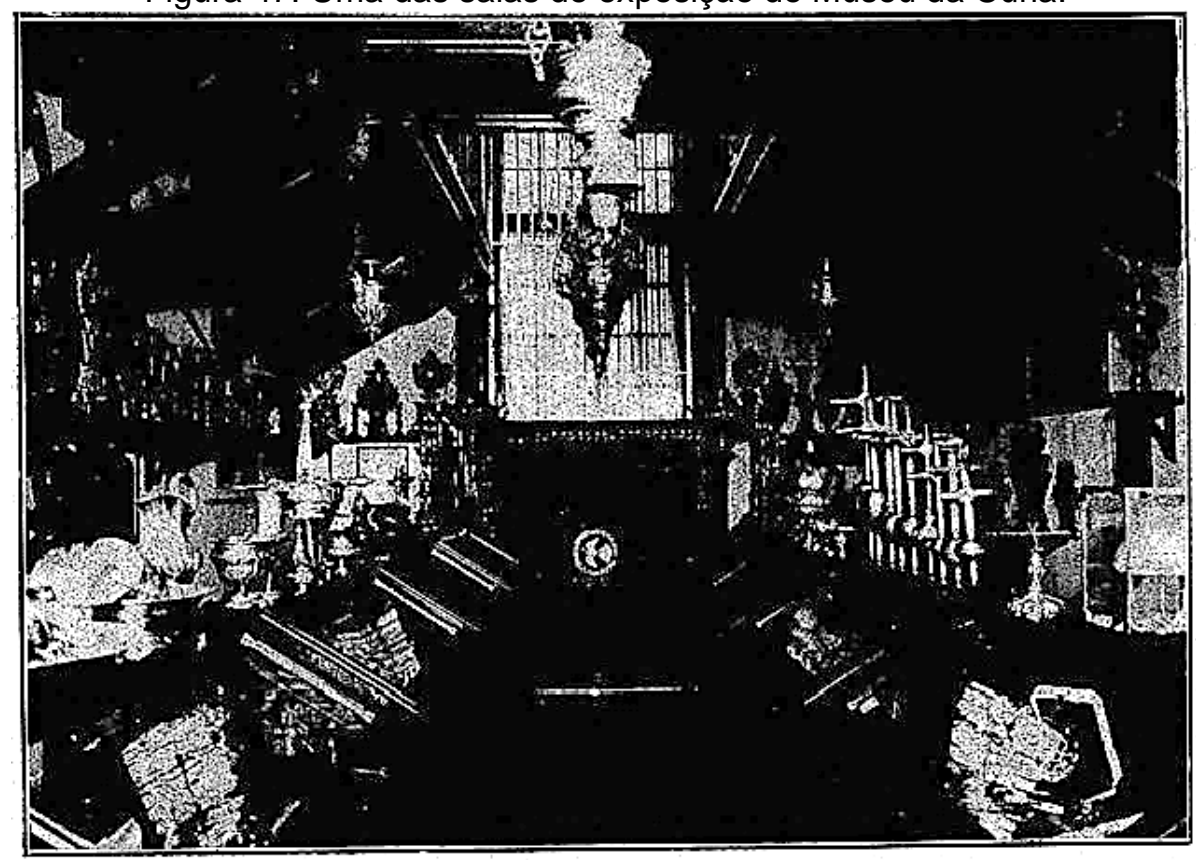

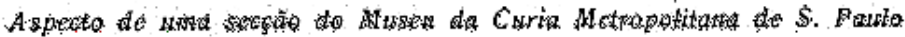

Fonte: Revista Illustração Brasileira, ํo 89, 1928. Abaixo da imagem, legenda original.

A imagem acima nos mostra uma grande sala, composta de vitrines nas duas laterais contendo peças que não nos foi possível identificar, porém supõese que sejam livros, pela posição em que se encontram. Acima das vitrines, temos pratarias diversas, como gomis, galhetas, salvas e cálices, à esquerda, e crucifixos, à direita. Na lateral esquerda, acima das vitrines, vemos uma espécie de prateleira, com esculturas de santos e mais objetos de prata. Há lampadários pendurados no teto. No centro da imagem, em frente ao que parece ser uma janela, vemos uma figura que se assemelha à imagem escultórica de um santo, sobre pequeno pedestal. 


\section{Figura 48: Exposição de tocheiros.}

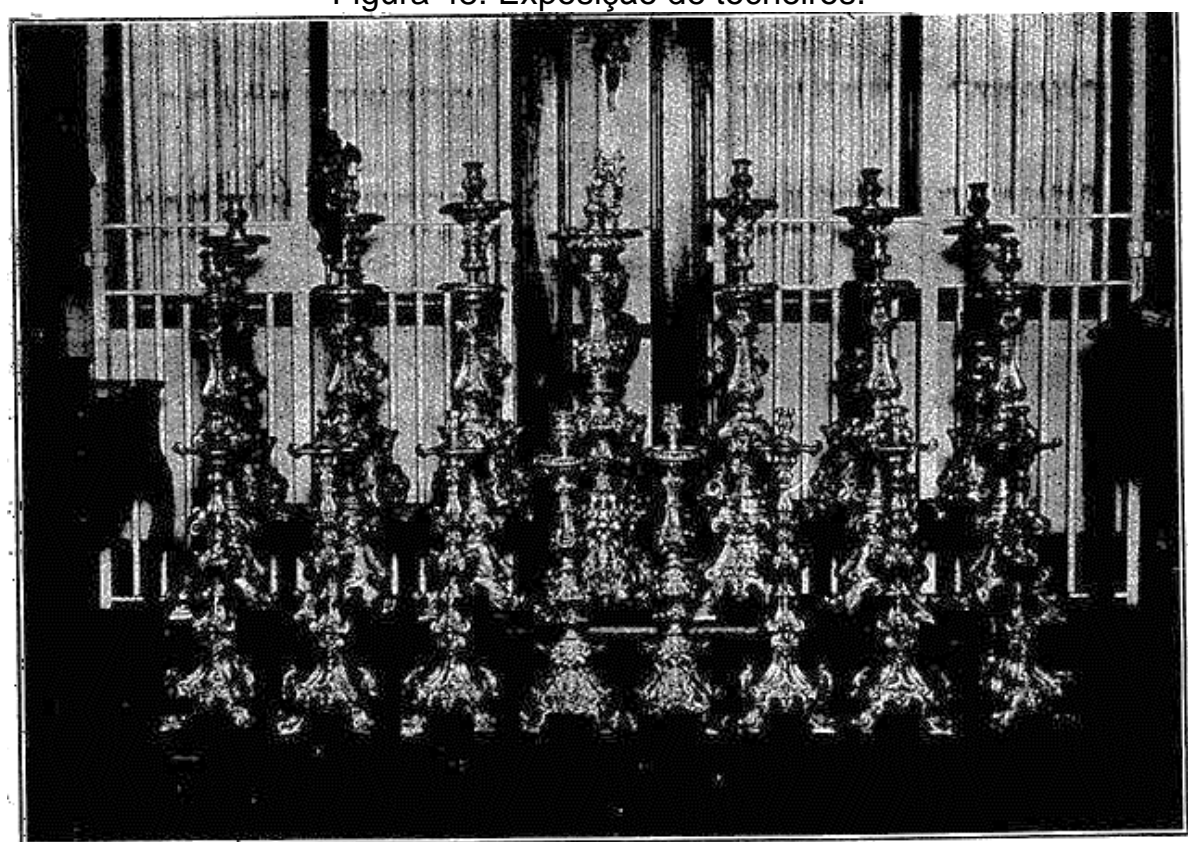

Rièa bariqueta de prata massiça, offerecida por $D$. Jêá $\forall$ a Cathedral de $\$$, Paulo

Fonte: Revista Illustração Brasileira, no 89, 1928. Abaixo da imagem, legenda original.

Os tocheiros apresentados acima foram oferecidos pelo rei $\mathrm{D}$. João $\mathrm{V}$ à antiga Igreja da Sé de São Paulo por ocasião da constituição do seu bispado, em 1745, como vimos, no catálogo ㄲo 52 do Museu da Cúria. Segundo esse catálogo, alguns itens da composição encontravam-se a serviço da Catedral. Esta informação se repete na atual catalogação do Museu de Arte Sacra de São Paulo.

A movimentação de objetos do Museu da Cúria para igrejas e celebrações específicas parece ter sido uma prática comum à época, visto que há anotações no verso de algumas páginas do catálogo a respeito de peças retiradas e posteriormente devolvidas.

A posição dos tocheiros na imagem, colocados à frente de uma janela, nos remete à descrição supracitada do artigo do jornal Diário Nacional: $A$ Democracia em Marcha (SP), que comenta a falta de iluminação no local. Sua localização na sala expositiva pode ser apontada na Figura 47, no segundo plano ao centro, em frente à janela, ainda que a imagem esteja muito escura. 
Figura 49: Pintura "Naufrágio do Sírio", de Benedito Calixto de Jesus, exposta no Salão de Conferência.

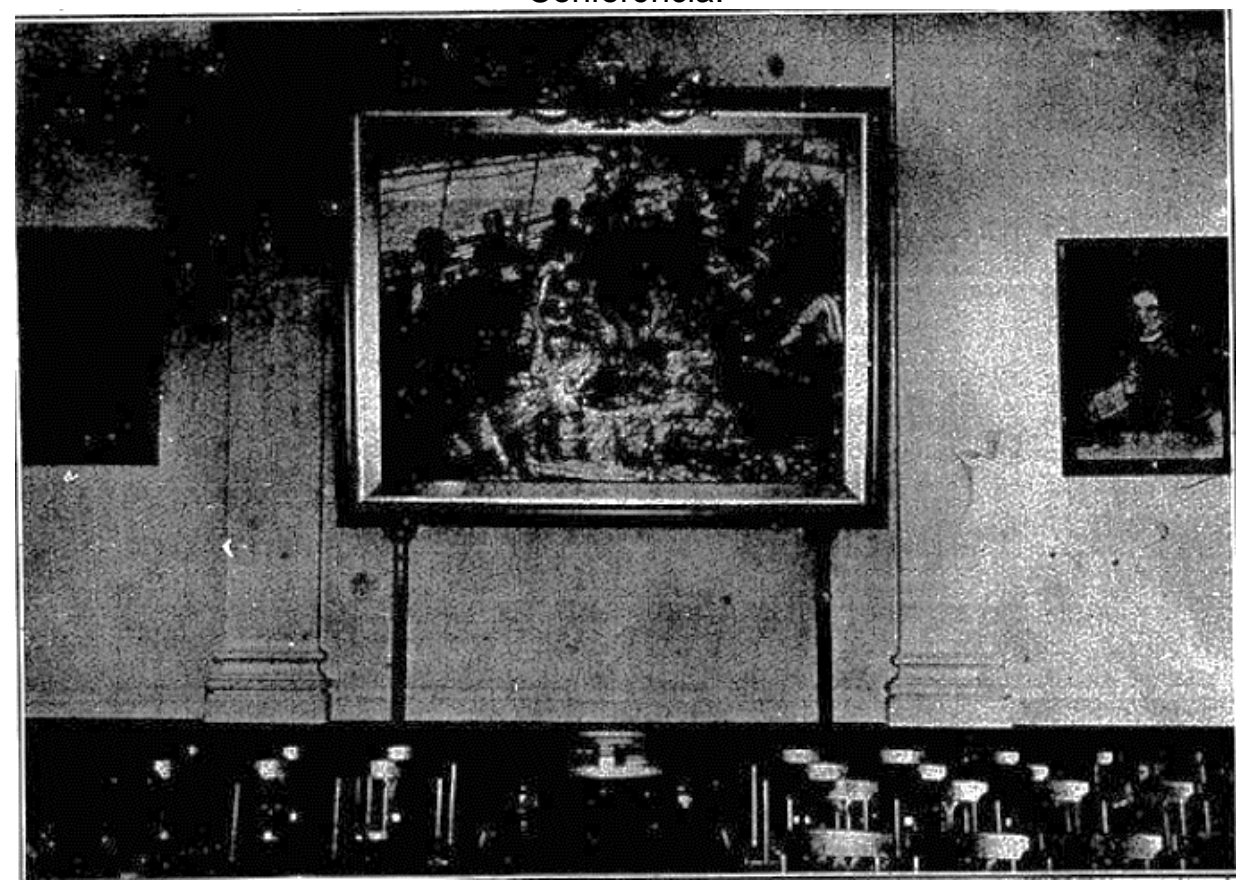

Fonte: Revista Illustração Brasileira, № 89, 1928.

A pintura acima, "Naufrágio do Sírio", de Benedito Calixto de Jesus, representa o naufrágio do navio de nome Sírio, episódio verdadeiro no qual faleceu o bispo Dom José de Camargo Barros, antecessor de Dom Duarte. Apesar de não estar inventariado no catálogo do Museu da Cúria de que dispomos, em 1928 o quadro se encontrava exposto no Salão de Conferência do Palácio da Cúria, conferindo uma importância à pintura. Segundo catalogação do MAS-SP, a obra é procedente do Salão Nobre do Palácio Pio XII, antiga residência Episcopal ${ }^{50}$.

\footnotetext{
50 Após a demolição do Palácio São Luiz na década de 1940, Dom José Gaspar comprou o Palácio Pio XII da família Revoredo. Construção do início do século XX, localizada no bairro do Paraíso, que recebeu pinturas e mobiliários do antigo Palácio São Luiz e do Museu da Cúria, como é o caso da pintura "Naufrágio do Sírio". Em 1970, Dom Evaristo Arns vendeu o local para compra de terrenos na periferia a fim de construir novas igrejas. Houve tentativas por parte do CONDEPHAAT de tombamento do imóvel (1971) e do jardim (1977), porém ambos os pedidos foram arquivados.
} 
Figura 50: Naufrágio do Sírio (1907). Benedito Calixto de Jesus. Óleo sobre tela. 203 x 267 x $17 \mathrm{~cm}$.

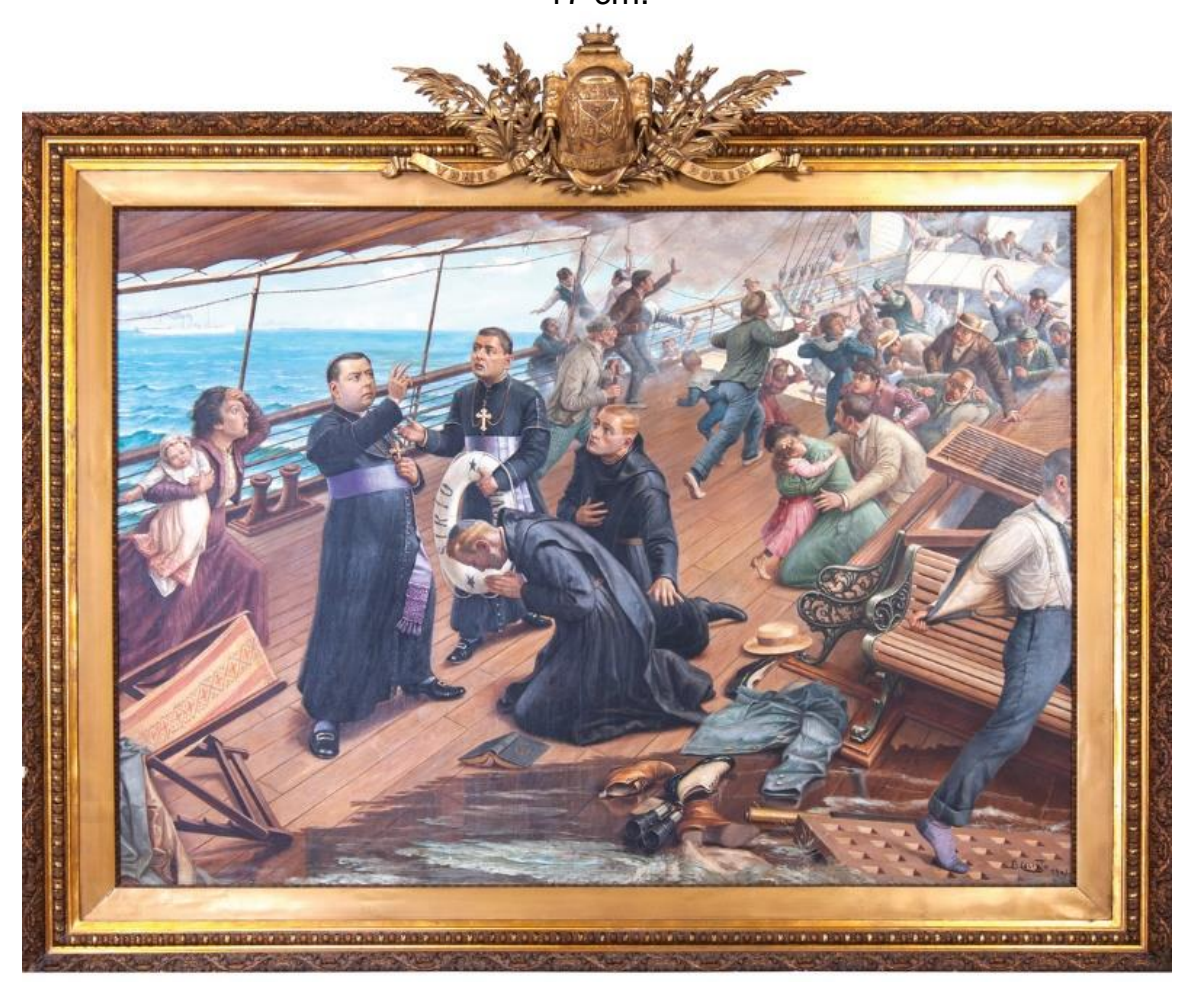

Fonte: Acervo Museu de Arte Sacra de São Paulo. Fotografia Iran Monteiro.

Com relação às pinturas, encontramos em pasta avulsa no ACMSP uma espécie de mapeamento das obras expostas entre as salas do segundo pavimento do Palácio da Cúria, onde ficavam as principais repartições eclesiásticas e o gabinete do Arcebispo, conhecido como Sala do Trono, sem data. Divididas por salas, com o título, autor, dimensão e técnica, os desenhos apresentam a posição do quadro na parede. Há um busto também listado (ANEXO B).

Apesar de as matérias de imprensa indicarem que o Museu se restringia a uma única sala, na expografia conferida nas imagens acima, na qual os objetos aparecem em diferentes cômodos do Palácio, podemos evidenciar que, na verdade, no início do Museu, o acervo encontrava-se espalhado pelas salas do Palácio, sendo utilizados todos os espaços para expor os objetos, da escadaria aos corredores.

Essa ideia também se confirma no Catálogo nº 52, que possui a indicação da localização dos objetos no Museu, estando dispostos em quatro salas; pelas paredes; mostruários; armário; cantos; mesas e banquetas; nos patamares; nas escadarias; na passagem para o Museu e na sala do diretor do Museu. 
Outra matéria ${ }^{51}$ sobre o Museu, publicada no jornal $A$ Republica: orgam do Partido Republicano (PR), de 03/04/1930, descreve as salas e os objetos presentes na exposição do Museu, sendo três grandes salas destinadas à exposição de objetos, documentos e relíquias relacionados à história religiosa de São Paulo; uma primeira sala, já organizada, que apresentava em suas vitrines relíquias, medalhas e condecorações da época de D. João VI e outra sala ainda em processo de organização, com quadros dos bispos de São Paulo dispostos em ordem cronológica.

Dentre as poucas imagens encontradas do Museu e de seus objetos expostos, podemos destacar também as imagens publicadas em 1955 no livro $A$ Igreja nos quatro séculos de São Paulo: 1554-1954 (Fig. 51-54):

\footnotetext{
${ }^{51}$ Além de listar alguns interessantes objetos presentes no Museu, a matéria levanta um ponto crucial acerca da arte sacra brasileira: seu valor de mercado e interesse estrangeiro em obter esse tipo de objeto, de forma legal ou não. Vê-se, já em 1930, esta discussão sendo posta a público, uma vez que já era difícil encontrar obras de artes pelo interior do Brasil, onde: “(...) antiquários espertos, sobretudo estrangeiros, adquiriram-nos por nonadas, ou trocaram por outros mais vistosos, mais modernos, porém menos preciosos. Fizeram com os seus ingênuos possuidores o negócio que os mais sabidos fizeram outrora com os índios: receberam ouro, em troca de espelhos e contas. Em transações dessas, foram exportadas muitas relíquias nossas (...)" (A República, $n^{\circ} 71,1930$, p.2). Vale ressaltar que o roubo e o tráfico ilícito de obras de arte e bens culturais, incluindo peças de arte sacra, são hoje o $3^{\circ}$ maior mercado ilegal do mundo, atrás apenas do tráfico de drogas e de armas (Eduardo Cosomano, Como funciona o mercado negro da arte? Revista Superinteressante Online. 31/10/2016. Disponível em: $<$ https://super.abril.com.br/cultura/como-funciona-o-mercado-negro-da-arte/>. Acesso em $21 \mathrm{de}$ jun 2019).
} 
Figura 51: Vista de sala de exposição de Museu.

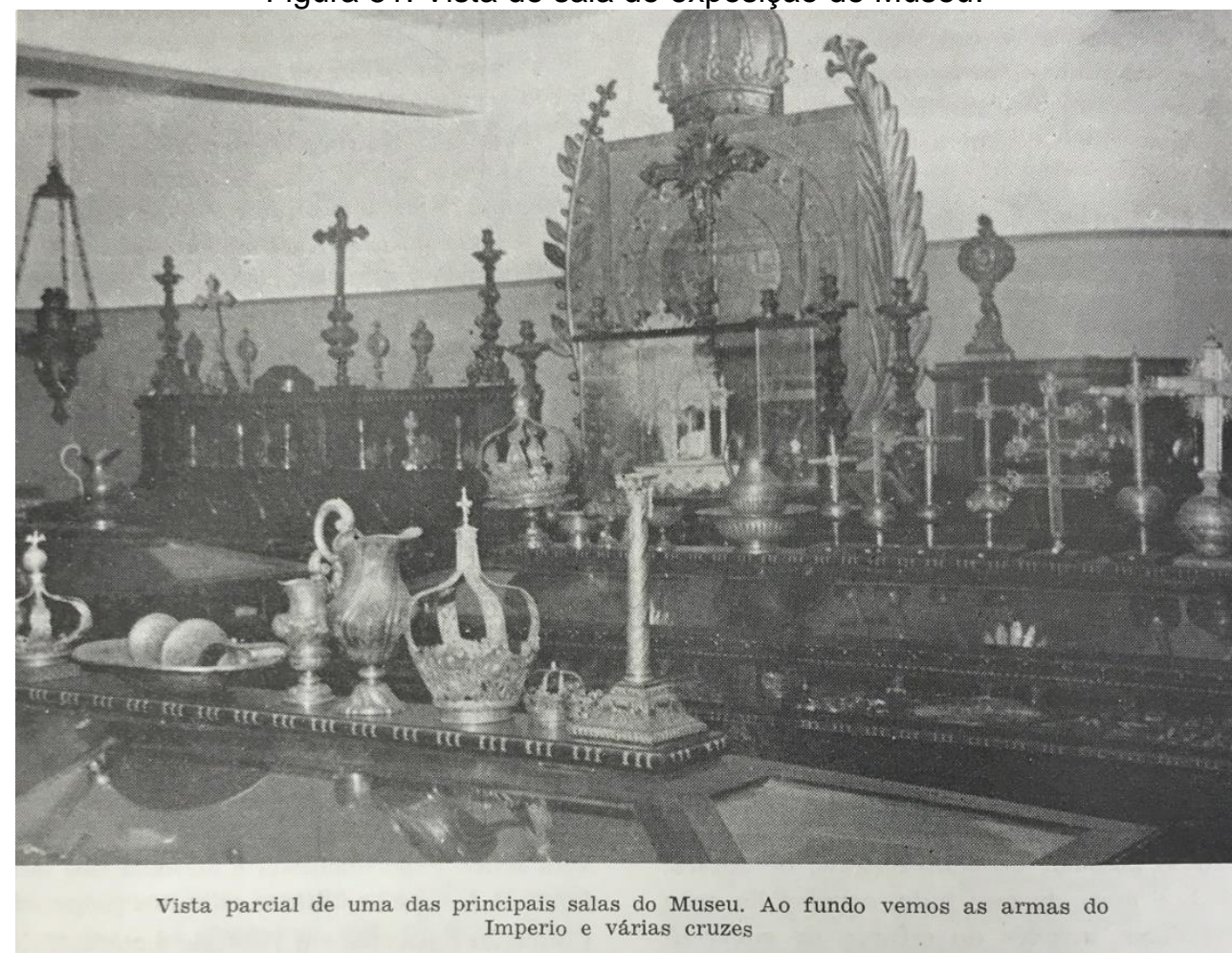

Fonte: A Igreja nos quatro séculos de São Paulo: 1554-1954, 1955, p.168. Abaixo da imagem, legenda original.

Conforme a legenda original da foto, a sala nela retratada, provavelmente era a principal, já que foi escolhida para representar o Museu. Vê-se que expunha objetos de tipologias diversas, mas ordenados de acordo com suas funções. Em primeiro plano, podemos observar o mobiliário expositivo de madeira e vidro, com objetos acima: coroa do Divino, bacia, cálice, gomil, duas coroas e castiçal.

No segundo plano, outra vitrine de madeira, de grandes dimensões, que parece estar no centro da sala, traz expostos um gomil (à esquerda), coroa, cálices e cruzes processionais. No terceiro plano, próximo à parede, mobiliário em formato de estante, contendo à esquerda tocheiros. Há cruzes acima do móvel, e vasos de santos óleos presos à parede; ao centro tocheiros, cruz relicário, resplendor e um oratório ou relicário dentro de uma redoma de vidro. Atrás da redoma, brasão do segundo império, que podemos reconhecer como aquele que pertenceu à antiga Sé de São Paulo, feito de madeira em talha dourada - e que, segundo o catálogo do Museu da Cúria, ficava sob o arco do cruzeiro. Para completar, no canto superior esquerdo da imagem, vemos um lampadário. 
Figura 52: Pia batismal exposta no Museu.

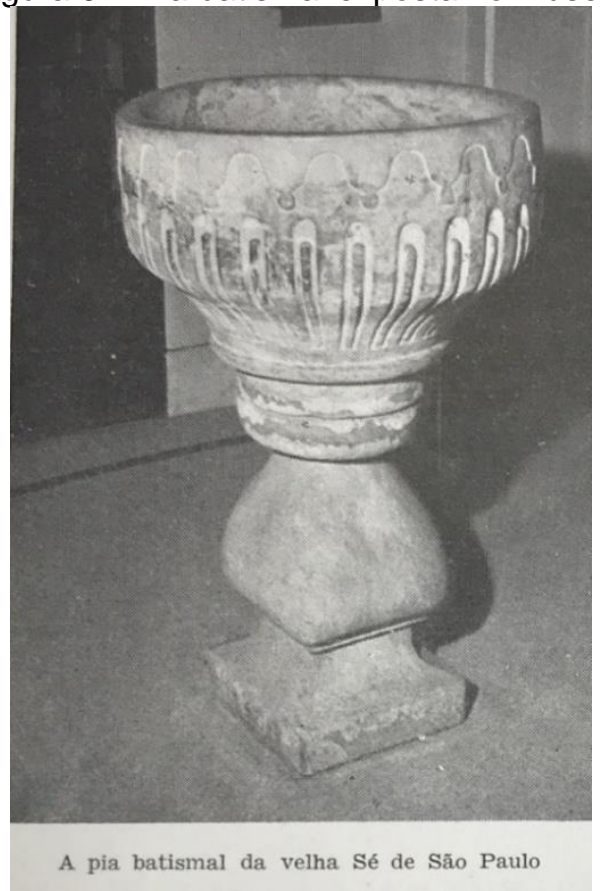

Fonte: A Igreja nos quatro séculos de São Paulo: 1554-1954, 1955, p. 169. Abaixo da imagem, legenda original.
Figura 53: Lampadários dependurados.

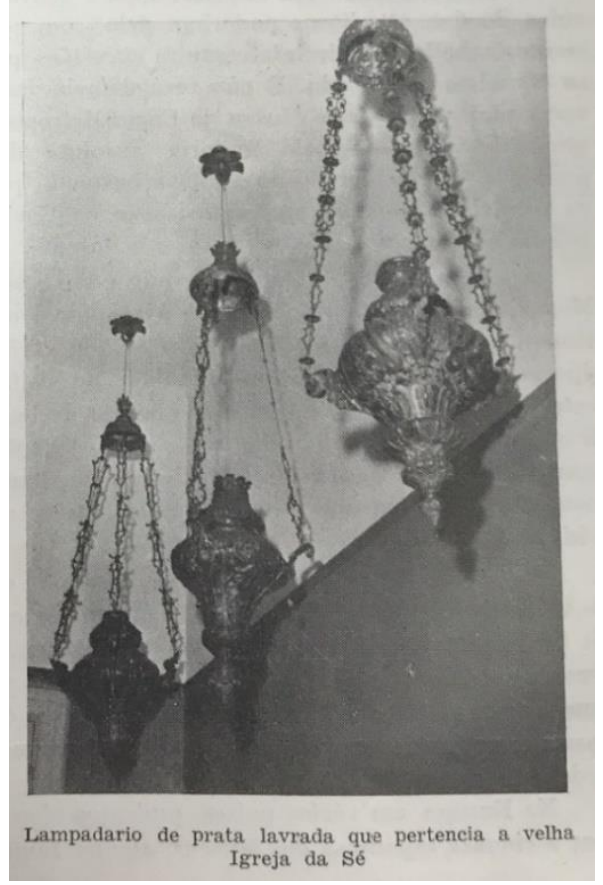

Fonte: A Igreja nos quatro séculos de São Paulo: 1554-1954, 1955, p. 169. Abaixo da imagem, legenda original.

As duas imagens acima apresentam objetos oriundos da antiga Sé de São Paulo. Apesar de as duas fotos estarem focadas nos objetos, podemos dizer que, no caso da pia batismal, se encontrava localizada próxima a uma parede, num ambiente interno, diferentemente de sua atual localização no MAS-SP, onde segue exposta no jardim do claustro, junto a outras 3 pias. 
Figura 54: Vitrine com diversos objetos expostos.

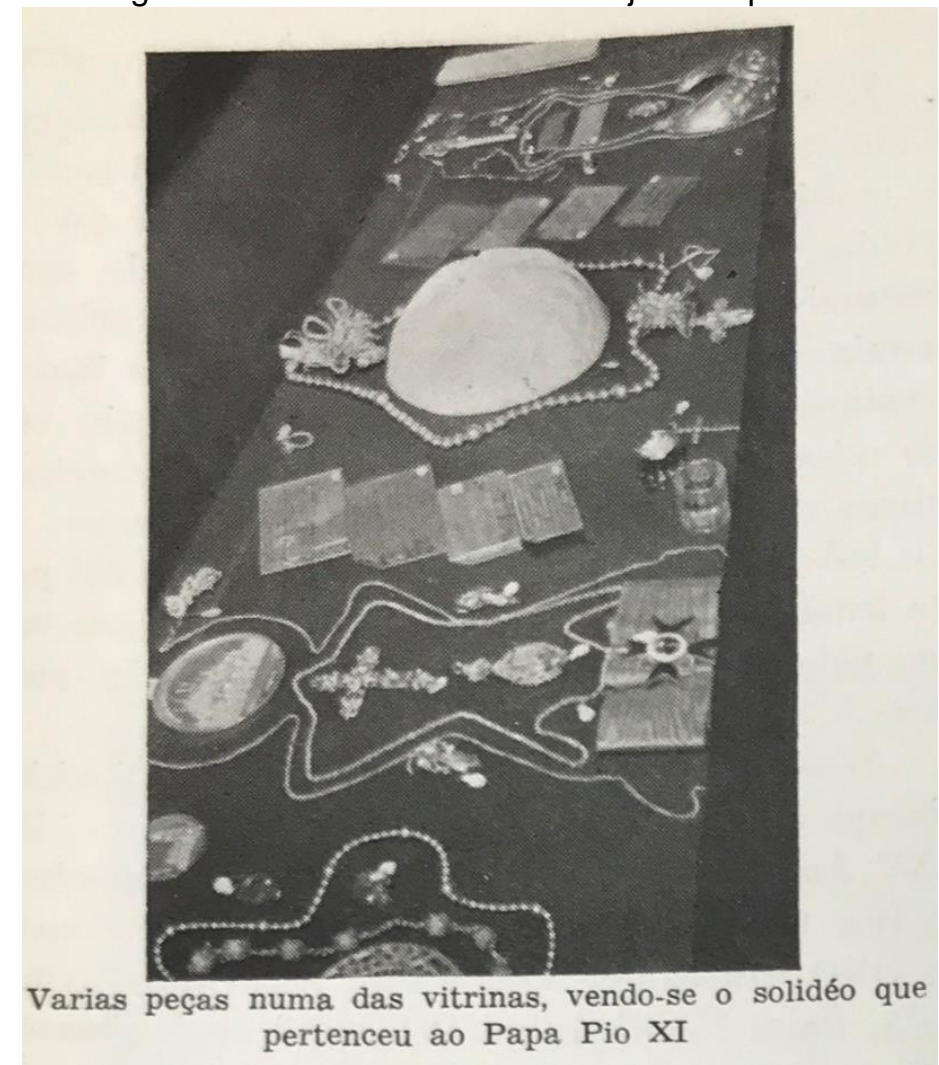

Fonte: A Igreja nos quatro séculos de São Paulo: 1554-1954, 1955, p.170. Abaixo da imagem, legenda original.

É possível observar na imagem acima que houve uma escolha temática na exposição dos objetos: joias, condecorações, cartões de prata e indumentária de autoridades eclesiásticas. Não se vê, a princípio, legenda dos objetos. O solidéu branco indicado pela legenda original da imagem como pertencente ao Papa Pio XI, aparece no catálogo do Museu da Cúria como tendo sido oferecido por Dom João Becker, arcebispo de Porto Alegre, a Dom Duarte.

Com relação ao mobiliário expositivo utilizado no Museu da Cúria, este nos remete ao usado no início do século XX nos museus brasileiros. Em formato retangular, de madeira e envidraçado, este tipo de vitrine era utilizado, por exemplo, pelo Museu Paulista na década de 1930 (Fig. 55). 
Figura 55: Sala expositiva do Museu Paulista, em 1937.

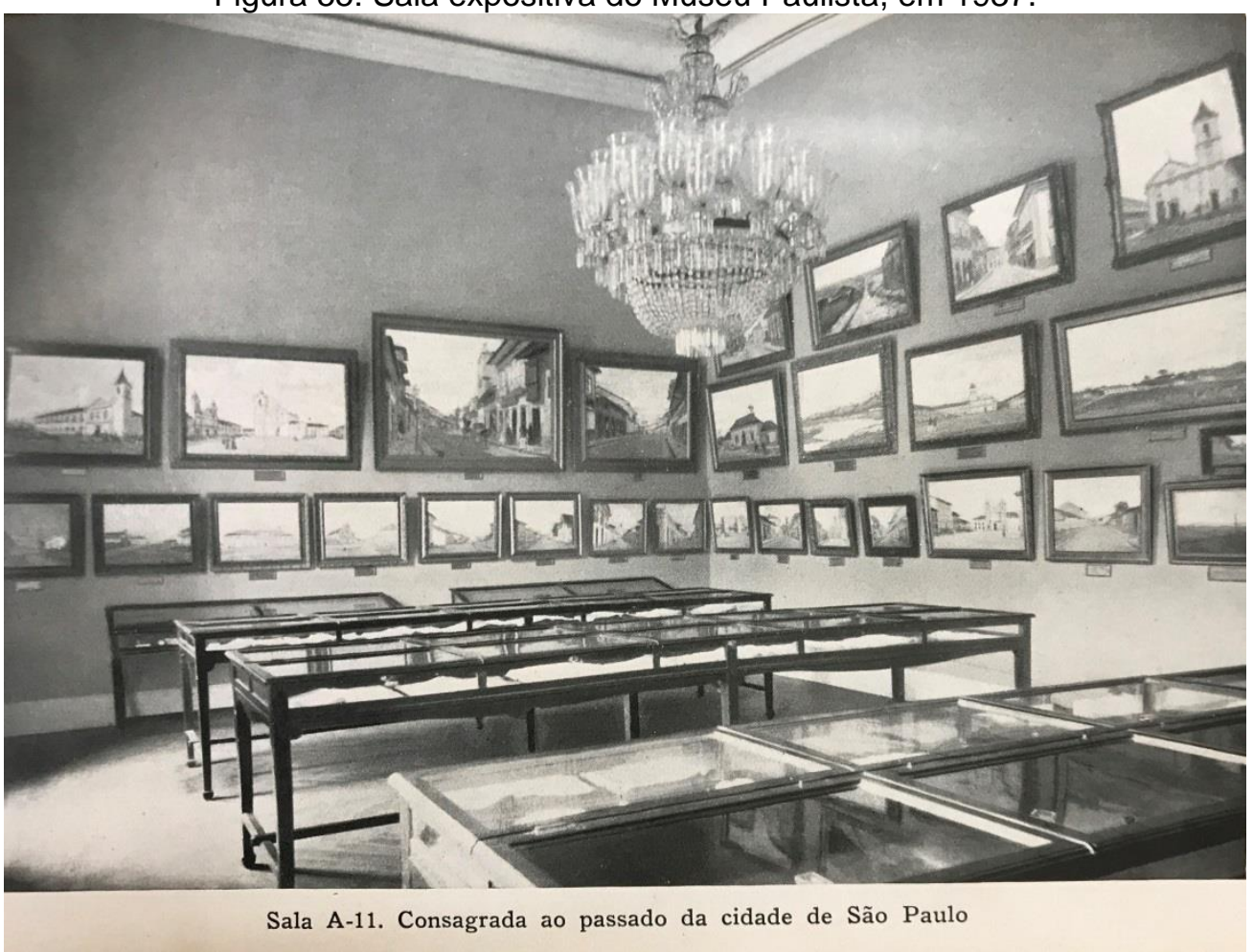

Fonte: Guia da Seção História do Museu Paulista, 1937.

Um ponto interessante a se observar na Figura 55, que retrata uma das salas do Museu Paulista, é a quantidade de pinturas pelas paredes e o número de vitrines dispostas numa mesma sala, uma prática expográfica comum à época e que poderemos observar também aplicada ao Museu da Cúria mais adiante. Conforme estudos de Heloisa Barbuy a respeito das exposições como fenômenos visuais, o apelo ao visual pode ser explicado como uma das transformações introduzidas com a modernidade a partir da metade do século XIX, com a industrialização e o capitalismo, estabelecendo uma cultura de exposições, entendidas como meios de comunicação essenciais que conjugam o binômio diversão e instrução (BARBUY, 2011, p. 258):

"Em São Paulo, na segunda metade do século XIX, a formação de um ambiente cosmopolita teve como componente relevante a ocorrência de uma sucessão de exposições abertas ao público. A cultura de exposições que então se instala, inclui formas populares ou leigas de veicular e absorver conhecimentos novos, na confluência de uma cultura científica com a curiosidade e promove, ainda, a difusão de vocabulário e valores científicos" (BARBUY, 2011, p. 258). 
Para Meneses (1994), uma característica basilar das exposições é seu caráter como convenção visual, uma organização de objetos para a produção de sentido (p. 22). A exposição de certos objetos no museu não se dá a partir de uma escolha espontânea ou natural, mas sim de uma exibição de objetos como suportes de significações proposto pela própria exposição (p. 24).

\subsubsection{Espacialização do Museu}

Ainda que muitos objetos estivessem expostos por entre os cômodos do Palácio, conforme apresentado no subcapítulo acima, havia salas expositivas exclusivas do Museu, com mobiliário expositivo próprio.

Uma vez que não foram encontrados outros registros documentais e fotográficos do Museu para ampliarmos a discussão sobre a sua expografia, optamos por recuperar da forma mais próxima possível o que pode ter sido a materialidade das salas de exposição do Museu, nos valendo da localização dos objetos indicada no Catálogo analisado para reinterpretar espacialmente os ambientes expositivos.

O exercício proposto baseia-se na metodologia de espacialização geohistórica desenvolvida pela professora da FAU-USP Beatriz Piccolotto Siqueira Bueno, que em sua tese de livre-docência acerca da perspectiva histórica do mercado imobiliário rentista, utiliza-se de Sistemas de Informações GeoHistóricas, fundamentais para espacializar bancos de dados complexos, para cruzar informações textuais e visuais a fim de reconstituir perfis materiais e sociais ${ }^{52}$.

O primeiro passo foi analisar a planta do Palácio da Cúria, encontrada no AHMSP. Comparando a prancha realizada em 1920 pelo arquiteto Abelardo Soares Caiuby com uma fotografia da fachada do edifício pronto (Fig. 56), concluímos que houve modificações estruturais no telhado, com a inclusão de uma mansarda, utilizada, segundo o Inventário de móveis, objetos de arte, alfaias, ornamentos e utensílios, de 1920, como oficinas do Arquivo.

52 Cf. BUENO, Beatriz Piccolotto Siqueira. A cidade como negócio: mercado imobiliário rentista, projetos e processo de produção do Centro Velho de São Paulo do século XIX à Lei do Inquilinato (1809-1942). 2018. Tese (Livre Docência em Arquitetura e Urbanismo) - Faculdade de Arquitetura e Urbanismo, Universidade de São Paulo, São Paulo, 2018. 
Figura 56: Cotejamento entre imagens da fachada do Palácio: projeto arquitetônico e fotografia.

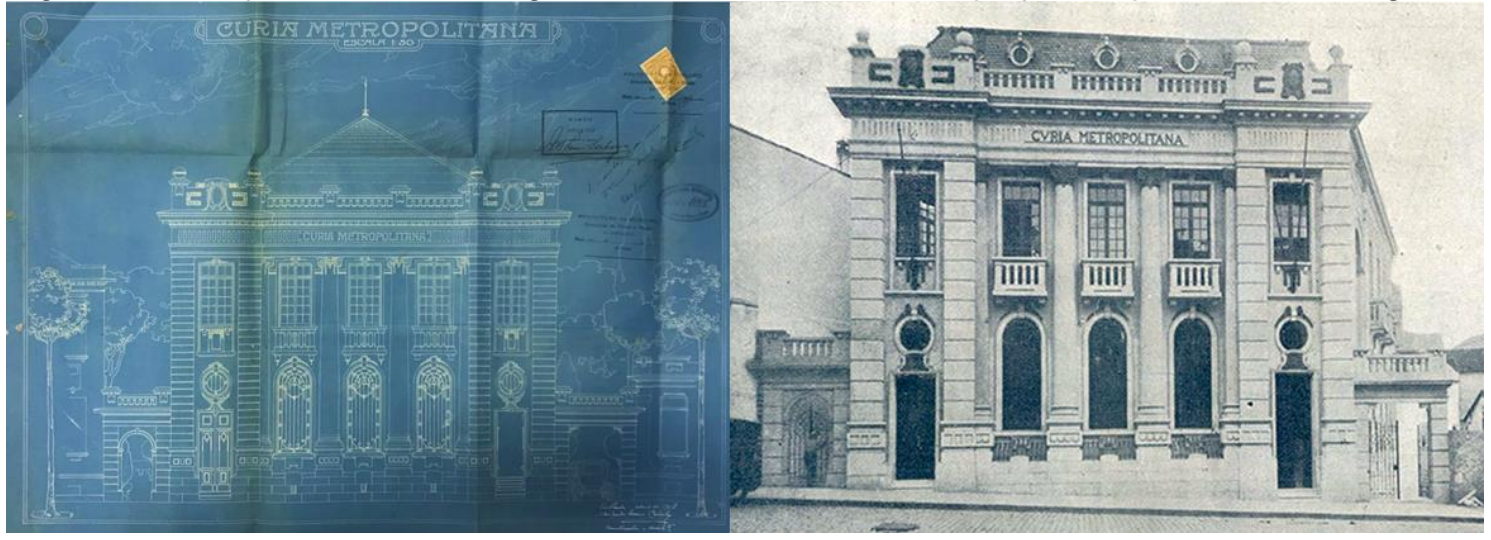

Também pudemos observar na planta dos pavimentos (Fig. 57) que não há sinalização da Capela do Palácio, bem como qualquer indicação de cômodos destinados ao Museu.

A partir destas modificações de projeto apontadas, supomos que talvez outras mudanças possam ter ocorrido ao longo da construção, bem como a alteração da denominação e utilização dos cômodos, decididas posteriormente ao término das obras. De qualquer forma, seguimos nosso exercício baseado na planta original encontrada.

Importante observar que, na planta dos pavimentos, não é possível compreender as medidas e escalas utilizadas para o desenho, então nos baseamos numa dimensão estimada para cada cômodo. 
Figura 57: Projeto aprovado: planta do $1^{\circ}$ e $2^{\circ}$ pavimentos. Abelardo Soares Caiuby, 1920.

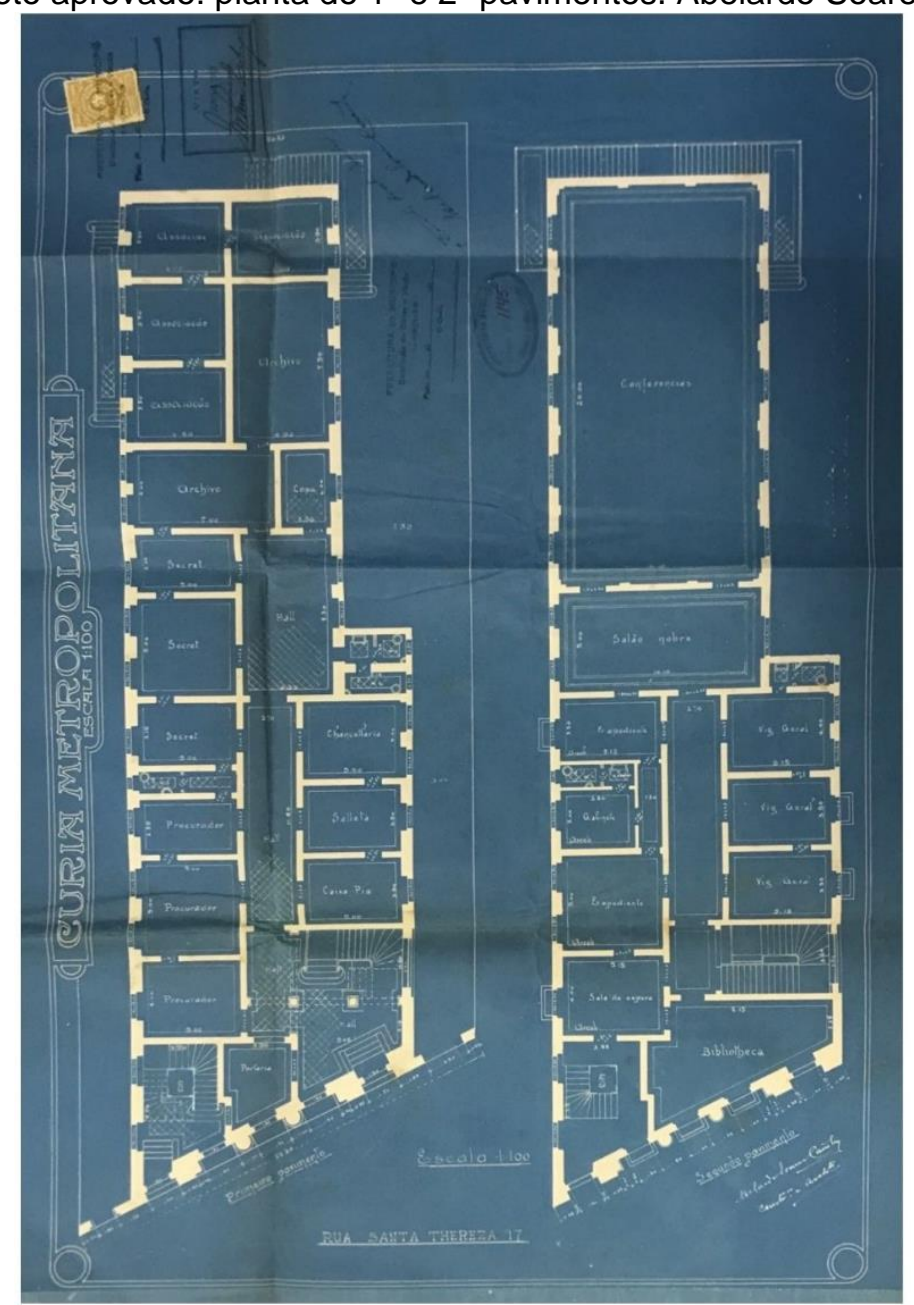

Fonte: Acervo AHMSP. Fotografia Luciana Barbosa, 2019. 
Figura 58: Ampliação e detalhamento da planta interna do Palácio da Cúria.
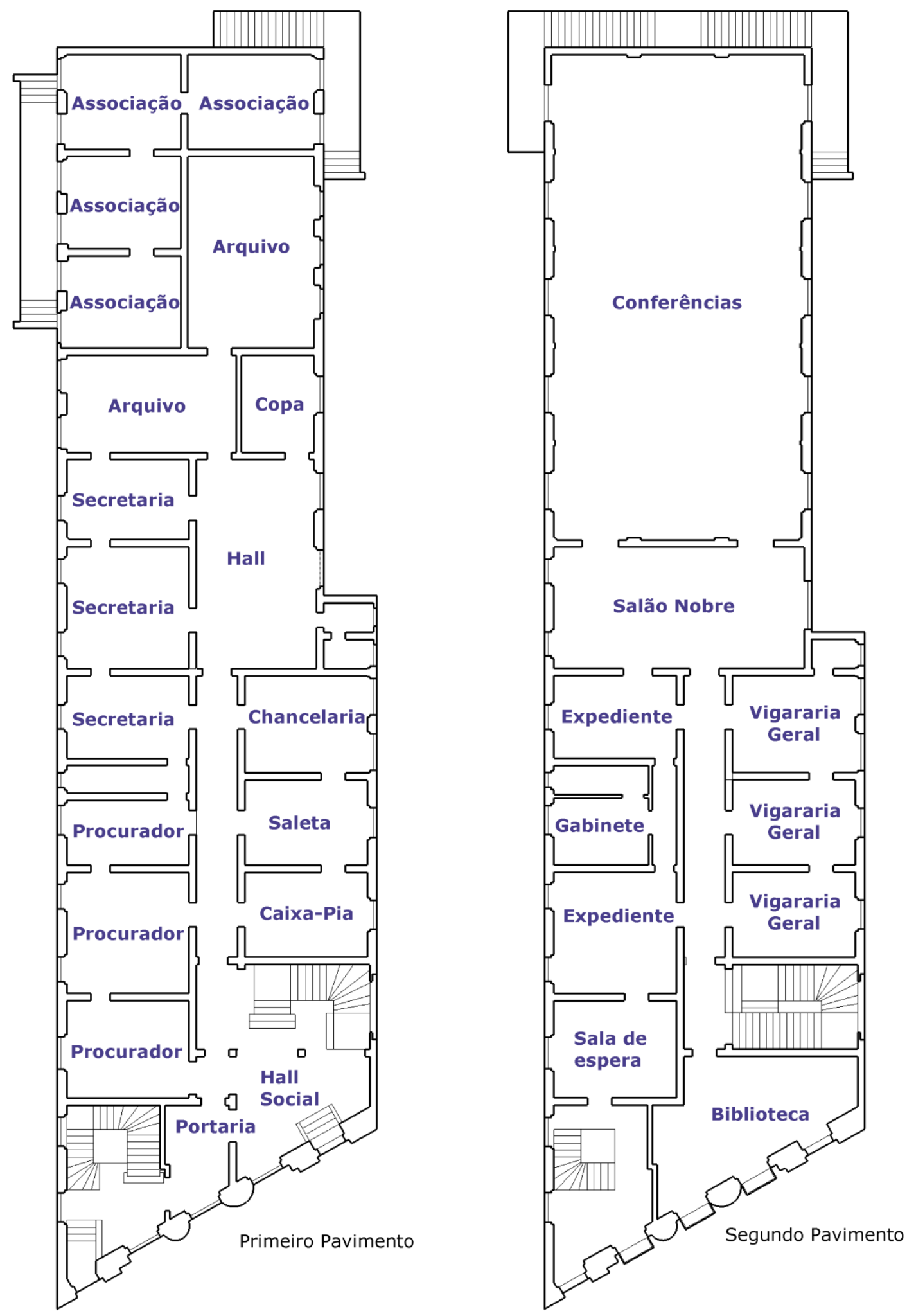

Rua Santa Thereza, 17

Cúria Metropolitana

sem escala

Desenho: Milena Cattini 
Como não foram encontradas outras referências que apontassem a localização exata das salas expositivas dentro do Palácio, entendemos que estas teriam surgido como anexos do Arquivo, uma vez que a coleta e gestão deste acervo eram realizadas pelo seu diretor, Francisco Collet. A partir desta hipótese, identificamos quatro salas no final do 1ำ pavimento, ao lado das duas salas do Arquivo, indicadas inicialmente na planta como "Associação", como supostamente utilizadas para exposição dos objetos (Fig. 59).

Figura 59: Vista das quatro salas apontadas como utilizadas para o Museu (1ำ pavimento).
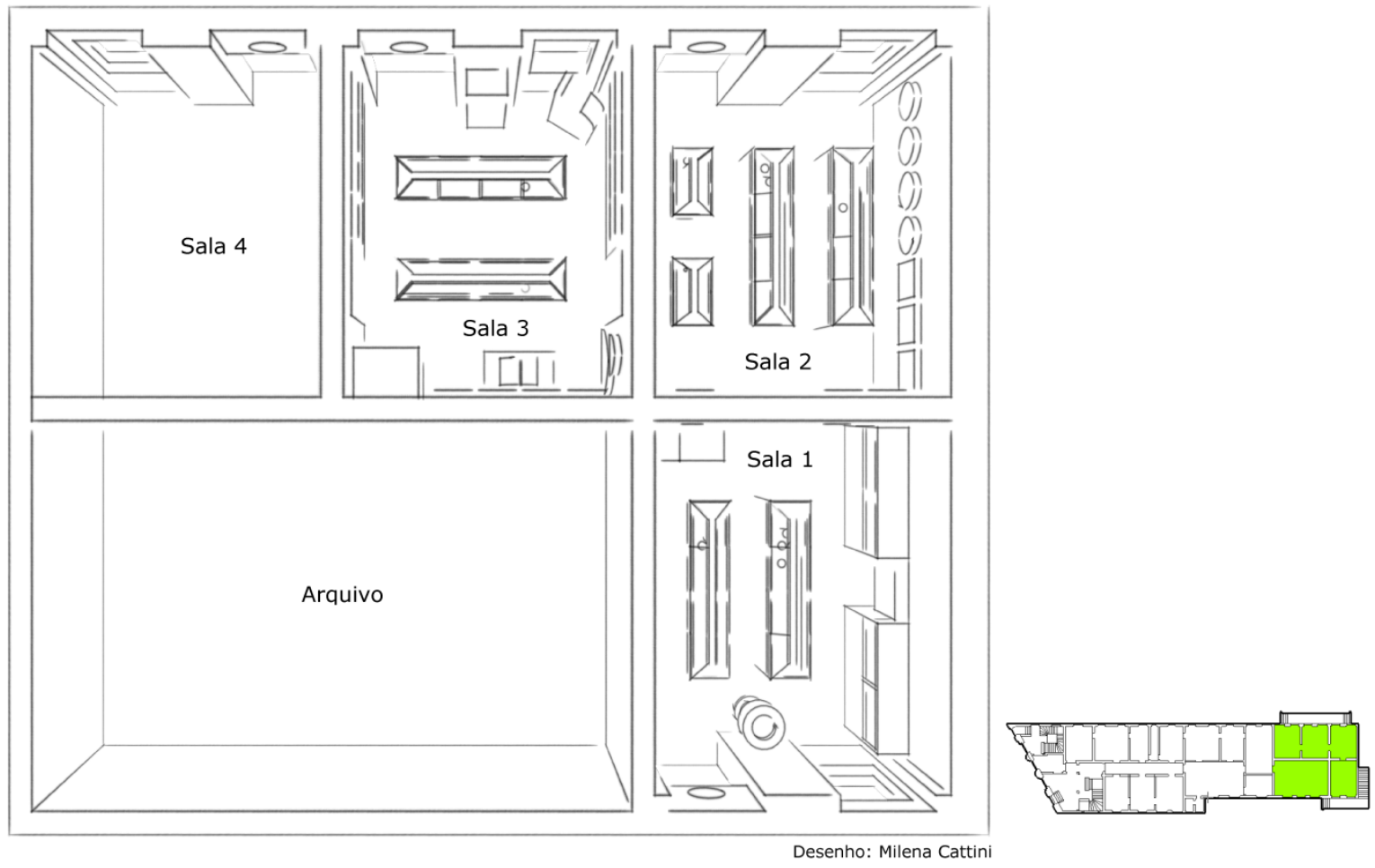

Necessário apontar que estas quatro salas, segundo a planta original, só possuem comunicação entre elas, sendo que a sala estabelecida por nós como Sala 1, tem acesso apenas por uma escada externa do Palácio. Não sabemos afirmar se isso foi modificado durante a construção, mas corrobora nossa suposição destas salas terem sido utilizadas como salas expositivas, por sua "privacidade" e acesso restrito, uma vez que o Palácio da Cúria era, antes de tudo, a sede administrativa da Igreja Católica em São Paulo. 
De acordo com o catálogo do Museu, os objetos encontrados entre as quatro salas expositivas estavam dispostos pelas paredes e mobiliários como mostruários, armários e mesas, sem indicar, no entanto, quais as suas posições dentro de cada ambiente. Tão pouco nos é dada a informação de suas medidas, para que pudéssemos dimensionar cada sala ${ }^{53}$.

Sem estas informações espaciais, nos valemos das poucas fotografias encontradas para reinterpretar as salas de exposição do Museu (Figuras 47, 48 e 51), que nos proporcionaram exemplos de mobiliários utilizados e formas de expor conjuntos de objetos de mesma tipologia.

Outra limitação encontrada no catálogo do Museu da Cúria é que, dos 1.227 objetos listados, 493 só possuem a indicação do mostruário a que pertencem, 54 objetos não possuem localização alguma e 8 estão indicados com localizações genéricas, como "passagem" e "escadaria". Os objetos com apenas os números dos mostruários foram analisados, porém não foi possível relacionálos com mostruários de outras salas, a fim de "recolocá-los" no ambiente correto, uma vez que, apesar de uma tentativa de expor os objetos de acordo com sua tipologia, muitas vezes os mostruários apresentavam objetos diversos em seu interior ${ }^{54}$.

Para a recriação dos ambientes expositivos, as medidas utilizadas tanto no desenho do mobiliário quanto dos objetos em si foram baseadas no que se conhece nestes tipos de peças, e de acordo com o tamanho da sala e número de mostruários existentes em cada uma.

A seguir, analisaremos os objetos presentes em cada sala expositiva e a expografia empregada, conforme as informações encontradas no Catálogo n. 52 - algumas descrições encontradas no catálogo eram muito extensas, então optamos por não as inserir nas planilhas de objetos, estando dispostas no ANEXO C. A lista dos objetos está ordenada de acordo com sua localização.

\footnotetext{
${ }^{53}$ Ao término da pesquisa descobrimos mais informações sobre a localização das vitrines após o convênio Mitra-Estado em 1969, comentada na pág. 286, porém não foram encontradas referências de suas medidas para serem utilizadas nesta parte do trabalho.

${ }^{54}$ Devido a grande quantidade de objetos sem indicação de localização definida, decidimos por não incluir neste trabalho as tabelas de inventário referentes a esses objetos.
} 


\section{Sala expositiva 1}

A sala de exposição no 1 seria acessada por escadaria externa do Palácio, de acordo com a nossa hipótese. Como primeira sala original do Museu, contemplava o maior número de peças em seus mostruários, paredes e mesas, num total de 247 objetos expostos.

As 4 estantes e as 8 vitrines de centro concentravam a prataria da coleção, composta por cálices, patenas, ostensórios, resplendores, cruzes e sacras, além de uma grande coleção de sinetes pertencentes a bispos e arcebispos de diversas dioceses brasileiras. Nas mesas laterais, missais e estantes de missal e frasco com óleo extraído das oliveiras do Jardim de Gethsemani, Jerusalém, Israel.

Já pelas paredes, era possível observar os retratos de D. Pedro II, D. João V e Papa Bento XIV, além de báculos, escudo de madeira com as chaves de S. Pedro, oriundo da antiga igreja de S. Pedro dos Clérigos, escudo com as Armas de Dom Duarte Leopoldo e Silva e um grande brasão imperial de madeira dourada da antiga Sé de São Paulo.

Nesta sala destacam-se também outros objetos da antiga lgreja da Sé de São Paulo: cruz relicário com relíquia de Santo Lenho, banqueta de tocheiros doada por D. João V e lampadário doado por D. Pedro I. 
Figura 60: Vista aérea da Sala 1.

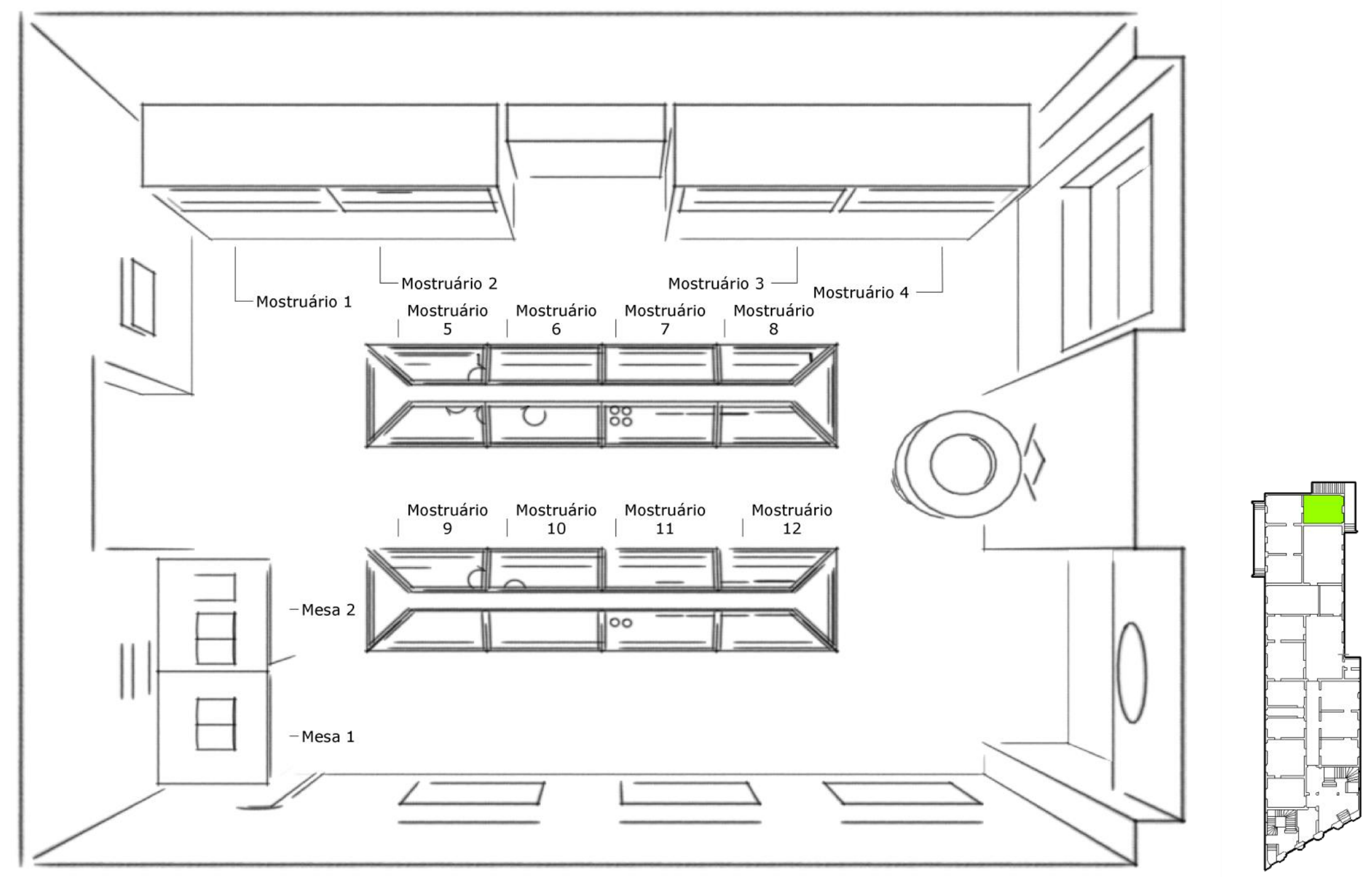

Desenho: Milena Cattini 
Figura 61: Perspectiva interna 1 da Sala 1.

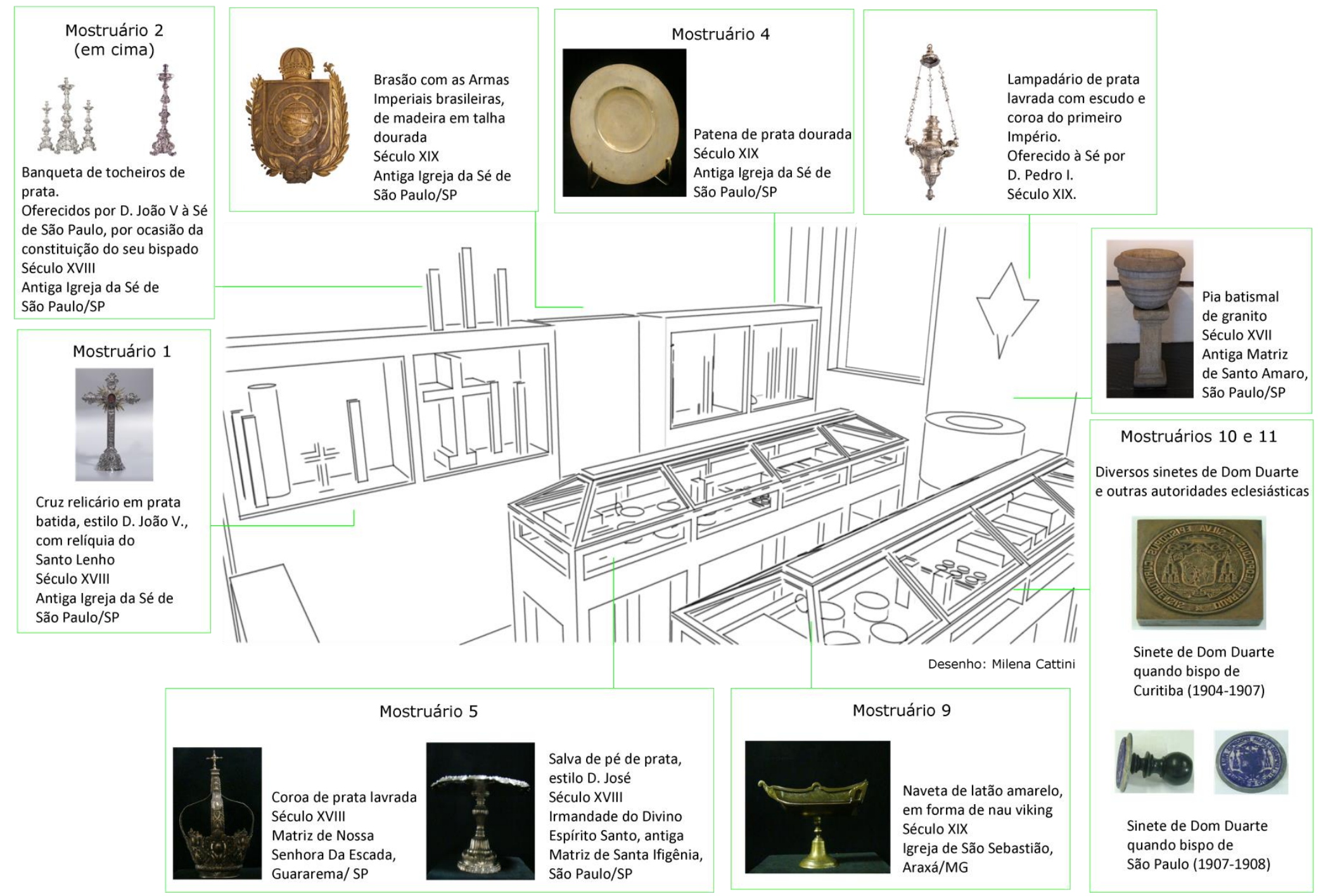


Figura 62: Perspectiva interna 2 da Sala 1.

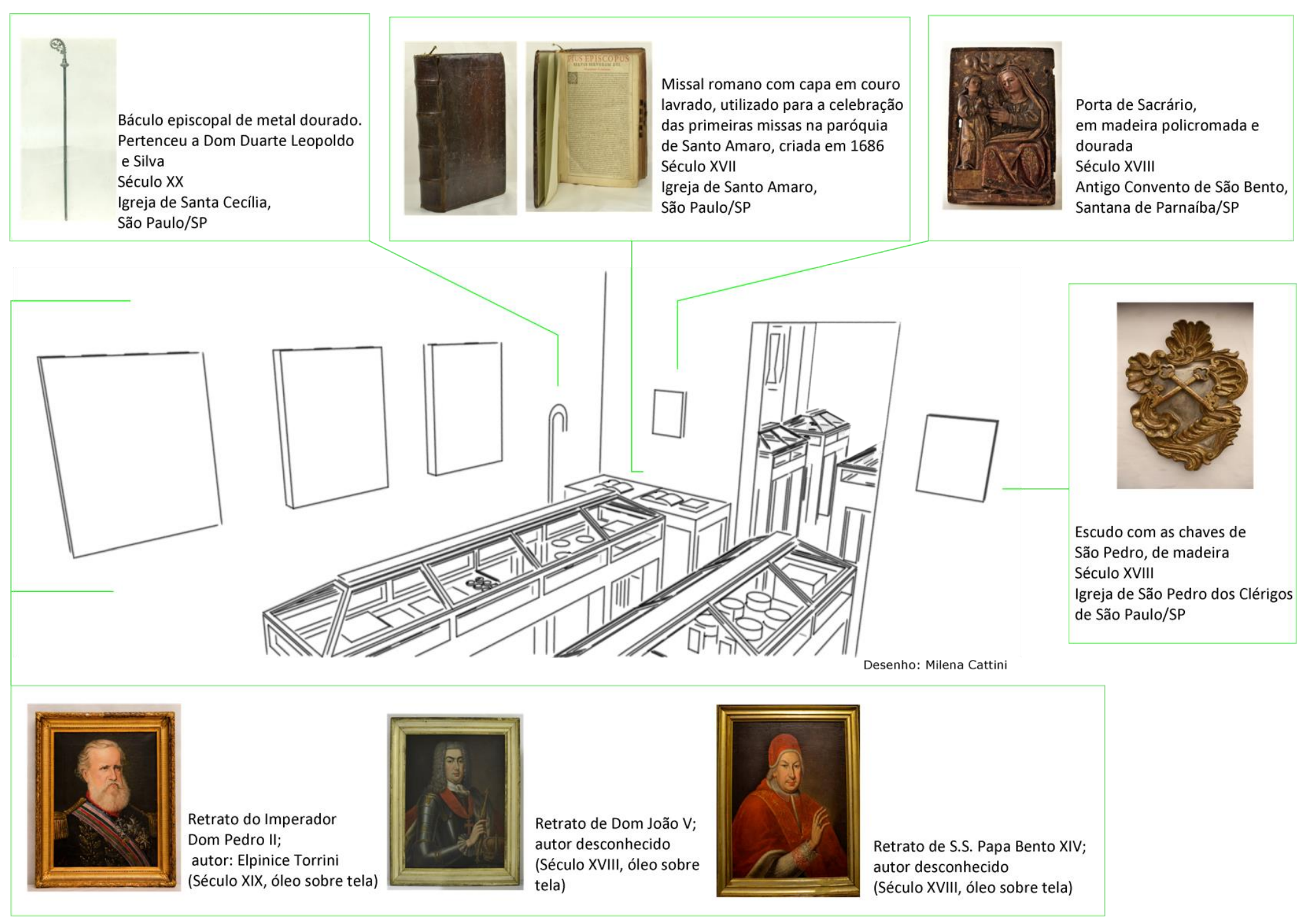


Tabela 5: Objetos expostos na Sala 1 do Museu da Cúria

\begin{tabular}{|c|c|c|c|c|c|c|c|c|c|c|}
\hline № Cat. & Objeto & Procedência & Pertenceu a & Doado por & Cidade & Estado & País & Sala & Mostruário & Descrição / Observação \\
\hline 6 & $\begin{array}{l}\text { Três das setes espadas } \\
\text { de Nossa Senhora Das } \\
\text { Dores }\end{array}$ & - & - & $\begin{array}{l}\text { Dom Duarte } \\
\text { Leopoldo e } \\
\text { Silva }\end{array}$ & Igarassu & Pernambuco & Brasil & 1 & 1 & $\begin{array}{l}\text { Oferecido à D. Duarte } \\
\text { durante visita. }\end{array}$ \\
\hline 13 & Tiras de linho e seda & - & - & - & Davnis & - & - & 1 & 1 & $\begin{array}{l}\text { Serviram nas cerimônias da } \\
\text { Sagração Episcopal do } \\
\text { Exmo. Sr. D. José Pereira } \\
\text { da Silva Barros, Arcebispo } \\
\text { titular de Davnis. }\end{array}$ \\
\hline 59 & Caneta e pena & - & $\begin{array}{l}\text { Monsenhor } \\
\text { Francisco de } \\
\text { Paula } \\
\text { Rodrigues } \\
\text { (Padre Chico) }\end{array}$ & - & - & - & - & 1 & 1 & $\begin{array}{l}\text { Última caneta e pena } \\
\text { usadas por Monsenhor Dr. } \\
\text { Francisco de Paula } \\
\text { Rodrigues (Padre Chico) no } \\
\text { dia } 18 / 06 \text {, assinando } \\
\text { requerimento do ver. Antonio } \\
\text { Rollim, pedindo dispensa de } \\
\text { proclamas a favor de Manoel } \\
\text { José Moreira e Maria das } \\
\text { Dores. Protocolo } n^{\circ} \text { 7902. }\end{array}$ \\
\hline 552 & Cartão de prata & - & - & \begin{tabular}{|l|} 
Monsenhor \\
Pereira Barros
\end{tabular} & - & - & - & 1 & 1 & Ver ANEXO C. \\
\hline 561 & $\begin{array}{l}\text { Cepto de prata dourada, } \\
\text { ouro, crisolitas e um } \\
\text { topázio }\end{array}$ & \begin{tabular}{|l|} 
Velho \\
Convento de \\
Santa Teresa \\
\end{tabular} & - & - & - & - & Brasil & 1 & 1 & - \\
\hline 588 & Solidéu & - & $\begin{array}{l}\text { Dom } \\
\text { Epaminondas } \\
\text { Nunes } \\
\text { D'Avila e } \\
\text { Silva, } \\
\text { primeiro } \\
\text { bispo de } \\
\text { Taubaté }\end{array}$ & - & Taubaté & São Paulo & Brasil & 1 & 1 & - \\
\hline 613 & $\begin{array}{l}\text { Pasta com encadernação } \\
\text { de madeira marchetada } \\
\text { de madrepérola }\end{array}$ & - & - & $\begin{array}{l}\text { Dona Francisca } \\
\text { M. de Souza } \\
\text { Queiroz }\end{array}$ & - & - & - & 1 & 1 & - \\
\hline 614 & $\begin{array}{l}\text { Relíquia do Santo Lenho } \\
\text { com cruz de prata. }\end{array}$ & \begin{tabular}{|l|} 
Velha Sé de \\
São Paulo
\end{tabular} & - & - & São Paulo & São Paulo & Brasil & 1 & 1 & - \\
\hline 629 & $\begin{array}{l}\text { Cálice de prata, copa } \\
\text { dourada }\end{array}$ & $\begin{array}{l}\text { Velha Sé de } \\
\text { São Paulo }\end{array}$ & - & - & São Paulo & São Paulo & Brasil & 1 & 1 & - \\
\hline
\end{tabular}




\begin{tabular}{|c|c|c|c|c|c|c|c|c|c|c|}
\hline № Cat. & Objeto & Procedência & Pertenceu a & Doado por & Cidade & Estado & País & Sala & Mostruário & Descrição / Observação \\
\hline 630 & Patena de prata dourada & $\begin{array}{l}\text { Velha Sé de } \\
\text { São Paulo }\end{array}$ & - & - & São Paulo & São Paulo & Brasil & 1 & 1 & - \\
\hline 631 & Patena de prata dourada & - & - & - & - & - & - & 1 & 1 & - \\
\hline 953 & Ambula de prata dourada & - & - & $\begin{array}{l}\text { Guilherme } \\
\text { Guinle }\end{array}$ & - & Bahia & Brasil & 1 & 1 & $\begin{array}{l}\text { Pertenceu a uma Igreja na } \\
\text { Bahia. Adquirida de um } \\
\text { padre sem fé e sem } \\
\text { escrúpulos pelo Sr. } \\
\text { Guilherme Guinle, e por este } \\
\text { oferecido ao Museu da } \\
\text { Cúria, por intermédio de } \\
\text { D.Heloisa Guinle Ribeiro. }\end{array}$ \\
\hline 58 & $\begin{array}{l}\text { Distintivo da "Adoração } \\
\text { Noturna Brasileira" }\end{array}$ & - & - & - & - & - & - & 1 & 2 & - \\
\hline 634 & Dois Agnus Dei & $\begin{array}{l}\text { Convento de } \\
\text { Santo Antonio }\end{array}$ & - & - & $\begin{array}{l}\text { Rio de } \\
\text { Janeiro }\end{array}$ & $\begin{array}{l}\text { Rio de } \\
\text { Janeiro }\end{array}$ & Brasil & 1 & 2 & $\begin{array}{l}\text { Oferecidos ao convento de } \\
\text { Santo Antonio do Rio de } \\
\text { Janeiro, pelo Papa Clemente } \\
\text { XIII. Anotação a lápis: outro } \\
\text { pelo Papa Clemente XI. }\end{array}$ \\
\hline 638 & $\begin{array}{l}\text { Cálice de prata dourada, } \\
\text { com a respectiva } \\
\text { colherinha }\end{array}$ & - & - & - & - & - & - & 1 & 2 & - \\
\hline 639 & Patena de prata dourada & - & - & - & - & - & - & 1 & 2 & - \\
\hline 640 & Patena de prata dourada & - & - & - & - & - & - & 1 & 2 & - \\
\hline 57 & $\begin{array}{l}\text { Anel de ametista } \\
\text { cravejado com pedras } \\
\text { preciosas }\end{array}$ & - & - & $\begin{array}{l}\text { Dom José } \\
\text { Marcondes } \\
\text { Homem de } \\
\text { Mello, } \\
\text { Arcebispo de } \\
\text { São Carlos } \\
(1906-1937)\end{array}$ & - & \begin{tabular}{|l}
- \\
-
\end{tabular} & - & 1 & 3 & 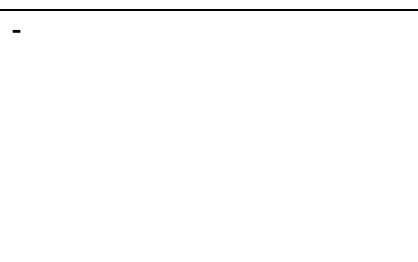 \\
\hline 585 & Caneta & - & - & - & São Paulo & São Paulo & Brasil & 1 & 3 & $\begin{array}{l}\text { Serviu para a assinatura do } \\
\text { contrato lavrado entre a } \\
\text { Prefeitura e o Arcebispado, } \\
\text { para a construção da } \\
\text { Catedral de São Paulo. }\end{array}$ \\
\hline
\end{tabular}




\begin{tabular}{|c|c|c|c|c|c|c|c|c|c|c|}
\hline № Cat. & Objeto & Procedência & Pertenceu a & Doado por & Cidade & Estado & País & Sala & Mostruário & Descrição / Observação \\
\hline 586 & Broche de ouro e coral & - & - & \begin{tabular}{|l|} 
José Carlos de \\
Macedo Soares
\end{tabular} & - & - & - & 1 & 3 & $\begin{array}{l}\text { Anotação: Retirado, ordem } \\
\text { do Sr. Cardeal para ser } \\
\text { vendido. }\end{array}$ \\
\hline 610 & $\begin{array}{l}\text { Rosário de ouro com cruz } \\
\text { do mesmo metal }\end{array}$ & $\begin{array}{l}\text { Capela do } \\
\text { Colégio de } \\
\text { Araçariguama }\end{array}$ & - & - & Araçariguama & São Paulo & Brasil & 1 & 3 & $\begin{array}{l}\text { Doado à Imagem de Nossa } \\
\text { Senhora da Conceição pelo } \\
\text { Dr. Fabio de Andrade. }\end{array}$ \\
\hline 612 & $\begin{array}{l}\text { Colherinha de prata } \\
\text { lavrada }\end{array}$ & $\begin{array}{l}\text { Capela do } \\
\text { Colégio de } \\
\text { Araçariguama }\end{array}$ & - & - & Araçariguama & São Paulo & Brasil & 1 & 3 & $\begin{array}{l}\text { Usada no Santo Sacrifício } \\
\text { da Missa. Trabalho artístico } \\
\text { e muito Antigo. Foi } \\
\text { encontrada soterrada junto à } \\
\text { Capela pelo sr. Bento de } \\
\text { Castro Gomide. }\end{array}$ \\
\hline 641 & $\begin{array}{l}\text { Anel de ouro com pedra } \\
\text { grande no centro e } 24 \\
\text { pequenas em volta }\end{array}$ & - & - & - & - & - & - & 1 & 3 & $\begin{array}{l}\text { Anotação: Retirado do } \\
\text { Museu, por ordem do Sr. } \\
\text { Cardeal Rossi para ser } \\
\text { vendido. }\end{array}$ \\
\hline 642 & $\begin{array}{l}\text { Anel de ouro com } \\
\text { ametista e, gravada a } \\
\text { imagem do Sagrado } \\
\text { Coração de Jesus }\end{array}$ & - & - & - & - & - & - & 1 & 3 & $\begin{array}{l}\text { Anotação: Retirado do } \\
\text { Museu, por ordem do Sr. } \\
\text { Cardeal Rossi para ser } \\
\text { vendido. }\end{array}$ \\
\hline 643 & $\begin{array}{l}\text { Anel de ouro e esmalte, } \\
\text { com pedra verde partida. }\end{array}$ & - & - & - & - & - & - & 1 & 3 & $\begin{array}{l}\text { Na parte interna do anel } \\
\text { estão gravadas as seguintes } \\
\text { datas: } 1888 \text { - } 8 \text { april. - } 1913 \text {. } \\
\text { Anotação: Retirado do } \\
\text { Museu, por ordem do Sr. } \\
\text { Cardeal Rossi para ser } \\
\text { vendido. }\end{array}$ \\
\hline 644 & $\begin{array}{l}\text { Patena de prata dourada } \\
\text { lisa }\end{array}$ & - & - & - & - & - & - & 1 & 3 & - \\
\hline 645 & $\begin{array}{l}\text { Caneta de ouro } \\
\text { cravejada de pequenos } \\
\text { diamantes e rubis }\end{array}$ & Santo Amaro & - & $\begin{array}{l}\text { Dom Duarte } \\
\text { Leopoldo e } \\
\text { Silva }\end{array}$ & São Paulo & São Paulo & Brasil & 1 & 3 & $\begin{array}{l}\text { Oferecida ao Exmo. Sr. } \\
\text { Arcebispo, Dom Duarte } \\
\text { Leopoldo e Silva, pelo } \\
\text { Vigário e paroquianos de } \\
\text { Santo Amaro. }\end{array}$ \\
\hline 646 & Caneta de ouro & - & - & - & - & - & - & 1 & 3 & $\begin{array}{l}\text { Com as seguintes iniciais } \\
\text { gravadas: Pe. D.L. }\end{array}$ \\
\hline 647 & $\begin{array}{l}\text { Topázio com figura } \\
\text { gravada, num aro de } \\
\text { ouro com argola }\end{array}$ & - & - & - & - & - & - & 1 & 3 & $\begin{array}{l}\text { Anotação: Retirado do } \\
\text { Museu, por ordem do Sr. } \\
\text { Cardeal Rossi para ser } \\
\text { vendido. }\end{array}$ \\
\hline
\end{tabular}




\begin{tabular}{|c|c|c|c|c|c|c|c|c|c|c|}
\hline № Cat. & Objeto & Procedência & Pertenceu a & Doado por & Cidade & Estado & País & Sala & Mostruário & Descrição / Observação \\
\hline 2 & Caldeirinha & $\begin{array}{l}\text { Convento } \\
\text { Franciscano }\end{array}$ & - & - & Itanhaém & São Paulo & Brasil & 1 & 4 & Fundado em 1655. \\
\hline 4 & Tigela de louça & - & - & - & - & - & - & 1 & 4 & - \\
\hline 5 & $\begin{array}{l}\text { Quatro peças de baixela. } \\
\text { Trazem gravado o selo } \\
\text { da ordem }\end{array}$ & $\begin{array}{l}\text { Mosteiro da } \\
\text { Visitação de } \\
\text { Annecy }\end{array}$ & - & - & Annecy & - & França & 1 & 4 & 然 \\
\hline 12 & Campa & $\begin{array}{l}\text { Irmandade do } \\
\text { SS. } \\
\text { Sacramento }\end{array}$ & - & - & Santos & São Paulo & Brasil & 1 & 4 & $\begin{array}{l}\text { Anunciava pelas ruas } \\
\text { daquela antiga cidade a } \\
\text { passagem do Santo Viatico. }\end{array}$ \\
\hline 23 & $\begin{array}{l}\text { Freio antigo com o } \\
\text { Brasão d'Armas, em } \\
\text { prata }\end{array}$ & - & $\begin{array}{l}\text { Barão de } \\
\text { Souza } \\
\text { Queiroz }\end{array}$ & - & - & - & - & 1 & 4 & - \\
\hline 548 & Campa & $\begin{array}{l}\text { Igreja Nossa } \\
\text { Senhora da } \\
\text { Conceição }\end{array}$ & - & - & Guarulhos & São Paulo & Brasil & 1 & 4 & $\begin{array}{l}\text { Pertenceu à Antiga } \\
\text { Irmandade de Nossa } \\
\text { Senhora dos Homens } \\
\text { Pretos, erecta em sua igreja, } \\
\text { na freguesia de Guarulhos. } \\
\text { A lgreja de N.S. do Rosário } \\
\text { foi benzida aos } 4 \text { de outubro } \\
\text { de } 1750 \text { (Arquivo 1-2-11 = } \\
\text { fls.10.). }\end{array}$ \\
\hline 648 & $\begin{array}{l}\text { Cálice de prata de lei, } \\
\text { dourado a fogo e } \\
\text { gravado. }\end{array}$ & $\mathrm{C}$ & - & - & - & - & - & 1 & 4 & - \\
\hline 649 & $\begin{array}{l}\text { Três patenas de prata } \\
\text { dourada }\end{array}$ & $\begin{array}{l}\text { Velha Sé de } \\
\text { São Paulo }\end{array}$ & - & - & São Paulo & São Paulo & Brasil & 1 & 4 & - \\
\hline 650 & Cálice de prata dourada & $\begin{array}{l}\text { Velha Sé de } \\
\text { São Paulo }\end{array}$ & - & - & São Paulo & São Paulo & Brasil & 1 & 4 & - \\
\hline 651 & $\begin{array}{l}\text { Caixa de prata para } \\
\text { hóstias }\end{array}$ & $\begin{array}{l}\text { Velha Sé de } \\
\text { São Paulo }\end{array}$ & - & - & São Paulo & São Paulo & Brasil & 1 & 4 & - \\
\hline 652 & $\begin{array}{l}\text { Caixa de prata dourada, } \\
\text { para o Santo Crisma }\end{array}$ & $\begin{array}{l}\text { Antiga Sé de } \\
\text { São Paulo }\end{array}$ & - & - & São Paulo & São Paulo & Brasil & 1 & 4 & - \\
\hline 653 & $\begin{array}{l}\text { Vaso para os santos } \\
\text { óleos, de prata dourada }\end{array}$ & $\begin{array}{l}\text { Velha Sé de } \\
\text { São Paulo }\end{array}$ & - & - & São Paulo & São Paulo & Brasil & 1 & 4 & $\begin{array}{l}\text { Com as Armas episcopais } \\
\text { de Dom Manuel } \\
\text { Ressureição, 3ํ Bispo de } \\
\text { São Paulo (Cfr. №38). }\end{array}$ \\
\hline
\end{tabular}




\begin{tabular}{|c|c|c|c|c|c|c|c|c|c|c|}
\hline № Cat. & Objeto & Procedência & Pertenceu a & Doado por & Cidade & Estado & País & Sala & Mostruário & Descrição / Observação \\
\hline 654 & $\begin{array}{l}\text { Imagem de Nossa } \\
\text { Senhora com o Menino } \\
\text { nos braços }\end{array}$ & - & - & - & - & - & - & 1 & 4 & $\begin{array}{l}\text { Trabalho artístico executado } \\
\text { em marfim. }\end{array}$ \\
\hline 655 & $\begin{array}{l}\text { Molde (barro) de uma } \\
\text { esfinge de Nossa } \\
\text { Senhora Do Carmo, em } \\
\text { alto relevo }\end{array}$ & - & - & - & - & - & - & 1 & 4 & - \\
\hline 656 & $\begin{array}{l}\text { Molde de barro de um } \\
\text { sinete em alto relevo de } \\
\text { Dom Pedro II Imperador } \\
\text { do Brasil }\end{array}$ & - & - & - & - & - & - & 1 & 4 & - \\
\hline 657 & $\begin{array}{l}\text { Três peças de madeira, } \\
\text { uma delas em formato de } \\
\text { cruz }\end{array}$ & - & - & - & - & - & - & 1 & 4 & $\begin{array}{l}\text { Parecendo tratar-se de } \\
\text { ornatos de altar. }\end{array}$ \\
\hline 658 & Antiga tigela de louça & - & - & - & - & - & - & 1 & 4 & - \\
\hline 659 & $\begin{array}{l}\text { Salva de cristal, com as } \\
\text { armas do Império }\end{array}$ & - & - & - & - & - & - & 1 & 4 & - \\
\hline 982 & Cálice de prata lisa & \begin{tabular}{|l} 
Matriz de \\
Nossa \\
Senhora Da \\
Escada
\end{tabular} & - & - & Guararema & São Paulo & Brasil & 1 & 4 & $(468,95$ gr.). \\
\hline 983 & Patena de prata & $\begin{array}{l}\text { Matriz de } \\
\text { Nossa } \\
\text { Senhora Da } \\
\text { Escada }\end{array}$ & - & - & Guararema & São Paulo & Brasil & 1 & 4 & (65 gr.). \\
\hline 984 & $\begin{array}{l}\text { Colherinha de prata para } \\
\text { cálice }\end{array}$ & $\begin{array}{l}\text { Matriz de } \\
\text { Nossa } \\
\text { Senhora Da } \\
\text { Escada }\end{array}$ & - & - & Guararema & São Paulo & Brasil & 1 & 4 & (3,40 gr.). \\
\hline 989 & $\begin{array}{l}\text { Enfeite de prata com } \\
\text { pedras (cristal) }\end{array}$ & \begin{tabular}{|l|} 
Matriz de \\
Nossa \\
Senhora Da \\
Escada \\
\end{tabular} & - & - & Guararema & São Paulo & Brasil & 1 & 4 & $\begin{array}{l}\text { Peso bruto: } 19,50 \mathrm{gr} \text {. Peso } \\
\text { líquido: cerca de } 10 \mathrm{gr} \text {. }\end{array}$ \\
\hline 990 & Patena de prata & $\begin{array}{l}\text { Matriz de } \\
\text { Nossa } \\
\text { Senhora Da } \\
\text { Escada } \\
\end{array}$ & - & - & Guararema & São Paulo & Brasil & 1 & 4 & (90,50 gr). \\
\hline
\end{tabular}




\begin{tabular}{|c|c|c|c|c|c|c|c|c|c|c|}
\hline № Cat. & Objeto & Procedência & Pertenceu a & Doado por & Cidade & Estado & País & Sala & Mostruário & Descrição / Observação \\
\hline 995 & $\begin{array}{l}\text { Tampa de vaso para os } \\
\text { Santos Óleos }\end{array}$ & $\begin{array}{l}\text { Matriz de } \\
\text { Nossa } \\
\text { Senhora Da } \\
\text { Escada }\end{array}$ & - & - & Guararema & São Paulo & Brasil & 1 & 4 & $\begin{array}{l}(12,10) \text { Alterado a lápis para } \\
12,80 \text { gr. }\end{array}$ \\
\hline 1008 & Muiraquitã & - & - & Bispo do Ceará & - & - & - & 1 & 4 & $\begin{array}{l}\text { Talismã dos índios } \\
\text { Tabajaras, usado entre eles } \\
\text { como presente de núpcias. } \\
\text { Oferecido Ao Museu da } \\
\text { Cúria pelo Exmo. Sr. Bispo } \\
\text { de Sobral (Ceará), por } \\
\text { intermédio de Monsenhor } \\
\text { Alberto T. Pequeno. }\end{array}$ \\
\hline 1019 & $\begin{array}{l}\text { Crucifixo de madeira, } \\
\text { com resplendor e } \\
\text { enfeites de prata }\end{array}$ & - & - & $\begin{array}{l}\text { Padre Paulo } \\
\text { Aurisol C. } \\
\text { Freire }\end{array}$ & - & $\begin{array}{l}\text { Rio Grande } \\
\text { do Sul }\end{array}$ & Brasil & 1 & 4 & $\begin{array}{l}\text { Oferta do Dr. Nelson Silveira } \\
\text { D'Avila, médico residente } \\
\text { em São José dos Campos, } \\
\text { ao Revmo. Padre Paulo } \\
\text { Aurisol C. Freire, que, por } \\
\text { sua vez, o ofereceu ao } \\
\text { Museu da Cúria, em } 25 \text { de } \\
\text { agosto de } 1938 \text {. Este } \\
\text { crucifixo procede do Rio } \\
\text { Grande do Sul e pertenceu } \\
\text { aos bisavós do referido } \\
\text { médico. }\end{array}$ \\
\hline 1104 & Livro de orações & - & - & $\begin{array}{l}\text { Cônego } \\
\text { Samuel } \\
\text { Fragoso, } \\
\text { vigário de } \\
\text { Oswaldo Cruz }\end{array}$ & $\begin{array}{l}\text { Oswaldo } \\
\text { Cruz }\end{array}$ & $\begin{array}{l}\text { Rio de } \\
\text { Janeiro }\end{array}$ & Brasil & 1 & 4 & $\begin{array}{l}\text { Contendo:"Apopstolado da } \\
\text { Oração" - "Novena a N.Sra. } \\
\text { De Lourdes" - "Horas de } \\
\text { piedade" - Exercícios } \\
\text { devotos para o mês de } \\
\text { Maria" - a "Notícia Histórica } \\
\text { sobre a origem e efeitos da } \\
\text { Medalha Milagrosa" seguida } \\
\text { de uma novena, reunidos } \\
\text { em um só volume } \\
\text { encadernado em veludo com } \\
\text { os seguintes dizeres } \\
\text { bordados a fio de ouro: } \\
\text { "A'S.M.I. o Senhor D. Pedro } \\
\text { II- 1889". Doado em } \\
\text { 08/03/1928. }\end{array}$ \\
\hline
\end{tabular}




\begin{tabular}{|c|c|c|c|c|c|c|c|c|c|c|}
\hline № Cat. & Objeto & Procedência & Pertenceu a & Doado por & Cidade & Estado & País & Sala & Mostruário & Descrição / Observação \\
\hline 1110 & $\begin{array}{l}\text { Meio bilhete da primeira } \\
\text { grande e extraordinária } \\
\text { loteria no Império }\end{array}$ & - & - & - & São Paulo & São Paulo & Brasil & 1 & 4 & $\begin{array}{l}\text { Para o monumento no } \\
\text { Ipiranga à Independência do } \\
\text { Brasil, com o prêmio maior } \\
\text { de } 1000 \text { contos de réis, } \\
\text { loteria essa decretada pela } \\
\text { lei provincial de São Paulo } \\
\text { no } 49 \text { de } 6 \text { de abril de } 1880 \text {. } \\
\end{array}$ \\
\hline 1111 & Caramujo & - & - & \begin{tabular}{l|} 
Major \\
Domingos \\
Ramos, \\
subcomandante \\
do 1ํㅡ.C.
\end{tabular} & - & - & - & 1 & 4 & $\begin{array}{l}\text { Tendo gravado em alto } \\
\text { relevo o Pai Nosso em } \\
\text { alemão. Oferecido ao Museu } \\
\text { da Cúria pelo sr. Major } \\
\text { Domingos Ramos, } \\
\text { subcomandante do } 1^{\circ} \text { B.C. } \\
\text { por intermédio do reverendo } \\
\text { capelão militar. }\end{array}$ \\
\hline 8 & Azulejos & $\begin{array}{l}\text { Antiga } \\
\text { Catedral de } \\
\text { Olinda }\end{array}$ & - & $\begin{array}{l}\text { Dom Duarte } \\
\text { Leopoldo e } \\
\text { Silva }\end{array}$ & Olinda & Pernambuco & Brasil & 1 & 5 & $\begin{array}{l}\text { Trazidos pelo exmo. sr. } \\
\text { Arcebispo de São Paulo, D. } \\
\text { Duarte Leopoldo e Silva } \\
\text { (dois exemplares). } \\
\text { Atualmente reconstruída. }\end{array}$ \\
\hline 9 & Azulejo da torre & $\begin{array}{l}\text { Catedral de } \\
\text { Humaiatá - } \\
\text { Paraguai }\end{array}$ & - & - & Humaiatá & - & Paraguai & 1 & 5 & $\begin{array}{l}\text { Foi trazido para a cidade de } \\
\text { São Sebastião do litoral } \\
\text { (Estado de SP), pelo capitão } \\
\text { da fragata João Alves } \\
\text { Nogueira. Demolida pelas } \\
\text { balas do Exército Brasileiro. }\end{array}$ \\
\hline 533 & Colher de pedreiro & - & - & - & São Paulo & São Paulo & Brasil & 1 & 5 & $\begin{array}{l}\text { Que serviu na cerimônia de } \\
\text { lançamento da pedra } \\
\text { fundamental da Igreja de } \\
\text { Nossa Senhora do Carmo, à } \\
\text { Rua Martiniano de Carvalho, } \\
\text { no dia } 23 \text { de março de } 1930 \text {. }\end{array}$ \\
\hline 534 & Colher de pedreiro & - & - & - & São Paulo & São Paulo & Brasil & 1 & 5 & $\begin{array}{l}\text { Que serviu na cerimônia de } \\
\text { lançamento da pedra } \\
\text { fundamental do Colégio de } \\
\text { Santo Agostinho, no dia } 20 \\
\text { de julho de 1930, na } \\
\text { presença de Sua Excia. O } \\
\text { Sr. Arcebispo Metropolitano, } \\
\text { Dom Duarte Leopoldo e } \\
\text { Silva. }\end{array}$ \\
\hline
\end{tabular}




\begin{tabular}{|c|c|c|c|c|c|c|c|c|c|c|}
\hline № Cat. & Objeto & Procedência & Pertenceu a & Doado por & Cidade & Estado & País & Sala & Mostruário & Descrição / Observação \\
\hline 535 & Colher de pedreiro & - & - & $\begin{array}{l}\text { Joaquim Dias } \\
\text { F. Coimbra }\end{array}$ & São Paulo & São Paulo & Brasil & 1 & 5 & $\begin{array}{l}\text { Que serviu na cerimônia de } \\
\text { lançamento da pedra } \\
\text { fundamental da Matriz do } \\
\text { Espírito Santo da Bela Vista, } \\
\text { no dia } 19 \text { de fevereiro de } \\
1905 \text {. Oferecida ao Museu } \\
\text { da Cúria pelo Sr. Joaquim } \\
\text { Dias F. Coimbra, que a } \\
\text { recebera da família do } \\
\text { finado coronel Manuel Luiz } \\
\text { Ferreira, 1ํ Provedor da } \\
\text { Irmandade do Espírito } \\
\text { Santo. }\end{array}$ \\
\hline 536 & Colher de pedreiro & - & - & - & São Carlos & São Paulo & Brasil & 1 & 5 & $\begin{array}{l}\text { Que serviu na cerimônia de } \\
\text { lançamento da primeira } \\
\text { pedra do "Colégio de São } \\
\text { Carlos", da Congregação } \\
\text { das Religiosas do } \\
\text { Santíssimo Sacramento, em } \\
\text { São Carlos do Pinhal, no dia } \\
3 \text { de outubro de } 1912 \text {. }\end{array}$ \\
\hline 539 & $\begin{array}{l}\text { Colher de pedreiro de } \\
\text { prata }\end{array}$ & - & - & - & São Paulo & São Paulo & Brasil & 1 & 5 & $\begin{array}{l}\text { Que serviu no lançamento } \\
\text { da primeira pedra do edifício } \\
\text { do Colégio de São Luiz, de } \\
\text { São Paulo, no dia } 7 \text { de } \\
\text { março de } 1932 \text {. }\end{array}$ \\
\hline 544 & $\begin{array}{l}\text { Colher de pedreiro de } \\
\text { prata }\end{array}$ & - & - & $\begin{array}{l}\text { Dona Guiomar } \\
\text { Correa Dias da } \\
\text { Silva }\end{array}$ & São Paulo & São Paulo & Brasil & 1 & 5 & $\begin{array}{l}\text { Que serviu no lançamento } \\
\text { da pedra fundamental do } \\
\text { Hospital Dom Antônio de } \\
\text { Alvarenga -- hoje "Instituto } \\
\text { Padre Chico". }\end{array}$ \\
\hline 572.1 & Salva de prata & $\begin{array}{l}\text { Irmandade do } \\
\text { Divino Espírito } \\
\text { Santo/Antiga } \\
\text { Matriz de } \\
\text { Santa Ifigênia } \\
\end{array}$ & - & - & São Paulo & São Paulo & Brasil & 1 & 5 & - \\
\hline 572.2 & Coroa de prata lavrada & $\begin{array}{l}\text { Irmandade do } \\
\text { Divino Espírito } \\
\text { Santo/Antiga } \\
\text { Matriz de } \\
\text { Santa Ifigênia } \\
\end{array}$ & - & - & São Paulo & São Paulo & Brasil & 1 & 5 & - \\
\hline
\end{tabular}




\begin{tabular}{|c|c|c|c|c|c|c|c|c|c|c|}
\hline № Cat. & Objeto & Procedência & Pertenceu a & Doado por & Cidade & Estado & País & Sala & Mostruário & Descrição / Observação \\
\hline 573 & Colher de pedreiro & - & - & - & São Paulo & São Paulo & Brasil & 1 & 5 & $\begin{array}{l}\text { Que serviu na cerimônia de } \\
\text { lançamento da pedra } \\
\text { fundamental da Matriz de } \\
\text { Santa Ifigênia, aos } 18 \text { de } \\
\text { dezembro de } 1904 \text {. }\end{array}$ \\
\hline 575 & $\begin{array}{l}\text { Concha de açúcar, feita } \\
\text { com moedas de prata de } \\
400 \text { réis, portuguesa, } \\
\text { com cabo também de } \\
\text { prata lavrada. }\end{array}$ & - & - & $\begin{array}{l}\text { Monsenhor } \\
\text { Joaquim Alves, } \\
\text { vigário de } \\
\text { Batatais }\end{array}$ & Batatais & São Paulo & Brasil & 1 & 5 & - \\
\hline 576 & $\begin{array}{l}\text { Objetos de escritório, } \\
\text { com os respectivos } \\
\text { cabos de prata } \\
\text { lavrada(peças) }\end{array}$ & - & $\begin{array}{l}\text { Duque de } \\
\text { Caxias }\end{array}$ & $\begin{array}{l}\text { Monsenhor } \\
\text { Alberto } \\
\text { Gonçalves, } \\
\text { bispo de } \\
\text { Ribeirão Preto }\end{array}$ & $\begin{array}{l}\text { Ribeirão } \\
\text { Preto }\end{array}$ & São Paulo & Brasil & 1 & 5 & $\begin{array}{l}\text { Foram arrematadas em } \\
\text { leilão pelo senador Pinheiro } \\
\text { Machado e por este } \\
\text { oferecidos ao Monsenhor } \\
\text { Alberto Gonçalves, então } \\
\text { senador pelo Estado do } \\
\text { Paraná e hoje Bispo de } \\
\text { Ribeirão Preto, que ofereceu } \\
\text { ao Museu da Cúria. }\end{array}$ \\
\hline 628 & $\begin{array}{l}\text { Concha de madrepérola } \\
\text { gravada }\end{array}$ & - & - & - & - & - & - & 1 & 5 & Para celebração do Batismo. \\
\hline 1015 & $\begin{array}{l}\text { Medalha romana } \\
\text { antiquíssima }\end{array}$ & - & $\begin{array}{l}\text { Antonio de } \\
\text { Queiroz } \\
\text { Telles }\end{array}$ & $\begin{array}{l}\text { Dona Anna } \\
\text { Emilia Fonseca } \\
\text { de Queiroz } \\
\text { Telles }\end{array}$ & - & - & - & 1 & 5 & - \\
\hline 1016 & Agulha de cozer, de osso & - & - & $\begin{array}{l}\text { Padre } \\
\text { Bartholomeu } \\
\text { Adorno }\end{array}$ & Ostia & - & Itália & 1 & 5 & $\begin{array}{l}\text { Encontrada nas escavações } \\
\text { de Ostia, Itália. Oferecida ao } \\
\text { Museu da Cúria pelo padre } \\
\text { Bartholomeu Adorno, do } \\
\text { Colégio Pio Latino } \\
\text { Americano em Roma, por } \\
\text { intermédio do padre José } \\
\text { A'ffonseca e Silva, } \\
\text { posteriormente Bispo } \\
\text { Auxiliar de São Paulo. }\end{array}$ \\
\hline 1027 & $\begin{array}{l}\text { Concha de madrepérola } \\
\text { para batismo }\end{array}$ & - & - & $\begin{array}{l}\text { Padre João } \\
\text { Kulay }\end{array}$ & - & - & - & 1 & 5 & - \\
\hline
\end{tabular}




\begin{tabular}{|c|c|c|c|c|c|c|c|c|c|c|}
\hline № Cat. & Objeto & Procedência & Pertenceu a & Doado por & Cidade & Estado & País & Sala & Mostruário & Descrição / Observação \\
\hline 1028 & $\begin{array}{l}\text { Concha de madrepérola } \\
\text { para batismo }\end{array}$ & - & - & $\begin{array}{l}\text { Cônego Manuel } \\
\text { Meireles Freire }\end{array}$ & - & - & - & 1 & 5 & - \\
\hline 1117 & Dois cinzeiros de prata & - & - & - & - & - & Chile & 1 & 5 & $\begin{array}{l}\text { Toque 800. Procedente do } \\
\text { Chile, trazidos pelo exmo. } \\
\text { Sr. Arcebispo de São Paulo } \\
\text { Dom José Gaspar } \\
\text { d"Afonseca e Silva, quando } \\
\text { voltou do Congresso } \\
\text { Eucarístico lá realizado em } \\
\text { 1941. }\end{array}$ \\
\hline 61 & Cartão de prata & - & - & $\begin{array}{l}\text { Dom Duarte } \\
\text { Leopoldo e } \\
\text { Silva }\end{array}$ & São Paulo & São Paulo & Brasil & 1 & 6 & $\begin{array}{l}\text { Oferecido ao Exmo. Sr. } \\
\text { Arcebispo D. Duarte } \\
\text { Leopoldo e Silva pelas } \\
\text { professorandas da Escola } \\
\text { Normal de S. Paulo. }\end{array}$ \\
\hline 136 & $\begin{array}{l}\text { Dois castiçais de metal } \\
\text { prateado (casquinha) }\end{array}$ & $\begin{array}{l}\text { Capela de } \\
\text { Santa Luzia }\end{array}$ & - & - & São Paulo & São Paulo & Brasil & 1 & 6 & $\begin{array}{l}\text { Capela situada na Rua } \\
\text { Tabatinguera. }\end{array}$ \\
\hline 545 & Relógio de ouro & - & $\begin{array}{l}\text { Dr. Padre } \\
\text { Vicente Pires } \\
\text { da Motta }\end{array}$ & - & - & - & Brasil & 1 & 6 & $\begin{array}{l}\text { Pertenceu ao Conselheiro } \\
\text { Dr. Padre Vicente Pires da } \\
\text { Motta, presidente que foi das } \\
\text { Províncias de São Paulo, } \\
\text { Pernambuco, Ceará, Minas } \\
\text { Gerais e Santa Catarina; } \\
\text { Vigário Capitular em } 1847 \text { e } \\
1952 ; \text { diretor da Faculdade } \\
\text { de Direito de São Paulo de } \\
1865 \text { até a sua morte, } \\
\text { ocorrida no dia } 30 \text { de } \\
\text { outubro de } 1882 .\end{array}$ \\
\hline 549 & $\begin{array}{l}\text { Pequena Imagem do } \\
\text { Senhor Bom Jesus de } \\
\text { marfim }\end{array}$ & - & - & $\begin{array}{l}\text { Dona Lucila } \\
\text { Ramos }\end{array}$ & - & - & - & 1 & 6 & Trabalho antigo. \\
\hline 551 & $\begin{array}{l}\text { Pequena faca rio- } \\
\text { grandense }\end{array}$ & - & - & - & - & - & Brasil & 1 & 6 & $\begin{array}{l}\text { Com cabo e bainha de prata } \\
\text { (Revolução de 1930). }\end{array}$ \\
\hline
\end{tabular}




\begin{tabular}{|c|c|c|c|c|c|c|c|c|c|c|}
\hline № Cat. & Objeto & Procedência & Pertenceu a & Doado por & Cidade & Estado & País & Sala & Mostruário & Descrição / Observação \\
\hline 572.3 & $\begin{array}{l}\text { Tope de bandeira, com o } \\
\text { respectivo símbolo, de } \\
\text { metal prateado }\end{array}$ & $\begin{array}{l}\text { Irmandade do } \\
\text { Divino Espírito } \\
\text { Santo/Antiga } \\
\text { Matriz de } \\
\text { Santa Ifigênia }\end{array}$ & - & - & São Paulo & São Paulo & Brasil & 1 & 6 & - \\
\hline 578 & Terço de madeira & - & $\begin{array}{l}\text { Dom Lino } \\
\text { Deodato } \\
\text { Rodrigues de } \\
\text { Carvalho, } \\
\text { oitavo bispo } \\
\text { de São Paulo } \\
(1873-1894)\end{array}$ & - & São Paulo & São Paulo & Brasil & 1 & 6 & - \\
\hline 587 & Cruz peitoral & - & $\begin{array}{l}\text { Dom Pedro } \\
\text { Maria } \\
\text { Lacerda, } \\
\text { décimo bispo } \\
\text { do Rio de } \\
\text { Janeiro }\end{array}$ & - & $\begin{array}{l}\text { Rio de } \\
\text { Janeiro }\end{array}$ & $\begin{array}{l}\text { Rio de } \\
\text { Janeiro }\end{array}$ & Brasil & 1 & 6 & - \\
\hline 604 & $\begin{array}{l}\text { Coroa de prata com } \\
\text { trabalho de filigrana }\end{array}$ & - & - & $\begin{array}{l}\text { Dona Julia de } \\
\text { Almeida Prado } \\
\text { Penteado }\end{array}$ & São Paulo & São Paulo & Brasil & 1 & 6 & $\begin{array}{l}\text { Anotação a lápis: Alteração } \\
\text { no } n^{\circ} \text { : da sala para no } 2 \text { e do } \\
\text { mostruário para nำ. }\end{array}$ \\
\hline 617 & $\begin{array}{l}\text { Crucifixo de bronze com } \\
\text { cruz de mármore }\end{array}$ & - & - & $\begin{array}{l}\text { Dom Duarte } \\
\text { Leopoldo e } \\
\text { Silva }\end{array}$ & - & - & - & 1 & 6 & - \\
\hline 776 & $\begin{array}{l}\text { Cruz de ouro e prata, } \\
\text { cravejada de pequenos } \\
\text { diamantes }\end{array}$ & $\begin{array}{l}\text { Procuradoria } \\
\text { da Mitra de } \\
\text { Aparecida }\end{array}$ & - & - & Aparecida & São Paulo & Brasil & 1 & 6 & $\begin{array}{l}\text { Anotação: Retirado por } \\
\text { ordem do Sr. Cardeal para } \\
\text { serem vendidas. }\end{array}$ \\
\hline 1094 & Medalha de prata & - & - & $\begin{array}{l}\text { Dom José } \\
\text { Gaspar de } \\
\text { A'ffonseca e } \\
\text { Silva, segundo } \\
\text { arcebispo de } \\
\text { São Paulo }\end{array}$ & - & - & - & 1 & 6 & $\begin{array}{l}\text { Anv.: São José. No reverso } \\
\text { traz a seguinte inscrição: } \\
\text { "Lembrança do meu } \\
\text { cardinalato - 11-13-14 xbro - } \\
1905 \text { - Joaquim Arcoverde." } \\
\text { Oferecida ao Museu da } \\
\text { Cúria pelo Exmo. Sr. } \\
\text { Arcebispo Metropolitano } \\
\text { Dom José Gaspar de } \\
\text { Affonseca e Silva. }\end{array}$ \\
\hline
\end{tabular}




\begin{tabular}{|c|c|c|c|c|c|c|c|c|c|c|}
\hline № Cat. & Objeto & Procedência & Pertenceu a & Doado por & Cidade & Estado & País & Sala & Mostruário & Descrição / Observação \\
\hline 1102 & $\begin{array}{l}\text { Alocuções dirigidas aos } \\
\text { seminaristas de Mântua }\end{array}$ & - & - & - & - & - & - & 1 & 6 & $\begin{array}{l}\text { Feitas pelo então bispo } \\
\text { dessa diocese Dom } \\
\text { Giuseppe Sarto depois } \\
\text { Sumo Pontífice com o nome } \\
\text { de Pio X. Oferta do padre } \\
\text { Carlos Regattieri ao Museu } \\
\text { da Cúria. }\end{array}$ \\
\hline 637 & Par de brincos & - & - & - & - & - & - & 1 & 7 & $\begin{array}{l}\text { Anotação: Retirado do } \\
\text { Museu, por ordem do Sr. } \\
\text { Cardeal Rossi para ser } \\
\text { vendido. }\end{array}$ \\
\hline 611 & $\begin{array}{l}\text { Cinco cópias incusas, de } \\
\text { gesso }\end{array}$ & $\begin{array}{l}\text { Palácio São } \\
\text { Luiz }\end{array}$ & - & - & São Paulo & São Paulo & Brasil & 1 & 8 & - \\
\hline 626 & $\begin{array}{l}\text { Prato de porcelana de } \\
\text { Sèvres, com as armas de } \\
\text { Napoleão III }\end{array}$ & $\begin{array}{l}\text { Palácio das } \\
\text { Tulherias }\end{array}$ & - & - & Paris & - & França & 1 & 8 & - \\
\hline 627 & Fragmento de mármore & $\begin{array}{l}\text { Catacumbas } \\
\text { de São Calisto }\end{array}$ & - & - & Roma & - & Itália & 1 & 8 & $\begin{array}{l}\text { com os seguintes dizeres: } \\
\text { "Px Ex Coem. Callisti". }\end{array}$ \\
\hline 991 & $\begin{array}{l}\text { Chave de Sacrário, com } \\
\text { fita }\end{array}$ & \begin{tabular}{|l|} 
Matriz de \\
Nossa \\
Senhora Da \\
Escada \\
\end{tabular} & - & - & Guararema & São Paulo & Brasil & 1 & 8 & Prata. Peso: 25,50 gr. Líq.. \\
\hline 992 & $\begin{array}{l}\text { Grande resplendor de } \\
\text { prata }\end{array}$ & \begin{tabular}{|l|} 
Matriz de \\
Nossa \\
Senhora Da \\
Escada \\
\end{tabular} & - & - & Guararema & São Paulo & Brasil & 1 & 8 & $(118,80 \mathrm{gr})$ \\
\hline 993 & $\begin{array}{l}\text { Resplendor de prata } \\
\text { médio }\end{array}$ & \begin{tabular}{|l} 
Matriz de \\
Nossa \\
Senhora Da \\
Escada
\end{tabular} & - & - & Guararema & São Paulo & Brasil & 1 & 8 & $(69,30 \mathrm{gr})$. \\
\hline 994 & $\begin{array}{l}\text { Resplendor de Prata } \\
\text { pequeno }\end{array}$ & $\begin{array}{l}\text { Matriz de } \\
\text { Nossa } \\
\text { Senhora Da } \\
\text { Escada }\end{array}$ & - & - & Guararema & São Paulo & Brasil & 1 & 8 & $(6,50 \mathrm{gr})$. \\
\hline
\end{tabular}




\begin{tabular}{|c|c|c|c|c|c|c|c|c|c|c|}
\hline № Cat. & Objeto & Procedência & Pertenceu a & Doado por & Cidade & Estado & País & Sala & Mostruário & Descrição / Observação \\
\hline 1014 & Prato de louça & - & - & - & - & - & - & 1 & 8 & $\begin{array}{l}\text { Fabricado por W \& T. Adans, } \\
\text { Tunstall, série de Vitórias } \\
\text { brasileiras. Traz no fundo a } \\
\text { Batalha de Lomas Valentina, } \\
\text { e na borda, as esfinges de } \\
\text { D. Pedro II --Conde D'Eu -- } \\
\text { Marquez de Herval -- } \\
\text { General Camara -- Visconde } \\
\text { Inhaúma -- e Duque de } \\
\text { Caxias. }\end{array}$ \\
\hline 1112 & $\begin{array}{l}\text { Primitivo distintivo, de } \\
\text { metal prateado }\end{array}$ & $\begin{array}{l}\text { Irmandade do } \\
\text { Santíssimo } \\
\text { Sacramento / } \\
\text { Sé }\end{array}$ & $\begin{array}{l}\text { Dona Nêne } \\
\text { Monteiro }\end{array}$ & - & São Paulo & São Paulo & Brasil & 1 & 8 & - \\
\hline 1120 & $\begin{array}{l}\text { Retrato do Mons. } \\
\text { Raimundo Marcolino da } \\
\text { Luz Cintra }\end{array}$ & - & - & $\begin{array}{l}\text { D. Guilhermina } \\
\text { Agnelina Luz } \\
\text { Cintra, irmã do } \\
\text { Monsenhor }\end{array}$ & - & - & - & 1 & 8 & Ver ANEXO C. \\
\hline 550 & $\begin{array}{l}\text { Relicário de prata, em } \\
\text { forma de custódia }\end{array}$ & - & - & - & - & - & - & 1 & 9 & Trabalho antigo. \\
\hline 666 & $\begin{array}{l}\text { Cruz processional tripla, } \\
\text { de prata }\end{array}$ & $\begin{array}{l}\text { Velha Igreja de } \\
\text { São Pedro dos } \\
\text { Clérigos }\end{array}$ & - & - & São Paulo & São Paulo & Brasil & 1 & 9 & - \\
\hline $672 / 759$ & Cruzes de ouro & $\begin{array}{l}\text { Procuradoria } \\
\text { da Mitra de } \\
\text { Aparecida }\end{array}$ & - & - & Aparecida & São Paulo & Brasil & 1 & 9 & $\begin{array}{l}\text { Anotação: Retirado por } \\
\text { ordem do Sr. Cardeal para } \\
\text { serem vendidas. }\end{array}$ \\
\hline $760 / 775$ & $\begin{array}{l}\text { Cruzes de ouro, com a } \\
\text { imagem do crucificado }\end{array}$ & $\begin{array}{l}\text { Procuradoria } \\
\text { da Mitra de } \\
\text { Aparecida }\end{array}$ & - & - & Aparecida & São Paulo & Brasil & 1 & 9 & $\begin{array}{l}\text { Anotação: Retirado por } \\
\text { ordem do Sr. Cardeal para } \\
\text { serem vendidas. }\end{array}$ \\
\hline $777 / 784$ & $\begin{array}{l}\text { Imagem de Nossa } \\
\text { Senhora Da Conceição, } \\
\text { berloques de ouro }\end{array}$ & $\begin{array}{l}\text { Procuradoria } \\
\text { da Mitra de } \\
\text { Aparecida }\end{array}$ & - & - & Aparecida & São Paulo & Brasil & 1 & 9 & $\begin{array}{l}\text { Anotação: Retirado por } \\
\text { ordem do Sr. Cardeal para } \\
\text { serem vendidas. }\end{array}$ \\
\hline 785 & $\begin{array}{l}\text { Medalha de ouro de } \\
\text { Nossa Senhora } \\
\text { Aparecida }\end{array}$ & $\begin{array}{l}\text { Procuradoria } \\
\text { da Mitra de } \\
\text { Aparecida }\end{array}$ & - & - & Aparecida & São Paulo & Brasil & 1 & 9 & $\begin{array}{l}\text { Anotação: Retirado por } \\
\text { ordem do Sr. Cardeal para } \\
\text { serem vendidas. }\end{array}$ \\
\hline 786 & Menino de ouro maciço & $\begin{array}{l}\text { Procuradoria } \\
\text { da Mitra de } \\
\text { Aparecida }\end{array}$ & - & - & Aparecida & São Paulo & Brasil & 1 & 9 & $\begin{array}{l}\text { Anotação: Retirado por } \\
\text { ordem do Sr. Cardeal para } \\
\text { serem vendidas. }\end{array}$ \\
\hline
\end{tabular}




\begin{tabular}{|c|c|c|c|c|c|c|c|c|c|c|}
\hline № Cat. & Objeto & Procedência & Pertenceu a & Doado por & Cidade & Estado & País & Sala & Mostruário & Descrição / Observação \\
\hline 787 & $\begin{array}{l}\text { Parte de escapulário de } \\
\text { ouro }\end{array}$ & \begin{tabular}{|l|} 
Procuradoria \\
da Mitra de \\
Aparecida \\
\end{tabular} & - & - & Aparecida & São Paulo & Brasil & 1 & 9 & $\begin{array}{l}\text { Anotação: Retirado por } \\
\text { ordem do Sr. Cardeal para } \\
\text { serem vendidas. }\end{array}$ \\
\hline 788 & $\begin{array}{l}\text { Berloque em forma de } \\
\text { coração, de ouro }\end{array}$ & $\begin{array}{l}\text { Procuradoria } \\
\text { da Mitra de } \\
\text { Aparecida }\end{array}$ & - & - & Aparecida & São Paulo & Brasil & 1 & 9 & $\begin{array}{l}\text { Anotação: Retirado por } \\
\text { ordem do Sr. Cardeal para } \\
\text { serem vendidas. }\end{array}$ \\
\hline 789 & $\begin{array}{l}\text { Chapa de ouro recortada } \\
\text { em forma de mão }\end{array}$ & $\begin{array}{l}\text { Procuradoria } \\
\text { da Mitra de } \\
\text { Aparecida }\end{array}$ & - & - & Aparecida & São Paulo & Brasil & 1 & 9 & $\begin{array}{l}\text { Anotação: Retirado por } \\
\text { ordem do Sr. Cardeal para } \\
\text { serem vendidas. }\end{array}$ \\
\hline $790 / 799$ & Relicários de ouro & $\begin{array}{l}\text { Procuradoria } \\
\text { da Mitra de } \\
\text { Aparecida }\end{array}$ & - & - & Aparecida & São Paulo & Brasil & 1 & 9 & $\begin{array}{l}\text { Anotação: Retirado por } \\
\text { ordem do Sr. Cardeal para } \\
\text { serem vendidas. }\end{array}$ \\
\hline 800 & $\begin{array}{l}\text { Objeto de toilette, de } \\
\text { ouro }\end{array}$ & $\begin{array}{l}\text { Procuradoria } \\
\text { da Mitra de } \\
\text { Aparecida }\end{array}$ & - & - & Aparecida & São Paulo & Brasil & 1 & 9 & $\begin{array}{l}\text { Anotação: Retirado por } \\
\text { ordem do Sr. Cardeal para } \\
\text { serem vendidas. }\end{array}$ \\
\hline 954 & $\begin{array}{l}\text { Cruz de ouro com a } \\
\text { imagem do Crucificado }\end{array}$ & $\begin{array}{l}\text { Procuradoria } \\
\text { da Mitra de } \\
\text { Aparecida }\end{array}$ & - & - & Aparecida & São Paulo & Brasil & 1 & 9 & $\begin{array}{l}\text { Anotação: Retiradas do } \\
\text { Museu para serem vendidas } \\
\text { por ordem do Sr. Cardeal } \\
\text { Rossi. }\end{array}$ \\
\hline 955 & $\begin{array}{l}\text { Cruz de ouro com a } \\
\text { imagem do Crucificado }\end{array}$ & $\begin{array}{l}\text { Procuradoria } \\
\text { da Mitra de } \\
\text { Aparecida }\end{array}$ & - & - & Aparecida & São Paulo & Brasil & 1 & 9 & $\begin{array}{l}\text { Anotação: Retiradas do } \\
\text { Museu para serem vendidas } \\
\text { por ordem do Sr. Cardeal } \\
\text { Rossi. }\end{array}$ \\
\hline 956 & $\begin{array}{l}\text { Cruz de ouro com a } \\
\text { imagem do Crucificado }\end{array}$ & $\begin{array}{l}\text { Procuradoria } \\
\text { da Mitra de } \\
\text { Aparecida }\end{array}$ & - & - & Aparecida & São Paulo & Brasil & 1 & 9 & $\begin{array}{l}\text { Anotação: Retiradas do } \\
\text { Museu para serem vendidas } \\
\text { por ordem do Sr. Cardeal } \\
\text { Rossi. }\end{array}$ \\
\hline 957 & $\begin{array}{l}\text { Cruz de ouro com a } \\
\text { imagem do Crucificado }\end{array}$ & $\begin{array}{l}\text { Procuradoria } \\
\text { da Mitra de } \\
\text { Aparecida }\end{array}$ & - & - & Aparecida & São Paulo & Brasil & 1 & 9 & $\begin{array}{l}\text { Anotação: Retiradas do } \\
\text { Museu para serem vendidas } \\
\text { por ordem do Sr. Cardeal } \\
\text { Rossi. }\end{array}$ \\
\hline 958 & $\begin{array}{l}\text { Cruz de ouro, sem a } \\
\text { imagem do Crucificado. }\end{array}$ & $\begin{array}{l}\text { Procuradoria } \\
\text { da Mitra de } \\
\text { Aparecida }\end{array}$ & - & - & Aparecida & São Paulo & Brasil & 1 & 9 & $\begin{array}{l}\text { Anotação: Retiradas do } \\
\text { Museu para serem vendidas } \\
\text { por ordem do Sr. Cardeal } \\
\text { Rossi. }\end{array}$ \\
\hline 959 & $\begin{array}{l}\text { Cruz de ouro, sem a } \\
\text { imagem do Crucificado. }\end{array}$ & $\begin{array}{l}\text { Procuradoria } \\
\text { da Mitra de } \\
\text { Aparecida }\end{array}$ & - & - & Aparecida & São Paulo & Brasil & 1 & 9 & $\begin{array}{l}\text { Anotação: Retiradas do } \\
\text { Museu para serem vendidas } \\
\text { por ordem do Sr. Cardeal } \\
\text { Rossi. }\end{array}$ \\
\hline
\end{tabular}




\begin{tabular}{|c|c|c|c|c|c|c|c|c|c|c|}
\hline № Cat. & Objeto & Procedência & Pertenceu a & Doado por & Cidade & Estado & País & Sala & Mostruário & Descrição / Observação \\
\hline 970 & $\begin{array}{l}\text { Cruz de ouro, sem a } \\
\text { imagem do Crucificado. }\end{array}$ & $\begin{array}{l}\text { Procuradoria } \\
\text { da Mitra de } \\
\text { Aparecida }\end{array}$ & - & - & Aparecida & São Paulo & Brasil & 1 & 9 & $\begin{array}{l}\text { Anotação: Retiradas do } \\
\text { Museu para serem vendidas } \\
\text { por ordem do Sr. Cardeal } \\
\text { Rossi. }\end{array}$ \\
\hline $958 / 970$ & $\begin{array}{l}\text { Cruz de ouro, sem a } \\
\text { imagem do Crucificado. }\end{array}$ & $\begin{array}{l}\text { Procuradoria } \\
\text { da Mitra de } \\
\text { Aparecida }\end{array}$ & - & - & Aparecida & São Paulo & Brasil & 1 & 9 & $\begin{array}{l}\text { Anotação: Retiradas do } \\
\text { Museu para serem vendidas } \\
\text { por ordem do Sr. Cardeal } \\
\text { Rossi. }\end{array}$ \\
\hline 971 & $\begin{array}{l}\text { Relicário de ouro } \\
\text { (berloques) }\end{array}$ & $\begin{array}{l}\text { Procuradoria } \\
\text { da Mitra de } \\
\text { Aparecida }\end{array}$ & - & - & Aparecida & São Paulo & Brasil & 1 & 9 & $\begin{array}{l}\text { Anotação: Retiradas do } \\
\text { Museu para serem vendidas } \\
\text { por ordem do Sr. Cardeal } \\
\text { Rossi. }\end{array}$ \\
\hline 972 & $\begin{array}{l}\text { Relicário de ouro } \\
\text { (berloques) }\end{array}$ & $\begin{array}{l}\text { Procuradoria } \\
\text { da Mitra de } \\
\text { Aparecida }\end{array}$ & - & - & Aparecida & São Paulo & Brasil & 1 & 9 & $\begin{array}{l}\text { Anotação: Retiradas do } \\
\text { Museu para serem vendidas } \\
\text { por ordem do Sr. Cardeal } \\
\text { Rossi. }\end{array}$ \\
\hline 973 & $\begin{array}{l}\text { Imagem de Nossa } \\
\text { Senhora Da Conceição } \\
\text { (berloque), de ouro } \\
\text { (casquinha). }\end{array}$ & \begin{tabular}{|l} 
Procuradoria \\
da Mitra de \\
Aparecida
\end{tabular} & - & - & Aparecida & São Paulo & Brasil & 1 & 9 & $\begin{array}{l}\text { Anotação: Retiradas do } \\
\text { Museu para serem vendidas } \\
\text { por ordem do Sr. Cardeal } \\
\text { Rossi. }\end{array}$ \\
\hline 974 & $\begin{array}{l}\text { Imagem de Nossa } \\
\text { Senhora Da Conceição, } \\
\text { berloques de ouro }\end{array}$ & $\begin{array}{l}\text { Procuradoria } \\
\text { da Mitra de } \\
\text { Aparecida }\end{array}$ & - & - & Aparecida & São Paulo & Brasil & 1 & 9 & $\begin{array}{l}\text { Anotação: Retiradas do } \\
\text { Museu para serem vendidas } \\
\text { por ordem do Sr. Cardeal } \\
\text { Rossi. }\end{array}$ \\
\hline 975 & $\begin{array}{l}\text { Imagem de Nossa } \\
\text { Senhora Da Conceição, } \\
\text { berloques de ouro }\end{array}$ & $\begin{array}{l}\text { Procuradoria } \\
\text { da Mitra de } \\
\text { Aparecida }\end{array}$ & - & - & Aparecida & São Paulo & Brasil & 1 & 9 & $\begin{array}{l}\text { Anotação: Retiradas do } \\
\text { Museu para serem vendidas } \\
\text { por ordem do Sr. Cardeal } \\
\text { Rossi. }\end{array}$ \\
\hline 976 & $\begin{array}{l}\text { Imagem de Nossa } \\
\text { Senhora Da Conceição, } \\
\text { berloques de ouro }\end{array}$ & $\begin{array}{l}\text { Procuradoria } \\
\text { da Mitra de } \\
\text { Aparecida }\end{array}$ & - & - & Aparecida & São Paulo & Brasil & 1 & 9 & $\begin{array}{l}\text { Anotação: Retiradas do } \\
\text { Museu para serem vendidas } \\
\text { por ordem do Sr. Cardeal } \\
\text { Rossi. }\end{array}$ \\
\hline 977 & $\begin{array}{l}\text { Par de brincos de ouro } \\
\text { (casquinha) }\end{array}$ & $\begin{array}{l}\text { Procuradoria } \\
\text { da Mitra de } \\
\text { Aparecida }\end{array}$ & - & - & Aparecida & São Paulo & Brasil & 1 & 9 & $\begin{array}{l}\text { Anotação: Retiradas do } \\
\text { Museu para serem vendidas } \\
\text { por ordem do Sr. Cardeal } \\
\text { Rossi. }\end{array}$ \\
\hline 978 & $\begin{array}{l}\text { Par de brincos de ouro } \\
\text { (casquinha) }\end{array}$ & \begin{tabular}{|l|} 
Procuradoria \\
da Mitra de \\
Aparecida
\end{tabular} & - & - & Aparecida & São Paulo & Brasil & 1 & 9 & $\begin{array}{l}\text { Anotação: Retiradas do } \\
\text { Museu para serem vendidas } \\
\text { por ordem do Sr. Cardeal } \\
\text { Rossi. }\end{array}$ \\
\hline
\end{tabular}




\begin{tabular}{|c|c|c|c|c|c|c|c|c|c|c|}
\hline № Cat. & Objeto & Procedência & Pertenceu a & Doado por & Cidade & Estado & País & Sala & Mostruário & Descrição / Observação \\
\hline 979 & $\begin{array}{l}\text { Par de brincos de ouro } \\
\text { (casquinha), incompleto }\end{array}$ & $\begin{array}{l}\text { Procuradoria } \\
\text { da Mitra de } \\
\text { Aparecida }\end{array}$ & - & - & Aparecida & São Paulo & Brasil & 1 & 9 & $\begin{array}{l}\text { Anotação: Retiradas do } \\
\text { Museu para serem vendidas } \\
\text { por ordem do Sr. Cardeal } \\
\text { Rossi. }\end{array}$ \\
\hline 980 & $\begin{array}{l}\text { Barrete de ouro, com seis } \\
\text { brilhantes e uma pedra } \\
\text { escura no centro }\end{array}$ & $\begin{array}{l}\text { Procuradoria } \\
\text { da Mitra de } \\
\text { Aparecida }\end{array}$ & - & - & Aparecida & São Paulo & Brasil & 1 & 9 & $\begin{array}{l}\text { Anotação: Retiradas do } \\
\text { Museu para serem vendidas } \\
\text { por ordem do Sr. Cardeal } \\
\text { Rossi. }\end{array}$ \\
\hline 997 & $\begin{array}{l}\text { Imagem da Imaculada } \\
\text { Conceição. Berloque de } \\
\text { ouro }\end{array}$ & $\begin{array}{l}\text { Palácio São } \\
\text { Luiz }\end{array}$ & - & - & São Paulo & São Paulo & Brasil & 1 & 9 & $\begin{array}{l}\text { Anotação: Retirada do } \\
\text { Museu para ser vendida } \\
\text { ordem do sr. Cardeal Rossi. }\end{array}$ \\
\hline 1004 & $\begin{array}{l}\text { Cruz de ouro de } 18 \\
\text { quilates, } 12 \mathrm{gr} .\end{array}$ & - & - & - & - & - & - & 1 & 9 & $\begin{array}{l}\text { Oferecida ao Museu da } \\
\text { Cúria pelo seu diretor, padre } \\
\text { Paulo Aurisol Cavalheiro } \\
\text { Freire. Retirado do Museu } \\
\text { para ser vendido, por ordem } \\
\text { do sr. Cardeal Rossi. }\end{array}$ \\
\hline 1021 & Naveta de prata & $\begin{array}{l}\text { Igreja de São } \\
\text { Sebastião do } \\
\text { Araxá }\end{array}$ & - & - & Araxá & $\begin{array}{l}\text { Minas } \\
\text { Gerais }\end{array}$ & Brasil & 1 & 9 & $\begin{array}{l}\text { Quem a trouxe foi o Exmo. } \\
\text { Sr. Bispo Auxiliar de São } \\
\text { Paulo, Dom José Gaspar de } \\
\text { Affonseca e Silva. }\end{array}$ \\
\hline 598 & Sinete & $\begin{array}{l}\text { Comarca } \\
\text { Eclesiástica de } \\
\text { Iguape }\end{array}$ & - & - & Iguape & São Paulo & Brasil & 1 & 10 & $\begin{array}{l}\text { Pertenceu a Comarca } \\
\text { Eclesiástica de Iguape, } \\
\text { outrora pertenceu ao } \\
\text { Bispado de São Paulo. }\end{array}$ \\
\hline 599 & Sinete & $\begin{array}{l}\text { Comarca } \\
\text { Eclesiástica de } \\
\text { Franca }\end{array}$ & - & - & Franca & São Paulo & Brasil & 1 & 10 & $\begin{array}{l}\text { Pertenceu a Comarca } \\
\text { Eclesiástica de Franca, que } \\
\text { outrora pertenceu ao } \\
\text { Bispado de São Paulo. }\end{array}$ \\
\hline 600 & Carimbo & $\begin{array}{l}\text { Monsenhor } \\
\text { Gastão Liberal } \\
\text { Pinto }\end{array}$ & - & - & São Paulo & São Paulo & Brasil & 1 & 10 & $\begin{array}{l}\text { Usado quando Vigário Geral } \\
\text { da Arquidiocese de São } \\
\text { Paulo (Rubrica), depois } \\
\text { Bispo de São Carlos. }\end{array}$ \\
\hline 601 & Carimbo & $\begin{array}{l}\text { Cônego } \\
\text { Sebastião } \\
\text { Leme da } \\
\text { Silveira Cintra }\end{array}$ & - & - & - & - & Brasil & 1 & 10 & $\begin{array}{l}\text { Usado quando ainda } \\
\text { Cônego. Hoje Cardeal } \\
\text { Arcebispo do Rio de Janeiro. }\end{array}$ \\
\hline
\end{tabular}




\begin{tabular}{|c|c|c|c|c|c|c|c|c|c|c|}
\hline № Cat. & Objeto & Procedência & Pertenceu a & Doado por & Cidade & Estado & País & Sala & Mostruário & Descrição / Observação \\
\hline 603 & Sinete (só negativo) & - & $\begin{array}{l}\text { Dom Silvério } \\
\text { Gomes } \\
\text { Pimenta, } \\
\text { bispo titular } \\
\text { de Camasco }\end{array}$ & - & Camasco & - & Itália & 1 & 10 & - \\
\hline 1005 & Jarro e bacia de prata & - & - & - & - & - & - & 1 & 10 & Ignota procedência. \\
\hline 1011 & Sinete & $\begin{array}{l}\text { Seminário } \\
\text { Provincial de } \\
\text { São Paulo } \\
\end{array}$ & - & - & São Paulo & São Paulo & Brasil & 1 & 10 & $\begin{array}{l}\text { Seminário situado na Av. } \\
\text { Tiradentes. }\end{array}$ \\
\hline 1012 & Carimbo & - & - & - & São Paulo & São Paulo & Brasil & 1 & 10 & $\begin{array}{l}\text { Encontrado em uma casa de } \\
\text { São Paulo, pelo Dr. Luiz } \\
\text { Pires. Tem estes dizeres: } \\
\text { "Davvila De Sampaulo". Ano } \\
\text { de } 1642 \text {. }\end{array}$ \\
\hline 1013 & Sinete & - & $\begin{array}{l}\text { Dom João } \\
\text { Batista } \\
\text { Corrêa Nery, } \\
\text { bispo do } \\
\text { Espírito } \\
\text { Santo (1896- } \\
1901)\end{array}$ & - & - & $\begin{array}{l}\text { Espírito } \\
\text { Santo }\end{array}$ & Brasil & 1 & 10 & $\begin{array}{l}\text { Pertenceu a Dom João } \\
\text { Baptista Correa Nery, } \\
\text { quando Bispo do Espírito } \\
\text { Santo. }\end{array}$ \\
\hline 1018 & Sinete & - & $\begin{array}{l}\text { Dom Carlos } \\
\text { Duarte Costa, } \\
\text { segundo } \\
\text { bispo de } \\
\text { Botucatu } \\
\end{array}$ & - & Botucatu & São Paulo & Brasil & 1 & 10 & - \\
\hline 1030 & Sinete & - & $\begin{array}{l}\text { Dom Duarte } \\
\text { Leopoldo e } \\
\text { Silva }\end{array}$ & $\begin{array}{l}\text { Dom Duarte } \\
\text { Leopoldo e } \\
\text { Silva }\end{array}$ & Curitiba & Paraná & Brasil & 1 & 10 & $\begin{array}{l}\text { Sinete de Dom Duarte } \\
\text { Leopoldo e Silva quando } \\
\text { segundo bispo de Curitiba } \\
(1904-1907) .\end{array}$ \\
\hline 1031 & Sinete & - & $\begin{array}{l}\text { Dom Duarte } \\
\text { Leopoldo e } \\
\text { Silva }\end{array}$ & $\begin{array}{l}\text { Dom Duarte } \\
\text { Leopoldo e } \\
\text { Silva }\end{array}$ & São Paulo & São Paulo & Brasil & 1 & 10 & - \\
\hline 1032 & $\begin{array}{l}\text { Idem, idem. Módulo } \\
\text { menor }\end{array}$ & - & $\begin{array}{l}\text { Dom Duarte } \\
\text { Leopoldo e } \\
\text { Silva }\end{array}$ & $\begin{array}{l}\text { Dom Duarte } \\
\text { Leopoldo e } \\
\text { Silva }\end{array}$ & São Paulo & São Paulo & Brasil & 1 & 10 & - \\
\hline 1033 & $\begin{array}{l}\text { Idem, idem para lacrar } \\
\text { correspondência, } \\
\text { pequeno }\end{array}$ & - & $\begin{array}{l}\text { Dom Duarte } \\
\text { Leopoldo e } \\
\text { Silva }\end{array}$ & $\begin{array}{l}\text { Dom Duarte } \\
\text { Leopoldo e } \\
\text { Silva }\end{array}$ & São Paulo & São Paulo & Brasil & 1 & 10 & - \\
\hline
\end{tabular}




\begin{tabular}{|c|c|c|c|c|c|c|c|c|c|c|}
\hline № Cat. & Objeto & Procedência & Pertenceu a & Doado por & Cidade & Estado & País & Sala & Mostruário & Descrição / Observação \\
\hline 1034 & Carimbo-assinatura & - & \begin{tabular}{|l|} 
Dom Duarte \\
Leopoldo e \\
Silva
\end{tabular} & $\begin{array}{l}\text { Dom Duarte } \\
\text { Leopoldo e } \\
\text { Silva }\end{array}$ & São Paulo & São Paulo & Brasil & 1 & 10 & - \\
\hline 1035 & $\begin{array}{l}\text { Carimbo do Tribunal } \\
\text { Eclesiástico - } 1938\end{array}$ & - & - & - & - & - & - & 1 & 10 & - \\
\hline 1036 & Clichê & - & $\begin{array}{l}\text { Vigário } \\
\text { Capitular da } \\
\text { Arquidiocese } \\
\text { de São Paulo }\end{array}$ & - & São Paulo & São Paulo & Brasil & 1 & 10 & $\begin{array}{l}\text { Do Vigário Capitular da } \\
\text { Arquidiocese de São Paulo. } \\
\text { 1938. Legenda em latim: } \\
\text { "Vicarius Capitulares } \\
\text { Archidioecesis Sancti Pauli" }\end{array}$ \\
\hline 1037 & Idem, idem sem legenda & - & - & - & - & - & - & 1 & 10 & - \\
\hline 1038 & Sinete & - & \begin{tabular}{|l|} 
Dom Duarte \\
Leopoldo e \\
Silva
\end{tabular} & \begin{tabular}{|l|} 
Dom Duarte \\
Leopoldo e \\
Silva
\end{tabular} & São Paulo & São Paulo & Brasil & 1 & 10 & $\begin{array}{l}\text { Duas peças: positivo e } \\
\text { negativo. }\end{array}$ \\
\hline 1039 & Sinete & - & $\begin{array}{l}\text { Dom Alberto } \\
\text { José } \\
\text { Gonçalves, } \\
\text { primeiro } \\
\text { bispo de } \\
\text { Ribeirão } \\
\text { Preto } \\
\end{array}$ & - & \begin{tabular}{|l|} 
Ribeirão \\
Preto
\end{tabular} & São Paulo & Brasil & 1 & 10 & - \\
\hline 1040 & Cliché & - & - & - & São Paulo & São Paulo & Brasil & 1 & 10 & $\begin{array}{l}\text { Com as Armas do 1ำ } \\
\text { Arcebispo de São Paulo, } \\
\text { Dom Duarte Leopoldo e } \\
\text { silva. }\end{array}$ \\
\hline 1068 & Sinete & - & \begin{tabular}{|l|} 
Dom Miguel \\
de Lima \\
Valverde, \\
arcebispo de \\
Olinda e \\
Recife \\
\end{tabular} & - & - & Pernambuco & Brasil & 1 & 10 & - \\
\hline 1070 & Sinete (clichê) & \begin{tabular}{|l|} 
Tribunal \\
Eclesiástico de \\
São Paulo
\end{tabular} & - & - & São Paulo & São Paulo & Brasil & 1 & 10 & - \\
\hline
\end{tabular}




\begin{tabular}{|c|c|c|c|c|c|c|c|c|c|c|}
\hline № Cat. & Objeto & Procedência & Pertenceu a & Doado por & Cidade & Estado & País & Sala & Mostruário & Descrição / Observação \\
\hline 594 & Sinete & - & $\begin{array}{l}\text { Dom } \\
\text { Benedicto } \\
\text { Paulo Alves } \\
\text { de Souza, } \\
\text { terceiro bispo } \\
\text { do Espírito } \\
\text { Santo }\end{array}$ & - & - & $\begin{array}{l}\text { Espírito } \\
\text { Santo }\end{array}$ & Brasil & 1 & 11 & Anotação a lápis: 2 sinetes. \\
\hline 595 & Sinete & - & $\begin{array}{l}\text { Dom } \\
\text { Epaminondas } \\
\text { Nunes } \\
\text { D'Avila e } \\
\text { Silva, } \\
\text { primeiro } \\
\text { bispo de } \\
\text { Taubaté }\end{array}$ & - & Taubaté & São Paulo & Brasil & 1 & 11 & - \\
\hline 1105 & Sinete & - & $\begin{array}{l}\text { Dom Ático } \\
\text { Eusébio da } \\
\text { Rocha, bispo } \\
\text { de Santa } \\
\text { Maria }\end{array}$ & - & Santa Maria & $\begin{array}{l}\text { Rio Grande } \\
\text { do Sul }\end{array}$ & Brasil & 1 & 11 & Anotação a lápis: 2 sinetes \\
\hline 1106 & Sinete & - & $\begin{array}{l}\text { Dom } \\
\text { Francisco de } \\
\text { Campos } \\
\text { Barreto, } \\
\text { segundo } \\
\text { bispo de } \\
\text { Campinas }\end{array}$ & - & Campinas & São Paulo & Brasil & 1 & 11 & - \\
\hline 1107 & Sinete & - & $\begin{array}{l}\text { Dom } \\
\text { Fernando } \\
\text { Taddei, } \\
\text { primeiro } \\
\text { bispo de } \\
\text { Jacarezinho }\end{array}$ & - & Jacarezinho & Paraná & Brasil & 1 & 11 & Anotação a lápis: 2 sinetes. \\
\hline 1108 & Sinete & - & $\begin{array}{l}\text { Dom Paulo } \\
\text { de Tarso } \\
\text { Campos, } \\
\text { segundo } \\
\text { bispo de } \\
\text { Santos }\end{array}$ & - & Santos & São Paulo & Brasil & 1 & 11 & Anotação a lápis: 2 sinetes. \\
\hline
\end{tabular}




\begin{tabular}{|c|c|c|c|c|c|c|c|c|c|c|}
\hline № Cat. & Objeto & Procedência & Pertenceu a & Doado por & Cidade & Estado & País & Sala & Mostruário & Descrição / Observação \\
\hline 1109 & Cinco (5) clichês & - & $\begin{array}{l}\text { Dom Paulo } \\
\text { de Tarso } \\
\text { Campos, } \\
\text { segundo } \\
\text { bispo de } \\
\text { Santos }\end{array}$ & - & Santos & São Paulo & Brasil & 1 & 11 & (25) \\
\hline 1109 & Um (1) Clichê & - & $\begin{array}{l}\text { Dom Paulo } \\
\text { de Tarso } \\
\text { Campos, } \\
\text { segundo } \\
\text { bispo de } \\
\text { Santos }\end{array}$ & - & Santos & São Paulo & Brasil & 1 & 11 & $\begin{array}{l}\text { Somente com o nome de D. } \\
\text { Paulo de Tarso Campos, } 2^{\circ} \\
\text { Bispo de Santos. }\end{array}$ \\
\hline 3 & $\begin{array}{l}\text { Espevitadeira de prata, } \\
\text { com sua respectiva salva }\end{array}$ & - & - & $\begin{array}{l}\text { Dr. José Carlos } \\
\text { de Macedo } \\
\text { Soares }\end{array}$ & - & - & - & 1 & 12 & - \\
\hline 577 & $\begin{array}{l}\text { Espevitadeira de prata, } \\
\text { com sua respectiva salva }\end{array}$ & - & - & $\begin{array}{l}\text { Dona Anna } \\
\text { Emilia Fonseca } \\
\text { de Queiroz } \\
\text { Telles }\end{array}$ & - & - & - & 1 & 12 & - \\
\hline $577-A$ & Espevitadeira de prata & - & - & - & - & - & - & 1 & 12 & $\begin{array}{l}\text { № do objeto riscado. } \\
\text { Anotação a lápis: Passou } \\
343 \text {. }\end{array}$ \\
\hline 636 & $\begin{array}{l}\text { Castiçal com } \\
\text { espevitadeira de prata }\end{array}$ & - & - & - & - & - & - & 1 & 12 & - \\
\hline 1020 & $\begin{array}{l}\text { Bomba de prata para } \\
\text { chimarrão }\end{array}$ & - & - & $\begin{array}{l}\text { Padre Paulo } \\
\text { Aurisol C. } \\
\text { Freire }\end{array}$ & - & $\begin{array}{l}\text { Rio Grande } \\
\text { do Sul }\end{array}$ & Brasil & 1 & 12 & $\begin{array}{l}\text { Pertenceu aos bisavós do } \\
\text { Dr. Nelson Silveira D'Avila, } \\
\text { médico residente em São } \\
\text { José dos Campos. Que a } \\
\text { ofereceu ao padre Paulo } \\
\text { Aurisol C. Freire, o qual, por } \\
\text { sua vez, a ofereceu ao } \\
\text { Museu da Cúria. }\end{array}$ \\
\hline 1 & $\begin{array}{l}\text { Quadro de Nossa } \\
\text { Senhora }\end{array}$ & $\begin{array}{l}\text { Antigo } \\
\text { Recolhimento } \\
\text { de Igarassu }\end{array}$ & - & $\begin{array}{l}\text { Dom Duarte } \\
\text { Leopoldo e } \\
\text { Silva }\end{array}$ & Iguarassu & Pernambuco & Brasil & 1 & - & - \\
\hline 7 & $\begin{array}{l}\text { Ornato de couro lavrado, } \\
\text { para banqueta de altar }\end{array}$ & $\begin{array}{l}\text { Antigo } \\
\text { Convento de } \\
\text { São Francisco }\end{array}$ & - & - & Itu & São Paulo & Brasil & 1 & - & $\begin{array}{l}\text { Objeto tipicamente paulista } \\
\text { dos séculos coloniais. } \\
\text { Atualmente demolido. A } \\
\text { fundação deste Convento } \\
\text { data do ano de } 1704 .\end{array}$ \\
\hline
\end{tabular}




\begin{tabular}{|c|c|c|c|c|c|c|c|c|c|c|}
\hline № Cat. & Objeto & Procedência & Pertenceu a & Doado por & Cidade & Estado & País & Sala & Mostruário & Descrição / Observação \\
\hline 11 & Vara de Provedor & $\begin{array}{l}\text { Irmandade do } \\
\text { SS. } \\
\text { Sacramento }\end{array}$ & - & - & Santos & São Paulo & Brasil & 1 & - & - \\
\hline 22 & Crucificado de marfim & $\begin{array}{l}\text { Velha Igreja } \\
\text { Matriz de } \\
\text { Santo Amaro }\end{array}$ & - & - & São Paulo & São Paulo & Brasil & 1 & - & Trabalho antigo. \\
\hline 53 & Disciplina de latão & $\begin{array}{l}\text { Antigo } \\
\text { Mosteiro de } \\
\text { Santa Teresa }\end{array}$ & - & - & - & - & - & 1 & - & - \\
\hline 54 & $\begin{array}{l}\text { Medalha de ouro } \\
\text { representando Nossa } \\
\text { Senhora das Dores }\end{array}$ & - & $\begin{array}{l}\text { Monsenhor } \\
\text { Francisco de } \\
\text { Paula } \\
\text { Rodrigues } \\
\text { (Padre Chico) }\end{array}$ & - & - & - & - & 1 & - & Antiquíssima. \\
\hline 55 & $\begin{array}{l}\text { Cruz - pendente da } \\
\text { Ordem de Cristo }\end{array}$ & - & - & $\begin{array}{l}\text { Dom José } \\
\text { Marcondes } \\
\text { Homem de } \\
\text { Mello, } \\
\text { Arcebispo de } \\
\text { São Carlos } \\
\text { (1906-1937) }\end{array}$ & - & - & - & 1 & - & - \\
\hline 56 & $\begin{array}{l}\text { Cruz - pendente da } \\
\text { Ordem de Cristo }\end{array}$ & - & - & $\begin{array}{l}\text { Dom José } \\
\text { Marcondes } \\
\text { Homem de } \\
\text { Mello, } \\
\text { Arcebispo de } \\
\text { São Carlos } \\
(1906-1937) \\
\end{array}$ & - & - & - & 1 & - & - \\
\hline 60 & $\begin{array}{l}\text { Insígnia da Legião de S. } \\
\text { Pedro }\end{array}$ & $\begin{array}{l}\text { Paróquia de } \\
\text { Santa Cecilia }\end{array}$ & - & - & São Paulo & São Paulo & Brasil & 1 & - & - \\
\hline 115 & $\begin{array}{l}\text { Rica lâmpada de prata } \\
\text { lavrada }\end{array}$ & $\begin{array}{l}\text { Velha Igreja de } \\
\text { São Pedro }\end{array}$ & - & - & São Paulo & São Paulo & Brasil & $\begin{array}{l}1- \\
\text { pendente }\end{array}$ & - & - \\
\hline 117 & $\begin{array}{l}\text { Três sacras antigas, de } \\
\text { prata lavrada }\end{array}$ & $\begin{array}{l}\text { Antiga Sé de } \\
\text { São Paulo }\end{array}$ & - & - & São Paulo & São Paulo & Brasil & 1-parede & - & $\begin{array}{l}\text { Trazem gravadas as Armas } \\
\text { de Portugal. }\end{array}$ \\
\hline 122 & $\begin{array}{l}\text { Grande lâmpada de prata } \\
\text { lavrada }\end{array}$ & $\begin{array}{l}\text { Antiga Sé de } \\
\text { São Paulo }\end{array}$ & - & - & São Paulo & São Paulo & Brasil & pendente & - & $\begin{array}{l}\text { Trazendo gravadas quatro } \\
\text { coroas imperiais brasileiras. } \\
\text { Trabalho antigo e de arte. }\end{array}$ \\
\hline
\end{tabular}




\begin{tabular}{|c|c|c|c|c|c|c|c|c|c|c|}
\hline № Cat. & Objeto & Procedência & Pertenceu a & Doado por & Cidade & Estado & País & Sala & Mostruário & Descrição / Observação \\
\hline 146 & $\begin{array}{l}\text { Quadro a óleo de D. } \\
\text { Pedro II }\end{array}$ & $\begin{array}{l}\text { Palácio São } \\
\text { Luiz }\end{array}$ & - & $\begin{array}{l}\text { Dom Duarte } \\
\text { Leopoldo e } \\
\text { Silva }\end{array}$ & São Paulo & São Paulo & Brasil & 1-parede & - & $\begin{array}{l}\text { Retrato do Imperador do } \\
\text { Brasil, Dom Pedro II. }\end{array}$ \\
\hline 155 & $\begin{array}{l}\text { Batuta com revestimento } \\
\text { de prata lisa }\end{array}$ & $\begin{array}{l}\text { Antigo coro da } \\
\text { antiga Sé de } \\
\text { São Paulo }\end{array}$ & - & - & São Paulo & São Paulo & Brasil & 1-parede & - & - \\
\hline 171 & Espadim & Sé de Mariana & - & $\begin{array}{l}\text { Cônego } \\
\text { Francisco de } \\
\text { Oliveira Braga, } \\
\text { Cura da Sé de } \\
\text { Mariana }\end{array}$ & Mariana & $\begin{array}{l}\text { Minas } \\
\text { Gerais }\end{array}$ & Brasil & 1-parede & - & $\begin{array}{l}\text { Arma das milícias fidalgas } \\
\text { nos tempos coloniais - } 1750 \text {. }\end{array}$ \\
\hline 178 & Báculo & - & $\begin{array}{l}\text { Dom Antonio } \\
\text { Candido } \\
\text { Alvarenga, } \\
\text { décimo bispo } \\
\text { de São Paulo } \\
(1898-1903)\end{array}$ & - & São Paulo & São Paulo & Brasil & 1-parede & - & $\begin{array}{l}\text { Oferecido ao Exmo. Sr. Dom } \\
\text { Antonio Candido Alvarenga, } \\
\text { décimo Bispo de São Paulo } \\
\text { (1899-1903) pelos seus } \\
\text { colegas de ordenação: Dom } \\
\text { Joaquim, Bispo do Ceara, } \\
\text { Monsenhor João Alves, } \\
\text { Monsenhor Candido Rosa, } \\
\text { Conego Antonio Pinheiro, } \\
\text { Conego Antonio Pereira } \\
\text { Bicudo, Conego Antonio G. } \\
\text { Benjamim, Padre Adelino } \\
\text { Montenegro, Vigário } \\
\text { Cassiano de Moraes, Vigário } \\
\text { Candido Correa e Padre } \\
\text { Antonio J. Castro. }\end{array}$ \\
\hline 179 & Báculo & $\begin{array}{l}\text { Paróquia de } \\
\text { Santa Cecília }\end{array}$ & $\begin{array}{l}\text { Dom Duarte } \\
\text { Leopoldo e } \\
\text { Silva }\end{array}$ & $\begin{array}{l}\text { Dom Duarte } \\
\text { Leopoldo e } \\
\text { Silva }\end{array}$ & São Paulo & São Paulo & Brasil & 1-parede & - & $\begin{array}{l}\text { Oferecido ao Exmo. Sr. Dom } \\
\text { Duarte Leopoldo e Silva por } \\
\text { ocasião da sua visita } \\
\text { pastoral em julho de } 1911 .\end{array}$ \\
\hline 180 & Báculo & - & $\begin{array}{l}\text { Dom Duarte } \\
\text { Leopoldo e } \\
\text { Silva }\end{array}$ & $\begin{array}{l}\text { Dom Duarte } \\
\text { Leopoldo e } \\
\text { Silva }\end{array}$ & São Paulo & São Paulo & Brasil & 1-parede & - & $\begin{array}{l}\text { Oferecido ao Exmo. Sr. Dom } \\
\text { Duarte Leopoldo e Silva } \\
\text { pelos Padres Amaral, } \\
\text { Morato, Resende, Siqueira e } \\
\text { Maximiano, em São Paulo, } \\
\text { aos } 4 \text { de abril de } 1904 .\end{array}$ \\
\hline
\end{tabular}




\begin{tabular}{|c|c|c|c|c|c|c|c|c|c|c|}
\hline № Cat. & Objeto & Procedência & Pertenceu a & Doado por & Cidade & Estado & País & Sala & Mostruário & Descrição / Observação \\
\hline 181 & Báculo & - & $\begin{array}{l}\text { Dom Joaquim } \\
\text { José Vieira, } \\
\text { bispo do } \\
\text { Ceará }\end{array}$ & - & - & Ceará & Brasil & 1-parede & - & $\begin{array}{l}\text { Oferecido ao Exmo. Sr. Dom } \\
\text { Joaquim José Vieira, Bispo } \\
\text { do Ceará, pelo povo de } \\
\text { Itapetininga, no dia } 9 \text { de } \\
\text { outubro de } 1883 .\end{array}$ \\
\hline 182 & Báculo & - & - & - & - & - & - & 1-parede & - & Sem oferecimento. \\
\hline 183 & Báculo incompleto & - & $\begin{array}{l}\text { Dom Antonio } \\
\text { Joaquim de } \\
\text { Melo, sexto } \\
\text { bispo de São } \\
\text { Paulo (1852- } \\
\text { 1861) }\end{array}$ & - & - & - & - & 1-parede & - & ( \\
\hline 243 & Pequeno báculo de prata & $\begin{array}{l}\text { Antiga Igreja } \\
\text { de São Pedro } \\
\text { dos Clérigos }\end{array}$ & - & - & São Paulo & São Paulo & Brasil & 1-parede & - & $\begin{array}{l}\text { Pertenceu a uma imagem } \\
\text { desta igreja. }\end{array}$ \\
\hline 259 & Relógio de mesa & $\begin{array}{l}\text { Irmãs da } \\
\text { Esperança }\end{array}$ & - & - & - & - & - & 1-mesa & - & $\begin{array}{l}\text { Artístico bronze formado por } \\
\text { uma pequena estátua do } \\
\text { paganismo recostada no } \\
\text { relógio, e tendo esculpidas } \\
\text { em relevo, na base, várias } \\
\text { insígnias da antiga Roma. } \\
\text { Oferecido ao Museu da } \\
\text { Cúria pela superiora desta } \\
\text { ordem. }\end{array}$ \\
\hline 274 & Quadro a óleo & - & - & - & - & - & Brasil & 1-parede & - & $\begin{array}{l}\text { Retrato de Bernardo José do } \\
\text { Lorena, capitão-general de } \\
\text { São Paulo de } 05 \text { de junho de } \\
1788 \text { a } 27 \text { de junho de } 1797 .\end{array}$ \\
\hline 312 & $\begin{array}{l}\text { Retrato de Sua } \\
\text { Santidade o Papa Pio IX }\end{array}$ & - & - & - & - & - & - & 1-parede & - & $\begin{array}{l}\text { Trabalho de esmalte sobre } \\
\text { aço circundado de metal } \\
\text { formando um porta-retrato. }\end{array}$ \\
\hline 336 & Punhal medieval & - & - & $\begin{array}{l}\text { Dr. José Carlos } \\
\text { de Macedo } \\
\text { Soares }\end{array}$ & - & - & - & 1-parede & - & - \\
\hline 387 & $\begin{array}{l}\text { Caixa de jacarandá, } \\
\text { forrada internamente de } \\
\text { veludo }\end{array}$ & $\begin{array}{l}\text { Igreja da } \\
\text { Ordem } \\
\text { Terceira do } \\
\text { Carmo }\end{array}$ & - & $\begin{array}{l}\text { Dom Duarte } \\
\text { Leopoldo e } \\
\text { Silva }\end{array}$ & São Paulo & São Paulo & Brasil & 1-mesa & - & Ver ANEXO C. \\
\hline
\end{tabular}




\begin{tabular}{|c|c|c|c|c|c|c|c|c|c|c|}
\hline № Cat. & Objeto & Procedência & Pertenceu a & Doado por & Cidade & Estado & País & Sala & Mostruário & Descrição / Observação \\
\hline 391 & Cilício & $\begin{array}{l}\text { Diocese de } \\
\text { Aracaju }\end{array}$ & - & $\begin{array}{l}\text { Dom José } \\
\text { Thomaz Gomes } \\
\text { da Silva, Bispo } \\
\text { de Aracaju }\end{array}$ & Aracaju & Sergipe & Brasil & 1-parede & - & $\begin{array}{l}\text { Pertenceu a um sacerdote } \\
\text { da Diocese de Aracaju. } \\
\text { Objeto mui antigo, oferecido } \\
\text { ao Museu da Cúria pelo } \\
\text { Exmo. Sr. Dom José } \\
\text { Thomaz Gomes da Silva, } \\
\text { Bispo daquela Diocese. } \\
\end{array}$ \\
\hline 403 & Porta de Sacrário & \begin{tabular}{|l} 
Antigo \\
Convento dos \\
Padre \\
Beneditinos da \\
Vila de \\
Parnaíba \\
\end{tabular} & - & $\begin{array}{l}\text { Joaquim Dias } \\
\text { de Coimbra }\end{array}$ & $\begin{array}{l}\text { Santana de } \\
\text { Parnaíba }\end{array}$ & São Paulo & Brasil & 1-parede & - & $\begin{array}{l}\text { O mosteiro teve início em } \\
1643 .\end{array}$ \\
\hline 423 & Salva de prata & - & - & $\begin{array}{l}\text { Frei Vicente } \\
\text { Maria Moreira, } \\
\text { da Ordem dos } \\
\text { Pregadores } \\
\text { (Dominicanos) }\end{array}$ & - & Goiás & Brasil & 1-parede & - & $\begin{array}{l}\text { Correspondente ao ano de } \\
1779, \text { que foram dadas em } \\
\text { benefício da Matriz de Santa } \\
\text { Luzia (Estado de Goiás), no } \\
\text { planalto central. Foram feitos } \\
\text { lá mesmo, como a lâmpada } \\
\text { do Santíssimo e outros } \\
\text { objetos daquela data. Eram } \\
\text { da família dos Bandeirantes } \\
\text { Sebastião Pompeu de Pina - } \\
\text { S.P.P. - e passaram à dos } \\
\text { Álvares -- Padre } \\
\text { Bartholomeu Alvares -- } \\
\text { P.B.A. -- Dá-Ihes o alto valor } \\
\text { que tem o fato de terem sido } \\
\text { feitos pelos bandeirantes, no } \\
\text { centro mesmo do Brasil, em } \\
\text { 1780, mais ou menos. } \\
\text { Oferecidos ao Museu da } \\
\text { Cúria pelo Revmo. Frei } \\
\text { Vicente Maria Moreira, da } \\
\text { Ordem dos Pregadores } \\
\text { (Dominicanos). }\end{array}$ \\
\hline
\end{tabular}




\begin{tabular}{|c|c|c|c|c|c|c|c|c|c|c|}
\hline № Cat. & Objeto & Procedência & Pertenceu a & Doado por & Cidade & Estado & País & Sala & Mostruário & Descrição / Observação \\
\hline 424 & Copo de prata & - & - & $\begin{array}{l}\text { Frei Vicente } \\
\text { Maria Moreira, } \\
\text { da Ordem dos } \\
\text { Pregadores } \\
\text { (Dominicanos) }\end{array}$ & - & Goiás & Brasil & 1-parede & - & $\begin{array}{l}\text { Correspondente ao ano de } \\
1779, \text { que foram dadas em } \\
\text { benefício da Matriz de Santa } \\
\text { Luzia (Estado de Goiás), no } \\
\text { planalto central. Foram feitos } \\
\text { lá mesmo, como a lâmpada } \\
\text { do Santíssimo e outros } \\
\text { objetos daquela data. Eram } \\
\text { da família dos Bandeirantes } \\
\text { Sebastião Pompeu de Pina - } \\
\text { S.P.P. - e passaram à dos } \\
\text { Álvares -- Padre } \\
\text { Bartholomeu Alvares -- } \\
\text { P.B.A. -- Dá-Ihes o alto valor } \\
\text { que tem o fato de terem sido } \\
\text { feitos pelos bandeirantes, no } \\
\text { centro mesmo do Brasil, em } \\
\text { 1780, mais ou menos. } \\
\text { Oferecidos ao Museu da } \\
\text { Cúria pelo Revmo. Frei } \\
\text { Vicente Maria Moreira, da } \\
\text { Ordem dos Pregadores } \\
\text { (Dominicanos). }\end{array}$ \\
\hline 531 & Medalhão de bronze & - & $\begin{array}{l}\text { Dom Joaquim } \\
\text { Arcoverde de } \\
\text { Albuquerque } \\
\text { Cavalcanti, } \\
\text { Cardeal do } \\
\text { Rio de } \\
\text { Janeiro } \\
(1850-1930) \\
\end{array}$ & $\begin{array}{l}\text { Frei Nicolau } \\
\text { Lerns, } \\
\text { Guardião do } \\
\text { Convento de } \\
\text { São Francisco }\end{array}$ & $\begin{array}{l}\text { Rio de } \\
\text { Janeiro }\end{array}$ & $\begin{array}{l}\text { Rio de } \\
\text { Janeiro }\end{array}$ & Brasil & 1-parede & - & - \\
\hline 532 & Missal & $\begin{array}{l}\text { Igreja de } \\
\text { Santo Amaro }\end{array}$ & - & - & São Paulo & São Paulo & Brasil & 1-mesa & - & $\begin{array}{l}\text { Serviu para a celebração } \\
\text { das primeiras Missas em } \\
1686 \text {. - Santo Amaro teve } \\
\text { predicamento de paróquia } \\
\text { por provisão de } 14 \text { de } \\
\text { janeiro de } 1686 .\end{array}$ \\
\hline 579 & $\begin{array}{l}\text { Duas séries de selos do } \\
\text { Vaticano }\end{array}$ & - & - & - & - & - & Vaticano & $\begin{array}{l}\text { 1-mesa } \\
n=2\end{array}$ & - & - \\
\hline
\end{tabular}




\begin{tabular}{|c|c|c|c|c|c|c|c|c|c|c|}
\hline № Cat. & Objeto & Procedência & Pertenceu a & Doado por & Cidade & Estado & País & Sala & Mostruário & Descrição / Observação \\
\hline 584 & $\begin{array}{l}\text { Frasco com óleo extraído } \\
\text { das oliveiras do Jardim } \\
\text { de Gethsemani }\end{array}$ & $\begin{array}{l}\text { Jardim de } \\
\text { Gethsemani }\end{array}$ & - & - & Jerusalém & - & Israel & $\begin{array}{l}\text { 1-mesa } \\
\text { no2 }\end{array}$ & - & - \\
\hline 589 & $\begin{array}{l}\text { Modelo de vasos e outras } \\
\text { peças usadas na Terra } \\
\text { Santa }\end{array}$ & - & - & $\begin{array}{l}\text { José Carlos de } \\
\text { Macedo Soares }\end{array}$ & - & - & - & $\begin{array}{l}1- \\
\text { banqueta }\end{array}$ & - & - \\
\hline 590 & $\begin{array}{l}\text { Livro manuscrito, em } \\
\text { pergaminho }\end{array}$ & - & - & - & - & - & - & $\begin{array}{l}1- \\
\text { banqueta }\end{array}$ & - & $\begin{array}{l}\text { Trabalho antigo de real } \\
\text { interesse. }\end{array}$ \\
\hline 591 & $\begin{array}{l}\text { Livro manuscrito, em } \\
\text { pergaminho antigo. }\end{array}$ & - & - & - & - & - & - & $\begin{array}{l}1- \\
\text { banqueta }\end{array}$ & - & $\begin{array}{l}\text { Anotação a lápis: Roubado } \\
1958 .\end{array}$ \\
\hline 592 & Livro antigo & - & - & - & Lisboa & - & Portugal & $\begin{array}{l}\text { 1- } \\
\text { banqueta }\end{array}$ & - & $\begin{array}{l}\text { Impresso em Lisboa, no ano } \\
\text { de } 1645 .\end{array}$ \\
\hline 593 & Calendário eclesiástico & - & - & - & - & - & Portugal & $\begin{array}{l}1- \\
\text { banqueta }\end{array}$ & - & $\begin{array}{l}\text { Usado em Portugal no ano } \\
\text { de } 1806 \text {. Anotação a lápis: } \\
\text { Não foi encontrado. }\end{array}$ \\
\hline 597 & Terço de contas torneada & - & $\begin{array}{l}\text { Frei Antonio } \\
\text { de Sant'Ana } \\
\text { Galvão }\end{array}$ & $\begin{array}{l}\text { Dom José } \\
\text { Gaspar de } \\
\text { A'ffonseca e } \\
\text { Silva, segundo } \\
\text { arcebispo de } \\
\text { São Paulo }\end{array}$ & - & São Paulo & Brasil & $\begin{array}{l}1- \\
\text { banqueta }\end{array}$ & - & $\begin{array}{l}\text { Doado pela família Freitas } \\
\text { Ferraz Dias, de Itu, a Dom } \\
\text { José Gaspar de A'ffonseca e } \\
\text { Silva, Bispo Auxiliar de São } \\
\text { Paulo, o qual o ofereceu ao } \\
\text { Museu da Cúria. }\end{array}$ \\
\hline 615 & $\begin{array}{l}\text { Par de caramujos } \\
\text { grandes }\end{array}$ & - & - & $\begin{array}{l}\text { Queiroz Telles, } \\
\text { bacharel }\end{array}$ & - & - & - & $\begin{array}{l}\text { 1-mesa } \\
\text { no2 }\end{array}$ & - & - \\
\hline 616 & Canon manuscrito & - & - & $\begin{array}{l}\text { Dom Duarte } \\
\text { Leopoldo e } \\
\text { Silva }\end{array}$ & - & - & Brasil & $\begin{array}{l}\text { 1-mesa } \\
\text { n-2 }\end{array}$ & - & $\begin{array}{l}\text { Encadernação de madeira e } \\
\text { respectivo estojo, também } \\
\text { de madeira. Obra artística } \\
\text { executada pelas Cônegas } \\
\text { de Santo Agostinho, que } \\
\text { ofereceram ao Exmo. Sr. } \\
\text { Arcebispo, nas festas } \\
\text { jubilares de Sua Excia. }\end{array}$ \\
\hline 618 & Quadro a óleo & - & - & - & - & - & - & 1-parede & - & $\begin{array}{l}\text { Pintura executada sobre } \\
\text { cobre, artística, de autor e } \\
\text { procedência desconhecidos. } \\
\text { Representa a Virgem Maria } \\
\text { com o Menino Jesus } \\
\text { adormecido. Notáveis as } \\
\text { sombras da pintura. }\end{array}$ \\
\hline
\end{tabular}




\begin{tabular}{|c|c|c|c|c|c|c|c|c|c|c|}
\hline № Cat. & Objeto & Procedência & Pertenceu a & Doado por & Cidade & Estado & País & Sala & Mostruário & Descrição / Observação \\
\hline 619 & Coroa com oito dezenas & - & - & - & - & - & - & 1 & - & $\begin{array}{l}\text { Contas de ouro, ocas. Cruz } \\
\text { de ouro maciço, cravejada } \\
\text { de diamantes. }\end{array}$ \\
\hline 620 & $\begin{array}{l}\text { Espada de prata de uma } \\
\text { imagem de São Paulo }\end{array}$ & - & - & - & - & - & - & 1-canto & - & - \\
\hline 621 & $\begin{array}{l}\text { Quadro a óleo de Sua } \\
\text { Santidade o Papa Bento } \\
\text { XIV }\end{array}$ & - & - & - & - & - & - & 1-parede & - & $\begin{array}{l}\text { Criador do Bispado de São } \\
\text { Paulo. }\end{array}$ \\
\hline 622 & $\begin{array}{l}\text { Quadro a óleo de Dom } \\
\text { João V }\end{array}$ & - & - & - & - & - & - & 1-parede & - & $\begin{array}{l}\text { Criador do Bispado de São } \\
\text { Paulo. }\end{array}$ \\
\hline 623 & $\begin{array}{l}\text { Retrato de Dom Antonio } \\
\text { de Macedo Costa }\end{array}$ & - & - & - & - & - & - & 1-parede & - & $\begin{array}{l}\text { Bispo do Pará (1860-1890) e } \\
\text { Arcebispo da Bahia (1890- } \\
\text { 1891). }\end{array}$ \\
\hline 624 & $\begin{array}{l}\text { Retrato de Dom Frei Vital } \\
\text { Maria Gonçalves de } \\
\text { Oliveira }\end{array}$ & - & - & - & - & - & - & 1-parede & - & $21^{\circ}$ Bispo de Olinda. \\
\hline 625 & $\begin{array}{l}\text { Alto relevo de bronze: } \\
\text { Sua Santidade o Papa } \\
\text { Bento XV. }\end{array}$ & - & - & $\begin{array}{l}\text { Coronel } \\
\text { Jeremias } \\
\text { Lunardelli }\end{array}$ & - & - & - & 1-parede & - & $\begin{array}{l}\text { Trabalho do gravador } \\
\text { Misruzzi. }\end{array}$ \\
\hline 660 & $\begin{array}{l}\text { Assinatura autografa de } \\
\text { São Carlos Borromeu }\end{array}$ & - & - & - & - & - & - & 1-parede & - & - \\
\hline 661 & Três sacras de prata & $\begin{array}{l}\text { Antiga } \\
\text { Irmandade da } \\
\text { Conceição/Sé }\end{array}$ & - & - & São Paulo & São Paulo & Brasil & 1-parede & - & - \\
\hline 662 & Três sacras de prata & - & - & - & - & - & - & 1-parede & - & - \\
\hline 663 & $\begin{array}{l}\text { Um par de antigas } \\
\text { arandelas de latão }\end{array}$ & - & - & - & - & - & - & $\begin{array}{l}\text { 1-parede } \\
\text { sobre a } \\
\text { porta }\end{array}$ & - & - \\
\hline 664 & $\begin{array}{l}\text { Escudo com as Armas } \\
\text { Imperiais brasileiras, } \\
\text { madeira }\end{array}$ & - & - & - & - & - & - & $\begin{array}{l}\text { 1-sobre } \\
\text { a porta }\end{array}$ & - & - \\
\hline 665 & $\begin{array}{l}\text { Grande escudo, com as } \\
\text { Armas Imperiais do Brasil }\end{array}$ & $\begin{array}{l}\text { Velha Sé de } \\
\text { São Paulo }\end{array}$ & - & - & São Paulo & São Paulo & Brasil & $\begin{array}{l}1- \\
\text { banqueta }\end{array}$ & - & $\begin{array}{l}\text { Onde estava sob o arco } \\
\text { cruzeiro. }\end{array}$ \\
\hline
\end{tabular}




\begin{tabular}{|c|c|c|c|c|c|c|c|c|c|c|}
\hline № Cat. & Objeto & Procedência & Pertenceu a & Doado por & Cidade & Estado & País & Sala & Mostruário & Descrição / Observação \\
\hline 667 & $\begin{array}{l}\text { Cruz de ferro, com } \\
\text { escudo de Santa Teresa } \\
\text { de Jesus. }\end{array}$ & $\begin{array}{l}\text { Antiga Igreja } \\
\text { de Santa } \\
\text { Teresa }\end{array}$ & - & - & São Paulo & São Paulo & Brasil & 1-canto & - & $\begin{array}{l}\text { Recortado em folha de cobre } \\
\text { pintado e servindo de } \\
\text { catavento. Esta cruz figurava } \\
\text { na torre da Antiga Igreja de } \\
\text { Santa Teresa, situada na rua } \\
\text { de Santa Teresa, esquina da } \\
\text { rua do Carmo, demolida em } \\
1910 .\end{array}$ \\
\hline 668 & Estante de missal & $\begin{array}{l}\text { Matriz de } \\
\text { Guarulhos }\end{array}$ & - & - & Guarulhos & São Paulo & Brasil & $\begin{array}{l}\text { 1-mesa } \\
\text { no-1 }\end{array}$ & - & $\begin{array}{l}\text { Obra muito antiga, de } \\
\text { madeira entalhada. }\end{array}$ \\
\hline 669 & Estante de missal & \begin{tabular}{|l|} 
Matriz de \\
Parnaíba
\end{tabular} & - & - & $\begin{array}{l}\text { Santana de } \\
\text { Parnaíba }\end{array}$ & São Paulo & Brasil & $\begin{array}{l}\text { 1-mesa } \\
\text { n-2 }\end{array}$ & - & $\begin{array}{l}\text { Obra muito antiga, de } \\
\text { madeira entalhada. }\end{array}$ \\
\hline 670 & $\begin{array}{l}\text { Imagem de Nossa } \\
\text { Senhora com o Menino }\end{array}$ & $\begin{array}{l}\text { Capela de } \\
\text { Santa Luzia }\end{array}$ & - & - & São Paulo & São Paulo & Brasil & \begin{tabular}{|l|}
$1-$ \\
apêndice
\end{tabular} & - & $\begin{array}{l}\text { Situada na rua } \\
\text { Tabatinguera. }\end{array}$ \\
\hline 671 & $\begin{array}{l}\text { Breve de Sua Santidade } \\
\text { o Papa Bento XIV }\end{array}$ & - & - & - & São Paulo & São Paulo & Brasil & $\begin{array}{l}1- \\
\text { quadro- } \\
\text { parede }\end{array}$ & - & $\begin{array}{l}\text { Dado a Dom Bernardo } \\
\text { Rodrigues Nogueira, 1ํo } \\
\text { Bispo de São Paulo, } \\
\text { concedendo indulgência } \\
\text { plenária aos que visitassem } \\
\text { a Igreja Catedral, no dia da } \\
\text { Sagração. } \\
\end{array}$ \\
\hline 812 & $\begin{array}{l}\text { Escudo com as Armas de } \\
\text { Dom Duarte Leopoldo e } \\
\text { Silva, Arcebispo de São } \\
\text { Paulo }\end{array}$ & - & - & - & - & - & - & $\begin{array}{l}\text { 1-sobre } \\
\text { a porta }\end{array}$ & - & - \\
\hline 632 & $\begin{array}{l}\text { Banqueta com cinco } \\
\text { castiçais maiores, dois } \\
\text { médios e dois menores } \\
\text { de prata lavrada }\end{array}$ & $\begin{array}{l}\text { Velha Sé de } \\
\text { São Paulo }\end{array}$ & - & - & São Paulo & São Paulo & Brasil & 1 & $1-2$ & $\begin{array}{l}\text { Anotação a lápis: } 4 \text { maiores } \\
\text { e } 2 \text { médios foram para a } \\
\text { catedral e o crucifixo } \\
\text { também. }\end{array}$ \\
\hline 632 & $\begin{array}{l}\text { Crucifixo em prata } \\
\text { lavrada }\end{array}$ & \begin{tabular}{|l|} 
Velha Sé de \\
São Paulo
\end{tabular} & - & - & São Paulo & São Paulo & Brasil & 1 & $1-2$ & - \\
\hline 633 & $\begin{array}{l}\text { Banqueta com seis } \\
\text { castiçais de prata lavrada }\end{array}$ & $\begin{array}{l}\text { Sé de São } \\
\text { Paulo }\end{array}$ & - & - & São Paulo & São Paulo & Brasil & 1 & $1-2-3$ & $\begin{array}{l}\text { Oferecida a Sé de São } \\
\text { Paulo pelo padre João } \\
\text { Duarte Franco, em 1795, } \\
\text { segundo os dizeres que traz } \\
\text { gravados. }\end{array}$ \\
\hline
\end{tabular}




\begin{tabular}{|c|c|c|c|c|c|c|c|c|c|c|}
\hline № Cat. & Objeto & Procedência & Pertenceu a & Doado por & Cidade & Estado & País & Sala & Mostruário & Descrição / Observação \\
\hline 574 & Seis castiçais de prata & $\begin{array}{l}\text { Irmandade N. } \\
\text { S. das Dores / } \\
\text { Sé }\end{array}$ & - & - & São Paulo & São Paulo & Brasil & 1 & $2-3$ & $\begin{array}{l}\text { Pertenceram à Irmandade } \\
\text { de N.Sra. Das Dores, da Sé. } \\
\text { Pesa cada um } 8750 \text { gr.. } \\
\text { Anotação a lápis: saiu para a } \\
\text { Catedral. }\end{array}$ \\
\hline 986 & Coroa de prata grande & \begin{tabular}{|l} 
Matriz de \\
Nossa \\
Senhora Da \\
Escada
\end{tabular} & - & - & Guararema & São Paulo & Brasil & 1 & 5-cima & Peso: 587,40 gr. \\
\hline 987 & $\begin{array}{l}\text { Coroa de prata pequena, } \\
\text { faltando a cruz do topo }\end{array}$ & $\begin{array}{l}\text { Matriz de } \\
\text { Nossa } \\
\text { Senhora Da } \\
\text { Escada }\end{array}$ & - & - & Guararema & São Paulo & Brasil & 1 & 5-cima & Peso: $64 \mathrm{gr}$. \\
\hline 988 & Coroa de prata pequena & \begin{tabular}{|l|} 
Matriz de \\
Nossa \\
Senhora Da \\
Escada \\
\end{tabular} & - & - & Guararema & São Paulo & Brasil & 1 & 5-cima & Peso: $56,45 \mathrm{gr}$ \\
\hline 400 & $\begin{array}{l}\text { Custódia para o Santo } \\
\text { Viático }\end{array}$ & $\begin{array}{l}\text { Antiga Matriz } \\
\text { da Vila de } \\
\text { Cotia } \\
\end{array}$ & - & \begin{tabular}{|l|} 
Padre José \\
Ferreira dos \\
Santos, vigário
\end{tabular} & Cotia & São Paulo & Brasil & 1 & $\begin{array}{l}\text { Canto do } \\
\text { mostruário } \\
12 \\
\end{array}$ & $\begin{array}{l}\text { Precioso trabalho antigo, de } \\
\text { prata lavrada, de real valor } \\
\text { artístico. }\end{array}$ \\
\hline 1126 & $\begin{array}{l}\text { Dois estojos de madeira } \\
\text { forrados }\end{array}$ & - & - & - & São Paulo & São Paulo & Brasil & 1 & chão & $\begin{array}{l}\text { Usados para colocar os } \\
\text { cálices registrados sob o no- } \\
1125 .\end{array}$ \\
\hline 1093 & $\begin{array}{l}\text { Relógio de mesa, bronze } \\
\text { dourado }\end{array}$ & - & $\begin{array}{l}\text { Dona Julieta } \\
\text { Guzzi Zanchi }\end{array}$ & - & - & - & - & 1 & Mesa & $\begin{array}{l}\text { Pertenceu a Dona Julieta } \\
\text { Guzzi Zanchi. Conforme } \\
\text { desejo expresso dessa } \\
\text { senhora, esse relógio, logo } \\
\text { após sua morte, deveria ser } \\
\text { entregue ao Museu da } \\
\text { Cúria, o que foi feito por seu } \\
\text { irmão, em 18-7-1940. }\end{array}$ \\
\hline
\end{tabular}




\begin{tabular}{|c|c|c|c|c|c|c|c|c|c|c|}
\hline № Cat. & Objeto & Procedência & Pertenceu a & Doado por & Cidade & Estado & País & Sala & Mostruário & Descrição / Observação \\
\hline 1125 & $\begin{array}{l}\text { Dois cálices de ouro } \\
\text { maciço, cravejado de } \\
\text { legítimas pedras } \\
\text { preciosas, com suas } \\
\text { respectivas patenas e } \\
\text { colherinhas }\end{array}$ & - & - & - & São Paulo & São Paulo & Brasil & 1 & Mesa & $\begin{array}{l}\text { Que serviram no Congresso } \\
\text { Eucarístico Nacional } \\
\text { realizado na Capital do } \\
\text { Estado de São Paulo, em } \\
\text { setembro de 1942. Foram } \\
\text { especialmente } \\
\text { confeccionados para este } \\
\text { fim, com os donativos } \\
\text { populares em ouro, joias, } \\
\text { etc. }\end{array}$ \\
\hline 137 & Seis castiçais de prata & \begin{tabular}{|l} 
Capela de \\
Santa Luzia
\end{tabular} & - & - & São Paulo & São Paulo & Brasil & 1 & $\begin{array}{l}\text { Mostruário } \\
\text { junto à } \\
\text { janela }\end{array}$ & $\begin{array}{l}\text { Capela situada na Rua } \\
\text { Tabatinguera. }\end{array}$ \\
\hline 147 & Pano bordado & \begin{tabular}{|l|} 
Basílica de \\
Nossa \\
Senhora \\
Aparecida e ao \\
Santuário do \\
Bom Jesus de \\
Pirapora
\end{tabular} & - & $\begin{array}{l}\text { Dom Duarte } \\
\text { Leopoldo e } \\
\text { Silva }\end{array}$ & - & - & - & 1 & $\begin{array}{l}\text { Mostruário } \\
\text { junto à } \\
\text { janela }\end{array}$ & $\begin{array}{l}\text { Bordado por Dona Angelina } \\
\text { Vergueiro Steidel, a pedido } \\
\text { de S. Excia. Revma. O Sr. } \\
\text { Arcebispo Metropolitano, } \\
\text { com trancelins e correntes } \\
\text { de ouro. Anotação: Retirado } \\
\text { para ser vendido, por ordem } \\
\text { do Cardeal Rossi. }\end{array}$ \\
\hline 404 & Bandeira francesa & - & - & - & - & - & - & 1 & $\begin{array}{l}\text { Mostruário } \\
\text { junto à } \\
\text { janela }\end{array}$ & $\begin{array}{l}\text { Trazendo numa das faces, } \\
\text { bordada a seda, a seguinte } \\
\text { inscrição: " Coeur Sacrè de } \\
\text { Jésus Espoir et Salut de la } \\
\text { France" e o emblema do } \\
\text { Coração de Jesus: no } \\
\text { reverso as seguintes } \\
\text { assinaturas a lápis: Jeanne } \\
\text { Bidaut, Marie Bidaut, } \\
\text { Josephine Bidaut. 1 Sept. } \\
1916\end{array}$ \\
\hline
\end{tabular}




\section{Sala expositiva 2}

A segunda sala expositiva do Museu possuía 11 mostruários e diversos objetos pendurados pela parede e teto, contemplando um total de 110 objetos por todos os espaços da sala.

Os objetos de prata e prata dourada são a grande maioria, tal qual na Sala 1, estando expostos por todos os mostruários, com destaque para a organização feita no mostruário 6, que agrupava objetos da Matriz de São Miguel e os mostruários 9, 10 e 11 que concentravam objetos da Igreja do M'Boy (Embu).

No mostruário 2 observa-se diversas joias e elementos de indumentária de autoridades eclesiásticas, como barretes, solidéus, cruzes peitorais, anéis e fivelas. Já o mostruário 8 concentrava objetos gerais pertencentes a Dom Duarte, como pasta de couro, despertador, tinteiros, placas de automóvel, sendo que muitos são oriundos da Vila Bethânia, residência do Arcebispo em São Vicente.

Pelas paredes, as pinturas dos doutores e evangelistas da Igreja, procedentes do antigo Recolhimento de Santa Teresa, e no teto os grandes lampadários de prata. 
Figura 63: Vista aérea da Sala 2.
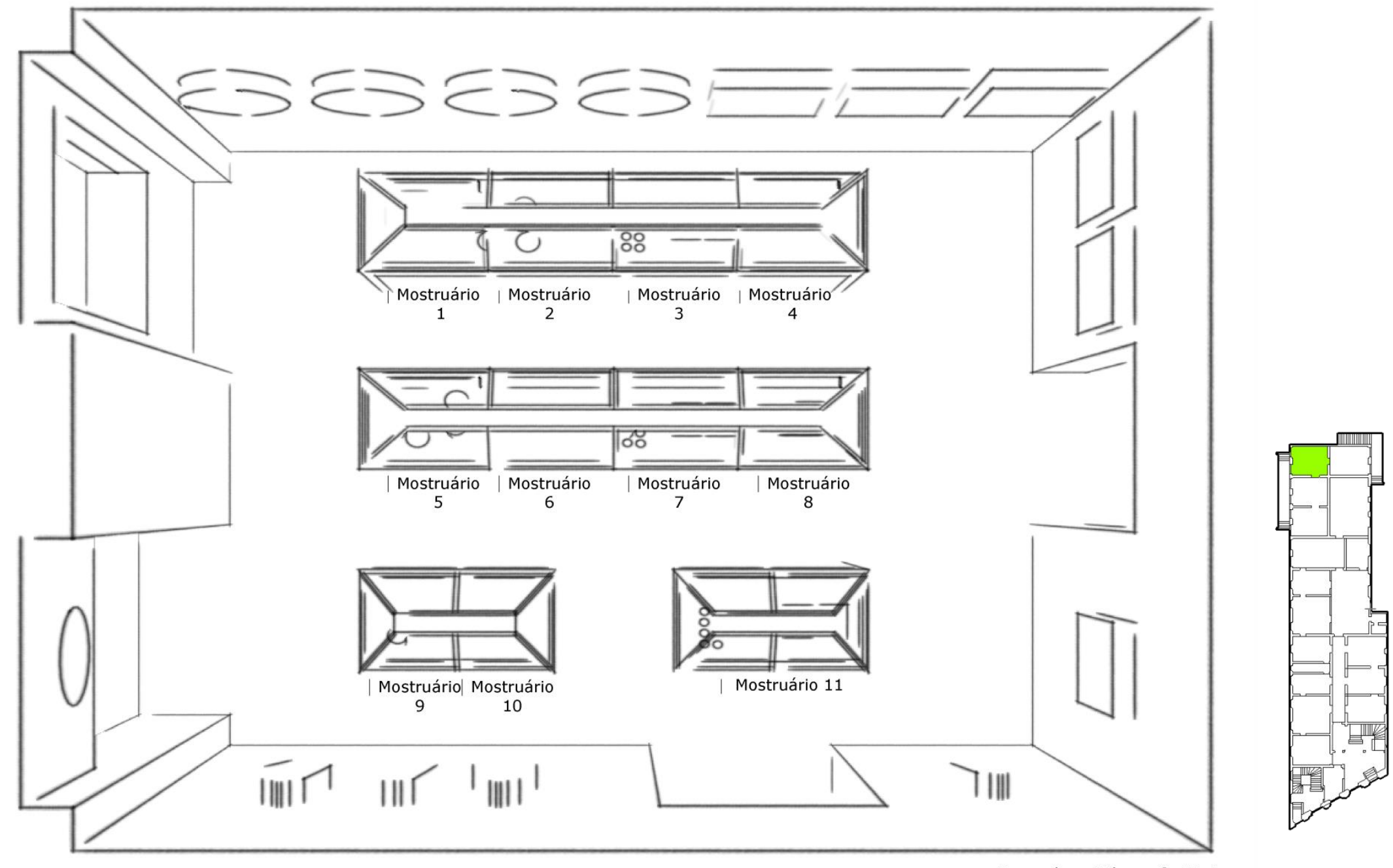

Desenho: Milena Cattin 
Figura 64: Perspectiva interna 1 da Sala 2.

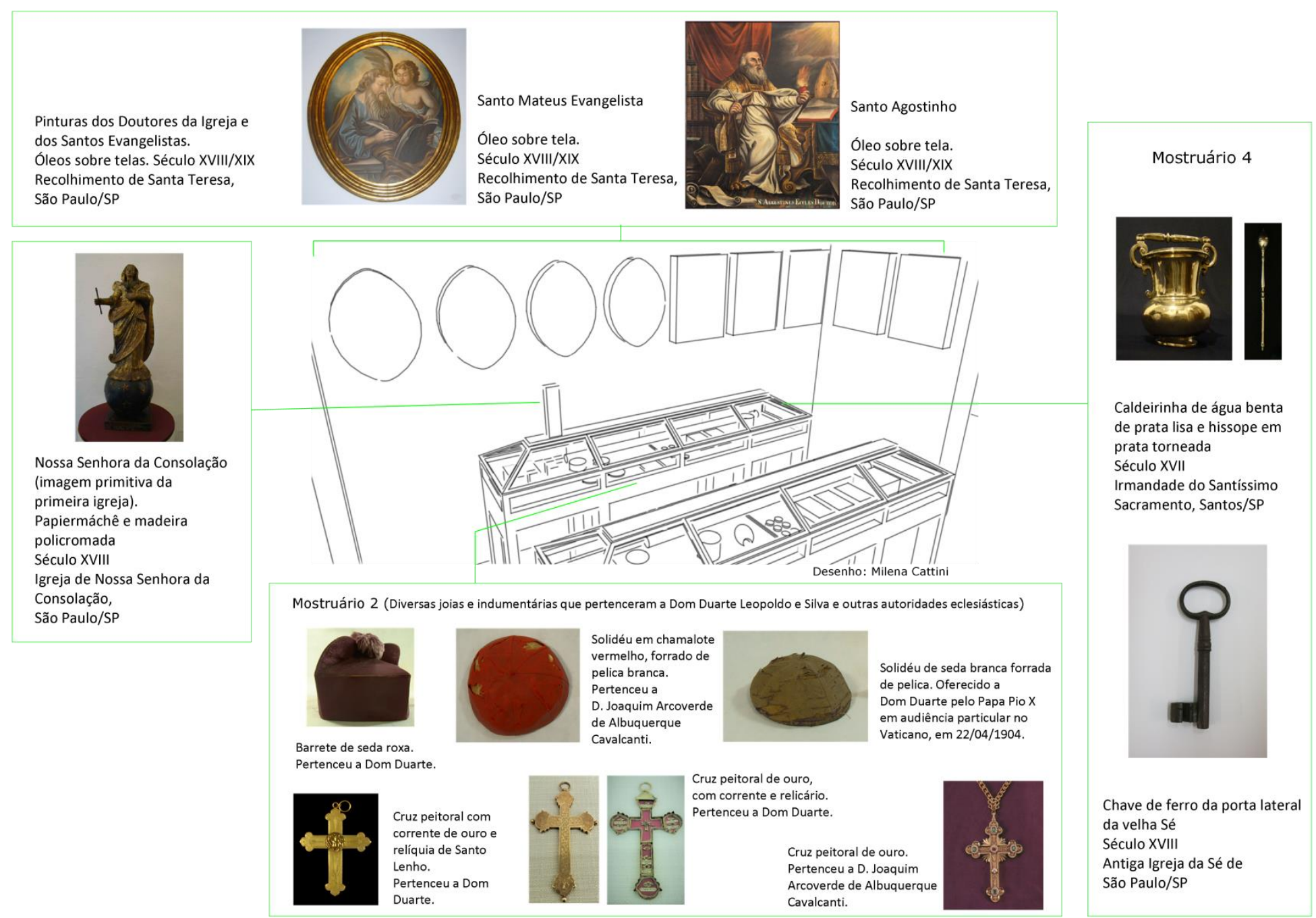


Figura 65: Perspectiva interna 2 da Sala 2.

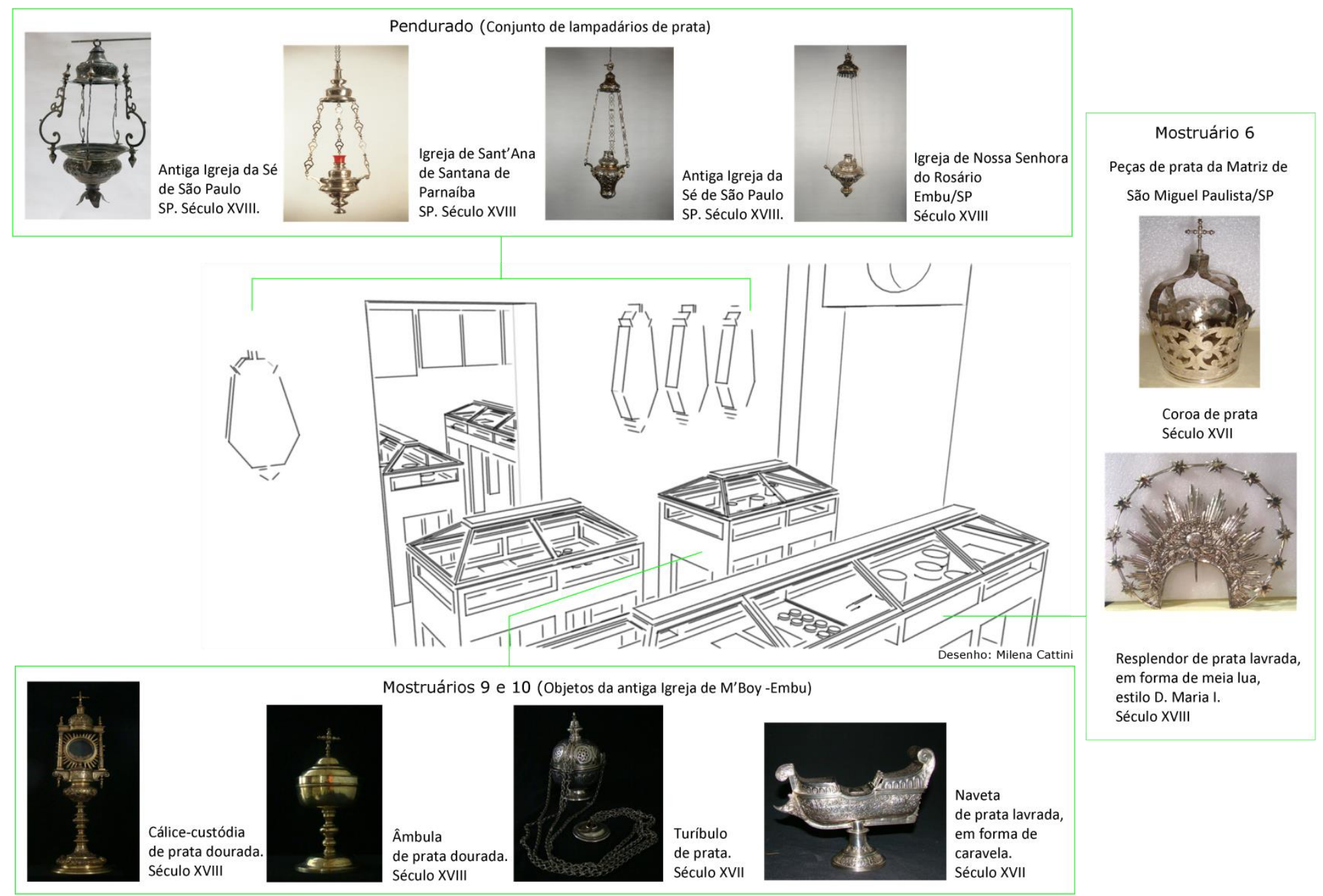


Tabela 6: Objetos expostos na Sala 2 do Museu da Cúria

\begin{tabular}{|c|c|c|c|c|c|c|c|c|c|c|}
\hline № & Objeto & Procedência & Pertenceu a & Doado por & Cidade & Estado & País & Sala & Mostruário & Descrição / Observação \\
\hline 18 & Turíbulo de prata & $\begin{array}{l}\text { Irmandade do } \\
\text { SS. } \\
\text { Sacramento }\end{array}$ & - & - & Santos & $\begin{array}{l}\text { São } \\
\text { Paulo }\end{array}$ & Brasil & 2 & 1 & - \\
\hline 19 & $\begin{array}{l}\text { Duas lanternas de } \\
\text { prata (D. Maria I) } \\
\text { para altar, que } \\
\text { acompanhavam o } \\
\text { Santo Vistico }\end{array}$ & $\begin{array}{l}\text { Irmandade do } \\
\text { SS. } \\
\text { Sacramento }\end{array}$ & - & - & Santos & $\begin{array}{l}\text { São } \\
\text { Paulo }\end{array}$ & Brasil & 2 & 1 & - \\
\hline 1041 & $\begin{array}{l}\text { Rico e belíssimo } \\
\text { roquete }\end{array}$ & - & - & $\begin{array}{l}\text { Dom Duarte } \\
\text { Leopoldo e } \\
\text { Silva }\end{array}$ & São Paulo & $\begin{array}{l}\text { São } \\
\text { Paulo }\end{array}$ & Brasil & 2 & 1 & 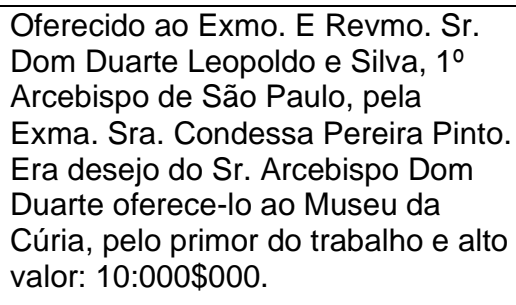 \\
\hline 1122 & Barrete e solidéu & - & - & - & - & - & - & 2 & 1 & $\begin{array}{l}\text { *Catálogo n. 52: Recebidos em } \\
\text { Roma, aos } 20 \text { de fevereiro de 1946, } \\
\text { pelo } 1^{\circ} \text { Cardeal Arcebispo de São } \\
\text { Paulo - Dom Carlos Carmelo de } \\
\text { Vasconcelos Motta das mãos de } \\
\text { Sua Santidade o Papa Pio XII. }\end{array}$ \\
\hline 1122 & Barrete e solidéu & - & - & - & - & - & - & 2 & 1 & $\begin{array}{l}{ }^{*} \text { Catálogo n. 53: Alva, cuja renda foi } \\
\text { confeccionada de fibra de } \\
\text { bananeira, na Baia. Oferta do } \\
\text { Cardeal Arcoverde ao Dom Duarte, } \\
\text { Arcebispo de São Paulo. Sala } 2 \text { - } \\
\text { mostruário } 1\end{array}$ \\
\hline 1042 & Roquete & - & - & $\begin{array}{l}\text { Dom Duarte } \\
\text { Leopoldo e } \\
\text { Silva }\end{array}$ & São Paulo & $\begin{array}{l}\text { São } \\
\text { Paulo }\end{array}$ & Brasil & 2 & 2 & $\begin{array}{l}\text { Oferecido a Dom Duarte Leopoldo e } \\
\text { Silva, 1ํ Arcebispo de São Paulo, } \\
\text { pela Exma. Sra. Dona Olga de } \\
\text { Paiva Neira. É obra de fino lavor e }\end{array}$ \\
\hline
\end{tabular}




\begin{tabular}{|c|c|c|c|c|c|c|c|c|c|c|}
\hline № & Objeto & Procedência & Pertenceu a & Doado por & Cidade & Estado & País & Sala & Mostruário & Descrição / Observação \\
\hline & & & & & & & & & & $\begin{array}{l}\text { nas condições do precedente: } \\
\text { 5:000\$000. }\end{array}$ \\
\hline 1043 & Faixa & - & $\begin{array}{l}\text { Dom Duarte } \\
\text { Leopoldo e Silva }\end{array}$ & $\begin{array}{l}\text { Dom Duarte } \\
\text { Leopoldo e } \\
\text { Silva }\end{array}$ & São Paulo & $\begin{array}{l}\text { São } \\
\text { Paulo }\end{array}$ & Brasil & 2 & 2 & - \\
\hline 1044 & Barrete & - & \begin{tabular}{|l} 
Dom Duarte \\
Leopoldo e Silva
\end{tabular} & $\begin{array}{l}\text { Dom Duarte } \\
\text { Leopoldo e } \\
\text { Silva }\end{array}$ & São Paulo & $\begin{array}{l}\text { São } \\
\text { Paulo }\end{array}$ & Brasil & 2 & 2 & - \\
\hline 1045 & Solidéu & - & $\begin{array}{l}\text { Dom Duarte } \\
\text { Leopoldo e Silva }\end{array}$ & $\begin{array}{l}\text { Dom Duarte } \\
\text { Leopoldo e } \\
\text { Silva }\end{array}$ & São Paulo & $\begin{array}{l}\text { São } \\
\text { Paulo }\end{array}$ & Brasil & 2 & 2 & - \\
\hline 1046 & $\begin{array}{l}\text { Cruz peitoral com } \\
\text { corrente em forma } \\
\text { de cordão }\end{array}$ & - & $\begin{array}{l}\text { Dom Duarte } \\
\text { Leopoldo e Silva }\end{array}$ & $\begin{array}{l}\text { Dom Duarte } \\
\text { Leopoldo e } \\
\text { Silva }\end{array}$ & São Paulo & $\begin{array}{l}\text { São } \\
\text { Paulo }\end{array}$ & Brasil & 2 & 2 & - \\
\hline 1047 & $\begin{array}{l}\text { Cruz peitoral com } \\
\text { corrente, de uso } \\
\text { cotidiano }\end{array}$ & - & $\begin{array}{l}\text { Dom Duarte } \\
\text { Leopoldo e Silva }\end{array}$ & $\begin{array}{l}\text { Dom Duarte } \\
\text { Leopoldo e } \\
\text { Silva }\end{array}$ & São Paulo & $\begin{array}{l}\text { São } \\
\text { Paulo }\end{array}$ & Brasil & 2 & 2 & - \\
\hline 1048 & Anel de ouro & - & $\begin{array}{l}\text { Dom Duarte } \\
\text { Leopoldo e Silva }\end{array}$ & $\begin{array}{l}\text { Dom Duarte } \\
\text { Leopoldo e } \\
\text { Silva }\end{array}$ & São Paulo & $\begin{array}{l}\text { São } \\
\text { Paulo }\end{array}$ & Brasil & 2 & 2 & - \\
\hline 1049 & Idem, idem & - & $\begin{array}{l}\text { Dom Duarte } \\
\text { Leopoldo e Silva }\end{array}$ & $\begin{array}{l}\text { Dom Duarte } \\
\text { Leopoldo e } \\
\text { Silva }\end{array}$ & São Paulo & $\begin{array}{l}\text { São } \\
\text { Paulo }\end{array}$ & Brasil & 2 & 2 & - \\
\hline
\end{tabular}




\begin{tabular}{|c|c|c|c|c|c|c|c|c|c|c|}
\hline № & Objeto & Procedência & Pertenceu a & Doado por & Cidade & Estado & País & Sala & Mostruário & Descrição / Observação \\
\hline 1050 & Anel de ouro & - & $\begin{array}{l}\text { Dom Duarte } \\
\text { Leopoldo e Silva }\end{array}$ & $\begin{array}{l}\text { Dom Duarte } \\
\text { Leopoldo e } \\
\text { Silva }\end{array}$ & São Paulo & $\begin{array}{l}\text { São } \\
\text { Paulo }\end{array}$ & Brasil & 2 & 2 & $\begin{array}{l}\text { Que pertenceu ao } 1^{\circ} \text { Arcebispo de } \\
\text { São Paulo, Dom Duarte Leopoldo e } \\
\text { Silva. (de cônego) Anotação no } \\
\text { verso: Objeto catalogado sob o no } \\
1050 \text { foi retirado do Museu no dia } 9 \\
\text { de novembro de 1939, pelo Exmo. E } \\
\text { Revmo. Sr. Arcebispo Metropolitano } \\
\text { Dom José Gaspar de A'ffonseca e } \\
\text { Siva. }\end{array}$ \\
\hline 1051 & $\begin{array}{l}\text { Par de fivelas de } \\
\text { ouro, com as } \\
\text { Armas } \\
\text { Arquiepiscopais }\end{array}$ & - & $\begin{array}{l}\text { Dom Duarte } \\
\text { Leopoldo e Silva }\end{array}$ & $\begin{array}{l}\text { Dom Duarte } \\
\text { Leopoldo e } \\
\text { Silva }\end{array}$ & São Paulo & $\begin{array}{l}\text { São } \\
\text { Paulo }\end{array}$ & Brasil & 2 & 2 & - \\
\hline 1052 & $\begin{array}{l}\text { Par de fivelas de } \\
\text { ouro }\end{array}$ & - & $\begin{array}{l}\text { Dom Duarte } \\
\text { Leopoldo e Silva }\end{array}$ & $\begin{array}{l}\text { Dom Duarte } \\
\text { Leopoldo e } \\
\text { Silva }\end{array}$ & São Paulo & $\begin{array}{l}\text { São } \\
\text { Paulo }\end{array}$ & Brasil & 2 & 2 & - \\
\hline 1053 & $\begin{array}{l}\text { Par de } \\
\text { abotoaduras de } \\
\text { ouro }\end{array}$ & - & $\begin{array}{l}\text { Dom Duarte } \\
\text { Leopoldo e Silva }\end{array}$ & $\begin{array}{l}\text { Dom Duarte } \\
\text { Leopoldo e } \\
\text { Silva }\end{array}$ & São Paulo & $\begin{array}{l}\text { São } \\
\text { Paulo }\end{array}$ & Brasil & 2 & 2 & - \\
\hline 1054 & $\begin{array}{l}\text { Tabaqueira de } \\
\text { chifre }\end{array}$ & - & $\begin{array}{l}\text { Dom Duarte } \\
\text { Leopoldo e Silva }\end{array}$ & $\begin{array}{l}\text { Dom Duarte } \\
\text { Leopoldo e } \\
\text { Silva }\end{array}$ & São Paulo & $\begin{array}{l}\text { São } \\
\text { Paulo }\end{array}$ & Brasil & 2 & 2 & - \\
\hline 1055 & $\begin{array}{l}\text { Tabaqueira de } \\
\text { galalite em forma } \\
\text { de revolver }\end{array}$ & - & \begin{tabular}{|l} 
Dom Duarte \\
Leopoldo e Silva
\end{tabular} & $\begin{array}{l}\text { Dom Duarte } \\
\text { Leopoldo e } \\
\text { Silva }\end{array}$ & São Paulo & $\begin{array}{l}\text { São } \\
\text { Paulo }\end{array}$ & Brasil & 2 & 2 & - \\
\hline 1056 & $\begin{array}{l}\text { Bengala com } \\
\text { castão de ouro }\end{array}$ & - & $\begin{array}{l}\text { Dom Duarte } \\
\text { Leopoldo e Silva }\end{array}$ & $\begin{array}{l}\text { Dom Duarte } \\
\text { Leopoldo e } \\
\text { Silva }\end{array}$ & São Paulo & $\begin{array}{l}\text { São } \\
\text { Paulo }\end{array}$ & Brasil & 2 & 2 & - \\
\hline 1057 & $\begin{array}{l}\text { Prato com as } \\
\text { Armas } \\
\text { Arquiepiscopais } \\
\text { gravadas }\end{array}$ & - & $\begin{array}{l}\text { Dom Duarte } \\
\text { Leopoldo e Silva }\end{array}$ & $\begin{array}{l}\text { Dom Duarte } \\
\text { Leopoldo e } \\
\text { Silva }\end{array}$ & São Paulo & $\begin{array}{l}\text { São } \\
\text { Paulo }\end{array}$ & Brasil & 2 & 2 & - \\
\hline
\end{tabular}




\begin{tabular}{|c|c|c|c|c|c|c|c|c|c|c|}
\hline № & Objeto & Procedência & Pertenceu a & Doado por & Cidade & Estado & País & Sala & Mostruário & Descrição / Observação \\
\hline 1058 & $\begin{array}{l}\text { Três espinhas de } \\
\text { ouro do palio }\end{array}$ & - & $\begin{array}{l}\text { Dom Duarte } \\
\text { Leopoldo e Silva }\end{array}$ & \begin{tabular}{|l|} 
Dom Duarte \\
Leopoldo e \\
Silva
\end{tabular} & São Paulo & $\begin{array}{l}\text { São } \\
\text { Paulo }\end{array}$ & Brasil & 2 & 2 & - \\
\hline 1059 & $\begin{array}{l}\text { Placa de } \\
\text { automóvel com as } \\
\text { Armas } \\
\text { Arquiepiscopais }\end{array}$ & - & $\begin{array}{l}\text { Dom Duarte } \\
\text { Leopoldo e Silva }\end{array}$ & $\begin{array}{l}\text { Dom Duarte } \\
\text { Leopoldo e } \\
\text { Silva }\end{array}$ & São Paulo & $\begin{array}{l}\text { São } \\
\text { Paulo }\end{array}$ & Brasil & 2 & 2 & - \\
\hline 1060 & $\begin{array}{l}\text { Três cruzes } \\
\text { episcopais }\end{array}$ & $\begin{array}{l}\text { Palácio São } \\
\text { Luiz }\end{array}$ & - & - & São Paulo & $\begin{array}{l}\text { São } \\
\text { Paulo }\end{array}$ & Brasil & 2 & 2 & - \\
\hline 1061 & Medalha & - & $\begin{array}{l}\text { Dona Ana Rosa, } \\
\text { mãe de Dom } \\
\text { Duarte }\end{array}$ & $\begin{array}{l}\text { Dom Duarte } \\
\text { Leopoldo e } \\
\text { Silva }\end{array}$ & Lourdes & - & França & 2 & 2 & $\begin{array}{l}\text { Que trouxe de Lourdes para sua } \\
\text { mãe, o Arcebispo de São Paulo. } \\
\text { Usou-a a veneranda Senhora até a } \\
\text { sua morte e usou-a também o } \\
\text { preclaro Arcebispo até entregar a } \\
\text { santa alma a Deus. }\end{array}$ \\
\hline 1090 & Chapéu & - & $\begin{array}{l}\text { Dom Duarte } \\
\text { Leopoldo e Silva }\end{array}$ & $\begin{array}{l}\text { Dom Duarte } \\
\text { Leopoldo e } \\
\text { Silva }\end{array}$ & São Paulo & $\begin{array}{l}\text { São } \\
\text { Paulo }\end{array}$ & Brasil & 2 & 2 & - \\
\hline 1115 & Barrete & - & $\begin{array}{l}\text { Dom Sebastião } \\
\text { Leme da Silveira } \\
\text { Cintra, segundo } \\
\text { Cardeal } \\
\text { Arcebispo do Rio } \\
\text { de Janeiro }\end{array}$ & - & \begin{tabular}{|l|} 
Rio de \\
Janeiro
\end{tabular} & \begin{tabular}{|l|} 
Rio de \\
Janeiro
\end{tabular} & Brasil & 2 & 2 & $\begin{array}{l}\text { Do } 2^{\circ} \text { Cardeal brasileiro Dom } \\
\text { Sebastião Leme da Silveira Cintra, } \\
\text { Arcebispo do Rio de Janeiro. Vide } \\
\text { no } 1113 \text { e } 1114 .\end{array}$ \\
\hline
\end{tabular}




\begin{tabular}{|c|c|c|c|c|c|c|c|c|c|c|}
\hline № & Objeto & Procedência & Pertenceu a & Doado por & Cidade & Estado & País & Sala & Mostruário & Descrição / Observação \\
\hline 1096 & $\begin{array}{l}\text { Cálice prateado e } \\
\text { patena dourada }\end{array}$ & Vila Bethania & $\begin{array}{l}\text { Dom Duarte } \\
\text { Leopoldo e Silva }\end{array}$ & - & \begin{tabular}{|l|} 
São \\
Vicente
\end{tabular} & $\begin{array}{l}\text { São } \\
\text { Paulo }\end{array}$ & Brasil & 2 & 3 & $\begin{array}{l}\text { Trazem a seguinte inscrição: } \\
\text { "D.Duarte Leopoldo - Villa Bethania } \\
\text { - São Vicente." Esses objetos } \\
\text { pertenceram ao Exmo. Sr. Dom } \\
\text { Duarte Leopoldo e Silva, 10 } \\
\text { Arcebispo Metropolitano de São } \\
\text { Paulo que os usava diariamente na } \\
\text { celebração do Santo Sacrifício da } \\
\text { Missa quando passava alguns dias } \\
\text { em Villa Bethania- São Vicente. S. } \\
\text { Excia. sempre fazia questão de } \\
\text { celebrar com este cálice. }\end{array}$ \\
\hline 17 & $\begin{array}{l}\text { Caldeirinha e } \\
\text { hissope de prata }\end{array}$ & $\begin{array}{l}\text { Irmandade do } \\
\text { SS. } \\
\text { Sacramento }\end{array}$ & - & - & Santos & $\begin{array}{l}\text { São } \\
\text { Paulo }\end{array}$ & Brasil & 2 & 4 & - \\
\hline 20 & Diadema de prata & $\begin{array}{l}\text { Irmandade do } \\
\text { SS. } \\
\text { Sacramento }\end{array}$ & - & - & Santos & $\begin{array}{l}\text { São } \\
\text { Paulo }\end{array}$ & Brasil & 2 & 4 & $\begin{array}{l}\text { Usado pela Magdalena na procissão } \\
\text { do Enterro. }\end{array}$ \\
\hline 21 & $\begin{array}{l}\text { Chave da porta } \\
\text { lateral }\end{array}$ & $\begin{array}{l}\text { Antiga Igreja } \\
\text { da Sé }\end{array}$ & - & - & São Paulo & $\begin{array}{l}\text { São } \\
\text { Paulo }\end{array}$ & Brasil & 2 & 4 & - \\
\hline 1064 & Prato de porcelana & $\begin{array}{l}\text { Convento de } \\
\text { Santa Teresa }\end{array}$ & - & - & São Paulo & $\begin{array}{l}\text { São } \\
\text { Paulo }\end{array}$ & Brasil & 2 & 4 & Compunha a baixela do Convento. \\
\hline 1065 & $\begin{array}{l}\text { Coleção de vasos } \\
\text { de porcelana }\end{array}$ & $\begin{array}{l}\text { Convento de } \\
\text { Santa Teresa }\end{array}$ & - & - & São Paulo & $\begin{array}{l}\text { São } \\
\text { Paulo }\end{array}$ & Brasil & 2 & 4 & $\begin{array}{l}\text { Assim discriminados: um grande } \\
\text { (impar), dois pares (algo menores), } \\
\text { um par (médio), outro par (médio, } \\
\text { pouco menor), um médio (impar) e } \\
\text { três pares pequenos: ao todo } 16 \\
\text { vasos. Ocupam todo o mostruário. }\end{array}$ \\
\hline 981 & Custódia e cálice & $\begin{array}{l}\text { Matriz de } \\
\text { Nossa } \\
\text { Senhora Da } \\
\text { Escada }\end{array}$ & - & - & Guararema & $\begin{array}{l}\text { São } \\
\text { Paulo }\end{array}$ & Brasil & 2 & 5 & $\begin{array}{l}\text { Conjunto de duas peças, podendo } \\
\text { servir de cálice e ostensório. Prata } \\
\text { lavrada, pesando } 908,33 \text { gr. E } \\
863,33 \text { gr. Respectivamente, } \\
\text { perfazendo o total de } 1771,66 \mathrm{gr} \text {. } \\
\text { Alterado o no da sala para no2 e }\end{array}$ \\
\hline
\end{tabular}




\begin{tabular}{|c|c|c|c|c|c|c|c|c|c|c|}
\hline № & Objeto & Procedência & Pertenceu a & Doado por & Cidade & Estado & País & Sala & Mostruário & Descrição / Observação \\
\hline & & & & & & & & & & $\begin{array}{l}\text { riscado banqueta e acrescentado o } \\
\text { n5 no mostruário }\end{array}$ \\
\hline 985 & $\begin{array}{l}\text { Relicário do Santo } \\
\text { Lenho }\end{array}$ & $\begin{array}{l}\text { Matriz de } \\
\text { Nossa } \\
\text { Senhora Da } \\
\text { Escada }\end{array}$ & - & - & Guararema & $\begin{array}{l}\text { São } \\
\text { Paulo }\end{array}$ & Brasil & 2 & 5 & $\begin{array}{l}\text { Cruz de prata (386,50 gr.). Alterado } \\
\text { o no da sala para } \mathrm{n}-2, \text { riscado } \\
\text { banqueta e acrescentado o nำ no } \\
\text { mostruário. }\end{array}$ \\
\hline 15 & $\begin{array}{l}\text { Um depósito de } \\
\text { metal prateado } \\
\text { para água }\end{array}$ & $\begin{array}{l}\text { Irmandade do } \\
\text { SS. } \\
\text { Sacramento }\end{array}$ & - & - & Santos & $\begin{array}{l}\text { São } \\
\text { Paulo }\end{array}$ & Brasil & 2 & 6 & Usado nas cerimônias do Lavapés. \\
\hline 1010 & $\begin{array}{l}\text { Quadro de prata } \\
\text { em relevo }\end{array}$ & - & - & - & - & - & - & 2 & 6 & $\begin{array}{l}\text { Representando o Sagrado Coração } \\
\text { de Jesus. Anotação a lápis: alterado } \\
\text { o nำ da sala para nำ e } \\
\text { acrescentado o n6 no mostruário. }\end{array}$ \\
\hline 1022 & $\begin{array}{l}\text { Cálice e custódia } \\
\text { de prata, em duas } \\
\text { peças. }\end{array}$ & $\begin{array}{l}\text { Matriz de São } \\
\text { Miguel }\end{array}$ & - & - & - & - & - & 2 & 6 & - \\
\hline 1023 & Cálice de prata & $\begin{array}{l}\text { Matriz de São } \\
\text { Miguel }\end{array}$ & - & - & - & - & - & 2 & 6 & - \\
\hline 1024 & $\begin{array}{l}\text { Coroa de prata, } \\
\text { pequena }\end{array}$ & $\begin{array}{l}\text { Matriz de São } \\
\text { Miguel }\end{array}$ & - & - & - & - & - & 2 & 6 & - \\
\hline 1025 & $\begin{array}{l}\text { Coroa de prata } \\
\text { pequena }\end{array}$ & $\begin{array}{l}\text { Matriz de São } \\
\text { Miguel }\end{array}$ & - & - & - & - & - & 2 & 6 & - \\
\hline 1026 & $\begin{array}{l}\text { Resplendor de } \\
\text { prata, grande }\end{array}$ & $\begin{array}{l}\text { Matriz de São } \\
\text { Miguel }\end{array}$ & - & - & - & - & - & 2 & 6 & - \\
\hline 1113 & Chapéu & - & $\begin{array}{l}\text { Dom Sebastião } \\
\text { Leme da Silveira } \\
\text { Cintra, segundo } \\
\text { Cardeal do Rio } \\
\text { de Janeiro }\end{array}$ & - & \begin{tabular}{|l|} 
Rio de \\
Janeiro
\end{tabular} & $\begin{array}{l}\text { Rio de } \\
\text { Janeiro }\end{array}$ & Brasil & 2 & 6 & $\begin{array}{l}\text { Do exmo. Sr. Cardeal Dom } \\
\text { Sebastião Leme da Silveira Cintra - } \\
\text { 20 Cardeal brasileiro - Arcebispo do } \\
\text { Rio de Janeiro, falecido em } 17 \text { de } \\
\text { outubro de } 1942 \text {. }\end{array}$ \\
\hline
\end{tabular}




\begin{tabular}{|c|c|c|c|c|c|c|c|c|c|c|}
\hline № & Objeto & Procedência & Pertenceu a & Doado por & Cidade & Estado & País & Sala & Mostruário & Descrição / Observação \\
\hline 1114 & Solidéu & - & $\begin{array}{l}\text { Dom Sebastião } \\
\text { Leme da Silveira } \\
\text { Cintra, segundo } \\
\text { Cardeal do Rio } \\
\text { de Janeiro }\end{array}$ & - & \begin{tabular}{|l|} 
Rio de \\
Janeiro
\end{tabular} & $\begin{array}{l}\text { Rio de } \\
\text { Janeiro }\end{array}$ & Brasil & 2 & 6 & $\begin{array}{l}\text { De Dom Sebastião Leme da Silveira } \\
\text { Cintra, Cardeal- Arcebispo do Rio } \\
\text { de Janeiro, que o usou } \\
\text { cotidianamente até seu falecimento. } \\
\text { Vide no } 1113 .\end{array}$ \\
\hline 1121 & $\begin{array}{l}\text { Bula do Santo } \\
\text { Padre Pio XII }\end{array}$ & - & - & - & - & - & - & 2 & 6 & $\begin{array}{l}\text { Nomeando S.Emcia. O Cardeal } \\
\text { Dom Sebastião Leme da Silveira } \\
\text { Cintra, Legado Pontifício "a letere" } \\
\text { ao IV Congresso Eucarístico } \\
\text { Nacional Brasileiro a realizar-se em } \\
\text { São Paulo no mês de setembro de } \\
1942 .\end{array}$ \\
\hline 1062 & $\begin{array}{l}\text { Urna com dois } \\
\text { pratos e } 36 \\
\text { bolinhas de cor }\end{array}$ & $\begin{array}{l}\text { Cabido de São } \\
\text { Paulo }\end{array}$ & - & - & São Paulo & $\begin{array}{l}\text { São } \\
\text { Paulo }\end{array}$ & Brasil & 2 & 7 & $\begin{array}{l}\text { Bolinhas nas seguintes cores: } 12 \\
\text { pretas, } 12 \text { brancas e } 12 \text { vermelhas. } \\
\text {-- de madeira, que se usava na } \\
\text { eleição dos cônegos do Cabido } \\
\text { Metropolitano de São Paulo. } \\
\text { Anotação a lápis: Retirado, com } \\
\text { autorização do cabido (ilegível). }\end{array}$ \\
\hline 1063 & $\begin{array}{l}\text { Terço de } \\
\text { Jerusalém, de } \\
\text { madeira, grande }\end{array}$ & $\begin{array}{l}\text { Palácio São } \\
\text { Luiz }\end{array}$ & - & - & São Paulo & $\begin{array}{l}\text { São } \\
\text { Paulo }\end{array}$ & Brasil & 2 & 7 & $\begin{array}{l}\text { Procedente do Palácio São Luiz e } \\
\text { quiçá de propriedade do 1ำ } \\
\text { Arcebispo de São Paulo. }\end{array}$ \\
\hline 1071 & $\begin{array}{l}\text { Custódia de prata } \\
\text { lavrada, dourada }\end{array}$ & $\begin{array}{l}\text { Antiga Igreja } \\
\text { de M'boy }\end{array}$ & - & - & Embu & $\begin{array}{l}\text { São } \\
\text { Paulo }\end{array}$ & Brasil & 2 & 7 & - \\
\hline 1097 & Pia de agua benta & - & $\begin{array}{l}\text { Dom Duarte } \\
\text { Leopoldo e Silva }\end{array}$ & $\begin{array}{l}\text { Dom Duarte } \\
\text { Leopoldo e } \\
\text { Silva }\end{array}$ & Santos & $\begin{array}{l}\text { São } \\
\text { Paulo }\end{array}$ & Brasil & 2 & 8 & $\begin{array}{l}\text { Lembrança da Irmandade de N.Sra. } \\
\text { Do Rosário Aparecida - Santos - } \\
1909 .\end{array}$ \\
\hline 1098 & Pasta de couro & - & $\begin{array}{l}\text { Dom Duarte } \\
\text { Leopoldo e Silva }\end{array}$ & $\begin{array}{l}\text { Dom Duarte } \\
\text { Leopoldo e } \\
\text { Silva }\end{array}$ & São Paulo & $\begin{array}{l}\text { São } \\
\text { Paulo }\end{array}$ & Brasil & 2 & 8 & $\begin{array}{l}\text { Com uma pequena placa de prata } \\
\text { com o nome recortado " Dom } \\
\text { Duarte". Pertenceu a D. Duarte } \\
\text { Leopoldo e Silva que a usava } \\
\text { diariamente. }\end{array}$ \\
\hline
\end{tabular}




\begin{tabular}{|c|c|c|c|c|c|c|c|c|c|c|}
\hline № & Objeto & Procedência & Pertenceu a & Doado por & Cidade & Estado & País & Sala & Mostruário & Descrição / Observação \\
\hline 1099 & $\begin{array}{l}\text { Pasta almofadada } \\
\text { com as Armas de } \\
\text { Dom Duarte, } \\
\text { bordada em seda } \\
\text { e ouro } \\
\end{array}$ & - & - & - & - & - & Brasil & 2 & 8 & - \\
\hline 1110 & $\begin{array}{l}\text { Plaquinha de } \\
\text { Nossa Senhora } \\
\text { Aparecida }\end{array}$ & - & $\begin{array}{l}\text { Dom Duarte } \\
\text { Leopoldo e Silva }\end{array}$ & - & São Paulo & $\begin{array}{l}\text { São } \\
\text { Paulo }\end{array}$ & Brasil & 2 & 8 & $\begin{array}{l}\text { Que sempre esteve no automóvel } \\
\text { de Dom Duarte Leopoldo e Silva. }\end{array}$ \\
\hline 1101 & Despertador & Vila Bethania & $\begin{array}{l}\text { Dom Duarte } \\
\text { Leopoldo e Silva }\end{array}$ & - & \begin{tabular}{|l|} 
São \\
Vicente
\end{tabular} & $\begin{array}{l}\text { São } \\
\text { Paulo }\end{array}$ & Brasil & 2 & 8 & $\begin{array}{l}\text { De uso de Dom Duarte Leopoldo e } \\
\text { Silva quando se encontrava na Villa } \\
\text { Bethania - São Vicente. }\end{array}$ \\
\hline 1103 & Pasta de couro & $\begin{array}{l}\text { Chancelaria } \\
\text { da Cúria de } \\
\text { São Paulo }\end{array}$ & - & - & São Paulo & $\begin{array}{l}\text { São } \\
\text { Paulo }\end{array}$ & Brasil & 2 & 8 & $\begin{array}{l}\text { Pertenceu a Chancelaria do então } \\
\text { bispado de São Paulo. Traz as } \\
\text { aramas imperiais do Brasil. }\end{array}$ \\
\hline 1116 & Mitra & - & $\begin{array}{l}\text { Dom Duarte } \\
\text { Leopoldo e Silva }\end{array}$ & - & São Paulo & $\begin{array}{l}\text { São } \\
\text { Paulo }\end{array}$ & Brasil & 2 & 8 & $\begin{array}{l}\text { Pertenceu ao primeiro Arcebispo de } \\
\text { São Paulo, Dom Duarte Leopoldo e } \\
\text { Silva, falecido a } 13 \text { de novembro de } \\
1938 .\end{array}$ \\
\hline 1118 & $\begin{array}{l}\text { Caneta tinteiro de } \\
\text { ouro }\end{array}$ & - & $\begin{array}{l}\text { Dom Duarte } \\
\text { Leopoldo e Silva }\end{array}$ & - & São Paulo & $\begin{array}{l}\text { São } \\
\text { Paulo }\end{array}$ & Brasil & 2 & 8 & $\begin{array}{l}\text { De uso diário do exmo. Sr. Dom } \\
\text { Duarte Leopoldo e Silva, } 1^{\circ} \\
\text { Arcebispo Metropolitano de São } \\
\text { Paulo. A cobertura é de ouro } 18 \\
\text { quilates. }\end{array}$ \\
\hline 1119 & $\begin{array}{l}\text { Tinteiro de prata } \\
\text { lavrada, com dois } \\
\text { recipientes }\end{array}$ & - & $\begin{array}{l}\text { Dom Duarte } \\
\text { Leopoldo e Silva }\end{array}$ & - & São Paulo & $\begin{array}{l}\text { São } \\
\text { Paulo }\end{array}$ & Brasil & 2 & 8 & $\begin{array}{l}\text { Pertenceu ao } 1^{\circ} \text { Arcebispo de São } \\
\text { Paulo, Dom Duarte Leopoldo e } \\
\text { Silva. Estão gravadas neste tinteiro } \\
\text { as Armas de s. excia. }\end{array}$ \\
\hline 1123 & $\begin{array}{l}\text { Placa do } \\
\text { automóvel de Dom } \\
\text { Duarte Leopoldo e } \\
\text { Silva }\end{array}$ & - & $\begin{array}{l}\text { Dom Duarte } \\
\text { Leopoldo e Silva }\end{array}$ & - & São Paulo & $\begin{array}{l}\text { São } \\
\text { Paulo }\end{array}$ & Brasil & 2 & 8 & - \\
\hline
\end{tabular}




\begin{tabular}{|c|c|c|c|c|c|c|c|c|c|c|}
\hline № & Objeto & Procedência & Pertenceu a & Doado por & Cidade & Estado & País & Sala & Mostruário & Descrição / Observação \\
\hline 1124 & $\begin{array}{l}\text { Caderneta da } \\
\text { Alfândega de } \\
\text { Santos }\end{array}$ & - & $\begin{array}{l}\text { Dom Duarte } \\
\text { Leopoldo e Silva }\end{array}$ & - & - & - & - & 2 & 8 & $\begin{array}{l}\text { Anotação: NOTA: alterar para } \\
\text { mostruário } 2 \text { o objeto que estão no } \\
\text { armário. A sobrepelis de Dom } \\
\text { Duarte que passou para esse } \\
\text { mostruário. }\end{array}$ \\
\hline 1072 & $\begin{array}{l}\text { Cálice de prata } \\
\text { dourada }\end{array}$ & $\begin{array}{l}\text { Antiga Igreja } \\
\text { de M'boy }\end{array}$ & - & - & Embu & $\begin{array}{l}\text { São } \\
\text { Paulo }\end{array}$ & Brasil & 2 & 9 & - \\
\hline 1073 & $\begin{array}{l}\text { Patena de prata } \\
\text { dourada }\end{array}$ & $\begin{array}{l}\text { Antiga Igreja } \\
\text { de M'boy }\end{array}$ & - & - & Embu & $\begin{array}{l}\text { São } \\
\text { Paulo }\end{array}$ & Brasil & 2 & 9 & - \\
\hline 1074 & Ambula dourada & $\begin{array}{l}\text { Antiga Igreja } \\
\text { de M'boy }\end{array}$ & - & - & Embu & $\begin{array}{l}\text { São } \\
\text { Paulo }\end{array}$ & Brasil & 2 & 9 & - \\
\hline 1075 & $\begin{array}{l}\text { Ambula de prata } \\
\text { para os Santos } \\
\text { Óleos }\end{array}$ & $\begin{array}{l}\text { Antiga Igreja } \\
\text { de M'boy }\end{array}$ & - & - & Embu & $\begin{array}{l}\text { São } \\
\text { Paulo }\end{array}$ & Brasil & 2 & 9 & Com três divisões (tubos). \\
\hline 1076 & Lâmpada de prata & $\begin{array}{l}\text { Antiga Igreja } \\
\text { de M'boy }\end{array}$ & - & - & Embu & $\begin{array}{l}\text { São } \\
\text { Paulo }\end{array}$ & Brasil & 2 & 9 & - \\
\hline 1077 & $\begin{array}{l}\text { Turíbulo, naveta e } \\
\text { colherinha de prata }\end{array}$ & $\begin{array}{l}\text { Antiga Igreja } \\
\text { de M'boy }\end{array}$ & - & - & Embu & $\begin{array}{l}\text { São } \\
\text { Paulo }\end{array}$ & Brasil & 2 & 9 & - \\
\hline 1078 & $\begin{array}{l}\text { Coroa grande, } \\
\text { cetro e bandeja, de } \\
\text { prata }\end{array}$ & $\begin{array}{l}\text { Antiga Igreja } \\
\text { de M'boy }\end{array}$ & - & - & Embu & $\begin{array}{l}\text { São } \\
\text { Paulo }\end{array}$ & Brasil & 2 & 9 & - \\
\hline 1079 & $\begin{array}{l}\text { Coroa pequena de } \\
\text { prata }\end{array}$ & $\begin{array}{l}\text { Antiga Igreja } \\
\text { de M'boy }\end{array}$ & - & - & Embu & \begin{tabular}{|l|} 
São \\
Paulo
\end{tabular} & Brasil & 2 & 9 & $\begin{array}{l}\text { Anotação a lápis: riscada a palavra } \\
\text { pequena. }\end{array}$ \\
\hline 1091 & Chave de prata & - & - & - & - & - & - & 2 & 9 & $\begin{array}{l}\text { Da caixa registrada sob o no } \\
\text { seguinte (1092) Anotação a lápis: } \\
\text { chave na resp. caixa. }\end{array}$ \\
\hline 1080 & $\begin{array}{l}\text { Diadema de prata, } \\
\text { com falta de uma } \\
\text { estrela }\end{array}$ & $\begin{array}{l}\text { Antiga Igreja } \\
\text { de M'boy }\end{array}$ & - & - & Embu & $\begin{array}{l}\text { São } \\
\text { Paulo }\end{array}$ & Brasil & 2 & 10 & - \\
\hline 1081 & $\begin{array}{l}\text { Nove (9) } \\
\text { resplendores de } \\
\text { prata }\end{array}$ & $\begin{array}{l}\text { Antiga Igreja } \\
\text { de M'boy }\end{array}$ & - & - & Embu & $\begin{array}{l}\text { São } \\
\text { Paulo }\end{array}$ & Brasil & 2 & 10 & - \\
\hline 1082 & $\begin{array}{l}\text { Coroa pequena de } \\
\text { ouro antigo }\end{array}$ & $\begin{array}{l}\text { Antiga Igreja } \\
\text { de M'boy }\end{array}$ & - & - & Embu & $\begin{array}{l}\text { São } \\
\text { Paulo }\end{array}$ & Brasil & 2 & 10 & - \\
\hline
\end{tabular}




\begin{tabular}{|c|c|c|c|c|c|c|c|c|c|c|}
\hline № & Objeto & Procedência & Pertenceu a & Doado por & Cidade & Estado & País & Sala & Mostruário & Descrição / Observação \\
\hline 1083 & $\begin{array}{l}\text { Rosário de contas } \\
\text { ocas e crucifixo de } \\
\text { ouro }\end{array}$ & $\begin{array}{l}\text { Antiga Igreja } \\
\text { de M'boy }\end{array}$ & - & - & Embu & $\begin{array}{l}\text { São } \\
\text { Paulo }\end{array}$ & Brasil & 2 & 10 & 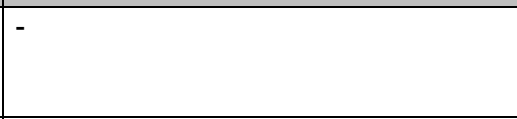 \\
\hline 1084 & $\begin{array}{l}\text { Correntinha de } \\
\text { ouro e figa } \\
\text { estragada }\end{array}$ & $\begin{array}{l}\text { Antiga Igreja } \\
\text { de M'boy }\end{array}$ & - & - & Embu & $\begin{array}{l}\text { São } \\
\text { Paulo }\end{array}$ & Brasil & 2 & 10 & $\begin{array}{l}\text { Anotação: Retirado do Museu, por } \\
\text { ordem do Sr. Cardeal Rossi para } \\
\text { ser vendido. }\end{array}$ \\
\hline 1085 & $\begin{array}{l}\text { Dois pares de } \\
\text { brincos com } \\
\text { pedras }\end{array}$ & $\begin{array}{l}\text { Antiga Igreja } \\
\text { de M'boy }\end{array}$ & - & - & Embu & $\begin{array}{l}\text { São } \\
\text { Paulo }\end{array}$ & Brasil & 2 & 10 & - \\
\hline 1086 & $\begin{array}{l}\text { Florão de prata } \\
\text { com pedras }\end{array}$ & $\begin{array}{l}\text { Antiga Igreja } \\
\text { de M'boy }\end{array}$ & - & - & Embu & \begin{tabular}{|l} 
São \\
Paulo
\end{tabular} & Brasil & 2 & 10 & - \\
\hline 1087 & $\begin{array}{l}\text { Dois resplendores } \\
\text { de prata, } \\
\text { pequenos }\end{array}$ & $\begin{array}{l}\text { Antiga Igreja } \\
\text { de M'boy }\end{array}$ & - & - & Embu & $\begin{array}{l}\text { São } \\
\text { Paulo }\end{array}$ & Brasil & 2 & 10 & - \\
\hline 1088 & $\begin{array}{l}\text { Paramento } \\
\text { Sagrado, bordado } \\
\text { a ouro }\end{array}$ & $\begin{array}{l}\text { Antiga Igreja } \\
\text { de M'boy }\end{array}$ & $\begin{array}{l}\text { Padre Belchior de } \\
\text { Pontes }\end{array}$ & - & Embu & $\begin{array}{l}\text { São } \\
\text { Paulo }\end{array}$ & Brasil & 2 & 11 & Completo. \\
\hline 1089 & Estola & $\begin{array}{l}\text { Antiga Igreja } \\
\text { de M'boy }\end{array}$ & - & - & Embu & $\begin{array}{l}\text { São } \\
\text { Paulo }\end{array}$ & Brasil & 2 & 11 & - \\
\hline 142 & $\begin{array}{l}\text { Quadro a óleo de } \\
\text { D. Pedro II }\end{array}$ & - & - & $\begin{array}{l}\text { Dom João } \\
\text { de Almeida } \\
\text { Ferrão, bispo } \\
\text { de } \\
\text { Campanha }\end{array}$ & Campanha & $\begin{array}{l}\text { Minas } \\
\text { Gerais }\end{array}$ & Brasil & $\begin{array}{l}\text { 2-sobre a } \\
\text { porta } \\
\text { interior }\end{array}$ & - & $\begin{array}{l}\text { Retrato do Imperador do Brasil, D. } \\
\text { Pedro II, quando contava com cinco } \\
\text { anos de idade. Esteve colocado na } \\
\text { sala da Câmara Municipal da cidade } \\
\text { de Campanha (Minas Gerais), } \\
\text { desde a infância do Imperador até a } \\
\text { sua maioridade, sendo então } \\
\text { substituído por outro quadro a óleo } \\
\text { e passando o primeiro a pertencer } \\
\text { ao Capitão Francisco Ferrão de } \\
\text { Almeida que o legou a seu filho, o } \\
\text { Exmo. Sr. Bispo de Campanha, } \\
\text { Dom João de Almeida Ferrão, pelo } \\
\text { qual foi oferecido ao Museu da } \\
\text { Cúria. }\end{array}$ \\
\hline
\end{tabular}




\begin{tabular}{|c|c|c|c|c|c|c|c|c|c|c|}
\hline № & Objeto & Procedência & Pertenceu a & Doado por & Cidade & Estado & País & Sala & Mostruário & Descrição / Observação \\
\hline 145 & Lâmpada de prata & $\begin{array}{l}\text { Igreja da } \\
\text { Senhora de } \\
\text { Sant'Ana }\end{array}$ & - & $\begin{array}{l}\text { Padre } \\
\text { Guilherme } \\
\text { Pompeu de } \\
\text { Almeida }\end{array}$ & \begin{tabular}{|l} 
Santana de \\
Parnaíba
\end{tabular} & $\begin{array}{l}\text { São } \\
\text { Paulo }\end{array}$ & Brasil & $\begin{array}{l}\text { 2- } \\
\text { pendente }\end{array}$ & - & Ver ANEXO C. \\
\hline 157 & $\begin{array}{l}\text { Lâmpada de prata } \\
\text { lavrada }\end{array}$ & $\begin{array}{l}\text { Velha Catedral } \\
\text { de São Paulo }\end{array}$ & - & - & São Paulo & $\begin{array}{l}\text { São } \\
\text { Paulo }\end{array}$ & Brasil & $\begin{array}{l}2- \\
\text { pendente }\end{array}$ & - & Trabalho antigo. \\
\hline 158 & $\begin{array}{l}\text { Lâmpada de prata } \\
\text { lavrada }\end{array}$ & $\begin{array}{l}\text { Velha Sé de } \\
\text { São Paulo }\end{array}$ & - & - & São Paulo & $\begin{array}{l}\text { São } \\
\text { Paulo }\end{array}$ & Brasil & $\begin{array}{l}2- \\
\text { pendente }\end{array}$ & - & Trabalho antigo. \\
\hline 159 & $\begin{array}{l}\text { Lâmpada de prata } \\
\text { lavrada }\end{array}$ & $\begin{array}{l}\text { Velha Sé de } \\
\text { São Paulo }\end{array}$ & - & - & São Paulo & $\begin{array}{l}\text { São } \\
\text { Paulo }\end{array}$ & Brasil & $\begin{array}{l}2- \\
\text { pendente }\end{array}$ & - & Trabalho antigo. \\
\hline 160 & $\begin{array}{l}\text { Lâmpada de prata } \\
\text { lavrada }\end{array}$ & $\begin{array}{l}\text { Velha Sé de } \\
\text { São Paulo }\end{array}$ & - & - & São Paulo & $\begin{array}{l}\text { São } \\
\text { Paulo }\end{array}$ & Brasil & $\begin{array}{l}\text {-- } \\
\text { pendente }\end{array}$ & - & Trabalho antigo. \\
\hline 161 & $\begin{array}{l}\text { Lâmpada de prata } \\
\text { lavrada }\end{array}$ & $\begin{array}{l}\text { Velha Sé de } \\
\text { São Paulo }\end{array}$ & - & - & São Paulo & $\begin{array}{l}\text { São } \\
\text { Paulo }\end{array}$ & Brasil & $\begin{array}{l}\text { - } \\
\text { pendente }\end{array}$ & - & Trabalho antigo. \\
\hline 255 & $\begin{array}{l}\text { Custódia de Metal } \\
\text { dourado a fogo }\end{array}$ & $\begin{array}{l}\text { Antiga Igreja } \\
\text { de São Pedro } \\
\text { dos Clérigos }\end{array}$ & - & - & São Paulo & $\begin{array}{l}\text { São } \\
\text { Paulo }\end{array}$ & Brasil & $\begin{array}{l}- \\
\text { banqueta }\end{array}$ & - & - \\
\hline 525 & $\begin{array}{l}\text { Última Bandeira da } \\
\text { monarquia }\end{array}$ & $\begin{array}{l}\text { Palácio do } \\
\text { Governo do } \\
\text { Estado de São } \\
\text { Paulo }\end{array}$ & - & $\begin{array}{l}\text { Comendador } \\
\text { Tiburtino } \\
\text { Mondim } \\
\text { Pestana }\end{array}$ & São Paulo & $\begin{array}{l}\text { São } \\
\text { Paulo }\end{array}$ & Brasil & 2-parede & - & $\begin{array}{l}\text { Que flutuava no Palácio do Governo } \\
\text { de São Paulo até o dia } 15 \text { de } \\
\text { novembro de } 1889 .\end{array}$ \\
\hline 529 & $\begin{array}{l}\text { Padrão da } \\
\text { Primeira bandeira } \\
\text { do Brasil } \\
\text { independente }\end{array}$ & - & - & $\begin{array}{l}\text { Dr. José } \\
\text { Carlos de } \\
\text { Macedo } \\
\text { Soares }\end{array}$ & - & - & - & 2-parede & - & - \\
\hline
\end{tabular}




\begin{tabular}{|c|c|c|c|c|c|c|c|c|c|c|}
\hline № & Objeto & Procedência & Pertenceu a & Doado por & Cidade & Estado & País & Sala & Mostruário & Descrição / Observação \\
\hline 571 & $\begin{array}{l}\text { Planta da Imperial } \\
\text { cidade de São } \\
\text { Paulo }\end{array}$ & - & - & $\begin{array}{l}\text { Padre } \\
\text { Arnaldo de } \\
\text { Moraes } \\
\text { Arruda }\end{array}$ & - & $\begin{array}{l}\text { São } \\
\text { Paulo }\end{array}$ & Brasil & 2-parede & - & $\begin{array}{l}\text { Levantada em } 1810 \text { pelo capitão de } \\
\text { engenharia Rufino José Felizardo e } \\
\text { Costa e copiada em } 1841 \text {. - } \\
\text { Oferecida ao Museu da Cúria pelo } \\
\text { padre Arnaldo de Moraes Arruda e } \\
\text { provém da biblioteca do sr. } \\
\text { Francisco Leme, de Itatiba, Estado } \\
\text { de São Paulo. }\end{array}$ \\
\hline 635 & $\begin{array}{l}\text { Dois castiçais de } \\
\text { prata lavrada }\end{array}$ & $\begin{array}{l}\text { Velha Sé de } \\
\text { São Paulo }\end{array}$ & - & - & São Paulo & $\begin{array}{l}\text { São } \\
\text { Paulo }\end{array}$ & Brasil & 2 & - & $\begin{array}{l}\text { Anotação a lápis: Altera o no da sala } \\
\text { para } 2 \text { e risca a banqueta. }\end{array}$ \\
\hline 863 & $\begin{array}{l}\text { Imagem de Nossa } \\
\text { Senhora Da } \\
\text { Consolação }\end{array}$ & $\begin{array}{l}\text { Matriz de } \\
\text { Nossa } \\
\text { Senhora Da } \\
\text { Consolação }\end{array}$ & - & - & São Paulo & \begin{tabular}{|l|} 
São \\
Paulo
\end{tabular} & Brasil & 2 & - & - \\
\hline 864 & $\begin{array}{l}\text { Quadro artístico de } \\
\text { tapeçaria: Martírio } \\
\text { de Santo Estevam }\end{array}$ & - & - & - & - & - & - & 2-parede & - & - \\
\hline 866 & $\begin{array}{l}\text { Quadro a óleo: } \\
\text { Clemente XIV }\end{array}$ & - & - & - & - & - & - & 2-parede & - & Eleito aos 19 de maio de 1769. \\
\hline 867 & $\begin{array}{l}\text { Litogravura: Dom } \\
\text { João VI }\end{array}$ & - & - & $\begin{array}{l}\text { Sociedade } \\
\text { Numismática } \\
\text { Brasileira }\end{array}$ & - & - & - & 2-parede & - & - \\
\hline 868 & $\begin{array}{l}\text { Quadro: Bustos e } \\
\text { Cronologia dos } \\
\text { Soberanos } \\
\text { portugueses }\end{array}$ & - & - & - & - & - & - & 2-parede & - & - \\
\hline 869 & $\begin{array}{l}\text { Quatro quadros a } \\
\text { óleo }\end{array}$ & - & - & - & - & - & - & 2-parede & - & $\begin{array}{l}\text { De Dom João VI, Dona Carlota } \\
\text { Joaquina, Dom Pedro IV de } \\
\text { Portugal (I do Brasil) e Dona Maria } \\
\text { Leopoldina. }\end{array}$ \\
\hline
\end{tabular}




\begin{tabular}{|c|c|c|c|c|c|c|c|c|c|c|}
\hline № & Objeto & Procedência & Pertenceu a & Doado por & Cidade & Estado & País & Sala & Mostruário & Descrição / Observação \\
\hline 999 & Clichê & - & - & $\begin{array}{l}\text { Padre } \\
\text { Heliodoro } \\
\text { Pires }\end{array}$ & - & - & - & 2-parede & - & $\begin{array}{l}\text { Clichê do frontispício de um dos } \\
\text { livros mais célebres na História } \\
\text { religiosa do Brasil. A obra, que } \\
\text { refuta o Jansenismo, foi escrita por } \\
\text { Dom Matheus da Incarnação Pinna, } \\
\text { um dos maiores teólogos brasileiros } \\
\text { do sec. XVIII. }\end{array}$ \\
\hline 1000 & $\begin{array}{l}\text { Gravura de Dom } \\
\text { Sebastião } \\
\text { Monteiro da Vide, } \\
\text { Arcebispo da } \\
\text { Bahia (1702-1722). }\end{array}$ & - & - & $\begin{array}{l}\text { Padre } \\
\text { Heliodoro } \\
\text { Pires }\end{array}$ & - & - & - & 2-parede & - & $\begin{array}{l}\text { Foi executada pelo pintor Oscar } \\
\text { Pereira da Silva para o livro " A } \\
\text { paisagem espiritual do Brasil" em } \\
\text { julho de } 1937 \text {. }\end{array}$ \\
\hline 1001 & Idem, menor & - & - & - & - & - & - & 2-parede & - & Idem. \\
\hline 1066 & $\begin{array}{l}\text { Seis quadros a } \\
\text { óleo dos Santos } \\
\text { Doutores da Igreja }\end{array}$ & $\begin{array}{l}\text { Convento de } \\
\text { Santa Teresa }\end{array}$ & - & - & São Paulo & $\begin{array}{l}\text { São } \\
\text { Paulo }\end{array}$ & Brasil & 2-parede & - & $\begin{array}{l}\text { São eles: S. Boaventura, Santo } \\
\text { Agostinho, Santo Ambrósio, Santo } \\
\text { Thomas, S. Jeronimo e São } \\
\text { Gregório. Estas telas são do grande } \\
\text { Pe. Jesuíno do Monte Carmelo. } \\
\text { Anotação a lápis: Retirado para } \\
\text { Catedral. }\end{array}$ \\
\hline 1067 & $\begin{array}{l}\text { Quatro quadros a } \\
\text { óleo, ovais, dos } \\
\text { Santos } \\
\text { Evangelistas }\end{array}$ & $\begin{array}{l}\text { Convento de } \\
\text { Santa Teresa }\end{array}$ & - & - & São Paulo & $\begin{array}{l}\text { São } \\
\text { Paulo }\end{array}$ & Brasil & 2-parede & - & $\begin{array}{l}\text { São eles: São João, São Marcos, } \\
\text { São Lucas e São Matheus. Estas } \\
\text { telas são do grande Pe. Jesuíno do } \\
\text { Monte Carmelo. Anotação a lápis: } \\
\text { (?) me parecem do pintor José } \\
\text { Jorge Pinto Veras! (ilegível) . } \\
\text { Retirado para Catedral. }\end{array}$ \\
\hline 16 & $\begin{array}{l}\text { Cruzes de prata } \\
\text { (renascimento } \\
\text { português) (Dois } \\
\text { exemplares). }\end{array}$ & $\begin{array}{l}\text { Irmandade do } \\
\text { SS. } \\
\text { Sacramento }\end{array}$ & - & - & Santos & $\begin{array}{l}\text { São } \\
\text { Paulo }\end{array}$ & Brasil & 2 & $1-9$ & - \\
\hline
\end{tabular}




\begin{tabular}{|c|c|c|c|c|c|c|c|c|c|c|}
\hline № & Objeto & Procedência & Pertenceu a & Doado por & Cidade & Estado & País & Sala & Mostruário & Descrição / Observação \\
\hline 596 & $\begin{array}{l}\text { Bengala com } \\
\text { castão de ouro }\end{array}$ & - & - & $\begin{array}{l}\text { Dom Duarte } \\
\text { Leopoldo e } \\
\text { Silva }\end{array}$ & São Paulo & $\begin{array}{l}\text { São } \\
\text { Paulo }\end{array}$ & Brasil & 2 & 3 & $\begin{array}{l}\text { Com as armas em relevo Do Exmo. } \\
\text { Sr. Dom Duarte Leopoldo e Silva, } \\
\text { Arcebispo de São Paulo, feita com a } \\
\text { madeira da porta da antiga Sé de } \\
\text { São Paulo. A bengala foi oferecida } \\
\text { ao Museu da Cúria pelo mesmo Sr. } \\
\text { Arcebispo. Anotação a lápis: altera } \\
\text { os no da sala para no } 2 \text { e do } \\
\text { mostruário para nำ. }\end{array}$ \\
\hline 517 & Ostensório antigo & - & - & $\begin{array}{l}\text { Dona } \\
\text { Margarida } \\
\text { Galvão }\end{array}$ & São Paulo & $\begin{array}{l}\text { São } \\
\text { Paulo }\end{array}$ & Brasil & 2 & 5 & $\begin{array}{l}\text { Oferecido ao Museu da Cúria pela } \\
\text { Associação de Santa Teresinha do } \\
\text { Menino Jesus, da Paróquia de } \\
\text { Santa Ifigênia, por intermédio de } \\
\text { sua presidente, Dona Margarida } \\
\text { Galvão. Anotação a lápis: Foi } \\
\text { riscado o no da sala (1) e substituído } \\
\text { pelo n 2, riscado o (x) do patamar e } \\
\text { acrescentado o nำ5 no mostruário. }\end{array}$ \\
\hline 581 & $\begin{array}{l}\text { Copo de bronze } \\
\text { lavrado }\end{array}$ & - & - & $\begin{array}{l}\text { Padre } \\
\text { Afonso Pozzi }\end{array}$ & - & - & - & 2 & 5 & 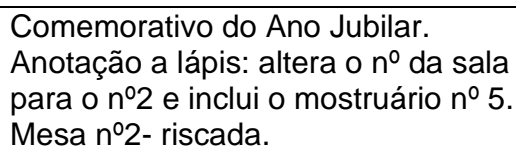 \\
\hline 582 & $\begin{array}{l}\text { Frasco com água } \\
\text { do Rio Jordão }\end{array}$ & - & - & - & - & - & Israel & 2 & 5 & $\begin{array}{l}\text { Anotação a lápis: Altera o } \mathrm{n}^{\circ} \text { da sala } \\
\text { para o } \mathrm{n}^{\circ} 2 \text { e inclui o no }{ }^{\circ} \text { do } \\
\text { mostruário } \mathrm{n}^{\circ} 5 \text {. Mesa nำ riscada }\end{array}$ \\
\hline 583 & $\begin{array}{l}\text { Frasco com água } \\
\text { do Rio Jordão }\end{array}$ & - & - & - & - & - & Israel & 2 & 5 & $\begin{array}{l}\text { Anotação a lápis: Altera o no da sala } \\
\text { para o } \mathrm{n}^{\circ} 2 \text { e inclui o } \mathrm{n}^{\circ} \mathrm{do} \\
\text { mostruário } \mathrm{n}^{\circ} 5 \text {. Mesa } \mathrm{n}^{\circ} \mathbf{2} \text { riscada }\end{array}$ \\
\hline
\end{tabular}




\begin{tabular}{|c|c|c|c|c|c|c|c|c|c|c|}
\hline № & Objeto & Procedência & Pertenceu a & Doado por & Cidade & Estado & País & Sala & Mostruário & Descrição / Observação \\
\hline 580 & Autógrafo & - & - & - & - & - & - & 2 & 6 & $\begin{array}{l}\text { Comunicação do falecimento do } \\
\text { Papa Pio IX e convite para o } \\
\text { subsequente Conclave que elegeria } \\
\text { o Papa Leão XII. Assinam três } \\
\text { Emmos. Srs. Cardeais e o } \\
\text { secretário, com os respectivos } \\
\text { sinetes. Anotação a lápis: Altera o } \\
\text { no da sala para no } 2 \text { e inclui o } \\
\text { mostruário nํ․ Mesa nำ -riscada. }\end{array}$ \\
\hline 609 & $\begin{array}{l}\text { Custódia de prata } \\
\text { dourada }\end{array}$ & - & - & $\begin{array}{l}\text { Guilherme } \\
\text { Guinle }\end{array}$ & - & - & - & 2 & 7 & 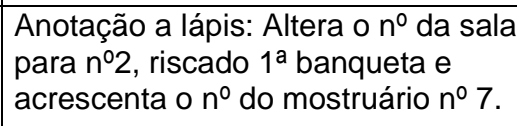 \\
\hline 1092 & $\begin{array}{l}\text { Caixa de madeira } \\
\text { forrada com couro }\end{array}$ & $\begin{array}{l}\text { Antiga Igreja } \\
\text { de M'boy }\end{array}$ & - & - & Embu & $\begin{array}{l}\text { São } \\
\text { Paulo }\end{array}$ & Brasil & 2 & Chão & $\begin{array}{l}\text { Onde era guardada a custódia de } \\
\text { prata catalogada sob o no } 1071 \text {. }\end{array}$ \\
\hline
\end{tabular}




\section{Sala expositiva 3}

A terceira sala expositiva apresentava 151 objetos e nos parece, depois da Sala 1, a com mais objetos ocupando todos os espaços da sala, uma vez que além de contar com um número grande de mostruários (8), ainda possuía uma mesa, 1 armário, diversos quadros, oratórios e sacrários pelas paredes e ainda objetos de grandes dimensões no chão, como a escultura de São Jorge e as cariátides da Capela do Palácio da Conceição, no Rio de Janeiro.

A respeito da escultura de São Jorge, em uma matéria do jornal O Estado de São Paulo de 1938 (p. 5), que traz a história dessa imagem utilizada nas procissões da cidade no século XIX, aponta que ela se encontrava exposta na terceira sala do "magnífico e glorioso" Museu da Cúria.

Nessa sala do Museu também vemos a intenção de agrupar objetos de uma mesma procedência, como nos mostruários 2 e 3, que concentram joias e objetos de prata da Ordem Terceira do Carmo de Santos, e no mostruário 6, que expunha cartões de prata oferecidos a Dom Duarte e doados ao Museu pelo mesmo.

Pelas paredes, os retratos dos bispos da diocese de São Paulo (Dom Bernardo Rodrigues Nogueira, Dom Frei Antônio da Madre de Deus Galvão, Dom Frei Manuel da Ressurreição, Dom Mateus de Abreu Pereira, Dom Manuel Joaquim Gonçalves de Andrade, Dom Antônio Joaquim de Melo, Dom Sebastião Pinto do Rego, Dom Lino Deodato Rodrigues de Carvalho, Dom Joaquim Arcoverde de Albuquerque Cavalcanti, Dom Antônio Cândido de Alvarenga, Dom José de Camargo Barros) com exceção do retrato de Dom Duarte Leopoldo e Silva e do 4ํㅡㅁispo de São Paulo, Dom Frei Miguel da Madre de Deus da Cruz, que não chegou a assumir a diocese ${ }^{55}$.

\footnotetext{
${ }^{55}$ Conforme explicação feita no Capítulo 2.1, nota 21, p. 57.
} 
Figura 66: Vista aérea Sala 3.
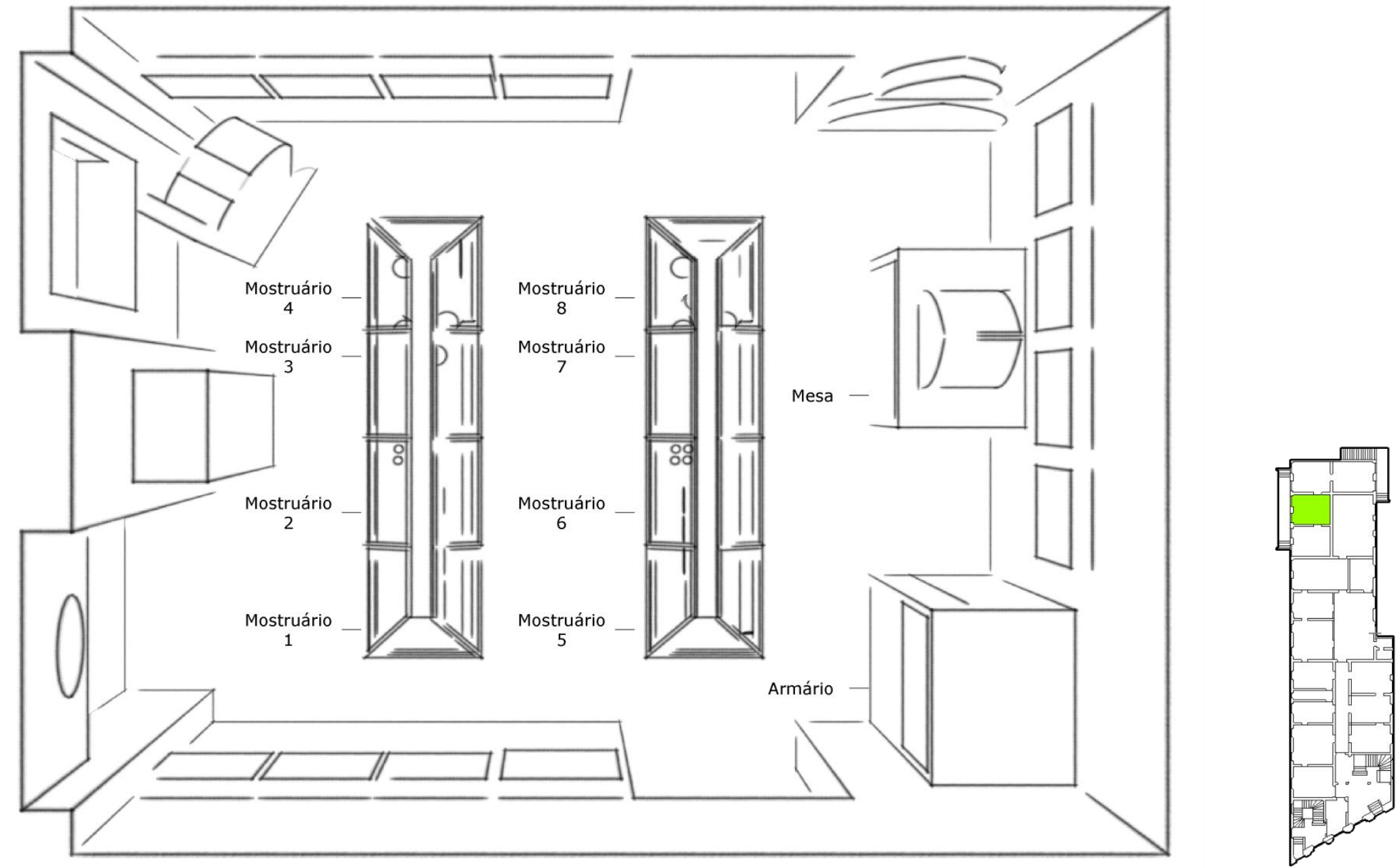

Desenho: Milena Cattini 
Figura 67: Perspectiva interna 1 da Sala 3.

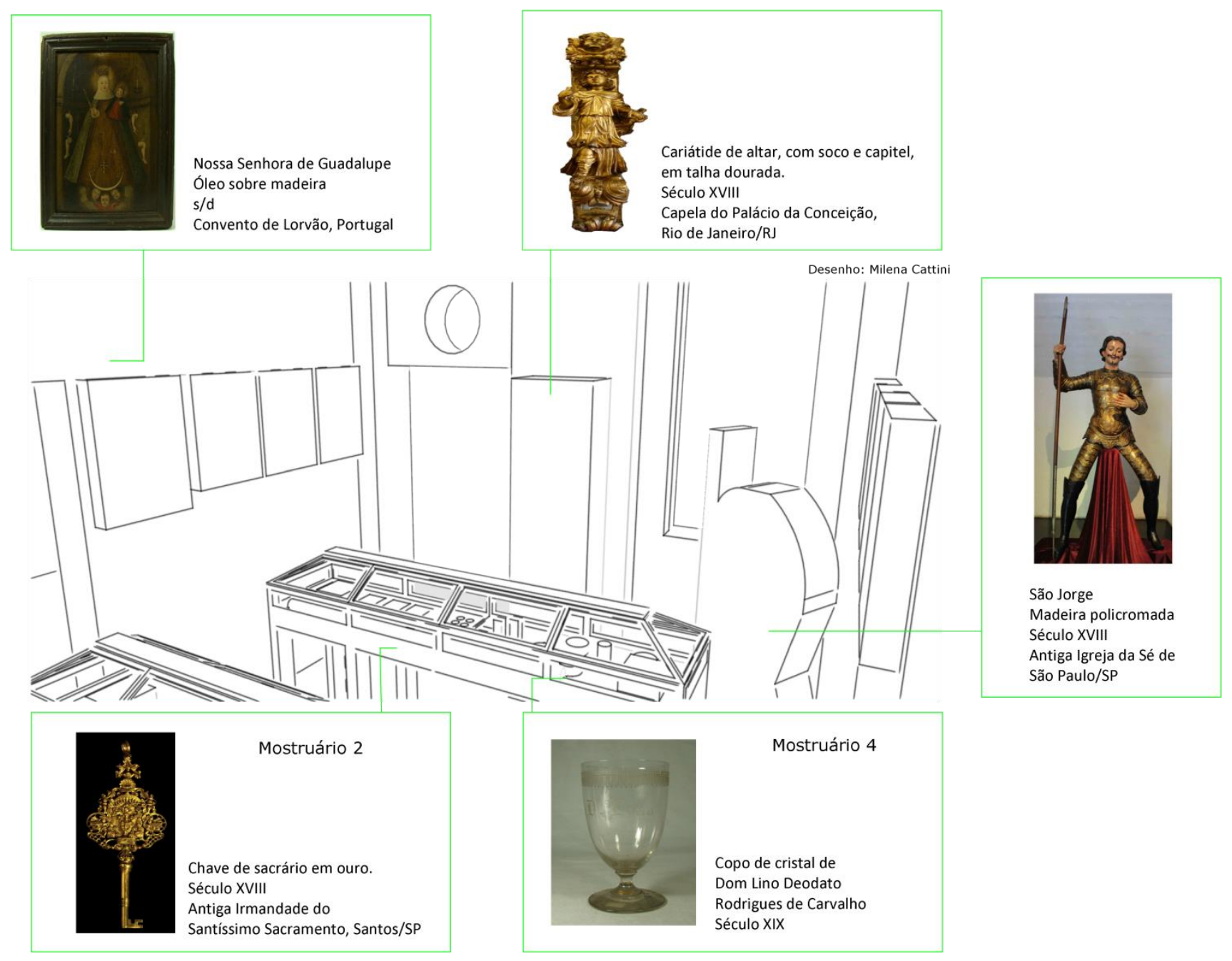


Figura 68: Perspectiva interna 2 da Sala 3.
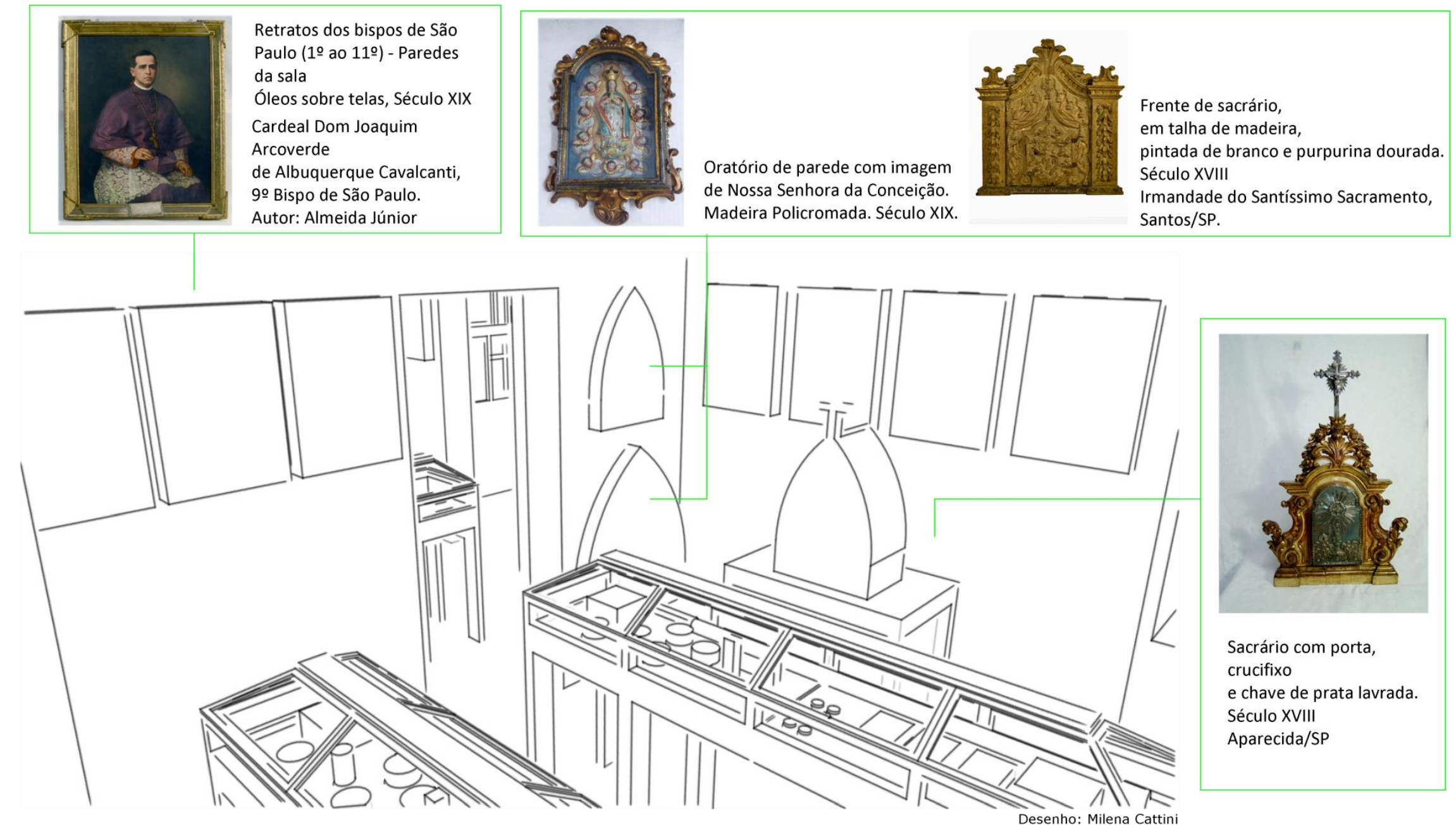
Tabela 7: Objetos expostos na Sala 3 do Museu da Cúria

\begin{tabular}{|c|c|c|c|c|c|c|c|c|c|c|}
\hline № & Objeto & Procedência & Pertenceu a & Doado por & Cidade & Estado & País & Sala & Mostruário & Descrição / Observação \\
\hline 27 & $\begin{array}{l}\text { Campa de } \\
\text { bronze, com } \\
\text { revestimento de } \\
\text { prata }\end{array}$ & $\begin{array}{l}\text { Irmandade do } \\
\text { SS. } \\
\text { Sacramento }\end{array}$ & - & - & Santos & $\begin{array}{l}\text { São } \\
\text { Paulo }\end{array}$ & Brasil & 3 & 1 & - \\
\hline 28 & $\begin{array}{l}\text { Três } \\
\text { abotoaduras de } \\
\text { ouro }\end{array}$ & $\begin{array}{l}\text { Venerável } \\
\text { Ordem } \\
\text { Terceira do } \\
\text { Carmo } \\
\end{array}$ & - & - & Santos & $\begin{array}{l}\text { São } \\
\text { Paulo }\end{array}$ & Brasil & 3 & 2 & - \\
\hline 28 & $\begin{array}{l}\text { Uma fivela de } \\
\text { ouro }\end{array}$ & $\begin{array}{l}\text { Venerável } \\
\text { Ordem } \\
\text { Terceira do } \\
\text { Carmo } \\
\end{array}$ & - & - & Santos & $\begin{array}{l}\text { São } \\
\text { Paulo }\end{array}$ & Brasil & 3 & 2 & - \\
\hline 28 & $\begin{array}{l}\text { Um anel de ouro } \\
\text { com pedra } \\
\text { ordinária }\end{array}$ & $\begin{array}{l}\text { Venerável } \\
\text { Ordem } \\
\text { Terceira do } \\
\text { Carmo }\end{array}$ & - & - & Santos & $\begin{array}{l}\text { São } \\
\text { Paulo }\end{array}$ & Brasil & 3 & 2 & - \\
\hline 28 & $\begin{array}{l}\text { Duas pulseiras } \\
\text { desenfiadas - } \\
\text { ouro, pérolas e } \\
\text { diamantes }\end{array}$ & $\begin{array}{l}\text { Venerável } \\
\text { Ordem } \\
\text { Terceira do } \\
\text { Carmo } \\
\end{array}$ & - & - & Santos & $\begin{array}{l}\text { São } \\
\text { Paulo }\end{array}$ & Brasil & 3 & 2 & - \\
\hline 28 & $\begin{array}{l}\text { Uma fivela de } \\
\text { prata }\end{array}$ & $\begin{array}{l}\text { Venerável } \\
\text { Ordem } \\
\text { Terceira do } \\
\text { Carmo } \\
\end{array}$ & - & - & Santos & $\begin{array}{l}\text { São } \\
\text { Paulo }\end{array}$ & Brasil & 3 & 2 & - \\
\hline 28 & $\begin{array}{l}\text { Duas pedras, } \\
\text { fantasia, com } \\
\text { aros de prata }\end{array}$ & $\begin{array}{l}\text { Venerável } \\
\text { Ordem } \\
\text { Terceira do } \\
\text { Carmo } \\
\end{array}$ & - & - & Santos & $\begin{array}{l}\text { São } \\
\text { Paulo }\end{array}$ & Brasil & 3 & 2 & - \\
\hline 30 & $\begin{array}{l}\text { Cruz de ouro, } \\
\text { em relicário } \\
\text { cravejado de } \\
\text { pedras } \\
\text { preciosas }\end{array}$ & - & $\begin{array}{l}\text { Monsenhor } \\
\text { Francisco de } \\
\text { Paula } \\
\text { Rodrigues } \\
\text { (Padre Chico) }\end{array}$ & - & - & - & - & 3 & 2 & - \\
\hline
\end{tabular}




\begin{tabular}{|c|c|c|c|c|c|c|c|c|c|c|}
\hline № & Objeto & Procedência & Pertenceu a & Doado por & Cidade & Estado & País & Sala & Mostruário & Descrição / Observação \\
\hline 31 & $\begin{array}{l}\begin{array}{l}\text { Relicário de } \\
\text { ouro }\end{array} \\
\end{array}$ & - & $\begin{array}{l}\text { Dom Lino } \\
\text { Deodato } \\
\text { Rodrigues de } \\
\text { Carvalho, } \\
\text { oitavo bispo de } \\
\text { São Paulo } \\
(1873-1894)\end{array}$ & - & - & - & - & 3 & 2 & - \\
\hline 34 & $\begin{array}{l}\text { Colherinha para } \\
\text { Missa }\end{array}$ & - & $\begin{array}{l}\text { Monsenhor } \\
\text { Francisco de } \\
\text { Paula } \\
\text { Rodrigues } \\
\text { (Padre Chico) }\end{array}$ & - & - & - & - & 3 & 2 & $\begin{array}{l}\text { Oferecida ao Monsenhor Dr. Francisco } \\
\text { de Paula Rodrigues (Padre Chico) por } \\
\text { ocasião do seu Jubileu Sacerdotal. A } \\
\text { moeda de que se fez a colherinha traz } \\
\text { a data do ano da sua ordenação. }\end{array}$ \\
\hline 40 & $\begin{array}{l}\text { Tabaqueira de } \\
\text { ouro }\end{array}$ & - & $\begin{array}{l}\text { Cônego } \\
\text { Antonio } \\
\text { Augusto Lessa }\end{array}$ & $\begin{array}{l}\text { Dom Duarte } \\
\text { Leopoldo e } \\
\text { Silva }\end{array}$ & - & - & - & 3 & 2 & $\begin{array}{l}\text { Cônego Antonio Augusto Lessa, } \\
\text { tesoureiro mor do Cabido e tesoureiro } \\
\text { da Caixa Pia. }\end{array}$ \\
\hline 45 & Agnus Dei & - & - & $\begin{array}{l}\text { Dom Duarte } \\
\text { Leopoldo e } \\
\text { Silva }\end{array}$ & São Paulo & $\begin{array}{l}\text { São } \\
\text { Paulo }\end{array}$ & Brasil & 3 & 2 & $\begin{array}{l}\text { Oferecido ao Exmo. Sr. Arcebispo D. } \\
\text { Duarte Leopoldo e Silva pela Superiora } \\
\text { e irmãs da Esperança - 22/05/1917. }\end{array}$ \\
\hline 46 & $\begin{array}{l}\text { Medalha de } \\
\text { ouro Jubileu de } \\
\text { Dom Joaquim } \\
\text { Arcoverde }\end{array}$ & - & - & - & - & - & - & 3 & 2 & $\begin{array}{l}\text { 1890-1915 - Dom Joaquim Arcoverde, } \\
\text { Arcebispo do Rio de Janeiro - } 26 \text { de } \\
\text { outubro. }\end{array}$ \\
\hline 50 & $\begin{array}{l}\text { Distintivo das } \\
\text { Irmãs da } \\
\text { Visitação }\end{array}$ & - & - & $\begin{array}{l}\text { Dom Duarte } \\
\text { Leopoldo e } \\
\text { Silva }\end{array}$ & - & - & - & 3 & 2 & - \\
\hline 28 & $\begin{array}{l}\text { Sete pares de } \\
\text { brincos de ouro, } \\
\text { sendo dois } \\
\text { grandes, três } \\
\text { médios e dois } \\
\text { pequenos }\end{array}$ & $\begin{array}{l}\text { Venerável } \\
\text { Ordem } \\
\text { Terceira do } \\
\text { Carmo }\end{array}$ & - & - & Santos & \begin{tabular}{|l|} 
São \\
Paulo
\end{tabular} & Brasil & 3 & 3 & - \\
\hline
\end{tabular}




\begin{tabular}{|c|c|c|c|c|c|c|c|c|c|c|}
\hline № & Objeto & Procedência & Pertenceu a & Doado por & Cidade & Estado & País & Sala & Mostruário & Descrição / Observação \\
\hline 28 & $\begin{array}{l}\text { Três anéis com } \\
\text { pedras grandes }\end{array}$ & $\begin{array}{l}\text { Venerável } \\
\text { Ordem } \\
\text { Terceira do } \\
\text { Carmo } \\
\end{array}$ & - & - & Santos & \begin{tabular}{|l|} 
São \\
Paulo
\end{tabular} & Brasil & 3 & 3 & - \\
\hline 28 & $\begin{array}{l}\text { Um broche - } \\
\text { peça fantasia, } \\
\text { de ouro, com } \\
\text { pedras }\end{array}$ & $\begin{array}{l}\text { Venerável } \\
\text { Ordem } \\
\text { Terceira do } \\
\text { Carmo }\end{array}$ & - & - & Santos & $\begin{array}{l}\text { São } \\
\text { Paulo }\end{array}$ & Brasil & 3 & 3 & - \\
\hline 28 & $\begin{array}{l}\text { Três brincos de } \\
\text { prata }\end{array}$ & $\begin{array}{l}\text { Venerável } \\
\text { Ordem } \\
\text { Terceira do } \\
\text { Carmo } \\
\end{array}$ & - & - & Santos & $\begin{array}{l}\text { São } \\
\text { Paulo }\end{array}$ & Brasil & 3 & 3 & - \\
\hline 28 & $\begin{array}{l}\text { Quatro broches } \\
\text { de prata, sendo } \\
\text { um grande e } \\
\text { três pequenos, } \\
\text { com pedras }\end{array}$ & $\begin{array}{l}\text { Venerável } \\
\text { Ordem } \\
\text { Terceira do } \\
\text { Carmo }\end{array}$ & - & - & Santos & \begin{tabular}{|l|} 
São \\
Paulo
\end{tabular} & Brasil & 3 & 3 & - \\
\hline 28 & $\begin{array}{l}\text { Um botão de } \\
\text { prata, com } \\
\text { pedras }\end{array}$ & $\begin{array}{l}\text { Venerável } \\
\text { Ordem } \\
\text { Terceira do } \\
\text { Carmo }\end{array}$ & - & - & Santos & $\begin{array}{l}\text { São } \\
\text { Paulo }\end{array}$ & Brasil & 3 & 3 & - \\
\hline 28 & $\begin{array}{l}\text { Um par de } \\
\text { brincos, prata } \\
\text { dourada }\end{array}$ & $\begin{array}{l}\text { Venerável } \\
\text { Ordem } \\
\text { Terceira do } \\
\text { Carmo } \\
\end{array}$ & - & - & Santos & $\begin{array}{l}\text { São } \\
\text { Paulo }\end{array}$ & Brasil & 3 & 3 & e \\
\hline 29 & $\begin{array}{l}\text { Um par de } \\
\text { brincos antigos } \\
\text { (pingentes) - de } \\
\text { ouro e } \\
\text { brilhantes } \\
\end{array}$ & $\begin{array}{l}\text { Paróquia do } \\
\text { Brás }\end{array}$ & - & - & São Paulo & \begin{tabular}{|l|} 
São \\
Paulo
\end{tabular} & Brasil & 3 & 3 & Pertenceu à imagem de Sant'Anna. \\
\hline 32 & $\begin{array}{l}\text { Duas cruzes } \\
\text { peitorais, de } \\
\text { ouro }\end{array}$ & - & - & - & São Paulo & $\begin{array}{l}\text { São } \\
\text { Paulo }\end{array}$ & Brasil & 3 & 3 & Dos primeiros bispos de São Paulo. \\
\hline 47 & $\begin{array}{l}\text { Joias antigas } \\
\text { (três peças) }\end{array}$ & - & - & - & Itanhaém & \begin{tabular}{|l|} 
São \\
Paulo
\end{tabular} & Brasil & 3 & 3 & - \\
\hline
\end{tabular}




\begin{tabular}{|c|c|c|c|c|c|c|c|c|c|c|}
\hline № & Objeto & Procedência & Pertenceu a & Doado por & Cidade & Estado & País & Sala & Mostruário & Descrição / Observação \\
\hline 26 & $\begin{array}{l}\text { Purificador de } \\
\text { metal branco }\end{array}$ & $\begin{array}{l}\text { Irmandade do } \\
\text { SS. } \\
\text { Sacramento }\end{array}$ & - & - & Santos & \begin{tabular}{|l|} 
São \\
Paulo
\end{tabular} & Brasil & 3 & 4 & - \\
\hline 37 & $\begin{array}{l}\text { Fotografia do } \\
\text { padre Fabiano } \\
\text { José Moreira de } \\
\text { Camargo }\end{array}$ & - & - & $\begin{array}{l}\text { Cônego } \\
\text { Martins } \\
\text { Ladeira }\end{array}$ & - & - & - & 3 & 4 & $\begin{array}{l}\text { Fotografia do padre Fabiano José } \\
\text { Moreira de Camargo, segundo } \\
\text { informações de Monsenhor Ezechias } \\
\text { Galvão da Fontoura. Pertenceu ao sr. } \\
\text { José Pereira Bueno, que a ofereceu, } \\
\text { em dezembro de 1920, ao então sr. } \\
\text { Conego Martins Ladeira, o qual, por } \\
\text { sua vez, fez dela presente ao Museu } \\
\text { da Cúria Metropolitana. O Padre } \\
\text { Fabiano José Moreira de Camargo era } \\
\text { natural de Sorocaba, onde nasceu aos } \\
4 \text { de junho de } 1807 \text { (cfr. autos de } \\
\text { gênero, } 2.68 .1343 \text { - fls.5), filho legítimo } \\
\text { de Manoel Aleves Moreira e Maria } \\
\text { Custodia de Camargo. Foi vigário } \\
\text { colado de Capivari, por prisão de treze } \\
\text { de fevereiro de } 1839 \text {. }\end{array}$ \\
\hline 38 & $\begin{array}{l}\text { Vaso para os } \\
\text { Santos óleos }\end{array}$ & - & $\begin{array}{l}\text { Dom Manoel } \\
\text { da } \\
\text { Ressureição, } \\
\text { terceiro bispo } \\
\text { de São Paulo } \\
(1774-1789) \\
\end{array}$ & - & - & - & - & 3 & 4 & ( \\
\hline 39 & Cálice de prata & $\begin{array}{l}\text { Irmandade do } \\
\text { SS. } \\
\text { Sacramento }\end{array}$ & - & - & Santos & \begin{tabular}{|l|} 
São \\
Paulo
\end{tabular} & Brasil & 3 & 4 & $\begin{array}{l}\text { Este cálice era levado nas procissões } \\
\text { do Enterro de Maria Madalena, } \\
\text { personagem bíblica, que, com S. João } \\
\text { Evangelista (João Guarino), as } 3 \\
\text { Marias (as Beús), a Veronica e o } \\
\text { Centurião Romano, costumava figurar } \\
\text { naquelas procissões acompanhando o } \\
\text { Senhor Morto. }\end{array}$ \\
\hline
\end{tabular}




\begin{tabular}{|c|c|c|c|c|c|c|c|c|c|c|}
\hline № & Objeto & Procedência & Pertenceu a & Doado por & Cidade & Estado & País & Sala & Mostruário & Descrição / Observação \\
\hline 49 & Fivela antiga & - & - & - & São Paulo & \begin{tabular}{|l|} 
São \\
Paulo
\end{tabular} & Brasil & 3 & 4 & - \\
\hline 51 & Copo de cristal & - & $\begin{array}{l}\text { Dom Lino } \\
\text { Deodato } \\
\text { Rodrigues de } \\
\text { Carvalho, } \\
\text { oitavo bispo de } \\
\text { São Paulo } \\
(1873-1894) \\
\end{array}$ & $\begin{array}{l}\text { Dom Duarte } \\
\text { Leopoldo e } \\
\text { Silva }\end{array}$ & - & - & - & 3 & 4 & - \\
\hline 52 & $\begin{array}{l}\text { Distintivo da } \\
\text { Venerável } \\
\text { Ordem Terceira } \\
\text { do Carmo }\end{array}$ & - & $\begin{array}{l}\text { Bernardo } \\
\text { Leopoldo e } \\
\text { Silva, pai de D. } \\
\text { Duarte }\end{array}$ & $\begin{array}{l}\text { Dom Duarte } \\
\text { Leopoldo e } \\
\text { Silva }\end{array}$ & - & \begin{tabular}{|l|} 
São \\
Paulo
\end{tabular} & Brasil & 3 & 4 & - \\
\hline 41 & Cartão de ouro & $\begin{array}{l}\text { Palácio São } \\
\text { Luiz }\end{array}$ & - & $\begin{array}{l}\text { Dom Duarte } \\
\text { Leopoldo e } \\
\text { Silva }\end{array}$ & São Paulo & \begin{tabular}{|l|} 
São \\
Paulo
\end{tabular} & Brasil & 3 & 6 & $\begin{array}{l}\text { Acompanhou o quadro "A Esmola", do } \\
\text { pintor Paulo do Valle, existente no } \\
\text { Palácio São Luiz. Traz os nomes dos } \\
\text { doadores do quadro. }\end{array}$ \\
\hline 42 & $\begin{array}{l}\text { Cartão de prata } \\
\text { e ouro }\end{array}$ & - & - & $\begin{array}{l}\text { Dom Duarte } \\
\text { Leopoldo e } \\
\text { Silva }\end{array}$ & São Paulo & \begin{tabular}{|l|} 
São \\
Paulo
\end{tabular} & Brasil & 3 & 6 & $\begin{array}{l}\text { Oferecido ao Exmo. Sr. Arcebispo D. } \\
\text { Duarte Leopoldo e Silva pela Escola } \\
\text { Normal do Brás. }\end{array}$ \\
\hline 43 & Cartão de prata & - & - & $\begin{array}{l}\text { Dom Duarte } \\
\text { Leopoldo e } \\
\text { Silva }\end{array}$ & São Paulo & \begin{tabular}{|l|} 
São \\
Paulo
\end{tabular} & Brasil & 3 & 6 & $\begin{array}{l}\text { Oferecido ao Exmo. Sr. Arcebispo D. } \\
\text { Duarte Leopoldo e Silva pelas } \\
\text { professorandas de } 1917 .\end{array}$ \\
\hline 44 & Cartão de prata & - & - & $\begin{array}{l}\text { Dom Duarte } \\
\text { Leopoldo e } \\
\text { Silva }\end{array}$ & São Paulo & \begin{tabular}{|l|} 
São \\
Paulo
\end{tabular} & Brasil & 3 & 6 & $\begin{array}{l}\text { Oferecido ao Exmo. Sr. Arcebispo D. } \\
\text { Duarte Leopoldo e Silva pelos } \\
\text { bacharéis de } 1916 \text { - Faculdade de } \\
\text { Direito de São Paulo. }\end{array}$ \\
\hline 28 & $\begin{array}{l}\text { Uma } \\
\text { abotoadura de } \\
\text { prata }\end{array}$ & $\begin{array}{l}\text { Venerável } \\
\text { Ordem } \\
\text { Terceira do } \\
\text { Carmo }\end{array}$ & - & - & Santos & \begin{tabular}{|l|} 
São \\
Paulo
\end{tabular} & Brasil & 3 & 9 & - \\
\hline
\end{tabular}




\begin{tabular}{|c|c|c|c|c|c|c|c|c|c|c|}
\hline № & Objeto & Procedência & Pertenceu a & Doado por & Cidade & Estado & País & Sala & Mostruário & Descrição / Observação \\
\hline 28 & $\begin{array}{l}\text { Uma estrela de } \\
\text { prata }\end{array}$ & $\begin{array}{l}\text { Venerável } \\
\text { Ordem } \\
\text { Terceira do } \\
\text { Carmo }\end{array}$ & - & - & Santos & \begin{tabular}{|l|} 
São \\
Paulo
\end{tabular} & Brasil & 3 & 9 & - \\
\hline 28 & $\begin{array}{l}\text { Um espadim de } \\
\text { prata }\end{array}$ & $\begin{array}{l}\text { Venerável } \\
\text { Ordem } \\
\text { Terceira do } \\
\text { Carmo }\end{array}$ & - & - & Santos & \begin{tabular}{|l|} 
São \\
Paulo
\end{tabular} & Brasil & 3 & 9 & - \\
\hline 36 & Sinete & - & $\begin{array}{l}\text { Dom Francisco } \\
\text { de Campos } \\
\text { Barreto, bispo } \\
\text { de Pelotas }\end{array}$ & - & - & - & - & 3 & 10 & - \\
\hline 28 & $\begin{array}{l}\text { Duas chaves de } \\
\text { sacrário, de } \\
\text { prata }\end{array}$ & $\begin{array}{l}\text { Venerável } \\
\text { Ordem } \\
\text { Terceira do } \\
\text { Carmo }\end{array}$ & - & - & Santos & \begin{tabular}{|l|} 
São \\
Paulo
\end{tabular} & Brasil & 3 & 12 & - \\
\hline 28 & $\begin{array}{l}\text { Um resplendor } \\
\text { de prata }\end{array}$ & \begin{tabular}{|l} 
Venerável \\
Ordem \\
Terceira do \\
Carmo \\
\end{tabular} & - & - & Santos & \begin{tabular}{|l|} 
São \\
Paulo
\end{tabular} & Brasil & 3 & 12 & - \\
\hline 28 & $\begin{array}{l}\text { Duas rosetas } \\
\text { com fios de ouro }\end{array}$ & $\begin{array}{l}\text { Venerável } \\
\text { Ordem } \\
\text { Terceira do } \\
\text { Carmo }\end{array}$ & - & - & Santos & $\begin{array}{l}\text { São } \\
\text { Paulo }\end{array}$ & Brasil & 3 & 12 & - \\
\hline 10 & $\begin{array}{l}\text { Toalha bordada } \\
\text { a ouro }\end{array}$ & $\begin{array}{l}\text { Igreja } \\
\text { Paroquial de } \\
\text { Nossa } \\
\text { Senhora da } \\
\text { Conceição de } \\
\text { Guarulhos }\end{array}$ & - & - & Guarulhos & \begin{tabular}{|l|} 
São \\
Paulo
\end{tabular} & Brasil & 3 & - & - \\
\hline
\end{tabular}




\begin{tabular}{|c|c|c|c|c|c|c|c|c|c|c|}
\hline № & Objeto & Procedência & Pertenceu a & Doado por & Cidade & Estado & País & Sala & Mostruário & Descrição / Observação \\
\hline 14 & $\begin{array}{l}\text { Lâmpadas de } \\
\text { pratas (dois } \\
\text { exemplares) }\end{array}$ & $\begin{array}{l}\text { Capela da } \\
\text { extinta } \\
\text { irmandade do } \\
\text { SS. } \\
\text { Sacramento }\end{array}$ & - & - & Santos & $\begin{array}{l}\text { São } \\
\text { Paulo }\end{array}$ & Brasil & 3 & - & $\begin{array}{l}\text { Nota: no dia } 9 \text { de julho de 1928, } \\
\text { conforme ordem por escrito do Exmo. } \\
\text { Sr. Arcebispo Metropolitano, foi } \\
\text { entregue pessoalmente, pelo Diretor } \\
\text { do Museu, ao Exmo. Sr. Bispo de } \\
\text { Santos - D. José Maria Parreira Lara, } \\
\text { uma lâmpada de prata completa e } \\
\text { perfeita, registrada no museu sob o } \\
\text { n14. }\end{array}$ \\
\hline 25 & $\begin{array}{l}\text { Duas lanternas } \\
\text { de metal branco }\end{array}$ & $\begin{array}{l}\text { Irmandade do } \\
\text { SS. } \\
\text { Sacramento }\end{array}$ & - & - & Santos & $\begin{array}{l}\text { São } \\
\text { Paulo }\end{array}$ & Brasil & $\begin{array}{l}\text { 3-sobre a } \\
\text { porta }\end{array}$ & - & - \\
\hline 28 & Um anel de ouro & $\begin{array}{l}\text { Venerável } \\
\text { Ordem } \\
\text { Terceira do } \\
\text { Carmo }\end{array}$ & - & - & Santos & $\begin{array}{l}\text { São } \\
\text { Paulo }\end{array}$ & Brasil & 3 & - & - \\
\hline 28 & $\begin{array}{l}\text { Dois pares de } \\
\text { brincos de prata }\end{array}$ & $\begin{array}{l}\text { Venerável } \\
\text { Ordem } \\
\text { Terceira do } \\
\text { Carmo }\end{array}$ & - & - & Santos & $\begin{array}{l}\text { São } \\
\text { Paulo }\end{array}$ & Brasil & 3 & - & - \\
\hline 33 & $\begin{array}{l}\text { Comenda de S. } \\
\text { Gonçalo Magno }\end{array}$ & - & - & - & - & - & - & 3 & - & - \\
\hline 35 & $\begin{array}{l}\text { Medalha de } \\
\text { ouro }\end{array}$ & - & - & $\begin{array}{l}\text { Dom Duarte } \\
\text { Leopoldo e } \\
\text { Silva }\end{array}$ & São Paulo & $\begin{array}{l}\text { São } \\
\text { Paulo }\end{array}$ & Brasil & 3 & - & $\begin{array}{l}\text { Representando a igreja de Santa } \\
\text { Cecilia, oferecida ao exmo. Sr. D. } \\
\text { Duarte Leopoldo e Silva. }\end{array}$ \\
\hline 132 & Crucifixo & - & - & - & - & - & - & 3-parede & - & $\begin{array}{l}\text { Imagem de chumbo colorido. Cruz de } \\
\text { madeira (pintada de preto) com } \\
\text { taboinha - I.N.R.I. - de prata. As } \\
\text { extremidades dos braços e topo da } \\
\text { cruz revestidos de adornos de prata } \\
\text { lavrada. }\end{array}$ \\
\hline
\end{tabular}




\begin{tabular}{|c|c|c|c|c|c|c|c|c|c|c|}
\hline № & Objeto & Procedência & Pertenceu a & Doado por & Cidade & Estado & País & Sala & Mostruário & Descrição / Observação \\
\hline 324 & $\begin{array}{l}\text { Oratório antigo } \\
\text { contendo uma } \\
\text { imagem do } \\
\text { Menino Jesus }\end{array}$ & - & - & $\begin{array}{l}\text { Dom Duarte } \\
\text { Leopoldo e } \\
\text { Silva }\end{array}$ & Mariana & $\begin{array}{l}\text { Minas } \\
\text { Gerais }\end{array}$ & Brasil & 3-parede & - & $\begin{array}{l}\text { Belíssima escultura de madeira., } \\
\text { trabalho antigo e de alto valor artístico, } \\
\text { procedente de Mariana. }\end{array}$ \\
\hline 392 & $\begin{array}{l}\text { Quadro a óleo } \\
\text { de madeira, } \\
\text { representando } \\
\text { Nossa Senhora } \\
\text { de Guadalupe. }\end{array}$ & $\begin{array}{l}\text { Convento de } \\
\text { Lorvão }\end{array}$ & - & $\begin{array}{l}\text { Dom Duarte } \\
\text { Leopoldo e } \\
\text { Silva }\end{array}$ & Lorvão & - & Portugal & 3-parede & - & $\begin{array}{l}\text { Trabalho muito antigo trazido do } \\
\text { Convento de Lorvão, Portugal, pelo Sr. } \\
\text { Gonçalo Coimbra e por este oferecido } \\
\text { ao Exmo. Sr. Arcebispo Dom Duarte } \\
\text { Leopoldo e Silva, o qual, por sua vez, } \\
\text { o ofereceu ao Museu da Cúria. } \\
\text { Anotação a lápis : Casa do } \\
\text { Bandeirante. }\end{array}$ \\
\hline 418 & $\begin{array}{l}\text { Colcha bordada } \\
\text { a ouro }\end{array}$ & $\begin{array}{l}\text { Palácio São } \\
\text { Cristóvão }\end{array}$ & - & $\begin{array}{l}\text { Dona Anna } \\
\text { Emilia } \\
\text { Fonseca de } \\
\text { Queiroz } \\
\text { Telles }\end{array}$ & $\begin{array}{l}\text { Rio de } \\
\text { Janeiro }\end{array}$ & \begin{tabular}{|l|} 
Rio de \\
Janeiro
\end{tabular} & Brasil & 3-parede & - & $\begin{array}{l}\text { Que guarnecia uma das mesas do } \\
\text { gabinete particular de Sua Majestade } \\
\text { Dom Pedro II, Imperador do Brasil, no } \\
\text { seu Palácio de São Cristóvão. } \\
\text { Arrematada em leilão de objetos que } \\
\text { pertenceram ao antigo monarca e } \\
\text { oferecida ao Dr. Jorge Tibiriçá, quando } \\
\text { Presidente do Estado de São Paulo, e } \\
\text { por este à Exma. Sra. Baronesa de } \\
\text { Jundiai. Dádiva da Exma. Sr. Dona } \\
\text { Anna Emilia Fonseca de Queiroz } \\
\text { Telles ao Museu da Cúria. }\end{array}$ \\
\hline 445 & $\begin{array}{l}\text { Porta do } \\
\text { Comungatório }\end{array}$ & $\begin{array}{l}\text { Velho } \\
\text { Convento de } \\
\text { Santa Teresa }\end{array}$ & - & $\begin{array}{l}\text { Francisco de } \\
\text { Salles Collet } \\
\text { e Silva, } \\
\text { diretor do } \\
\text { Arquivo e } \\
\text { Museu da } \\
\text { Cúria } \\
\end{array}$ & $\begin{array}{l}\text { Rio de } \\
\text { Janeiro }\end{array}$ & \begin{tabular}{|l|} 
Rio de \\
Janeiro
\end{tabular} & Brasil & 3-parede & - & $\begin{array}{l}\text { Edificado em 1685, por Dom José de } \\
\text { Barros Alarcon, primeiro Bispo do Rio } \\
\text { de janeiro. }\end{array}$ \\
\hline
\end{tabular}




\begin{tabular}{|c|c|c|c|c|c|c|c|c|c|c|}
\hline № & Objeto & Procedência & Pertenceu a & Doado por & Cidade & Estado & País & Sala & Mostruário & Descrição / Observação \\
\hline 447 & $\begin{array}{l}\text { Bandeira do } 7^{0} \\
\text { de Voluntários }\end{array}$ & - & - & - & São Paulo & \begin{tabular}{|l|} 
São \\
Paulo
\end{tabular} & Brasil & $\begin{array}{l}\text { 3-armário } \\
\text { de canto }\end{array}$ & - & Ver ANEXO C. \\
\hline 538 & $\begin{array}{l}\text { Duas cariátides } \\
\text { folhadas a ouro }\end{array}$ & $\begin{array}{l}\text { Altar-Mor da } \\
\text { Capela do } \\
\text { Palácio da } \\
\text { Conceição }\end{array}$ & - & \begin{tabular}{|l|} 
Dom \\
Sebastião \\
Leme da \\
Silveira \\
Cintra, \\
Arcebispo \\
do Rio de \\
Janeiro \\
\end{tabular} & \begin{tabular}{|l|} 
Rio de \\
Janeiro
\end{tabular} & \begin{tabular}{|l|} 
Rio de \\
Janeiro
\end{tabular} & Brasil & 3 & - & $\begin{array}{l}\text { Riquíssimo trabalho de arte antiga, } \\
\text { procedente do citado Palácio, } \\
\text { residência episcopal do Rio de Janeiro. }\end{array}$ \\
\hline 563 & $\begin{array}{l}\text { Porta do } \\
\text { sacrário }\end{array}$ & $\begin{array}{l}\text { Antiga Capela } \\
\text { da extinta } \\
\text { Irmandade do } \\
\text { S. Sacramento }\end{array}$ & - & - & Santos & \begin{tabular}{|l|} 
São \\
Paulo
\end{tabular} & Brasil & 3 & - & - \\
\hline 564 & $\begin{array}{l}\text { Tradicional } \\
\text { Imagem de } \\
\text { Sant'Ana }\end{array}$ & $\begin{array}{l}\text { Primitiva } \\
\text { Capela de } \\
\text { Parnaíba }\end{array}$ & - & $\begin{array}{l}\text { Francisco de } \\
\text { Salles Collet } \\
\text { e Silva, } \\
\text { diretor do } \\
\text { Arquivo e } \\
\text { Museu da } \\
\text { Cúria } \\
\end{array}$ & $\begin{array}{l}\text { Santana } \\
\text { de } \\
\text { Parnaíba }\end{array}$ & \begin{tabular}{|l|} 
São \\
Paulo
\end{tabular} & Brasil & 3 & - & Ver ANEXO C. \\
\hline 801 & $\begin{array}{l}\text { Sacrário com } \\
\text { porta revestida } \\
\text { em prata, chave } \\
\text { e crucifixo } \\
\text { também de } \\
\text { prata }\end{array}$ & - & - & - & Aparecida & \begin{tabular}{|l|} 
São \\
Paulo
\end{tabular} & Brasil & 3 & - & - \\
\hline 802 & $\begin{array}{l}\text { Cinzeiro e } \\
\text { fosfeira de ferro } \\
\text { com pé }\end{array}$ & - & - & - & - & - & - & 3 & - & - \\
\hline 883 & $\begin{array}{l}\text { Imagem } \\
\text { mutilada de São } \\
\text { Francisco } \\
\text { Xavier, de } \\
\text { marfim }\end{array}$ & - & - & - & - & - & - & 3 & - & - \\
\hline
\end{tabular}




\begin{tabular}{|c|c|c|c|c|c|c|c|c|c|c|}
\hline № & Objeto & Procedência & Pertenceu a & Doado por & Cidade & Estado & País & Sala & Mostruário & Descrição / Observação \\
\hline 887 & $\begin{array}{l}\text { Antiga lâmpada } \\
\text { de prata }\end{array}$ & - & - & - & - & - & - & $\begin{array}{l}\text { 3- } \\
\text { pendente }\end{array}$ & - & - \\
\hline 888 & $\begin{array}{l}\text { Antiga lâmpada } \\
\text { de prata }\end{array}$ & - & - & - & - & - & - & $\begin{array}{l}\text { 3- } \\
\text { pendente }\end{array}$ & - & - \\
\hline 889 & $\begin{array}{l}\text { Lâmpada de } \\
\text { metal prateado }\end{array}$ & - & - & - & - & - & - & $\begin{array}{l}\text { 3- } \\
\text { pendente }\end{array}$ & - & - \\
\hline 890.1 & $\begin{array}{l}\text { Lustre para seis } \\
\text { velas }\end{array}$ & - & $\begin{array}{l}\text { Monsenhor } \\
\text { João de Barros } \\
\text { Uchôa }\end{array}$ & - & - & - & - & $\begin{array}{l}\text { 3- } \\
\text { pendente }\end{array}$ & - & $\begin{array}{l}\text { №s 890: Coleção de objetos de } \\
\text { madeira dourados. }\end{array}$ \\
\hline 890.2 & $\begin{array}{l}\text { Idem para três } \\
\text { velas }\end{array}$ & - & $\begin{array}{l}\text { Monsenhor } \\
\text { João de Barros } \\
\text { Uchôa }\end{array}$ & - & - & - & - & $\begin{array}{l}\text { 3- } \\
\text { pendente }\end{array}$ & - & $\begin{array}{l}\text { №s 890: Coleção de objetos de } \\
\text { madeira dourados. }\end{array}$ \\
\hline 890.3 & $\begin{array}{l}\text { Idem menor, } \\
\text { para três velas }\end{array}$ & - & $\begin{array}{l}\text { Monsenhor } \\
\text { João de Barros } \\
\text { Uchôa }\end{array}$ & - & - & - & - & $\begin{array}{l}3- \\
\text { pendente }\end{array}$ & - & $\begin{array}{l}\text { №s 890: Coleção de objetos de } \\
\text { madeira dourados. }\end{array}$ \\
\hline 890.4 & $\begin{array}{l}\text { Idem, para três } \\
\text { lâmpadas }\end{array}$ & - & $\begin{array}{l}\text { Monsenhor } \\
\text { João de Barros } \\
\text { Uchôa }\end{array}$ & - & - & - & - & $\begin{array}{l}\text { 3- } \\
\text { pendente }\end{array}$ & - & $\begin{array}{l}\text { №s 890: Coleção de objetos de } \\
\text { madeira dourados. }\end{array}$ \\
\hline 890.5 & Lanterna & - & $\begin{array}{l}\text { Monsenhor } \\
\text { João de Barros } \\
\text { Uchôa }\end{array}$ & - & - & - & - & $\begin{array}{l}3- \\
\text { pendente }\end{array}$ & - & $\begin{array}{l}\text { №-s 890: Coleção de objetos de } \\
\text { madeira dourados. }\end{array}$ \\
\hline 890.6 & $\begin{array}{l}\text { Dois } \\
\text { candelabros de } \\
\text { mesa }\end{array}$ & - & $\begin{array}{l}\text { Monsenhor } \\
\text { João de Barros } \\
\text { Uchôa }\end{array}$ & - & - & - & - & 3-mesa & - & $\begin{array}{l}\text { №s 890: Coleção de objetos de } \\
\text { madeira dourados. }\end{array}$ \\
\hline 890.7 & $\begin{array}{l}\text { Dois castiçais } \\
\text { maiores }\end{array}$ & - & $\begin{array}{l}\text { Monsenhor } \\
\text { João de Barros } \\
\text { Uchôa }\end{array}$ & - & - & - & - & 3-mesa & - & $\begin{array}{l}\text { №s 890: Coleção de objetos de } \\
\text { madeira dourados. }\end{array}$ \\
\hline
\end{tabular}




\begin{tabular}{|c|c|c|c|c|c|c|c|c|c|c|}
\hline № & Objeto & Procedência & Pertenceu a & Doado por & Cidade & Estado & País & Sala & Mostruário & Descrição / Observação \\
\hline 890.8 & $\begin{array}{l}\text { Dois castiçais } \\
\text { médios }\end{array}$ & - & $\begin{array}{l}\text { Monsenhor } \\
\text { João de Barros } \\
\text { Uchôa }\end{array}$ & - & - & - & - & 3-mesa & - & $\begin{array}{l}\text { №s 890: Coleção de objetos de } \\
\text { madeira dourados. }\end{array}$ \\
\hline 890.9 & $\begin{array}{l}\text { Dois castiçais } \\
\text { pequenos }\end{array}$ & - & $\begin{array}{l}\text { Monsenhor } \\
\text { João de Barros } \\
\text { Uchôa }\end{array}$ & - & - & - & - & 3-mesa & - & $\begin{array}{l}\text { №s 890: Coleção de objetos de } \\
\text { madeira dourados. }\end{array}$ \\
\hline 890.10 & $\begin{array}{l}\text { Castiçal } \\
\text { pequeno }\end{array}$ & - & $\begin{array}{l}\text { Monsenhor } \\
\text { João de Barros } \\
\text { Uchôa }\end{array}$ & - & - & - & - & 3-mesa & - & $\begin{array}{l}\text { №s 890: Coleção de objetos de } \\
\text { madeira dourados. }\end{array}$ \\
\hline 890.11 & $\begin{array}{l}\text { Três taças ou } \\
\text { fruteiras }\end{array}$ & - & $\begin{array}{l}\text { Monsenhor } \\
\text { João de Barros } \\
\text { Uchôa }\end{array}$ & - & - & - & - & 3-mesa & - & $\begin{array}{l}\text { №s 890: Coleção de objetos de } \\
\text { madeira dourados. }\end{array}$ \\
\hline 890.12 & $\begin{array}{l}\text { Taça ou fruteira } \\
\text { menor }\end{array}$ & - & $\begin{array}{l}\text { Monsenhor } \\
\text { João de Barros } \\
\text { Uchôa }\end{array}$ & - & - & - & - & 3-mesa & - & $\begin{array}{l}\text { №s 890: Coleção de objetos de } \\
\text { madeira dourados. }\end{array}$ \\
\hline 890.13 & Três arandelas & - & $\begin{array}{l}\text { Monsenhor } \\
\text { João de Barros } \\
\text { Uchôa }\end{array}$ & - & - & - & - & 3-parede & - & $\begin{array}{l}\text { №s 890: Coleção de objetos de } \\
\text { madeira dourados. }\end{array}$ \\
\hline 890.14 & $\begin{array}{l}\text { Retrato } \\
\text { incompleto }\end{array}$ & - & $\begin{array}{l}\text { Monsenhor } \\
\text { João de Barros } \\
\text { Uchôa }\end{array}$ & - & - & - & - & $\begin{array}{l}\text { 3-na } \\
\text { arandela }\end{array}$ & - & $\begin{array}{l}\text { №s 890: Coleção de objetos de } \\
\text { madeira dourados. }\end{array}$ \\
\hline 891 & \begin{tabular}{|l|} 
Canastra de \\
madeira \\
entalhada
\end{tabular} & - & $\begin{array}{l}\text { Monsenhor } \\
\text { João de Barros } \\
\text { Uchôa }\end{array}$ & - & - & - & - & 3 & - & - \\
\hline 892 & $\begin{array}{l}\text { Oratório de } \\
\text { madeira }\end{array}$ & - & - & - & - & - & - & 3 & - & - \\
\hline 893 & $\begin{array}{l}\text { Oratório de } \\
\text { madeira, com } \\
\text { guarnição } \\
\text { superior } \\
\text { entalhada }\end{array}$ & - & - & - & - & - & - & 3 & - & - \\
\hline
\end{tabular}




\begin{tabular}{|c|c|c|c|c|c|c|c|c|c|c|}
\hline № & Objeto & Procedência & Pertenceu a & Doado por & Cidade & Estado & País & Sala & Mostruário & Descrição / Observação \\
\hline 894 & $\begin{array}{l}\text { Oratório ou } \\
\text { nicho de } \\
\text { madeira, } \\
\text { pintado a óleo }\end{array}$ & $\begin{array}{l}\text { Matriz de } \\
\text { Piracaia }\end{array}$ & - & - & Piracaia & $\begin{array}{l}\text { São } \\
\text { Paulo }\end{array}$ & Brasil & 3 & - & $\begin{array}{l}\text { Nele foi celebrada a } 1^{\underline{a}} \text { missa naquela } \\
\text { paróquia. Rústico. }\end{array}$ \\
\hline 895 & $\begin{array}{l}\text { Sacrário de } \\
\text { madeira em } \\
\text { forma de globo }\end{array}$ & $\begin{array}{l}\text { Matriz de Mogi } \\
\text { das Cruzes }\end{array}$ & - & - & $\begin{array}{l}\text { Mogi das } \\
\text { Cruzes }\end{array}$ & $\begin{array}{l}\text { São } \\
\text { Paulo }\end{array}$ & Brasil & 3 & - & Muito antigo. \\
\hline 896 & $\begin{array}{l}\text { Sacrário de } \\
\text { madeira antigo }\end{array}$ & $\begin{array}{l}\text { Matriz de Mogi } \\
\text { das Cruzes }\end{array}$ & - & - & $\begin{array}{l}\text { Mogi das } \\
\text { Cruzes }\end{array}$ & $\begin{array}{l}\text { São } \\
\text { Paulo }\end{array}$ & Brasil & 3 & - & - \\
\hline 897 & $\begin{array}{l}\text { Imagem de São } \\
\text { José }\end{array}$ & $\begin{array}{l}\text { Matriz de } \\
\text { Parnaíba }\end{array}$ & - & - & \begin{tabular}{|l} 
Santana \\
de \\
Parnaíba
\end{tabular} & $\begin{array}{l}\text { São } \\
\text { Paulo }\end{array}$ & Brasil & 3 & - & $\begin{array}{l}\text { Anotação a lápis: Procissão. (?) no no } \\
\text { da sala. }\end{array}$ \\
\hline 898 & $\begin{array}{l}\text { Dois porta } \\
\text { toalhas antigos }\end{array}$ & - & - & - & - & - & - & 3 & - & $\mathrm{CH}$ \\
\hline 899 & $\begin{array}{l}\text { Missal em sua } \\
\text { respectiva caixa } \\
\text { de madeira }\end{array}$ & - & - & - & - & - & - & 3 & - & $\begin{array}{l}\text { Que traz pregado na tampa um cartão } \\
\text { de prata com estes dizeres: "Oferecido } \\
\text { ao llmo. Cabido da Sé de São Paulo } \\
\text { pelo respectivo Prelado Diocesano D. } \\
\text { Lino D.R. de Carvalho - 1883." }\end{array}$ \\
\hline 900 & Missal & - & - & $\begin{array}{l}\text { Dom } \\
\text { Benedito } \\
\text { Paulo Alves } \\
\text { de Souza, } \\
\text { bispo do } \\
\text { Espirito } \\
\text { Santo }\end{array}$ & - & - & Brasil & 3 & - & $\begin{array}{l}\text { Oferecido pelo Revmo. Cabido de São } \\
\text { Paulo ao Exmo. Monsenhor Ezequias } \\
\text { Galvão Fontoura, no áureo jubileu de } \\
\text { sua Ordenação Sacerdotal. Monsenhor } \\
\text { Ezequias ofereceu-o a Dom Benedito } \\
\text { Paulo Alves de Souza, Bispo do } \\
\text { Espírito Santo, por ter sido usado este } \\
\text { Missal na cerimônia da Sagração de } \\
\text { Sua Excia. aos } 21 \text { de abril de } 1918 . \\
\text { Dom Benedito, por sua vez, ofereceu-o } \\
\text { ao Museu da Cúria. }\end{array}$ \\
\hline
\end{tabular}




\begin{tabular}{|c|c|c|c|c|c|c|c|c|c|c|}
\hline № & Objeto & Procedência & Pertenceu a & Doado por & Cidade & Estado & País & Sala & Mostruário & Descrição / Observação \\
\hline 902 & Copo de cristal & - & - & $\begin{array}{l}\text { Dom Duarte } \\
\text { Leopoldo e } \\
\text { Silva }\end{array}$ & - & - & Brasil & 3 & - & $\begin{array}{l}\text { Traz pintados o escudo e a legenda: } \\
\text { "Vivat Joannes.V" Oferecido pelo } \\
\text { Monsenhor Joaquim Honório da } \\
\text { Silveira, Reitor do Seminário de São } \\
\text { Padro, de Natal, Estado do Rio Grande } \\
\text { do Norte, ao Exmo.Sr. Dom Duarte } \\
\text { Leopoldo e Silva, Arcebispo } \\
\text { Metropolitano de São Paulo". }\end{array}$ \\
\hline 903 & $\begin{array}{l}\text { Imagem de São } \\
\text { Francisco de } \\
\text { Paula }\end{array}$ & $\begin{array}{l}\text { Matriz de } \\
\text { Parnaíba }\end{array}$ & - & - & $\begin{array}{l}\text { Santana } \\
\text { de } \\
\text { Parnaíba }\end{array}$ & $\begin{array}{l}\text { São } \\
\text { Paulo }\end{array}$ & Brasil & 3 & - & - \\
\hline 904 & $\begin{array}{l}\text { Baralho } \\
\text { histórico Ibero- } \\
\text { americano }\end{array}$ & - & - & \begin{tabular}{|l} 
Padre \\
Antonio \\
Martins de \\
Souza
\end{tabular} & - & - & - & 3 & - & $\begin{array}{l}\text { Fabricado exclusivamente para as } \\
\text { Exposições de Sevilha e Barcelona -- } \\
1929-- \text { em comemoração do } \\
\text { Descobrimento e Colonização do Novo } \\
\text { Mundo. Oferta do padre Antonio } \\
\text { Martins de Souza. Anotação a lápis: } \\
\text { (?). }\end{array}$ \\
\hline 905 & $\begin{array}{l}\text { Imagem de São } \\
\text { Jorge }\end{array}$ & - & - & - & São Paulo & $\begin{array}{l}\text { São } \\
\text { Paulo }\end{array}$ & Brasil & 3 & - & - \\
\hline 906 & \begin{tabular}{|l} 
Imagem \\
mutilada de um \\
santo Monge
\end{tabular} & $\begin{array}{l}\text { Matriz de } \\
\text { Parnaíba }\end{array}$ & - & - & \begin{tabular}{|l} 
Santana \\
de \\
Parnaíba
\end{tabular} & $\begin{array}{l}\text { São } \\
\text { Paulo }\end{array}$ & Brasil & 3 & - & $\begin{array}{l}\text { Anotação a lápis: llegível ... Do } \\
\text { Mosteiro de São Bento. }\end{array}$ \\
\hline 907 & $\begin{array}{l}\text { Dois ornatos de } \\
\text { altar, de couro } \\
\text { lavrado, } \\
\text { pintados }\end{array}$ & $\begin{array}{l}\text { Convento do } \\
\text { Carmo }\end{array}$ & - & - & $\begin{array}{l}\text { Mogi das } \\
\text { Cruzes }\end{array}$ & \begin{tabular}{|l|} 
São \\
Paulo
\end{tabular} & Brasil & 3 & - & (Cfr. Histor. Sob o nำ7). \\
\hline 908 & $\begin{array}{l}\text { Dez castiçais de } \\
\text { madeira }\end{array}$ & \begin{tabular}{|l|} 
Matriz de \\
Porto Feliz \\
\end{tabular} & - & - & \begin{tabular}{|l|} 
Porto \\
Feliz \\
\end{tabular} & \begin{tabular}{|l|} 
São \\
Paulo \\
\end{tabular} & Brasil & 3 & - & - \\
\hline 909.1 & $\begin{array}{l}\text { Dois castiçais } \\
\text { maiores }\end{array}$ & $\begin{array}{l}\text { Convento do } \\
\text { Carmo }\end{array}$ & - & - & $\begin{array}{l}\text { Mogi das } \\
\text { Cruzes }\end{array}$ & \begin{tabular}{|l|} 
São \\
Paulo
\end{tabular} & Brasil & 3 & - & № 909: Seis objetos de madeira. \\
\hline 909.2 & $\begin{array}{l}\text { Um castiçal } \\
\text { menor }\end{array}$ & $\begin{array}{l}\text { Convento do } \\
\text { Carmo }\end{array}$ & - & - & $\begin{array}{l}\text { Mogi das } \\
\text { Cruzes }\end{array}$ & \begin{tabular}{|l|} 
São \\
Paulo
\end{tabular} & Brasil & 3 & - & № 909: Seis objetos de madeira. \\
\hline
\end{tabular}




\begin{tabular}{|c|c|c|c|c|c|c|c|c|c|c|}
\hline № & Objeto & Procedência & Pertenceu a & Doado por & Cidade & Estado & País & Sala & Mostruário & Descrição / Observação \\
\hline 909.3 & $\begin{array}{l}\text { Castiçal para } \\
\text { duas velas }\end{array}$ & $\begin{array}{l}\text { Convento do } \\
\text { Carmo }\end{array}$ & - & - & $\begin{array}{l}\text { Mogi das } \\
\text { Cruzes }\end{array}$ & $\begin{array}{l}\text { São } \\
\text { Paulo }\end{array}$ & Brasil & 3 & - & № 909: Seis objetos de madeira. \\
\hline 909.4 & $\begin{array}{l}\text { Porta - palma, } \\
\text { maior }\end{array}$ & $\begin{array}{l}\text { Convento do } \\
\text { Carmo }\end{array}$ & - & - & $\begin{array}{l}\text { Mogi das } \\
\text { Cruzes }\end{array}$ & $\begin{array}{l}\text { São } \\
\text { Paulo }\end{array}$ & Brasil & 3 & - & $\begin{array}{l}\text { № 909: Seis objetos de madeira. } \\
\text { Anotação a lápis: Dep. } 5.5 \text { (?) }\end{array}$ \\
\hline 909.5 & $\begin{array}{l}\text { Porta - palma } \\
\text { menor }\end{array}$ & $\begin{array}{l}\text { Convento do } \\
\text { Carmo }\end{array}$ & - & - & $\begin{array}{l}\text { Mogi das } \\
\text { Cruzes }\end{array}$ & $\begin{array}{l}\text { São } \\
\text { Paulo }\end{array}$ & Brasil & 3 & - & $\begin{array}{l}\text { № 909: Seis objetos de madeira. } \\
\text { Anotação a lápis: Dep. } 5.5 \text { (?) }\end{array}$ \\
\hline 910 & $\begin{array}{l}\text { Bandeira } \\
\text { portuguesa }\end{array}$ & $\begin{array}{l}\text { Palácio da } \\
\text { Cúria }\end{array}$ & - & - & São Paulo & \begin{tabular}{|l|} 
São \\
Paulo
\end{tabular} & Brasil & 3 & - & $\begin{array}{l}\text { Usada na ornamentação do Salão } \\
\text { Nobre da Cúria Metropolitana de São } \\
\text { Paulo, por ocasião da recepção de } \\
\text { Sua Eminência o Sr. Cardeal } \\
\text { Cerejeira, Patriarca de Lisboa, quando } \\
\text { de sua visita a esta capital, em } 1934 .\end{array}$ \\
\hline 911 & $\begin{array}{l}\text { Cravo (piano } \\
\text { antigo) }\end{array}$ & $\begin{array}{l}\text { Mosteiro de } \\
\text { Santa Clara }\end{array}$ & - & - & Sorocaba & $\begin{array}{l}\text { São } \\
\text { Paulo }\end{array}$ & Brasil & 3 & - & $\begin{array}{l}\text { Pertenceu a uma jovem que ingressou } \\
\text { no Mosteiro de santa Clara, de } \\
\text { Sorocaba, a qual, a pedido de seu } \\
\text { Bispo, Dom José Carlos de Aguirre, o } \\
\text { ofereceu ao Museu da Cúria. }\end{array}$ \\
\hline 912 & $\begin{array}{l}\text { Oito cadeiras } \\
\text { antigas }\end{array}$ & - & - & - & - & - & - & 3 & - & Com assento de couro lavrado. \\
\hline 913 & $\begin{array}{l}\text { Duas cadeiras } \\
\text { muito antigas }\end{array}$ & - & - & - & - & - & - & 3 & - & $\begin{array}{l}\text { Com assento e espaldar alto, de couro } \\
\text { lavrado e pregado com pregos de } \\
\text { metal. }\end{array}$ \\
\hline 914 & Três cadeiras & - & - & - & - & - & - & 3 & - & $\begin{array}{l}\text { Com assento e espaldar baixo, de } \\
\text { couro lavrado e pregado com pregos } \\
\text { de metal, muito mais antigas que as } \\
\text { precedentes. }\end{array}$ \\
\hline 915 & $\begin{array}{l}\text { Cadeira de } \\
\text { fechar }\end{array}$ & - & - & - & - & - & - & 3 & - & $\begin{array}{l}\text { Com assento e espaldar baixo, de } \\
\text { couro lavrado e pregado com pregos } \\
\text { de metal, muito antiga. }\end{array}$ \\
\hline
\end{tabular}




\begin{tabular}{|c|c|c|c|c|c|c|c|c|c|c|}
\hline № & Objeto & Procedência & Pertenceu a & Doado por & Cidade & Estado & País & Sala & Mostruário & Descrição / Observação \\
\hline 916 & $\begin{array}{l}\text { Cadeira de } \\
\text { braços, de } \\
\text { madeira }\end{array}$ & - & - & - & - & - & - & 3 & - & $\begin{array}{l}\text { Com assento estofado e forrado de } \\
\text { veludo, espaldar de madeira lavrada e } \\
\text { pintada. }\end{array}$ \\
\hline 917 & Sofá antigo & - & - & - & - & - & - & 3 & - & $\begin{array}{l}\text { Com assento em palhinha e espaldar } \\
\text { estofado e forrado de oleado. }\end{array}$ \\
\hline 918 & \begin{tabular}{|l|} 
Jogo de três \\
peças: canapê e \\
duas cadeiras \\
\end{tabular} & $\begin{array}{l}\text { Palácio da } \\
\text { Cúria }\end{array}$ & - & - & São Paulo & $\begin{array}{l}\text { São } \\
\text { Paulo }\end{array}$ & Brasil & 3 & - & $\begin{array}{l}\text { Procedentes da Sala do Clero, da } \\
\text { Cúria Metropolitana. }\end{array}$ \\
\hline 919 & $\begin{array}{l}\text { Mostruário de } \\
\text { lembranças das } \\
\text { revoluções de } \\
1924 \text { e } 1932 \\
\end{array}$ & - & - & - & - & - & - & 3 & - & - \\
\hline 920 & Antiga mesa & $\begin{array}{l}\text { Cabido de São } \\
\text { Paulo }\end{array}$ & - & - & São Paulo & $\begin{array}{l}\text { São } \\
\text { Paulo }\end{array}$ & Brasil & 3 & - & $\begin{array}{l}\text { Da sala do Cabido de São Paulo, } \\
\text { criado em } 1746 .\end{array}$ \\
\hline 921 & Mitra & - & $\begin{array}{l}\text { Cardeal } \\
\text { Arcoverde }\end{array}$ & $\begin{array}{l}\text { Dom André } \\
\text { Arcoverde, } \\
\text { bispo de } \\
\text { Taubaté }\end{array}$ & - & - & Brasil & 3 & - & - \\
\hline 922 & Solidéu & - & $\begin{array}{l}\text { Dom Sebastião } \\
\text { Leme da } \\
\text { Silveira Cintra, } \\
\text { segundo } \\
\text { Cardeal do Rio } \\
\text { de Janeiro } \\
\end{array}$ & - & \begin{tabular}{|l|} 
Rio de \\
Janeiro
\end{tabular} & $\begin{array}{l}\text { Rio de } \\
\text { Janeiro }\end{array}$ & Brasil & 3 & - & - \\
\hline 923 & $\begin{array}{l}\text { Paramento } \\
\text { Sagrado }\end{array}$ & - & $\begin{array}{l}\text { Padre Diogo } \\
\text { Antonio Feijó }\end{array}$ & - & - & - & - & 3 & - & - \\
\hline 924 & $\begin{array}{l}\text { Seis mitras de } \\
\text { diversos } \\
\text { prelados }\end{array}$ & - & - & - & - & - & - & 3 & - & - \\
\hline 925 & $\begin{array}{l}\text { Murça de } \\
\text { Cônego }\end{array}$ & - & $\begin{array}{l}\text { Monsenhor } \\
\text { Ezequias } \\
\text { Galvão da } \\
\text { Fontoura } \\
\end{array}$ & - & - & - & - & 3 & - & - \\
\hline
\end{tabular}




\begin{tabular}{|c|c|c|c|c|c|c|c|c|c|c|}
\hline № & Objeto & Procedência & Pertenceu a & Doado por & Cidade & Estado & País & Sala & Mostruário & Descrição / Observação \\
\hline 926 & $\begin{array}{l}\text { Capa de } \\
\text { Asperges }\end{array}$ & - & - & $\begin{array}{l}\text { Carmelitos } \\
\text { Descalços }\end{array}$ & - & - & - & 3 & - & Doado em 06/10/1929. \\
\hline 927 & $\begin{array}{l}\text { Véu de ombros } \\
\text { bordado }\end{array}$ & - & - & - & - & - & - & 3 & - & - \\
\hline 928 & $\begin{array}{l}\text { Manto branco } \\
\text { de seda } \\
\text { bordado }\end{array}$ & - & - & - & - & - & - & 3 & - & $\begin{array}{l}\text { Usado em uma Imagem de N.Senhora. } \\
\text { Anotação a lápis: (?) }\end{array}$ \\
\hline 929 & $\begin{array}{l}\text { Manto azul de } \\
\text { seda bordado }\end{array}$ & - & - & - & - & - & - & 3 & - & Usado em uma Imagem de N.Senhora. \\
\hline 930 & Chapéu & - & $\begin{array}{l}\text { Cardeal } \\
\text { Arcoverde }\end{array}$ & - & - & - & Brasil & 3 & - & - \\
\hline 931 & $\begin{array}{l}\text { Bandeira } \\
\text { brasileira de } \\
\text { seda bordada }\end{array}$ & - & - & - & - & - & - & 3 & - & - \\
\hline 932 & Estola & - & - & - & - & - & - & 3 & - & - \\
\hline 933 & $\begin{array}{l}\text { Paramento } \\
\text { Sagrado }\end{array}$ & - & - & - & - & - & - & 3 & - & - \\
\hline 934 & $\begin{array}{l}\text { Duas bolsas } \\
\text { para corporaes }\end{array}$ & - & - & - & - & - & - & 3 & - & ( \\
\hline 936 & $\begin{array}{l}\text { Breve de Sua } \\
\text { Santidade o } \\
\text { Papa Pio VI }\end{array}$ & - & - & - & - & - & - & 3-parede & - & $\begin{array}{l}\text { Que declara Sant'Ana Padroeira } \\
\text { principal da cidade de São Paulo e } \\
\text { Diocese do mesmo nome. }\end{array}$ \\
\hline 937 & $\begin{array}{l}\text { Retrato em } \\
\text { Litogravura de } \\
\text { Frei Francisco } \\
\text { de Mont'Alverne }\end{array}$ & - & - & - & - & - & - & 3-parede & - & - \\
\hline 938 & $\begin{array}{l}\text { Retrato em } \\
\text { litogravura de } \\
\text { Dom Manuel do } \\
\text { Monte } \\
\text { Rodrigues de } \\
\text { Araújo }\end{array}$ & - & - & - & - & - & - & 3-parede & - & $\begin{array}{l}\text { Conde do Irajá, 9 Bispo do Rio de } \\
\text { Janeiro. }\end{array}$ \\
\hline
\end{tabular}




\begin{tabular}{|c|c|c|c|c|c|c|c|c|c|c|}
\hline № & Objeto & Procedência & Pertenceu a & Doado por & Cidade & Estado & País & Sala & Mostruário & Descrição / Observação \\
\hline 939 & \begin{tabular}{|l|} 
Retrato a óleo \\
de Dom \\
Bernardo \\
Rodrigues \\
Nogueira
\end{tabular} & - & - & - & São Paulo & \begin{tabular}{|l|} 
São \\
Paulo
\end{tabular} & Brasil & 3-parede & - & Primeiro Bispo de São Paulo. \\
\hline 940 & $\begin{array}{l}\text { Retrato a óleo } \\
\text { de Dom Frei } \\
\text { Antonio da } \\
\text { Madre de Deus } \\
\text { Galvão }\end{array}$ & - & - & - & São Paulo & \begin{tabular}{|l|} 
São \\
Paulo
\end{tabular} & Brasil & 3-parede & - & 2 Bispo de São Paulo. \\
\hline 941 & $\begin{array}{l}\text { Retrato a óleo } \\
\text { de Dom Frei } \\
\text { Manuel da } \\
\text { Ressureição }\end{array}$ & - & - & - & São Paulo & \begin{tabular}{|l|} 
São \\
Paulo
\end{tabular} & Brasil & 3-parede & - & 3ํㅗispo de São Paulo. \\
\hline 942 & $\begin{array}{l}\text { Retrato a óleo } \\
\text { de Dom } \\
\text { Matheus de } \\
\text { Abreu Pereira }\end{array}$ & - & - & - & São Paulo & \begin{tabular}{|l|} 
São \\
Paulo
\end{tabular} & Brasil & 3-parede & - & 4ํㅗispo de São Paulo. \\
\hline 943 & $\begin{array}{l}\text { Retrato a óleo } \\
\text { de Dom Manuel } \\
\text { Joaquim } \\
\text { Gonçalves de } \\
\text { Andrade }\end{array}$ & - & - & - & São Paulo & \begin{tabular}{|l|} 
São \\
Paulo
\end{tabular} & Brasil & 3-parede & - & 5 Bispo de São Paulo. \\
\hline 944 & $\begin{array}{l}\text { Retrato a óleo } \\
\text { de Dom Antonio } \\
\text { Joaquim de } \\
\text { Mello }\end{array}$ & - & - & - & São Paulo & \begin{tabular}{|l|} 
São \\
Paulo
\end{tabular} & Brasil & 3-parede & - & 6 Bispo de São Paulo. \\
\hline 945 & $\begin{array}{l}\text { Retrato a óleo } \\
\text { de Dom } \\
\text { Sebastião Pinto } \\
\text { do Rego }\end{array}$ & - & - & - & São Paulo & \begin{tabular}{|l|} 
São \\
Paulo
\end{tabular} & Brasil & 3-parede & - & $7^{0}$ Bispo de São Paulo. \\
\hline
\end{tabular}




\begin{tabular}{|c|c|c|c|c|c|c|c|c|c|c|}
\hline № & Objeto & Procedência & Pertenceu a & Doado por & Cidade & Estado & País & Sala & Mostruário & Descrição / Observação \\
\hline 946 & $\begin{array}{l}\text { Retrato a óleo } \\
\text { de Dom Lino } \\
\text { Deodato } \\
\text { Rodrigues de } \\
\text { Carvalho } \\
\end{array}$ & - & - & - & São Paulo & $\begin{array}{l}\text { São } \\
\text { Paulo }\end{array}$ & Brasil & 3-parede & - & 8ํㅗispo de São Paulo. \\
\hline 947 & $\begin{array}{l}\text { Retrato a óleo } \\
\text { de Dom } \\
\text { Joaquim } \\
\text { Arcoverde de } \\
\text { Albuquerque }\end{array}$ & - & - & - & São Paulo & \begin{tabular}{|l|} 
São \\
Paulo
\end{tabular} & Brasil & 3-parede & - & 9 Bispo de São Paulo. \\
\hline 948 & $\begin{array}{l}\text { Retrato a óleo } \\
\text { de Dom Antonio } \\
\text { Candido de } \\
\text { Alvarenga }\end{array}$ & - & - & - & São Paulo & \begin{tabular}{|l|} 
São \\
Paulo
\end{tabular} & Brasil & 3-parede & - & 10ํBispo de São Paulo. \\
\hline 949 & $\begin{array}{l}\text { Retrato a óleo } \\
\text { de Dom José de } \\
\text { Camargo Barros }\end{array}$ & - & - & - & São Paulo & \begin{tabular}{|l|} 
São \\
Paulo
\end{tabular} & Brasil & 3-parede & - & 11ํㅗispo de São Paulo. \\
\hline 950 & $\begin{array}{l}\text { Retrato a óleo } \\
\text { de Dom José de } \\
\text { Camargo Barros } \\
\text { (busto) }\end{array}$ & - & - & - & São Paulo & $\begin{array}{l}\text { São } \\
\text { Paulo }\end{array}$ & Brasil & 3-parede & - & 11ํBispo de São Paulo. \\
\hline 951 & $\begin{array}{l}\text { Duas peças de } \\
\text { damasco } \\
\text { vermelho e um } \\
\text { cordão de borla }\end{array}$ & - & - & - & - & - & - & 3-mesa & - & $\begin{array}{l}\text { Parecendo tratar-se de cortina de } \\
\text { baldaquino. }\end{array}$ \\
\hline 952 & $\begin{array}{l}\text { Pequeno } \\
\text { oratório com a } \\
\text { Imagem do } \\
\text { Menino Jesus }\end{array}$ & - & - & - & - & - & - & 3-mesa & - & - \\
\hline 1006 & $\begin{array}{l}\text { Crucifixo antigo } \\
\text { de madeira }\end{array}$ & $\begin{array}{l}\text { Matriz de } \\
\text { Guarulhos }\end{array}$ & - & - & Guarulhos & \begin{tabular}{|l|} 
São \\
Paulo
\end{tabular} & Brasil & 3 & - & - \\
\hline
\end{tabular}




\begin{tabular}{|c|c|c|c|c|c|c|c|c|c|c|}
\hline № & Objeto & Procedência & Pertenceu a & Doado por & Cidade & Estado & País & Sala & Mostruário & Descrição / Observação \\
\hline 1007 & $\begin{array}{l}\text { Imagem de } \\
\text { Nossa Senhora } \\
\text { Da Conceição, } \\
\text { de madeira, } \\
\text { com resplendor } \\
\text { de prata }\end{array}$ & $\begin{array}{l}\text { Matriz de } \\
\text { Guarulhos }\end{array}$ & - & - & Guarulhos & $\begin{array}{l}\text { São } \\
\text { Paulo }\end{array}$ & Brasil & 3 & - & Muito antiga. \\
\hline 1009 & Pedra D'Ara & $\begin{array}{l}\text { Capela da } \\
\text { Fazenda de } \\
\text { Santa Teresa }\end{array}$ & - & - & - & $\begin{array}{l}\text { São } \\
\text { Paulo }\end{array}$ & Brasil & 3 & - & $\begin{array}{l}\text { Serviu na Capela da Fazenda de } \\
\text { Santa Teresa, situada no Km. } 7 \text { do } \\
\text { ramal de Campo-Limpo a Bragança, } \\
\text { propriedade do escritor Paulo Setúbal. } \\
\text { (Cfr. Carta na seção } 3^{\text {a }} \text { " Documentos } \\
\text { interessantes"). }\end{array}$ \\
\hline 1017 & Crucifixo antigo & - & - & - & - & - & - & 3 & - & - \\
\hline 1029 & Oratório antigo & - & - & $\begin{array}{l}\text { Cônego } \\
\text { Manuel } \\
\text { Meireles } \\
\text { Freire }\end{array}$ & - & - & - & 3 & - & $\begin{array}{l}\text { Com imagens de N.Senhor dos } \\
\text { Passos e outra de N.Sra. Das Dores e } \\
\text { mais um rosário de azeviche com cruz } \\
\text { de madeira e madrepérola. Oferta do } \\
\text { Revmo. Cônego Manuel Meirelles } \\
\text { Freire, que os recebeu de uma família } \\
\text { com a garantia de contarem mais de } \\
\text { um século. }\end{array}$ \\
\hline 1029 & $\begin{array}{l}\text { Rosário de } \\
\text { azeviche com } \\
\text { cruz de madeira } \\
\text { e madrepérola }\end{array}$ & - & - & - & - & - & - & 3 & - & - \\
\hline
\end{tabular}




\begin{tabular}{|c|c|c|c|c|c|c|c|c|c|c|}
\hline № & Objeto & Procedência & Pertenceu a & Doado por & Cidade & Estado & País & Sala & Mostruário & Descrição / Observação \\
\hline 901 & $\begin{array}{l}\text { Caixa com } \\
\text { báculo }\end{array}$ & & & & - & - & - & 3 & 2 & $\begin{array}{l}\text { Traz na tampa dois cartões de prata } \\
\text { com os seguintes dizeres: "loachin } \\
\text { Arcoverde de Albuquerque Cavalcanti } \\
\text { S.R.E.III Id. Decem MCMV Cardinali } \\
\text { Creato-Pont. Colll.P.L. } \\
\text { Americanum. Exaltationem-Olim- } \\
\text { Alumni-Merito-Plaudens-Amoris Ac- } \\
\text { Devotionis-Pignus-Illi-Corde-Vovet. } \\
\text { Offereço ao meu sobrinho D. André } \\
\text { Arcoverde este báculo. Rio de janeiro } \\
\text { 28 de outubbro de 1925. Cardeal } \\
\text { Joaquim Arcoverde". Anotação a lápis: } \\
\text { Nota- O báculo e os dois cartões de } \\
\text { prata foram retirados da caixa e } \\
\text { colocados juntos no mesmo } \\
\text { mostruário. Alterado mostruário no3 } \\
\text { para n². }\end{array}$ \\
\hline 48 & $\begin{array}{l}\text { Joias antigas } \\
\text { (cinco peças) }\end{array}$ & $\begin{array}{l}\text { Irmandade do } \\
\text { SS. } \\
\text { Sacramento }\end{array}$ & - & - & Santos & $\begin{array}{l}\text { São } \\
\text { Paulo }\end{array}$ & Brasil & 3 & $2-3$ & - \\
\hline 567 & Salva de prata & - & - & - & São Paulo & $\begin{array}{l}\text { São } \\
\text { Paulo }\end{array}$ & |Brasil & 3 & $\begin{array}{l}\text { mostruário } \\
\text { Dos obj. da } \\
\text { Revolução } \\
\text { Paulista }\end{array}$ & $\begin{array}{l}\text { "Pro São Paulo Fiant Eximia". } \\
\text { Oferecida pela joalheria "Casa Castro" } \\
\text { à Cúria Metropolitana de São Paulo, } \\
\text { que na mesma salva recolheu grande } \\
\text { quantidade de alianças de ouro, } \\
\text { trocadas por outras de ferro feitas por } \\
\text { aquela joalheria, e que o heroico povo } \\
\text { paulista usou na memoranda } \\
\text { campanha do ouro para o bem de São } \\
\text { Paulo, nos dias da Revolução } \\
\text { Constitucionalista de } 9 \text { de julho de } \\
1932 \text {. }\end{array}$ \\
\hline
\end{tabular}




\section{Sala expositiva 4}

A 4 ${ }^{\text {a }}$ sala expositiva apresenta apenas seis objetos, sendo que dois estavam localizados em outra sala e foram transferidos para a Sala 4, conforme anotação encontrada, o que nos leva a crer que esta seria uma nova sala a ser preenchida, de acordo com a necessidade de mais espaço para os objetos.

Ainda segundo o Catálogo n. 52, esta sala não possuía nenhum mobiliário expositivo, estando os objetos, supõem-se, pendurados pela parede, de acordo com sua natureza (quadros, diplomas e fotografia).

Tabela 8: Objetos expostos na Sala 4 o Museu da Cúria

\begin{tabular}{|c|c|c|c|c|c|c|}
\hline № & Objeto & $\begin{array}{l}\text { Proce- } \\
\text { dência }\end{array}$ & Cidade & Estado & País & Descrição / Observação \\
\hline 865 & $\begin{array}{l}\text { Dois quadros, } \\
\text { litogravura: Dom } \\
\text { Pedro I e D. } \\
\text { Carolina } \\
\text { Leopoldina }\end{array}$ & - & - & - & - & $\begin{array}{l}\text { Anotação a lápis: Altera o no da } \\
\text { sala para no } 4 \text {. E Parte ilegível. }\end{array}$ \\
\hline 870 & $\begin{array}{l}\text { Mapa da } \\
\text { Revolução } \\
\text { Constitucionalista } \\
\text { de } 1932 \text { - J.W.R. }\end{array}$ & - & - & - & - & $\begin{array}{l}\text { Anotação a lápis: Altera o no da } \\
\text { sala para no } 4 \text {. E Parte ilegível }\end{array}$ \\
\hline 998 & $\begin{array}{l}\text { Fotografia do } \\
\text { Largo da Sé }\end{array}$ & - & $\begin{array}{l}\text { São } \\
\text { Paulo }\end{array}$ & $\begin{array}{l}\text { São } \\
\text { Paulo }\end{array}$ & Brasil & $\begin{array}{l}\text { Tirada logo depois da demolição da } \\
\text { Velha Catedral. Anotação a lápis: } \\
\text { Alterado o nº da sala para n4 } \\
\text { Numismática. }\end{array}$ \\
\hline 1002 & Diploma & - & $\begin{array}{l}\text { São } \\
\text { Paulo }\end{array}$ & $\begin{array}{l}\text { São } \\
\text { Paulo }\end{array}$ & Brasil & $\begin{array}{l}\text { Conferido ao Exmo. Sr. Dom } \\
\text { Duarte Leopoldo e Silva, Arcebispo } \\
\text { de São Paulo, Presidente de Honra } \\
\text { do Primeiro Congresso de } \\
\text { Numismática Brasileira, que se } \\
\text { realizou na cidade de São Paulo de } \\
24 \text { a } 31 \text { de março de } 1936 \text {. } \\
\text { Anotação a lápis: Alterado o no da } \\
\text { sala para n4, Numismática }\end{array}$ \\
\hline 1003 & $\begin{array}{l}\text { Diploma de } \\
\text { Grande oficial da } \\
\text { Ordem da } \\
\text { Benemerência }\end{array}$ & - & $\begin{array}{l}\text { São } \\
\text { Paulo }\end{array}$ & $\begin{array}{l}\text { São } \\
\text { Paulo }\end{array}$ & Brasil & $\begin{array}{l}\text { Conferido pelo Presidente da } \\
\text { República Portuguesa ao Exmo. } \\
\text { Sr. Arcebispo de São Paulo, Dom } \\
\text { Duarte Leopoldo e Silva, aos } 21 \text { de } \\
\text { março de 1935, e entregue ao } \\
\text { mesmo Sr. Arcebispo em } 1938 \text {. } \\
\text { Anotação a lápis: Alterado o no da } \\
\text { sala para n4, Numismática. }\end{array}$ \\
\hline
\end{tabular}




\section{Patamares}

Conforme já apontado, os objetos do Museu eram expostos pelos diversos cômodos do Palácio da Cúria. Segundo o catálogo, são listados 142 objetos localizados entre 5 patamares, que entendemos estarem relacionados às escadas existentes. Entretanto, não há indicação de a qual escada se refere cada patamar.

Ao analisarmos a planta do edifício, verificamos a existência de 3 escadas: uma localizada na entrada do Palácio à esquerda (entrada do Arcebispo), uma na entrada principal do Palácio à direita, e uma localizada na parte externa do edifício, nos fundos, onde ficaria a entrada para a Sala 1 do Museu.

Excluindo a escada externa do Museu, uma vez que não seriam colocados objetos do lado de fora do Palácio, para chegarmos ao número de patamares indicados no catálogo consideramos que os degraus de acesso às entradas do Palácio pela rua eram entendidos como escadas, sendo então os halls de entrada relacionados como patamares.

Figura 69: Perspectiva do $1^{\circ}$ patamar, Entrada do Arcebispo (1ํㅜ pavimento).

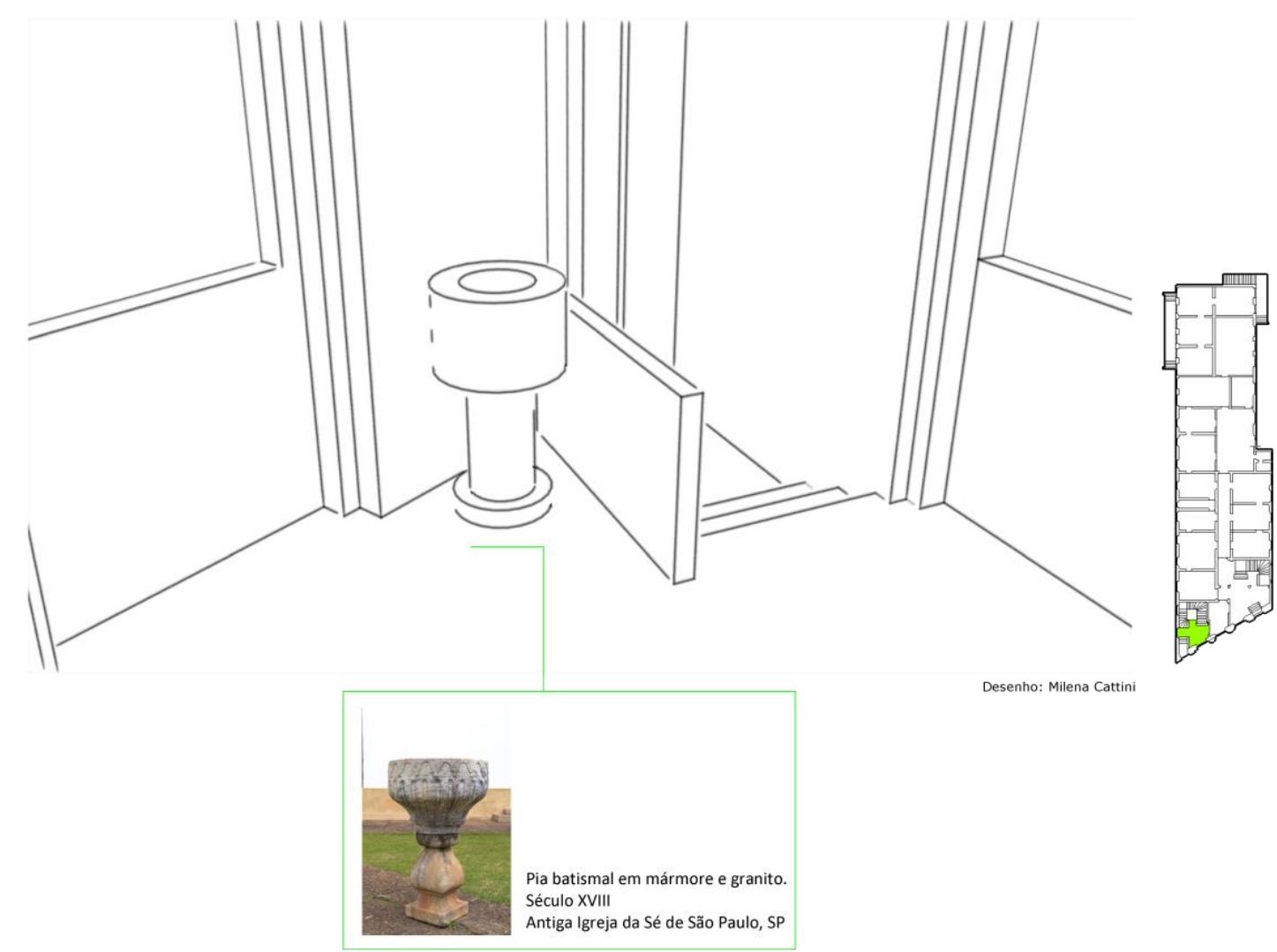


Figura 70: Perspectiva do $3^{\circ}$ patamar, Entrada principal (1ํpavimento).

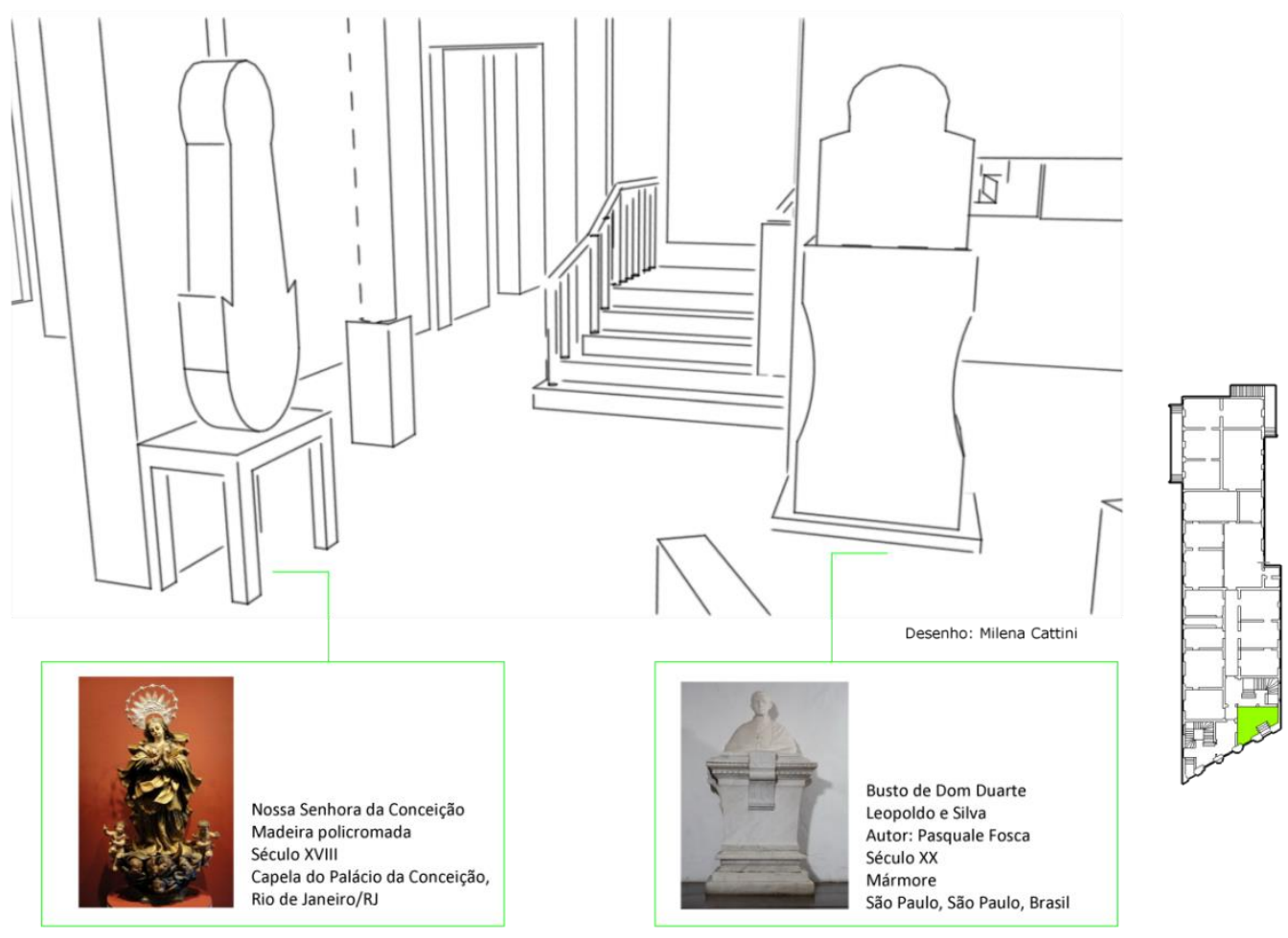

Figura 71: Perspectiva do $5^{\circ}$ patamar ( $2^{\circ}$ pavimento).

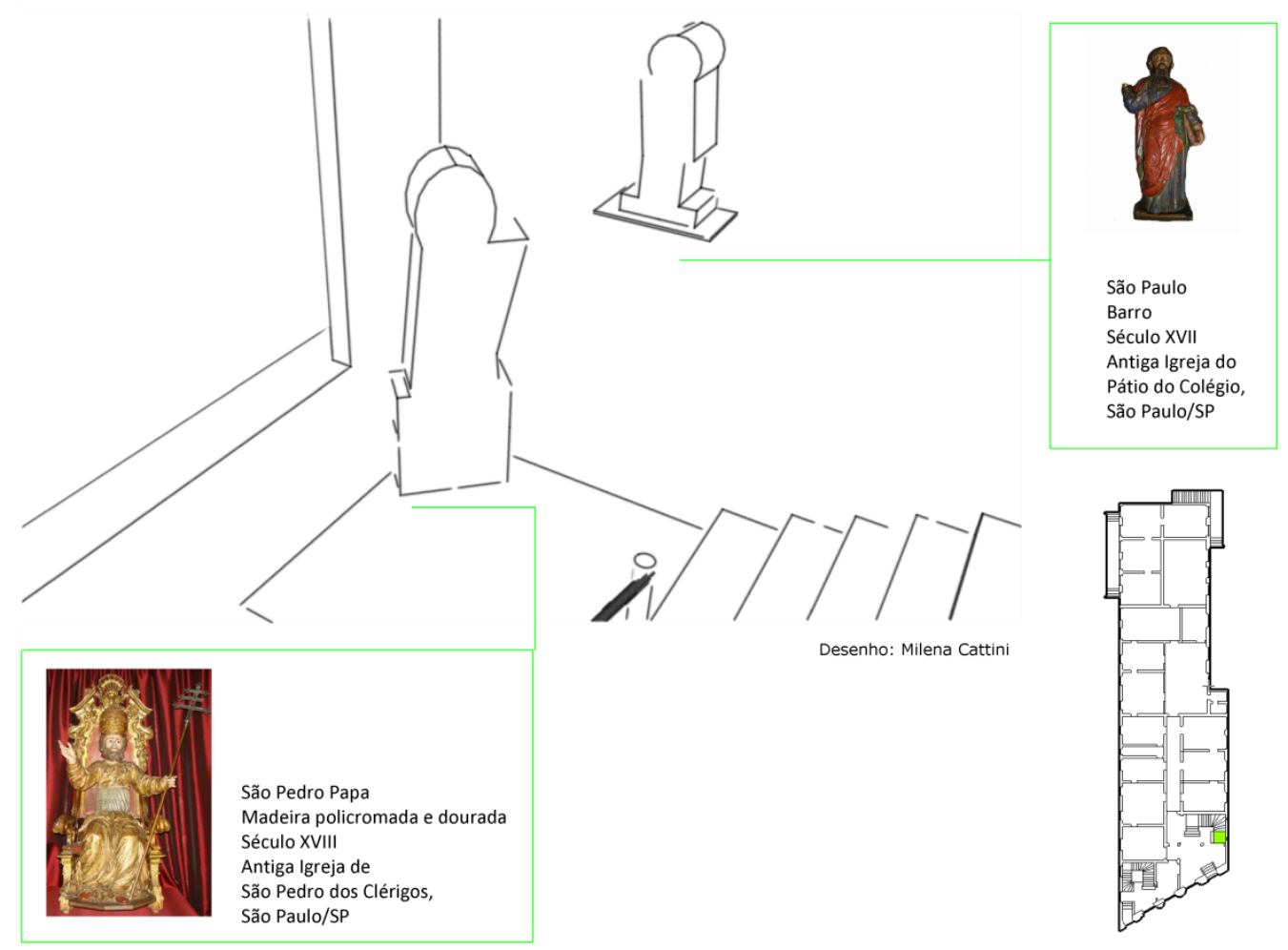


Tabela 9: Objetos expostos pelos patamares do Palácio da Cúria

\begin{tabular}{|c|c|c|c|c|c|c|c|c|c|}
\hline № & Objeto & Procedência & Pertenceu a & Doado por & Cidade & Estado & País & Patamar & Descrição / Observação \\
\hline 543 & $\begin{array}{l}\text { Custódia para o } \\
\text { Santo Viático }\end{array}$ & $\begin{array}{l}\text { Igreja de Nossa } \\
\text { Senhora da } \\
\text { Abadia de } \\
\text { Muquem }\end{array}$ & - & - & Muquem & Goiás & Brasil & 1 & Belíssimo trabalho de prata lavrada. \\
\hline 547 & Lavabo & $\begin{array}{l}\text { Velha Matriz de } \\
\text { Parnaíba }\end{array}$ & - & - & $\begin{array}{l}\text { Santana de } \\
\text { Parnaíba }\end{array}$ & São Paulo & Brasil & 1 & $\begin{array}{l}\text { Matriz edificada em } 1646 \text {, consertada } \\
\text { em } 1812 \text { e reformada em 1882-1883. } \\
\text { A Paróquia de Parnaíba foi } \\
\text { canonicamente erecta no dia } 14 \text { de } \\
\text { novembro de } 1625 \text {. }\end{array}$ \\
\hline 569 & Azulejos & Igreja da Sé & - & $\begin{array}{l}\text { Arcebispo da } \\
\text { Bahia e } \\
\text { Primaz do } \\
\text { Brasil }\end{array}$ & Salvador & Bahia & Brasil & 1 & $\begin{array}{l}\text { Tradicional e histórica Igreja, um dos } \\
\text { mais importantes monumentos da } \\
\text { arte histórica nacional. Construída } \\
\text { em meados do sec. XVI, foi ampliada } \\
\text { no sec.XVII e enriquecida de } \\
\text { notáveis obras de talha, azulejos } \\
\text { policromados e etc. }\end{array}$ \\
\hline 570 & $\begin{array}{l}\text { Cálice de prata } \\
\text { lisa }\end{array}$ & - & - & $\begin{array}{l}\text { Dona Nicota } \\
\text { Borges }\end{array}$ & - & - & - & 1 & $\begin{array}{l}\text { Trabalho antigo. Traz gravado o } \\
\text { nome do Padre Anchieta, mas o } \\
\text { cálice não tem relação com o } \\
\text { venerável taumaturgo do Brasil. }\end{array}$ \\
\hline 803 & $\begin{array}{l}\text { Pia batismal de } \\
\text { mármore }\end{array}$ & $\begin{array}{l}\text { Velha Sé de São } \\
\text { Paulo }\end{array}$ & - & - & São Paulo & São Paulo & Brasil & 1 & - \\
\hline 804 & $\begin{array}{l}\text { Pia batismal de } \\
\text { granito }\end{array}$ & $\begin{array}{l}\text { Matriz de Santo } \\
\text { Amaro }\end{array}$ & - & - & São Paulo & São Paulo & Brasil & 1 & - \\
\hline 806 & Cofre de madeira & - & - & - & - & - & - & 1 & Muito antigo. \\
\hline
\end{tabular}




\begin{tabular}{|c|c|c|c|c|c|c|c|c|c|}
\hline № & Objeto & Procedência & Pertenceu a & Doado por & Cidade & Estado & País & Patamar & Descrição / Observação \\
\hline 1069 & Sino de bronze & Capela de Maricá & - & $\begin{array}{l}\text { Dr. José } \\
\text { Carlos de } \\
\text { Macedo } \\
\text { Soares }\end{array}$ & Maricá & Rio de Janeiro & Brasil & 1 & $\begin{array}{l}\text { Com as seguintes palavras gravadas } \\
\text { em alto-relevo: "Jesus-Maria-José". } \\
\text { Procede dos ascendentes do Exmo. } \\
\text { Sr. Dr. José Carlos de Macedo } \\
\text { Soares, que doou ao Museu da Cúria } \\
\text { Metropolitana de São Paulo }\end{array}$ \\
\hline 605 & $\begin{array}{l}\text { Estatueta de } \\
\text { bronze do } \\
\text { bandeirante } \\
\text { Antonio Raposo } \\
\text { Tavares }\end{array}$ & - & - & $\begin{array}{l}\text { Dom Duarte } \\
\text { Leopoldo e } \\
\text { Silva }\end{array}$ & - & - & - & 2 & $\begin{array}{l}\text { Escultura de Couchet, adquirida para } \\
\text { o Museu da Cúria pelo Exmo. Sr. } \\
\text { Arcebispo Metropolitano de São } \\
\text { Paulo, Dom Duarte Leopoldo e Silva. }\end{array}$ \\
\hline 606 & $\begin{array}{l}\text { Estatueta de } \\
\text { bronze do } \\
\text { bandeirante } \\
\text { Fernão Dias } \\
\text { Paes Leme }\end{array}$ & - & - & $\begin{array}{l}\text { Dom Duarte } \\
\text { Leopoldo e } \\
\text { Silva }\end{array}$ & - & - & - & 2 & $\begin{array}{l}\text { Escultura de Couchet, adquirida para } \\
\text { o Museu da Cúria pelo Exmo. Sr. } \\
\text { Arcebispo Metropolitano de São } \\
\text { Paulo, Dom Duarte Leopoldo e Silva. }\end{array}$ \\
\hline 831 & $\begin{array}{l}\text { Pedra D'Ara do } \\
\text { Altar-Mor }\end{array}$ & $\begin{array}{l}\text { Velha Sé de São } \\
\text { Paulo }\end{array}$ & - & - & São Paulo & São Paulo & Brasil & 2 & - \\
\hline 832 & Pedra D'Ara & $\begin{array}{l}\text { Antiga Igreja de } \\
\text { Nossa Senhora } \\
\text { Do Rosário dos } \\
\text { Homens Pretos }\end{array}$ & - & $\begin{array}{l}\text { Pedro Correa, } \\
\text { sacristão da } \\
\text { Igreja }\end{array}$ & São Paulo & São Paulo & Brasil & 2 & $\begin{array}{l}\text { Igreja situada no antigo Largo do } \\
\text { Rosário, hoje Praça Antonio Prado. } \\
\text { Foi a pedra d'Ara sagrada por Dom } \\
\text { Matheus de Abreu Pereira, 4 Bispo } \\
\text { de São Paulo, no ano de } 1812 \text {, e } \\
\text { oferecida ao Museu da Cúria pela } \\
\text { família do falecido sr. Pedro Correa, } \\
\text { sacristão que foi da mesma igreja. }\end{array}$ \\
\hline
\end{tabular}




\begin{tabular}{|c|c|c|c|c|c|c|c|c|c|}
\hline № & Objeto & Procedência & Pertenceu a & Doado por & Cidade & Estado & País & Patamar & Descrição / Observação \\
\hline 833 & $\begin{array}{l}\text { Placa de } \\
\text { mármore com a } \\
\text { seguinte } \\
\text { inscrição: "100 } \\
\text { dias de } \\
\text { indulgencias a } \\
\text { todos os fieis que } \\
\text { beijarem esta } \\
\text { cruz e resarem } \\
\text { um Padre } \\
\text { Nosso.". }\end{array}$ & - & - & - & - & - & - & 2 & $\begin{array}{l}\text { Faz parte da cruz, registrada sob o } n^{\circ} \\
838 .\end{array}$ \\
\hline 834 & $\begin{array}{l}\text { Quadro a óleo: O } \\
\text { Filho Pródigo }\end{array}$ & - & $\begin{array}{l}\text { Joaquim } \\
\text { Carneiro } \\
\text { Bastos }\end{array}$ & $\begin{array}{l}\text { Joaquim Dias } \\
\text { F. Coimbra }\end{array}$ & - & - & - & 2 & Anotação a lápis ilegível. \\
\hline 835 & Mesa antiga & - & - & - & - & - & - & 2 & - \\
\hline 537 & $\begin{array}{l}\text { Imagem de } \\
\text { madeira de } \\
\text { Nossa Senhora } \\
\text { da Conceição }\end{array}$ & $\begin{array}{l}\text { Altar-Mor da } \\
\text { Capela do } \\
\text { Palácio da } \\
\text { Conceição }\end{array}$ & - & $\begin{array}{l}\text { Dom } \\
\text { Sebastião } \\
\text { Leme da } \\
\text { Silveira } \\
\text { Cintra, } \\
\text { Arcebispo do } \\
\text { Rio de } \\
\text { Janeiro } \\
\end{array}$ & $\begin{array}{l}\text { Rio de } \\
\text { Janeiro }\end{array}$ & Rio de Janeiro & Brasil & 3 & Ver ANEXO C. \\
\hline 837 & $\begin{array}{l}\text { Retrato a óleo do } \\
\text { Sindico do } \\
\text { Recolhimento de } \\
\text { Santa Teresa, } \\
\text { Dr. Antonio } \\
\text { Francisco de } \\
\text { Aguiar e Castro }\end{array}$ & - & - & - & São Paulo & São Paulo & Brasil & 3 & $\begin{array}{l}\text { Como consta do cartão de prata } \\
\text { preso ao quadro, que traz os } \\
\text { seguintes dizeres: " Ao Exmo. Sr. Dr. } \\
\text { Antonio Francisco de Aguiar e } \\
\text { Castro. Gratidão do Recolhimento de } \\
\text { Santa Theresa de Jesus ao seu } \\
\text { benemérito Syndico. São Paulo, 12- } \\
\text { 7-905". }\end{array}$ \\
\hline 839 & $\begin{array}{l}\text { Quadro a óleo: } \\
\text { Santo Inácio de } \\
\text { Loyola e São } \\
\text { Luiz de Gonzaga }\end{array}$ & - & - & - & - & - & - & 3 & - \\
\hline
\end{tabular}




\begin{tabular}{|c|c|c|c|c|c|c|c|c|c|}
\hline № & Objeto & Procedência & Pertenceu a & Doado por & Cidade & Estado & País & Patamar & Descrição / Observação \\
\hline 840 & $\begin{array}{l}\text { Antigo espadão } \\
\text { de cavalaria }\end{array}$ & - & - & - & - & - & - & 3 & - \\
\hline 841 & $\begin{array}{l}\begin{array}{l}\text { Antiga baioneta } \\
\text { triangular }\end{array} \\
\end{array}$ & - & - & - & - & - & - & 3 & - \\
\hline 842 & \begin{tabular}{|l|} 
Espadim feito de \\
moedas chinesas \\
\end{tabular} & - & - & - & - & - & - & 3 & - \\
\hline 843 & $\begin{array}{l}\text { Fotografia de um } \\
\text { verso escrito por } \\
\text { Dom Pedro II }\end{array}$ & - & - & - & - & - & - & 3 & $\begin{array}{l}\text { E também das assinaturas de } \\
\text { pessoas que certificaram a } \\
\text { autenticidade da composição e } \\
\text { escrita do dito verso, no dia } 25 \text { de } \\
\text { março de } 1846 \text {, pelo Imperador do } \\
\text { Brasil, na cidade de Itu. }\end{array}$ \\
\hline 844 & $\begin{array}{l}\text { Retrato a bico de } \\
\text { pena do } \\
\text { Arcediago da Sé } \\
\text { de São Paulo, } \\
\text { José Gomes de } \\
\text { Almeida }\end{array}$ & - & - & - & - & São Paulo & Brasil & 3 & Falecido em 1844. \\
\hline 845 & \begin{tabular}{|l|} 
Quadro a óleo: \\
Nossa Senhora \\
\end{tabular} & - & - & - & - & - & - & 3 & 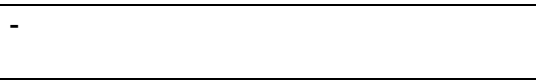 \\
\hline 846 & \begin{tabular}{|l|} 
Retrato a bico de \\
pena de Sua \\
Eminência o Sr. \\
Cardeal Dom \\
Sebastião Leme \\
da Silveira Cintra \\
\end{tabular} & - & - & - & - & - & - & 3 & Arcebispo do Rio de Janeiro. \\
\hline 847 & $\begin{array}{l}\text { Imagem de } \\
\text { barro: São } \\
\text { Domingos de } \\
\text { Gusmão }\end{array}$ & - & - & - & - & - & - & 3 & $\begin{array}{l}\text { Anotação a lápis: Barro cozido, altura } \\
40 \mathrm{cms} \text {. }\end{array}$ \\
\hline 848 & $\begin{array}{l}\text { Antiga imagem } \\
\text { de madeira: São } \\
\text { José }\end{array}$ & Matriz de Itu & - & $\begin{array}{l}\text { Padre José } \\
\text { Maria Drost } \\
\text { Monteiro, } \\
\text { vigário da } \\
\text { Matriz }\end{array}$ & Itu & São Paulo & Brasil & 3 & - \\
\hline
\end{tabular}




\begin{tabular}{|c|c|c|c|c|c|c|c|c|c|}
\hline № & Objeto & Procedência & Pertenceu a & Doado por & Cidade & Estado & País & Patamar & Descrição / Observação \\
\hline 855 & $\begin{array}{l}\text { Tinteiro grande, } \\
\text { com estatueta do } \\
\text { Arcanjo São } \\
\text { Miguel, de } \\
\text { chumbo } \\
\end{array}$ & $\begin{array}{l}\text { Antigo Seminário } \\
\text { Episcopal de São } \\
\text { Paulo }\end{array}$ & - & - & São Paulo & São Paulo & Brasil & 4 & - \\
\hline 856 & Mesa antiga & - & - & - & - & - & - & 4 & Igual a registrada sob o $n^{\circ} 835$. \\
\hline 857 & $\begin{array}{l}\text { Dois candelabros } \\
\text { (tocheiros) de } \\
\text { ferro }\end{array}$ & - & - & - & - & - & - & 4 & e \\
\hline 565 & Pia Batismal & $\begin{array}{l}\text { Primitiva Matriz } \\
\text { de Parnaíba }\end{array}$ & - & - & $\begin{array}{l}\text { Santana de } \\
\text { Parnaíba }\end{array}$ & São Paulo & Brasil & 5 & $\begin{array}{l}\text { Edificada em } 1646 \text {, consertada em } \\
1812 \text { e reformada em } 1882-1883 \text {. A } \\
\text { paróquia teve ereção canônica aos } \\
14 \text { dias de novembro de } 1625 \text {. }\end{array}$ \\
\hline 878 & $\begin{array}{l}\text { Imagem de São } \\
\text { Pedro, sentado e } \\
\text { coroado com a } \\
\text { tiara }\end{array}$ & $\begin{array}{l}\text { Antiga Igreja de } \\
\text { São Pedro dos } \\
\text { Clérigos }\end{array}$ & - & - & São Paulo & São Paulo & Brasil & 5 & - \\
\hline 884 & $\begin{array}{l}\text { Imagem mutilada } \\
\text { de Nossa } \\
\text { Senhora com o } \\
\text { Menino, de } \\
\text { massa }\end{array}$ & $\begin{array}{l}\text { Antiga Matriz de } \\
\text { Parnaíba }\end{array}$ & - & - & $\begin{array}{l}\text { Santana de } \\
\text { Parnaíba }\end{array}$ & São Paulo & Brasil & 5 & Anotação a lápis: 98 cms. \\
\hline 885 & $\begin{array}{l}\text { Imagem mutilada } \\
\text { de São Paulo, } \\
\text { em massa }\end{array}$ & $\begin{array}{l}\text { Primitiva Igreja } \\
\text { do Colégio }\end{array}$ & - & - & São Paulo & São Paulo & Brasil & 5 & Anotação a lápis: 81 cms. \\
\hline 143 & $\begin{array}{l}\text { Quadro antigo, a } \\
\text { óleo, } \\
\text { representando } \\
\text { uma das } \\
\text { estações da Via } \\
\text { Sacra }\end{array}$ & $\begin{array}{l}\text { Antiga Capela } \\
\text { dos Îndios }\end{array}$ & - & - & Carapicuíba & São Paulo & Brasil & 5-parede & $\begin{array}{l}\text { A velha e populosa aldeia de } \\
\text { Carapicuíba, onde por muitos anos } \\
\text { doutrinou o virtuoso Padre Belchior } \\
\text { de Pontes, da Companhia de Jesus. }\end{array}$ \\
\hline
\end{tabular}




\begin{tabular}{|c|c|c|c|c|c|c|c|c|c|}
\hline № & Objeto & Procedência & Pertenceu a & Doado por & Cidade & Estado & País & Patamar & Descrição / Observação \\
\hline 996 & $\begin{array}{l}\text { Canastra } \\
\text { pequena, de } \\
\text { madeira, com } \\
\text { três fechaduras } \\
\text { antigas }\end{array}$ & $\begin{array}{l}\text { Matriz de Nossa } \\
\text { Senhora Da } \\
\text { Escada }\end{array}$ & - & - & Guararema & São Paulo & Brasil & 1ㅇ patamar & Servia quiçá de cofre. \\
\hline 296 & $\begin{array}{l}\text { Quadro - Retrato } \\
\text { do venerando } \\
\text { sacerdote } \\
\text { Redentorista, } \\
\text { padre João } \\
\text { Batista } \\
\text { Schaumberger }\end{array}$ & - & - & - & - & - & - & 1-parede & Ver ANEXO C. \\
\hline 382 & Garrucha & - & - & $\begin{array}{l}\text { Padres } \\
\text { Redentoristas } \\
\text { da Penha }\end{array}$ & São Paulo & São Paulo & Brasil & 1-parede & Ver ANEXO C. \\
\hline 453 & $\begin{array}{l}\text { Retrato a óleo de } \\
\text { Monsenhor Dr. } \\
\text { Anacleto José } \\
\text { Ribeiro Coutinho }\end{array}$ & - & - & - & - & - & - & 1-parede & Ver ANEXO C. \\
\hline 454 & $\begin{array}{l}\text { Retrato a óleo do } \\
\text { Arcediago } \\
\text { Monsenhor Dr. } \\
\text { Joaquim Manuel } \\
\text { Gonçalves de } \\
\text { Andrade }\end{array}$ & - & - & - & - & - & - & 1-parede & Ver ANEXO C. \\
\hline 455 & $\begin{array}{l}\text { Retrato a óleo do } \\
\text { Conselheiro } \\
\text { Padre Dr. } \\
\text { Vicente Pires da } \\
\text { Motta }\end{array}$ & - & - & - & - & - & - & 1-parede & Ver ANEXO C. \\
\hline 460 & Candeeiro & - & - & - & $\begin{array}{l}\text { Santana de } \\
\text { Parnaíba }\end{array}$ & São Paulo & Brasil & 1-parede & $\begin{array}{l}\text { Usado pelos antigos moradores de } \\
\text { Parnaíba. }\end{array}$ \\
\hline
\end{tabular}




\begin{tabular}{|c|c|c|c|c|c|c|c|c|c|}
\hline № & Objeto & Procedência & Pertenceu a & Doado por & Cidade & Estado & País & Patamar & Descrição / Observação \\
\hline 546 & $\begin{array}{l}\text { Aquarela que } \\
\text { representa a } \\
\text { Matriz de Antonio } \\
\text { Dias }\end{array}$ & - & - & - & - & - & Brasil & 1-parede & $\begin{array}{l}\text { A Matriz de Antonio Dias fica em } \\
\text { Ouro Preto, Minas Gerais. }\end{array}$ \\
\hline 805 & $\begin{array}{l}\text { Mapa das } \\
\text { Américas }\end{array}$ & - & - & - & - & - & - & 1-parede & $\begin{array}{l}\text { Pelo padre João Baptista Homann, } \\
\text { membro da Sociedade de Geografia } \\
\text { de Norimberga. }\end{array}$ \\
\hline 807 & $\begin{array}{l}\text { Retrato a óleo de } \\
\text { Monsenhor Dr. } \\
\text { Anacleto José } \\
\text { Ribeiro Coutinho }\end{array}$ & - & - & - & - & - & - & 1-parede & - \\
\hline 808 & $\begin{array}{l}\text { Três quadros a } \\
\text { bico de pena }\end{array}$ & - & - & - & - & - & - & 1-parede & $\begin{array}{l}\text { №1- Observatório do Morro do } \\
\text { Castelo (Rio de Janeiro); №2- } \\
\text { Gnomo mural Do pátio interno do } \\
\text { Seminário Episcopal de São Paulo; e } \\
\text { o №3- Gnomo do Jardim do mesmo } \\
\text { Seminário, construído ambos por Frei } \\
\text { Germano de Annecy, em } 1859 \text {. }\end{array}$ \\
\hline 809 & $\begin{array}{l}\text { Mandado, } \\
\text { assinado pelo } \\
\text { Conselheiro João } \\
\text { Manuel Severino } \\
\text { da Costa }\end{array}$ & - & - & - & - & - & - & 1-parede & $\begin{array}{l}\text { Chamando à Corte o padre Diogo } \\
\text { Antonio Feijó. }\end{array}$ \\
\hline 810 & $\begin{array}{l}\text { Retrato de } \\
\text { Monsenhor Dr. } \\
\text { Fergo O'Connor } \\
\text { de Camargo } \\
\text { Dauntre }\end{array}$ & - & - & $\begin{array}{l}\text { Dr. Ricardo } \\
\text { Gumbleton } \\
\text { Dauntre }\end{array}$ & - & - & - & 1-parede & - \\
\hline 811 & $\begin{array}{l}\text { Retrato do padre } \\
\text { Ildefonso Xavier } \\
\text { Ferreira }\end{array}$ & - & - & - & - & - & - & 1-parede & $\begin{array}{l}\text { Que na mesma noite da } \\
\text { Proclamação da Independência - } 7 \\
\text { de setembro de } 1822 \text { - aclamou Dom } \\
\text { Pedro I Imperador do Brasil. }\end{array}$ \\
\hline
\end{tabular}




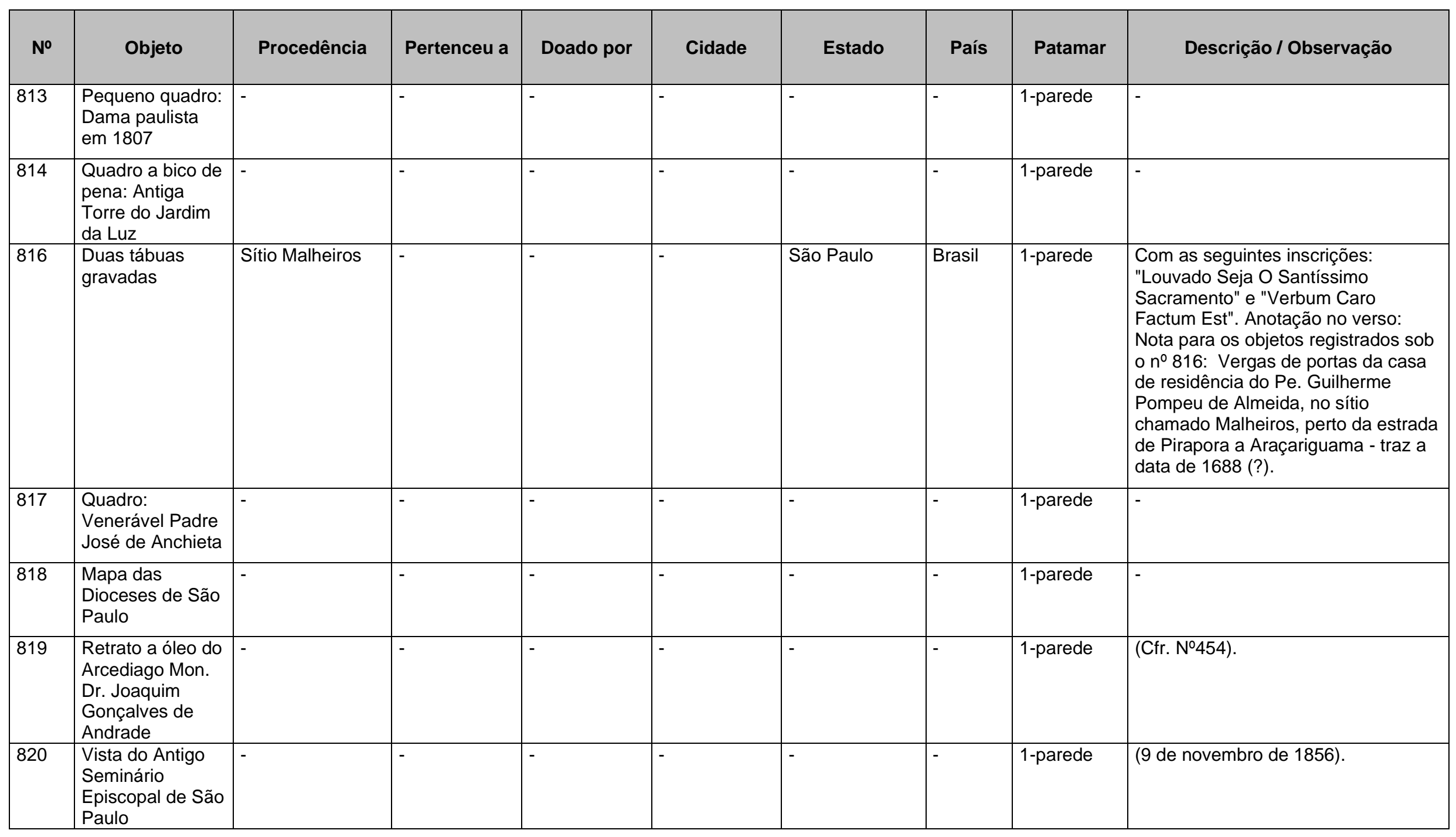




\begin{tabular}{|c|c|c|c|c|c|c|c|c|c|}
\hline № & Objeto & Procedência & Pertenceu a & Doado por & Cidade & Estado & País & Patamar & Descrição / Observação \\
\hline 824 & $\begin{array}{l}\text { Assinatura dos } \\
\text { membros do } \\
\text { primeiro governo } \\
\text { de São Paulo } \\
\text { (1555). Fac- } \\
\text { símile }\end{array}$ & - & - & - & - & - & - & 1-parede & - \\
\hline 457 & Candeeiro & - & - & - & $\begin{array}{l}\text { Pirapora do } \\
\text { Bom Jesus }\end{array}$ & São Paulo & Brasil & 1-pendente & $\begin{array}{l}\text { Usado pelos antigos povoadores de } \\
\text { Pirapora. }\end{array}$ \\
\hline 821 & $\begin{array}{l}\text { Retrato a óleo do } \\
\text { Marques de } \\
\text { Pombal. }\end{array}$ & - & - & - & - & - & - & $\begin{array}{l}\text { 1-sobre a } \\
\text { escada para } \\
\text { o porão }\end{array}$ & - \\
\hline 815 & \begin{tabular}{|l|} 
Imagem do \\
Senhor dos \\
Passos \\
\end{tabular} & $\begin{array}{l}\text { Igreja da Boa } \\
\text { Morte }\end{array}$ & - & - & São Paulo & São Paulo & Brasil & $\begin{array}{l}\text { 1-sobre um } \\
\text { aparador }\end{array}$ & $\begin{array}{l}\text { Originária da cidade do Porto, } \\
\text { Portugal. }\end{array}$ \\
\hline 163 & $\begin{array}{l}\text { Busto de D. } \\
\text { Pedro I }\end{array}$ & - & - & \begin{tabular}{|l|} 
Paulino \\
Macahubas
\end{tabular} & Mariana & Minas Gerais & Brasil & 2-parede & - \\
\hline 456 & $\begin{array}{l}\text { Quatro retratos a } \\
\text { óleo de Santos } \\
\text { Doutores da } \\
\text { Igreja }\end{array}$ & - & - & - & - & - & - & 2-parede & $\begin{array}{l}\text { (Cfr. № 827). Riscado o nome do } \\
\text { objeto. Anotação a lápis: Par de } \\
\text { brincos de brilhante. Anotação: } \\
\text { Retirado do Museu para ser vendido } \\
\text { por ordem de Dom Agnelo Rossi } \\
\text { Cardeal de São Paulo. }\end{array}$ \\
\hline 826 & $\begin{array}{l}\text { Quadro da } \\
\text { inauguração } \\
\text { oficial da } \\
\text { exposição de } \\
\text { São Paulo } \\
\end{array}$ & - & - & - & São Paulo & São Paulo & Brasil & 2-parede & $\begin{array}{l}\text { Exposição por ocasião do } \\
\text { cinquentenário da imigração (8- } \\
\text { 1937). }\end{array}$ \\
\hline 827.1 & $\begin{array}{l}\text { Quadro a óleo: } \\
\text { Inspiração de } \\
\text { São Gregório }\end{array}$ & $\begin{array}{l}\text { Convento antigo } \\
\text { de Santa Teresa }\end{array}$ & - & - & São Paulo & São Paulo & Brasil & 2-parede & Quatro quadros a óleo. (Cfr.n456). \\
\hline
\end{tabular}




\begin{tabular}{|c|c|c|c|c|c|c|c|c|c|}
\hline № & Objeto & Procedência & Pertenceu a & Doado por & Cidade & Estado & País & Patamar & Descrição / Observação \\
\hline 827.2 & $\begin{array}{l}\text { Quadro a óleo: } \\
\text { Êxtase de Santo } \\
\text { Agostinho }\end{array}$ & $\begin{array}{l}\text { Convento antigo } \\
\text { de Santa Teresa }\end{array}$ & - & - & São Paulo & São Paulo & Brasil & 2-parede & - \\
\hline 827.3 & $\begin{array}{l}\text { Quadro a óleo: } \\
\text { Meditação de } \\
\text { Santo Ambrósio }\end{array}$ & $\begin{array}{l}\text { Convento antigo } \\
\text { de Santa Teresa }\end{array}$ & - & - & São Paulo & São Paulo & Brasil & 2-parede & - \\
\hline 827.4 & $\begin{array}{l}\text { Quadro a óleo: } \\
\text { Tentação de São } \\
\text { Jeronimo }\end{array}$ & $\begin{array}{l}\text { Convento antigo } \\
\text { de Santa Teresa }\end{array}$ & - & - & São Paulo & São Paulo & Brasil & 2-parede & - \\
\hline 828 & $\begin{array}{l}\text { Nicho antigo de } \\
\text { madeira }\end{array}$ & $\begin{array}{l}\text { Antiga Igreja do } \\
\text { Colégio dos } \\
\text { Padres Jesuítas }\end{array}$ & - & - & Araçariguama & São Paulo & Brasil & 2-parede & $\begin{array}{l}\text { Anotação no verso: Nicho da Antiga } \\
\text { Igreja do Colégio dos Padres } \\
\text { Jesuítas, bairro do Colégio, Paróquia } \\
\text { de Araçariguama, invocação de N. } \\
\text { Sra. Da Conceição e Sto. Ignacio. }\end{array}$ \\
\hline 829 & Crucifixo antigo & - & - & - & - & - & - & 2-parede & - \\
\hline 830 & $\begin{array}{l}\text { Crucifixo antigo, } \\
\text { com resplendor } \\
\text { de prata }\end{array}$ & - & - & - & - & - & - & 2-parede & - \\
\hline 458 & Roqueira & - & - & - & $\begin{array}{l}\text { Pirapora do } \\
\text { Bom Jesus }\end{array}$ & São Paulo & Brasil & 3-banco & $\begin{array}{l}\text { Usada pelos antigos, nas tradicionais } \\
\text { festividades do Senhor Bom Jesus } \\
\text { de Pirapora. }\end{array}$ \\
\hline 849 & $\begin{array}{l}\text { Antigo anjinho de } \\
\text { madeira }\end{array}$ & - & - & - & - & - & - & $\begin{array}{l}\text { 3-coluna da } \\
\text { escada }\end{array}$ & - \\
\hline 168 & Oratório & - & $\begin{array}{l}\text { Monsenhor } \\
\text { Julio Bicalho }\end{array}$ & - & - & - & Brasil & 3-parede & $\begin{array}{l}\text { Oferecido a Monsenhor Julio Bicalho } \\
\text { - Secretário do Bispado de Mariana, } \\
\text { Bispo eleito e resignatário do Pará - } \\
\text { por Dona Teresa Christina, Imperatriz } \\
\text { do Brasil, que o recebera de sua } \\
\text { mãe. }\end{array}$ \\
\hline
\end{tabular}




\begin{tabular}{|c|c|c|c|c|c|c|c|c|c|}
\hline № & Objeto & Procedência & Pertenceu a & Doado por & Cidade & Estado & País & Patamar & Descrição / Observação \\
\hline 169 & Oratório & Sé de Mariana & $\begin{array}{l}\text { Cônego } \\
\text { Antonio } \\
\text { Cyrillo }\end{array}$ & - & Mariana & Minas Gerais & Brasil & 3-parede & - \\
\hline 170 & Oratório & Sé de Mariana & $\begin{array}{l}\text { Cônego } \\
\text { Antonio } \\
\text { Cyrillo }\end{array}$ & - & Mariana & Minas Gerais & Brasil & 3-parede & - \\
\hline 172 & $\begin{array}{l}\text { Anjinho de } \\
\text { madeira }\end{array}$ & $\begin{array}{l}\text { Matriz de Nossa } \\
\text { Senhora do Pilar }\end{array}$ & - & - & Ouro Preto & Minas Gerais & Brasil & 3-parede & Procedente do primitivo Altar-mor. \\
\hline 175 & Ex-voto & $\begin{array}{l}\text { Igreja de São } \\
\text { Francisco de } \\
\text { Paula }\end{array}$ & - & - & Mariana & Minas Gerais & Brasil & 3-parede & $\begin{array}{l}\text { Com os seguintes dizeres escritos no } \\
\text { quadro: " Milagre que fez São } \\
\text { Francisco e Sta. Rita a Antonio Julio } \\
\text { de S. Novaes, indo na torre e } \\
\text { tocando o sino para abrandar os } \\
\text { trevoins Ihe veio um raio sobre o } \\
\text { ombro que caiu por terra queimando- } \\
\text { se muito, chamando pelos ditos } \\
\text { Santos foi salvo a } 17 \text { de maio de } \\
1818 \text { ". }\end{array}$ \\
\hline 263 & $\begin{array}{l}\text { Quadro antigo de } \\
\text { duas vistas }\end{array}$ & $\begin{array}{l}\text { Antiga Igreja de } \\
\text { São Pedro dos } \\
\text { Clérigos }\end{array}$ & - & - & São Paulo & São Paulo & Brasil & 3-Parede & $\begin{array}{l}\text { Pintura a óleo sobre madeira que, de } \\
\text { um lado, representa Nossa Senhora } \\
\text { do Rosário e, de outro lado São } \\
\text { Domingos. }\end{array}$ \\
\hline 266 & $\begin{array}{l}\text { Prato de } \\
\text { porcelana de } \\
\text { Limoges }\end{array}$ & - & - & $\begin{array}{l}\text { Dr. José } \\
\text { Carlos de } \\
\text { Macedo } \\
\text { Soares }\end{array}$ & - & - & - & 3-Parede & $\begin{array}{l}\text { Com estampa representando Santa } \\
\text { Cecília. }\end{array}$ \\
\hline 340 & $\begin{array}{l}\text { Quadro muito } \\
\text { antigo, pintura a } \\
\text { óleo sobre vidro, } \\
\text { representando } \\
\text { São Domingos } \\
\text { de Gusmão } \\
\end{array}$ & - & - & $\begin{array}{l}\text { Joaquim } \\
\text { Benedito } \\
\text { Braga Junior }\end{array}$ & - & - & - & 3-Parede & - \\
\hline
\end{tabular}




\begin{tabular}{|c|c|c|c|c|c|c|c|c|c|}
\hline № & Objeto & Procedência & Pertenceu a & Doado por & Cidade & Estado & País & Patamar & Descrição / Observação \\
\hline 345 & Quadro & - & $\begin{array}{l}\text { Barão } \\
\text { Homem de } \\
\text { Mello }\end{array}$ & $\begin{array}{l}\text { Dom José } \\
\text { Marcondes } \\
\text { Homem de } \\
\text { Mello, } \\
\text { Arcebispo de } \\
\text { São Carlos } \\
\text { (1906-1937) }\end{array}$ & São Carlos & São Paulo & Brasil & 3-Parede & $\begin{array}{l}\text { Pertenceu ao Barão Homem de } \\
\text { Mello, tendo na frente o seguinte } \\
\text { dístico: "Prospecto do Seminário } \\
\text { Episcopal de Mariana 1854" Traz no } \\
\text { verso os seguintes dizeres } \\
\text { explicativos: "Este é o fiel prospecto } \\
\text { do Episcopal Seminário de Mariana } \\
\text { em que estive estudando desde maio } \\
\text { de } 1847 \text { até novembro de } 1852 ; \text { foi } \\
\text { ele tirado por um curioso -Julio } \\
\text { Augusto Vieira Couto -- e de lá } \\
\text { remetido aqui para São Paulo por um } \\
\text { amigo meu, conforme a carta junta. } \\
\text { São Paulo } 11 \text { de fevereiro de } 1854 \\
\text { Francisco Inacio Marcondes Homem } \\
\text { de Mello." }\end{array}$ \\
\hline 352 & $\begin{array}{l}\text { Retrato do Padre } \\
\text { Bento Dias } \\
\text { Pacheco }\end{array}$ & - & - & - & - & - & Brasil & 3-Parede & $\begin{array}{l}\text { Distinto sacerdote ituano, pai da } \\
\text { pobreza e carinhoso protetor dos } \\
\text { morféticos, aos quais, por mais de } \\
\text { quarenta anos, prestou } \\
\text { desinteressadamente os seus } \\
\text { serviços de capelão médico, } \\
\text { enfermeiro e criado, com a máxima } \\
\text { paciência e bondade. Nasceu em Itu, } \\
\text { no ano de } 1819 \text { e ali faleceu aos } 6 \text { de } \\
\text { março de } 1911 \text {, com } 93 \text { anos de } \\
\text { idade. }\end{array}$ \\
\hline 364 & Martelo antigo & $\begin{array}{l}\text { Antiga Matriz de } \\
\text { Itapecerica }\end{array}$ & - & - & $\begin{array}{l}\text { Itapecerica da } \\
\text { Serra }\end{array}$ & São Paulo & Brasil & 3-Parede & $\begin{array}{l}\text { Foi encontrado sob o assoalho da } \\
\text { Antiga Matriz de Itapecerica e que se } \\
\text { presume ter sido deixado ali por } \\
\text { esquecimento de algum operário, } \\
\text { empregado na construção da igreja. }\end{array}$ \\
\hline
\end{tabular}




\begin{tabular}{|c|c|c|c|c|c|c|c|c|c|}
\hline № & Objeto & Procedência & Pertenceu a & Doado por & Cidade & Estado & País & Patamar & Descrição / Observação \\
\hline 376 & $\begin{array}{l}\text { Forqueta de } \\
\text { andor de } \\
\text { jacarandá }\end{array}$ & $\begin{array}{l}\text { Convento de } \\
\text { Santo Antonio }\end{array}$ & - & - & Santos & São Paulo & Brasil & 3-Parede & - \\
\hline 429 & $\begin{array}{l}\text { Bandeira da } \\
\text { "Guerra dos } \\
\text { Farrapos" }\end{array}$ & - & $\begin{array}{l}\text { General } \\
\text { Portilho }\end{array}$ & $\begin{array}{l}\text { Dona Cecilia } \\
\text { Porto Trigo }\end{array}$ & - & - & - & 3-Parede & $\begin{array}{l}\text { Que pertenceu ao General Portilho e } \\
\text { por ele oferecida a seu sobrinho } \\
\text { Francisco Gomes Porto. Falecido } \\
\text { este, a viúva Dona Maria Macedônia } \\
\text { Gomes Porto ofereceu-a a Dona } \\
\text { Cecilia Porto Trigo, sua neta, que, } \\
\text { por sua vez, a ofereceu ao Museu da } \\
\text { Cúria. }\end{array}$ \\
\hline 439 & $\begin{array}{l}\text { Retrato de Santa } \\
\text { Maria Madalena }\end{array}$ & - & $\begin{array}{l}\text { Padre Nicolau } \\
\text { da Estreita } \\
\text { Observância } \\
\text { dos Menores } \\
\text { Descalços }\end{array}$ & - & - & - & - & 3-Parede & $\begin{array}{l}\text { Pertencia ao verdadeiro servo de } \\
\text { Deus, padre Nicolau da Estreita } \\
\text { Observância dos Menores } \\
\text { Descalços. Pregador, falecido em } 2 \\
\text { de junho de } 1749 \text {, com } 79 \text { anos de } \\
\text { idade e } 64 \text { de Religião. }\end{array}$ \\
\hline 441 & A Santa Face & \begin{tabular}{|l|} 
Capela de Nossa \\
Senhora da \\
Conceição, do \\
bairro de \\
Caucaia \\
\end{tabular} & - & $\begin{array}{l}\text { Luiz Manuel } \\
\text { de Oliveira, } \\
\text { zelador da } \\
\text { capela }\end{array}$ & Cotia & São Paulo & Brasil & 3-parede & $\begin{array}{l}\text { Antigo trabalho de ferro fundido. A } \\
\text { Capela ficava distante três léguas da } \\
\text { Vila de Cotia. }\end{array}$ \\
\hline 459 & $\begin{array}{l}\text { Relógio de sol } \\
\text { (1801) }\end{array}$ & $\begin{array}{l}\text { Velha Sé de São } \\
\text { Paulo }\end{array}$ & - & - & São Paulo & São Paulo & Brasil & 3-Parede & $\begin{array}{l}\text { Edificada em 1589, reedificada em } \\
1745 \text { e demolida em } 1912 \text {. }\end{array}$ \\
\hline 461 & $\begin{array}{l}\text { Fotografia da } \\
\text { Coroação da } \\
\text { Milagrosa } \\
\text { Imagem de } \\
\text { Nossa Senhora } \\
\text { Aparecida }\end{array}$ & - & - & $\begin{array}{l}\text { Francisco de } \\
\text { Salles Collet } \\
\text { e Silva, } \\
\text { diretor do } \\
\text { Arquivo e } \\
\text { Museu da } \\
\text { Cúria } \\
\end{array}$ & - & - & - & 3-Parede & Tirada aos 8 de setembro de 1904. \\
\hline
\end{tabular}




\begin{tabular}{|c|c|c|c|c|c|c|c|c|c|}
\hline 501 & $\begin{array}{l}\text { Retrato a óleo do } \\
\text { Cônego Manuel } \\
\text { Emygdio } \\
\text { Bernardes }\end{array}$ & & & - & São Paulo & São Paulo & Brasil & 3-parede & $\begin{array}{l}\text { Tesoureiro-Mor do Cabido de São } \\
\text { Paulo, nascido em } 1799 \text { e ordenado } \\
\text { Presbítero no dia 10 de junho de } \\
\text { 1822: Cônego aos } 17 \text { de maio de } \\
\text { 1840: tesoureiro-mor aos } 4 \text { de } \\
\text { novembro de } 1857 \text {. Faleceu em São } \\
\text { Paulo no dia } 12 \text { de setembro de } \\
\text { 1887. }\end{array}$ \\
\hline
\end{tabular}




\begin{tabular}{|c|c|c|c|c|c|c|c|c|c|}
\hline № & Objeto & Procedência & Pertenceu a & Doado por & Cidade & Estado & País & Patamar & Descrição / Observação \\
\hline 541 & $\begin{array}{l}\text { Imagem de } \\
\text { Santa } \\
\text { Escolástica }\end{array}$ & $\begin{array}{l}\text { Mosteiro de } \\
\text { Santa Clara }\end{array}$ & - & $\begin{array}{l}\text { Revda. Madre } \\
\text { Abadessa do } \\
\text { Mosteiro }\end{array}$ & Sorocaba & São Paulo & Brasil & 3-parede & $\begin{array}{l}\text { Trabalho rústico e bastante antigo } \\
\text { feito de barro. Mosteiro fundado em } \\
\text { 1804, Por Dona Manuela, Dona Rita } \\
\text { e Dona Ana, filhas do Alferes } \\
\text { Francisco Xavier de Oliveira, e foi } \\
\text { oferecido ao Museu da Cúria, com a } \\
\text { licença do Exmo. Sr. Dom José } \\
\text { Carlos de Aguirre, primeiro Bispo de } \\
\text { Sorocaba, pela Revma. Madre } \\
\text { Abadessa do dito Mosteiro. } \\
\text { Anotação a lápis: (ilegível) Foi } \\
\text { propriamente imagem de Santo } \\
\text { Amaro, transformado } \\
\text { (posteriormente) em Santa } \\
\text { Escolástica (o véu é postiço!) } \\
\text { (ilegível). }\end{array}$ \\
\hline 542 & $\begin{array}{l}\text { Imagem de São } \\
\text { José }\end{array}$ & $\begin{array}{l}\text { Mosteiro de } \\
\text { Santa Clara }\end{array}$ & - & $\begin{array}{l}\text { Revda. Madre } \\
\text { Abadessa do } \\
\text { Mosteiro }\end{array}$ & Sorocaba & São Paulo & Brasil & 3-parede & $\begin{array}{l}\text { Trabalho antigo e bastante rústico e } \\
\text { feito de barro. Anotação a lápis: Casa } \\
\text { do Bandeirante. }\end{array}$ \\
\hline 462 & $\begin{array}{l}\text { Lâmpada de } \\
\text { prata } \\
\text { (incompleta) }\end{array}$ & $\begin{array}{l}\text { Capela do } \\
\text { Santíssimo } \\
\text { Sacramento da } \\
\text { Antiga Catedral } \\
\text { da Sé }\end{array}$ & - & - & São Paulo & São Paulo & Brasil & 3-pendente & Anotação a lápis:? \\
\hline 463 & $\begin{array}{l}\text { Lâmpada de } \\
\text { prata } \\
\text { (incompleta) }\end{array}$ & $\begin{array}{l}\text { Irmandade de } \\
\text { São Pedro }\end{array}$ & - & - & - & - & - & 3-pendente & - \\
\hline 838 & Cruz de mármore & - & - & - & - & - & - & $\begin{array}{l}\text { 3-sobre a } \\
\text { porta }\end{array}$ & $\begin{array}{l}\text { Comemorativa da passagem de } \\
\text { século. (Cfr. №833). }\end{array}$ \\
\hline
\end{tabular}




\begin{tabular}{|c|c|c|c|c|c|c|c|c|c|}
\hline № & Objeto & Procedência & Pertenceu a & Doado por & Cidade & Estado & País & Patamar & Descrição / Observação \\
\hline 440 & $\begin{array}{l}\text { Quadro do Natal. } \\
\text { Pintura a óleo } \\
\text { sobre madeira }\end{array}$ & $\begin{array}{l}\text { Capela de São } \\
\text { João }\end{array}$ & - & $\begin{array}{l}\text { Paulo } \\
\text { Mathias, } \\
\text { antigo zelador } \\
\text { da capela }\end{array}$ & São Paulo & São Paulo & Brasil & $\begin{array}{l}\text { 3-sobre a } \\
\text { porta- } \\
\text { exterior }\end{array}$ & $\begin{array}{l}\text { Trabalho antigo, do forro do coro } \\
\text { secular da Capela de São João. }\end{array}$ \\
\hline 452 & Escudo & - & - & - & - & - & - & 4-parede & $\begin{array}{l}\text { Armas de Dom José de Barros } \\
\text { Alarcão, com a seguinte inscrição: " } \\
\text { D.D. } \\
\text { IOSEPHUS.DE.BARROS.DE.ALARC } \\
\text { ÃO.PRIMUS.EPISC.IANUA.HUIUS.C } \\
\text { AENOBII.FUDATOR.ET.PTECTOR." }\end{array}$ \\
\hline 530 & \begin{tabular}{|l} 
Bandeira \\
Nacional da \\
República
\end{tabular} & $\begin{array}{l}\text { Catedral de São } \\
\text { Paulo }\end{array}$ & - & - & São Paulo & São Paulo & Brasil & 4-parede & $\begin{array}{l}\text { Flutuou no cimo da Catedral por } \\
\text { ocasião das grandes festas com que } \\
\text { se comemorou o primeiro centenário } \\
\text { da Independência do Brasil - } 7 \text { de } \\
\text { setembro de } 1922 \text {. }\end{array}$ \\
\hline 853 & $\begin{array}{l}\text { Quatro quadros } \\
\text { em litografia }\end{array}$ & - & - & - & - & - & - & 4-parede & $\begin{array}{l}\text { São de costumes regionais da época } \\
\text { do Brasil Colônia. }\end{array}$ \\
\hline 854 & $\begin{array}{l}\text { Duas pinturas em } \\
\text { madeira }\end{array}$ & $\begin{array}{l}\text { Mosteiro de } \\
\text { Santa Clara }\end{array}$ & - & - & Taubaté & São Paulo & Brasil & 4-parede & Muito antigas. \\
\hline 858 & $\begin{array}{l}\text { Dois quadros: } \\
\text { São Joaquim e } \\
\text { Sant'Ana }\end{array}$ & - & - & - & - & - & - & 4-parede & $\begin{array}{l}\text { Pintura a óleo sobre cobre, de } \\
\text { grande valor artístico. São antigos, } \\
\text { de autor não identificado. }\end{array}$ \\
\hline 859 & $\begin{array}{l}\text { Mapa de } \\
\text { recenseamento } \\
\text { da Capitânia de } \\
\text { São Paulo }\end{array}$ & - & - & - & - & - & - & 4-parede & $\begin{array}{l}\text { Em 1722, mandado fazer pelo então } \\
\text { governador capitão general Dom Luiz } \\
\text { Antonio de Souza Botelho Mourão. }\end{array}$ \\
\hline 860 & $\begin{array}{l}\text { Quadro a óleo: } \\
\text { Batismo de N.S.. } \\
\text { Jesus Cristo }\end{array}$ & $\begin{array}{l}\text { Batistério da } \\
\text { Velha Sé }\end{array}$ & - & - & São Paulo & São Paulo & Brasil & 4-parede & $\begin{array}{l}\text { Anotação a lápis: Retirado para } \\
\text { Catedral. }\end{array}$ \\
\hline
\end{tabular}




\begin{tabular}{|c|c|c|c|c|c|c|c|c|c|}
\hline № & Objeto & Procedência & Pertenceu a & Doado por & Cidade & Estado & País & Patamar & Descrição / Observação \\
\hline 861 & $\begin{array}{l}\text { Quadro a óleo: } \\
\text { Ascensão do } \\
\text { Nosso Senhor }\end{array}$ & - & - & - & - & - & - & 4-parede & - \\
\hline 862 & $\begin{array}{l}\text { Coleção de seis } \\
\text { quadros a óleo }\end{array}$ & - & - & - & - & - & - & 4-parede & $\begin{array}{l}\text { Representando cada qual uma das } \\
\text { Dores de Nossa Senhora. (Falta uma } \\
\text { dor). }\end{array}$ \\
\hline 935 & $\begin{array}{l}\text { Bandeirinha } \\
\text { Pontifícia de } \\
\text { seda }\end{array}$ & - & - & - & - & - & - & $5-$ & $\begin{array}{l}\text { Usada no Congresso Eucarístico de } \\
\text { Buenos Aires. }\end{array}$ \\
\hline 162 & $\begin{array}{l}\text { Pingentes de um } \\
\text { velho lustre }\end{array}$ & \begin{tabular}{|l|} 
Igreja de São \\
Francisco de \\
Assis
\end{tabular} & - & - & Ouro Preto & Minas Gerais & Brasil & 5 -parede & Sobre a imagem do Menino Deus. \\
\hline 174 & $\begin{array}{l}\text { Imagem de São } \\
\text { José (marfim) e } \\
\text { Sant'Ana (peça } \\
\text { inteiriça) }\end{array}$ & $\begin{array}{l}\text { Matriz de Antonio } \\
\text { Pires }\end{array}$ & - & - & Ouro Preto & Minas Gerais & Brasil & 5-parede & $\begin{array}{l}\text { Assim chamada devido ao nome do } \\
\text { fundador, natural de Taubaté. }\end{array}$ \\
\hline 315 & $\begin{array}{l}\text { Imagem de } \\
\text { Nossa Senhora } \\
\text { (em vulto) }\end{array}$ & - & - & $\begin{array}{l}\text { Padre } \\
\text { redentorista } \\
\text { Estevam } \\
\text { Maria, vigário } \\
\text { da Penha }\end{array}$ & São Paulo & São Paulo & Brasil & 5-parede & Trabalho antigo de madeira. \\
\hline 316 & $\begin{array}{l}\text { Imagem de } \\
\text { Sant'Ana ( em } \\
\text { vulto) }\end{array}$ & - & - & $\begin{array}{l}\text { Padre } \\
\text { redentorista } \\
\text { Estevam } \\
\text { Maria, vigário } \\
\text { da Penha }\end{array}$ & São Paulo & São Paulo & Brasil & 5-parede & Trabalho antiga de madeira. \\
\hline 317 & Cabeça de Cristo & - & - & $\begin{array}{l}\text { Padre } \\
\text { redentorista } \\
\text { Estevam } \\
\text { Maria, vigário } \\
\text { da Penha }\end{array}$ & São Paulo & São Paulo & Brasil & 5-parede & Belíssimo trabalho de barro. \\
\hline
\end{tabular}




\begin{tabular}{|c|c|c|c|c|c|c|c|c|c|}
\hline № & Objeto & Procedência & Pertenceu a & Doado por & Cidade & Estado & País & Patamar & Descrição / Observação \\
\hline 334 & $\begin{array}{l}\text { Quatro cabeças } \\
\text { de imagens }\end{array}$ & - & - & $\begin{array}{l}\text { Padre } \\
\text { redentorista } \\
\text { Estevam } \\
\text { Maria, vigário } \\
\text { da Penha }\end{array}$ & São Paulo & São Paulo & Brasil & 5-parede & Trabalho de barro. \\
\hline 335 & $\begin{array}{l}\text { Imagem de São } \\
\text { Lourenço, } \\
\text { Diácono e Mártir }\end{array}$ & - & $\begin{array}{l}\text { Tenente } \\
\text { Lourenço } \\
\text { Antonio } \\
\text { Braga }\end{array}$ & $\begin{array}{l}\text { Joaquim } \\
\text { Benedito } \\
\text { Braga Junior }\end{array}$ & - & - & - & 5-parede & $\begin{array}{l}\text { Trabalho de barro, muito antigo, que } \\
\text { pertencia ao Tenente Lourenço } \\
\text { Antonio Braga, natural de Portugal, } \\
\text { que em } 1807 \text { já residia na então Vila } \\
\text { de Santos. } 32 \mathrm{~cm} \text {. de altura. }\end{array}$ \\
\hline 343 & $\begin{array}{l}\text { Bandeira de } \\
\text { damasco } \\
\text { vermelha com } \\
\text { bordados de } \\
\text { ouro, tendo no } \\
\text { centro o } \\
\text { emblema do } \\
\text { Divino Espírito } \\
\text { Santo. }\end{array}$ & $\begin{array}{l}\text { Paroquial Igreja } \\
\text { de Santa Ifigênia }\end{array}$ & - & - & São Paulo & São Paulo & Brasil & 5-parede & $\begin{array}{l}\text { Servia nas festividades do Divino, } \\
\text { que se realizavam na paroquia. } \\
\text { Anotação a lápis: Não foi encontrada. }\end{array}$ \\
\hline 344 & $\begin{array}{l}\text { Bandeira de } \\
\text { damasco } \\
\text { vermelha tendo } \\
\text { no centro o } \\
\text { emblema do } \\
\text { Divino Espírito } \\
\text { Santo. }\end{array}$ & $\begin{array}{l}\text { Antiga Igreja da } \\
\text { Sé }\end{array}$ & - & - & São Paulo & São Paulo & Brasil & 5-parede & $\begin{array}{l}\text { Servia nas festividades do Divino } \\
\text { Espírito Santo. Anotação a lápis: Não } \\
\text { foi encontrada. }\end{array}$ \\
\hline
\end{tabular}




\begin{tabular}{|c|c|c|c|c|c|c|c|c|c|}
\hline № & Objeto & Procedência & Pertenceu a & Doado por & Cidade & Estado & País & Patamar & Descrição / Observação \\
\hline 413 & $\begin{array}{l}\text { Crucifixo com } \\
\text { peanha de barro }\end{array}$ & - & - & $\begin{array}{l}\text { R.P. Roberto } \\
\text { Hausmair, } \\
\text { redentorista }\end{array}$ & São Paulo & São Paulo & Brasil & 5 -parede & $\begin{array}{l}\text { Pertenceu a Alexandrina - última } \\
\text { índia remanescente do antigo } \\
\text { aldeamento de São Miguel, falecida a } \\
15 \text { anos. Esta Imagem, presente de } \\
\text { velho missionário, conservou-se por } \\
\text { muitíssimos anos em casa de seus } \\
\text { antepassados. Doado em } \\
22 / 04 / 1927 \text {. Anotação a lápis: } \\
\text { pedestal (em cima da palavra } \\
\text { peanha). }\end{array}$ \\
\hline 510 & $\begin{array}{l}\text { Imagem de São } \\
\text { José } \\
\text { (incompleta) de } \\
\text { madeira } \\
\end{array}$ & $\begin{array}{l}\text { Capela de Santa } \\
\text { Luzia }\end{array}$ & - & - & São Paulo & São Paulo & Brasil & 5-parede & Capela situada na Rua Tabatinguera. \\
\hline 511 & $\begin{array}{l}\text { Imagem de São } \\
\text { João Batista, de } \\
\text { barro }\end{array}$ & $\begin{array}{l}\text { Capela de Santa } \\
\text { Luzia }\end{array}$ & - & - & São Paulo & São Paulo & Brasil & 5 -parede & $\begin{array}{l}\text { Trabalho antigo. Capela situada na } \\
\text { Rua Tabatinguera. }\end{array}$ \\
\hline 512 & $\begin{array}{l}\text { Imagem de São } \\
\text { Francisco de } \\
\text { Paula, de barro }\end{array}$ & $\begin{array}{l}\text { Capela de Santa } \\
\text { Luzia }\end{array}$ & - & - & São Paulo & São Paulo & Brasil & 5-parede & $\begin{array}{l}\text { Capela situada na Rua Tabatinguera. } \\
\text { Trabalho antigo. Está mutilada. }\end{array}$ \\
\hline 513 & $\begin{array}{l}\text { Imagem de } \\
\text { Nossa Senhora } \\
\text { da Conceição, de } \\
\text { madeira }\end{array}$ & $\begin{array}{l}\text { Capela de Santa } \\
\text { Luzia }\end{array}$ & - & - & São Paulo & São Paulo & Brasil & 5-parede & $\begin{array}{l}\text { Capela situada na Rua Tabatinguera. } \\
\text { Trabalho antigo. Anotação a lápis: } \\
\text {...(ilegível) do Parto. }\end{array}$ \\
\hline 514 & $\begin{array}{l}\text { Antiga Imagem } \\
\text { do Menino Jesus }\end{array}$ & $\begin{array}{l}\text { Capela de Santa } \\
\text { Luzia }\end{array}$ & - & - & São Paulo & São Paulo & Brasil & 5-parede & Capela situada na rua Tabatinguera. \\
\hline 518 & $\begin{array}{l}\text { Bandeja de } \\
\text { madeira }\end{array}$ & - & $\begin{array}{l}\text { Dom Lucio } \\
\text { Antunes de } \\
\text { Souza, } \\
\text { primeiro } \\
\text { Bispo de } \\
\text { Botucatu } \\
(1909-1924)\end{array}$ & - & Botucatu & São Paulo & Brasil & 5-parede & $\begin{array}{l}\text { Obra de marchetaria, com as Armas } \\
\text { Episcopais de Dom Lucio Antunes de } \\
\text { Souza, 10 Bispo de Botucatu (1909- } \\
\text { 1924), ao qual pertenceu. }\end{array}$ \\
\hline
\end{tabular}




\begin{tabular}{|c|c|c|c|c|c|c|c|c|c|}
\hline № & Objeto & Procedência & Pertenceu a & Doado por & Cidade & Estado & País & Patamar & Descrição / Observação \\
\hline 871 & $\begin{array}{l}\text { Fotografia da } \\
\text { antiga Matriz de } \\
\text { Nossa Senhora } \\
\text { Do O' }\end{array}$ & - & - & - & - & - & - & 5-parede & - \\
\hline 872 & $\begin{array}{l}\text { Fotografia da } \\
\text { antiga Matriz de } \\
\text { Itu }\end{array}$ & - & - & - & - & - & - & 5-parede & - \\
\hline 873 & $\begin{array}{l}\text { Fotografia da } \\
\text { antiga Matriz da } \\
\text { Consolação }\end{array}$ & - & - & - & - & - & - & 5 -parede & - \\
\hline 874 & $\begin{array}{l}\text { Três fotografias } \\
\text { da antiga Igreja } \\
\text { do Colégio }\end{array}$ & $\begin{array}{l}\text { Antiga Igreja do } \\
\text { Colégio }\end{array}$ & - & - & São Paulo & São Paulo & Brasil & 5-parede & $\begin{array}{l}\text { Antes da demolição, durante a } \\
\text { demolição e Altar-Mor. }\end{array}$ \\
\hline 875 & $\begin{array}{l}\text { Duas cópias } \\
\text { fotográficas, } \\
\text { coloridas do } \\
\text { Papa Leão XIII }\end{array}$ & - & - & - & - & - & - & 5-parede & - \\
\hline 876 & $\begin{array}{l}\text { Litogravura: } \\
\text { Diversas fase da } \\
\text { vida de Dom } \\
\text { Pedro II, } \\
\text { Imperador do } \\
\text { Brasil }\end{array}$ & - & - & - & - & - & - & 5-parede & Desde a Aclamação até o desterro. \\
\hline 877 & $\begin{array}{l}\text { Quadrinho a } \\
\text { óleo: Cardeal } \\
\text { Dom Sebastião } \\
\text { Leme da Silveira } \\
\text { Cintra (J.W.R.) }\end{array}$ & - & - & - & - & - & - & 5-parede & 然 \\
\hline 879 & $\begin{array}{l}\text { Quadro de } \\
\text { litografia em } \\
\text { pano de seda }\end{array}$ & - & - & - & - & - & - & 5-parede & $\begin{array}{l}\text { Comemora as Conclusões } \\
\text { Teológicas a respeito do Sacramento } \\
\text { da Penitência, segundo a doutrina de } \\
\text { Santo Tomaz de Aquino. }\end{array}$ \\
\hline
\end{tabular}




\begin{tabular}{|c|c|c|c|c|c|c|c|c|c|}
\hline № & Objeto & Procedência & Pertenceu a & Doado por & Cidade & Estado & País & Patamar & Descrição / Observação \\
\hline 880 & $\begin{array}{l}\text { Duas bandeiras } \\
\text { do Espírito Santo }\end{array}$ & - & - & - & - & - & - & 5-parede & - \\
\hline 881 & $\begin{array}{l}\text { Imagem de } \\
\text { Nossa Senhora } \\
\text { Da Conceição }\end{array}$ & - & - & - & - & - & - & 5-parede & Trabalho muito antigo, de madeira. \\
\hline 882 & $\begin{array}{l}\text { Imagem tosca de } \\
\text { Santo Antonio, } \\
\text { de madeira }\end{array}$ & - & - & - & - & - & - & 5-parede & - \\
\hline 886 & $\begin{array}{l}\text { Imagem de São } \\
\text { João Batista, de } \\
\text { gesso }\end{array}$ & - & - & - & - & - & - & 5-parede & - \\
\hline 464 & $\begin{array}{l}\text { Lâmpada de } \\
\text { prata } \\
\text { (incompleta) }\end{array}$ & - & - & - & - & Mato Grosso & Brasil & 5-pendente & - \\
\hline 850 & $\begin{array}{l}\text { Diploma (em } \\
\text { branco) de Irmão } \\
\text { Terceiro de São } \\
\text { Francisco }\end{array}$ & - & - & - & Mariana & Minas Gerais & Brasil & $\begin{array}{l}\text { Escada do } \\
3^{\circ} \text { para o } 4^{\circ} \\
\text { pat. }\end{array}$ & - \\
\hline 836 & Retrato a óleo & - & - & - & - & - & - & $\begin{array}{l}\text { Escada } \\
\text { para o } \\
\text { 3patamar }\end{array}$ & - \\
\hline 851 & $\begin{array}{l}\text { Diploma da } \\
\text { Diretoria Geral } \\
\text { de Estatística }\end{array}$ & - & - & $\begin{array}{l}\text { Dom Duarte } \\
\text { Leopoldo e } \\
\text { Silva }\end{array}$ & São Paulo & São Paulo & Brasil & \begin{tabular}{|l|} 
Escadaria \\
do $3^{\circ}$ para o \\
4을atamar
\end{tabular} & $\begin{array}{l}\text { Conferindo a medalha de prata ao } \\
\text { Exmo. Sr. Dom Duarte Leopoldo e } \\
\text { Silva, Arcebispo de São Paulo: } 1^{\circ} \text { de } \\
\text { setembro de } 1922 \text {. }\end{array}$ \\
\hline
\end{tabular}




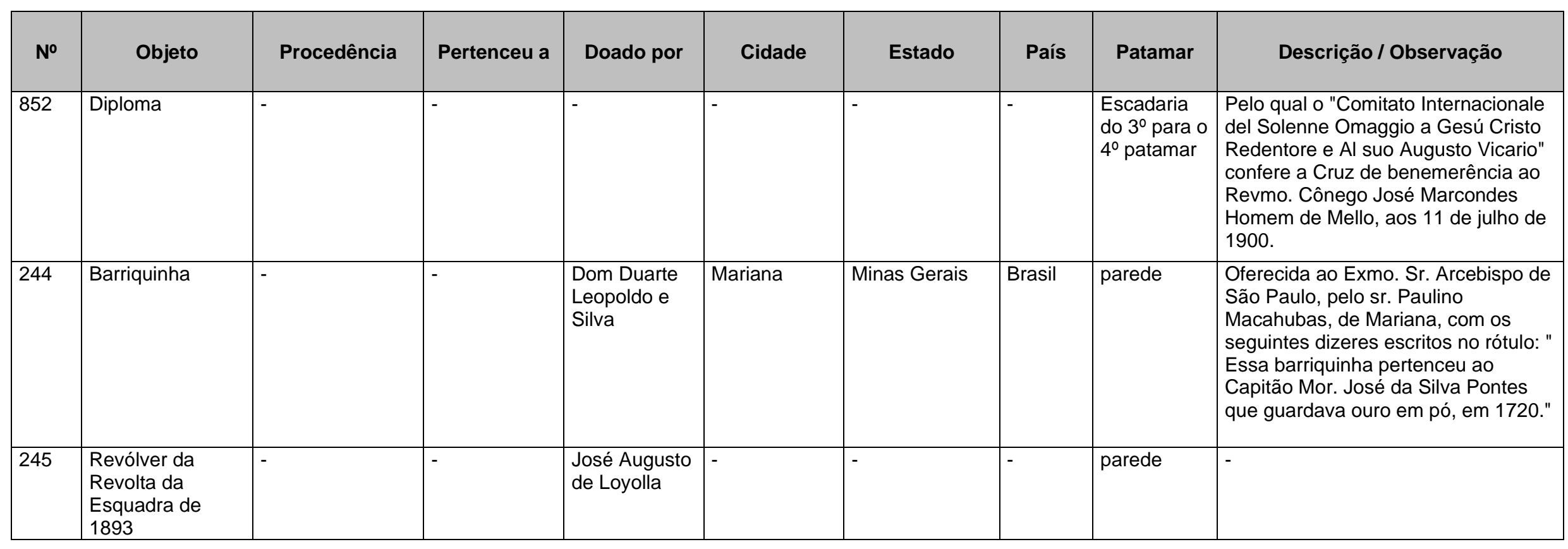




\section{Salas do $2^{\circ}$ pavimento}

Durante pesquisa no ACMSP foi encontrado um esboço de levantamento topográfico das pinturas existentes no $2^{\circ}$ pavimento do Palácio da Cúria, onde se encontravam as principais repartições eclesiásticas e o gabinete do Arcebispo, conhecido como Sala do Trono (ANEXO B).

Neste levantamento podemos observar um grande número de obras do pintor Benedito Calixto, além de outros quadros que não constam no Catálogo de objetos do Museu.

Interessante observar que a maioria das obras são paisagens, retratos de locais de São Paulo e do litoral paulista, com predominância de edifícios religiosos mas não só.

Figura 72: Salas do $2^{\circ}$ pavimento
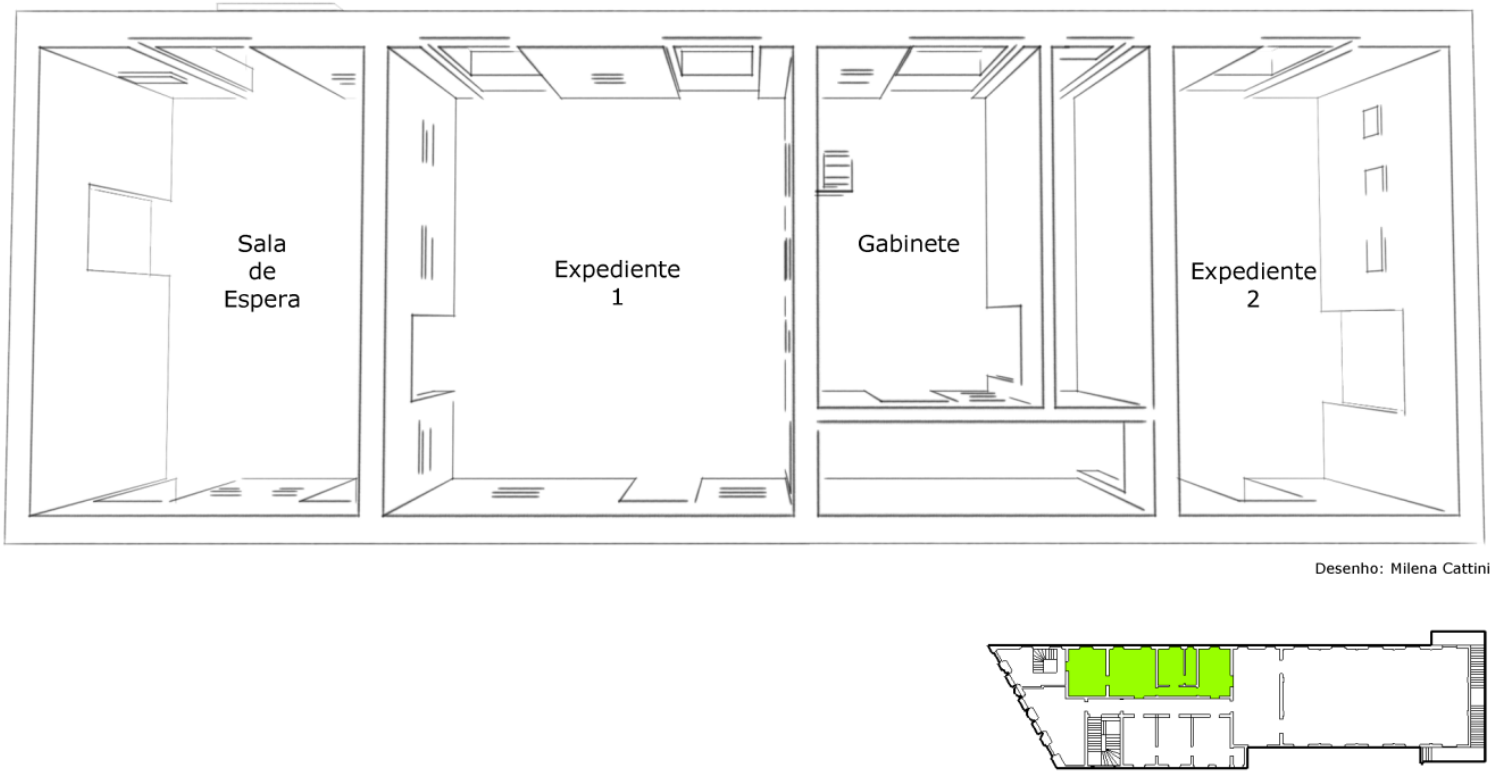
Figura 73: Perspectiva da Sala de espera ( $2^{\circ}$ pavimento).
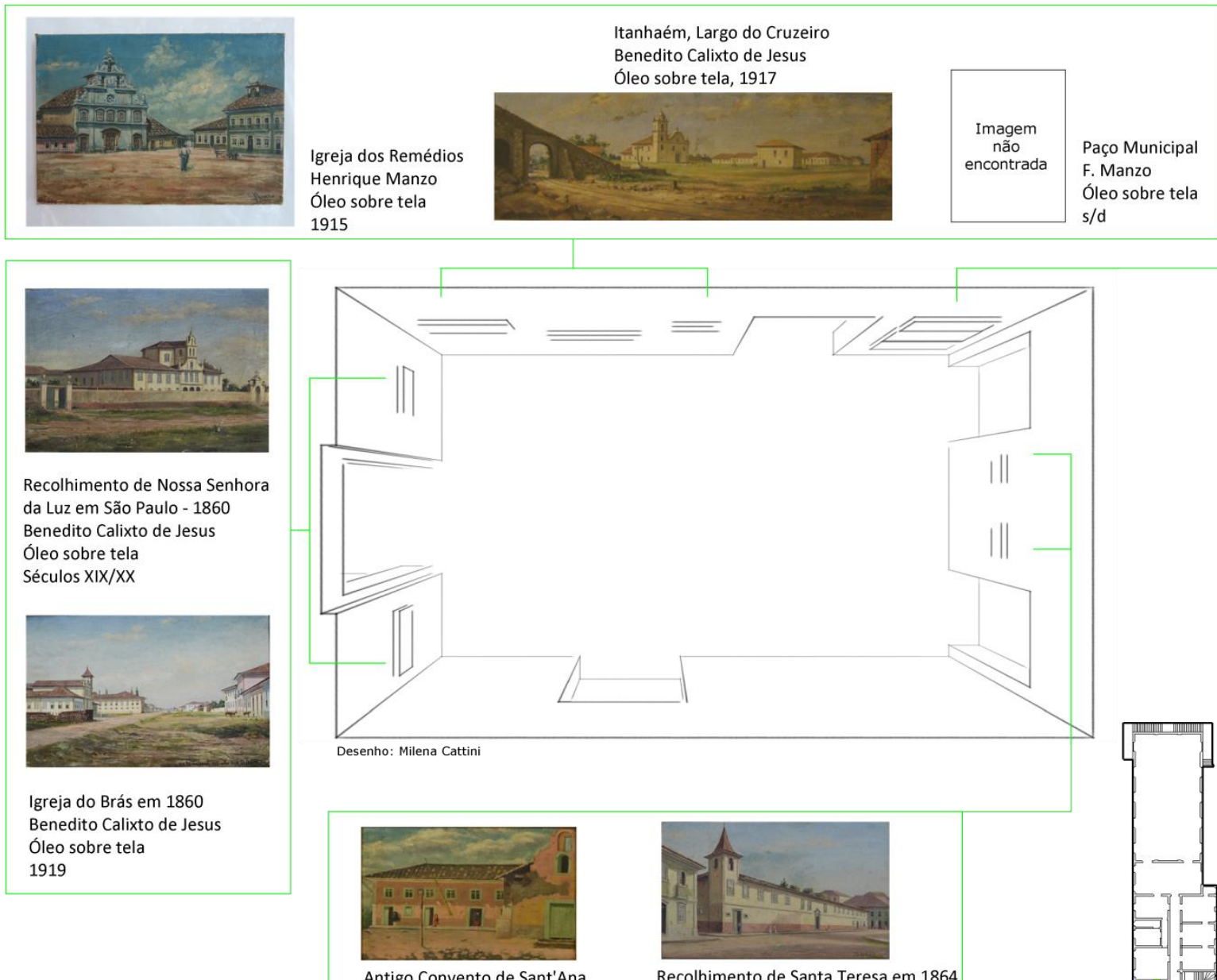

Antigo Convento de Sant'Ana Desconhecido

Óleo sobre madeira

$\mathrm{s} / \mathrm{d}$

da Luz em São Paulo - 1860

Benedito Calixto de Jesus

Oleo sobre tela
Séculos $\mathrm{XIX} / \mathrm{XX}$

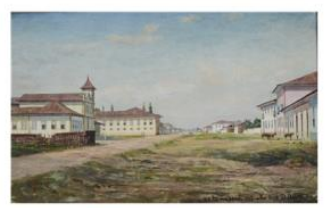

Igreja do Brás em 1860

Benedito Calixto de Jesus

Óleo sobre tel

1919
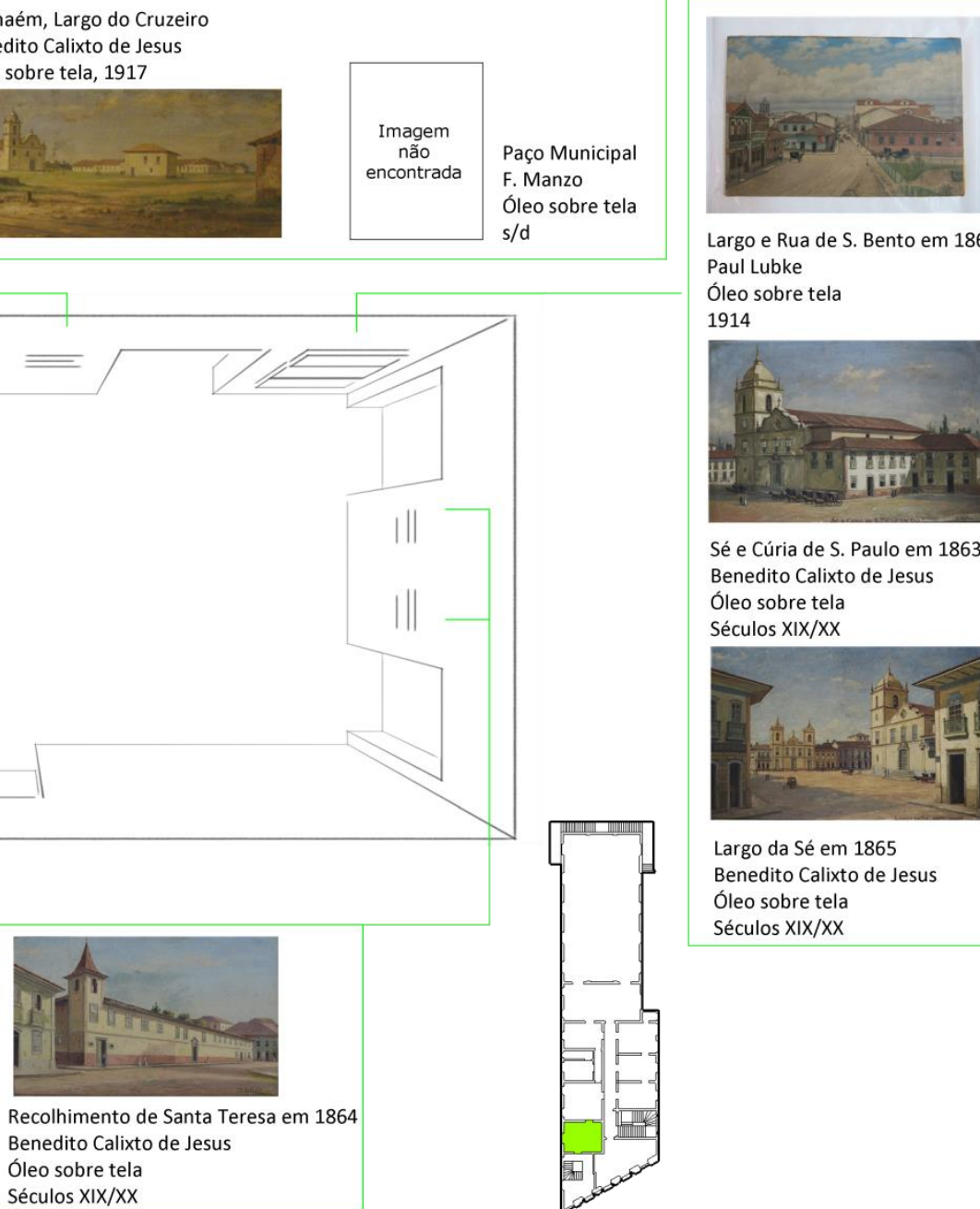

Largo e Rua de S. Bento em 1860 Paul Lubke

Óleo sobre tela

1914

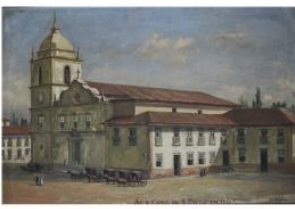

Sé e Cúria de S. Paulo em 1863

Benedito Calixto de Jesus

Óleo sobre tela

Séculos XIX/XX

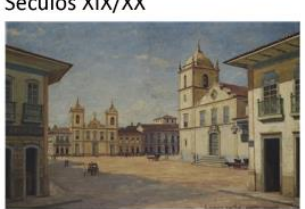

Largo da Sé em 1865

Benedito Calixto de Jesus

Óleo sobre tela

Séculos XIX/XX 
Figura 74: Perspectiva da Sala de Expediente 1 (2ํㅡ pavimento).

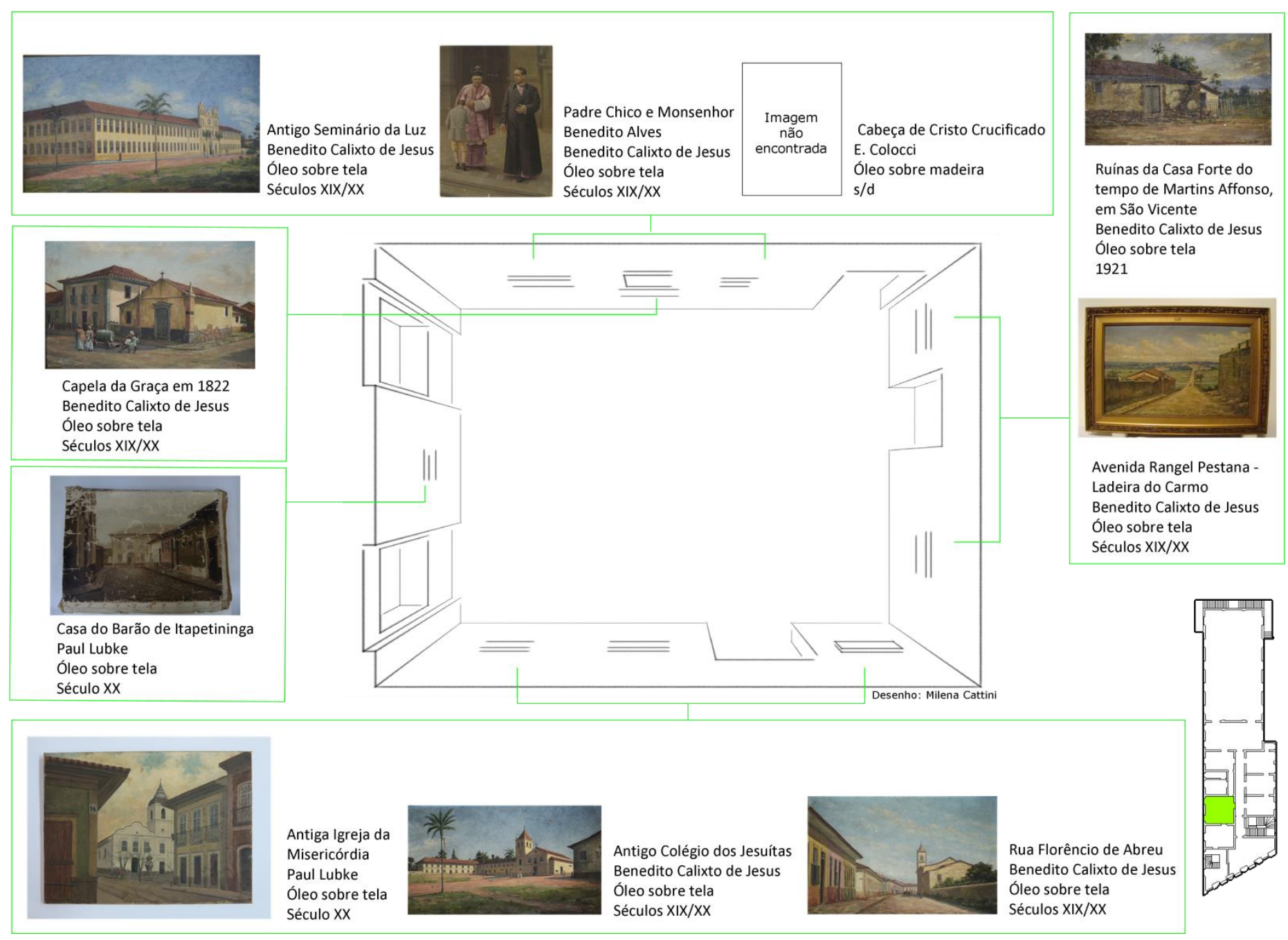


Figura 75: perspectiva do Gabinete - Sala do Trono ( $2^{\circ}$ pavimento).

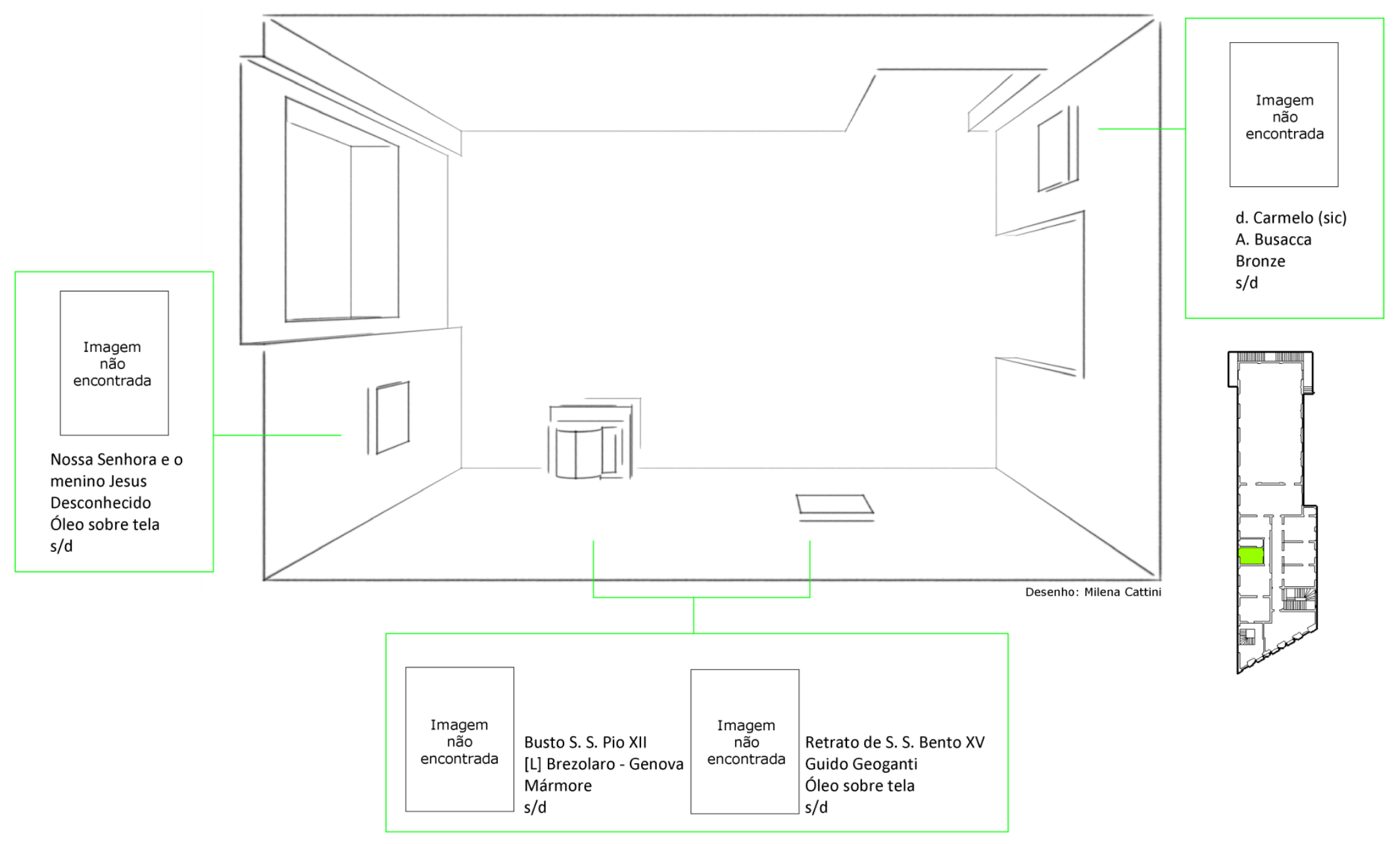


Figura 76: Perspectiva da Sala de Expediente 2 ( $2^{\circ}$ pavimento).

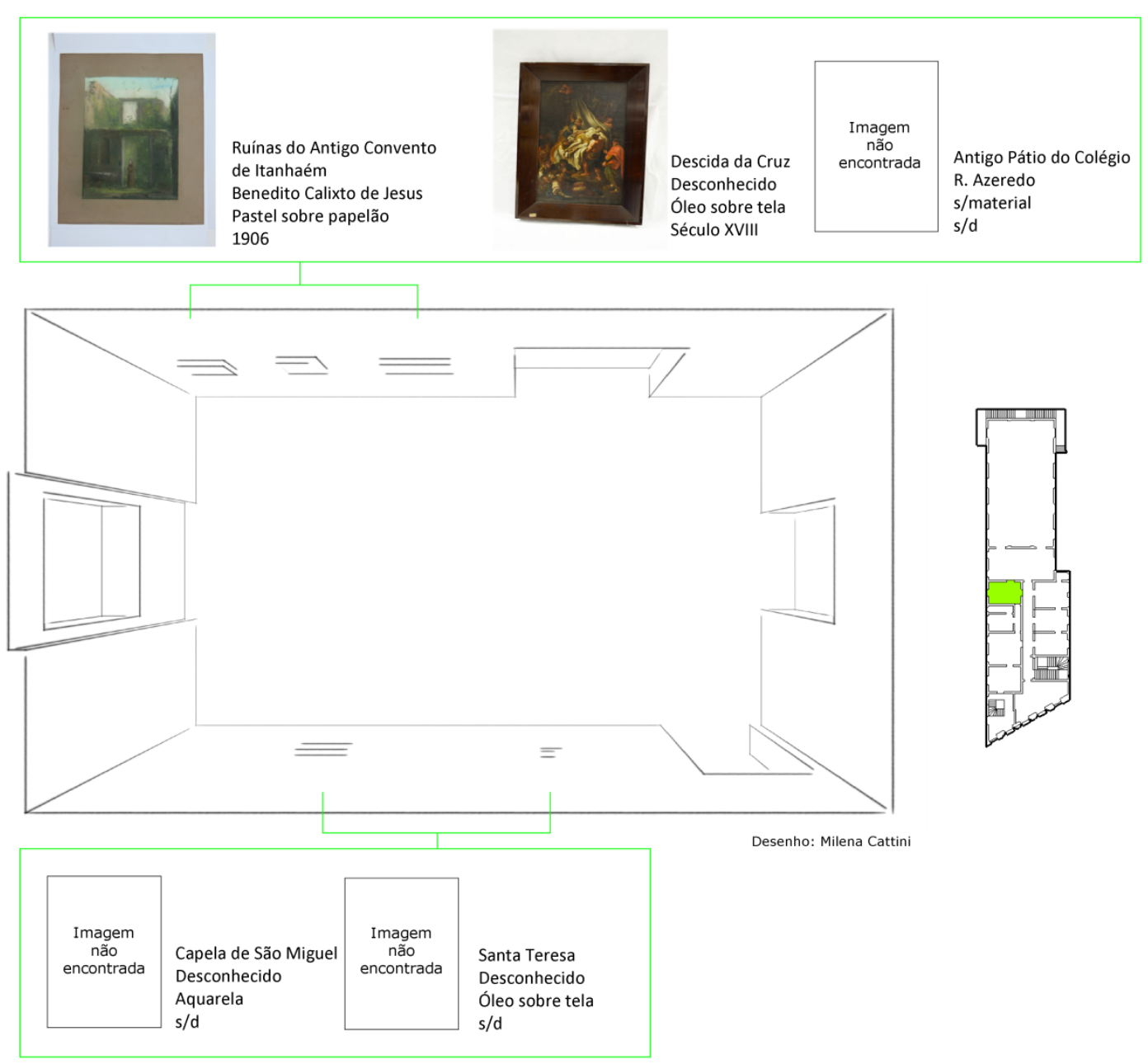




\subsection{Funcionamento do Museu}

Durante nossa pesquisa, não encontramos documentos de comunicação voltada ao público que nos ajudassem a compreender o funcionamento do Museu como uma instituição estabelecida, como catálogo do acervo impresso, folders ou outros documentos e materiais gráficos. Interessante pensar que durante os cerca de 50 anos do Museu, não foi produzido, ou não se guardou, nenhum material de divulgação, sendo que a Igreja Católica possui uma tradição em produzir materiais de divulgação, como os periódicos paroquiais.

Entretanto, vale apontar que os próprios museus paulistas não possuíam esse tipo de divulgação, como é o caso do Museu Paulista, que teve seu primeiro guia de exposições publicado em $1907^{56}$, quando ainda era um museu de história natural, durante a gestão de Hermann von Ihering (1894-1916), e o segundo publicado apenas em 193757, já na gestão de Affonso Taunay (1917-1945).

A falta de divulgação do Museu nos leva a pensar que, ainda que bem estabelecido dentro da Igreja Católica, o Museu da Cúria era desconhecido para o grande público.

Os artigos em jornais e revistas da época corroboram o desconhecimento do público sobre a existência de um museu de arte sacra na Cúria Metropolitana, bem como também de um arquivo aberto à consulta. Com títulos como "Um museu rico que São Paulo desconhece", os artigos buscavam incentivar o público a visitar o museu.

No último parágrafo do artigo a respeito do museu, no livro $A$ Igreja nos quatro séculos de São Paulo: 1554-1954, faz-se uma súplica para que o museu não caia no esquecimento: "Aqui, novamente, renovamos o nosso apelo, ao nobre povo de São Paulo, para que não seja esquecido o Museu da Cúria Metropolitana que, na verdade, é um legítimo relicário de nossas tradições e gloriosos fastos de nossa História" (1955, p. 111).

\footnotetext{
${ }^{56}$ Cf: GUIA pelas Colleccoes do Museu Paulista. São Paulo: Cardozo Filho, 1907.

57 Cf: TAUNAY, Afonso d’Escragnolle. Guia da Secção Histórica do Museu Paulista. São Paulo, Imprensa Oficial do Estado de São Paulo, 1937.
} 
Interessante apontar como o autor do artigo emprega a palavra relicário, indicando sua percepção de que o museu é um local de guarda e exposição de objetos que representam uma memória sagrada que deva ser preservada e mantida intocável.

Essa ideia do objeto como relíquia do passado é discutida por Ulpiano $\mathrm{T}$. Bezerra de Meneses em seu artigo "Do teatro da memória ao laboratório da História: a exposição museológica e o conhecimento histórico", ao apontar que os objetos históricos nos Museus de História caracterizam-se, muitas vezes, por um sentido imutável contaminado por alguma realidade transcendental; "são excluídos de circulação e não só têm seu valor de uso drenado, como trazem para qualquer uso prático eventual a pecha do sacrilégio" (MENESES, 1994, p. 18).

A ideia de museu relicário também é discutida por Diane Ghirardo dentro da perspectiva arquitetônica dos museus, caracterizando esse tipo de museu como edifícios que introduzem uma ideia de simulacro entre o prédio e a coleção que abriga, propondo um conjunto de salões, galerias, pátios e uma ordem hierárquica expositiva. Esse tipo de arquitetura tinha como função desde 0 século XIX "educar as massas burguesas emergentes na estrutura de gosto apropriada pelas classes elevadas e imbuí-las do devido respeito pela obra de arte" (GHIRARDO, 2002, p. 82).

A discussão em torno do processo de musealização e arquitetura dos museus também é levantada pela museóloga Rita Capurro (2018, p. 49) ao abordar a transformação de igrejas em museus eclesiásticos. Ela argumenta que esses dois elementos unem as ideias de "museu" e "sagrado", ainda que esse paralelo seja apenas para semelhanças, sem considerar o aspecto da religião, que possui características particulares.

Essa comparação também é discutida por François Mairesse, ao abordar as semelhanças entre os museus e os templos: 


\begin{abstract}
"Ao lado dessas evoluções que podem ser seguidas de acordo com a história do museu, instituições sagradas (templos, igrejas, locais de peregrinação) também se desenvolveram dispositivos de exibição que parecem surpreendentemente semelhantes aos clássicos museus: visitas, venda de catálogos ou lembranças, etc. Ao mesmo tempo, muitos lugares anteriormente sagrados (templos, igrejas, etc.) tornaram-se ambos os museus e locais históricos" (MAIRESSE, 2019, p. 16).
\end{abstract}

Segundo Vinício Stein Campos (1977, p. 119), estando os objetos do Museu distribuídos pelos vários andares do Palácio da Cúria, o público não conseguia acessá-los completamente; "apenas reduzido número de interessados poderia visita-lo e assim mesmo sem que dessa visita lograsse maior proveito, em face da maneira com que se achavam expostas as peças da extraordinária coleção".

Entre as anotações supracitadas do Pe. João Kulay há a informação de que o museu passava por uma reorganização e que "embora com muitas peças que atualmente não estão expostas, não proíbe as visitas, dentro do horário das 13 às 16 horas, com o número de 3 a 4 pessoas no máximo". Supõe-se que a falta de objetos se dá pelos empréstimos realizados para exposições, como a do IV Centenário de São Paulo, à qual voltaremos mais à frente.

A necessidade de indicar que não exista uma proibição de visitação nos remete às dificuldades relatadas por Mário de Andrade em visitar o museu durante sua pesquisa sobre as pinturas do Pe. Jesuíno do Monte Carmelo, para o Serviço do Histórico e Artístico Nacional - SPHAN (antigo IPHAN). Em carta enviada em 12 de março de 1943 a Rodrigo Melo Franco de Andrade, diretor do SPHAN, Mário apresenta relatório de suas atividades de fevereiro, entre elas, sua ida ao Museu da Cúria: 
"Conforme vos disse no meu relatório anterior, tendo terminado, com os elementos que possuía, as anotações de ordem crítica relativas à obra pictórica do $\mathrm{P}$. Jesuíno do Monte Carmelo, ao invés de por tudo isso em redação definitiva, me dedico atualmente a "catar" documentos e elementos que enriqueçam o trabalho e em principal lhe preencham as lacunas. Está claro que uma pesquisa deste gênero não se circunscreve exclusivamente a recolher dados que possam servir ao meu trabalho particular. Mas embora arquivos e museus paulistas sejam de uma pobreza de documentação artística que não raro atinge a penúria, os nossos fichários vão se aumentando paulatinamente.

Entre outras pesquisas realizadas, uma visita nova ao Museu da Cúria Metropolitana de São Paulo, agora que conheço regularmente a obra de $P$. Jesuíno, veio me trazer alguns problemas a mais, extremamente.... desagradáveis.

Um deles aliás, não se refere a Jesuíno propriamente, mas ao filho dele, escultor, o Eliseu, autor de um S. Jorge admirável. Sobre este e seu autor, eu vinha colecionando dados que já me pareciam importantes para uma comunicação de interesse para a Revista do Serviço. A comunicação ainda pode e deverá ser feita. Mas o interesse diminuiu, pois o $\mathrm{S}$. Jorge de Eliseu do Monte Carmelo não passa de uma cópia, mais bem-feita, de outra imagem mais antiga, que foi venerada aqui na capital e agora cavalga um canto do Museu da Cúria.

Dois casos, mais ou menos parecidos, e muito mais intrincados, descobri a respeito do $P$. Jesuíno. Nas minhas observações críticas eu não só já recusara ao meu biografado uma série de quadros provenientes do convento de Santa Teresa a ele atribuídos, como duvidara fosse toda a série de um artista só. Esta dúvida não só se reforçou agora, como se complicou extraordinariamente por ter eu descoberto que alguns desses quadros são réplicas de outros, atualmente jogados no alto escuro e escuso das paredes de uma escadaria do Museu. $E$ ainda o problema de um dos quadros ituanos de Jesuíno, um Batismo de Cristo, problema já difícil de resolver por si por causa de uma réplica existente também em Itu, agora se complicou desesperadoramente, com uma réplica nova, existente no Museu. Nada me foi possível estudar ainda. Esses quadros têm de ser retirados da escureza e altura em que morreram, têm de ser fotografados, mas tudo esbarra diante de sorrisos lerdos de funcionários pouco menos que analfabetos. Desanima a gente. $O$ Museu da Cúria se não vive às moscas é porque nem as moscas têm qualquer interesse nele. Vá agora a gente querer retirar de um lugar de fato o mais difícil e incômodo, um quadro enorme que incontestavelmente foi guindado ali "para sempre". Infelizmente parece que o espírito de eternidade das religiões se dilata para além do domínio inofensivo das almas do outro mundo. De maneira que arquivos como quadros, tudo é jogado eternamente nas regiões paradas de uma Terra sem Mal. E sem malícia. Que um funcionário do Serviço do Patrimônio malicie, e eis todo um paraíso que se inferniza de súbito, sem que os seus arcanjos the compreendam mais o único sentido paradisíaco de existência, a pasmaceira. (...)" (ANDRADE, 1981, p. 172-173. Grifos nossos). 
O interessante relato de Mário de Andrade expõe diversas dificuldades em relação à pesquisa histórica artística de objetos religiosos. Além da falta de documentação a respeito da produção artística nos museus e arquivos, o acesso aos objetos também é dificultado.

A situação do Museu da Cúria apresentada por ele não é das mais animadoras; recorrendo à expressão "às moscas", Mário de Andrade deixa a entender que não há público interessado em visitar o Museu, que possui objetos e pinturas "jogados" pelos cantos escuros do Palácio da Cúria.

Mário de Andrade já havia relatado a Rodrigo M. F. de Andrade, anos antes, a dificuldade em fotografar monumentos religiosos, onde "sacristães e outras pessoas competentes opõem recusas ora formais ora evasivas a este trabalho, apesar das credenciais que apresento" (ANDRADE, 1981, p. 80).

A ideia de que o museu existia, porém sem o conhecimento do público, também é corroborada por Eduardo Etzel que, tal qual Mário de Andrade, se vale de uma analogia para descrever o Museu:

\begin{abstract}
"Dom Duarte Leopoldo e Silva, primeiro e culto arcebispo de São Paulo, vislumbrando o vertiginoso progresso da cidade $e$ prevendo as consequências desastrosas para nosso acervo histórico-religioso, reuniu o que pode das nossas restantes e antigas preciosidades, testemunhos de nosso passado religioso, no chamado Museu da Cúria, antes um depósito fechado a sete chaves do que um museu" (ETZEL, 1974, p. 130. Grifo nosso).
\end{abstract}

Já Dom Clemente Maria da Silva-Nigra aponta que, apesar da riqueza e importância das peças, elas estavam em um local seguro (o novo Palácio da Cúria), "mas acanhado demais, [em condições que] jamais permitiram uma visitação pública" (MAS, 1970, p.9). Pode-se relacionar esta afirmação ao fato de que o acervo, formado por uma grande quantidade de objetos de diversas dimensões e formatos, era exposto em apenas 4 pequenas salas utilizadas pelo Museu e por alguns cômodos do Palácio, conforme tratado no Capítulo 3.3. 


\subsection{Cessão de peças para exposições}

Na introdução ao primeiro catálogo elaborado pelo MAS-SP em 1970, em decorrência de sua abertura, seu primeiro diretor, Pedro Antônio de Oliveira Ribeiro Neto, escreve que o acervo da Mitra apesar de há muito famoso, "mas por pouquíssimos conhecido", era "exposto em parcelas mínimas em exposições especiais que anteriormente se realizaram no Brasil" (MAS, 1970, p. 8).

Isto indica que, ainda que o Museu da Cúria fosse uma instituição pouco divulgada e desconhecida do grande público, seu acervo era prestigiado em artigos em jornais e revistas e procurado para compor eventos e exposições.

A Liga das Senhoras Católicas de São Paulo organizou, em 1926, uma comemoração em homenagem ao centenário da Imperatriz Leopoldina, com apresentações e jantares no Theatro Municipal. Em nota publicada no jornal $O$ Estado de S. Paulo, A Liga pede que se torne público o agradecimento ao arcebispo Dom Duarte, que cedeu grande parte do mobiliário e comendas do Museu, "há muitos anos instituído", para o espetáculo (O Estado de S. Paulo, n. 17.453, 1926, p. 6).

Em 1932, para as comemorações do IV Centenário da cidade de São Vicente, foi organizada uma exposição retrospectiva de arte antiga, no Palacete do Trocadero em São Paulo, com objetos do século XVI a XVIII. A comissão organizadora da exposição foi recebida por Dom Duarte no Palácio São Luiz, que colocou à disposição o "raro e precioso mobiliário do Palácio S. Luiz, com tudo o que o guarnece, como também todos os valiosíssimos objetos do Museu da Cúria, que é, como se sabe, o mais selecionado repositório de arte antiga de São Paulo" (Diário Nacional: A Democracia em Marcha, n. 1.358, 1932, p. 5). A Igreja do Carmo também colaborou com a exposição emprestando móveis e pinturas.

A Sociedade Numismática Brasileira realizou em 1936, no Theatro Municipal, o primeiro Congresso Numismático Brasileiro, patrocinado pelo governo do Estado de São Paulo. Dentre as atividades, foi organizada uma exposição que contou com itens da Casa da Moeda, do Museu Histórico Nacional, Museu Paulista, Museu da Cúria, Ministério das Relações Exteriores da Guerra e de colecionadores particulares. 
O acervo presente no Museu da Cúria também foi solicitado para as comemorações do IV Centenário da cidade de São Paulo, participando de duas mostras: "Exposição de História de São Paulo no Quadro da História do Brasil", na Oca, e na recomposição dos ambientes na Casa do Bandeirante.

A “Exposição de História de São Paulo no Quadro da História do Brasil"58, idealizada por Jaime Cortesão e seus assistentes Mário Neme e Ernani Silva Bruno, foi aberta em 30 de setembro de 1954, no pavilhão da Oca, localizada no recém-inaugurado Parque do Ibirapuera. Com o objetivo de apresentar um panorama da história paulistana a partir de uma perspectiva histórica, geográfica e política, a exposição era dividida em nove seções.

A quinta seção da exposição, "A Capitania de São Paulo e a Expansão Mineradora", era dedicada à ampliação geográfica do território paulista e sua importância no contexto nacional das bandeiras, apresentando trinta mapas inéditos de bandeirantes e sertanistas.

Próximo à conclusão da seção dava-se destaque às festividades e ao culto católico, apresentando peças religiosas setecentistas emprestadas do Museu da Cúria e do Museu Paulista.

Segundo carta enviada pelo presidente da Comissão do IV Centenário, Guilherme de Almeida, ao Cardeal Dom Vasconcelos Motta, a participação dos objetos do Museu da Cúria era indispensável para o êxito da exposição:

\begin{abstract}
"Embora em pequeno número, [os objetos solicitados] constituem elementos indispensáveis à Exposição, permitindo, ao lado de igualmente cedidas por Instituições congêneres, nacionais e estrangeiras, apresentar ao visitante uma visão de conjunto, tão perfeita quanto possível, dos acontecimentos culminantes da vida do povo paulista e de sua repercussão na história do Brasil" (ACMSP, pasta Museu).
\end{abstract}

Em anexo à carta supracitada, seguiu-se a lista de objetos solicitados (Fig. 76), com a observação de que as peças seriam retiradas por empréstimo, cercadas de todas as garantias de conservação, sendo devolvidas ao final da exposição, previsto para 25 de janeiro de 1955.

58 Sobre a exposição, ver RIBEIRO, David W. A. Cartografia das relações: as condições da produção intelectual e os percursos da escrita histórica de Jaime Cortesão no Brasil (19401957). 2015. 260 p. Dissertação (Mestrado em História Social) - Faculdade de Filosofia, Letras e Ciências Humanas, Universidade de São Paulo, São Paulo, 2015. 
Figura 77: Lista de objetos solicitados por Guilherme de Almeida para exposição.

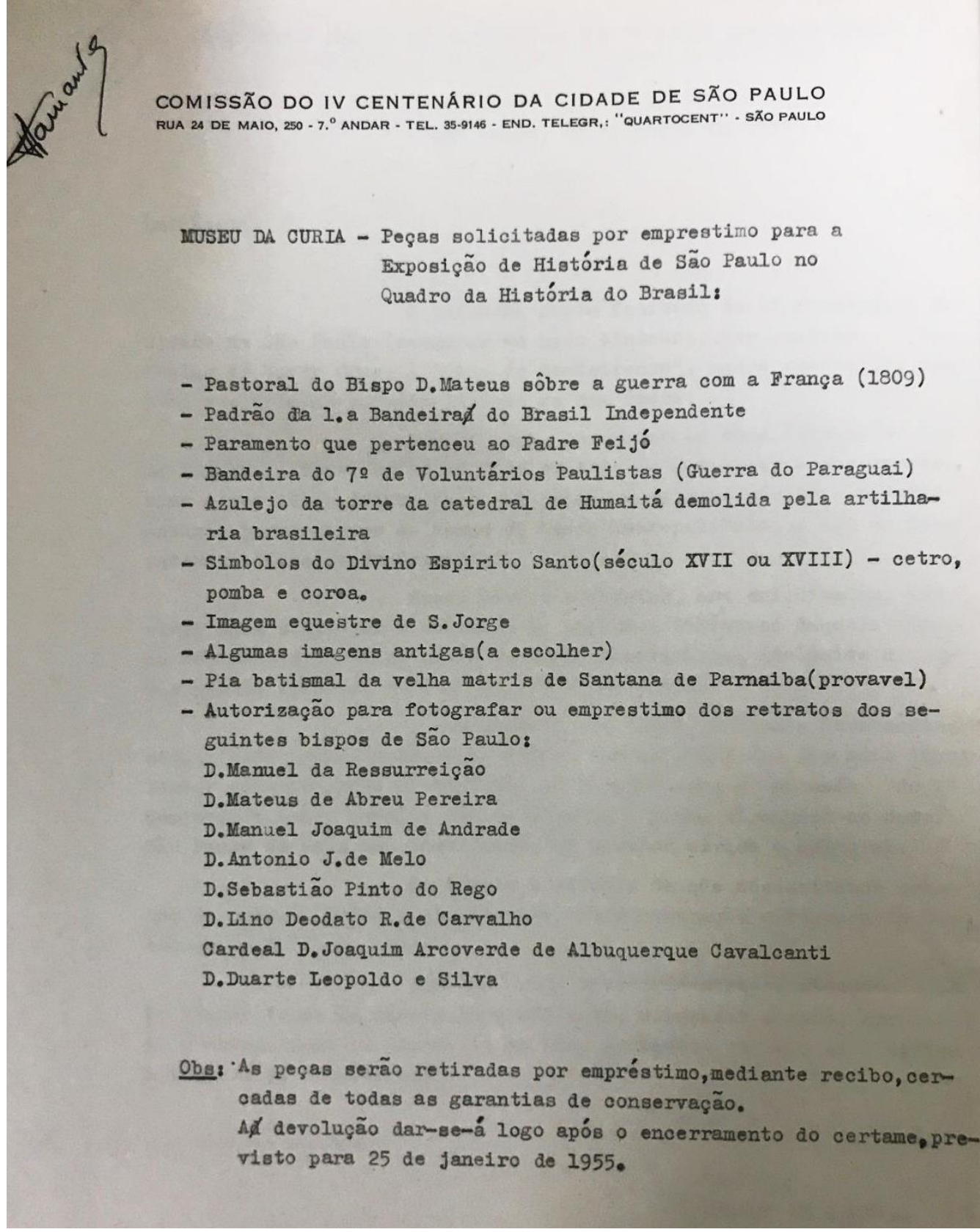

Fonte: ACMSP, pasta Museu. Fotografia Luciana Barbosa,2019.

É possível observar na listagem de objetos solicitados a imagem equestre de São Jorge. Segundo RIBEIRO, a imagem do santo estava disposta no final da seção, junto ao mural de Tarsila do Amaral,

"O painel de encerramento da seção é um mural de Tarsila do Amaral (...), no qual se representa uma procissão de Corpus Christi na São Paulo de meados dos Setecentos, próximo de uma imagem de São Jorge em madeira, desmontável, e que era conduzida a cavalo nessas mesmas procissões" (RIBEIRO, 2015, p. 171-172). 
Também segundo RIBEIRO, na quarta seção "São Paulo no Império", que apresentava a influência política de São Paulo no período imperial, havia disposto no "painel dedicado à Maioridade de D. Pedro II, com um retrato a óleo do monarca aos quinze anos cedido pelo Museu da Cúria Metropolitana de São Paulo" (RIBEIRO, 2015, p.183).

Já para compor a cenografia da Casa do Bandeirante ${ }^{59}$, Guilherme de Almeida e seu assistente Paulo Florençano solicitaram ao Cardeal mobiliários e imagens do acervo da Cúria. Inaugurado ao público em 30 de outubro de 1955, o novo espaço de memória reconstituído na "velha casa do Butantã" passou por reformas para poder se transformar na ideia de exemplar típico da época áurea das bandeiras.

Para a recomposição dos ambientes internos de uma habitação rural paulista nos séculos XVI e XVII, a Casa do Bandeirante contou com objetos emprestados de particulares e de museus, como Museu Paulista e Museu do Ouro de Sabará, MG, além de itens comprados em cidades no interior de São Paulo e Minas Gerais.

Segundo SANTOS (2016. p. 146), do Museu da Cúria foram solicitados os seguintes objetos:

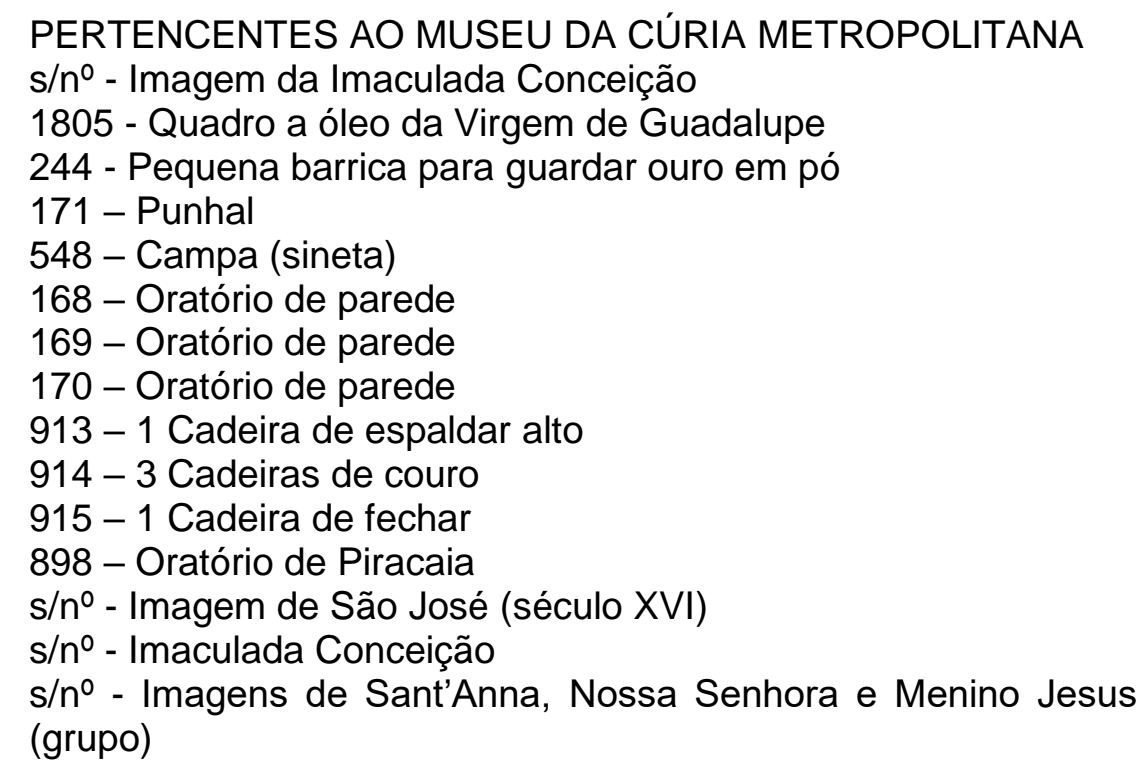

${ }^{59}$ Sobre a construção simbólica da Casa do Bandeirante, cf. SANTOS, A. M. Z. dos. A Casa do Bandeirante como espaço museológico (1954-1964). 2016. 266 f. Dissertação (Mestrado) Programa de Pós-Graduação Interunidades em Museologia da Universidade de São Paulo, 2016. 
Interessante apontar que ambas as exposições solicitaram à Cúria que os prazos de devolução dos objetos fossem estendidos, em virtude da prorrogação das exposições e seus sucessos de público. O empréstimo para a "Exposição de História de São Paulo" durou até o final de 1955; já os objetos cedidos para a Casa do Bandeirante retornaram somente em 1963, após protestos por parte da Cúria de que se devolvessem os objetos já há muito emprestados, de acordo com cartas encontradas no ACMSP.

Também no ano de 1955, o Museu da Cúria cedeu 127 objetos para a "Exposição Nacional de Arte Sacra", realizada durante o 36을 Congresso Eucarístico Internacional do Rio de Janeiro, organizado por Dom Clemente Maria da Silva-Nigra (ACMSP, Pasta Museu). 


\section{CAPÍTULO 4: UM NOVO MUSEU DE ARTE SACRA EM SÃO PAULO}

\subsection{Tratativas para criação de um novo museu de arte sacra da Cúria}

Ao longo de sua existência, o Museu da Cúria permaneceu sob a gestão do Arquivo da Cúria, ambos estabelecidos no interior do Palácio da Cúria, no centro de São Paulo. Apesar do valioso acervo do Museu, constituído primordialmente nas primeiras décadas do século $\mathrm{XX}$, era preciso elevá-lo ao reconhecimento nacional como importante acervo religioso paulista, na forma de um museu de arte sacra propriamente dito. A Cúria, porém, não dispunha de condições financeiras para realiza-lo, levando as autoridades eclesiásticas a buscar uma solução viável.

Em 1960, a Fundação Armando Álvares Penteado (FAAP), aproveitando as tratativas de empréstimo de obras do Museu para figurarem na exposição de arte brasileira a ser realizada, fez uma proposta oficial para instalação definitiva do acervo da Cúria em suas dependências.

Segundo carta de 13 de dezembro de 1960 (ACMSP, pasta Museu), enviada pela presidente da Fundação Annie Álvares Penteado ao Cardeal Vasconcelos Motta, em face das conversações já mantidas com o bispo-auxiliar Dom Paulo Rolim Loureiro, a proposta era de que os objetos ocupassem um dos salões no andar térreo do edifício Museu-Escola, com a denominação "Museu de Arte Sacra - Propriedade da Cúria Metropolitana de São Paulo". No convênio a ser firmado constariam todas as cláusulas necessárias para a preservação do acervo, bem como os direitos e deveres do comodatário.

Ainda na carta, Annie Penteado ressalta que 0 ideal seria inaugurar 0 museu junto à nova exposição, ainda que o tempo para os trâmites estivessem apertados, porém a Fundação faria todo o esforço necessário para que fosse possível a realização do convênio e montagem em tempo hábil.

Apesar dos apelos e do aparente bom relacionamento com a FAAP, a proposta não foi aceita. Outro projeto estudado pela Cúria foi a transferência do acervo para a Pontifícia Universidade Católica de São Paulo (PUC-SP), fundada em 1946, porém também sem sucesso. 
Em agosto de 1969, o Arcebispo Dom Agnelo Rossi envia uma carta em resposta ao prefeito de São Paulo Paulo Maluf para discutir as propostas existentes para se criar um museu de arte sacra na cidade (ACMSP, pasta Museu).

Segundo a carta de Dom Rossi, os Conselhos da Arquidiocese já haviam feito estudos para viabilizar a ideia, preferindo confiá-la à PUC-SP. No entanto, neste meio tempo, tanto a Prefeitura quanto o Governo do Estado haviam manifestado interesse em contribuir para tal empreitada: a Prefeitura propôs uma nova construção no Pátio do Colégio e o Estado, o aproveitamento de parte do Mosteiro da Luz, sendo que o arcebispo já havia recebido uma licença especial da Santa Sé para instalação provisória do Museu nesse Mosteiro.

Dom Agnelo Rossi termina a carta dizendo que é preciso um entendimento entre os governos e a Cúria, pois esta não tem outro interesse senão "a instalação e manutenção condigna do Museu, para que sirva à cultura de nossa gente".

Interessante observar aqui a forma como Dom Rossi se refere ao acervo, tratando-o com um bem cultural e não apenas um acervo religioso da Igreja Católica. Essa visão mais abrangente do acervo como um patrimônio cultural a ser preservado, no entanto, não condiz com algumas ações tomadas por ele na década de 1960, quando algumas peças do acervo foram vendidas para sanar problemas financeiros da instituição, como já mencionado acima.

Quanto à proposta da Prefeitura citada por Dom Rossi, é possível que esteja relacionada à tentativa de se criar o Museu da Cidade de São Paulo no antigo Solar da família Crespi-Prado, na década de $1960^{60}$. O novo museu seria formado pela coleção pessoal a ser doada por Renata Crespi, após o falecimento de seu marido, Fábio Prado, e pelo acervo da Cúria Metropolitana.

\footnotetext{
60 Sobre a coleção da família Crespi-Prado, cf. SANTOS, Tamira Naia dos. Fundação CrespiPrado: trajetória de uma coleção museológica. 2016. Dissertação (Mestrado em Museologia) Museologia, Universidade de São Paulo, São Paulo, 2016.

Sobre a criação do Museu da Casa Brasileira (MCB), cf. GUERRA, José Wilton Nascimento. O Projeto de Ernani Silva Bruno: uma discussão sobre as bases de criação, implantação e gestão do Museu da Casa Brasileira (1970-1979). 2015. Dissertação (Mestrado em Museologia) Museologia, Universidade de São Paulo, São Paulo, 2015.
} 
Segundo minuta de contrato de comodato encontrada no ACMSP (pasta Museu), sem data e assinaturas, a Cúria Metropolitana e a Fundação Museu da Cidade de São Paulo, formada pela Comissão Executiva presidida por Renata Crespi, tendo Lucas Nogueira Garcez e Ary Torres como vice-presidentes, Paulo Duarte como secretário-geral e Francisco Matarazzo Sobrinho como tesoureiro, acordavam o comodato por 90 anos dos objetos presentes no Museu da Cúria e dos documentos encontrados no Arquivo da Cúria, sendo que seriam transferidos apenas os documentos até o ano de 1917.

Neste contrato consta que a Cúria sempre contaria com um representante no Conselho Diretor da Fundação e que as solicitações de certidões de documentos deveriam ser requeridas diretamente à Cúria, que enviaria os pedidos ao Museu e este se responsabilizaria por expedi-las.

Apesar das adiantadas tratativas e do projeto de viabilidade ter sido concluído, o comodato não foi levado à diante ${ }^{61}$.

A Cúria Metropolitana acabou por firmar um convênio de comodato de seu acervo com o Governo do Estado. O Museu de Arte Sacra de São Paulo (MASSP) foi criado pelo Decreto-Lei de 28 de outubro de 1969, assinado pelo governador Roberto Costa de Abreu Sodré.

Com relação ao mobiliário expográfico utilizado no Museu da Cúria, descobrimos por meio da pesquisa realizada por Erica Bowersox a respeito do Museu Nossa Senhora Aparecida (MNSA) (2019) que as vitrines de madeira, com tampo triangular de vidro, foram doadas ao MNSA em 1971 pelo arcebispo Dom Paulo Evaristo Arns, segundo correspondência entre Conceição Borges, então diretora do museu de Aparecida, e o padre Galvão:

\footnotetext{
"Os móveis pertencentes ao antigo Museu da Cúria Metropolitana de São Paulo foram doados por Dom Paulo Evaristo Arns, em abril de 1971, para o Museu Nossa Senhora Aparecida. Na ocasião da doação todos foram usados no "Museu Documentação", localizado no $3^{\circ}$ andar da Torre. Porém, não despertou interesse aos visitantes. Posteriormente, alguns móveis foram utilizados no Museu Histórico, Didático e Pedagógico, denominado "Museu dos Ciclos Sócio-Econômicos do Vale do Paraíba". Com o encerramento do Museu, os móveis foram cedidos para iniciar o Museu do Seminário de Santa Terezinha, em Tietê (SP)" (BOWERSOX, 2019, p. 95).
}

61 ACERVO MUSEU DA CASA BRASILEIRA. O Solar Fábio Prado. [Catálogo]. São Paulo: Museu da Casa Brasileira. Secretaria de Cultura, Esportes e Turismo. 1971. p. 16. 
$\mathrm{Na}$ Figura 78 podemos observar as vitrines sendo utilizadas nas exposições do $2^{\circ}$ e $3^{\circ}$ andar, respectivamente, da Torre da Basílica no Santuário de Nossa Senhora Aparecida. Na primeira imagem, as vitrines do MNSA expõem uma coleção de bonecos artesanais vestindo trajes de diversas nacionalidades; já na segunda imagem, a vitrine é utilizada no Museu dos Ciclos Socioeconômicos do Vale do Paraíba, inaugurado em 1975 no 3a andar da Torre Brasília, no módulo relativo ao Ciclo Bandeirista (BOWERSOX, 2019, p. 100 e 123).

Figura 78: Vitrines do Museu da Cúria utilizadas no MNSA, década de 1970.

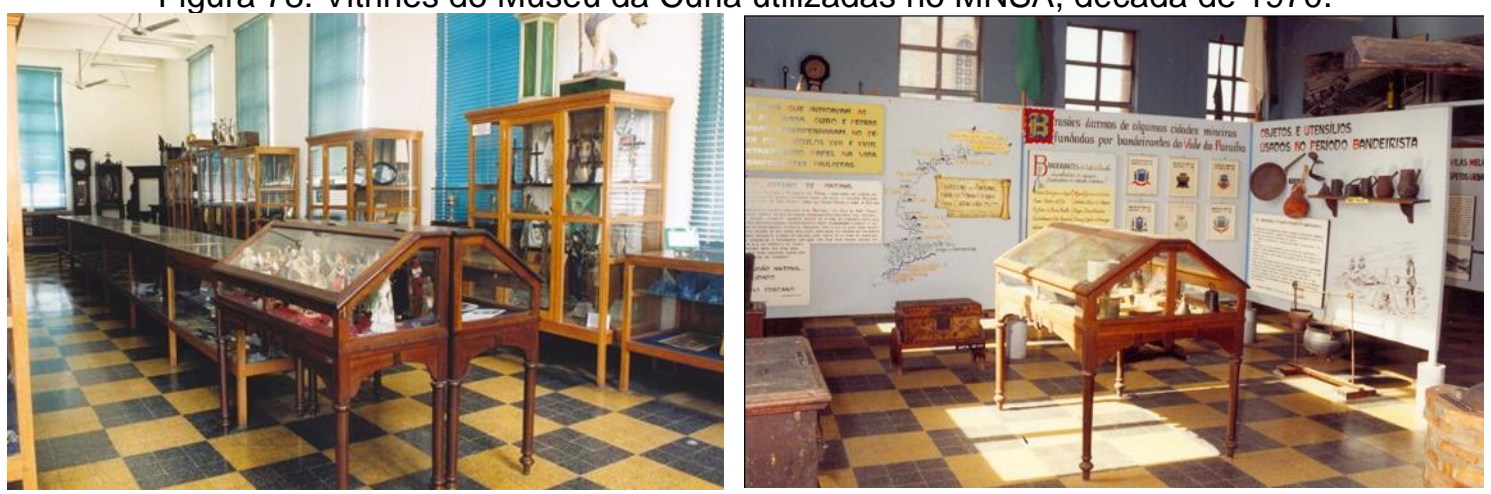

Fonte: Museu Nossa Senhora Aparecida - Santuário Nacional de Aparecida.

\subsection{Transformando o Museu do Arcebispo em Museu do Estado}

O convênio assinado em 1969 entre a Mitra Arquidiocesana e o Governo Estado de São Paulo para a criação do Museu de Arte Sacra (MAS) se inseria na nova política administrativa do Estado que, desde a criação da Secretaria de Cultura, Esporte e Turismo em 1967 (Decreto 49.165/67), vinha organizando e agregando instituições culturais que antes estavam dispersas em outras Secretarias, como o Serviço de Museus Históricos (SMH) criado em 1963 e o CONDEPHAAT, criado em 1968 (GUERRA, 2015, p. 36-37). 
Essa nova política na gestão do Governador Roberto Costa de Abreu Sodré, junto com o Secretário da Fazenda Luis Arrôbas Martins e o Secretário Da Cultura, Esportes e Turismo Orlando Gabriel Zancaner, possibilitou a criação de três museus temáticos na cidade de São Paulo; além do MAS, foram criados o Museu da Imagem e do Som (MIS) e o Museu do Mobiliário Artístico e Histórico Brasileiro em 1970 - que no ano seguinte passou a denominar-se Museu da Casa Brasileira (MCB).

Segundo GUERRA, a respeito da constituição destes novos museus:

"O primeiro dado relevante que diferencia este novo museu [o $\mathrm{MCB}$ ] dos demais até então criados na esfera do Estado, é o fato de que ao contrário dos conhecidos Museus Históricos e Pedagógicos (MHP), constituídos dentro do Serviço de Museus Históricos a partir de 1956, o Museu do Mobiliário Artístico e Histórico Brasileiro, assim como seus co-irmãos Museu de Arte Sacra e Museu da Imagem e do Som, foi pensado, discutido e concebido dentro de uma outra pasta (Secretaria de Cultura, Esportes e Turismo) e no âmbito do Conselho Estadual de Cultura, sem nenhuma participação do SMH" (GUERRA, 2015, p. 38).

Sob a supervisão de Arrôbas Martins, estes museus puderam ser criados e implementados a partir de projetos técnicos-administrativos específicos, ao contrário do que ocorria pelo interior, com a criação dos Museus Históricos e Pedagógicos (MHP) sem a provisão de uma estrutura mínima, podendo contar com o apoio de uma equipe técnica que tinha entre seus principais membros a museóloga Waldisa Rússio Camargo Guarnieri, importante figura para a museologia brasileira (GUERRA, 2015, p. 36-37).

Segundo placa fixada na entrada do Museu de Arte Sacra de São Paulo (2020), quando de sua inauguração, em 1970:

"Nestes antigos campos do Guaré, para onde, em fins do século $\mathrm{XVI}$, Domingos Luis, o Carvoeiro, transferiu a Capela de Nossa Senhora da Luz; ao firme abrigo das taipas que a devoção de Frei Antônio de Sant'Ana Galvão ergueu, no término do século XVIII, para a mesma Capela e para o Recolhimento de Nossa Senhora da Conceição da Luz, o Governo do Estado e a Arquidiocese de São Paulo decidiram instalar o MUSEU DE ARTE SACRA DE SÃO PAULO, como sinal de culto às nossas tradições, da fé e na perenidade do espírito e de crença na arte que liga o passado ao futuro". 
O local escolhido para o novo Museu de Arte Sacra de São Paulo (MAS) foi o Mosteiro da Imaculada Conceição da Luz. Fundado e construído por Frei Antônio de Sant' Anna Galvão62, em 1774, é considerado um dos mais importantes monumentos arquitetônicos coloniais paulistas do século XVIII, tombado pelo Instituo do Patrimônio Histórico e Artístico Nacional (IPHAN) em 1943, pelo Conselho de Defesa do Patrimônio Histórico, Artístico e Arquitetônico do Estado de São Paulo (CONDEPHAAT) em 1979, e pelo Conselho Municipal de Preservação do Patrimônio Histórico, Cultural e Ambiental da Cidade de São Paulo (CONPRESP) em 1991.

Este exemplar apresenta atributos específicos de grande relevância no contexto da cidade, por sua singularidade arquitetônica, sendo um dos raros exemplos de planta octogonal do período, e histórica, como última chácara conventual urbana da cidade de São Paulo.

O Mosteiro da Luz foi construído em taipa de pilão, técnica construtiva amplamente utilizada em São Paulo devido à inexistência da pedra e da cal na região. A terra, material disponível nos arredores da aldeia jesuítica, tornou-se a alternativa viável para a construção de igrejas, edifícios públicos e residências da época.

Para a instalação do novo museu, o Mosteiro passou por reformas para poder receber a coleção do Museu da Cúria, pagas pelo Fundo Estadual de Cultura (FEC), com projeto e montagem do museu realizado por Arthur Jorge de Carvalho, que havia executado o projeto do Museu da Bahia e da exposição histórica do IV Centenário de São Paulo.

\begin{abstract}
"Obras de vulto foram realizadas pelo Estado com o objetivo de se restaurar no edifício histórico, quando possível, o ambiente na forma original. Os tacos modernos das salas e os ladrilhos hidráulicos, imitando mármore, foram substituídos, respectivamente, por madeira legítima, maciça, de ipê, larga e com cravos da época, e lajotas de barro queimado. Foram restauradas todas as madeiras dos batentes e guarnições antigas que haviam sido mutiladas com a colocação de rodapés. Foram eliminadas tintas sobrepostas. Toda a parte elétrica e os sistemas de segurança foram elaborados com o perfeito entrosamento entre os métodos modernos de comunicação e o estilo do prédio. A reforma, sem perder em autenticidade, adequou-se as finalidades museológicas (MAS-SP, 1970, p. 17).
\end{abstract}

62 Frei Antônio de Sant'Anna Galvão (1739-1822) foi canonizado pelo Papa Bento XVI, durante sua visita ao Brasil, em 11 de maio de 2007, sendo o primeiro santo brasileiro. 
Com a aprovação da Mitra e das Irmãs Concepcionistas - que lá residiam e ainda residem -, o MAS foi instalado na ala esquerda térrea do edifício principal do Mosteiro da Luz.

Além da coleção do antigo Museu da Cúria, com cerca de 1.300 peças segundo seu primeiro catálogo, o acervo do novo MAS contou com a coleção inicial do Governo do Estado, composta por 133 peças incorporadas via aquisições através do Fundo Estadual de Cultura (FEC), para melhor compor o "aspecto histórico, artístico e decorativo do conjunto" (MAS-SP, 1970, p. 19).

$O$ acervo do MAS também foi composto por doações espontâneas e uma pequena coleção de 15 peças pertencentes à Ordem das Irmãs Concepcionistas e que passaram a ficar sob a guarda do $\mathrm{Museu}^{63}$.

Incorporou-se também ao acervo do Museu a coleção do Museu de Presépios, composto por presépios e outras peças doadas pela Prefeitura de São Paulo ao Governo do Estado de São Paulo em 1970, e que funcionava, desde os festejos do IV Centenário da cidade de São Paulo na marquise do Parque do Ibirapuera. Representada por cerca de 130 conjuntos presepistas destaca-se o Presépio Napolitano doado por Ciccillo Matarazzo, com suas 1620 peças do século XVIII, um dos maiores presépios do gênero remanescentes no mundo.

A inauguração do MAS foi realizada em 29 de junho de 1970 com cerimonial que contou com a presença de autoridades eclesiásticas e governamentais. Para a celebração, foi executada, pela primeira vez publicamente, a gravação da Missa do Padre André da Silva Gomes, composta em São Paulo em 1775.

63 Ao longo de seus 50 anos de existência, foi aplicada uma política de aquisições que ampliou
significativamente a coleção museológica do MAS, contando hoje com cerca de 15.000 objetos.
Desde 2007, o MAS é gerido pela Organização Social Associação Museu de Arte Sacra de São
Paulo (SAMAS). O acervo da Cúria continua a lhe pertencer em comodato. Outra parte do acervo
do MAS, formada por outros modos, continua a pertencer ao Estado, através da Secretaria de
Cultura e Economia Criativa do Estado de São Paulo.
As Organizações Sociais de Cultura são modelos de gestão compartilhada que vigora no Estado
de São Paulo desde 2004 (SECRETARIA DE CULTURA E ECONOMIA CRIATIVA DO ESTADO
DE SÃO <http://www.transparenciacultura.sp.gov.br/organizacoes-sociais-de-cultura/o-que-sao/>. Acesso em: 22/06/2020. 
Na Introdução do primeiro catálogo do MAS-SP, de 1970, o primeiro diretor do Museu Pedro Antônio de Oliveira Ribeiro Neto discorre sobre o processo de criação do Museu, a importância de seu acervo e dos artistas cujas obras o compõe.

Ribeira Neto finaliza o texto apontando a escolha de uma expografia clara e didática a fim de difundir a arte paulista:

\begin{abstract}
"A lista das preciosidades artísticas que dispomos é longa e variada. Fizemos o possível para torna-la clara, senão didática. Se as suas despretensiosas explicações servirem de orientação a quem visita o Museu e de guia aos interessados em conhecer e estudar as suas peças de arte, teremos cumprida a nossa missão. O importante nisso é que aprendamos a amar e cultivar a arte sacra que São Paulo guardou" (MAS-SP, 1970, p. 10).
\end{abstract}

Ao sinalizar que o acervo é composto por obras de arte ${ }^{64}$, fica clara a ruptura conceitual do modelo museológico, transformando o antigo Museu da Cúria, cuja musealização dos objetos se deu, principalmente, por seus valores históricos uma vez que representavam a materialidade remanescente de um passado colonial apagado pelas transformações da época, em um museu de arte, cuja especificidade se baseia em conceitos estéticos e estilísticos para apresentar e expor o acervo.

\footnotetext{
64 No primeiro catálogo do MAS constam ainda verbetes com a biografia dos principais artistas do acervo, bem como texto de Dom Clemente da Silva-Nigra a respeito do escultor Frei Agostinho de Jesus.
} 


\section{CAPÍTULO 5: OUTROS MUSEUS ECLESIÁSTICOS PIONEIROS NO BRASIL}

Buscando por datas de criação de museus de arte sacra no Brasil, procedemos a um levantamento no Guia de Museus Brasileiros e na plataforma Museusbr, ambos do Instituto Brasileiro de Museus (IBRAM), que apontam a existência, hoje, no país, de cerca de 76 museus voltados aos bens culturais da Igreja Católica, espalhados por 19 estados e fundados entre as décadas de 1930 e 2000.

Dentre os listados, é possível destacar cinco museus pioneiros: o Museu Sacro Franciscano da Venerável Ordem Terceira de São Francisco da Penitência, no Rio de Janeiro/RJ, de 1933; o Museu das Missões, em São Miguel das Missões/RS, de 1940; o Museu de Arte Sacra da Universidade Federal da Bahia, em Salvador/BA, de 1959; o Museu Arquidiocesano de Arte Sacra, em Mariana/MG, de 1962; e o Museu de Arte Sacra de São Paulo, de 1970. Quanto a esses anos oficiais, porém, importante assinalar que assim como o Museu de Arte Sacra de São Paulo tem suas origens já no início do século XX, conforme tratado na presente pesquisa, também os demais têm por certo histórias que se iniciam bem antes das configurações hoje consideradas como os marcos iniciais de suas respectivas histórias.

Para uma melhor inserção de nosso estudo de caso no movimento de criação de museus de arte sacra no Brasil do século XX, consideramos interessante apresentar, em breves linhas, a história de cada um deles, conforme segue.

Museu Sacro Franciscano da Venerável Ordem Terceira de São Francisco da Penitência, no Rio de Janeiro/RJ, com ano oficial de criação em 1933

A Venerável Ordem Terceira de São Francisco da Penitência do Rio de Janeiro foi fundada em 1619 pelo casal português Luiz de Figueiredo e Antônia Carneiro, irmãos noviços da Ordem Terceira da Penitência de Lisboa. Com a autorização dos frades do Convento de Santo Antônio, localizado no Morro da Carioca, no Rio de Janeiro, a Ordem se estabeleceu em um terreno doado pelo Convento ao lado esquerdo da Igreja de Santo Antônio, onde foi erigida uma Capela Primitiva. A atual edificação da Igreja teve início em 1657, sendo concluída em 1772 (MUSEU SACRO FRANCISCANO, 2020). 
A administração da Ordem convocou José Francisco Felix de Mariz, museólogo, professor do Museu Histórico Nacional e funcionário da Venerável Ordem, para organizar o museu, que teve sua inauguração em 17 de setembro de 1933. Em seu acervo é possível encontrar variados objetos do culto religioso, como esculturas, alfaias, andores, lanternas, insígnias.

O Museu Sacro chegou a ficar fechado entre 1960 e 2000, sendo reaberto em 2003 após restauros realizados tanto na Igreja da Ordem Terceira de São Francisco da Penitência quanto no Museu.

\section{Museu das Missões, em São Miguel das Missões/RS, de 1940}

O Museu das Missões foi criado a partir do Decreto-lei ํㅡ 2.077, de 8 de março de 1940, pelo presidente Getúlio Vargas, com o objetivo "reunir e conservar as obras de arte ou de valor histórico relacionadas com os Sete Povos das Missões Orientais, fundados pela Companhia de Jesus naquela região do país" (MUSEU DAS MISSÕES, 2020).

Localizado dentro do Sítio Histórico São Miguel Arcanjo, em São Miguel das Missões/RS, reconhecido pela UNESCO como Patrimônio Cultural da Humanidade, o Museu é composto pelo Pavilhão Lucio Costa, nome dado em homenagem ao arquiteto e urbanista que projetou o museu, onde se encontra a exposição de longa duração, e a Casa do Zelador, que abriga o Núcleo Expositivo Memória e História e a parte administrativa do museu.

O acervo, composto por 92 objetos, sendo que 85 são esculturas missioneiras em madeira policromada dos séculos XVII e XVIII, foi formado, em sua maioria, a partir do recolhimento dos objetos de locais de culto doméstico ou de pequenas capelas comunitárias da região pelo primeiro zelador do museu (equivalente a curador), João Hugo Machado (MUSEU DAS MISSÕES, 2020). É considerada a maior coleção pública do Mercosul nesse gênero e que, por muito tempo, foi o único museu dedicado ao tema das missões jesuíticas (MUSEU DAS MISSÕES, 2020). 


\section{Museu de Arte Sacra da Universidade Federal da Bahia, em Salvador/BA, de 1959}

Já o Museu de Arte Sacra da Universidade Federal da Bahia está localizado no antigo Convento de Santa Teresa D'Ávila em Salvador, conjunto arquitetônico do século XVII, tombado pelo Instituto do Patrimônio Histórico Artístico Nacional (IPHAN) em 1938 e declarado Patrimônio da Humanidade pela UNESCO em 1985.

Inaugurado em 10 de agosto de 1959, foi criado a partir do convênio entre a Universidade Federal da Bahia (UFBA) e a Arquidiocese de Salvador. Mantido como órgão suplementar da Universidade, foi o primeiro museu universitário da Bahia, servindo hoje como laboratório de ensino aos alunos da UFBA.

Com acervo de cerca de 5 mil peças, a missão do museu é "divulgar e expor a arte sacra cristã através de ações de preservação, pesquisa e comunicação, buscando contribuir para o desenvolvimento sociocultural do Estado, valorizando sua memória histórica e artística" (MAS/UFBA, 2020). Seu regimento data de 1972.

\section{Museu Arquidiocesano de Arte Sacra, em Mariana/MG, de 1962}

O Museu Arquidiocesano de Arte Sacra de Mariana é gerido pela Arquidiocese de Mariana e está instalado na Casa Capitular, edifício no estilo rococó do início do século XIX, que serviu como sede para as reuniões regulamentares dos Cônegos do Cabido até 1926, quando foi doado à Mitra para abrigar a Cúria Metropolitana e o Arquivo (PREFEITURA DE MARIANA, 2020).

Em 1961, o espaço foi reorganizado por Dom Oscar de Oliveira para abrigar o museu, sendo inaugurado oficialmente em 22 de setembro de 1962. A coleção é formada por objetos de arte religiosa do barroco mineiro oriundas de igrejas, capelas, do antigo Seminário Menor de Mariana e do Palácio Episcopal, além de doações e legados (COPPOLA, 2005, p. 10).

Seu acervo, que inclui obras do Mestre Athayde e outras atribuídas a Aleijadinho, está disposto por salas temáticas de acordo com suas tipologias: culto, escultura, pintura, indumentária litúrgica e mobiliário (PREFEITURA DE MARIANA, 2020). 


\section{Museu de Arte Sacra de São Paulo, de 1969}

O Museu de Arte Sacra de São Paulo, equipamento da Secretaria de Cultura e Economia Criativa do Estado de São Paulo, foi criado a partir do convênio firmado entre a Cúria Metropolitana e o Estado em 28 de outubro de 1969, a fim de estabelecer um local apropriado para a guarda do acervo sacro pertencente ao antigo Museu da Cúria.

O local escolhido para seu estabelecimento foi a ala esquerda térrea do Mosteiro de Nossa Senhora da Imaculada Conceição da Luz, fundado e construído por Frei Antônio de Sant'Anna Galvão em 1774, e ocupado pelas irmãs Concepcionistas.

O acervo do recém-criado Museu de Arte Sacra, instalado em 29 de junho de 1970, era formado por objetos do antigo Museu da Cúria, alguns poucos itens das irmãs Concepcionistas, o acervo do Museu dos Presépios, cujo Presépio Napolitano ocupa a antiga Casa do Capelão desde 1999, e objetos adquiridos para compor o perfil da instituição.

O museu abriga hoje uma das mais importantes coleções de arte sacra do país, com mais de quatro mil peças criadas entre os séculos $X V I$ e $X X$, composta por pinturas, esculturas, altares, oratórios e outros mobiliários religiosos, trabalhos de prataria e ourivesaria sacra, numismática e livros raros, além da coleção de presépios, com destaque para o Presépio Napolitano, formado por 1.600 peças do século XVIII doado por Ciccilo Matarazzo.

Com ênfase na imaginária colonial paulista, pode-se encontrar obras de grandes artistas, como Antônio Francisco Lisboa, o "Aleijadinho", Frei Agostinho da Piedade, Frei Agostinho de Jesus, Manuel da Costa Athayde, Padre Jesuíno do Monte Carmelo, Almeida Júnior, Benedito Calixto e Anita Malfatti.

Assim, se levarmos em conta apenas as datas oficiais, aquele que é considerado o mais antigo museu de arte sacra no Brasil é o Museu Sacro Franciscano da Venerável Ordem Terceira de São Francisco da Penitência, no Rio de Janeiro, de 1933. Entretanto, entendemos que as datas oficiais de criação dos museus de arte sacra, apesar de serem marcos significativos de uma fase de maior estruturação museológica desse tipo de instituição, não correspondem, na verdade, ao momento em que esses museus foram fundados. 
Segundo matéria publicada no Jornal do Commercio (RJ) em 1934, a respeito das notícias da sucursal baiana, relatava-se a futura inauguração do Museu D. Marcos Teixeira, a ser instalado em três amplos salões na Igreja Matriz da Conceição da Praia (elevada a Basílica em 1946), em Salvador, pelo Pe. Manuel Barbosa, que também pretendia instalar anexo ao museu um arquivo contendo livros de documentos da Matriz. O anúncio da criação do museu havia sido feito no ano anterior pelo $\mathrm{Pe}$. Barbosa durante exposição de arte sacra na Matriz da Conceição, ocasião em que aproveitou para saudar Dom Duarte.

De acordo com a notícia, o futuro Museu D. Marcos Teixeira seria o primeiro de arte e história religiosa a ser instalado nas regiões Norte e Nordeste e terceiro do Brasil, pois até aquele momento "somente São Paulo tem o esplendido Museu da Cúria fundado por Dom Leopoldo e Mariana, o museu de arte e história instalado por D. Helvecio [Arcebispo de Mariana]" (Jornal do Commercio no 240,1934, p. 6).

Interessante notar que o citado museu de Mariana, o Museu Arquidiocesano de Arte Sacra, viria a ser inaugurado oficialmente apenas em 22 de setembro de 1962 por Dom Oscar de Oliveira. Entretanto, a Casa Capitular onde está localizado hoje era utilizada pela Mitra Arquidiocesana como Cúria e Arquivo Eclesiástico desde $1926^{65}$.

Assim, é possível supor que o caso de Mariana se assemelhe ao do Museu da Cúria de São Paulo, no qual os objetos foram sendo recolhidos ao longo dos anos e expostos de forma embrionária até a oficialização dos espaços como um museu melhor estruturado.

Ainda na referida matéria do Jornal do Commercio (1934), é interessante observar que o Pe. Manuel Barbosa faz um apelo ao clero baiano e às famílias que possuíssem arte religiosa, para que doassem os objetos ao museu para a formação das seguintes seções que o museu apresentaria:

\footnotetext{
65 IPHAN. Casa Capitular (Mariana, MG). Disponível em: $<$ http://portal.iphan.gov.br/ans.net/tema_consulta.asp?Linha=tc_belas.gif\&Cod=1325>. Acesso em: $20 / 05 / 2020$.
} 
- Iconografia (pinturas, esculturas etc.)

- Liturgia (cálices, missais, ornamentos e alfaias)

- Epigrafia (inscrições antigas em pedra ou madeira)

- Sigilografia (sinos, sinetes etc.)

- Heráldica (brasões esculpidos ou em fotografias)

- Numismática (moedas e medalhas com motivos

religiosos)

- Etnografia (objetos indígenas)

- Diplomacia (documentos históricos)

- Torêutica (Arte de cinzelar ou esculpir em metal, madeira ou marfim)

- Mobiliário (de diversos estilos)

A concepção de um museu dos bens da Igreja e um arquivo para os documentos da Matriz, elaborada por Pe. Manuel Barbosa, pode ter sido inspirada pelas ações de Dom Duarte, o qual é citado pelo padre, uma vez que em 1934, o Museu e Arquivo da Cúria já eram reconhecidas instituições eclesiais, ainda que talvez desconhecidas do público em geral.

Como é possível observar nos históricos das instituições apontadas acima, a formação dos acervos de bens culturais da Igreja se dá, em sua maioria, da conscientização do clero em recolher os objetos presentes nas comunidades a afim de salvaguardar sua materialidade a partir do entendimento da importância histórica e artística destes objetos para aquele determinado grupo. 


\section{Considerações finais}

Essa dissertação buscou investigar, sob a ótica da história dos museus, coleções e exposições, a criação do Museu da Cúria Metropolitana de São Paulo, instituição pioneira na preservação dos bens culturais da Igreja Católica no Brasil, por iniciativa de Dom Duarte Leopoldo e Silva, 1ํArcebispo de São Paulo.

O Museu foi constituído nas primeiras décadas do século XX como local de guarda de objetos recolhidos de Igrejas, irmandades e outros doados à Cúria, como forma de preservar o passado católico paulista, que estava por se perder com as diversas transformações urbanas e políticas ocorridas a partir do final do século XIX no Estado de São Paulo.

Com o presente trabalho, concentrado no caso paulista do Museu da Cúria Metropolitana de São Paulo, buscamos contribuir para uma melhor compreensão dos processos antecedentes, por meio dos quais um museu de arte sacra pôde germinar, décadas antes de seu início oficial.

As iniciativas de museus eclesiásticos no Brasil foram surgindo ao longo do século XX. A escassa historiografia a respeito do tema implica em suposições relacionadas ao recolhimento dos objetos por parte das igrejas a fim de salvaguardar seus acervos, tal qual Dom Duarte Leopoldo e Silva fez em relação ao patrimônio paulista que estava se perdendo com as constantes demolições e transformações da cidade de São Paulo.

A valorização destes bens preservados revela o papel fundamental da arte dentro das ações da Igreja juntamente às suas comunidades crentes, que sentem que este patrimônio cultural Ihes pertence, bem como também àqueles que não integram essa comunidade de fiéis, mas que também apreciam seu significado eclesial66.

66 I Congreso Internacional Europae Thesauri. Beja, 23 de novembro de 2006. Los museos de la Iglesia al inicio de un nuevo milenio. Disponível em:

<http://www.vatican.va/roman_curia/pontifical_commissions/pcchc/documents/rc_com_pcchc_2 0061123_europae-thesauri_sp.html\#_ftn4>.Acesso em: 13/02/2020. 
A preservação desses bens culturais por meio dos museus eclesiásticos ou de arte sacra garantem não só a conservação física do objeto, mas sua simbologia histórica-religiosa como testemunhos de experiências diretamente ligadas às noções de identidade, herança e patrimônio cultural.

A partir do estudo de caso do Museu da Cúria Metropolitana de São Paulo, pudemos compreender melhor as transformações políticas e sociais da cidade, tendo como ponto de vista aquele da Igreja Católica, que no início do século $\mathrm{XX}$ tentava manter sua hegemonia perante as outras religiões que avançavam pelo país, e que buscava fortalecer seu papel junto à elite paulista, por meio da construção e reformas de seus templos.

As ações do clero paulista influenciaram diretamente a forma como seus bens patrimoniais eram entendidos e as melhores maneiras de preservá-los, fosse na destinação dos objetos a outros templos, fosse na forma de um museu eclesiástico, cujas práticas museológicas, como as conhecemos hoje, ainda não eram disseminadas e aplicadas.

A figura de Dom Duarte Leopoldo e Silva à frente da Arquidiocese de São Paulo, simboliza todas essas transformações políticas e religiosas, por sua atuação firme e sempre presente junto aos agentes transformadores, fossem estes políticos, "barões do café" ou pessoas comuns do povo.

Graças ao seu pioneirismo em criar o Museu da Cúria podemos hoje ter contato com uma parte importante de nossa história colonial por meio dos tantos objetos litúrgicos, artísticos e históricos que foram coletados ao longo da primeira metade do século XX. Além disso, esta ação também nos proporciona reflexões acerca da maneira com que esses bens foram recolhidos, a partir das escolhas da própria Igreja Católica em abandonar, demolir e reconstruir seu próprio patrimônio arquitetônico.

Assim, nosso trabalho buscou apresentar como a Igreja Católica entende seus bens culturais, de que forma estão inseridos dentro do contexto eclesiástico e como são transformados em objetos museológicos a partir da iniciativa de salvaguardar esses bens que de diferentes maneiras estão em risco. 
Buscamos resgatar a memória do Museu da Cúria, por meio da investigação acerca de sua criação, formação de acervo, análise da expografia adotada, sua organização e funcionamento ao longo dos anos, até culminar no convênio com o Estado de São Paulo para a criação do Museu de Arte Sacra de São Paulo.

Não tivemos a pretensão de esgotar o assunto, mas sim de desenvolver uma historiografia inicial acerca de Dom Duarte e o Museu da Cúria para compreendermos melhor as formas pelas quais objetos sacros são musealizados e seu papel como documentos históricos.

O grande desafio durante toda a investigação foi a escassez de documentos originais do Museu que nos ajudassem a entender a dinâmica da instituição, como regimentos, relatórios ou outros documentos de cunho administrativo, e também a existência de uma lacuna a respeito da historicidade da criação dos museus de arte sacra no Brasil.

Além da pesquisa em arquivos e instituições culturais, fizemos um levantamento focado da documentação existente nas instituições diretamente relacionadas ao objeto de pesquisa: Arquivo da Cúria e Museu de Arte Sacra.

Com a investigação nos periódicos, que se tornou nossa principal fonte de pesquisa, em especial o Correio Paulistano e o jornal O Estado de S. Paulo, encontramos diversos artigos que descreviam não só o interior do Palácio da Cúria, como o Museu em si, e que sempre apontavam a importância do museu como uma instituição de salvaguarda do passado religioso paulista e a iniciativa pioneira de Dom Duarte.

Nossa pesquisa bibliográfica partiu à procura de artigos, dissertações e teses publicadas por pesquisadores que discutissem a gestão e preservação dos bens culturais da Igreja e suas potencialidades para nos ajudar a compreender melhor nosso objeto. Além dessas referências bibliográficas, também procuramos inserir autores que discutissem as diversas temáticas que tangem esta pesquisa.

O Capítulo 1 foi desenvolvido após o início da pesquisa a partir da necessidade de entender as ações preservacionistas executadas por Dom Duarte dentro do âmbito da Cúria, uma vez que a Igreja Católica possui leis que definem todos os aspectos da doutrina, haveria então leis a respeito da proteção de seus bens culturais? Essa pesquisa foi importante compreender alguns 
processos ao longo da história da Igreja e do desenvolvimento de suas leis, principalmente os instrumentos desenvolvidos para salvaguarda de seus bens.

Assim, apontamos algumas ações de Papas que se destacaram neste cenário preservacionista, também levantamos os principais Concílios e os Documentos Elaborados a respeito da salvaguarda dos bens da Igreja, os Códigos de Direito Canônico de 1917, que se enquadra no período estudado, e o de 1983.

Neste capítulo também apresentamos o contexto das regulamentações no Brasil, onde a Igreja Católica era regida, até a Proclamação da República em 1889, pelo Código Canônico e pelas Constituições Portuguesas devido ao regime do Padroado, que representava a concessão dada pelo Papado à Coroa Portuguesa de administrar os assuntos religiosos em suas colônias.

Com essa pesquisa pudemos constatar que essas ações de preservação sempre tinham um viés político de reafirmação do poder da Igreja Católica. E esse uso político da arte inclusive observamos durante a nossa investigação nas ações do próprio Dom Duarte para legitimar o poder da Igreja Paulista durante a Primeira República.

Também apresentamos neste capítulo uma discussão do ponto de vista da musealização de objetos sagrados, contextualizando o papel colecionista da Igreja Católica e seus tesouros eclesiásticos E o objeto sacro como fonte documental e os processos museológicos necessários para esse tipo de coleção.

No Capítulo 2 analisamos a figura de Dom Duarte e sua atuação política como $1^{\circ}$ Arcebispo de São Paulo. Para compreender suas ações preservacionistas, entre elas a criação do Museu da Cúria, foi necessário se aprofundar tanto em sua biografia como principalmente entender o cenário político paulista no qual ele estava inserido, uma vez que Dom Duarte acompanhou desde o início do seu sacerdócio, em 1892, as mudanças políticas entre Estado-Igreja Pós-Proclamação, com a laicização do país, pensamento ultramontano dos bispos reformadores - que buscavam estarem mais próximos das orientações da Igreja de Roma, sobretudo em relação à doutrina e à disciplina do clero, a imigração de um grande número de padres italianos no final do século 19 e início do século 20, que trouxeram consigo uma compreensão religiosa e artística diferente daquela do clero brasileiro, como também o 
crescente de novas religiões no país, e as próprias transformações arquitetônicas, sociais e culturais da cidade de SP, que nessa virada do século se transformava numa metrópole aos moldes europeus, a cidade-exposição e que vivia um progresso econômico com a cultura do café e se destacava no cenário nacional.

Assim fizemos uma apresentação de Dom Duarte, traçando seu perfil como um homem devoto, um intelectual de personalidade reservada, um colecionador e apreciador das artes, Dom Duarte atua como uma espécie de mecenas da arte religiosa, contratando artistas da época, como Benedito Calixto, do qual era amigo inclusive. $E$ analisamos aqui também seus principais feitos à frente da Arquidiocese.

Também discutimos a importância da construção do Palácio da Cúria em 1920 como parte desse projeto de reafirmação do poder da Igreja Católica em $\mathrm{SP}$, sendo o Palácio considerado o $1^{\circ}$ de seu tipo, pois à época as Cúrias funcionavam nos palácios episcopais ou nas respectivas catedrais.

O Palácio foi construído no lugar do Recolhimento de Santa Teresa, primeiro de seu tipo em São Paulo, e é possível que a escolha do local se deu muito por sua posição estratégica no centro da cidade - Pateo do Colégio, futura Catedral da Sé. E lá funcionavam além das repartições eclesiásticas, o Arquivo e o Museu da Cúria.

E é importante destacar o Arquivo para a história do Museu, pois seu primeiro diretor, Francisco de Salles Collet e Silva foi o grande responsável pelo recolhimento dos objetos que compuseram o Museu.

O Arquivo foi criado em 1918, por Dom Duarte a fim de cumprir as determinações estabelecidas no CIC de 1917 a respeito da organização dos arquivos eclesiásticos. E Dom Duarte além de propor essa organização dos arquivos, determina em 1921 que todas as paróquias realizassem a duplicata de seus livros (batismo, casamento...) e os enviasse à Cúria, juntamente com documentos mais antigos de interesse histórico visando a sua preservação.

Essa ação foi importantíssima para tornar o Arquivo não só um exemplo de instituição de seu tipo a ser seguida por outras Cúrias, como grande fonte de pesquisa sobre a história da Arquidiocese. 
Neste capítulo 2 também nos aprofundamos na contextualização histórica da diocese de São Paulo até ser elevada à Arquidiocese, e discutimos a necessidade da Igreja Católica de se expandir territorialmente acompanhando o crescimento econômico do Estado, com a criação de novas dioceses e paróquias, que demandavam mais párocos e consequentemente mais objetos para culto.

E abordamos as consequências dessa expansão e modernização urbana, em especial na cidade de São Paulo, com as reformas e demolições dos templos desde o final do século 19 de acordo com as exigências modernas da época. As igrejas de traços coloniais foram sendo substituídas por templos maiores e mais de acordo com o estilo europeu vigente - eliminando qualquer traço caipira de seu passado que já não condizia com o seu novo status de metrópole.

E com tantas reformas e reconstruções em andamento, nos perguntamos o que aconteceu com os objetos e ornamentos presentes nesses templos, então apresentamos aqui alguns caminhos desses objetos. Nós sabemos que muitos acabaram sob a guarda da Cúria Metropolitana, o que levou à criação do Museu da Cúria, porém outros tantos se perderam, ou acabaram em antiquários ou então doados posteriormente aos museus.

No Capítulo 3 apresentamos o Museu da Cúria, investigando como foi o processo de criação e organização desta instituição museológica e quais foram os procedimentos estabelecidos para sua preservação.

Nós aprofundamos a investigação a respeito da constituição do museu, concluindo, a partir das fontes analisadas, que o Museu da Cúria se iniciou de forma embrionária a partir do retorno de Dom Duarte a São Paulo, em 1907, ainda como bispo da cidade, tomando contornos como instituição museológica de fato somente a partir de 1918, com a criação do Arquivo da Cúria.

Não conseguimos definir uma data oficial de criação do Museu, mas entendemos que foi uma construção junto às ações do Arquivo da Cúria, a presença de Francisco Collet com 1을 diretor do Arquivo e do Museu, em contato direto com documentos das dioceses e paróquias do Estado enviados à Cúria, proporcionou um levantamento do patrimônio religioso paulista e dos objetos que talvez merecessem serem recolhidos e salvaguardados na Cúria. 
Nós encontramos inventários e cartas de doadores datados a partir da década de 1920, bem como as menções ao Museu aparecem nos periódicos apenas a partir de 1922 - então os dados analisados corroboram nossa hipótese que a criação do Arquivo em 1918 e o novo Palácio da Cúria em 1920 possibilitaram a criação e o desenvolvimento do Museu.

Entretanto, as formas com que os objetos foram sendo incorporados de fato ao acervo do Museu da Cúria ao longo do tempo segue incerta em alguns pontos. Além de algumas poucas cartas de doação de objetos, as fontes analisadas sempre apontam para uma ação de recolhimento por parte de Dom Duarte e de Francisco Collet, no intuito de salvaguardar a arte religiosa paulista, mas sem indicar como foram realizadas essas coletas.

Nossas principais fontes documentais para análise do acervo foram os dois catálogos encontrados no Arquivo da Cúria, um datilografado e outro manuscrito. Ambos sem data, mas que supomos terem sido usados com inventários entre 1920 e 1940, ainda que utilizado até a década 1960 dada as anotações manuscritas encontradas neles. E a partir da combinação e tabulação desses catálogos, chegamos a 1.127 objetos, a grande maioria do Estado de SP e da cidade SP, com predominância de objetos do século 18.

Destacamos na dissertação as principais tipologias encontradas após análise do catálogo - prataria, ourivesaria, imaginária, pintura e numismática, sendo ilustradas com alguns objetos que nós destacamos por entendemos serem importantes dentro da coleção de acordo com suas procedências e descrições apresentadas no catálogo.

No Capítulo 3 também discutimos a expografia do Museu e, mais uma vez, a escassez de documentos se tornou um desafio para entendermos como esses objetos eram expostos no Museu.

Então a partir das poucas fotografias encontradas e de algumas fontes documentais, entendemos que no Museu o acervo se encontrava em quatro salas expositivas e também alguns objetos estavam espalhados pelas salas das repartições do Palácio, escadarias, halls de entrada e corredores - e ainda que muitos destes objetos fora das salas expositivas não estivessem inventariados no Catálogo, como as pinturas que decoravam os gabinetes no segundo pavimento do Palácio e o mobiliário, nós sabemos que esses objetos foram musealizados ao longo do tempo, uma vez que estão no MAS hoje. 
Finalizamos o capítulo com a análise do funcionamento do Museu e cessão de objetos para exposições. Muitas fontes de pesquisa indicavam que o Museu era desconhecido do público, não possuía espaço adequado para visitação - que tinha um horário bem restrito de funcionamento e número reduzido de público por visita.

Porém, ainda que o museu fosse desconhecido do grande público e que houvesse uma dificuldade em visita-lo, o seu acervo era sim conhecido, prestigiado em artigos de jornais e solicitado para compor exposições pela cidade, como sua participação nas comemorações do $4^{\circ}$ Centenário de SP em 1954, participando da "Exposição de História de São Paulo no Quadro da História do Brasil" na Oca, e na inauguração da Casa do Bandeirante.

No Capítulo 4 apresentamos as estratégias desenvolvidas pela Cúria paulista para encontrar uma instituição capaz de se responsabilizar por seu acervo, uma vez que a Cúria não tinha recursos financeiros para manter o Museu. Então conseguimos mapear algumas tratativas da década de 1960, com a FAAP, com a PUC-SP e que por fim culminou no convênio estabelecido entre a Cúria e o Governo do Estado em 1969 para a criação do MAS, inaugurado em 1970.

Apresentamos ainda como se deu a assinatura desde convênio a partir das novas políticas culturais dentro do Governo do Estado, que resultaram não só na criação do MAS, como do Museu da Imagem e do Som (MIS) e do Museu da Casa Brasileira (MCB) e abordamos o início do Museu de Arte Sacra de São Paulo.

No Capítulo 5 fizemos um levantamento por datas de criação de museus de arte sacra no Brasil, a fim de melhor inserir nosso objeto de estudo no movimento de criação de museus dessa tipologia no século XX.

As datas encontradas são entre as décadas de 1930 e 2000, - mas entendemos que essas datas oficiais de criação, apesar de significarem marcos importantes na estruturação museológica dessas instituições, não correspondem, necessariamente, ao momento em que esses museus foram iniciados de fato.

Então nós apresentamos aqui o histórico de cinco instituições pioneiras, que corroboram essa hipótese, de que a formação dos acervos de bens culturais da Igreja se dá, em sua maioria, primeiramente da conscientização do clero em recolher esses objetos. 
A partir do entendimento da função deste objeto como documento histórico integrante da construção da memória e identidade religiosa daquele determinado grupo e que deve ser preservado, ainda que, como no caso apresentado do Museu da Cúria, seja uma coleção que representa, também, a destruição dessa mesma memória que se quer preservar, o acervo do Museu da Cúria foi constituído em grande parte por um patrimônio que estava em vias de desaparecer com a autorização desse mesmo clero. 


\section{Bibliografia e Fontes ${ }^{67}$}

\section{Referências bibliográficas}

\section{Museus, coleções, museologia}

BREFE, A. C. F. O Museu Paulista - Affonso de Taunay e a memória nacional, 19171945. São Paulo: Editora UNESP; Museu Paulista, 2005.

BRULON, B. Provocando a Museologia: o pensamento germinal de Zbynek Z. Stránský e a Escola de Brno. Anais do Museu Paulista, São Paulo, v. 25, n. 1, p. 403-425, abr. 2017.

Da artificação do sagrado nos museus: entre o teatro e a sacralidade. Anais do Museu Paulista: História e Cultura Material, vol. 21, no 2, São Paulo, Jul/Dez, 2013.

BRUNO, M. C. O. Os Territórios da Memória e a Memória dos Territórios. Palestra proferida na Universidade Lusófona de Humanidades e Tecnologias na inauguração do Centro de estudos interdisciplinares de educação e desenvolvimento - CEIED. LisboaPortugal, 2015

CAMPOS, V. S. Elementos de Museologia: História dos Museus. 3ํvol. - Brasil. São Paulo: Secretaria de Cultura, Esportes e Turismo, 3 v., 1977.

CERAVOLO, S. M. Apontamentos sobre a documentação de Museus. In: Observatório da Museologia Baiana. Blog, postado em 25/12/2012. Disponível em: $<$ http://observatoriodamuseologiabaiana.blogspot.com.br/2012/11/apontamentossobre-documentacao-de.html>. Acesso em: 10 out. 2018.

ESTATUTO DOS MUSEUS. Disponível em: <http://www.planalto.gov.br/ccivil_03/_Ato2007-2010/2009/Lei/L11904.htm>. Acesso em: 14/04/2019.

GUARNIERI, W. R. C. Museu: um aspecto das organizações culturais num país em desenvolvimento. São Paulo, 1977. 168 f. Dissertação (Mestrado). Fundação Escola de Sociologia e Política de São Paulo, 1977

. Museologia e Identidade. In: BRUNO, Maria Cristina Oliveira. Araújo (Coord.). Waldisa Rússio Camargo Guarnieri: textos e contextos de uma trajetória profissional. São Paulo, Pinacoteca do Estado de São Paulo, Governo do Estado de São Paulo, 2010. $1 \mathrm{v}$.

GONÇALVES, J. R. S. Antropologia dos objetos: coleções, museus e patrimônios. Ministério da Cultura, Instituto do Patrimônio Histórico e Artístico Nacional, Departamento de Museus e Centros Culturais, 2007.

GHIRARDO, D. y. Arquitetura contemporânea: uma história concisa. São Paulo: Editora Martins Fontes, 2002. 304p.

GUERRA, J. W. N. O Projeto de Ernani Silva Bruno: uma discussão sobre as bases de criação, implantação e gestão do Museu da Casa Brasileira (1970-1979). 2015.

${ }^{67}$ De acordo com a Associação Brasileira de Normas Técnicas (ABNT NBR 6023), sistema autor-data. 
Dissertação (Mestrado em Museologia) - Museologia, Universidade de São Paulo, São Paulo, 2015.

HALL, S. A identidade cultural na pós-modernidade. $3^{\text {a }}$ ed. Rio de Janeiro: DP\&A, 1999. HUYSEN, A. Seduzidos pela memória. Rio de Janeiro: Aeroplano, 2004.

IPHAN. Tesauro para bens móveis e integrados. Rio de Janeiro, 2006.

LARA FILHO, D. Museu, objeto e informação. Transinformação, Campinas, n. 21, v. 2, p. 163-169, maio/agosto, 2009.

LEMOS, A. C. O que é patrimônio histórico. Primeiros Passos, v. 51. São Paulo: Brasiliense, 1981.

LEWIS, G. O Papel dos Museus e o Código de Ética Profissional. IN Boylan, Patrick J. (ed). Como Gerir um Museu: Manual Prático. ICOM, 2004.

MENESES, U. T. B. de. Do teatro da memória ao laboratório da História: a exposição museológica e o conhecimento histórico. Anais do Museu Paulista: História e Cultura Material, v. 2, n. 1, p. 9-42, 01 jan. 1994.

LUGLI, A. Naturalia et mirabilia: il collezionismo enciclopedico nelle Wunderkammern d'Europa. Gabriele Mazzotta editore, 1983. 262p.

NASCIMENTO, R. O objeto museal como objeto de conhecimento. Cadernos de Sociomuseologia, Portugal, v. 3, n. 3, maio 2009.

OLIVEIRA, H. de S. (org.) O Museu Paulista e a gestão Afonso Taunay [recurso eletrônico]: escrita da história e historiografia, séculos XIX e XX. São Paulo: Museu

Paulista da USP, 2017. 191 p. Disponível em: < http://www.mp.usp.br/sites/default/files/o_museu_paulista_e_a_gestao_afonso_taunay. pdf>. Acesso em: 20/11/2020.

POMIAN, K. Colecção. In: Enciclopédia Einaudi. 1. Memória-História. Porto: Imprensa Oficial - Casa da Moeda, 1985. p. 51-86.

POULOT, D. Le musée d'histoire en France entre traditions nationales et soucis identitaires. Anais do Museu Paulista, São Paulo, vol.15, n.2, pp. 293-316, jul.dez.2007. Museu e museologia. Belo Horizonte: Autêntica, 2013. 160p.

\section{Arte sacra, museologia e musealização de bens eclesiásticos}

AFONSO, A. N. Museus da Igreja - Missão pastoral e cultural. Paulus Editora, Lisboa, 2015. 224p.

ALVES, M. de B. A escola jesuítica e a produção sacra no Grão-Pará e Maranhão. III Encontro de História da Arte - História da Arte e instituições culturais: Perspectivas em Debate 2007.

Disponível em: https://www.ifch.unicamp.br/eha/atas/2007/ALVES,\%20Moema\%20de\%20Bacelar.pdf >. Acesso em: 15/02/2021. 
AMARAL, V.; MORAES, B.; BORGES, F. D. C. M. F. Inventário de bens culturais - igreja matriz Santo Antonio. Encontro Nacional de Ensino, Pesquisa e Extensão, Presidente Prudente, 19 a 22 de outubro, 2015.

Colloquium Humanarum, vol. 12, n. Especial, 2015, p. 265-272. Disponível em: < http://www.unoeste.br/site/enepe/2015/suplementos/area/Humanarum/Arquitetura\%20 e\%20Urbanismo/INVENT\%C3\%81RIO\%20DE\%20BENS\%20CULTURAIS\%20\%E2\%8 0\%93\%20IGREJA\%20MATRIZ\%20SANTO\%20ANTONIO.pdf>. Acesso em: $12 / 03 / 2019$.

ANDRADE, M. R. De M. 1893-1945. Mário de Andrade: cartas de trabalho, correspondência com Rodrigo Mello Franco de Andrade [1936-1945]. Brasília: SPHAN / Fundação Nacional Pró-Memória, 1981.

ARAUJO, E. Barroco ardente e sincrético luso-afro-brasileiro. ARAUJO, Emanoel (org.). São Paulo: Museu Afro Brasil, 2018. 395 p.

ARROYO, L. Igrejas de São Paulo: introdução ao estudo dos templos mais característicos de São Paulo nas suas relações com a crônica da cidade. São Paulo: Companhia Editora Nacional, 1966. 2. ed. revista e atualizada.

BERTO, J. P. A preservação de Bens Culturais Sacros: os Museus de Arte Sacra e suas especificidades. Anais. VIII Seminário Nacional do CMU - Memória e acervos documentais, o arquivo como espaço produtor de conhecimento. Unicamp / Centro de Memória - Unicamp (CMU). Campinas, SP, 2016.

História, gestão e preservação: os bens culturais eclesiásticos na diocese de Limeira-SP. 2018. 1 recurso online (403 p.). Tese (doutorado) - Universidade Estadual de Campinas, Instituto de Filosofia e Ciências Humanas, Campinas, SP.

CAMPOS, A. A. Arte Sacra no Brasil Colonial. São Paulo: COM ARTE, 2012.

CAPURRO, R. Reinterpreting a sacred place. When a church becomes a museum from an ecclesiastical point of view. In: Museology and the Sacred - Materials for a discussion. Editor François Mairesse. ICOFOM 41st Annual Symposium, Tehran (Iran), 15-19 October 2018.

CARVALHO, A. C. Rememoração: arte religiosa como documento histórico. Coleções do Acervo Artístico-Cultural dos Palácios do Governo e do Museu de Arte Sacra de São Paulo. In: Rememoração: arte religiosa como documento histórico. Coleções do Acervo Artístico-Cultural dos Palácios do Governo e do Museu de Arte Sacra de São Paulo. São Paulo, 2015. P. 16-20.

CASTAGNA, P. A Seção de Música do Arquivo da Cúria Metropolitana de São Paulo. Brasiliana, Revista Quadrimestral da Academia Brasileira de Música, Rio de Janeiro, n.1, p.16-27, jan. 1999.

CASTRO, A. L. S. O museu: do sagrado ao segredo: uma abordagem sobre informação museológica e comunicação. 1995. 144 f. Dissertação (Mestrado em Ciência da Informação) - Universidade Federal do Rio de Janeiro / Instituto Brasileiro de Informação em Ciência e Tecnologia, Rio de Janeiro, 1995.

COLOMBO FILHO. In: Arte sacra colonial: barroco memória viva. Percival Tirapeli (org.). São Paulo: UNESP, 2001. 287 p. 
CONTE, M. B. A(s) vida(s) da pia de água benta da primeira igreja de São Paulo no Museu Paulista da USP. Dissertação (Mestrado). Universidade Lusófona de Humanidades e Tecnologias, Departamento de Museologia da Faculdade de Ciências Sociais e Humanas. Lisboa, 2011.

COPPOLA, S. A. A. Costurando a memória: o acervo têxtil do Museu Arquidiocesano de Arte Sacra de Mariana. Dissertação (mestrado) - Universidade Federal de Minas Gerais, Escola de Belas Artes. Mariana. 2005, $220 f$.

DALTON, S. Barro paulista. In: Barro paulista: a tradição bandeirante do imaginário em barro cozido. Dalton Sala (org.), Museografia: Maria Alice Milliet. São Paulo: Museu de Arte Sacra de São Paulo, 2014. 59 p.

DIAS, M. H. G., Doutores e Doutoras da igreja. In: Doutores e Doutoras da igreja: a beleza do testemunho da vida e da palavra. Marcos Horácio Gomes Dias, Vanessa Beatriz Bortulucce (curadoria). São Paulo: Museu de Arte Sacra de São Paulo, 2017. 48 p.

ETZEL, E. O barroco no Brasil: psicologia e remanescentes em São Paulo, Goiás, Mato Grosso Paraná, Santa Catarina, Rio Grande do Sul. 2. ed.. São Paulo: Melhoramentos, 1974. 314 p.

Imagens religiosas de São Paulo. São Paulo: Melhoramentos, 1971. 302 p.

FABRINO, R. J. H. Guia de Identificação de Arte Sacra. IPHAN. Rio de Janeiro, 2012.

GHIRARDELLO, N. Patrimônio religioso, o que é isso? UNESPCIÊNCIA, Edição 102, 01 de novembro de 2018.2 Disponível em: <http://unespciencia.com.br/2018/11/01/urbanismo-102/>. Acesso em: 24/04/2019.

KUHN, J. C. S. Resistências Sagradas: Pátio do Colégio, secularização e reconstrução. 146f. Dissertação (Mestrado) - Faculdade de Arquitetura e Urbanismo, Universidade de São Paulo, São Paulo, 2016.

LEMOS, C. A. C. Museu de Arte Sacra de São Paulo. Catálogo. In: Godinho, Antônio de Oliveira (org). O Museu de Arte Sacra de São Paulo. São Paulo: Banco Safra, 1983. 269 p.

LEOPOLDO e Silva. In: ENCICLOPÉDIA Itaú Cultural de Arte e Cultura Brasileiras. São Paulo: Itaú Cultural, 2019. Disponível em: $<$ http://enciclopedia.itaucultural.org.br/pessoa259848/leopoldo-e-silva>. Acesso em: 22/06/2019.

MAIRESSE, F. The sacred in the prism of museology, v. 47, n.1-2, 2019.

Museology and the Sacred - Materials for a discussion. Editor François Mairesse. ICOFOM 41st Annual Symposium, Tehran (Iran), 15-19 October 2018.

MARAVALL, J. A. A cultura do barroco. São Paulo: Edusp, 1997.

MUSEU DE ARTE SACRA DE SÃO PAULO (MAS-SP). Museu de Arte Sacra de São Paulo. Maria Inês Lopes Coutinho (Org.). São Paulo, 2014. 331 p.

Catálogo. Pedro Antonio de Oliveira Neto, José Miguel Soares Filho (org.). São Paulo: Ypiranga, 1970. 284 p. 
PIZA, V. T. A Presença da Igreja nas Artes Visuais nos 450 anos da cidade de São Paulo. In A Igreja de São Paulo: presença católica na histórica da cidade. Maria Angela Vilhena e João Décio Passos (orgs.). São Paulo: Paulinas, 2005.

PHILIPPOV, K. A obra religiosa de Benedito Calixto de Jesus através do mecenato de Dom Duarte Leopoldo e Silva na Igreja de Santa Cecília. 2016. 240 p. Tese (Doutorado) - Universidade Estadual de Campinas, Instituto de Filosofia e Ciências Humanas, Campinas, SP.

ROQUE, M. I. O Sagrado no Museu. Lisboa: Universidade Católica Editora, 2011. $362 p$.

Sagrado e arte: arte religiosa de Portugal e Brasil em acervos museológicos. In Museologia e Patrimônio - Revista Eletrônica do Programa de Pós-Graduação em Museologia e Patrimônio - Unirio | MAST - vol.13, no1, 2020, p. 10-46.

Entre o Sagrado e o Profano: práticas museológicas de iniciativa eclesiástica. Anais do Museu Histórico Nacional, Rio de Janeiro, v. 43, 2011. pp 67-89.

STRÖM, H. W. Religion in Museums: Euthanized Sacredness, in the Beholder's Eye, or a Multi-Tool for Shifting Needs? In: Museology and the Sacred - Materials for a discussion. Editor François Mairesse. ICOFOM 41st Annual Symposium, Tehran (Iran), 15-19 October 2018.

TIRAPELI, P. Igrejas barrocas do Brasil. Ed. Metalivros, São Paulo, 2008, 334p.

. Igrejas Paulistas - Barroco e Rococó. 2. ed. São Paulo: Editora Unesp/Imprensa Oficial do Estado de São Paulo, 2004. v. 01. 372p.

Retábulos maneiristas, barrocos e rococós no estado de São Paulo. IV CIBI Congresso Internacional do Barroco Iberoamericano.. 2006. p. 273-287

(org.). Arte Sacra Colonial: Barroco Memória Viva. São Paulo: Editora UNESP, Imprensa Oficial do Estado, 2001.

In: Fragmentos: coleções de Rafael Schunk e Museu de Arte Sacra de São Paulo. Curadoria Percival Tirapeli; textos Percival Tirapeli e Rafael Schunk. São Paulo: Museu de Arte Sacra de São Paulo, 2016,

A musealização do sagrado. In Museologia e Patrimônio - Revista Eletrônica do Programa de Pós-Graduação em Museologia e Patrimônio - Unirio | MAST - vol.13, no1, 2020, p. 123-143.

TOMMASO, W. Arte Sacra e Arte Religiosa. Imagem de culto e imagem de devoção. s/d. Disponível em:

<https://www.academia.edu/15548862/Arte_Sacra_e_Arte_Religiosa_Imagem_de_cult o_e_imagem_de_devo\%C3\%A7\%C3\%A3o>. Acesso em: 15/05/2021.

UNIVERSIDADE CATÓLICA PORTUGUESA; FUNDAÇÃO DA CASA DE BRAGANÇA. Thesaurus - Vocabulário de Objectos do Culto Católico. Lisboa: 2004. 


\section{Igreja Católica}

A Igreja nos Quatro Séculos de São Paulo: 1554-1954. São Paulo: Editora Documentários Ltda, 1955.

ARQUIDIOCESE DE SÃO PAULO. História dos Bispos e Arcebispos. Dom Duarte Leopoldo e Silva. Disponível em: < http://www.arquisp.org.br/historia/dos-bispos-earcebispos/arcebispos/dom-duarte-leopoldo-e-silva>. Acesso em: 12/09/2018.

BENCOSTTA, M. L. A. Cultura escolar e história eclesiástica: reflexões sobre a ação romanizadora pedagógica na formação de sacerdotes católicos e o Seminário Diocesano de Santa Maria (1915-1919). Cad. CEDES, Campinas, v. 20, n. 52, p. 88103, nov. 2000. Disponível em: <http://www.scielo.br/scielo.php?script=sci_arttext\&pid=S0101$32622000000300007 \&$ Ing $=e n \& n r m=i s o>$. Acesso em: 01/05/2019

CANUTO, A. Demolições no Complexo da Sé de São Paulo: Construindo uma História Social das Transformações Espaciais Paulistanas. 2019.

CASIMIRO, A. P. B. S. Constituições Primeiras do Arcebispado da Bahia: Educação, Lei, Ordem e Justiça no Brasil Colonial. In: LOMBARDI, José Claudinei; SAVIANI, Dermeval; NASCIMENTO, Maria Isabel de Moura. (Org.). Navegando pela História da Educação Brasileira. Campinas - SP: Graf. FE: HISTEDBR, 2006, p. 1- 10. Disponível em: < http://www.histedbr.fe.unicamp.br/navegando/artigos_frames/artigo_005.html>. Acesso em: 01/05/2019.

COMISSÃO PARA OS BENS CULTURAIS DA IGREJA / Coleção Pastoral da Cultural Carta circular sobre a necessidade e urgência da inventariação e catalogação dos bens culturais da Igreja - Pastoral da Cultura - Caderno 1. Brasília: CNBB, 2017.

COMMISSION FOR CULTURAL HERITAGE OF THE CHURCH. s/d. s/p. Disponível em:

http://www.vatican.va/roman_curia/pontifical_commissions/pcchc/documents/rc_com_p cchc_pro_20051996_en.html>. Acesso em: 12/01/2018.

CONSTITUIÇÕES APOSTÓLICAS. Pastor Bonus, sobre a Cúria Romana, 28 de junho de 1988, Papa João Paulo II. Disponível em: < http://w2.vatican.va/content/john-paulii/pt/apost_constitutions/documents/hf_jp-ii_apc_19880628_pastor-bonus.html>.

Acesso em 07/01/2018.

CONSTITUIÇÃO CONCILIAR. Sacrosanctum Concilium Sobre A Sagrada Liturgia. Concílio Vaticano II. Disponível em: <http://www.vatican.va/archive/hist_councils/ii_vatican_council/documents/vatii_const_19631204_sacrosanctum-concilium_po.html>. Acesso em: 07/01/2018.

CONSTITUIÇÕES PRIMEIRAS DO ARCEBISPADO DA BAHIA. Coimbra, Colégio das Artes da Companhia de Jesus, 1720; VIDE, Sebastião Monteiro. Constituições Primeiras do Arcebispado da Bahia. Estudo introdutório e edição de Bruno Fleiter, Evergton Sales, Istvan Jancsó (orgs.). São Paulo, Editora da Universidade de São Paulo, 2010 (Documenta Uspiana; 4).

DANTAS, A. Dom Duarte Leopoldo. São Paulo, Sociedade Impressora Pannartz, 1974. $144 p$. 
DIAS, M. H. G., Doutores e Doutoras da igreja. In: Doutores e Doutoras da igreja: a beleza do testemunho da vida e da palavra. Marcos Horácio Gomes Dias, Vanessa Beatriz Bortulucce (curadoria). São Paulo: Museu de Arte Sacra de São Paulo, 2017. 48 p.

GOMES, E. S. A Reaproximação Estado-Igreja no Brasil durante a República Velha (1889-1930). Revista de Cultura Teológica, v. 16, n. 62, jan/mar 2008.

LAGE, A. C. P. DOS CONVENTOS E RECOLHIMENTOS PARA OS COLÉGIOS DE FREIRAS: AS DIFERENÇAS DA EDUCAÇÃO FEMININA CATÓLICA NOS SÉCULOS XVIII E XIX. Educ. rev., Belo Horizonte, v. 32, n. 3, p. 47-69, Sept. $2016 . \quad$ Available from <http://www.scielo.br/scielo.php?script=sci_arttext\&pid=S0102$46982016000300047 \&$ lng=en\&nrm=iso $>$. access on 01 Aug. 2020.

MARCHI, E. Pastoral coletiva do episcopado brasileiro - 1915: há cem anos a construção de uma igreja. Revista Relegens Thréskeia, [S.I.], v. 5, n. 1, p. 164-180, jun. 2016. ISSN 2317-3688. Disponível em: <https://revistas.ufpr.br/relegens/article/view/46788>. Acesso em: 05/03/2019.

MARCHISANO, D. F.; CHENIS, Pe. C. CARTA CIRCULAR "A FUNÇÃO PASTORAL DOS MUSEUS ECLESIÁSTICOS". Vaticano, 2001. Disponível em: <http://www.vatican.va/roman_curia/pontifical_commissions/pcchc/documents/rc_com_ pcchc_20010815_funzione-musei_po.html >. Acesso em: 12/01/2018.

MATTOS, S. de M. A Igreja Matriz da Vila de São Paulo e a Velha Sé. São Paulo, 1986.

MEDEIROS, W. S. Concílio Vaticano I (1869 - 1870): centralização do catolicismo. Revista Eletrônica Discente História.com, v. 1 n. 1, 2013. Disponível em: < https://www3.ufrb.edu.br/seer/index.php/historiacom/article/view/19>. Acesso em: 01/05/2019.

MENEZES, I. P. Bens culturais da Igreja. São Paulo: Loyola, 2006.

ROMANO, C. de T. Santa Cecília: uma paróquia na confluência dos interesses da elite paulistana e da igreja católica entre 1895 e 1920. 2008. Tese (Doutorado em História Social) - Faculdade de Filosofia, Letras e Ciências Humanas, Universidade de São Paulo, São Paulo, 2008.

ROSENDHAL, Z. Espaço e Religião: uma abordagem geográfica. 2.ed. Rio de Janeiro: Eduerj, 2002, 92p.

CORRÊA, R. L. Difusão e territórios diocesanos no Brasil, 1551-1930. Scripta Nova. Revista electrónica de geografía y ciencias sociales. Barcelona: Universidad de Barcelona, 1 de agosto de 2006, vol. X, núm. 218 (65). Disponível em: <http://www.ub.es/geocrit/sn/sn-218-65.htm>. Acesso em: 20/05/2020.

SALVADOR, C. C.; EMBIL, J. M. U. Dicionário de Direito Canônico. Tradução e adaptação de Jesús Hortal. São Paulo: Edições Loyola, 1993.

SANTIROCCHI, I. D. Uma questão de revisão de conceitos: Romanização Ultramontanismo - Reforma. Temporalidades - Revista Discente do Programa de Pósgraduação em História da UFMG, vol. 2, n.ำ 2, Agosto/Dezembro de 2010. Disponível em: < https://periodicos.ufmg.br/index.php/temporalidades/article/view/5387>. Acesso em: 01/05/2019. 
SOUZA, N. (org.). Catolicismo em São Paulo: 450 anos de presença da Igreja Católica em São Paulo. 1554-2004. São Paulo: Paulinas, 2004.

VILLAÇA, A. C. O Pensamento Católico no Brasil. Rio de Janeiro: Civilização Brasileira, 2006.

WERNET, A. A Igreja Paulista no século XIX - A Igreja paulista no século XIX: A reforma de D. Antônio Joaquim de Melo (1851-1861). São Paulo: Ática, 1987.

\section{História do Brasil e de São Paulo}

BARBUY, H. M. S. A cidade-exposição: comércio e cosmopolitismo em São Paulo, 1860-1914. 1. ed. São Paulo: EDUSP, v. 1. 2006. 304 p.

O Brasil vai a Paris em 1889: um lugar na Exposição Universal. Anais do Museu Paulista: História e Cultura Material, [S. I.], v. 4, n. 1, p. 211-261, 1996.

BOSI, E. Memória da cidade: lembranças paulistanas. Instituto de Estudos Avançados. São Paulo: USP, vol. 1, n. 1, p. 199-200, 1987.

CYMBALISTA, R. Sangue, ossos e terras. Os mortos e a ocupação do território lusobrasileiro séculos XVI e XVII. Tese (Doutorado em Estruturas Ambientais Urbanas) Faculdade de Arquitetura e Urbanismo, Universidade de São Paulo, São Paulo, 2006. $428 \mathrm{f}$.

CUNHA, M. C. P. (org.) O Direito à Memória: patrimônio histórico e cidadania. São Paulo: Departamento do Patrimônio Histórico, p.25, 1992.

Discurso do Papa João Paulo II aos participantes na Assembleia Plenária da Pontifícia Comissão para os Bens Culturais da igreja. 31 de março de 2000. Disponível em: $<$ https://w2.vatican.va/content/john-paul-ii/pt/speeches/2000/jan-mar/documents/hf_jpii_spe_20000331_cultural-heritage.html>. Acesso em: 12/01/2018.

MARTINS, A. E. São Paulo antigo - 1554-1910. São Paulo, Ed. Paz e Terra, 2003. 550p.

MARTINS, J. S. História e arte no Cemitério da Consolação. 2008. Disponível em: < https://www.prefeitura.sp.gov.br/cidade/upload/cemiterio_baixa_1219246534.pdf>.

Acesso em: 22/06/2019.

São Paulo no século XX: primeira metade. São Paulo: Imprensa Oficial do Estado de São Paulo, 2011. v. 4. 120p.

NASCIMENTO, J. L. São Paulo no século XIX. São Paulo: Imprensa Oficial do Estado de São Paulo, 2011. v. 3. 136p.

LEFRÉVRE, J. E. A. De beco a avenida - A história da Rua São Luiz. Edusp, 2006, $312 p$.

ROSSI, M. S. Circulação e mediação da obra de arte na Belle Époque paulistana. Anais do Museu Paulista: História e Cultura Material, [S. I.], v. 6, n. 1, p. 83-119, 1999.

TOLEDO, B. L. São Paulo: três cidades em um século. São Paulo, Ed. Duas Cidades, 1983. 180p. 
TOLEDO, R. P. A capital da vertigem: uma história de São Paulo de 1900 a 1954. Rio de Janeiro, Ed. Objetiva, 2015. 582p.

\section{Fontes}

\section{Arquivos consultados}

Arquivo da Cúria Metropolitana de São Paulo (Arquivo Dom Duarte Leopoldo e Silva)

Anuários eclesiásticos (1907-1954).

Atas de ereções e Patrimônio das Capelas (1775-1900). Cód.: 06-02-026.

Boletim Eclesiástico (1918-1922).

Catálogos do Museu da Cúria (s/d). Cód.: 06-03-052; 06-03-053.

Diários da Cúria Metropolitana (1920-1923). Cód.: 11-02-019; 11-02-036.

Diários de Cartas da Vigaria do Bispado (1904-1906). Cód.: 02-03-005; 02-03-006.

Diários de visitas pastorais (1906-1920. Cód.: 11-02-067; 11-02-062; 11-02-049; 11-02063; 12-01-013.

Diários pessoais de Dom Duarte Leopoldo e Silva (1907-1911). Cód.: 02-01-038; 11-02048.

Inventários da Igreja da Sé (1747-1921). Cód.: 01-02-020; 06-03-051; 59-01-034.

Inventários de móveis, objetos de arte, alfaias, ornamentos e utensílios (1920). Cód.: 06-13-041.

Livro de Contas do Palácio São Luiz. Cód.: 55-01-013.

Livros de Correspondências da Cúria (1920-1924). Cód.: 07-03-062; 07-03-063.

Livros de Tombo da Arquidiocese (1909-1930). Cód.: 06-01-006; 06-03-041; 19-02-035.

Livro de Visitas do Arquivo da Cúria (1931). Cód.: 11-02-042.

Pastas avulsas (s/ cód.): MAS; Museu; Museu/Música.

Pastas com fotografias do Museu e Acervo: PF-04-01-035; PF-04-01-036; PF-05-01-12; PF-05-01-13; PF-05-01-29; PF-05-02-55; PF-07-02-22; PF-07-02-28; PF-04-01-59; PF07-01-31; PF-04-01-27; PF-04-01-38; PF-04-02-22; PF-06-03-33; PF-04-02-18; PF-0403-09; PF-04-03-02; AF-01-02-21; AF-01-04-24; AF-01-05-12; AF-01-05-13; AF-01-0514; AF-01-05-15; PF-02-04-57; PF-02-04-58; PF-02-04-59; PF-02-04-60; PF-04-01-57; PF-04-01-58; PF-04-01-22; PF-04-01-23; PF-04-01-24; PF-04-01-25; PF-04-01-26; PF04-02-25; PF-04-02-26; PF-04-02-27; PF-04-02-28; PF-04-02-29.

Protocolo - Registro e Provisões (1920-1921). Cód.: 19-01-012; 19-01-003. 


\section{Arquivo Histórico Municipal de São Paulo (AHMSP)}

Série Obras Particulares / Ano 1918 / cx. 51 / Doc. 53:

- Processo no 193197-S: plantas do Edifício da Cúria Metropolitana de São Paulo.

- Processo no 522109-C: Demolição do convento situado à Rua de Santa Teresa e esquina Rua do Carmo.

\section{Instituto de Estudos Brasileiros (IEB-USP)}

Acervo: Ernani Silva Bruno. Código de Ref.: ESB(24)2-22. BIBLIOGRAFIA. Título: Livros de interesse para o SPHAN, existentes na cúria metropolitana de São Paulo. São Paulo, SP. [S.d.].

Acervo: Ernani Silva Bruno. Código de Ref.: ESB(27)7-61. LISTA. Título: Objetos da cúria. São Paulo, SP. [entre 1969 e 1979].

Acervo: José Honório Rodrigues Código de Ref.: JHR-D125-007. NOTíCIA. Título: Nos arquivos da Cúria, a história do Brasil-Colônia. s.l. [1/1974?].

Acervo: José Honório Rodrigues. Código de Ref.: JHR-D125-008. NOTíCIA. Título: Arquivo da Cúria deixa a praça para o metrô. s.l. [17/1/1974].

Acervo: José Honório Rodrigues. Código de Ref.: JHR-D125-011. PERIÓDICO. Título: Boletim do CEPEHIB (Centro de Pesquisa e Estudos de História da Igreja no Brasil). São Paulo, SP. [1/1981].

Acervo: Mário de Andrade. Código de Ref.: MA-SPHAN-130. CARTA/ OFÍCIO. [Rodrigo Mello Franco de Andrade diz estar de acordo com a sugestão de Mário de Andrade de fotografar as pinturas existentes no Museu da Cúria, mesmo com as dificuldades encontradas por parte do pessoal do Museu. Rio de Janeiro, RJ. 24/3/1943.

Acervo: Mário de Andrade. Código de Ref.: MA-C-CP6428. BILHETE. Agradecimento pela menção ao filho Carlos em crônica musical de MA. 08 nov. 1933.

Acervo: Mário de Andrade. Código de Ref.: MA-DP-065. REQUERIMENTO. Título: Requerimento à Cúria Metropolitana de São Paulo. São Paulo, SP. [de 1/10/1920 a 6/10/1920].

Acervo: Waldisa Russio. Código de Ref.: WR-EXP-NAC-0080. LIVRETO. Título: Andores, opas e anjos: passa a procissão. São Paulo, SP. [de 1/8/1985 a 17/11/1985].

Acervo: Waldisa Russio. Código de Ref.: WR-GTM-0045. RELATÓRIO. Título: Relatório do Grupo Técnico de Museus - GTM. São Paulo, SP. [entre 1976 e 1977].

Acervo: Waldisa Russio. Código de Ref.: WR-GTM-0083. DOSSIÊ. Título: MUSEU DE ARTE SACRA. São Paulo, SP. [entre 1976 e 1977].

Acervo: Waldisa Russio. Código de Ref.: WR-RS-PAORN-001. ENVELOPE / OFÍCIO / Organograma. Descrição: Conjunto de documentos remetidos por Pedro Antônio de Oliveira Ribeiro Neto, Diretor do Museu de Arte Sacra, para Waldisa Rússio, na qualidade de coordenadora do Grupo Técnico de Museus (Secretaria de Estado da Cultura, Ciência e Tecnologia). São Paulo, SP. 12/10/1976. 


\section{Fontes iconográficas e tridimensionais (objetos) em Arquivos e Coleções}

\section{Arquivo Público do Estado de São Paulo (APESP)}

Consulta on-line ao acervo iconográfico da instituição.

\section{Museu da Casa Brasileira (MCB)}

Contato on-line com o Núcleo de Documentação e Pesquisa a respeito da procedência de objetos do antigo Museu da Cúria no acervo da instituição.

\section{Museu da Cidade de São Paulo (MCSP)}

Contato e consulta on-line ao acervo iconográfico da instituição.

\section{Museu de Arte de São Paulo (MASP)}

Contato on-line com o Centro de Pesquisa a respeito das obras participantes da exposição A Mão do Povo Brasileiro, em 1969 e em 2016.

MASP. A Mão do Povo Brasileiro. Adriano Pedrosa e Tomás Toledo (orgs.). Catálogo. 320p. MASP, 2016

\section{Museu de Arte Sacra de São Paulo (MAS-SP)}

Contato on-line e consulta in loco aos acervos bibliográfico, arquivístico e iconográfico da instituição.

\section{Periódicos consultados}

\section{Biblioteca Nacional - Hemeroteca digital:}

A Cigarra (SP)

A Republica: orgam do Partido Republicano (PR)

Correio da Manhã (RJ)

Diário de Pernambuco (PE)

Correio de S. Paulo (SP)

Correio Paulistano (SP)

Diário Nacional: A Democracia em Marcha (SP)

Diário Oficial de São Paulo (SP)

Illustração Brasileira (FRA)

Jornal do Brasil (RJ)

Jornal do Commercio (RJ)

O Imparcial (RJ)

O Paiz (RJ)

O Estado de S. Paulo (SP)

Diário de Sorocaba (SP)

O Legionário (SP)

Boletim Eclesiástico (SP)

\section{Sites institucionais}

Arquidiocese de Campinas - www.arquidiocesecampinas.com

Arquidiocese de São Paulo - www.arquisp.org.br

Edizioni Capitolo Vaticano - www.edizionicapitolovaticano.it

Prefeitura de Mariana - www.mariana.mg.gov.br

Museu Sacro Franciscano - www.saofranciscodapenitencia.org.br

Museu de Arte Sacra de São Paulo - www.museuartesacra.org.br 
Mosteiro da Imaculada Conceição da Luz - www.mosteirodaluz.org.br Museu de Arte Sacra UFBA - www.mas.ufba.br

Museu das Missões - www.museudasmissoes.museus.gov.br

Museus Vaticanos - www.museivaticani.va

Paróquia Coração Imaculado de Maria - www.capelapuc.org.br

Stato dela Cittá del Vaticano - www.vaticanstate.va 


\title{
ANEXOS
}

\begin{abstract}
ANEXO A - Pequeno glossário de arte sacra e objetos de culto católico (destinado a auxiliar a melhor compreensão de termos utilizados ao longo do trabalho).
\end{abstract}

Fontes: Museu de Arte Sacra de São Paulo, 2021; TIRAPELI, 2007, p. 133-134;

UNIVERSIDADE CATÓLICA PORTUGUESA; FUNDAÇÃO DA CASA DE

BRAGANÇA. Thesaurus - Vocabulário de Objectos do Culto Católico. Lisboa, 2004.

Acanto: motivo decorativo, presente originalmente num capitel coríntio que representa a folha de acanto espinhoso. Simboliza o sacrifício.

Alfaias: peças de uso em missa: paramentos, vasos, castiçais.

Altar: construção fixa ou móvel sobre a qual se celebra o sacrifício da missa.

Alta-mor: altar ou retábulo principal de uma igreja ou capela, posicionado na parede da capela-mor, onde se coloca o santo padroeiro.

Âmbula, cibório ou píxide: vasilha de diversos formatos e tamanhos com tampa. Destina-se a colocar as partículas (hóstias) para consagração ou já consagradas que serão distribuídas ao povo. É também usada para guardar as partículas consagradas que sobrarem, as quais serão depositadas no sacrário.

Anel: De ouro, simboliza a caridade e possui uma pedra preciosa que significa a união do Bispo com a Igreja e sua inquebrantável fidelidade. A ametista, de cor roxa, é a pedra por excelência das joias eclesiásticas.

Anjo tocheiro: escultura de anjo portando tocheiro ou castiçal grande para velas.

Arcaz: grande arca ou cômoda com gavetões para guardar paramentos e outros acessórios.

Atributo: símbolo, insígnia ou qualquer elemento numa escultura, pintura, ou gravura, vinculado, como convenção, à identificação de determinado santo.

Báculo: insígnia de bispo. O terminal superior é recurvado ou em forma de nó e voluta (crossa).

Baldaquino: cobertura decorativa sobre o altar.

Banqueta: conjunto composto de seis tocheiros e um crucifixo, postado sobre o altar com objetivo de ornar os altares com decência. Os altares laterais das capelas e igrejas também possuíam banquetas de prata, apenas o tamanho as diferenciava. 
Barroco: estilo artístico do século XVII e parte do século XVIII, período da Reforma Protestante, contra a reforma católica e política absolutista; estilisticamente associado às formas em movimento, dramaticidade de expressões, colorido intenso, sombras e luzes.

Caldeirinha e hissope (ou aspersório): pequena vasilha na qual se mergulha o hissope, usado, nas igrejas, para aspergir água benta sobre os fiéis.

Cálice: Recipiente que recebe o vinho, no ofertório, vinho este transformado em Sangue de Cristo na Consagração. Objeto normalmente feito em prata e raramente em ouro, tendo sempre o interior da taça dourado. É o mais importante e mais antigo dos vasos sagrados de que se serve a liturgia católica. Somente um bispo pode consagrar o cálice por uma benção própria.

Candelabro: grande castiçal, com várias ramificações, a cada uma das quais corresponde um foco de luz.

Cantaria: obra de pedra aparelhada.

Capela-mor: capela principal, onde fica o altar-mor de uma igreja.

Cariátide: figura feminina, de corpo inteiro ou meio corpo, sobre a qual se assenta uma cornija ou arquitrave.

Castiçal: utensílio que se usa para suporte de uma vela.

Catedral: principal igreja de um bispado ou arcebispado; igreja episcopal de uma cidade ou diocese.

Ciriais: acompanham, uma de cada lado, a cruz processional nas procissões que se realizavam em torno das igrejas ou pelas ruas, especialmente na de Corpus Cristi. As irmandades os mandavam fazer com ostentação para que pudessem apresentar suas procissões com mais louvor.

Coroa: ornato com que se cinge a cabeça. Utilizadas nas imagens com o objetivo de prestar uma homenagem ao santo. Geralmente são doadas por particulares ou Irmandades.

Coroamento: parte superior ou remate de ornamento.

Credência: pequena mesa ao pé do altar onde se colocam galhetas, cálice e acessórios de missa.

Cruz: objeto formado por duas barras que se cruzam perpendicularmente e podem ter diferentes funções, como no caso da cruz menor, que pode ficar sobre o altar, ou da cruz processional, isto é, a que guia a procissão de entrada.

Douramento: processo de revestimento com ouro em peças ornamentais. 
Espevitadeira: instrumento utilizado para apagar e aparar a ponta queimada do pavio da vela. Apoia-se numa salva.

Esquife: Féretro descoberto ou com tampa envidraçada, guardado na igreja, para expor o defunto durante as exéquias ou para a apresentação permanente dos seus restos mortais.

Ermida: pequena capela localizada fora de um povoado.

Faldistório: Cadeira de braços, dobrável, com os pés cruzados em X e sem espalda. Reservado ao bispo ou a um prelado de elevado nível hierárquico, utiliza-se em cerimónias litúrgicas especiais, na ausência da cátedra episcopal.

Festão: ornamento floral em talha permanente.

Fitomórfico: peça que tem forma vegetal.

Frontão: espécie de empena que serve para coroar a parte central do frontispício da igreja; costuma-se falar também em frontão com relação ao remate do retábulo.

Galhetas (par): duas jarras pequenas, de vidro ou prata, colocadas sobre uma bandeja onde estão, separadamente, a água e o vinho que vão ser usados na Celebração Eucarística.

Genuflexório: móvel para oração de joelhos. Integra um alçado, cujo topo funciona como apoio para cotovelos ou estante para livros de orações, e um estrado móvel ou articulado, para os joelhos. Ambos os apoios são, em geral, almofadados.

Gomil ou Jarra: contém água, junto à bacia, para lavar as mãos do padre depois da preparação das ofertas na Missa. Usada em todas as celebrações eucarísticas.

Imaginária: arte de esculpir ou talhar imagens religiosas em madeira ou outros materiais; conjunto de imagens que constituem o acervo da espécie em determinado museu, igreja etc.

Incenso: é uma resina aromática, que pode ser extraída de várias plantas, usada no turíbulo. Produz uma fumaça que sobe aos céus, simbolizando nossas preces e orações a Deus.

Joias: no século XVIII, período de mais forte extração tanto do ouro como dos diamantes no Brasil, predominavam as joias de prata com lascas de diamantes e crisólitas. Essas, empregadas em joalheria desde a Antiguidade, foram as pedras mais utilizadas, muitas vezes combinadas a topázios e turmalinas. $\mathrm{O}$ hábito de se oferecer joias às santas de maior devoção estendia-se também às irmandades que ofereciam distintivos ornados de pedrarias que, colocados nas costas dos paramentos sacerdotais, as identificavam durante as missas. 
Lanternas de mão: montadas sobre varas de prata e levadas nas procissões pelos irmãos ministros das irmandades.

Maneirismo: período estilístico da segunda metade do $\mathrm{XVI}$; na arte brasileira também denominado jesuítico ou proto barroco.

Missal: livro usado pelo sacerdote para a celebração da Missa.

Naveta: Objeto utilizado para se colocar o incenso.

Nicho: cavidade ou vão em parede, muro, retábulo, arco-cruzeiro etc. para colocação de objetos ou imagens ornamentais.

Oratório doméstico: imagens colocadas num armário de portas envidraçadas ou um nicho com representações religiosas ou uma cruz, colocados no espaço doméstico para devoção privada.

Ostensório ou custódia: espécie de vaso onde a hóstia consagrada (que assim se torna o corpo de Cristo) é exposta numa abertura coberta por dois vidros, como uma janela redonda. Nele fica exposto o Santíssimo para adoração dos fiéis e para dar a benção Eucarística. É usado na procissão de Corpus Christi, ficando sempre entre duas ou mais velas acesas.

Palmas: objetos em forma vegetal feitas de prata ricamente cinzeladas e montadas em vasos entre os tocheiros sobre o altar-mor, eram, em geral, oferta das irmandades religiosas para maior riqueza do culto.

Panejamento: diz-se da roupagem de imagens pintadas ou esculpidas com relação às dobras ou ondulações das vestes.

Paramentos: panos ou vestes litúrgicos ou alfaias de uma igreja.

Patena: disco circular, geralmente de ouro ou prata, que serve para colocar a hóstia grande a ser consagrada durante a celebração da missa. Representa simbolicamente a pedra sobre a qual repousou o corpo de Cristo.

Pedra d'ara: pedra natural, talhada num só bloco, consagrada e encastrada na mesa de altar.

Pia batismal: cuba para a água utilizada durante a cerimônia do batismo. Colocada diretamente no chão, é geralmente elevada por pedestal e coberta por tampa.

Porta paz: destinava-se a cobrir o anel e a mão nas cerimônias em que os bispos eram obrigados a dar o anel ao beija-mão a grande quantidade de fiéis. Os chamados porta pazes de mão eram pequenos quadros de prata trazendo a imagem de um santo na face externa e uma alça para os dedos na face interna. Alguns porta-pazes de prata prolongavam-se formando pés e eram colocados sobre os altares ao lado das imagens, facilitando o beijo devoto dos fiéis. 
Porta-votos: nele eram depositados os votos perpétuos que os religiosos ou devotos de irmandade escreviam em pequenos pedaços de papel e ofereciam a Deus

Policromia: trabalho de revestimento com pintura e douramento, especialmente imagens de talha, com duas ou mais cores.

Púcaro ou vaso purificatório: vasos feitos sempre em prata representavam na antiga liturgia o símbolo da purificação. Deviam ter o pé mais baixo que o cálice da missa e eram apresentados com água, aos fiéis, para beberem um gole após haverem comungado. Com a mudança das regras litúrgicas, os vasos purificatórios caíram em desuso

Quartelão (quartela, peanha): peça que, em estrutura ornamental, serve de sustentação a imagens.

Relicário: objeto destinado à guarda de relíquias de santos em forma de busto ou outras.

Resplendor: círculo ou auréola com raios de metal que se põe na cabeça das imagens de santos ou em crucifixos, custódias etc.

Retábulo: estrutura ornamental de pedra ou talha de madeira que se eleva na parte posterior do altar; quanto ao estilo, genericamente obedece a seguinte classificação: jesuítico ou maneirista (início do século XVII); nacional português (1680-1720); joanino (1720-1760); rococó (1760-1816); e neoclássico (século $\mathrm{XIX)}$.

Rocaille (rocalha): elemento ornamental concheado, introduzido na ornamentação de portadas, arcos-cruzeiros, retábulos, painéis de pintura, molduras etc.

Rococó: estilo ornamental surgido na França durante o reinado de Luís XV (1710-1774) e caracterizado pelo uso de curvas caprichosas e formas assimétricas e pela delicadeza dos elementos decorativos, como conchas estilizadas (rocailles), laços, flores, folhagens, que tendiam à uma elegância requintada; no Brasil perdura até o neoclassicismo (1816).

Sacra: cada um dos três quadros de oração onde estavam escritos os textos em latim, da parte fixa da missa. Eram colocados sobre o altar para auxiliar 0 sacerdote.

Salomônico: diz-se de uma coluna torsa ou lavrada em espiral.

Sacrário ou Tabernáculo: caixa ou vão com porta, quase sempre ao centro do altar, onde se guardam as hóstias.

Sino ou Sineta: sininhos tocados pelo acólito no momento da consagração. 
Talha: trabalho ornamental em alto ou baixo-relevo, feito por artífice, geralmente na madeira.

Tarja: peça de pintura, escultura ou talha com ornamentos, na qual se vê um escudo ou inscrição.

Teca: pequeno estojo, geralmente de metal, onde se leva a Eucaristia para os doentes. Usa-se também, em tamanho maior, na celebração eucarística, para conter as partículas.

Torêutica: arte de cinzelar e esculpir em metal, madeira ou marfim.

Trono: espécie de pedestal, colocado no vão da tribuna do camarim do altar, onde se expõe imagens e crucifixos.

Turíbulo: recipiente contendo carvão em brasa no qual se queima incenso nas procissões, nas celebrações eucarísticas e na benção do Santíssimo. É suspenso por correntes, pelas quais um acólito o faz oscilar para ativar as brasas do carvão e aumentar a nuvem de incenso. São raros os turíbulos dos séculos XVII e XVIII que se preservaram. Dotados de pouca resistência, por serem feitos com lâminas finas de prata que se tornavam mais finas ainda pelo excesso de cinzelado, furavam facilmente com o calor do braseiro a que eram submetidos. Predominantemente redondos no século XVII, eram de formas bastante variadas no XVIII. Já no século XIX, os turíbulos refletem a presença de novas técnicas introduzidas pela Revolução Industrial.

Vaso para santos óleos: recipientes de prata que são usados para guardar os óleos utilizados nos Sacramentos.

Voluta: ornato em forma de espiral.

Zoomorfo: representação de forma de animal. 
ANEXO B - Mapeamento das pinturas pelas salas do Palácio da Cúria Fonte: ACMSP. Oito páginas encontradas.

$$
\begin{aligned}
& \text { Sala do Trono } \\
& \text { Junto a. Trono } \\
& \text { No1 Retrato a óleo S.S.BentoXV }-1.12 \times 85 \mathrm{~cm} \text {. } \\
& \text { Autor quido Geoganti } \\
& \text { Bronze-b. barmelo } \\
& \text { N } 2 \\
& \text { alt. } 50 \text { ont. Autor A. Busacea } \\
& \text { Marmore-Busto S.S. P. XXII } \\
& N \cdot 3 \text { alt. } 72 \mathrm{~cm} \text {. Autor } h \text {. Brezolaro-genova } \\
& \begin{array}{l}
\text { N= Thela a óleo N.Senhora eo menino Jesus. } \\
2.15 \times 1.85 \mathrm{~cm} . \text { Autor desconhecido }
\end{array}
\end{aligned}
$$

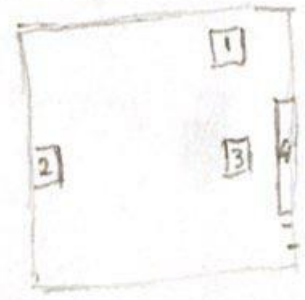




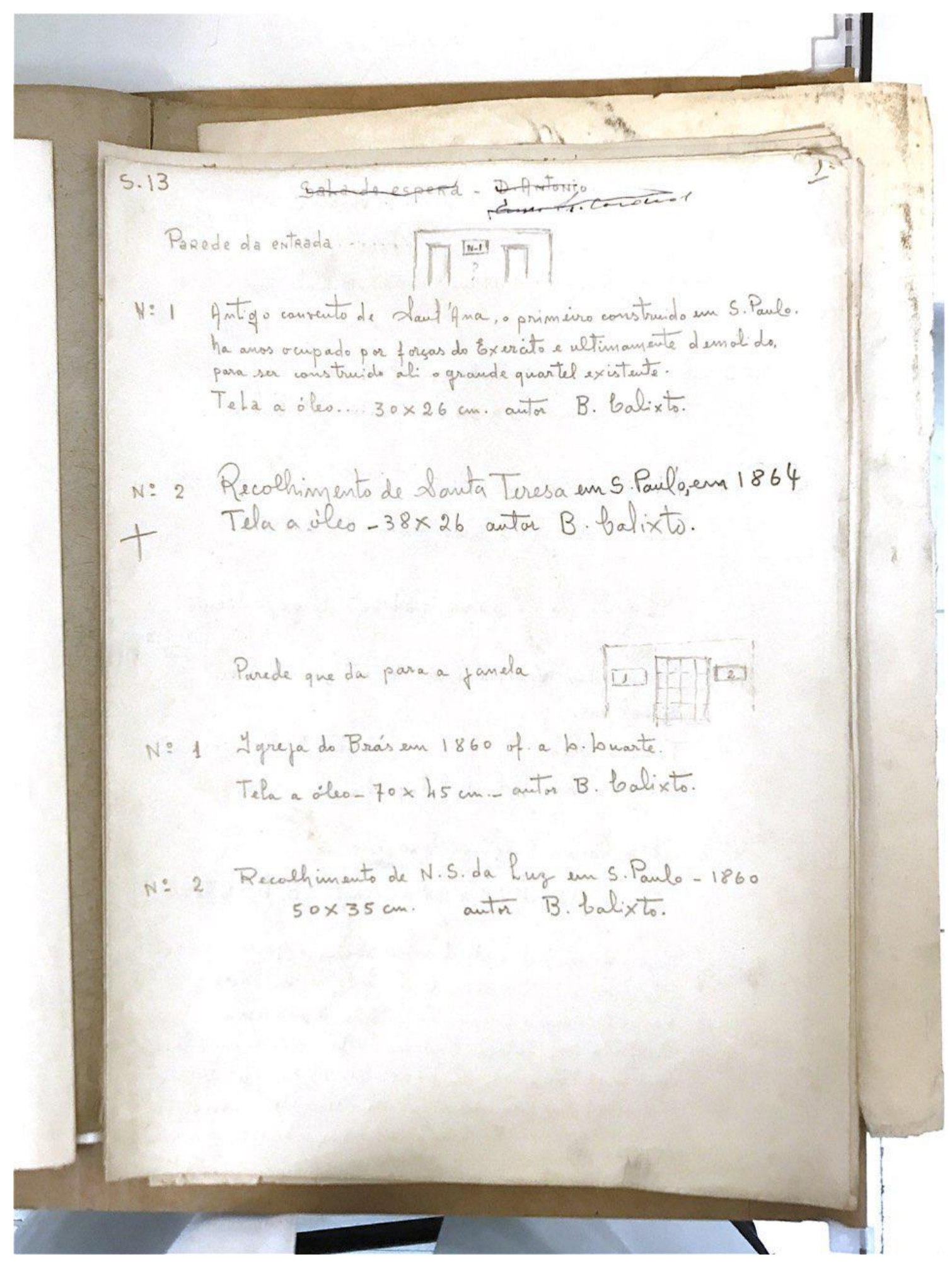




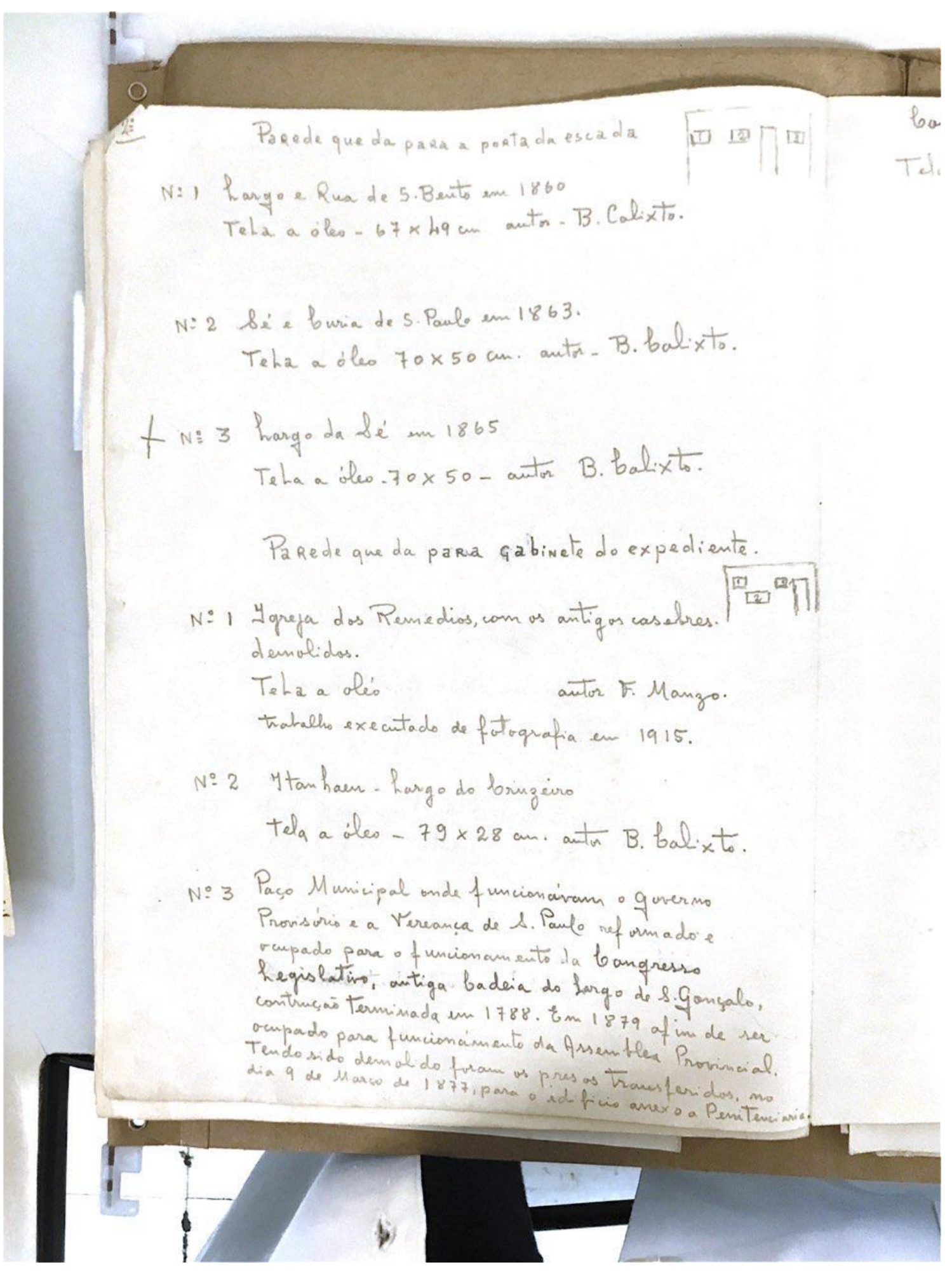




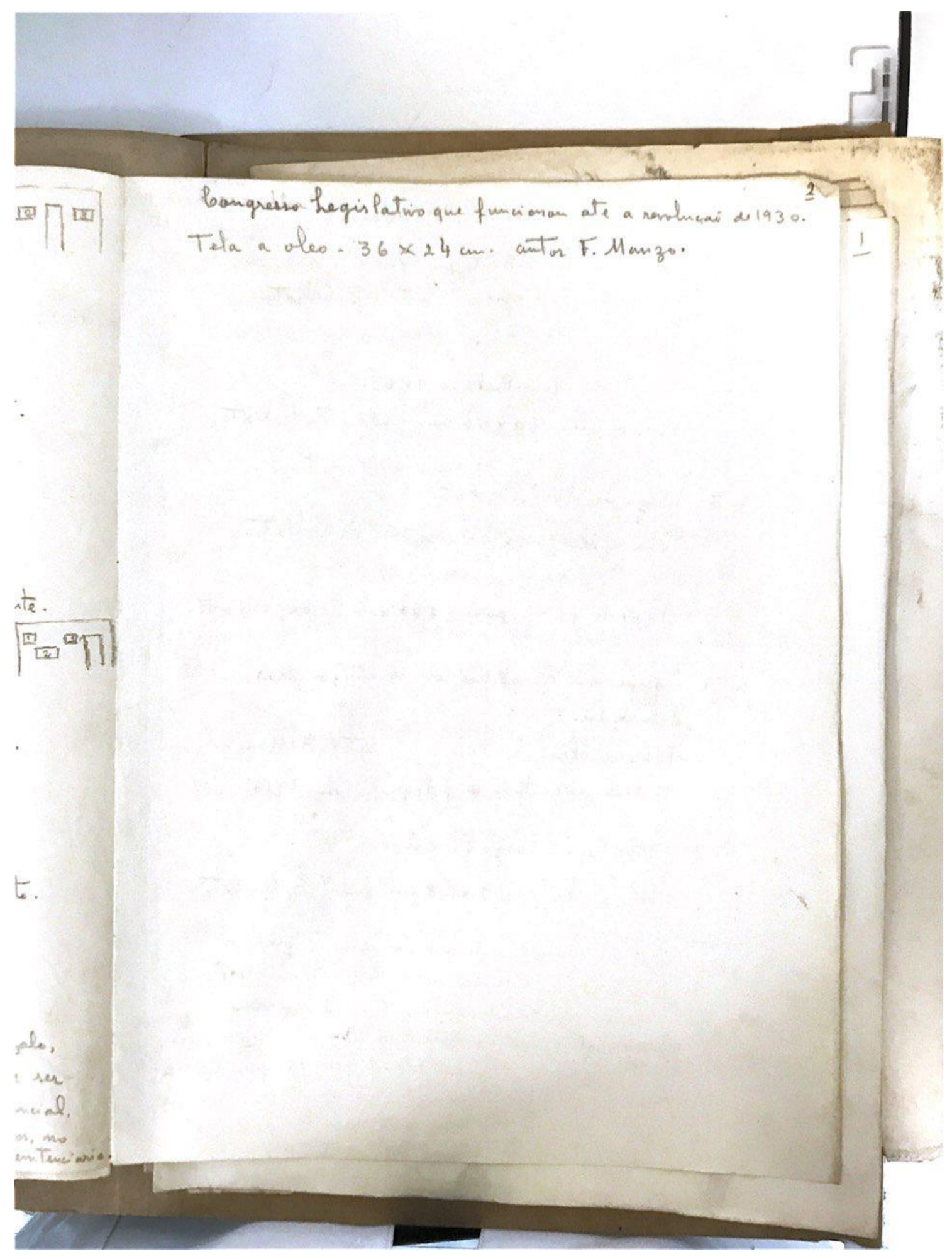




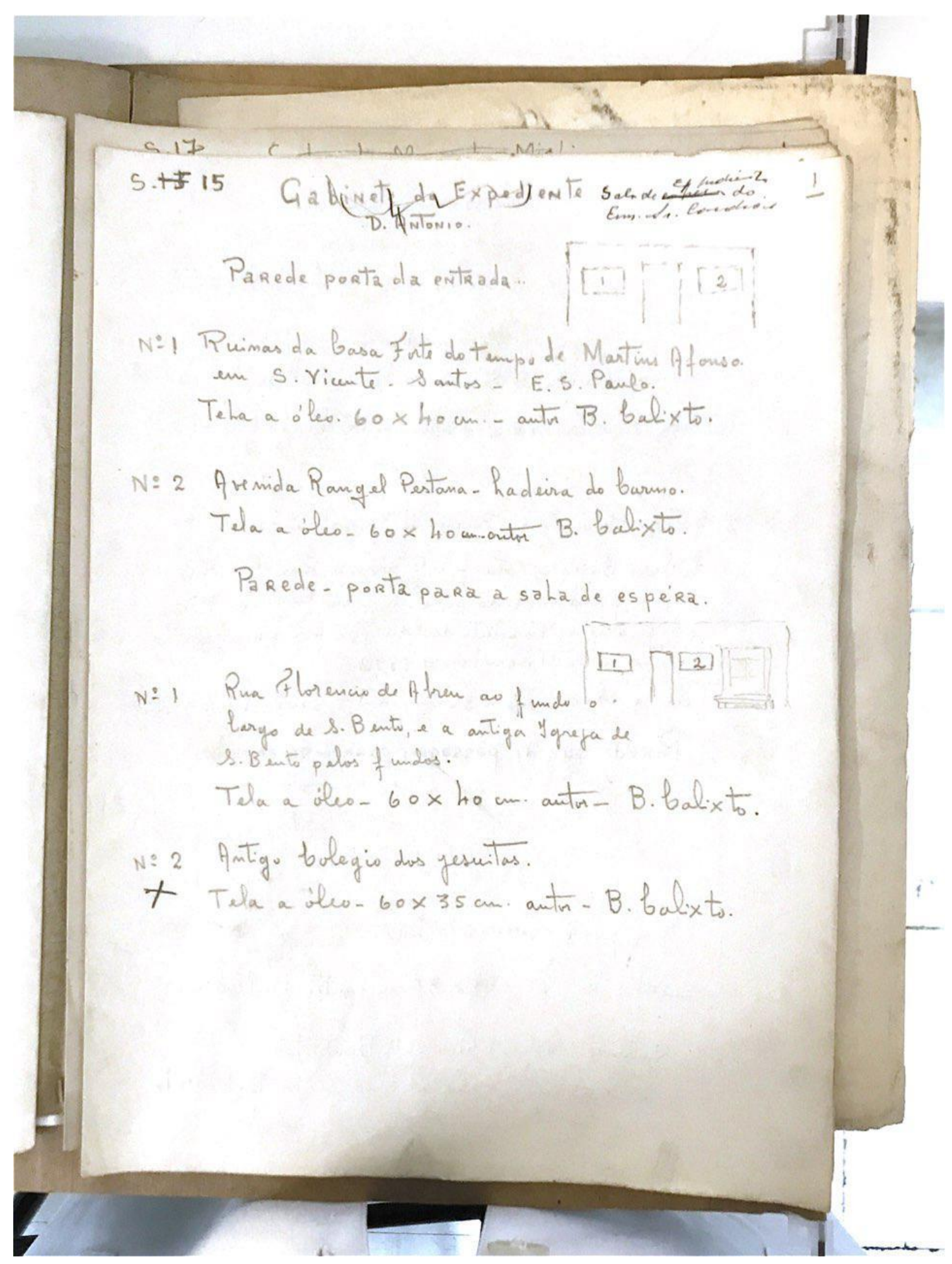




\section{Parede da janeta queda parao potio.}

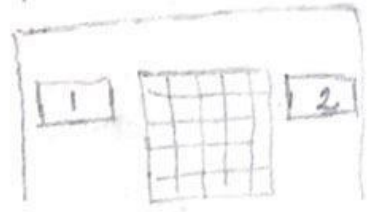

N:1 Antga Yapreja da Misericiodia no hargo do mesmo mane, esquina da Rua birreita demalida em 1888 Tela a vlio. $48 \times 35$ un antor Paul hiubke.

N.2 Antigo Palacete das Barois de Ylapetininga na Rua hitero Badaro, com frente para a Rua Dereita e que foidemolido para en sen ligar ser edificado. Yiaduto do thá que fri inang urado

Tela a olio- Hox30cm antar Paul hintthe. Parede que dia passagem para o reservado

No1 Antigo denimario da Luz

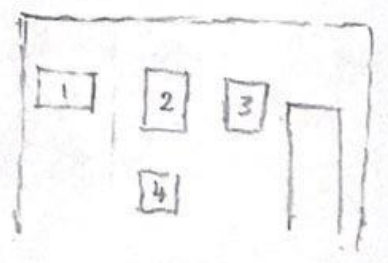
Tela a óleo $-60 \times 35 \mathrm{~cm}$. antr B. balixto.

$N=2$ Retrado Padre bhico. D. Besidito box45 cm. Tela a bleo antr B. balixto 


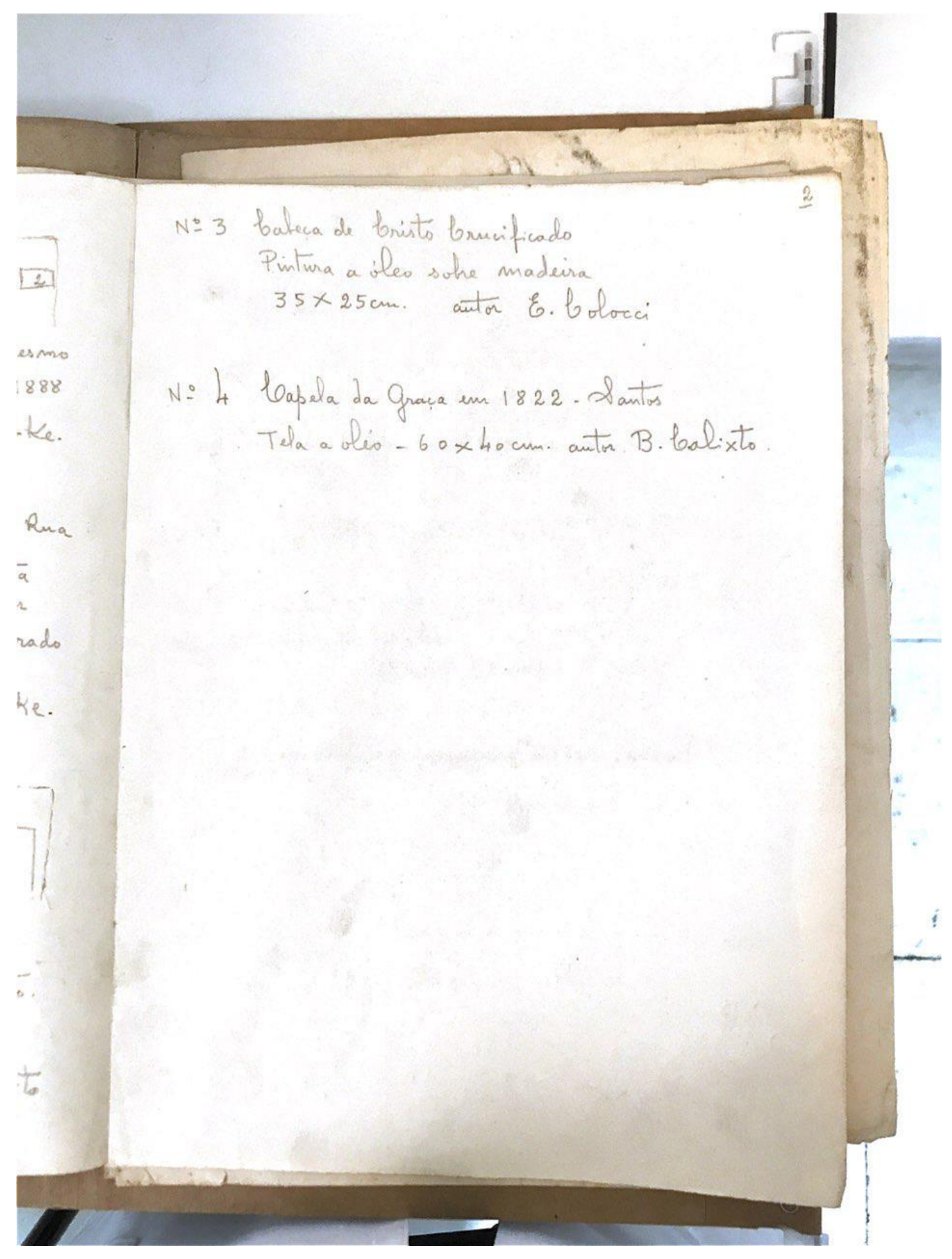




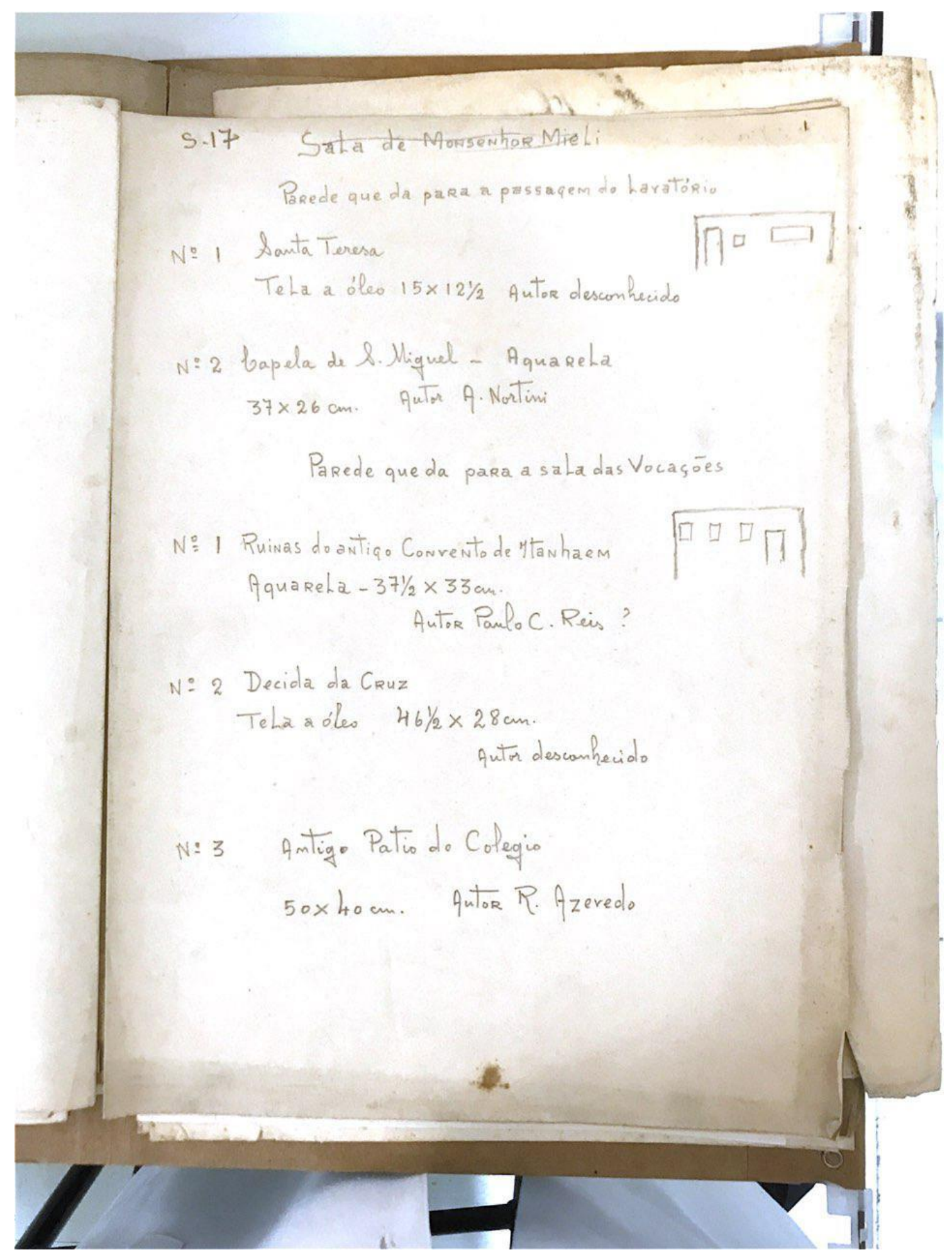




\section{ANEXO C - Descrições mais extensas dos objetos listados no catálogo no 52 do Museu da Cúria, e não incluídas, por sua extensão, nas tabelas de objetos apresentadas no Capítulo 3.3.1.}

Fonte: ACMSP, 06-03-052.

\section{Objeto no 145 - Lâmpada de prata}

Oferecida pelo Padre Guilherme Pompeu de Almeida. Histórico da referida lâmpada, registrado no livro de tombo, do ano de 1747, de Parnaíba, existente no arquivo da Cúria Metropolitana de São Paulo: armário 2, prateleira 2, no 9, folha 94: "Do legado pio que deixou o Reverendo Padre Guilherme Pompeu de Almeida para o azeite da lâmpada do Santíssimo Sacramento da Matriz desta freguesia, que consta da verba do seu testamento que é a seguinte: Legado $=42 \$ 120$, Verba do testamento: Declaro que fiz umas casas de campo no Campo da Vila de Parnaíba, e por minha devoção ao ofereci ao Santíssimo Sacramento; e como fiz venda delas a meu compadre Antonio Correa Garcia por dois mil cruzados, ou pelo que constar da escritura de venda, que passei, mando que deste dinheiro se mande fazer uma lâmpada de prata de obra lisa, que tenha de peso trinta e três marcos, e se ponha a dita lâmpada na Capela- Mor da Matriz de Parnaíba, e o mais do dinheiro dos dois mil cruzados se ponha a juros para render para o azeite da dita lâmpada em louvor do Santíssimo Sacramento; e não se continha mais no traslado da verba, que do dito testamento se tirou, o qual aqui para constar bem fielmente copiei; e por ser verdade me assino. O Vigário Manuel Mendes de Almeida. Deste legado, depois da lâmpada feita restarão quatrocentos e vinte e um mil, cento e vinte reais os quais o Reverendo visitador Manuel da Costa de Andrade por seu moto próprio deu a juros por escritura a Dom Simão de Toledo, morador da cidade de São Paulo, em cujo poder ainda se acha e de presente corre pleito na Ouvidoria Geral por parte da Irmandade do Santíssimo desta Vila em que se trata de sua cobrança. Dos juros deste dinheiro se acham cento e trinta e dois mil e oitocentos reais, depositados em poder do Reverendo Pároco desta freguesia. A Irmandade os recebeu e por sua conta corre a administração, e sei que de presente tem João da Fonseca de Amaral, que os tomou a juros por uma escritura passada no ano de 1751 pelo Tabelião José Ribeiro de Siqueira no seu livro de notas. Do sobredito Dom Simam de Toledo por não ter mais bens, só se pode tomar em pagamento uma morada de casas no páteo do Colégio da dita cidade, e a mesma Irmandade a administra e recebe os seus lucros. Vigário Manoel Mendes de Almeida".

\section{Objeto no 293 - Pequeno quadro contendo um cartão branco no qual está colada uma cruz (fita de papel preto)}

Pequeno quadro, cuja base há uma madeixa de cabelos brancos com estes dizeres: "Na câmara ardente orei segundo int. de V. Excia. Toquei esta esfinge na Veneranda fronte do saudoso Arcebispo de Mariana, Dom Silvério G. Pimenta e de sua cabeça extrai estes cabelos. Mariana 01 de setembro de 1922 + Antonio Bispo"

No verso do quadro vem uma estampa que representa N.S.J.C. no Horto das Oliveiras, com a seguinte inscrição: "Mon Père que votre volonté se fasse et non la mienne". Este quadro foi oferecido ao Exmo. Sr. Arcebispo de São Paulo pelo Exmo. Sr. Dom Antonio Augusto de Assis, então Bispo Titular de Dioclecianópolis, atualmente Arcebispo - Bispo de Jaboticabal.

\section{Objeto no 295 - Taça}

Serviu no banquete realizado nesta cidade de São Paulo, no dia 7 de setembro de 1822, dia da Proclamação da Independência do Brasil, no qual banquete estiveram presentes as pessoas ilustres que faziam parte da comitiva do Príncipe Regente na ocasião em que proferiu o grito de "Independência ou Morte". Esta taça pertenceu à finada Dona Veridiana Valéria da Silva Prado, que a ofereceu, como recordação daquela data histórica, ao Revmo. Monsenhor Manuel Vicente da Silva, por morte do qual passou às 
mãos da Família Santos Silva e, falecido o chefe desta, a viúva Dona Paula dos Santos Silva fez presente da taça ao Revmo. Sr. Vigário de Santo Amaro, Padre José Maria Fernandes, o qual, por sua vez, a ofereceu ao Museu da Cúria.

\section{Objeto no 296 - Quadro}

Retrato do venerando sacerdote Redentorista, padre João Batista Schaumberger, barbaramente assassinado na estrada da Freguesia da Penha de França, de São Paulo, aos 31 de março de 1908, quando ao voltar desta cidade para aquela freguesia, queria fazer a pé um trecho do caminho, exercício necessário à sua saúde. O crime foi perpetrado por um indivíduo ("Guasca" de apelido) que, pouco antes, obtivera ordem de Habeas-corpus por ter sido preso na ocasião em que invadia uma fazenda da Ordem do Carmo. O facínora desfechou dois tiros a queima roupa na pobre vítima, que morreu quase instantaneamente. Foi piedoso religioso e sacerdote modelo, por muitos, ainda invocado como mártir. Viera para o Brasil em 1903, passando a residir a mór parte do tempo em Aparecida. Está sobre o retrato um pedaço de pano perfurado pela bala mortífera: retalho da batina que vestia no momento o virtuoso sacerdote. (v. no 381: garrucha de que se utilizou o assassino do Padre Schaumberger).

\section{Objeto no 309 - Chapa de metal sobre a qual está impresso em Lacre um selo da Ordem Terceira da Penitenciária do Maranhão}

No verso da chapa está colado um retalho de jornal com os seguintes dizeres: "308 anos. Foi encontrado no quintal do Seminário de Santo Antonio, e acha-se em nosso escritório um sinete de bronze pertencente aos Frades Menores que dirigiam, em tempos idos, aquele convento e Igreja. O Sinete é de forma elíptica, tendo no centro do verso uma coroa encimada pelo emblema da Redenção e na base, duas mãos cruzadas. Circulam a coroa estas palavras: "Sigilum. 3. A Ordines Penitentia Maranhori", que podem ser assim traduzidas: "Selo da Ordem Terceira da Penitencia, em Maranhão". No reverso do sinete ainda se lê: Julho de 1600. Tem portanto a ninharia de 308 anos, e, contudo, acha-se em perfeito estado. Oferecido ao Museu da Cúria pelo Exmo. Sr. Dom Helvécio Gomes de Oliveira.

\section{Objeto no 322 - Caixa de rapé de prata oxidada}

Caixa de rapé de prata oxidada, tendo gravados sobre a tampa os seguintes dizeres: "Ao Ilmo. E Revmo. Sr. Pe. Lino do Monte Carmelo Luna. Consulado de La Rep.a Oriental del Uruguay, em Pernambuco". Oferecida ao Museu da Cúria pelo Exmo. Sr. Dom Sebastião Leme da Silveira Cintra, então Arcebispo Coadjutor, hoje Arcebispo do Rio De Janeiro. Nota: O Padre Mestre Lino do Monte Carmelo Luna nasceu em Recife a 23 de setembro de 1821 e ali faleceu aos 23 de junho de 1874. Sentindo vocação para o estado sacerdotal, entrou para o Convento do Carmo, no dia 01 de fevereiro de 1842, e fez profissão solene no ano seguinte, nas mãos do Padre Frei Carlos de São José, depois Bispo do Maranhão, e de quem fora discípulo. Exerceu o magistério, tendo recebido, em 1850, a patente de Leitor em Teologia. Ocupou, na Ordem Carmelita os seguintes cargos: Mestre de Noviços, Sub Prior, Secretário da Província do Brasil e, posteriormente, Provincial da Ordem, com o privilégio de usar solidéu e anel. Era Cavaleiro da Ordem de Cristo, Cônego honorário da Catedral de Olinda, Promotor do Bispado e pregador da Capela Imperial. Exerceu o cargo de bibliotecário da biblioteca de Pernambuco. Foi sócio fundador do Instituto Arqueológico e Geográfico de Pernambuco, sócio correspondente do Instituto Histórico e sócio honorário de várias associações literárias. Foi, depois do sábio Frei Caneca, o mais notável Carmelita brasileiro, pelo seu saber e pelas suas obras religiosas e literárias.

\section{Objeto no 325 - Par de fivelas de prata}

Par de fivelas de prata, que pertenceu ao Exmo. Monsenhor Ezechias Galvão da Fontoura e por ele oferecido ao Museu da Cúria. 
Nota: Este par de fivelas foi dado a Monsenhor Ezechias, quando apenas tonsurado, em 1858, pelo então estudante de Teologia e Mestre de disciplina do Seminário Episcopal de São Paulo- Padre Nuno de Faria Paiva, natural de Mogi das Cruzes e que depois de ordenado exerceu o paroquiato de Nazareth, Sant'Ana (Rio de Janeiro) e Santos. Foi também capelão do exército, na Guerra do Paraguai e, pelos relevantes serviços prestados à Religião e à Pátria, foi agraciado pela Santa Sé com o título de Monsenhor.

\section{Objeto no 363 - Cruz peitoral com a imagem de Nosso Senhor Jesus Cristo}

Cruz peitoral com a imagem de N.S. Jesus Cristo, belíssimo trabalho de filigranas de ouro antigo, que foi de uso pessoal de Dom Matheus de Abreu Pereira, quarto Bispo de São Paulo. Pertenceu a Dom José de Camargo Barros, undécimo Bispo de São Paulo, a quem fora oferecida, quando Bispo de Curitiba, pelo Revmo. Cônego João Evangelista Braga, Vigário Colado de Mogi Mirim, que a fez acompanhar de um Cartão com os seguintes dizeres: "Ao Exmo. E Revmo. Cônego José de Camargo Barros, Bispo eleito da nova Diocese de Curitiba. Tem o prazer de pedir-lhe que se digne de aceitar esta pequena lembrança - cruz peitoral de oiro antigo - que foi de uso pessoal de S. Excia. Revma. O Sr. D. Matheus Abreu Pereira, quarto Bispo de São Paulo, que em setembro de 1798 visitou as paroquias da Lapa e Castro na então $5^{\text {a }}$ Com. ${ }^{a}$, depois Prov..$^{a}$ e hoje Estado do Paraná. Me foi transmitida, a 23 de setembro de 1889, na casa no28 à Rua da Glória, da Capital, pelas Exmas. Sras. Donas Anna Bourroul e Maria Lucia, por ocasião de um sermão que preguei na capelinha de № Senhora dos Aflitos. Por uma espécie de voto, por inteiro patriotismo, reservei-a ao $1^{\circ}$ Bispo do Paraná, que é $\mathrm{S}$. Excia. - Apenas peço uma benção para mim e os meus. Amigo e companheiro de trabalhos-Braga. Mogi Mirim 19 de dez $^{\circ}$ de 1893. E. de São Paulo". Oferecido ao Museu da Cúria pela Exma. Sr. Dona Anna de Camargo Barros.

\section{Objeto no 382 - Garrucha}

Oferecida ao Museu da Cúria pelos Revmos. Padres Redentoristas da Penha. Esta garrucha veio acompanhada de um certificado firmado pelo Revmo. Padre Estevam Maria, Reitor da Casa da Penha, nos seguintes termos: Veio acompanhada de um certificado firmado pelo Revmo. Padre Estevam Maria, Reitor da Casa da Penha, nos seguintes termos: "Essa garrucha é o instrumento que o bandido Guasca matou na Av. Celso Garcia O Redentorista P. João Schaunberger. A garrucha foi guardada na Delegacia do Braz sob o $n^{\circ} 23$, com os dizeres: "N²3. Garrucha que pertenceu ao Guasca..." O Exmo. Sr. Dr. Ribeiro Cardoso, Secretário da justiça, entregou-a a pedido dos Padres Redentoristas e estes entregam-na (sic) ao Exmo. Sr. Arcebispo Metropolitano para ser guardada no Museu da Cúria Metropolitana de São Paulo. "In fide" Pe. Estevam Maria M. Reitor da Casa da Penha. Penha aos 2 de maio de 1924" (V. à pag. 35, n-295, notícia sobre o assassinato do padre Schaumberger).

\section{Objeto no 384 - Cruz de ouro}

Contendo no anverso um Emblema da Sagrada Eucaristia, circundado com os dizeres: "Irmandade do Santíssimo Sacramento da Candelária" e no reverso, os dizeres: "Ao irmão Benemérito - Monsenhor Alberto Gonçalves". Esta medalha foi criada pela Mesa Administrativa da Irmandade, em sessão de 29 de agosto de 1899 e sancionada pelo Capítulo em 28 de dezembro do mesmo ano, para ser usada pelos Irmãos Beneméritos ou Benfeitores. (CFR. Carta do secretário da Irmandade de 4 de outubro de 1924) Oferecida ao Museu da Cúria pelo Exmo. Sr. Dom Alberto José Gonçalves, Bispo de Ribeirão Preto.

\section{Objeto n385 - Medalha de bronze}

Tendo no anverso a inscrição: "Basílica Metropolitana di San Marco Venezia" e no reverso: "Nel 828 ordinata dal Doge Giustino Partecipazio Dal Giovanni Edificata 976 Incendiò e il Doge S. Pietro Orseolo la Riedifica - 1043 La continua il Doge 
Contarini - 1071 Compiuta - 1094 Consacrata. - Questa Basilica - che in sublime slancio religioso - al Patrono S. Marco Evangelista - Venezia Rep. Dedicava - per munificenze e trofei - di Cittadini e Dodi preclari - sontuosamente arrichita ed ornata da otto secoli - alle ammirazioni del mondo - in suo splendore conservasi - monumento di arte e di fede".

\section{Objeto no 387 - Caixa de Jacarandá}

Trabalho artístico e de estilo antigo, feita de madeira que em tempos idos fora empregada na construção da Igreja da Ordem Terceira do Carmo, desta capital. Traz sobre a tampa pequena placa de ouro, na qual estão gravados os seguintes dizeres: "Ao Exmo. Revmo. Sr. D. Duarte Leopoldo e Silva Arcebispo Paulopolitano. Lembrança da inauguração da Igreja da V.O.T.N.S. Carmo. São Paulo, 19-10-1924." A caixa contém riquíssima pasta de couro da Rússia, forrada internamente de seda adamascada e tem, na parte externa, à esquerda, as Armas Archiepiscopal de São Paulo, em ouro, e à direita, a data: 19-10-1924. - Oferecida ao Museu da Cúria pelo Exmo Sr. Dom Duarte Leopoldo e Silva, Arcebispo Metropolitano.

\section{Objeto no 422 - Jogo de breviário de uso pessoal de Sua Santidade o Papa Pio X}

Papa Pio X ofereceu ao Exmo. Sr. Dom Francisco do Rego Maia, Arcebispo titular de Nicopolis, por este oferecido a Dom Sebastião Leme da Silveira Cintra, enquanto Bispo Coadjutor do Rio de Janeiro, o qual, por sua vez o ofereceu ao Museu da Cúria. Traz no tomo $1^{\circ}$ o oferecimento autografo de sua Santidade: "Venerabili fratri Francisco do Rego Maia Archiepiscopo titulari Nicopolitano grati et benevolenti amicus ergo. Die 13 Maji 1911 (a) Pius PP.X"

Cópia original de dois documentos que acompanham esta preciosa relíquia:

Vaticano 14 Maggio 1911

Monsignor Giovanni Bressan

Capellano Segreto di Sua Santité

Inchinato al bacio del Sacro Annello, ossequia rispettosamente l'lllmo e Revd. Mons. Francesco do Rego Maia Arcivescovo de Nicopoli e per disposizione del Santo Padre, Gli transmette um Breviario, che Sua Santitá há usato in questi primi anni del Pontificato fino al giorno 12 di questo mese.

Rio de janeiro, 10 de outubro de 1927

A S. Exa. Revma. O Sr. Dom Duarte Leopoldo e Silva, Arcebispo de São Paulo, ofereço este breviário de Pio X, lembrança de S. Santidade ao Sr. Dom Francisco do Rego Maia, e deste a mim. Nas mãos de $\mathrm{V}$. Exa. A preciosa relíquia está melhor guardada e será atestado seguro da grande afeição e o profundo reconhecimento que para seu bispo tem.

+ Sebastião Arceb. De Phars. Codjutor de S. Eminência.

\section{Objeto no 447 - Bandeira}

A cerimônia da benção desta bandeira, bordada por senhoras paulistas e por elas oferecida ao $7^{\circ}$ Batalhão de Voluntários da Pátria, realizou-se na Catedral de São Paulo aos 9 de julho de 1865, tendo oficiado o Bispo Dom Sebastião Pinto Rego. Das mãos do ilustre prelado paulista passou o pavilhão - que se devia cobrir de glória na célebre tomada da ilha da Redenção e em toda a campanha contra o Paraguai - para as mãos do Presidente da Província, Dr. João Chrispiniano Soares, o qual, depois de vibrante discurso de exortação cívica, o entregou ao comandante do $7^{\circ} \stackrel{0}{ }$, tenente-coronel Francisco Joaquim Pinto Pacca. Voltou a bandeira quando findou a guerra, a $1^{\circ}$ de março de 1870, dos campos do Paraguai, empunhada por um reduzido grupo de voluntários daquela unidade a qual, no fim da campanha, para formar batalhão, teve que fundir-se, sob o no 35 , com os restantes também paulistas do $42^{\circ}$ e $45^{\circ}$ batalhões, e foi entregue ao Corpo Capitular da Sé, às 4 horas da tarde de 27 de abril de 1870. 0 
glorioso emblema da Pátria, que voltava salpicado de sangue e perfurado pelas balas paraguaias, mas virgem do contato impuro das mãos inimigas, foi entregue perante a tropa, pelo comandante do 53으, coronel Antonio Martins do Amorim Rangel, ao Presidente da Província, Dr. Antonio Candido de Andrade Rocha que, por seu turno, o entregou ao Vigário Capitular, Arcediago Dr. Joaquim Manuel Gonçalves Andrade, sendo a relíquia por este colocada ao pé do altar-mor. Subiu então ao púlpito o padre Francisco de Paula Rodrigues, que proferiu belíssimo discurso alusivo ao grandioso e comovente ato, findo o qual discurso, cantou-se o TE DEUM, oficiando o Arcediago Monsenhor Joaquim Manuel Gonçalves de Andrade. -- No laço de fita da coroa de louros lê-se a seguinte inscrição: "Campanha do Paraguay - Aos voluntários Paulistas - Ilha do Carvalho 2 e 24 de maio de 1865 - 18 de julho - Estabelecim.to Pikiciri Angostura Tupium - O corpo Academico de 1870".

\section{Objeto no 448 - Cruz peitoral}

De Sua Eminência o Sr. Cardeal Dom Joaquim Arcoverde de Albuquerque Cavalcanti, Arcebispo do Rio de Janeiro, que a usou até o dia de sua morte. Traz gravadas na superfície as Armas de Sua Eminência, quando Bispo de São Paulo - 1894-1897. --Monsenhor Moura Guimarães, Secretário de Sua Eminência, entregou-a ao exmo Sr. Dom Duarte Leopoldo e Silva, por determinação de mesmo senhor Cardeal, que declarou que fosse a cruz destinada ao Arcebispado de São Paulo, depois de seu falecimento.

\section{Objeto no 453 - Retrato a óleo de Monsenhor Dr. Anacleto José Ribeiro Coutinho} Nasceu na cidade de Campos, Estado do Rio de Janeiro, em 1800. Matriculou-se no curso jurídico de São Paulo, em 1829. Recebeu o grau de bacharel, em 1833, e o de doutor em direito, em 1834. Lente catedrático de direito eclesiástico em 10 de outubro do mesmo ano. Presidente da Câmara Municipal de São Paulo, no quadriênio de 18531857. Vigário Geral de Dom Antonio Joaquim de Mello, bispo de São Paulo, por provisão de 28 de outubro de 1852. Foi por Sua Santidade o Papa Pio IX agraciado com o título de Monsenhor. Exerceu por muitos anos as funções de capelão do Recolhimento de Santa Teresa. Faleceu em São Paulo aos 10 de setembro de 1881.

\section{Objeto no 454 - Retrato a óleo do Arcediago Monsenhor Dr. Joaquim Manuel Gonçalves de Andrade}

Veio para o Brasil no ano de 1827, a chamado de seu tio, Dom Joaquim Manuel Gonçalves de Andrade, 5ํㅗ Bispo de São Paulo. Nasceu na Freguesia de São Braz do Campanário, Ilha da Madeira, Portugal, aos 7 de novembro de 1807. Recebeu a sagrada ordem do Presbiterato aos 24 de julho de 1831, em São Paulo. Bacharelou-se em Direito, no ano de 1833. Cônego em 16 de maio de 1841. Por nomeação do governo provincial, administrou as obras de reconstrução da velha catedral entre os anos de 1845 a 1850. Arcediago aos 14 de julho de 1869. Monsenhor honorário da Capela Imperial. Administrou a Província de São Paulo como vice-presidente de 1875 a 1878. Vigário Capitular em 1852 - 18623 1873. Dom Sebastião Pinto Rego, 7ํㅗispo de São Paulo, o nomeou Vigário Geral, por provisão de 13 de abril de 1863, cargo que serviu por sucessiva provisão de Dom Lino Deodato Rodrigues de Carvalho, 8ㅇ Bispo de São Paulo, de $1^{\circ}$ de julho de 1873 até o seu falecimento, ocorrido em São Paulo a 6 de fevereiro de 1879.

\section{Objeto no 455 - Retrato a óleo do Conselheiro Padre Dr. Vicente Pires da Motta}

Nasceu em São Paulo, onde foi batizado, na Sé, aos 10 de setembro de 1799. Filho de Manoel Antonio Paes da Motta. Recebeu a sagrada ordem de Presbítero aos 8 de setembro de 1822. Formado em ciências jurídicas e sociais pela Faculdade de Direito de São Paulo, em 1832. Recebeu o grau de doutor, em 1833. Lente substituto na mesma Faculdade, em 1833, e lente catedrático, em 1834. Diretor da Faculdade de Direito, em 1865: cargo que exerceu até sua morte. Membro do Conselho Geral da Província de 
São Paulo de 1828 a 1834. Deputado a assembleia Provincial de 1834-35, 1836-37, 1838-39 e 1840-41. Vigário Capitular de 1847 a 1852. Vice-Presidente da Província de São Paulo em diversos anos de 1834 a 1869. Presidente efetivo de 1848 a 1851 e de 1861 a 1864. Presidente das Províncias de Pernambuco, Ceará, Minas e Santa Catarina. Faleceu em São Paulo no dia 30 de outubro de 1882.

\section{Objeto no 537 - Imagem de N.S. da Conceição}

Belíssimo e rico trabalho de arte antiga, oferecido ao Museu da Cúria pelo Exmo. Sr. Cardeal Dom Sebastião Leme da Silveira Cintra, Arcebispo do Rio de Janeiro.

Nota: O Palácio da Conceição foi primitivamente "Hospício da Conceição" dos Capuchinhos franceses, que o haviam edificado em 1668 e nele permanecido por espaço de 40 anos, mais ou menos, a serviço da catequese dos índios. Dom Francisco de São Jeronimo, 3ํㅗispo do Rio de Janeiro (1701-1721) o reconstruiu, adaptando-o para ser seu Palácio Episcopal, tendo falecido a 7 de março de 1721 e sido sepultado na dita capela do mesmo Palácio. No Palácio da Conceição residiram 9 Bispos: Dom Francisco de São Jeronimo, Dom Antonio de Guadalupe, Dom João da Cruz, Dom Antonio do Desterro Magalhães, Dom José Joaquim Mascarenhas Castelo Branco, Dom José Caetano da Silva Coutinho, Dom Manuel do Monte Rodrigues Araújo, Dom Pedro Maria de Lacerda e Dom José Pereira da Silva Barros. Ali também residiram dois Arcebispos: Dom João Esberard e Dom Joaquim Arcoverde de Albuquerque Cavalcanti.

\section{Objeto no 552 - Cartão de prata}

Oferecido a Dom José Pereira da Silva Barros, Bispo do rio de Janeiro. Traz os seguintes dizeres: "Conde de Santo Agostinho - llustre Arcebispo do Rio de Janeiro Creador da Parochia de Sant'Anna e de São Benedicto da Barra do Piray - Povo Agradecido-Barra do Piray, 4-2-93." Oferecido ao Museu da Cúria pelo Exmo. Monsenhor Pereira Barros. Nota: Dom José Pereira da Silva Barros foi o último Bispo do Rio de Janeiro. O primeiro Arcebispo foi Dom João Esberard. Dom José Pereira da Silva Barros, em 1893, retirou-se para Taubaté e foi, pelo Papa Leão XIII nomeado Arcebispo Auxiliar de Darnis. Barra do Piray é atualmente a sede do Bispado do mesmo nome, criado por Sua Santidade o Papa Pio XI, pela Bula "Ad supremae Apostolicae Sedis" de 4 de dezembro de 1922.

\section{Objeto no 564 - Imagem de Sant'Ana}

Imagem venerada na primitiva Capela de Parnaíba, construída em 1580 em sua honra, como padroeira da povoação. Esta imagem foi benzida com licença do bacharel Padre Bartolomeu Simões Pereira, primeiro administrador da Prelatura do Rio de Janeiro. Pelos anos de 1624-1625, Susanna Dias e André Fernandes, seu filho, fizeram diversas doações de terras para o patrimônio da Capela e para o culto da referida Santa. Transferida, mais tarde, a Capela para o local onde se ergueu a Igreja de São Bento, para lá foi transferida a imagem, onde permaneceu até o ano de 1646, data em que foi colocada definitivamente no Altar-Mor da primitiva Matriz, edificada no mesmo local em que se encontra a atual. Em 1812, tendo ruído a Capela-Mor da Matriz, foi a mesma reformada pelo padre Gonçalves Lima, o qual, então, colocou sobre o Altar-Mor outra imagem de Sant'Ana, que é a mesma atualmente ali venerada. Foi por esta ocasião retirada para uma dependência interna da Matriz a histórica e tradicional imagem, mais tarde, a instâncias do sr. F. de Salles Collet e Silva, trazida para o Museu da Cúria.

\section{Objeto no 1120 - Retrato do Monsenhor Raimundo Marcolino da Luz Cintra}

- Daguerreotipo. - Oferta de sua irmã D. Guilhermina Agnelina Luz Cintra ao Museu da Cúria.

Notas biográficas: "Monsenhor Raimundo Cintra nasceu em Itu a 30 de Janeiro de 1830, filho do Alferes Luiz Manuel da Luz e de D. Raimunda Flora do Monte Carmelo. Ordenou-se em São Luiz do Paraitinga em janeiro de 1855 por ocasião da visita pastoral que o Bispo de São Paulo Dom Antonio Joaquim de Melo fazia a este lugar, indo cantar 
a sua primeira missa na Igreja de N. Sra. do Patrocínio em sua cidade natal. Em 1852, antes da sua ordenação, saiu com Dom Antonio Joaquim de Melo a tirar esmolas para a fundação de um seminário em São Paulo, sendo, portanto, um dos que cooperaram com as suas atividades para a realização deste empreendimento. Depois de ter exercido, por alguns anos, o cargo de capelão da Sé catedral de São Paulo, foi em 1858 nomeado vigário da Vila de Una. Foi secretário de visitas pastorais de quatro bispos: Dom Antonio Joaquim de Melo, de 1858 a 1862; Dom Sebastião Pinto do Rego, de 11862 a 1868; Dom Lino Deodato Rodrigues de Carvalho, de 1871 a 1892; e Dom Joaquim Arcoverde de Albuquerque Cavalcanti, de 1894 a 1897. Foi cônego honorário da Sé catedral de São Paulo e, em 1897, foi agraciado por S. Santidade o Papa Leão XIII com as honras de monsenhor honorário e capelão de S. Santidade. Faleceu com 71 anos de idade, em Uma, no dia 27 de março de 1901. Foi sepultado no dia 28 de março de 1901 sob o arco do presbitério da Igreja matriz de Uma onde paroquiou cerca de 42 anos. - (Notas extraídas d"' A cidade de Itu" de 14 de abril de 1901). 